\title{
Kompetencje informatyczne nauczycieli muzyki
}


盗 


\section{PIOTR SOSZYŃSKI}

\section{Kompetencje informatyczne nauczycieli muzyki}

\section{STAN POSTULOWANY A RZECZYWISTY}


Piotr Soszyński - Uniwersytet Łódzki, Wydział Nauk o Wychowaniu Katedra Edukacji Artystycznej, 91-408 Łódź, ul. Pomorska 46/48

\title{
RECENZENT
}

Elżbieta Szubertowska

\section{SKŁAD KOMPUTEROWY}

Piotr Soszyński

\section{PROJEKT OKŁADKI \\ Barbara Grzejszczak}

Fotografia na okładce: Copyright (C) 2010 Corel Corporation

Wydrukowano z gotowych materiałów dostarczonych do Wydawnictwa UŁ przez Wydział Nauk o Wychowaniu

C Copyright by Uniwersytet Łódzki, Łódź 2014

Wydane przez Wydawnictwo Uniwersytetu Łódzkiego

Wydanie I. W.06569.14.0.D

ISBN (wersja drukowana) 978-83-7969-132-6

ISBN (ebook) 978-83-7969-718-2

\author{
Wydawnictwo Uniwersytetu Łódzkiego \\ 90-131 Łódź, ul. Lindleya 8 \\ www.wydawnictwo.uni.lodz.pl \\ e-mail: ksiegarnia@uni.lodz.pl \\ tel. (42) 6655863 , faks (42) 6655862
}




\section{Spis treści}

Wstęp

1. Technologia informacyjno-komunikacyjna w edukacji estetycznej

1.1. Pojęcie technologii informacyjno-komunikacyjnej (TIK) 16

1.2. TIK wobec współczesnych problemów pedagogiki 18

1.3. TIK jako narzędzie wypowiedzi artystycznej 23

1.4. Rola TIK we współczesnej dydaktyce przedmiotów estetycznych $\quad 26$

1.5. Przyczyny oporu we wprowadzaniu TIK do warsztatu

pracy nauczyciela 33

2. Kompetencje informatyczne nauczyciela muzyki w klasach IV-VI szkoły podstawowej

2.1. Pojęcie kompetencji - ustalenia definicyjne $\quad 40$

2.2. Pojęcie kompetencji informatycznych nauczyciela 48

2.3. Stan badań nad kompetencjami informatycznymi nauczycieli muzyki 50

2.4. Postulowany zakres kompetencji informatycznych nauczyciela muzyki w świetle dokumentów

2.4.1. Standardy przygotowania nauczycieli w zakresie technologii informacyjnej i informatyki 56

2.4.2. Standardy kształcenia nauczycieli 60

2.4.3. Warunki uzyskiwania stopni awansu zawodowego przez nauczycieli 69

2.4.4. Standardy edukacji kulturalnej $\quad 70$

2.4.5. Podstawa programowa kształcenia ogólnego 71

2.4.6. Zalecenia Unii Europejskiej 72

2.5. Kompetencje informatyczne w programach kształcenia kandydatów na nauczycieli muzyki w uczelniach regionu łódzkiego $\quad 74$

2.5.1. Uniwersytet Łódzki 76

2.5.2. Akademia Muzyczna im. G. i K. Bacewiczów w Łodzi 77

2.5.3. Kolegium Nauczycielskie w Zgierzu 78

3. Założenia metodologiczne badań

3.1. Przedmiot i cele badań $\quad 81$

3.2. Problemy i hipotezy badawcze $\quad 83$

3.3. Metody i techniki badawcze $\quad 84$

3.4. Zmienne i ich wskaźniki $\quad 87$

3.5. Narzędzia badawcze $\quad 88$ 
3.5.1. Ankieta dla nauczyciela $\quad 89$

3.5.2. Ankieta dla dyrektora szkoły $\quad 89$

3.6. Organizacja badań 90

4. Analiza wyników badań

4.1. Prezentacja wyników badań ilościowych 92

4.1.1. Charakterystyka badanej grupy 92

4.1.2. Stopień wykorzystania TIK przez badanych nauczycieli 96

- Zastosowania $\quad 97$

- Oprogramowanie 113

- Częstotliwość 131

- Sprzęt 143

4.1.3. Przyczyny niedostatecznego wykorzystania TIK
w opiniach badanych nauczycieli

4.1.4. Poziom kompetencji informatycznych badanych nauczycieli $\quad 162$

4.2. Porównanie postulowanego i rzeczywistego stanu kompetencji informatycznych badanej grupy nauczycieli $\quad 170$

4.2.1. Ustalenie wyznaczników postulowanego stanu kompetencji informatycznych nauczycieli muzyki $\quad 170$

4.2.2. Zestawienie stanu rzeczywistego (SR) kompetencji informatycznych badanych nauczycieli z trzema wersjami stanu postulowanego (SP)

4.2.3. Rozbieżności między stanem postulowanym i rzeczywistym kompetencji informatycznych badanych nauczycieli

4.3. Przyczyny rozbieżności między stanem postulowanym i rzeczywistym kompetencji informatycznych badanych nauczycieli 196

4.3.1. Przyczyny związane z postawą nauczyciela 198

4.3.2. Przyczyny związane z systemem kształcenia i dokształcania nauczycieli 202

4.3.3. Przyczyny związane z organizacją funkcjonowania szkoły 206

4.4. Motywacje nabywania kompetencji informatycznych w kontekście indywidualnych przypadków - analiza wywiadów 209

4.4.1. Przypadek N1 212

4.4.2. Przypadek N2 220

4.4.3. Przypadek N3 226

4.4.4. Przypadek N4 232

4.4.5. Przypadek N5 239

4.4.6. Przypadek N6 244

4.4.7. Przypadek N7 250

4.4.8. Podsumowanie wyników badań jakościowych 257 
5. Wnioski i postulaty

5.1. Wnioski i postulaty w kontekście pedeutologicznym

5.2. Wnioski i postulaty dotyczące organizacji pracy szkoły

5.3. Wnioski i postulaty dotyczące dydaktyki muzyki - rozwiązania praktyczne

5.4. Wnioski i postulaty dotyczące teorii wychowania estetycznego

5.5. Zakończenie

Bibliografia

Aneks

- Formularz ankiety dla nauczyciela muzyki

- Formularz ankiety dla dyrektora szkoły

Indeks tabel 



\section{Wstęp}

odjęta tematyka rozważań sytuuje się na styku dwóch dużych obszarów dociekań pedagogicznych. $Z$ jednej strony podejmuje problem pedeutologiczny, dociekając w jakie kompetencje powinien być wyposażony współczesny nauczyciel, $\mathrm{z}$ drugiej zaś dotyka aktualnych problemów teorii wychowania estetycznego przez zawężenie podmiotu badań do nauczycieli muzyki.

$\mathrm{W}$ aspekcie pedeutologicznym, przedmiot badań, jakim są kompetencje informatyczne nauczyciela, podejmowany jest $\mathrm{w}$ literaturze fachowej od niedawna. Trudno też mówić o tradycji myśli pedeutologicznej, skoncentrowanej na wyposażeniu dydaktycznego warsztatu nauczyciela w narzędzia informatyczne. Oczywista przyczyna takiego stanu rzeczy to zaledwie półtorej dekady obecności przedmiotów informatycznych w podstawach programowych kształcenia ogólnego. Mimo to można mówić jeśli nie o tradycji to o pewnej ciągłości rozważań i poglądów na temat informatycznych kompetencji nauczycieli, wpisującej się w szerszy dyskurs o obecności narzędzi informatycznych w edukacji, a reprezentowanych na polskim gruncie przez takich autorów, jak Stanisław Juszczyk, Bronisław Siemieniecki czy Wacław Strykowski. Starają się oni wyznaczać standardy zarówno wykorzystywania technologii informacyjno-komunikacyjnej w edukacji, jak i właśnie kompetencji nauczycieli w tym zakresie. Mimo dużej popularności tej tematyki, publikacje prezentujące oryginalne przemyślenia i oryginalne rozwiązania nie są zbyt liczne. Prace wymienionych wyżej autorów stanowią zwykle podstawę do opracowań dotyczących konieczności korzystania z narzędzi informatycznych w edukacji, korzyści i zagrożeń płynących z takiej praktyki oraz jej wychowawczych uwarunkowań.

W tym kontekście rozważania na temat nauczyciela muzyki nie stanowią zauważalnego nurtu i reprezentowane są jedynie przez pojedyncze artykuły, dotyczące wybiórczo potraktowanych zastosowań narzędzi informatycznych w dydaktyce muzyki, bądź roli technologii informacyjno-komunikacyjnej w edukacji kulturalnej młodzieży. W nurcie publikacji poruszających problemy praktycznego wykorzystania dedykowanych edu- 
kacji muzycznej aplikacji, wyróżniają się artykuły Mirosława Grusiewicza. Pozostali autorzy dość licznych publikacji eksponują zwykle aspekt technologiczny i koncentrują się na mniej lub bardziej szczegółowym omówieniu działania programu, ograniczając się w ten sposób do pobieżnej instrukcji jego obsługi. Bardzo rzadko prezentowane są bezpośrednie odniesienia do treści kształcenia, a i w takich przypadkach ograniczają się do oczywistych rozwiązań, pozbawionych waloru oryginalności.

Ciekawe w tym zakresie są przytoczone w pracy źródła anglojęzyczne, opisujące przykłady praktycznych rozwiązań, wprzęgających nowoczesne technologie do dydaktyki muzyki. Jednak różnice zarówno technologiczne, rzeczywistości edukacyjnej, jak i kulturowe nie pozwalają na proste przeniesienie zachodnich rozwiązań na grunt polski i każą budować własną strategię wykorzystywania nowych technologii w dydaktyce muzyki. Wspólne i niezależne od różnic kulturowych jest bowiem większe zainteresowanie uczniów poznawaniem muzyki, gdy mogą przy tym korzystać z narzędzi informatycznych, o czym świadczą badania ${ }^{1}$.

Perspektywa wychowania estetycznego każe dostrzegać w TIK nowe narzędzia zarówno poznawania, jak i współtworzenia kultury. Choć postulat autokreacji człowieka poprzez sztukę, formułowany przez Herberta Reada, Bogdana Suchodolskiego czy Irenę Wojnar nie poddał się półwiecznej próbie czasu, to nowe narzędzia wymagają nowego spojrzenia na ich potencjał i funkcje, nowego spojrzenia na niepomiernie rozszerzoną perspektywę biernego i czynnego uczestnictwa w kulturze. Tego właśnie obszaru dotyka tematyka niniejszych badań.

$\mathrm{Na}$ technologiczne uwarunkowania współczesnego wychowania estetycznego wskazują coraz śmielej formułowane jego nowe zadania, będące bezpośrednim kontekstem podjętych tu badań. Konieczność aktualizacji teorii wychowania estetycznego w zakresie zadań, dostrzegają i postulują Krystyna Pankowska, Janusz Gajda, czy sama Irena Wojnar. Ta ostatnia podkreśla problem tożsamości, który jest „bardzo dzisiaj aktualny, bardzo żywy, pojawiający się w różnych konfiguracjach; jest to w pewnym sensie temat dnia"2. Z jednej strony, zjawiska globalizacji wspierane właśnie nowymi technologiami, prowokują do namysłu nad zagadnieniem ciągłości,

\footnotetext{
${ }^{1}$ Por. np.: Wai-Chung Ho, Student's experiences with and preferences for using information technology in music learning in Shanghai's secondary schools, „British Journal of Educational Technology” 2007, vol. 38, No 4 p. 699-714; [źródło:] http://web.ebscohost.com/ehost/pdf?vid=6\&hid=106\&sid=4c30556c-8e13-4d37-b037-a838119ca049\%40sessionmgr110 (stan z dnia 06.03.2010).

${ }^{2}$ I. Wojnar, Wychowanie estetyczne dziś. W czterdziestą rocznicę śmierci Herberta Reada, [w:] K. Pankowska (red.), Sztuka i wychowanie. Współczesne problemy edukacji estetycznej, Warszawa 2010, s. 20.
} 
wspólnoty, której istotnym spoiwem byłaby „uniwersalna koncepcja sztuki i uniwersalna potrzeba wrażliwości na człowieka, poza różnicami lokalnymi czy regionalnymi”" Z drugiej zaś, lokalna czy regionalna odmienność, łączy się z „dziedzictwem, z tradycją lokalną, z językiem ojczystym, ze sztuką, która obrazuje pewien sposób istnienia ukształtowany przez hi-

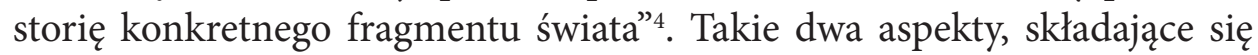
na współcześnie rozumiane budowanie tożsamości, harmonijnie łączącej wspólnotowość z odrębnością, i w dużej mierze moderowane nieznanymi wcześniej możliwościami technologii informacyjno-komunikacyjnej, wymagają według Wojnar uwzględnienia w rozważaniach nad samą sztuką, jak i obecnością sztuki w procesie wychowania.

W diagnozie formułowanej przez K. Pankowską, dominuje natomiast postulat poszerzenia namysłu nad teorią wychowania estetycznego zarówno w sferze przedmiotowej, podmiotowej, jak i narzędziowej. W tych zakresach, niniejsza praca dotyka postulatu włączenia nauki o nowych mediach do narzędzi opisu oddziaływań sztuki na człowieka oraz włączenia do pola swych zainteresowań wszechobecnej sztuki popularnej, czy działań okołoartystycznych, charakterystycznych dla sztuki masowej. „Trudno sobie wyobrazić, by w sytuacji niemal codziennych licznych kontaktów ze sztuką wychowanie estetyczne, jego rola i znaczenie były tak niewielkie, jak zdarzało się do tej pory" ". Jest to tym ważniejsze, że autorka zauważa niebezpieczeństwo w postaci ekspansji nowej postawy wobec sztuki - populizmu kulturalnego, którego „podstawą jest przekonanie, że to co się podoba tzw. zwykłym ludziom, jest ważniejsze od tego, co proponuje kultura elitarna, w której uczestnictwo wymaga przygotowania i niejakiego wysiłku”6.

Stanowisko takie podziela J. Gajda, który uważa, „że współcześnie traci sens podział na kulturę elitarną i popularną - jako wyższego i niższego poziomu" . Jednocześnie formułuje szereg aktualnych pytań, dotyczących roli nowych mediów w edukacji: „Czy media, komputeryzacja i sieć wspomagają i ułatwiają nam naszą edukację, służą uspołecznieniu jednostki, pobudzają jej inwencję, czy wręcz przeciwnie - ogłupiają zalewem błahych

\footnotetext{
${ }^{3}$ Ibidem, s. 21.

${ }^{4}$ Ibidem, s. 20.

${ }^{5}$ K. Pankowska, Wstęp, [w:] eadem (red.), Sztuka i wychowanie..., s. 12.

${ }^{6}$ Eadem, Sztuka i kultura wspótczesna. Garść refleksji nad nowymi kontekstami wychowania estetycznego, [w:] M. Zalewska-Pawlak (red.), Sztuka i wychowanie w dialogu polsko-włoskim, Łódź 2005, s. 31.

${ }^{7}$ J. Gajda, Wspótczesne pojmowanie twórczości i sztuki, [w:] K. Pankowska (red.), Sztuka i wychowanie..., s. 91.
} 
informacji i bezkrytycznego korzystania z nich, utrwalają negatywne wzory zachowania, rozleniwiają? Czy wirtualne zwielokrotnienie - cyberbycie w cyberprzestrzeni [...] pobudza wyobraźnię i wyzwala dużą skalę możliwości kreacyjnych, czy prowadzi do zatarcia granic między światem realnym i wyimaginowanym?"8.

Niniejsza praca wpisuje się w postulaty zarówno rozszerzenia perspektywy współczesnego wychowania estetycznego na przejawy wszechobecnej estetyzacji różnych sfer życia codziennego, jak i dostrzeżenia potencjału nowoczesnych i powszechnych narzędzi w obcowaniu ze sztuką oraz jej tworzeniu. Kontekst pedeutologiczny natomiast zawiera się w postulacie wyposażenia nauczycieli przedmiotów artystycznych w narzędzia pozwalające na takie właśnie, rozszerzone spojrzenie i możliwości oddziaływania na ucznia - czyli wychowania przez sztukę.

Oprócz kontekstu naukowego zauważalny jest kontekst społeczno-polityczny, wyrażający się publicznie artykułowanymi postulatami organizacji społecznych wobec polityki oświatowej państwa. Wyżej formułowane postulaty są bowiem obecne w dyskusji nad kształtem edukacji młodego pokolenia. Naturalną bowiem jest chęć ucieleśnienia nowych idei, stąd działania na rzecz głośniejszego, a więc instytucjonalnego, grupowego artykułowania postulatów, będących wynikiem pierwotnego, naukowego namysłu. Środowiska opiniotwórcze, które propagują w mniejszym bądź większym zakresie uwzględnienie postulatów pedagogów w rzeczywistości edukacyjnej, reprezentowane są choćby przez cytowane w kolejnych rozdziałach instytucje: Radę do Spraw Informatyzacji Edukacji oraz Polską Radę Muzyczną, które podejmują działania w obydwu nakreślonych tu obszarach - pedeutologii oraz wychowania estetycznego. Poruszają więc problemy zarówno kompetencji nauczyciela, jak i zakresu włączenia nowych technologii do działań w ramach szkolnego przedmiotu muzyka. Dokumenty, będące narzędziami wpływania obydwu instytucji na politykę edukacyjną państwa, są przedmiotem analizy niniejszej pracy.

Tematyka badań miała także swe źródła w refleksji autora na temat rzeczywistości szkolnej, która streszczała się do konstatacji, iż nauczyciele muzyki unikają narzędzi informatycznych w swojej pracy, a niechęć ta ma swoje źródło w braku kompetencji informatycznych. W szczególności ów brak dotyczy zwykle jednego ze składników kompetencji - niejednolicie określanego w różnych źródłach jako świadomość, rozumienie czy też

\footnotetext{
${ }^{8}$ Ibidem, s. 98.
} 
pragnienie zastosowania wiedzy i umiejętności z zakresu technologii informacyjno-komunikacyjnej (TIK) ${ }^{9}$. Obserwacja ta wobec entuzjastycznego podejścia uczniów do narzędzi informatycznych, pozwalającego na zwiększenie ich motywacji do uczenia się, zainspirowała autora do poszukiwań przyczyn takiego stanu rzeczy.

Powyższe wnioski wynikają w dużej mierze z własnego doświadczenia pedagogicznego. W ciągu kilkunastu lat autor starał się wdrażać technologię informacyjną do dydaktyki przedmiotów muzycznych jako nauczyciel muzyki w gimnazjum ogólnokształcącym, nauczyciel teoretycznych przedmiotów muzycznych w szkole muzycznej (klasy IV-VI), czy w końcu wykładowca przedmiotów związanych z dydaktyką muzyki na kierunku pedagogicznym Uniwersytetu Łódzkiego. Brak powszechnie obowiązujących rozwiązań metodycznych w zakresie zastosowania TIK w dydaktyce muzyki zmusił również autora do refleksji teoretycznej na ten temat.

Wspomniane doświadczenia pedagogiczne wskazały z jednej strony na stosunek uczniów do narzędzi informatycznych stosowanych w dydaktyce muzyki (entuzjastyczny, stymulujący, inspirujący, pełny zaciekawienia), z drugiej zaś strony - na stosunek ogromnej większości nauczycieli (zdystansowany, niechętny, nieporadny, pełny obaw czy wręcz uprzedzeń ${ }^{10}$ ). Wyniki zagranicznych badań, potwierdzające pozytywny wpływ zastosowania TIK na chęć uczniów do podejmowania działań twórczych w muzy$\mathrm{ce}^{11}$, utwierdziły autora w swoich obserwacjach.

Wobec takich wniosków autor zdecydował się skonfrontować rzeczywisty stan kompetencji informatycznych nauczycieli muzyki ze stanem, który postulowany jest w dokumentach programowych, odnoszących się do sylwetki nauczyciela oraz studenta kierunku nauczycielskiego. W rozbieżności obu poziomów kompetencji - postulowanego i rzeczywistego - autor upatruje podstawową przyczynę niedostatecznego wykorzystywania TIK na lekcjach muzyki. Elementem diagnozy będą również warunki organizacyjne pracy placówki szkolnej, które mogą stanowić barierę dla najbardziej

\footnotetext{
${ }^{9}$ Szczegółowe omówienie składników kompetencji według różnych źródeł znajduje się w rozdziale 2.2. niniejszej pracy.

${ }^{10}$ Ciekawe badania nt. tzw. technostresu u nauczycieli przedstawia: Mohammed Al-Fudail, Harvey Mellar, Investigating teacher stress when using technology, „Computers \& Education” 2008, vol. 51, p. 1103-1110; [źródło:] http://www.sciencedirect.com/science/article/pii/S0360131507001352 (stan z dnia 07.03.2010).

${ }^{11}$ Por. np.: Pamela Burnard, Reframing creativity and technology: promoting pedagogic chance In music education, "Journal of Music, Technology and Education" 2007, vol. 1, No 1, p. 37-55; [źródło:] http://web.ebscohost. com/ehost/pdf?vid=14\&hid=5\&sid=4c30556c-8e13-4d37-b037-a838119ca049\%40sessionmgr110 (stan $\mathrm{z}$ dnia 07.03.2010).
} 
zmotywowanego nauczyciela. Zostaną zbadane takie przyczyny, jak: braki w wyposażeniu szkół w zakresie wystarczającej ilości stanowisk komputerowych czy przenośnych zestawów multimedialnych (laptop i rzutnik multimedialny), oprogramowania edukacyjnego oraz użytkowego, przydatnego w dydaktyce muzyki, organizacja planu zajęć szkolnych uniemożliwiająca korzystanie z pracowni informatycznej przez nauczyciela muzyki a także wpływ środowiska szkolnego (dyrekcja, inni nauczyciele, uczniowie) na chęć podwyższania poziomu swoich kompetencji.

Kluczowym więc pojęciem dla całej pracy jest pojęcie kompetencji. Oparciem dla rozważań na ten temat były przede wszystkim stanowiska Marii Czerepaniak-Walczak oraz Astrid Męczkowskiej, które najpełniej ujęły problem zakresu pojęcia kompetencji, w tym kompetencji nauczyciela.

Względy organizacyjne kazały ograniczyć badaną grupę nauczycieli. Ponieważ przedmiot muzyka realizowany jest w szkołach podstawowych (ponad 100 placówek na terenie Łodzi) oraz gimnazjach (blisko 100 placówek), zdecydowano się na objęcie badaniem wszystkich szkół jednego rodzaju dla uzyskania całościowego obrazu wybranej grupy. Wybór szkół podstawowych podyktowany był faktem, że ich zadaniem jest wprowadzenie ucznia w świat sztuki, który w tym wieku rzadko bywa skażony pozaformalnymi sposobami samorealizacji. Uczeń szkoły podstawowej nie jest jeszcze świadomym uczestnikiem kultury muzycznej ${ }^{12}$, stąd rola nauczyciela jako wskazującego drogi wykorzystania technologii informacyjno-komunikacyjnej jest tym ważniejsza, że posiada walor odkrywczości, pozbawiony jeszcze elementów konkurowania z wszechobecną technologią.

Do ustalenia rzeczywistego stanu kompetencji informatycznych nauczycieli posłużyła metoda sondażu diagnostycznego, w której wykorzystano wzory ankiet własnej konstrukcji, adresowane do wszystkich nauczycieli muzyki łódzkich szkół podstawowych oraz ich dyrektorów. Stan postulowany kompetencji informatycznych wywiedziono z dokumentów prawnych, określających pożądaną sylwetkę nauczyciela muzyki oraz dokumentów zawierających postulaty środowisk żywo zainteresowanych takimi regulacjami (Polska Rada Muzyczna oraz Rada do Spraw Informatyzacji Edukacji). Wyrazem praktycznej realizacji tak ustalonych postulatów są programy

\footnotetext{
${ }^{12}$ Por. cele kształcenia dla przedmiotu muzyka na 2 i 3 etapie kształcenia obowiązującej podstawy programowej: Rozporzadzenie Ministra Edukacji Narodowej z dnia 23 grudnia 2008 r. w sprawie podstawy programowej wychowania przedszkolnego oraz kształcenia ogólnego w poszczególnych typach szkót (Dz.U. Nr 4, poz. 17, z 15 stycznia 2009). Załącznik nr 2 - Podstawa programowa kształcenia ogólnego dla szkót podstawowych i gimnazjów.
} 
kształcenia kandydatów na nauczycieli muzyki, które również zostały przeanalizowane w odniesieniu do uczelni regionu łódzkiego.

Dla poznania innych, nieprzewidywalnych na wstępnym etapie badań przyczyn rozpatrywanej rozbieżności oraz przyjrzenia się motywacjom nauczycieli, czy też indywidualnym ścieżkom dochodzenia do decyzji o stosowaniu bądź unikaniu nowych technologii, zastosowano również badania jakościowe. W tej części posłużono się grupowym studium indywidualnych przypadków, którym objęto siedmioro nauczycieli, wyłonionych na podstawie wyrażonej zgody na przeprowadzenie wywiadu.

Celem bezpośrednim badań jest zatem ustalenie źródeł niedostatecznego wykorzystywania narzędzi informatycznych w dydaktyce muzyki, których istnienie autor spodziewa się znaleźć przede wszystkim w niedostatecznych kompetencjach informatycznych nauczycieli muzyki, a dokładniej w braku tego składnika kompetencji, który wiąże się z motywacją do odpowiedniego i odpowiedzialnego działania. Celem natury ogólniejszej jest natomiast zasygnalizowanie potrzeby poszukiwań płaszczyzny wspólnej dla wciąż odrębnych rzeczywistości: szkolnej i pozaszkolnej edukacji muzycznej, czy szerzej - edukacji estetycznej młodego człowieka. Duży potencjał w tym zakresie, drzemiący w nowoczesnych technologiach, stwarza bowiem coraz większe możliwości przede wszystkim w zakresie twórczym, tak eksponowanym w teorii wychowania estetycznego pod hasłem edukacji przez sztukę.

Tytułowa diagnoza rozbieżności może przyczynić się do poprawy sytuacji, wskazując obszary wymagające innego niż dotąd podejścia, innej perspektywy lub szczegółowych rozwiązań. Intencją autora jest ujęcie takiej diagnozy w kilku kontekstach. Kontekst pedeutologiczny dotyczyć będzie odmiennego rozmieszczenia akcentów w kształceniu przyszłych lub dokształcaniu obecnych nauczycieli tak, by w ich warsztacie mieściło się świadome i pozbawione obaw korzystanie z narzędzi informatycznych. Diagnoza w kontekście dydaktyki muzyki dotyczyć będzie takich rozwiązań, które angażując TIK są w stanie uatrakcyjnić proces poznawania muzyki klasycznej bądź ludowej, w większości pozostającej poza polem naturalnych zainteresowań młodzieży szkolnej.

Naturalnym rozwinięciem takiego ujęcia będzie kontekst dotyczący teorii wychowania estetycznego, u podstaw której leży kształtowanie kultury estetycznej wychowanka. Dramatyczny rozdźwięk między pozaszkolnym i szkolnym światem muzyki nie pozwala bowiem na ukształtowanie spójne- 
go systemu wartości. Próba zbliżenia obu światów choćby na płaszczyźnie jedynie narzędzi poznania lub tworzenia, jest cennym potencjałem drzemiącym w nowoczesnej choć bardzo dobrze znanej i przyjaznej „cyfrowemu tubylcowi” technologii.

Taką tendencję zbliżenia na gruncie współkreacji wykazują współczesne media, zachęcając do bardziej czynnego uczestnictwa odbiorców w kreowaniu kultury medialnej. „Era dotcomów się skończyła. Z jej prochów narodziła się era sieci społecznych [...] ludzie biorą media we własne ręce - prowadzą dialog z mediami masowymi, tworzą własne społeczności sieciowe, uczą się myśleć, pracować i przetwarzać kulturę na nowe sposoby”13.

$\mathrm{Na}$ strukturę pracy składają się trzy główne części. Część pierwsza, teoretyczna, obejmująca dwa początkowe rozdziały, koncentruje się na roli technologii informacyjno-komunikacyjnej we współczesnej pedagogice, ze specjalnym uwzględnieniem edukacji estetycznej, co każe również zastanowić się nad obecnością nowych mediów w sztuce. Prezentowane są tu stanowiska zarówno pedagogów jak i teoretyków sztuki (tu głównie Ryszarda W. Kluszczyńskiego) na temat udziału nowych mediów w obydwu rozpatrywanych obszarach. Drugi segment tej części pracy koncentruje się na pojęciu kompetencji informatycznych nauczyciela muzyki. Rozpatrywane tu jest kluczowe pojęcie dla całej pracy - kompetencje, oraz analizowane są dokumenty określające postulowany stan kompetencji informatycznych nauczycieli muzyki a także ich naturalne rozwinięcie, jakim są programy kształcenia kandydatów na nauczycieli muzyki w uczelniach regionu łódzkiego.

Kolejny rozdział pracy, trzeci, koncentruje się na metodologii badań, zarówno ilościowych jak i jakościowych. Oprócz przedmiotu badań, celów, metod, technik, narzędzi, omówiono również samą organizację badań.

Kolejny segment poświęcony jest prezentacji i analizie wyników badań (rozdziały 4. i 5.). Oprócz tytułowych przyczyn rozbieżności stanu rzeczywistego i postulowanego kompetencji informatycznych badanej grupy nauczycieli, zaprezentowano wyniki badań jakościowych, które pozwoliły na zidentyfikowanie motywacji nabywania kompetencji informatycznych oraz zauważenie specyficznego mechanizmu tego procesu. Tę część kończą wnioski i postulaty formułowane w kilku aspektach, w tym w formie praktycznych rozwiązań dydaktycznych, możliwych do zastosowania przez na-

\footnotetext{
${ }^{13} \mathrm{H}$. Jenkins, Kultura konwergencji. Zderzenie starych i nowych mediów, tłum. M. Bernatowicz, M. Filipiak, Warszawa 2007, s. VII.
} 
uczycieli muzyki, wzbraniających się do tej pory przed wykorzystywaniem narzędzi informatycznych w swojej pracy.

Taki praktyczny aspekt pracy pozwoli z jednej strony na uzupełnienie braków w dostępności podobnych wzorów rozwiązań, z drugiej zaś, może dostarczyć dodatkowych bodźców do działania tym z nauczycieli muzyki, którzy wciąż uważają technologię informacyjno-komunikacyjną za mało użyteczną dydaktycznie lub mało przyjazną dla nauczyciela-humanisty.

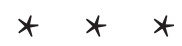

Niniejsza praca powstała w toku przewodu doktorskiego. Autor wykorzystał w niej wcześniej opublikowane, własne artykuły, dotyczące poruszanej tu tematyki. Te fragmentaryczne ujęcia teoretyczne, zebrane, rozszerzone i przedstawione tutaj jako integralna całość, można znaleźć m.in. w serii monografii wydawanych przez Uniwersytet Łódzki, pod redakcją Mirosławy Zalewskiej-Pawlak: Sztuka i wychowanie w dialogu polsko-włoskim (2005), Samotność oswojona przez sztukę. Pedagogiczne rozważania i doświadczenia (2007), Sztuka wobec zakresów wolności człowieka liberalnego. Pedagogiczne rozważania i doświadczenia (2009), Szkoła XXI wieku - szkoła edukacji estetycznej. Projekt nadziei (2011).

W tym miejscu chciałbym wyrazić swoją ogromną wdzięczność prof. Mirosławie Zalewskiej-Pawlak, która pełniąc funkcję promotora mojego przewodu doktorskiego, w dużym stopniu stała się współtwórcą kształtu niniejszej publikacji. Dziękuję za życzliwe podejście, przepełnione wartościami ważnymi zarówno w publikacjach, jak i w życiu Pani Profesor: podmiotowością, wolnością, odpowiedzialnością, spotkaniem i dialogiem. Bez nich, duchowy akt komunikacji nie byłby możliwy. 


\section{Technologia informacyjno-komunikacyjna w edukacji estetycznej}

\subsection{Pojęcie technologii informacyjno-komunikacyjnej (TIK)}

Problem zasygnalizowany w tytule niniejszego podrozdziału wymaga pewnego uporządkowania. Znajdujemy tu bowiem niekonsekwencję, odzwierciedlającą różnorodne podejście do problemu. Funkcjonują w literaturze często zamiennie takie określenia, jak: technologia informatyczna, technologia informacyjna czy technologia informacyjno-komunikacyjna ${ }^{1}$. Określenia te charakteryzują odmienne rozumienie sposobu rozłożenia akcentów m.in. w kształceniu przyszłych nauczycieli. Dokumenty dotyczące wymagań stawianych przed nauczycielem w zakresie TIK posługują się wszystkimi powyższymi określeniami.

Standardy przygotowania nauczycieli w zakresie technologii informacyjnej $i$ informaty $k^{2}$ już w samym tytule rozróżniają technologię informacyjną i informatykę jako rozdzielne zakresy kompetencji przyszłego nauczyciela. Mówiąc dalej o nauczycielu technologii informacyjnej³, autorzy wyjaśniają, że „To określenie nauczyciela jest związane z propozycją Rady zmiany nazwy przedmiotów informatyka w szkole podstawowej i w gimnazjum na technologia informacyjna, gdyż taki jest faktycznie zakres nauczania w ramach tych przedmiotów" 4 . Autorzy konsekwentnie stosują obydwa pojęcia: informatyka oraz technologia informacyjna w odniesieniu do odrębnie rozumianych przedmiotów szkolnych, podstaw programowych czy w końcu specjalności nauczyciela. Dokument nie przesądza o zakresie znaczeniowym obydwu pojęć, natomiast w przypisie 5. wyjaśnia, że „Termin technologia informacyjna (TI) w niektórych publikacjach występuje jako technologia informacyjna i komunikacyjna (TIK), zwłaszcza w kontekście stosowania tej technologii w poznawaniu innych dziedzin. Dalej posługujemy się określeniem technologia informacyjna, które obejmuje swoim za-

\footnotetext{
${ }^{1}$ Por.: A. Cichocki, Wymiary kompetencji informacyjno-medialnych nauczyciela, [w:] J. Izdebska (red.), Media elektroniczne $w$ życiu dziecka $w$ kontekście wartości wychowawczych oraz zagrożeń, Białystok 2008, s. 165.

${ }^{2}$ Rada ds. Edukacji Informatycznej i Medialnej, Standardy przygotowania nauczycieli w zakresie technologii informacyjnej i informatyki, Warszawa 2003.

${ }^{3}$ Ibidem, s. 1.

${ }^{4}$ Ibidem, s. 18, (przypis końcowy nr 2).
} 


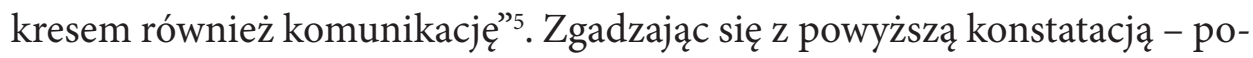
zyskanie bowiem informacji i jej wykorzystanie wymaga wpierw dotarcia do niej, a więc umiejętności komunikacji - zawęzimy nieco zakres terminologiczny omawianej problematyki i w niniejszej pracy stosować będziemy zamiennie terminy technologia informacyjna oraz technologia informacyjno-komunikacyjna, uważając je za znaczeniowo identyczne.

Próbę uporządkowania poruszanych tu pojęć podjął Stanisław Jusz$\mathrm{czyk}^{6}$, według którego technologia informatyczna (ang. informatics technology) obejmuje „całokształt działań technicznych związanych ze sposobami projektowania architektury oraz wytwarzania technicznych środków informatyki, np. układów scalonych, procesorów i komputerów oraz konstruowania oprogramowania systemowego, narzędziowego i użytkowego"7. Technologia informacyjna natomiast (ang. information technology) to „całokształt metod i narzędzi przetwarzania informacji, obejmujące metody poszukiwania i selekcji informacji, jej gromadzenia, zapisywania, przechowywania, przetwarzania, a wreszcie jej przesyłania lub usuwania”. Znajdujemy tu zatem wyraźne rozgraniczenie zagadnień związanych z projektowaniem i budową narzędzi informatycznych (sprzętu komputerowego oraz oprogramowania), określanych jako technologia informatyczna, oraz zagadnień związanych z pozyskiwaniem i zarządzaniem informacją, a określanych mianem technologia informacyjna.

Juszczyk kontynuując definiowanie interesujących nas pojęć stwierdza, że „wprowadzając do technologii informacyjnych zagadnienia związane z (tele)komunikacją otrzymujemy zintegrowane technologie informacyjno-komunikacyjne" i rozwija sformułowane przez W. Furmanka ${ }^{10}$ kluczowe umiejętności w zakresie technologii informacyjno-komunikacyjnych, do których mają należeć: „- efektywne korzystanie z narzędzi oferowanych przez technologie, - korzystanie z nowoczesnych środków gromadzenia i przetwarzania informacji, - skuteczne komunikowanie się w sposób pośredni z programem komputerowym przez urządzenia wejścia oraz pośrednie komunikowanie się z innymi użytkownikami systemu informacyjnego

\footnotetext{
${ }^{5}$ Ibidem, s. 18.

${ }^{6}$ S. Juszczyk, Edukacja na odległość. Kodyfikacja pojęć, reguł i procesów, Toruń 2002.

${ }^{7}$ Ibidem, s. 10.

${ }^{8}$ Ibidem, s. 10.

${ }^{9}$ Ibidem, s. 10-11.

${ }^{10}$ W. Furmanek, Kluczowe umiejętności technologii informacyjnych (eksplikacja pojęć), [w:] S. Juszczyk (red.), Edukacja medialna w społeczeństwie informacyjnym, Torun 2002, s. 123.
} 
z wykorzystaniem specjalnego oprogramowania użytkowego, - krytyczny odbiór informacji multimedialnych i ich wykorzystanie w procesie kształcenia lub pracy zawodowej, - umiejętność pracy w zespole, pracowanie na rzecz sukcesu zespołu oraz umiejętność prezentacji wytworów działania zespołu oraz - umiejętność samoprezentacji”"l. Zwraca uwagę ujawnione tutaj jedno ze znaczeń pojęcia komunikacja, które dotyczy komunikowania się z komputerem i tym samym jeszcze mocniej scala oba przymiotniki pojęcia technologii informacyjno-komunikacyjnej. Potwierdza to także słuszność decyzji Rady ds. Edukacji Informatycznej i Medialnej, dotyczącej zamiennego stosowania pojęć technologii informacyjnej oraz technologii informacyjno-komunikacyjnej.

Zatem już z samej terminologii wynika dylemat dla edukacji - w tym edukacji estetycznej - wspomaganej komputerowo: który z aspektów nowej technologii zasługuje na pierwszoplanowe potraktowanie: sztuka komunikacji czy może informatyczne aspekty samej technologii. A właściwie w jakich proporcjach oba te elementy uwzględnić w praktyce szkolnej. Od tych proporcji zależy bowiem, czy w technologii informacyjnej odnajdziemy ucieczkę od świata rzeczywistego, fascynację atrakcyjnym przedmiotem rozrywki, czy też odnajdziemy w niej radość kontaktu z drugim człowiekiem, możliwość nieskrępowanej wypowiedzi, twórczej manifestacji, artystycznej aktywności. Który z przymiotników dotyczących technologii wyeksponujemy: informatyczna, informacyjna czy komunikacyjna? W szystkie one bowiem winny być uwzględnione w zasobach kompetencyjnych nauczyciela, tworząc jedną, nierozdzielną dyspozycję. Wobec trudności ze znalezieniem wspólnego dla wszystkich aspektów określenia technologii, używać będziemy zamiennie wszystkich trzech wymienionych, różnicując ich zastosowanie kontekstem, wyróżniającym czasem techniczną (informatyczną), czasem informacyjną a czasem komunikacyjną stronę technologii.

\subsection{TIK wobec współczesnych problemów pedagogiki}

Rewolucja informatyczna bezpowrotnie zmieniła wizerunek człowieka, społeczeństwa, świata. Wąski wycinek tego świata, jakim jest proces dydaktyczny, czy szeroko pojęta pedagogika nie pozostał tu wyjątkiem. Zmienia się rola szkoły, nauczyciela, obraz jego pracy, zakres kompetencji, zmienia się również sposób pojmowania wiedzy. „Zmiany w dydaktyce współczes-

\footnotetext{
${ }^{11}$ S. Juszczyk, Edukacja na odległość..., s. 11-12.
} 
nej dokonują istotnych przewartościowań w sposobie podejścia do wiedzy. Wiedza staje się obecnie raczej zbiorem umiejętności (oraz informacji), stanowiących bazę dla mądrości, która jest ostatecznie wartością najwyższą"12. Nieograniczone możliwości gromadzenia tych informacji, jakie posiada dziś użytkownik internetu sprawia, że zdolność ich przefiltrowania, odrzucenia bezwartościowych, często błędnych źródeł, sama weryfikacja informacji, ich przydatności, staje się umiejętnością niezbędną i pierwszoplanową do zbudowania wiedzy. Dla pedagogiki sytuacja ta oznacza diametralną zmianę wizerunku nauczyciela - zmusza go do wyjścia z roli nieomylnego źródła informacji i zajęcia pozycji przewodnika i współodkrywcy. Jest to o tyle trudne, że nowe technologie są dla nauczyciela również nowe i najczęściej on sam cierpi na brak takiego kompetentnego przewodnika.

Technologia, jako narzędzie komunikacji i przetwarzania informacji, może generować niedostrzegalne dotąd zagrożenia dla różnych sfer funkcjonowania jej użytkownika. Mimo pozornego bezmiaru możliwości w zakresie przekazu informacji, czy niekontrolowanej swobody wyboru treści, zarówno odbieranych jak nadawanych, jednym z możliwych pól takiego zagrożenia jest wolność rozumiana co najmniej w aspekcie twórczym. $\mathrm{Na}$ ogólnym poziomie sformułował je już McLuhan w swoich słynnych zdaniach: „stajemy się tym, na co patrzymy” oraz „kształtujemy nasze narzędzia, a potem one kształtują nas". Zdania te odnoszą się do wzajemnych relacji między środkami komunikowania a podmiotami takiej komunikacji. Ten rzadko uświadamiany przez doświadczających go efekt zasadza się na wzajemnej interakcji, w której „najpierw ludzie modyfikują i kształtują narzędzia komunikacji, a potem zwrotnie one modyfikują i kształtują ich jako podmioty postrzegające i poznające świat oraz samych siebie"13. Czy nie musimy więc obawiać się zinformatyzowanego spojrzenia na kulturę? ${ }^{14}$ Spojrzenia, które skupia się na czytelnym, łatwym i szybkim wyniku działań - chociażby artystycznych - bez wnikania w skomplikowane algorytmy ich powstania: motywy, inspiracje, rozterki, przemyślenia twórcy. Czy nie chcąc obciążać umysłu zbyt wieloma obliczeniami i analizami nie będziemy oczekiwać od świata przede wszystkim przyjaznego interface’u? Na gruncie

${ }^{12}$ A. Cichocki, Wymiary kompetencji informacyjno-medialnych nauczyciela, [w:] J. Izdebska (red.), Media elektroniczne w życiu dziecka..., s. 165.

${ }^{13}$ I. S. Fiut, Media@ Internet. Szkice filozoficzno-medioznawcze z lat 2000-2006, Kraków 2006, s. 11.

${ }^{14}$ Z. Melosik nazywa kulturą upozorowania stan, w którym „rzeczywistość społeczna miesza się z medialną do granic nierozróżnialności” - Z. Melosik, Mass media, edukacja i przemiany kultury wspótczesnej, [w:] T. Lewowicki, B. Siemieniecki, Rola i miejsce technologii informacyjnej w okresie reform edukacyjnych $w$ Polsce, Toruń 2003, s. 44 . 
pedagogicznym, gdzie nowe narzędzia wydają się niezwykle interesujące, bardzo łatwo ulec takiej pokusie niezamierzonego spłycenia przekazywanych treści, skupiając się na atrakcyjnej formie przekazu.

Inne słynne zdanie, tym razem McKenzie Warka: „nie mamy już korzeni, mamy anteny", zwraca uwagę na rodzaj wynaturzenia wolności oferowanej przez technologię informacyjno-komunikacyjną, prowadzące do braku fundamentów własnej kultury. Ta swoista wolność „od” kultury wynikać ma bezpośrednio z funkcjonowania internetu, jako pola międzykulturowej wymiany myśli. Kluszczyński powołując się na to zdanie twierdzi, że „sieć buduje [...] nową, własną kulturę, wykorzystując w tym celu, wzorem bricoleura $^{15}$ Lévi-Straussa, fragmenty kultur zastanych. Ta nowa kultura internetu jest jednak pozbawiona organizującego ją od wewnątrz systemu. Nie ma też fundamentu wspólnych ideologii"16. Oczywiste jest, że kultura stworzona z tak wielu różnych, nieprzystających często do siebie elementów, nie może tworzyć spójnej konstrukcji, zdolnej do zakorzenienia systemu wartości. W tym należy upatrywać kolejnego zagrożenia, któremu próbuje się przeciwstawić chociażby poprzez eksponowanie pierwiastka regionalności w różnych przejawach życia społecznego: polityce, kulturze, pedagogice $i$ in.

Pedagogika nie funkcjonuje w oderwaniu od jakiejkolwiek płaszczyzny życia społeczności. Próbuje nadążyć również za rewolucyjnymi zmianami, wyznaczanymi przez nowe media elektroniczne. Problemem jednak jest bezwładność systemu edukacyjnego oraz samej praktyki pedagogicznej w połączeniu z niezwykłym tempem zmian zachodzących w samych mediach, jak i w świadomości ich użytkowników. Włączenie alfabetyzacji informatycznej do rodzimych programów nauczania zbiegło się z boomem na zakładanie firm internetowych oraz obsługującej je infrastruktury. Wyposażenie szkół w sprzęt komputerowy z dostępem do internetu działo się równolegle $\mathrm{z}$ końcem ery dotcomów ${ }^{17}$. Aktualna $\mathrm{w}$ dzisiejszej peda-

\footnotetext{
${ }^{15}$ Ktoś uprawiający bricolage - bricoleur, to ten, kto używa własnych rąk, posługując się środkami zastępczymi w porównaniu do zawodowców, jak pisze Lévi-Strauss. Posługuje się, innymi słowy, tym co ma na podorędziu, elementami „gotowymi”, istniejącymi zanim bricoleur zwróci na nie uwagę, chcąc przystosować do własnych celów (na gruncie np. sztuk plastycznych analogicznym działaniem byłby zapewne collage). [J. Żak-Bucholc, Bricolag Lévi-Straussa i dekonstrukcjonizm Derridy [2], www.racjonalista.pl/kk.php/s,2508/k,2 (stan $\mathrm{z}$ dnia 17.04.2008)].

${ }^{16}$ R. W. Kluszczyński, Net art - nowe terytorium sztuki, [w:] M. Hopfinger (red.), Nowe media w komunikacji społecznej w XX wieku. Antologia, Warszawa 2002, s. 428.

${ }^{17}$ Por.: H. Jenkins, Kultura konwergencji..., s. VII.
} 
gogice problematyka wykorzystywania sieci jako źródła informacji ${ }^{18}$, wraz z jej dobrodziejstwami i zagrożeniami, współegzystuje z nowym sposobem korzystania z mediów informatycznych, opartym na współuczestnictwie i współtworzeniu zamiast dotychczasowego biernego odbioru. Stan permanentnego zapóźnienia wydaje się nieuchronny, a wysiłki podejmowane przez kreatorów polityki edukacyjnej nie mają szans, by nadążyć za takim tempem zmian. Do tego zmian trudnych, czy wręcz niemożliwych do przewidzenia nawet przez wielkie korporacje zajmujące się rynkiem internetowym i informatycznym.

Tak jak programu nauczania nie można „wyposażyć” w relatywnie trwałe elementy, nie poddające się presji ciągłych zmian ekosystemu informatycznego, tak i kompetencje informatyczne nauczyciela nie mogą być pojmowane jako stały i niezmienny składnik jego warsztatu. Potrzeba elastyczności i szybkości reagowania, niezależnie od instytucjonalnie formułowanych postulatów i nakazów, jest w dziedzinie nowych mediów niezbędna i tak jest przedstawiana w licznych publikacjach ${ }^{19}$. Nie można bowiem uczyć o monitorach kineskopowych gdy uczniowie dysponują ekranami dotykowymi, nie można jedynie uczyć pozyskiwania informacji gdy uczniowie sami te informacje tworzą i publikują. Dzisiejszym wyzwaniem dla pedagogiki jest uświadomienie uczniom zasad współtworzenia a nie tylko korzystania z sieci, pamiętając, że „dzisiejsze” jest pojęciem wyjątkowo nietrwałym. Zadania na jutro nie są jeszcze znane, dlatego tak niezbędna jest elastyczność w samodzielnym reagowaniu pedagogów na nowe wyzwania, nie czekając na podpowiedzi i rozwiązania systemowe.

Narzędzia informatyczne w zadziwiająco łagodny sposób wpisały się i nadal wpisują w główne idee Nowego Wychowania. Indywidualny sposób korzystania z nich, podkreślony hipertekstualnością oraz brakiem cenzury, sprawiają, że poznawanie świata jest dla współczesnego ucznia „procesem samodzielnej eksploracji, a nie biernego przyswajania z góry narzuconych treści”20. „Akcentowanie samodzielności poznawczej, zainteresowań wychowanka, jego potrzeb, jak również psychologicznych różnic między

\footnotetext{
${ }^{18}$ Por.: zadania nauczyciela formułowane przez: B. Kędzierska, Informatyczne kształcenie i doskonalenie nauczycieli, Kraków 2005, s. 5.

${ }^{19}$ Por. np.: Morbitzer J. (red.), Techniki komputerowe w przekazie edukacyjnym, Kraków, 2002; [także:] Lewowicki T., Siemieniecki B. (red.), Media w edukacji - szanse i zagrożenia, Toruń, 2008; eadem, Rola i miejsce technologii informacyjnej w okresie reform edukacyjnych w Polsce, Toruń, 2003.

${ }^{20}$ S. Sztobryn, Pedagogika Nowego Wychowania, [w:] Z. Kwieciński, B. Śliwerski (red.), Pedagogika. Podręcznik akademicki, t. 1, Warszawa 2004, s. 286.
} 
ludźmi”21, poparte możliwościami twórczymi (programy komputerowe) i społecznymi (portale społecznościowe) to podstawowe atrybuty TIK, wzmacniane jeszcze przez atrakcyjność narzędzi, natychmiastowość efektów, możliwość opublikowania wyników swojej pracy i jej recenzji przez innych użytkowników. Coraz większa część wychowania przenosi się więc do przestrzeni wirtualnej i możemy mówić o Nowym Wirtualnym Wychowaniu. Jednak - niezależnie od stopnia utopijności zasad Nowego Wychowania - jego założenia dotyczyły szkoły, jako pola działań pedagogicznych. To pole współczesna szkoła traci i musi starać się o jego odzyskiwanie. Poznanie więc przez wychowawców środowiska wirtualnego wychowania jest niezbędnym i podstawowym zadaniem, tak, jak dzieje się to w marketingu: żeby zdobyć zaufanie klienta należy rozpoznać atuty konkurencji.

Kategoria wolności nie jest atrybutem współczesnej szkoły, dlatego tak atrakcyjne dla młodego człowieka są media informatyczne, tworzone i rozwijane na bazie wolności ze wszystkimi jej konsekwencjami. Takie narzędzia, jak „klucze” do oceny trafności wypowiedzi, testy z przedmiotów humanistycznych, czy tzw. „pytania pedagogiczne”22, stanowią skuteczną zaporę w rozwijaniu wyobraźni ucznia, osobowości twórczej, kreatywności, które współcześny uczeń odnajduje poza szkołą.

Współczesna pedagogika rozstrzygnęła już dylemat, czy należy wykorzystywać nowoczesne narzędzia informatyczne. „Nauczyciele, zorientowani w swej dotychczasowej pracy przede wszystkim na słowo, będą musieli uznać, że w nowej cywilizacji najważniejszym czynnikiem kulturotwórczym staje się informacja przetworzona w grafikę i obraz na ekranie kompute-

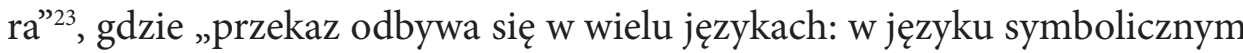
(komunikaty słowne i graficzne), w języku obrazów wizualnych, słuchowych i audiowizualnych, a także w języku działań, dzięki stosowaniu mediów działaniowych i interaktywnych" ${ }^{24}$. Aktualnym dylematem są jedynie sposoby wykorzystania nowych możliwości, ich praktyczna realizacja. Jeśli edukacja dotycząca technologii informacyjnych, wsparta edukacją estetyczną, wskażą młodemu człowiekowi przykłady kreatywnych zastosowań tego narzędzia, pobudzi w nim twórczą motywację, media elektroniczne staną

\footnotetext{
${ }^{21}$ Ibidem, s. 287.

${ }^{22}$ H. Depta, O wychowanie estetyczne na miarę naszych czasów, [w:] K. Pankowska (red.), Sztuka i wychowanie..., s. 34 .

${ }^{23}$ A. Cichocki, Wymiary kompetencji..., s. 161.

${ }^{24}$ W. Strykowski, Rola mediów i edukacji medialnej we współczesnym społeczeństwie, „Chowanna” 2003, tom 1 (20), s. 116-117; [źródło:] http://chowanna.us.edu.pl/vol/ch20.pdf (stan z dnia 9.10.2010).
} 
się sprzymierzeńcem w samorealizacji i rozwoju - w tym rozwoju społecznym, intelektualnym i emocjonalnym. Te trzy niewzruszone filary procesu wychowania nie mogą pozostać ślepe na wszechobecny proces zmian cywilizacyjnych, prowadzących do powszechnej informatyzacji, wraz z jej dobrodziejstwami jak i zagrożeniami.

\subsection{TIK jako narzędzie wypowiedzi artystycznej}

Wraz z powstaniem net-artu diametralnie zmieniła się sytuacja ontologiczna sztuki. Nowa struktura dzieła sztuki i jego podstawowa cecha hipermedialność - zmieniła nie tylko zakres pojęcia aktu twórczego, ale w konsekwencji zburzyła jasną do tej pory granicę między twórcą a odbiorcą nowego dzieła.

Tą nową formę aktywności artystycznej Kluszczyński określa jako hipermedialne dzieło interaktywne. Interaktywność oznacza zerwanie $\mathrm{z}$ dotychczasowym, jednokierunkowym przekazem od nadawcy (twórcy) do odbiorcy i pozwala na działanie zwrotne, które determinuje kolejne reakcje nadawcy. „Piano as an Image Media [Fortepian jako medium wizualne - instalacja Toshia Iwai, 1995] jest klasycznym przykładem interaktywnego dzieła-instrumentu, na którym odbiorca komponuje i wykonuje zarazem własne dzieło [audiowizualne]"25. Hipermedialność polega natomiast na nielinearnej konstrukcji dzieła, która na wzór internetowego sposobu nawigacji poprzez hipertekst (czyli linki lub odsyłacze), pozwala na dowolny (a więc indywidualny) kierunek poznawania dzieła, dowolny poziom jego zrozumienia. „Dzieło takie - pisze Kluszczyński - istnieje w postaci audiowizualnego, multimedialnego hipertekstu: formy złożonej, wielowarstwowej i oczekującej na naszą interwencję[...] Hipertekst natomiast, wielopoziomowa i wieloelementowa struktura, nie determinuje ani też nie uprzywilejowuje żadnego kierunku percepcji (i odpowiednio: rozumienia)"26.

Kluszczyński wyróżnia trzy poziomy strukturalne sztuki komputerowej $^{27}$. Poziom hardware czyli sprzętowy - jego odpowiednikiem w sztuce tradycyjnej jest ludzki umysł w sensie materialnym, fizycznym. Drugi po-

\footnotetext{
${ }^{25}$ R. W. Kluszczyński, Sztuka multimediów, [w:] M. Hopfinger (red.), Nowe media w komunikacji społecznej w XX wieku. Antologia, Warszawa 2002, s. 506.

${ }^{26}$ R. W. Kluszczyński, Net art - nowe terytorium sztuki, [w:] M. Hopfinger (red.), Nowe media..., s. 420.

${ }^{27}$ R. W. Kluszczyński, Sztuka multimediów..., s. 507-508.
} 
ziom to software czyli oprogramowanie, system algorytmów przetwarzających informacje - należałoby go utożsamić z całokształtem doświadczenia i wiedzy, jaką człowiek dysponuje w zakresie konkretnej dziedziny, np. muzyki. Ostatni z poziomów to tzw. artware, na który składają się estetyczne wybory zarówno twórcy jak i odbiorcy. Poziom software’owy jest właśnie tym, który pozwala wypełnić lukę w wiedzy użytkownika i zastąpić ją np. muzycznym doświadczeniem twórcy oprogramowania. Zakres takiego elektronicznego ekwiwalentu jest oczywiście daleko mniejszy od doświadczenia „żywego" kompozytora i pozwala użytkownikowi jedynie na dokonanie estetycznych wyborów z gotowych elementów, zaproponowanych przez twórcę. Mimo tych ograniczeń, pozwala odbiorcy na doświadczenie wcześniej dla niego niedostępne - tworzenia muzyki. Przynajmniej namiastki tworzenia... Pozostaje tylko podsunąć odpowiednie narzędzie, aby potencjalny użytkownik zechciał poznać i poczuć ten rodzaj wolności tworzenia.

Nielinearność konstrukcji artystycznej oparta na hipertekstualności, stawia również odbiorcę przed dylematem: w jaki sposób odczytywać tak zbudowane dzieło. I nie jest to tradycyjny dylemat wieloznaczności przekazu artystycznego, o którym pisał Umberto Eco, postulując uznanie odbiorcy dzieła za ostatecznego jego współtwórcę, przypisującego dziełu subiektywne znaczenie, a więc nadającemu mu ostateczny kształt. Nowy dylemat nobilituje odbiór dzieła do procesu tworzenia jego formalnego obrazu: jak skonstruować przekaz z elementów, które dostarczył twórca, lub - bardziej technologicznie - jak nawigować pomiędzy obiektami hipertekstu. Według Kluszczyńskiego „suma tych wszystkich wyborów wyznacza dzieło - wspólny wytwór artysty ([który] dostarczył tworzywa oraz reguł wyboru i konstrukcji) i odbiorcy ([który] dokonał selekcji tworzywa, określił przebieg procesu odbiorczego oraz stworzył strukturę dzieła - obiektu percepcji)”28. „Stawanie się dzieła” czyli nawigacja też jest aktem twórczym i konstrukcyjnym elementem dzieła sztuki.

W przypadku muzyki rola nawigatora bardzo bliska jest roli, jaką do tej pory pełnił odtwórca, nadając utworowi muzycznemu - w pewnych wąsko zakreślonych estetycznych granicach - ostateczny kształt, zgodny z własnymi wyborami artystycznymi. Sprawę jeszcze bardziej komplikuje problem odtwórcy zbiorowego (orkiestra, zespół aktorski, ekipa filmowa), wśród

\footnotetext{
${ }^{28}$ R. W. Kluszczyński, Film, wideo, multimedia. Sztuka ruchomego obrazu w erze elektronicznej, Warszawa 1999, s. 32.
} 
których należy wyróżnić najważniejszego interpretatora (dyrygenta, reżysera), narzucającego swoją koncepcję pozostałym. Każde z ogniw tworzenia dzieła ma tu swój zakres wolności: wypowiedzi, interpretacji, konstruowania i przypisywania znaczenia. Każdy z odtwórców jest na poły twórcą i odbiorcą.

Hipermedialne dzieło interaktywne pozwala na zawężenie kręgu współtwórców i współodbiorców do zaledwie dwóch podmiotów: twórczego artysty oraz współtworzącego odbiorcy. Taka dysproporcja w ilości podmiotów, realizujących dzieło muzyczne oraz interaktywne dzieło sztuki hipermedialnej, istnieje mimo strukturalnego podobieństwa obu dziedzin wypowiedzi artystycznej. Obie bowiem pozbawione są aspektu materialnego. W pierwszym przypadku tworzywem są dźwięki składające się na harmonię, w drugim - obiekty multimedialne, tworzące wirtualną rzeczywistość.

Wyparcie roli odtwórcy w sztuce hipermedialnej stało się możliwe dzięki zastosowaniu technologii informacyjno-komunikacyjnej, ale technologia nie mogła przecież przejąć atrybutów twórczych, stąd całkiem naturalne stało się przejęcie ich przez odbiorcę. Twórczego odbiorcę. Kluszczyński twierdzi, że to „rozwój technologiczny [...] wspomógł kształtowanie się nowych tendencji i idei artystycznych zmierzających ku dematerializacji sztuki oraz do przekształcenia odbiorcy w twórczego uczestnika procesów artystycznych (interaktora)"29. Ta inna, zaangażowana rola odbiorcy współtworzącego, każe wnioskować, że to technologia wywalczyła dla odbiorcy nowy, ogromny obszar wolności. Jest to - jak twierdzi Jay David Bolter „oczywisty podział pracy, polegający na tym, by pozwolić komputerowi robić to, co może on robić dobrze, a ludziom pozwolić interweniować tam, gdzie wymagane są ich uzdolnienia" ${ }^{30}$.

Cyberkulturę zatem może dzisiaj wzbogacić niemal każdy, przyjmując rolę twórczego odbiorcy. To jednak prowadzić może do wypaczonego poczucia wolności, czyli anarchii, mimo leżących u podstaw takiego działania szlachetnych idei równości, możliwości nieskrępowanego rozwoju i zużytkowania własnych talentów.

O tych szlachetnych ideach wolności, rozumianej jako możliwość współuczestnictwa w globalnej kulturze, podkreślających konieczność ale i nieuchronność dzielenia się wspólnym dorobkiem, pisał Witkacy: „Dusz

\footnotetext{
${ }^{29}$ R. W. Kluszczyński, Net art..., s. 417.

${ }^{30}$ J. D. Bolter, Komputer: maszyna i narzędzie, [w:] M. Hopfinger (red.), Nowe media..., s. 361.
} 
ludzkich nie należy zacieśniać, nie należy z nich robić rozważnych skąpców, zazdrosnych o współużycie skarbów, które się mimo ich woli gromadzą. Współudział w całej sumie kultury wszystkich jest krańcowym punktem dążeń rozwoju społecznego"31.

Innym aspektem wolności wynikającej z technologii jest opisane przez McLuhana zjawisko wyzwolenia od kultury druku. To kontrowersyjne stwierdzenie zasadza się na dostrzeżeniu jednowymiarowości narzuconej nam przez Gutenberga, każącego w wielkim stopniu, bezzasadnie uprzywilejować tylko jeden ze zmysłów - wzrok. Ta dominacja zubożyła nasze rozumienie świata oraz wyobraźnię, która w swej pierwotnej - a więc naturalnej - formie, karmiona była wielozmysłowo. Pisał McLuhan: „Zburzenie równowagi między zmysłami prowadzi do utraty «wyobraźni» pojmowanej jako stan boskiej wręcz równowagi między ludzkimi zmysłami, stan występujący wówczas, gdy żaden ze zmysłów nie zyskał przewagi dzięki technice materialnej. Zniewolenie wzroku przez technikę druku oddaje ludzką duszę we władanie «rozumu», który niszczy «wyobraźnię», ów bardziej pierwotny i autentyczny status egzystencji”'32.

W tym kontekście technologię informacyjno-komunikacyjną należy rozumieć jako szansę powrotu do naturalnego sposobu odbioru świata. „Człowiek nowej kultury elektronicznej może odzyskać «pełne pole egzystencji», utracone wskutek wielowiekowej dominacji druku, czyli «oka zamiast ucha»"33. Szansą rozwoju zatem, która drzemie w technologii przyszłości jest przewrotnie powrót do archaicznego sposobu doświadczania świata. Pojęcie globalnej wioski nie ma - według słów McLuhana - monosensorycznego wymiaru. To jeszcze inny rodzaj wolności, którą zawdzięczamy technologii.

\subsection{Rola TIK we współczesnej dydaktyce przedmiotów estetycznych}

Sztuka, będąca przedmiotem edukacji estetycznej, w obecnych czasach nie jest już ani synonimem piękna, ani też przestrzenią zarezerwowaną dla nielicznych wybrańców. Sztuka jest dziś swobodną wypowiedzią, towarem, przekazem, oprawą tego przekazu, medium, hobby, manifestacją własnych

\footnotetext{
${ }^{31}$ S. Witkiewicz, Dziwny człowiek, Lwów 1903, [za:] M. Hopfinger, Technika przyszłości, [w:] idem (red.), Nowe media..., s. 355.

${ }^{32}$ M. McLuhan, Galaktyka Gutenberga, [w:] idem, Wybór pism, tłum. K. Jakubowicz, Warszawa 1975, s. 281-300; [za:] Z. Suszczyński, Hipertekst a "galaktyka Gutenberga", [w:] M. Hopfinger, Nowe media..., s. 522.

${ }^{33}$ Z. Suszczyński, Hipertekst..., s. 524.
} 
poglądów, zainteresowań, wartości, czy choćby działaniem terapeutycznym. Sztuka bardzo spowszedniała nie tylko przez lawinowy wzrost kanałów medialnych udostępniających ją, ale także dlatego, że granice jej uległy ogromnemu poszerzeniu zarówno ontologicznie (wszerz) jak i aksjologicznie (tu niestety w dół). Rynek i showbusiness sprawiły, że miarą sztuki stał się sukces komercyjny - wartości artystyczne zejść musiały na plan dalszy.

Dwie cechy zatem opisują dzisiejszy status sztuki: powszechność (zarówno w odbiorze jak i możliwościach jej uprawiania) oraz jej inflacja. Obie cechy są ściśle ze sobą sprzężone i nawzajem się stymulują. Obie nie są jednoznacznie pozytywne ani jednoznacznie negatywne. Implikują jedynie konieczność funkcjonowania kompetentnego przewodnika po aksjologicznym świecie sztuki, którym na gruncie edukacji instytucjonalnej jest nauczyciel przedmiotów estetycznych: muzyk, plastyk. Ma on za zadanie ukształtować nie tylko świadomego odbiorcę sztuki, ale urzeczywistniając idee Herberta Reada, Bogdana Suchodolskiego czy Ireny Wojnar - wprowadzić wychowanka w świat czynnego współtworzenia kultury. Instytucja przewodnika jest tu jednak specyficznie traktowana, bowiem jak pisze Henryk Depta „zasadnicza, głęboko wychowawcza wartość sztuki zawarta jest nie tyle w udzielanych odpowiedziach, ile w stawianych przez nią pytaniach. Pytaniach otwartych”34, które „sprzyjają zarówno poznawczej, jak i moralnej aktywności odbiorcy" ${ }^{35}$. Zatem działanie takiego przewodnika to przede wszystkim zachęta do aktywnego odbioru sztuki oraz prowokowanie do działania twórczego, opartego na zasadach wolności budowania dialogu z dziełem sztuki, bo „to właśnie on, odbiorca - każdy na swój sposób - coronat opus (wieńczy dzieło)"36.

Obie omawiane cechy sytuacji, w jakiej znalazła się sztuka - a więc jej powszechność oraz „aksjologiczny chaos” pozwalający na współistnienie wartościowego przekazu obok tandety i kiczu jest charakterystyczny dla zasobów światowej sieci internetowej - najbardziej demokratycznego współczesnego medium - wraz z jej oprzyrządowaniem, czyli technologią informacyjno-komunikacyjną. Naturalnym zatem wydaje się nie przeciwstawianie sobie obu sposobów komunikacji - sztuki i technologii - ale ich harmonijne połączenie w kontekście pedagogicznym a szczególnie w edukacji estetycznej.

\footnotetext{
${ }^{34} \mathrm{H}$. Depta, O wychowanie estetyczne na miarę naszych czasów, s. 34.

${ }^{35}$ Ibidem, s. 35.

${ }^{36}$ Ibidem, s. 35 .
} 
Jest więc pewna płaszczyzna wspólna dla technologii informacyjno-komunikacyjnej i edukacji. Chcąc jednak zawęzić pojęcie edukacji wyłącznie do edukacji estetycznej, należy najpierw dostrzec elementy wspólne obszarów omawianej technologii oraz sztuki. Pierwszym skojarzeniem przy tak postawionym problemie jest oczywiście sztuka multimedialna oraz sztuka sieci (tzw. net art lub Web art ${ }^{37}$ ). Mamy tu jednak do czynienia z prostym połączeniem dwóch niekoniecznie spójnych światów, co zatem nie musi świadczyć o istnieniu wspólnych elementów obu dziedzin, tym bardziej, że ewentualny brak takiej spójności mógłby uchodzić za jeden ze środków artystycznej ekspresji. W spólnymi elementami są natomiast np.: odwzorowywanie świata rzeczywistego (gdzie wizja artystyczna jest odpowiednikiem świata wirtualnego), czy też ideowe dążenie do dialogu (w którym medium jest albo technologia albo dzieło sztuki). Już z tych dwóch cech można próbować stworzyć bardzo ogólną definicję, wspólną zarówno dla pojęcia technologii informacyjno-komunikacyjnej jak i sztuki. Mogłaby ona sprowadzać się do: formy dialogu na temat jakiegoś wycinka rzeczywistości. Dialogu asynchronicznego, bo nie prowadzonego w czasie rzeczywistym.

Kwintesencją przedmiotów estetycznych jest prowokowanie do działań twórczych. Narzędzia informatyczne dają taką szansę bądź w postaci kreatywnego wykorzystania programów komputerowych, bądź w twórczym odbiorze nowoczesnego dzieła sztuki, opartego na interaktywnej i hipertekstualnej współkreacji ${ }^{38}$. M. Grusiewicz, porównując komputer do instrumentu - wzorem idei Carla Orffa - dostępnego dla każdego, opisuje niewykorzystany przez szkołę twórczy potencjał narzędzi informatycznych: „Nie spotkałem do tej pory szkoły, która wprowadzałaby elementy twórczości z wykorzystaniem programów komputerowych. Tymczasem młodzież dość powszechnie wykorzystuje te programy na własny użytek. Tworzy ona muzykę w określonym stylu i rozprowadza ją przez strony internetowe"39. Trudno takie cele osiągnąć wykorzystując jedynie elektroniczne wersje encyklopedii czy słowników. Opisywana przez Grusiewicza sytuacja definiuje

${ }^{37}$ Obydwa pojęcia definiuje Ryszard Kluszczyński [w:] R. W. Kluszczyński, Społeczeństwo informacyjne. Cyberkultura. Sztuka multimediów, Kraków 2002, s. 132-134.

${ }^{38}$ Dobrym przykładem twórczego wykorzystania TIK jest opisane przez Jima Vennemeyera własne doświadczenie w zastosowaniu komputerów i instrumentów MIDI do prób kompozytorskich uczniów, który nazywa połączeniem technik Orffa z technologią komputerową: J. Vennemeyer, Orff + technology = composition for Kids, „Teaching Music” [serial online], June 1999; 6(6):36. Available from: Academic Search Complete, Ipswich, MA. Accessed March 16, 2010.

${ }^{39} \mathrm{M}$. Grusiewicz, Twórczość muzyczna młodzieży z wykorzystaniem programów komputerowych - zarys problemu, [w:] L. Kataryńczuk-Mania, J. Karcz (red.), Edukacja artystyczna wobec przemian społeczno-oświatowych, Zielona Góra 2002, s. 171. 
różnicę, jaka dzieli polską i choćby amerykańską rzeczywistość edukacyjną, dotyczącą sposobów wykorzystania TI na lekcji muzyki ${ }^{40}$. Opisy takich obcych polskiej szkole rozwiązań, publikowane przez Music Teachers National Association, służą amerykańskim nauczycielom muzyki, nie narażając ich na błądzenie i szukanie rozwiązań już wypróbowanych ${ }^{41}$. Taka baza doświadczeń oraz bogata baza sprzętowa pozwala na powszechne wykorzystywanie TI do tworzenia muzyki, a nie tylko informowania o niej. Popularne opracowania metodyczne opisują rozwiązania bazujące na pracowni informatycznej wzbogaconej o instrumenty midi i komercyjne oprogramowanie oraz wpisujące się w narodowe standardy kształcenia muzycznego ${ }^{42}$. Stąd rodzime rozwiązania nie mają możliwości bezpośredniego czerpania z obcych doświadczeń. Takie różnice - wzorców, sprzętu, rozwiązań systemowych - zapewne jeszcze długo pozostaną podstawową przyczyną opisywanego przez Grusiewicza spostrzeżenia.

Wracając do początkowych uwag na temat współczesnej sztuki - dzieło, które prowokuje do współtworzenia jest dla edukacji estetycznej nieocenioną pomocą. A jeśli przy tym każe korzystać $\mathrm{z}$ atrakcyjnego dla dziecka i znanego mu narzędzia, efekt w postaci zainteresowania tworzeniem będzie zwielokrotniony.

Niewątpliwie rozwój nowych form sztuki (szczególnie audiowizualnych) wykorzystujących techniki komputerowe sprawia, że komputer powoli staje się niezbędny w uprawianiu sztuki ${ }^{43}$, a przynajmniej do tego zachęca, czy wręcz prowokuje. „Ludzie korzystają z sieci po to, aby współuczestniczyć i tworzyć, a nie po to, aby biernie otrzymywać informacje. Infostrada to błędna nazwa. Nie chodzi tu o informację, ale o społeczność, współudział i kreację" ${ }^{44}$. To, że technika nie zastąpi kontaktu twórcy z takim materiałem jak glina, farba, płótno itp. nie oznacza dyskwalifikacji tego narzędzia. „Niematerialność materii tworzenia” jest przecież równie charakterystyczna dla

\footnotetext{
${ }^{40}$ Por. także: M. Grusiewicz, Komputer w edukacji muzycznej - konieczność, zagrożenie czy nadzieja?, [w:] J. Morbitzer (red.), Komputer w Edukacji. 14. Ogólnopolskie sympozjum naukowe, Kraków 2004.

${ }^{41}$ Por. np.: Shana Kirk, Do Music Teachers Have a Responsibility to Teach with Technology?, „American Music Teacher" 2006, August/September, p. 72-73; [źródło:] http://web.ebscohost.com/ehost/pdf?vid=6\&hid=106\&si$\mathrm{d}=4 \mathrm{c} 30556 \mathrm{c}-8 \mathrm{e} 13-4 \mathrm{~d} 37-\mathrm{b} 037-\mathrm{a} 838119 \mathrm{ca} 049 \% 40$ sessionmgr110 (stan z dnia 06.03.2010).

${ }^{42}$ Por.: Thomas E. Rudolph, Teaching Music with Technology, Chicago 2004; [źródło:] http://books.google. $\mathrm{pl} /$ books?id=OnPnMsWOkVAC (stan $\mathrm{z}$ dnia 20.02.2012).

${ }^{43}$ Por.: M. Jackowski, Podmiotowość w nauczaniu sztuki w globalnym społeczeństwie informacyjnym, http:// jjk.nazwa.pl/ensil/index.php?option=com_weblinks\&task=view\&catid=123\&id=47 (stan z dnia 11.11.2004).

${ }^{44}$ A. Bruckman, Cyberspace is not a Disneyland: The Role of the Artist In a Networked Word, http://www. ahip.getty.edu/cyberpub/bruckman.html, stan z 1995 r.; [za:] D. Romanowska, Sieć sztuki, [w:] W. Godzic, A. Bednarz (red.), Humanista w cyberprzestrzeni, Rabid, Kraków 1999, s. 140.
} 
muzyki czy poezji. Należy także zauważyć, że istniejący w technice komputerowej potencjał jest w stanie zaspokoić ekspresję twórczą, mało tego - specyfika tego narzędzia sprawia, że niektóre formy aktywności twórczej są niemożliwe do realizacji bez technologii komputerowej. Jeśli więc wychowanie przez sztukę - jak postulowali H. Read, a w Polsce B. Suchodolski i I. Wojnar - ma obejmować wszystkie dziedziny sztuki, zarówno w aspekcie odbioru jak i ekspresji twórczej, to wydaje się niemożliwe spełnienie tego postulatu bez twórczego wykorzystania możliwości drzemiących w technologii komputerowej. Zatem wychowanie przez sztukę bez udziału technologii informacyjno-komunikacyjnych wydaje się być obecnie niemożliwe, a przynajmniej znacznie zubożone.

Sieć (internet) spełniać może dwojaką rolę w edukacji (w tym edukacji estetycznej). Po pierwsze jest medium, za pośrednictwem którego możliwy jest kontakt zarówno z prowadzącym zajęcia (kurs, wykład, warsztat itp.), z resztą grupy uczestniczącej w zajęciach, jak i z dowolnymi użytkownikami sieci o podobnych zainteresowaniach (w tym ekspertami i mistrzami). Po drugie zaś, internet jest nieprzebranym źródłem wiedzy, opracowań analitycznych i syntetycznych, materiałów edukacyjnych, zasobów źródłowych, prezentacji multimedialnych i innych. Obie te role zdają się spełniać triadę postulatów S. Szumana o udostępnianiu, uprzystępnianiu i upowszechnianiu sztuki ${ }^{45}$, lub szerzej - wiedzy. Czy jednak samo wychowanie do sztuki wyczerpuje zakres możliwości oddziaływań technologii informacyjno-komunikacyjnej na jednostkę? Czy możliwe jest działanie twórcze za pośrednictwem komputera, internetu? Czy zatem wychowanie przez sztukę może odbywać się za pośrednictwem i z pomocą wyżej wspomnianych narzędzi?

Oczywiście rzeczywistość pokazuje, że jest to możliwe. Dowodzą tego nowe formy sztuki, w tym sztuki hipermedialnej, czy hipertekstualnej. Nową wartością takiego dzieła jest uświadamianie odbiorcy jego wolności we współtworzeniu, a przez to zachęcanie go do samodzielnej kreacji, motywowanie do działania artystycznego. Ten potencjał dostrzega Kluszczyński, pisząc: „Dzieło hipermedialne zyskuje również na wartości wówczas, kiedy zachowania interaktywne są motywowane pragnieniem dążenia ku nieznanemu, kiedy formują rozwijające się doświadczenie" ${ }^{36}$. Technologia informacyjno-komunikacyjna jest w stanie u wielu jej użytkowników taką motywację wyzwolić, niezależnie od jej źródeł. Jeśli jest to tylko fascyna-

\footnotetext{
${ }^{45}$ S. Szuman, O sztuce i wychowaniu estetycznym, Warszawa 1969, s. 108-119.

${ }^{46}$ R. W. Kluszczyński, Sztuka multimediów, s. 511.
} 
cja narzędziem, czy oszołomienie wywołane ogromem nieznanych dotąd efektów i możliwości, to cel, jakim jest zmotywowanie do działań artystycznych, jest w stanie „rozgrzeszyć” nikłość motywów takich działań. „Udostępniając skomplikowaną technikę w uproszczonej formie, komputer sprzyja nowemu rodzajowi amatorstwa. [ponieważ] System komputerowy ma charakter wielopoziomowy" ${ }^{47}$.

Tę zaletę dostrzega zarówno zachodnioeuropejska jak i amerykańska praktyka pedagogiczna, formułując jednocześnie pełne obaw dylematy, charakterystyczne dla sytuacji, w której twórcze działania ucznia, wsparte nowoczesną technologią, pozwalają na niebezpiecznie mało świadome zbliżenie się do efektu pozornego profesjonalizmu ${ }^{48}$. Ten rodzaj twórczej wolności wymaga pielęgnowania dominacji człowieka nad narzędziem. Zbyt łatwo bowiem ulec pokusie oddania kompetencji twórczych komputerowym algorytmom, którym do wykreowania przypadkowego „dzieła sztuki” wystarcza skompletowanie losowo wybranych elementów ${ }^{49}$. Uruchamianie takich procesów nie ma już nic wspólnego z pojęciem twórczej wolności. Przestrzega przed tym Jay David Bolter, pisząc: „Komputer jest z jednej strony maszyną wywodzącą się z mechaniczno-dynamicznej tradycji Zachodu, z drugiej zaś - ręcznym narzędziem ze starożytnej tradycji rzemieślniczej. By inspirować twórcze wykorzystanie komputerów, najlepszym sposobem jest eksponowanie owego drugiego dziedzictwa przed pierwszym, narzędzia przed maszyną"50. Taka forma współegzystencji pozwala na rodzaj sprzężenia zwrotnego między wyobraźnią twórcy a technologicznym narzędziem. Przy pierwszym kontakcie to wyobraźnia pobudzona zostaje nowymi możliwościami, ta jednak, po pewnym czasie zaczyna wykraczać poza granice świeżo poznanego narzędzia i artykułuje nowe potrzeby w zakresie realizacji swych potrzeb twórczych. Taki samonapędzający się mechanizm zapewnia nieustanny rozwój tak technologicznych rozwiązań, jak i artystycznych form wyrazu.

Trzeba jednak odróżnić zastosowanie technik komputerowych jako narzędzia sztuki w działaniach edukacyjnych i jako narzędzia edukacji w dzia-

\footnotetext{
${ }^{47}$ J. D. Bolter, Komputer: maszyna i narzędzie, [w:] M. Hopfinger (red.), Nowe media..., s. 363.

${ }^{48}$ Por: Crow B., Musical creativity and the new technology, "Music Education Research" [serial online]. March 2006, 8 (1), p. 122-123. Available from: Academic Search Complete, Ipswich, MA. Accessed March 14, 2010.

${ }^{49}$ Tego rodzaju obawy formułuje raport: Edexel (2003), Examiners' reports - GCSE Music (1426), London, Edexel, [za:] Crow B., Musical creativity..., op. cit.; p. 122; [GCSE - General Certificate of Secondary Education - przyp. autora].

${ }^{50}$ J. D. Bolter, Komputer: maszyna i narzędzie, s. 360.
} 
łaniach twórczych. O ile pierwsze dotyczy włączenia działań artystycznych z udziałem komputera do programów nauczania i wydaje się być oczywiste, to drugie z zastosowań budzi wiele wątpliwości co do zakresu udziału technik informacyjno-komunikacyjnych w procesie dydaktycznym. Skrajną postacią takiego podejścia jest tzw. e-learning czyli zdalny proces nauczania-uczenia się za pomocą internetu (bądź intranetu).

Taka forma kształcenia nie jest czymś zupełnie nowym. Nowością byłaby natomiast próba realizacji tą drogą przedmiotów estetycznych. Kim miałby być adresat takiego kształcenia? W naszym systemie edukacyjnym przedmioty estetyczne umieszczone są w programie nauczania szkoły podstawowej (wychowanie muzyczne i plastyczne) oraz gimnazjum (sztuka, muzyka, plastyka). W tym jednak zakresie wiekowym e-learning nie jest (jeszcze) wykorzystywany. Studia on-line nie są również stosowane na uczelniach artystycznych $^{51}$. Pozostają do rozważenia studia pedagogiczne o specjalnościach artystycznych oraz wszelkiego rodzaju kursy dokształcające, podyplomowe dla nauczycieli przedmiotów artystycznych, bądź po prostu dla zainteresowanych tą dziedziną amatorów. Te ostatnie są już z powodzeniem stosowane jako technologiczne rozwinięcie kursów korespondencyjnych, ograniczonych do bardzo pobieżnej wiedzy typu poradnikowego (nauka rysunku, malowania, gry na wybranych instrumentach muzycznych itp. $)^{52}$.

Problem wykorzystywania nowoczesnej technologii w procesie uczenia się, rozpatrywany od strony zdobywającego wykształcenie dotyczy nie tylko ucznia (studenta). Nauczyciel jest przecież zobowiązany, zarówno poprzez imperatyw wewnętrzny jak i instytucjonalnie, do samodoskonalenia, uaktualniania swej wiedzy, śledzenia nowych dokonań, odkryć, teorii. „Działalność innowacyjna jest niezbędnym elementem właściwego wykonywania zawodu nauczyciela. Nie powinno w nim być miejsca na rutynę i skostnienie, a nauczycielska praca powinna polegać na stałym wzbogacaniu doświadczenia pedagogicznego o nowe składniki, wprowadzaniu no-

\footnotetext{
${ }^{51}$ Od kilku lat uczelnie amerykańskie (m.in. Boston University, University of Northern Iowa, Kent State University) oferują studia online w zakresie edukacji muzycznej zarówno na poziomie Masters jak i Doctoral. Wykaz amerykańskich uczelni prowadzących ten rodzaj studiów znajduje się na stronie: http://musiced.about. com/od/musicschools/a/musicdegree.htm (stan z dnia 10.01.2010).

${ }^{52}$ Z. Osiński cytuje wnioski z amerykańskich badań, według których „E-learning spełnia swoją rolę jedynie jako uzupełnienie i zwiększenie efektywności i atrakcyjności tradycyjnych metod. Traktowany jako samoistna metoda doskonalenia wiedzy i umiejętności często prowadzi do negatywnych zjawisk"; Z. Osiński, Technologia informacyjna w edukacji humanistycznej, Toruń 2006, s. 95.
} 
wych, lepszych rozwiązań konkretnych problemów pedagogicznych"53. Nie wydaje się to w pełni możliwe bez zastosowania nowych narzędzi poznania, nowych technologii.

Szczególnego znaczenia nabiera ten problem w przypadku pedagoga przedmiotów estetycznych, dla którego rozwoju zawodowego niezbędny jest nieustanny kontakt $\mathrm{z}$ wielorakimi przejawami sztuki, w tym sztuki tworzonej współcześnie. Ma on być przecież nie tylko odbiorcą sztuki, ale jej propagatorem i kreatorem zainteresowań twórczych swoich wychowanków. Umiejętne korzystanie z technologii informacyjno-komunikacyjnych znajduje tu więc kolejne potwierdzenie swojej wartości w procesie edukacji estetycznej, tym razem w odniesieniu do pedagoga przedmiotów estetycznych.

\subsection{Przyczyny oporu we wprowadzaniu TIK do warsztatu pracy nauczyciela}

Stan zagubienia, w jakim znalazła się część nauczycieli sprawia, że na temat wykorzystania komputerów w edukacji oraz ich wpływu na proces wychowania narosło wiele mitów i niesłusznych sądów ${ }^{54}$, spowodowanych głównie - paradoksalnie - ogromnym rozpowszechnieniem tego narzędzia. Znaczna większość użytkowników technologii informacyjno-komunikacyjnych, czy to w celach zawodowych, czy też wyłącznie dla rozrywki, opanowała wiedzę na jej temat w bardzo pobieżnym zakresie. Zwykle wyraża się ona w znajomości podstawowej obsługi co najwyżej kilku aplikacji, a to mocno ogranicza horyzonty wyobraźni co do potencjalnych zastosowań tej technologii. Wyobraźnia natomiast jest niezbędna przy próbie połączenia dwóch ważnych dla niniejszej pracy pojęć: technologii informacyjno-komunikacyjnej oraz edukacji estetycznej.

Ograniczenia takie są efektem chaotycznego charakteru samokształcenia w tej dziedzinie lub - u nauczycieli, których kształcenie obejmowało już technologię informatyczną - specyficznego rozumienia i traktowania wiedzy i umiejętności informatycznych. Wyraźnie daje się to zauważyć na przy-

\footnotetext{
${ }^{53}$ A. D. Popławska, Podmiotowość uczestników procesu kształcenia w społeczeństwie informacyjnym, http:// gazeta-it.pl/200305225085/Podmiotowosc-uczestnikow-procesu-ksztalcenia-w-spoleczenstwie-informa.html (stan z dnia 11.11.2004).

${ }^{54}$ Por.: A. Stanisławska, Uczyć się w Internecie. Kilka wybranych problemów z metodyki zdalnego nauczania, http://www.puw.pl/downloads/docs/1_elearning/2_teoria_elearning/referat\%20Media\%20a\%20edukacja04_2002. pdf (stan z dnia 11.11.2004).
} 
kładzie szkolnych przedmiotów, dotyczących tych umiejętności, a nazywanych edukacja medialna, technologia informatyczna, informatyka czy zajęcia komputerowe. Przedmioty te, doczekawszy się uwzględnienia w szkolnych programach nauczania, nie doczekały się jednak odpowiedniej praktyki. Dwutorowość edukacji, charakterystyczna dla innych nośników informacji oraz emocji, zawodzi w przypadku nauki o mediach elektronicznych. Nauka języka ojczystego obejmuje od początku edukacji dziecka umiejętność pisania liter, składania ich w wyrazy, zasad ortografii, gramatyki itd. - czyli „nauki o języku”, nauki o medium, jakim jest język. Równolegle uczeń zgłębia tajniki literatury, poznaje dzieła literackie, uczy się je rozumieć, interpretować, odróżniać rzeczy ważne od nieważnych, wartościowe od bezwartościowych, szlachetne od godnych pogardy, piękne od ohydnych. Ten sam podział funkcjonuje w przedmiotach estetycznych. Na lekcjach muzyki czy plastyki, oprócz technik plastycznych, nazw nut, dziecko poznaje dzieła sztuki, ucząc się je interpretować i odróżniać od bezwartościowego kiczu, próbuje własnych sił twórczych, wykorzystując wiadomości o technikach i narzędziach artystycznego wyrazu. W tych wszystkich przypadkach dostrzegamy w przekazie element zarówno technologii, jak i sztuki.

W przypadku edukacji z zakresu technologii informacyjnej, zarówno uczniów szkół podstawowych jak i studentów kierunków pedagogicznych, rzecz wygląda zupełnie inaczej. Treścią jej jest niemal wyłącznie umiejętność obsługi i znajomość funkcjonowania narzędzia, jakim jest komputer ${ }^{55}$, mimo iż podstawy programowe oraz podręczniki zawierają sugestie kształcenia umiejętności wartościowania materiałów hipermedialnych, ich oceny zarówno pod względem merytorycznym, jak i aksjologicznym, zasad komunikowania się, korzystania z technologii jako medium, narzędzia wypowiedzi, środka ekspresji - w tym ekspresji twórczej. Mimo tego skłonni jesteśmy zauważać w komputerze przede wszystkim samą kwintesencję zaawansowanej technologii, na dodatek nieprzyjaznej bo nieznanej.

Przyczyna tej sytuacji wydaje się tkwić w kompetencjach nauczycieli edukacji informatycznej. O ile nauczyciel języka polskiego jest znawcą literatury - a nie tylko zasad pisowni, nauczyciel muzyki jest muzykiem - a nie znawcą nut, zaś nauczyciel plastyki jest znawcą sztuk plastycznych - a nie tylko rodzajów pędzli czy sposobów nakładania farby, o tyle nauczyciel przedmiotów informatycznych jest zwykle informatykiem - ekspertem od

\footnotetext{
${ }^{55}$ Por.: A. Siemińska-Łosko, Internet w przygotowaniu nauczycieli do stosowania technologii informacyjnej, Toruń 2006, s. 196.
} 
budowy i zasad funkcjonowania narzędzi multimedialnych. Jego wykształcenie nie obejmuje sposobów twórczego wykorzystania tego narzędzia, czy aksjologicznej weryfikacji bezmiaru informacji w zasobach internetowych. Nie jest humanistą. Problem ten zauważa K. Strykowski, pisząc: „osobliwość współczesnych mediów polega również na tym, że posiadają one niejako dwie strony: humanistyczną i techniczną. Pełne korzystanie z nich wymaga paralelnie dwóch umiejętności: właściwego odczytywania znaczeń i przekazów medialnych oraz umiejętności obsługi technicznej" ${ }^{56}$.

Fakt braku rozpowszechnionych studiów pedagogicznych w zakresie edukacji estetycznej, organizowanych w trybie on-line, może świadczyć o wyjątkowych trudnościach, na jakie natrafia próba połączenia obu obszarów. Mogą to być trudności trojakiego rodzaju (pomijając aspekt finansowy): technologiczne, metodyczne lub światopoglądowe (niechęć kadry nauczycielskiej do nowego sposobu nauczania ${ }^{57}$ ). Być może przyszłe badania wykażą, czy owe trudności mają charakter obiektywny i jednoznacznie skazujący na fiasko próby podjęcia takiego wyzwania. Na użytek niniejszej pracy warto jedynie zauważyć, że większość studiów organizowanych w trybie on-line posiłkuje się również metodami tradycyjnego spotkania twarzą w twarz, chociażby na etapie egzaminu końcowego. Taka metoda, nazywana „mieszaną”, z powodzeniem dałaby się zastosować w tych sytuacjach, gdzie specyfika zajęć (ćwiczeń) nie znajduje odpowiednich rozwiązań technologicznych, zapewniających wysoką jakość kształcenia, wymagających bezpośredniego kontaktu nauczyciela z uczniem (lub lepiej: przewodnika $\mathrm{z}$ uczacym się).

Przeciwstawienie nauczania tradycyjnego oraz opartego na technikach informacyjno-komunikacyjnych, często uwypukla bezpośredni kontakt nauczyciela z uczącym się, jako dający więcej możliwości interakcji, działający na większą ilość zmysłów, a przez to skuteczniejszy w procesie poznania, rozumienia i zapamiętywania. Tymczasem metodyka nauczania bezpośredniego coraz chętniej wykorzystuje przekaz audiowizualny, wprowadzając obraz i dźwięk jako bardziej skuteczne i atrakcyjne elementy w porównaniu z tekstem mówionym czy czytanym ${ }^{58}$. Pokaz czy demonstracja pozwala przyswajać wiedzę w sposób bardziej skuteczny i trwały niż lektura czy wykład. „Uczenie obrazkami to sposób atrakcyjniejszy dla nauczyciela, a tym

\footnotetext{
${ }^{56}$ W. Strykowski, Rola mediów i edukacji medialnej..., s. 119.

57 Por.: Z. Osiński, E-learning w kształceniu i dokształcaniu nauczycieli, http://zbyszeko.startowy.com/ \#Moje_ksi\%C4\%85\%C5\%BCkiiartyku\%C5\%82y (stan z dnia 11.11.2004).

${ }^{58}$ G. Dryden, J. Vos, Rewolucja w uczeniu się, Poznań 2000, s. 101.
} 
bardziej dla ucznia. Obrazów nie da się sylabizować, dukać, ani recytować. Obrazy samoistnie narzucają się naszej percepcji, potrafią całkowicie pochłonąć uwagę, przykuć wzrok i zatrzymać. Obrazy łatwiej się zapamiętuje, ponieważ do ich magazynowania wykorzystywane są inne mechanizmy biologiczne - skuteczniejsze" 59 .

Funkcjonuje w świadomości „ideowych” przeciwników technologii komputerowych model ich użytkownika zatopionego w wirtualnym świecie, tracącego poczucie rzeczywistości, czasu, systemu wartości czy choćby tylko poczucia dobrego smaku. Jednak ucieczka od rzeczywistości - zamierzona czy też nie - w świat wirtualnych pseudo-przeżyć, pseudo-uczuć, pseudo-wzruszeń i pseudo-wartości, nie jest ciemną stroną technologii informacyjno-komunikacyjnych. To tylko ułomność psychiki ludzkiej, która znalazłszy nowego sprzymierzeńca $\mathrm{w}$ walce $\mathrm{z}$ nieakceptowanym, lub zaledwie tolerowanym światem, próbuje zepchnąć odpowiedzialność na pozbawioną możliwości obrony maszynę. To Człowiek, zniechęcony porażkami w swej misji doskonalenia świata, często zwraca się ku lepszej, choć wymyślonej rzeczywistości, przyznając się tym samym do bezsilności.

Nie jest wcale nowym zjawiskiem ucieczka w świat fikcji - literatury czy filmu. Jedynie medium się zmieniło i - jak przystało na XXI wiek - jest w pełni multimedialne. Słynne pierwowzory wirtualnych światów - z Don Kichotem na czele - ukazują wirtualność jakby „w drugiej potędze”, bo i tworzywo, i treść, stanowią o nierealności zarówno samego opisu, jak i jego bohaterów. Mimo to, nikt przecież nie postuluje negowania podręczników z powodu niebezpiecznej atrakcyjności świata literackiego, który grozi alienacją pochłoniętego nim bez reszty czytelnika. Sam komputer więc, czy sam internet, nie jest przyczyną aksjologicznej demencji świata jego użytkowników - przeciwnie - to niezauważanie i odwracanie się od problemu w działaniach pedagogicznych może prowadzić do zgoła zgubnych skutków. Stąd w programach nauczania znalazła się Edukacja czytelnicza i medialna, a na studiach pedagogicznych wykładany jest przedmiot Media w edukacji. Po to, by człowiek zapanował nad technologią a nie na odwrót.

Niebezpieczeństwo stosowania technologii informacyjno-komunikacyjnej kryje się często w sposobie jej traktowania. Jeśli chcemy aby była ona narzędziem poznania, źródłem wiadomości czy wygodnym medium, okaże się niezwykle pomocna a nawet niezastąpiona. Jeżeli natomiast urzek-

\footnotetext{
${ }^{59}$ K. Karauda, Oglądanie czy czytanie. Ogólnie o problemach metodyki zdalnego nauczania, http://www.puw. $\mathrm{pl} /$ elearning.html? akcja=elearning $\& \mathrm{P}[$ aid] $=281$ (stan $\mathrm{z}$ dnia 11.11.2004).
} 
nie nas forma - atrakcyjna i efektowna powierzchowność, ulegniemy fascynacji narzędziem, nobilitując je do rangi podmiotu naszych działań, wówczas pierwotny cel - wychowawcze działanie sztuki - ulegnie zatarciu, zniekształceniu, tak jak np. kolekcjonerstwo może przeobrazić się w zwykłe zbieractwo albo fascynacja sztuką filmową w pozbawione refleksji wpatrywanie się w ekran.

Problem leży w proporcjach. Skrajne postawy, zarówno bezkrytycznie afirmujące technologię informacyjno-komunikacyjną za jej nowoczesność, atrakcyjność, wygodę itp., każące odrzucić „przestarzałe” dogmaty i atrybuty procesu dydaktycznego, jak i - wręcz przeciwnie - niezauważanie rozwijającego się świata, bagatelizowanie problemów związanych z nową technologią, spychanie ich na margines zainteresowań pedagogicznych, są nie do przyjęcia. Umiar i kompromis jest w tej sytuacji pożądanym rozwiązaniem, a granice tej trudno osiągalnej równowagi winny wyznaczać zakres udziału nowoczesnej technologii we współczesnej edukacji, w tym edukacji estetycznej.

Wciąż jednak lekcje muzyki czy - w nieco mniejszym stopniu - plastyki, opierają się korzystaniu z nowoczesnych, technicznych środków dydaktycznych. Przyczyn takiego stanu rzeczy jest wiele. Wśród najważniejszych w dalszym ciągu wymienbia się brak sprzętu, jako konsekwencja niedoinwestowania szkół. W tej dziedzinie widoczną oznaką poprawy są akcje informatyzacji szkół (np. „pracownia komputerowa w każdej szkole”), nie pozwala to jednak na prowadzenie innych lekcji niż informatyka w jedynej takiej pracowni w placówce o 20 oddziałach klasowych.

Kolejną - nie wiem czy nie najważniejszą - przyczyną hamującą wykorzystanie nowych technologii w edukacji estetycznej jest świadomość nauczycieli. Wielu z nich obawia się utraty autorytetu, demonstrując swoją nikłą wiedzę informatyczną w konfrontacji z używającymi jej powszechnie uczniami $^{60}$. Wielu jest zdania, że bezduszna maszyna służąca rozrywce nie jest w stanie sprostać wzniosłym celom edukacji przez sztukę, duża część natomiast nie zna żadnych programów komputerowych użytecznych w dydaktyce muzyki ${ }^{1}$. Kolejne przyczyny, na podstawie obserwacji rzeczywistości szkolnej i akademickiej formułuje Barbara Kędzierska: [nauczyciele] "- nie potrafią obsługiwać sprzętu, - nie znają metod i technik komputero-

\footnotetext{
${ }^{60}$ Por.: R. Pachociński, Oświata XXI wieku. Kierunki przeobrażeń, Warszawa 1999, s. 117.

${ }^{61}$ Por.: D. Siemieniecka-Gogolin, Zdolności i postawa twórcza a styl użytkowania elektronicznych mediów, Toruń 2005, s. 61-62.
} 
wych, - nie wiedzą, w jaki sposób komputer może być pomocny w procesie uczenia się i nauczania, - nie potrafią opanować lęku, obaw i emocjonalnych zahamowań przed nieznanym światem technologii informacyjnej, - nie zdają sobie sprawy z konieczności poznania urządzenia, które coraz szybciej staje się niezbędnym narzędziem pracy i rozrywki”"62.

„Szkoła tradycyjna jest niechętna nowej technologii. Uczniowie przygotowują się do życia skierowanego ku przyszłości, choć szkoła zamknięta jest w przeszłości. Wiedza jest nadal przekazywana w tradycyjnej klasie szkolnej w postaci linearnej (to różni zasadniczo sposób zdobywania doświadczeń przez młode pokolenie poza szkołą)" ${ }^{63}$. Szkoła nie ma dużych szans w wyścigu technologicznym ze środowiskiem pozaszkolnym ucznia, który nie czekając na nauczyciela-przewodnika, sam penetruje nowe wirtualne przestrzenie. I czyni to $\mathrm{z}$ wielkim zaangażowaniem, skuszony powierzchowną atrakcyjnością technologicznego narzędzia.

Badania opinii nauczycieli na temat wykorzystania technologii informacyjno-komunikacyjnej w edukacji, przytoczone przez Krzysztofa Niewiadomskiego ${ }^{64}$, ujawniają pełen sprzeczności schemat myślenia na ten temat. W opiniach pedagogów obok siebie znalazły się: zaleta różnorodności informacji oraz zarzut małej wartości zdobywanych tą drogą informacji, rozwój intelektualny oraz ograniczenie rozwoju w innych kierunkach, łatwość komunikacji oraz ograniczenie kontaktów. Oznacza to, że technologiczne narzędzia posiadają olbrzymi potencjał, który można spożytkować zarówno do działań jednoznacznie pozytywnych jak i jednoznacznie negatywnych i to do nauczyciela-przewodnika należy ukazanie tej lepszej strony, zachęcenie użytkownika do działań rozwijających intelektualnie, twórczo, społecznie, zdrowotnie, zwracając uwagę na zagrożenia wynikające z bezrefleksyjnego i biernego sposobu korzystania $\mathrm{z}$ technologii informacyjno-komunikacyjnej.

Obawy nauczycieli dotyczące wyparcia ich przez technologię nie mogą być źródłem fałszywej konkurencji między człowiekiem a narzędziem. Przecież ani drukowany podręcznik, ani kreda czy długopis, nie zagroziły pozycji nauczyciela w procesie nauczania-uczenia się. Rolą technologii nie

\footnotetext{
${ }^{62}$ B. Kędzierska, Informatyczne kształcenie i doskonalenie nauczycieli, Kraków 2005, s. 73.

${ }^{63}$ A. Cichocki, Wymiary kompetencji informacyjno-medialnych nauczyciela, [w:] J. Izdebska (red.), Media elektroniczne..., s. 160.

${ }^{64}$ K. Niewiadomski, Pozytywne i negatywne aspekty wykorzystania komputerów w edukacji, [w:] J. Migdałek, B. Kędzierska (red.), Informatyczne przygotowanie nauczycieli. Konkurencja edukacji informatycznej, Kraków 2002, s. 381-385.
} 
jest zastąpienie nauczyciela, a jedynie przybliżenie uczniowi tego, co bez technologii byłoby niemożliwe do zobaczenia, wypróbowania, wytrenowania. Technologia może spełniać ważną rolę w uczeniu się, ale nie jest w stanie zastąpić dobrego nauczyciela ${ }^{65}$.

Wszystkie te "pedeutologiczne” przyczyny mają swe źródło w tym, że tempo rozwoju narzędzi technologicznych mocno przewyższa tempo, w jakim nauczyciel jest w stanie się do nowych warunków zaadaptować, lub głębiej - w braku tzw. kultury informatycznej, czy - jak pisze W. Strykowski - kompetencji medialnych o charakterze intelektualno-kulturowym ${ }^{66}$. „Owa kultura - jak pisze Włodzimierz Prokopiuk - to nie tylko dysponowanie zobiektywizowanym systemem wiedzy, to przede wszystkim, aspekt przekształcającego stosunku do świata. Jej kształtowanie u kandydatów na nauczycieli zależy od jakości środowiska informatycznego uczelni pedagogicznych, jako centralnego ogniwa w systemie edukacji ustawicznej" ${ }^{67}$. Do tej pory jednak tylko nieliczne Akademie Muzyczne w Polsce, z których w większości rekrutują się nauczyciele muzyki szkół ogólnokształcących, zdecydowały się wprowadzić do swych programów przedmiot traktujący o zastosowaniach muzycznych programów komputerowych w dydaktyce ${ }^{68}$. A przecież „integracja treści informatycznych z treściami poszczególnych przedmiotów należy dzisiaj do najistotniejszych problemów w procesie informatyzacji szkolnictwa"69.

Tymczasem czy wolno nauczycielowi sztuki pominąć w programie nauczania coraz większej i ważniejszej dziedziny sztuki tworzonej przy pomocy narzędzi informatycznych? Taka luka w edukacji estetycznej sprawi, że pominiemy również ogromny potencjał twórczy tych narzędzi oraz - co gorsze - zignorujemy potencjał twórczy uczniów.

${ }^{65}$ D. Adams, M. Hamm, Media and Literacy. Learning in the Information Age - Issues, Ideas, and Teaching Strategies, Springfield, Illinois, USA 2006, s. 217: „Technology has a role in learning, but it is not a substitute for good teachers".

${ }^{66}$ A. Cichocki, Wymiary kompetencji..., s. 166; [por.:] W. Strykowski, Kompetencje medialne: pojęcie, obszary, formy kształcenia, [w:] W. Strykowski, W. Skrzydlewski (red.), Kompetencje medialne społeczeństwa wiedzy, Poznań 2004, s. 33-34.

${ }^{67}$ W. Prokopiuk, Kompetencje medialne nauczycieli i uczniów w konfrontacji z potrzeba personalizowania procesów pedagogicznych (edukacyjnych), [w:] J. Izdebska (red.), Media elektroniczne w życiu dziecka..., s. 144.

${ }^{68}$ Brakuje również w Polsce instytucji, która wzorem amerykańskiego Technology Institute for Music Educators (TI:ME) organizowałaby kursy dla nauczycieli muzyki z zakresu wykorzystania technologii informacyjnej w edukacji muzycznej; [por.:] A. Burns, Integrating Technology into Your Elementary Music Classroom, „General Music Today" [serial online]. Fall 2006; 20(1), p. 6-10. Available from: Academic Search Complete, Ipswich, MA. Accessed March 16, 2010.

${ }^{69}$ B. Kędzierska, Informatyczne kształcenie..., s. 66. 


\section{Kompetencje informatyczne nauczyciela muzyki w klasach IV-VI szkoły podstawowej}

\subsection{Pojęcie kompetencji - ustalenia definicyjne}

Pojęcie „kompetencji” nie jest pojęciem jednoznacznym. XX-wieczne encyklopedyczne i opracowania dotyczące pedagogiki traktują hasło kompetencje dosyć zdawkowo. W Słowniku pedagogicznym ${ }^{1}$ z 1984 roku, Słowniku słów kluczowych z pedagogiki ${ }^{2}$ z roku 1988, ani w Encyklopedii pedagogicznej ${ }^{3}$ z roku 1993, nie znajdziemy go w ogóle. Słownik pedagogiki pracy sygnalizuje obecność pojęcia kompetencji na gruncie pedagogiki, kładąc jednak nacisk na jej znaczenie prawno-administracyjne: „zakres pełnomocnictw i uprawnień, zakres działania organu władzy lub innej jednostki organizacyjnej, zakres czyjejś wiedzy, umiejętności, odpowiedzialności”5. $\mathrm{Z}$ ostatniego fragmentu tej definicji dowiadujemy się zatem, że na kompetencje w odniesieniu do podmiotów procesu dydaktyczno-wychowawczego, składać się mają trzy elementy: wiedza, umiejętności oraz odpowiedzialność, traktowane koniunktywnie, przy czym definicja nie precyzuje rodzaju odpowiedzialności (etyczna, moralna, administracyjna lub inna) ani też jej zakresu przedmiotowego (odpowiedzialność za konieczność zastosowania odpowiedniej wiedzy i umiejętności, czy też może odpowiedzialne jej stosowanie).

Słownik 100 tysięcy potrzebnych słów $w^{6}$, wydany w 2005 roku, podziela trójskładnikowy charakter pojęcia kompetencji, jednak obok wiedzy i umiejętności wymienia doświadczenie w miejsce odpowiedzialności ${ }^{7}$.

Nowy słownik pedagogiczny ${ }^{8}$ z 1998 roku (oraz następne wydania) dostrzega już pojęcie kompetencji na gruncie pedagogiki i określa je jako „Zdolność do osobistej samorealizacji” oraz „zdolność do określonych ob-

\footnotetext{
${ }^{1}$ Słownik pedagogiczny, W. Okoń, Warszawa 1984.

${ }^{2}$ Stownik słów kluczowych z pedagogiki, Z. Gawlina i in. (red.), Kraków 1988.

${ }^{3}$ Encyklopedia pedagogiczna, W. Pomykało (red.), wyd. 1, Warszawa 1997.

${ }^{4}$ Stownik pedagogiki pracy, L. Koczniewska-Zagórska, T. W. Nowacki, Z. Wiatrowski (red.), Wrocław-Warszawa-Kraków-Gdańsk-Łódź 1986.

${ }^{5}$ Ibidem, s. 123.

${ }^{6}$ Stownik 100 tysięcy potrzebnych stów, J. Bralczyk (red.), Warszawa 2005.

${ }^{7}$ Ibidem, s. 308.

${ }^{8}$ Nowy stownik pedagogiczny, W. Okoń, Warszawa 1998.
} 
szarów zadan'”" Jest to niezwykle lapidarne ujęcie, posiadające pewne cechy wspólne z następnym, daleko szerszym źródłem.

Dopiero Encyklopedia pedagogiczna XXI wieku ${ }^{10} \mathrm{z}$ roku 2003 obszernie omawia interesujące nas zagadnienie, poświęcając mu aż 7 kolumn tekstu zredagowanego przez Astrid Męczkowską ${ }^{11}$. Autorka zwraca na wstępie uwagę, że kompetencja to „jedno z ważnych pojęć pedagogicznych, którym trudno jest przyznać jednoznaczny zakres znaczeniowy z powodu silnie osadzonych w myśleniu pedagogicznym potocznych konotacji tegoż pojęcia oraz, co jest z tym związane, jego podatności na interferencję z sądami wartościującymi”"12. Dowiadujemy się więc, że kompetencja jest po pierwsze pojęciem wieloznacznym oraz, że oprócz potocznego rozumienia jest ważnym pojęciem pedagogicznym. Po takim wstępie Męczkowska wyprowadza z etymologii łacińskiego czasownika competere (nadawać się, współzawodniczyć, zajmować określoną pozycję) szeroką „perspektywę pojmowania kompetencji, w której jej podstawowe znaczenie będzie nawiązywać do potencjału podmiotu, wyznaczającego jego zdolności wykonania określonych typów działań"13. Jest to zgoła odmienne podejście do problemu zdefiniowania pojęcia kompetencji, jako zdolności do działania, które akcentuje jej stronę „potencjalną”, zamiast wyliczania komponentów, składających się na ten potencjał.

W tym kontekście Męczkowska zauważa dwa podstawowe dla kontekstu pedagogicznego ujęcia kompetencji: jako potencjał podmiotu o charakterze adaptacyjnym lub transgresyjnym ${ }^{14}$. Adaptacyjne ujęcie kładzie nacisk na „dostosowanie działania do warunków wyznaczanych przez charakter otoczenia”15 $\mathrm{i}$ „przywołuje behawiorystyczne konotacje sprawnego i efektywnego działania jako podstawowej z pożądanych form aktywności człowieka"16. Skutkiem zaakcentowania kategorii efektywności w takim podejściu, jest pojęcie kompetencji oznaczające „dyspozycję do instru-

${ }^{9}$ Ibidem, s. 174-175.

${ }^{10}$ Encyklopedia pedagogiczna XXI wieku, t. 2 G-Ł, T. Pilch (red.), Warszawa 2003.

${ }^{11}$ Ibidem, s. 693.

12 Ibidem.

${ }^{13}$ Ibidem.

14 „Działania transgresyjne - ekspansywne i twórcze - polegają na intencjonalnym wychodzeniu poza to, czym jesteśmy i co posiadamy. Przełamują one dotychczasowe granice osiągnięć i tworzą nowe wartości. Dzięki nim rozszerza się prywatne terytorium, wzbogaca nasze doświadczenie, zwiększa zakres kontroli. Osiąganie kolejnych celów transgresyjnych nie tylko nie redukuje motywacji do podejmowania dalszych działań, ale wręcz zwiększa ją". [Za:] http://www.charaktery.eu/slownik-psychologiczny/T/129/Transgresja/ (stan z dnia 10.02.2012).

${ }^{15}$ Encyklopedia pedagogiczna XXI wieku, s. 693.

${ }^{16}$ Ibidem, s. 694. 
mentalnego działania, związaną z wiedzą, umiejętnościami, motywacją do działania oraz przekonaniem podmiotu o posiadaniu owej dyspozycji"17. Z perspektywy transgresyjnej natomiast określa Męczkowska kompetencję jako "głęboko zinterioryzowaną strukturę poznawczą, tkwiącą u podstaw zachowań oraz dyspozycji podmiotu”, a „domenę zastosowania kompetencji podmiotu stanowi rzeczywistość kulturowa"18. W tym rozumieniu kompetencja „jest efektem aktywności podmiotu w konstruowaniu własnego poznania, nie zaś bezpośredniej recepcji treści kulturowego przekazu”'19. Także tutaj ważne miejsce zajmują wiedza i umiejętności, choć „nie decydują o ostatecznym kształcie kompetencji podmiotu, lecz przyjmują charakter narzędzi, umożliwiających jej dalsze kreowanie przez podmiot na drodze twórczego konstruowania własnych struktur poznawczych oraz dyspozycji do działania"20.

Obydwa zatem podejścia do rozumienia kompetencji omawiane przez Męczkowską opierają się na bazie zbudowanej z wiedzy i umiejętności, wzbogacając je o świadomość oraz motywację do działania w ujęciu adaptacyjnym oraz aktywne i twórcze poznanie w ujęciu transgresyjnym. Takie rozumienie kompetencji potwierdza ujęcie B. Poćwiardowskiej, która w suplemencie do tej samej Encyklopedii pedagogicznej XXI wieku (wydanym 7 lat później) wskazuje na adaptacyjny i transgresyjny nurt pojmowania kompetencji, omawiając hasło „Kompetencje wychowawcze rodziców”21.

Analizę różnic w definiowaniu kompetencji wyczerpująco omawia M. Czerepaniak-Walczak ${ }^{22}$, wskazując chociażby na różnicę podmiotów, do których analizowane sformułowanie się odnosi. I tak - według autorki dwa podstawowe sposoby rozumienia pojęcia kompetencji, używane w dokumentach regulujących rzeczywistość edukacyjną, odnoszą się bądź do ucznia, definiując tym określeniem zasób nabywanych umiejętności, bądź dotyczą nauczyciela i utożsamiane są z zakresem uzyskanych przez niego uprawnień.

Oprócz różnej interpretacji podmiotowej, rozbieżności interpretacyjne wypływają z różnej interpretacji przedmiotowej i dotyczą głównie samego

\footnotetext{
${ }^{17}$ Ibidem.

${ }^{18}$ Ibidem, s. 695.

${ }^{19}$ Ibidem, s. 696.

${ }^{20}$ Ibidem.

${ }^{21}$ Encyklopedia pedagogiczna XXI wieku, Suplement A-Ż, T. Pilch (red.), Warszawa 2010, s. 245-249.

${ }^{22}$ M. Czerepaniak-Walczak, Aspekty i źródła profesjonalnej refleksji nauczyciela, Toruń 1997; także: eadem, Kompetencja: słowo kluczowe czy „wytrych” w edukacji?, „Neodidagmata” 1999, nr 24, s. 53-66.
} 
zakresu pojęcia kompetencji. Jak zauważa autorka, często i w sposób nieuprawniony, stosuje się zamiennie pojęcia kompetencji oraz kwalifikacji. Te ostatnie mają jednak daleko mniejszy zakres, sprowadzający się zwykle do zakresu uprawnień udokumentowanych odpowiednimi zaświadczeniami. W taki właśnie sposób traktowane jest pojęcie kwalifikacji w Karcie Nauczyciela, która w rozdziale 3 mówi: „Art. 9. 1. Stanowisko nauczyciela może zajmować osoba, która: 1) posiada wyższe wykształcenie z odpowiednim przygotowaniem pedagogicznym lub ukończyła zakład kształcenia nauczycieli i podejmuje pracę na stanowisku, do którego są to wystarczające kwalifikacje”23. Tak więc „wystarczającymi kwalifikacjami” są tu ukończenie odpowiedniej uczelni oraz przygotowanie pedagogiczne.

Już same próby formułowania spodziewanych efektów edukacji ucznia posługują się tymi dwoma pojęciami. Jeśli zdefiniujemy cel edukacyjny jako np. poznanie twierdzenia Pitagorasa, utożsamimy cel z kwalifikacją ucznia; jeśli jednak cel edukacyjny sformułowany zostanie jako umiejętność zastosowania twierdzenia Pitagorasa $w$ zadaniach tekstowych, utożsamimy tym samym cel edukacyjny z wąsko rozumianą kompetencją, czyli wiedzą wzbogaconą o umiejętność i gotowość do odpowiedniego działania, popartego doświadczeniem szkolnym i świadomością optymalnego wyboru metody rozwiązania problemu. Rzecz jasna, że aby odpowiednio zastosować twierdzenie trzeba je najpierw poznać i zrozumieć. Oznacza to, że kwalifikacje są niezbędne, aby posiąść kompetencje, bądź też, że w pojęciu kompetencji zawiera się całkowicie pojęcie kwalifikacji.

Możemy zatem przyjąć pewien wyjściowy i podstawowy dla kolejnych rozważań zakres pojęcia kompetencji, wspólny dla większości przypadków stosowania tego pojęcia, jego różnych definicji, jak i pozostający w zgodzie z pozanaukowym kontekstem językowym, jako: „zdolność i gotowość do wykonywania zadań na określonym poziomie" (jak proponuje H. O. Jenkins $^{24}$ ) lub: „wyuczalna umiejętność robienia rzeczy dobrze, sprawności niezbędne do radzenia sobie z problemami” (wg D. Fontany ${ }^{25}$ ). Wobec takiego tła znaczeniowego, Czerepaniak-Walczak proponuje następujące interpretacje pojęcia kompetencji w kontekście pedagogicznym: „uświadamiane sobie przez człowieka jego dyspozycje osiągane w ciągu życia

\footnotetext{
${ }^{23}$ Ustawa z dnia 26 stycznia 1982 r. - Karta Nauczyciela, Dz.U. z 2006 r., Nr 97, poz. 674 z późn. zm.

${ }^{24}$ H. O. Jenkins, Getting it Right. A Handbook for Successful School Leadership, Blackwell Education, Oxford 1991; [za:] M. Czerepaniak-Walczak, Aspekty i źródła..., s. 87.

${ }^{25}$ D. Fontana, Psychology for Teachers, Macmillan Publisher, Basingstoke 1992; [za:] M. Czerepaniak-Walczak, Aspekty i źródła..., s. 87.
} 
poprzez wyuczenie"26, bądź - bardziej chyba użyteczna do opisu sytuacji edukacyjnej - „świadomy, wyuczany, satysfakcjonujący, choć nie niezwykły, poziom sprawności warunkujący efektywne zachowanie się (działanie) w jakiejś dziedzinie"27. Jest to podejście zgodne z propozycją A. Męczkowskiej $^{28}$, eksponującą stan potencjalny osoby kompetentnej, jako zdolność do odpowiedniego, pożądanego i efektywnego działania.

Czerepaniak-Walczak proponuje również drugie podejście do sposobu definiowania kompetencji, jako połączenie dwóch cytowanych ${ }^{29}$ już kategorii: wiedzy i umiejętności, i uzupełnia je o element eksponujący jej dynamiczność, czyli: „szczególną właściwość, wyrażającą się w demonstrowaniu" $^{30}$ [tejże umiejętności - przyp. P. S.]. Owo demonstrowanie, będące kluczem do rozróżnienia kwalifikacji i kompetencji, odbywać się musi na odpowiednio wysokim poziomie. Poziom ten mają wyznaczać standardy społeczne, którym demonstrujący podlega. Dodatkowymi elementami, o jakie Czerepaniak-Walczak każe wzbogacić definicję kompetencji, są: „świadomość potrzeby i konsekwencji takiego właśnie zachowania” oraz „przyjmowanie na siebie odpowiedzialności za nie”31. Łatwo wyobrazić sobie te elementy w odniesieniu do kompetencji zawodowych lekarza, który decydując o zastosowaniu wybranej przez siebie kuracji ma nie tylko świadomość potrzeby oraz konsekwencji jej wdrożenia, ale również przyjmuje odpowiedzialność za zastosowanie właśnie tej, a nie innej kuracji. Analogicznie - praca kompetentnego pedagoga, który podobnie jak lekarz próbuje wpływać na zachowanie organizmu (tyle, że w sferze zachowań sterowanych świadomością), polega na świadomym potrzeb i konsekwencji doborze odpowiedniej „kuracji” (czyli procesu edukacyjnego), za zastosowanie którego bierze całkowitą odpowiedzialność. Tak zaplanowany i realizowany proces edukacyjny jest domeną pedagoga kompetentnego, a nie jedynie wykwalifikowanego.

Ważne jest tu zauważenie, że atrybutem tak rozumianych kompetencji jest dynamizm, wynikający z relacji człowiek-świat. W relacji takiej bowiem obydwa elementy są zmiennymi. Nabycie jakiejś kompetencji nie gwarantuje jej niezmiennej aktualności. Trzeba liczyć się z możliwością

\footnotetext{
${ }^{26}$ M. Czerepaniak-Walczak, Aspekty i źródła..., s. 87.

${ }^{27}$ Ibidem.

${ }^{28}$ Encyklopedia pedagogiczna XXI wieku, s. 693.

${ }^{29}$ Stownik pedagogiki pracy, s. 123; także: Słownik 100 tysięcy potrzebnych słów, J. Bralczyk (red.), s. 308.

${ }^{30}$ M. Czerepaniak-Walczak, Aspekty i źródła..., s. 89.

${ }^{31}$ Ibidem.
} 
utraty kompetencji, co każe nieustannie uaktualniać wszystkie składniki kompetencji - wiedzę, umiejętności, świadomość, odpowiedzialność oraz potrzebę.

Czerepaniak-Walczak po prezentacji różnych sposobów i tendencji $\mathrm{w}$ definiowaniu czy rozumieniu kompetencji, proponuje pozostać przy jej zdaniem - najtrafniejszej, „według której kompetencja - to harmonijna kompozycja wiedzy, sprawności, rozumienia oraz pragnienia" ${ }^{2}$, podkreślając jednocześnie, że „umiejętność, czyli wiedza proceduralna (wiedzieć, jak) stanowi sedno kompetencji”33. Tak rozumiane znaczenie kompetencji zawiera w sobie wszystkie omówione wyżej elementy, tzn.: kwalifikacje (czyli wiedza i umiejętność sprawnego posługiwania się nią), świadomość jej zastosowań (czyli rozumienie) oraz świadomość potrzeby i odpowiedzialności (czyli pragnienie). Te trzy konstytutywne cechy kompetencji związane są ze sobą, tworząc wedle zaproponowanej definicji „harmonijną kompozycję", co oznacza, że zarówno proporcje składników, jak i ich wzajemne zależności powinny podlegać specjalnym zasadom, których jednak autorka nie konkretyzuje. Proponuję jednak uznać tę definicję kompetencji za najwłaściwszą wobec jej najpełniejszego znaczenia i najlepszego rozróżnienia od innych podobnych pojęć, w szczególności pojęcia kwalifikacji.

W podobny sposób definiuje kompetencje w swych dokumentach Parlament Europejski. W załączniku do Zalecenia Parlamentu Europejskiego i Rady [Europy - przyp. P. S.] z dnia 18 grudnia 2006 roku w sprawie kompetencji kluczowych w procesie uczenia się przez całe życie, kompetencje definiowane są jako „połączenie wiedzy, umiejętności i postaw odpowiednich do sytuacji" ${ }^{34}$. Odnajdujemy tu dwa składniki kompetencji proponowane przez Czerepaniak-Walczak: wiedzę i umiejętności, natomiast rozumienie i pragnienie można uznać za ujęte łącznie, pod pojęciem „postaw odpowiednich do sytuacji” („attitudes appropriate to the context”). Oczywiście nie możemy jednoznacznie określić, o jakie postawy autorom powyższej definicji chodziło, jednak rozumienie oraz pragnienie świadomego i odpowiedzialnego skorzystania z posiadanej wiedzy i umiejętności, odpowiednio do sytuacji, niewątpliwie można określić mianem pożądanej postawy nauczyciela. W takim rozumieniu obie definicje są zbieżne, choć na nieco różnym stopniu uszczegółowienia.

\footnotetext{
${ }^{32}$ Ibidem, s. 88.

${ }^{33}$ Ibidem.

${ }^{34}$ Zalecenia Parlamentu Europejskiego i Rady z dnia 18 grudnia 2006 roku w sprawie kompetencji kluczowych $w$ procesie uczenia się przez całe życie, PE-CONS 3650/1/06 REV 1, ANNEX, s. 3.
} 
Wśród przytoczonych definicji pojęcia kompetencji zauważyć można bezpośredni bądź pośredni udział wiedzy i umiejętności. Do tych, które bezpośrednio przytaczają oba składniki należą definicje zaproponowane przez: Koczniewską-Zagórską i in. (Słownik pedagogiki pracy), Bralczyka (Słownik 100 tysięcy potrzebnych słów), trzy propozycje Czerepaniak-Walczak (Aspekty i źródła profesjonalnej refleksji nauczyciela) oraz Parlament Europejski (Zalecenia Parlamentu Europejskiego i Rady z dnia 18 grudnia 2006 roku $w$ sprawie kompetencji kluczowych w procesie uczenia się przez całe życie). Inne propozycje w sposób niejawny zaliczają wiedzę i umiejętności w skład definicji kompetencji, używając określeń znaczeniowo pokrywających się z wiedzą i umiejętnościami: „zdolność wykonywania określonych działan” (Męczkowska w Encyklopedii pedagogicznej XXI wieku, Jenkins w Getting it Right...), „umiejętność robienia rzeczy dobrze” (Fonatana w Psychology for Teachers...), „wyuczone i uświadamiane dyspozycje” lub „sprawności” (Czerepaniak-Walczak w Aspekty i źródła...). Przyjąć zatem należy, że wiedza i umiejętności, które wyczerpują zakres pojęcia kwalifikacji, stanowią dwa niezmienne składniki pojęcia kompetencji, stanowiąc consensus wśród autorów wszystkich przytoczonych propozycji.

Zmiennym pozostaje trzeci składnik definicji kompetencji, odróżniający je od kwalifikacji a formułowany w przytoczonych propozycjach jako: "odpowiedzialność" (Koczniewska-Zagórska i in. w Słowniku Pedagogiki Pracy), „doświadczenie” (Bralczyk w Słowniku 100 tysięcy potrzebnych słów), „szczególna właściwość, wyrażająca się w demonstrowaniu”, „świadomość potrzeby i konsekwencji takiego właśnie zachowania oraz przyjmowanie na siebie odpowiedzialności za nie”, „rozumienie oraz pragnienie” (trzy propozycje Czerepaniak-Walczak w Aspekty i źródła...), „postawy odpowiednie do sytuacji” (Parlament Europejski w Zaleceniach Parlamentu Europejskiego...).

Trzy z nich akcentują czynne stosowanie wiedzy i umiejętności, jako wyróżnik kompetencji. Są to propozycje: Bralczyka („doświadczenie”), Czerepaniak-Walczak („szczególna właściwość, wyrażająca się w demonstrowaniu”) oraz Parlamentu Europejskiego („postawy odpowiednie do sytuacji”). Znaczeniowo nie wyczerpują one znamion pozostałych propozycji - można przecież podjąć działania nieświadomie, nieodpowiedzialnie, nierozumnie i wbrew własnemu przekonaniu.

Kolejne próby nazwania składnika odróżniającego kompetencje od kwalifikacji koncentrują się na potencjalnych właściwościach kompetent- 
nego podmiotu, wyrażających jego stosunek do ewentualnego działania: „odpowiedzialność”, „świadomość potrzeby i konsekwencji”, „rozumienie oraz pragnienie", nie przesądzając, czy odpowiednie działanie zostało podjęte, czy też nie. Innymi słowy, można w sposób odpowiedzialny mieć świadomość potrzeby i konsekwencji stosowania technologii informatycznej, wyrażający się rozumieniem i pragnieniem jej użycia, a mimo wszystko napotykać na ograniczenia (wewnętrzne bądź zewnętrzne), które skutkują niepodjęciem kompetentnych działań. Można bowiem być odpowiedzialnym i zaniechać wykorzystania komputera, podejrzewając np. nielegalność jego oprogramowania, można być świadomym potrzeb i konsekwencji ale jednocześnie leniwym, można rozumieć i pragnąć wykorzystywać sprzęt komputerowy, którym szkoła jednak nie dysponuje.

Dla ujednolicenia wymienionych tutaj definicji pojęcia kompetencji zasadnym będzie ujęcie trzeciego składnika (oprócz wiedzy i umiejętności) w dwie kategorie: bierną (dyspozycje kompetentnego podmiotu), do której zaliczyć możemy: „odpowiedzialność”, „świadomość potrzeby i konsekwencji”, „rozumienie oraz pragnienie” (w odniesieniu do zastosowania w praktyce wiedzy i umiejętności); oraz drugą kategorię - czynną (wymagającą wykazania się działaniem opartym na wiedzy i umiejętnościach), do której zaliczyć należy: „doświadczenie”, „szczególną właściwość, wyrażającą się w demonstrowaniu” oraz „postawy odpowiednie do sytuacji”. Ponieważ nie jest zadaniem niniejszej pracy rozstrzygnięcie który z autorów proponowanych definicji ma rację, a który nie, pozostaje stwierdzić, że chcąc pogodzić stanowiska wszystkich, kompromisowa definicja kompetencji zawierać powinna oprócz wiedzy i umiejętności składnik formułowany zarówno jako dyspozycja (kategoria bierna), jak i działanie (kategoria czynna).

Dla wygody kolejnych rozważań pozostaje jedynie nazwać ów trzeci składnik kompetencji wspólnym określeniem, pod którym w dalszym ciągu rozumieć będziemy zarówno jego część bierną: rozumienie i pragnienie, świadomość potrzeby i konsekwencji takiego właśnie zachowania oraz przyjmowanie na siebie odpowiedzialności za nie, jak i część czynną: doświadczenie, demonstrowanie czy postawę odpowiednią do sytuacji. Część czynną zwięźle nazwać można „działaniem”, w czym mieści się doświadczenie (jako wynik działania), demonstrowanie i odpowiednia do sytuacji postawa (polegająca właśnie na działaniu a nie jego zaniechaniu). Część bierna skupia się na tym, by owo działanie było odpowiedzialne - musi bowiem wtedy być świadome, rozumne i wynikać z potrzeby działające- 
go. Działamy odpowiedzialnie wtedy, gdy mamy uświadomioną, opartą na wiedzy potrzebę takiego działania. Sumując powyższe syntezy obu części (biernej i czynnej) rozpatrywanego składnika pojęcia kompetencji otrzymamy określenie „odpowiedzialne działanie”.

Uwzględniając powyższe rozważania próba definicji pojęcia kompetencji, w kompromisowy sposób łącząca w sobie wszystkie omawiane w tym rozdziale propozycje, łączy w sobie trzy elementy: wiedzę, umiejętności oraz odpowiedzialne działanie. Pod tym ostatnim elementem oczywiście rozumieć będziemy wszystkie rozpatrywane wyżej określenia, przyjmując ich prawdziwość (mimo ich jednostkowego niewyczerpującego zakresu), nie pretendując tym samym do autorstwa nowej definicji, a jedynie syntetyzując znane dotychczas, do formy pozwalającej na jej czytelne używanie w dalszych rozważaniach.

\subsection{Pojęcie kompetencji informatycznych nauczyciela}

Wielość publikacji na temat kompetencji nauczyciela, szczególnie w dobie ogromnej dominacji mediów elektronicznych i informatycznych, nie przekłada się na jednoznaczność czy trwałość rozwiązańn ${ }^{35}$. Wiele z propozycji dotyczących kompetencji informatycznych, ujmuje je jako znajomość terminologii informatycznej, zestawu programów komputerowych, umiejętność korzystania $\mathrm{z}$ internetu, technicznej obsługi sprzętu komputerowego itp. Jednak dla dalszych rozważań za punkt wyjścia uznać należy ustalenia związane z samym terminem kompetencji, nie ograniczając ich do znajomości zestawu konkretnych narzędzi.

Korzystając zatem ze sformułowanej w poprzednim rozdziale definicji kompetencji, mianem kompetencji informatycznych (informacyjnych bądź informacyjno-komunikacyjnych) należy określić „harmonijną kompozycję" wiedzy informatycznej, umiejętności sprawnego posługiwania się nią oraz odpowiedzialnego działania czyli wykorzystywania w sytuacjach dydaktycznych. Oczywiste, że zakres - szczególnie wiedzy i umiejętności -

\footnotetext{
${ }^{35}$ Por. m.in.: W. Jabłoński, J. Wacławiak, S. Wszelak, Komputer i Internet w pracy nauczyciela, Toruń, 2003; E. Kobyłecka, E. Kozioł (red.), W poszukiwaniu wyznaczników kompetencji nauczyciela XXI wieku, Zielona Góra, 2002; M. Michalewska, P. Kowolik (red.), Kompetencje nauczycieli w reformowanej szkole, Katowice, 2003; J. Migdałek, M. Zając (red.), Informatyczne przygotowanie nauczycieli: kompetencje i standardy kształcenia, Kraków, 2006; W. Osmańska-Furmanek, Nowe technologie informacyjne w edukacji, Zielona Góra, 1999; R. Pachociński, Technologia a oświata, Warszawa, 2002; A. Serdyński, Kompetencje informatyczno-medialne nauczyciela, Szczecin, 2007; A. Aftański, Kompetencje informatyczne i moralne nauczycieli $-w$ dobie budowy społeczeństwa infor macyjnego, „Kultura i Edukacja” 2004, nr 1, s. 78-86.
} 
zależeć musi od konieczności jej zastosowania i będzie różny choćby w odniesieniu do nauczycieli informatyki oraz nauczycieli innych przedmiotów. Niezbędny (wymagany) poziom kompetencji określają standardy kompetencji, formułowane w odniesieniu do konkretnej sytuacji zawodowej. Istniejące standardy kompetencji informatycznych w odniesieniu do nauczycieli sugerują, że kompetencje są stopniowalne, a więc można mieć mniejsze lub większe kompetencje, oraz - co ważniejsze - kompetencje mogą rosnąć bądź maleć. Oczywiście zmiana taka dotyczy obu stron: zarówno kompetencji wymaganych, określanych aktami prawnymi, jak i kompetencji nabywanych przez adresatów takich aktów.

Jeśli zatem połączymy niezbędny zasób wiedzy informatycznej i umiejętności sprawnego posługiwania się narzędziami informatycznymi oraz wzbogacimy je o składnik nazwany wcześniej odpowiedzialnym działaniem, pod którym kryć się będzie rozumienie i pragnienie, postawa odpowiednia do sytuacji, demonstrowanie, doświadczenie, świadomość potrzeby i konsekwencji odpowiedniego zachowania oraz przyjmowanie na siebie odpowiedzialności za nie, to możemy uznać takie zestawienie za opis kompetencji nauczyciela w zakresie technologii informatycznej, w rozumieniu, jakie przyjęliśmy w rozdziale 2.1 .

Sprawą drugorzędną dla niniejszych rozważań jest zakwalifikowanie kompetencji informatycznych nauczyciela (w tym nauczyciela muzyki) do konkretnej kategorii kompetencji. Poprzestańmy tylko na stwierdzeniu, iż mieszczą się one w kompetencjach dydaktyczno-metodycznych, nie rozstrzygając o ich ważności, a więc ich ewentualnej przynależności do grupy kompetencji w różnych źródłach nazywanych kluczowymi, niezbędnymi, koniecznymi, bazowymi itd. Ważniejsze z punktu widzenia tematu niniejszej pracy jest ustalenie, czy współczesny nauczyciel muzyki posiada kompetencje informatyczne.

Przyjęliśmy, że kompetencje to harmonijna kompozycja wiedzy, umiejętności oraz składnika, który dla zwięzłości definicji nazwaliśmy odpowiedzialnym działaniem. To, co przyszły nauczyciel opanowuje na zajęciach $\mathrm{z}$ technologii informacyjnej, czy też w ramach samokształcenia to wciąż w ogromnej większości wiedza i umiejętności. Można powiedzieć - zaledwie wiedza i umiejętności. Pozostałe składniki kompetencji, a więc „rozumienie i pragnienie, odpowiednia postawa, świadomość potrzeby i konsekwencji oraz odpowiedzialność" zastosowania TI w procesie edukacyjnym nie znajdują potwierdzenia swojej wagi w programach nauczania przy- 
szłych nauczycieli, rzadko też bywa wynikiem samokształcenia. Oznacza to, że wiedza i umiejętności, w które przyszły nauczyciel jest wyposażony, to zaledwie kwalifikacje i dopiero uświadomienie sobie i zrozumienie konieczności zastosowania technologii informacyjno-komunikacyjnej skutkuje zaistnieniem „pragnienia świadomego i odpowiedzialnego” zastosowania jej w działaniach edukacyjnych. Pomijając zatem w tym miejscu problem zasadności włączenia języka nowoczesnych mediów do edukacji młodego człowieka należy zauważyć, że słaby stopień informatyzacji metod nauczania wynika nie z braku kwalifikacji a z braku szeroko rozumianych kompetencji informatycznych nauczycieli. W głębszej zaś warstwie, przyczyn tego stanu rzeczy należy upatrywać w niejednoznacznym, a czasem wręcz błędnym rozumieniu samego pojęcia kompetencji.

Składnik nazwany odpowiedzialnym działaniem w przypadku kompetencji informatycznych posiada wyjątkową wagę. Ze względu na niespotykaną w innych dziedzinach dynamikę rozwoju technologii informacyjno-komunikacyjnej, wiedza i umiejętności w tym zakresie ulegają szczególnie szybkiej dezaktualizacji. Dlatego niezbędna jest ciągła aktualizacja i przystosowywanie posiadanych kwalifikacji informatycznych do sytuacji nowych, nieznanych wcześniej, niemożliwych do przewidzenia w toku edukacji instytucjonalnej. Takie podejście wymaga natomiast głębokiej motywacji, zgodnie z przytoczonymi wcześniej definicjami pojęcia kompetencji „rozumienia i pragnienia, odpowiedniej postawy, świadomości potrzeby i konsekwencji oraz odpowiedzialności".

\subsection{Stan badań nad kompetencjami informatycznymi nauczycieli muzyki}

W ostatniej dekadzie dokonano wielu badań kompetencji informatycznych nauczycieli, wszystkie jednak mają wycinkowy charakter, najczęściej ograniczony przez kryterium terytorialne ${ }^{36}$. Na terenie wielu województw, w tym województwa łódzkiego, przeprowadzono badania dotyczące wykorzystania technologii informacyjno-komunikacyjnej w procesie edukacyjnym w roku $2008^{37}$. Badaniem objęto 291 szkół województwa łódzkiego

\footnotetext{
${ }^{36}$ Wiele takich badań dokonano w ramach Programu Operacyjnego Kapitał Ludzki - Priorytet IV: Szkolnictwo wyższe i nauka.

${ }^{37}$ P. Patora (opr.), Raport z badania realizacji priorytetu MEN „Ocena jakości pracy szkoły w zakresie informatyzacji procesu edukacyjnego - zastosowanie technologii informacyjnej i komunikacyjnej” w województwie łódzkim; źródło: http://www.kuratorium.lodz.pl/data/other/raport_2.pdf (stan z dnia 22.01.2010).
} 
różnego typu (szkoły podstawowe, gimnazja, licea ogólnokształcące, licea profilowane, technika, zasadnicze szkoły zawodowe oraz szkoły policealne) i dotyczyło pierwszego semestru roku szkolnego 2007/2008. Z badań tych wynika, że wykorzystanie technologii informacyjno-komunikacyjnej w ramach przedmiotów nieinformatycznych oscyluje w granicach $3 \%{ }^{38}$, natomiast lekcje muzyki w szkołach podstawowych w $3,2 \%$ przeprowadzone były w pracowni komputerowej a 5,2\% z użyciem mobilnego zestawu multimedialnego (laptop i projektor) ${ }^{39}$. Taki wynik niekoniecznie świadczyć musi o miernym poziomie wiedzy i umiejętności nauczycieli w zakresie $\mathrm{TI}^{40}$. Te przecież od wielu lat wchodzą w skład standardów kształcenia przyszłych nauczycieli, co w połączeniu z dominującą wciąż nieformalną drogą zdobywania umiejętności w tym zakresie, każe szukać przyczyn tak niskiego wyniku badań w innych niż stopień opanowania TI przez nauczycieli obszarach. Potwierdzają to zdanie dane, według których $84 \%$ nauczycieli szkół podstawowych województwa łódzkiego posiada umiejętności informatyczne ${ }^{41}$. Ważnym wskaźnikiem jest również procent szkół, w których dyrektor ujmuje w planie nadzoru wykorzystanie technologii informacyjnej i komunikacyjnej przez nauczycieli (dla szkół podstawowych wskaźnik ten wynosi $86 \%)^{42}$.

Badania kompetencji informatycznych nauczycieli stanowią również temat dwóch publikacji Barbary Kędzierskiej ${ }^{43}$. Dotyczą one badań przeprowadzonych w odstępie siedmiu lat (1996-2003), co daje podstawę do porównań obu stanów oraz „oceny tempa wprowadzania nowoczesnych technologii w szkole, która w opinii wielu uważana jest za środowisko, do którego wszystkie wynalazki techniczne trafiają na samym końcu społecznego łańcucha" 44 .

We wstępie wcześniejszej z publikacji autorka deklaruje, że „głównym celem badań było sprawdzenie czy aktualny sposób i zakres informatycznego kształcenia i doskonalenia nauczycieli kształtuje kompetencje, dzięki którym nauczyciele będą w stanie wprowadzić uczniów w świat techno-

\footnotetext{
${ }^{38}$ Ibidem, s. $14-15$.

${ }^{39}$ Ibidem, s. 17.

${ }^{40} \mathrm{TI}$ - Technologia Informacyjna - termin stosowany zamiennie z TIK. Por.: rozdział 1. przypis 5.

${ }^{41}$ P. Patora (opr.), Raport $z$ badania realizacji priorytetu MEN..., s. 8.

${ }^{42}$ Ibidem, s. 28.

${ }^{43}$ B. Kędzierska, Informatyczne kształcenie i doskonalenie nauczycieli, Kraków 2005; [oraz:] eadem, Kompetencje informatyczne $w$ kształceniu ustawicznym, Warszawa 2007.

${ }^{44}$ B. Kędzierska, Kompetencje informatyczne..., s. 178.
} 
logii informacyjno-komunikacyjnych i przygotować ich do umiejętnego wykorzystania nowoczesnych narzędzi w zdobywaniu wiedzy, inspirując ich jednocześnie do twórczych działań, samorealizacji i samorozwoju”45. Badania zostały wykonane w latach 1996-1997, w szkołach podstawowych oraz średnich Polski południowej, Wyższej Szkole Pedagogicznej w Krakowie oraz Wojewódzkim Ośrodku Metodycznym w Krakowie. Nauczyciele muzyki stanowili 2\% ogółu 224 badanych nauczycieli szkół podstawowych i średnich. Aż jedna trzecia badanych stwierdziła, że nie posiada żadnej wiedzy „na temat komputera i jego możliwości”46, a co dziesiąty respondent uważał wiedzę informatyczną za niepotrzebną w pracy pedagogicznej ${ }^{47}$. Ciekawe jest zestawienie wypowiedzi uczniów z zacytowanymi wcześniej wynikami badań szkół województwa łódzkiego w zakresie wykorzystania metod i technik komputerowych na lekcjach innych niż informatyka. Z danych uzyskanych od uczniów szkół podstawowych i średnich Polski południowej wynika, że 3\% z nich spotkało się w szkole z taką praktyką, co pozornie jest zaskakująco zbieżne $z$ wynikami dotyczącymi województwa łódzkiego ${ }^{48}$. Pozornie - ponieważ trzyprocentowy wynik uzyskany w łódzkich badaniach dotyczył deklaracji nauczycieli na temat ilości zajęć nieinformatycznych, przeprowadzonych z udziałem TIK. A więc statystycznie ujmując blisko 100\% uczniów łódzkich szkół miało kontakt z TIK na 3\% zajęć nieinformatycznych, a tylko 3\% badanych uczniów szkół Polski południowej spotkało się z podobną praktyką. Rozdźwięk taki może być jednak skutkiem doboru innej grupy respondentów - lepszy wynik łódzkich szkół wynikał bowiem z odpowiedzi nauczycieli, zaś dramatycznie niski wskaźnik w szkołach Polski południowej wynikał z odpowiedzi uczniów. Tendencja do dowartościowania się nauczycieli spotkać się tu mogła z tendencją do obniżonego obrazu kompetencji informatycznych nauczycieli w oczach uczniów.

Taki dobór respondentów mógł również skutkować dużymi rozbieżnościami wyników przy faktycznie zbliżonym modelu korzystania z TIK przez nauczycieli obu regionów. Jeśli bowiem z łódzkich badań wynika ponadtrzyprocentowy wskaźnik opisujący ilość lekcji muzyki przeprowadzonych w pracowni komputerowej, to oznacza, przy równomiernym rozkła-

\footnotetext{
${ }^{45}$ B. Kędzierska, Informatyczne kształcenie i doskonalenie..., s. 7.

${ }^{46}$ Ibidem, s. 86.

${ }^{47}$ Ibidem, s. 87.

${ }^{48}$ Por. odesłanie do przypisu 38.
} 
dzie, ok. 1 lekcję w roku przeprowadzoną w pracowni komputerowej przez wszystkich nauczycieli muzyki. Jeśli natomiast przyjąć rozkład najmniej zrównoważony, to jeden nauczyciel, który wszystkie lekcje muzyki prowadziłby w pracowni komputerowej "pracuje” statystycznie na 30 innych, którzy technologii informacyjnej na swoich zajęciach w ogóle nie wykorzystują. W takim przypadku również wynikałby wskaźnik 3\% uczniów szkół Polski południowej, którzy zetknęli się z TIK na zajęciach nieinformatycznych, przy czym owo „zetknięcie” byłoby bardzo intensywne, bo stuprocentowe.

Omawiane badania Barbary Kędzierskiej nie różnicują wyników dotyczących kompetencji informatycznych nauczycieli czy też korzystania z TIK w zależności od nauczanego przedmiotu, jednak zawierają interesujące zestawienie programów nauczania przedmiotów informatycznych na poszczególnych kierunkach Wyższych Szkół Pedagogicznych w Kielcach, Krakowie, Rzeszowie i Słupsku. Porównując programy nauczania przedmiotów informatycznych na kierunku Wychowanie muzyczne czterech wymienionych uczelni ${ }^{49}$ możemy zauważyć, że najmniejszą wagę do kompetencji informatycznych przyszłych nauczycieli wychowania muzycznego przykłada się WSP w Kielcach i WSP w Krakowie. Na obu uczelniach na przedmiot informatyczny przeznaczono mniej niż 30 godzin a ich program ogranicza się do alfabetyzacji komputerowej (WSP w Kielcach) lub korzystania z oprogramowania użytkowego (WSP w Krakowie). Uczelnie w Rzeszowie i Słupsku natomiast już w 1996 roku włączyły do programów nauczania sposoby wykorzystania komputera w nauczaniu muzyki, przeznaczając na ten cel odpowiednio: między 60 a 120 godzin (WSP w Rzeszowie) oraz między 30 a 60 godzin dydaktycznych (WSP w Słupsku).

Asumptem do podjęcia przez Barbarę Kędzierską kolejnych (po siedmioletniej przerwie) badań była opinia nauczycieli uczestniczących w warsztatach informatyczno-metodycznych, z których autorka wywnioskowała, że „W nauczaniu poszczególnych przedmiotów nieinformatycznych [...] ciągle jeszcze komputerowe systemy multimedialne wykorzystywane są sporadycznie" ${ }^{50}$ oraz, że "opóźnia się proces włączania nowoczesnych środków dydaktycznych w proces kształcenia i doskonalenia" ${ }^{51}$. W badaniach uczestniczyli nauczyciele szkół podstawowych, gimnazjalnych, ponadgim-

\footnotetext{
${ }^{49}$ Ibidem, s. 118. Należy pamiętać, że badania odzwierciedlają stan z 1997 roku.

${ }^{50}$ B. Kędzierska, Kompetencje informatyczne..., s. 178.

${ }^{51}$ Ibidem.
} 
nazjalnych oraz uczelni pedagogicznych a także studenci tychże uczelni w sumie 1686 osób.

Wyłaniający się obraz pozytywnej zmiany w częstotliwości wykorzystywania narzędzi informatycznych widoczny jest głównie w grupach nauczycieli czynnych zawodowo, którzy, według wyników badań, częściej sięgają do komputera niż studenci uczelni pedagogicznych. Także „potwierdzeniem rosnącej roli narzędzi informacyjno-komunikacyjnych jest radykalnie malejąca liczba nauczycieli niekorzystających z komputera - dzisiaj jest ich zaledwie $4,6 \%$, podczas gdy w ostatnich latach ubiegłego dziesięciolecia blisko połowa ankietowanych nie przyznawała się do wspierania swoich działań tymi narzędziami" ${ }^{2}$. Niestety, z badań nie wynika ocena nauczycieli muzyki w tym zakresie - jedyne przypadki podziału na specjalności, jakie znajdujemy w badaniach Kędzierskiej dotyczą studentów. I tak dowiadujemy się, że studenci wychowania artystycznego ${ }^{53}$ mają we własnej opinii zdecydowanie najsłabsze kompetencje $\mathrm{w}$ zakresie technologii informacyjnej, wyniki studentów pedagogiki - choć nieco lepsze - należą również do najsłabszych spośród 13 badanych specjalności ${ }^{54}$. Budzi również niepokój, iż studenci wychowania artystycznego deklarują brak w planach studiów przedmiotu dotyczącego zastosowań komputera w nauczaniu przedmiotu kierunkowego ${ }^{55}$, ograniczając się jedynie do poznania programów użytkowych.

W pozostałych zestawieniach wyników badań Kędzierskiej nie pojawia się osobna grupa przyszłych lub aktualnych nauczycieli muzyki czy przedmiotów estetycznych. Autorka, badając kompetencje informatyczne, skupiła swoją uwagę na trzech grupach reprezentujących trzy szczeble kunsztu pedagogicznego: studenci kierunków pedagogicznych, czynni zawodowo nauczyciele oraz wykładowcy uczelni pedagogicznych. Takie rozgraniczenie - charakterystyczne dla większości prac dotyczących kompetencji informatycznych nauczycieli - nie pozwala na prostą paralelę z niniejszą pracą, skoncentrowaną na czynnych zawodowo nauczycielach jednej tylko specjalności.

\footnotetext{
52 Ibidem, s. 191. Należy pamiętać, że „dzisiaj” oznacza stan z 2003 roku, a porównanie dotyczy obydwu badań autorki - z 1996 oraz 2003 roku.

${ }^{53}$ Autorka nie precyzuje specjalności ani kierunku studiów, używając zamiennie przymiotnika „artystyczne” bądź skrótu „wych. art.” w odniesieniu do „kierunków i dziedzin”; [por.:] ibidem, s. 202, 206, 227.

${ }^{54}$ Ibidem, s. 206.

${ }^{55}$ Ibidem, s. 227.
} 
Tematu kompetencji informatycznych nauczycieli różnych typów szkół oraz studentów uczelni pedagogicznych dotyczy kilka niepublikowanych doktoratów: Ryszarda Błaszkiewicza Kompetencje informatyczne nauczycieli w reformowanej szkole (2003), Arkadiusza Wąsińskiego Poziom kultury informatycznej nauczycieli szkół podstawowych (2001), Roberta Lisa Wiedza i sprawności informatyczne nauczycieli w szkolnictwie zawodowym (1999), Rafała Kołodziejczyka Wiedza i umiejętności informatyczne studentów pierwszego roku uczelni pedagogicznych (2008) oraz Magdaleny Andrzejewskiej Procedury awansu zawodowego a poziom kompetencji informacyjno-komunikacyjnych nauczycieli (2007). Zakres ich jednak wykracza daleko poza nakreślony tutaj obszar zarówno specjalnościowy (nauczyciele muzyki szkół podstawowych), jak i terytorialny (łódzkie szkoły podstawowe). Zakres przedmiotowy wymienionych badań mimo podobieństwa tytułów również odbiega od niniejszej pracy i skupia się przede wszystkim na wiedzy i umiejętnościach nauczycieli w zakresie znajomości budowy komputerów czy stosowania pakietu programów biurowych Microsoft Office ${ }^{56}$, co w niewielkim stopniu przekłada się na umiejętność zastosowania TIK w dydaktyce własnego przedmiotu, w szczególności przedmiotu muzyka.

Ponadto istnieje dużo opracowań pobieżnych i wycinkowych, dotyczących stosunku nauczycieli do TIK, wykorzystania TIK na różnych zajęciach (bez podziału na przedmioty), bądź dotyczących wąskiego terenu, jednej lub kilku szkół, a także opinie studentów kierunków pedagogicznych, ankiety internetowe itp.

\subsection{Postulowany zakres kompetencji informatycznych nauczyciela muzyki w świetle dokumentów}

Przygotowanie informatyczne nauczycieli jest dziś niezbędnym składnikiem jego wykształcenia. Mówią o tym wszystkie aktualnie obowiązujące dokumenty bądź projekty dokumentów, opisujące zadania czy sylwetkę nauczyciela w sposób bezpośredni (od Standardów kształcenia nauczycieli57, przez Standardy przygotowania nauczycieli w zakresie technologii informa-

\footnotetext{
${ }^{56}$ Taka tematyka charakterystyczna jest dla wielu publikacji (szczególnie wczesnych), dotykających podstawowych zastosowań TI w dydaktyce różnych przedmiotów. [Por.] np.: M. Tanaś, Edukacyjne zastosowania komputerów, Warszawa, 1997; Siemieniecki B., Komputer w edukacji. Podstawowe problemy technologii informacyjnej, Toruń, 2002;

${ }^{57}$ Rozporządzenie Ministra Edukacji Narodowej i Sportu z dnia 7 września 2004 r. w sprawie standardów kształcenia nauczycieli, Dz.U. z 2004 r., Nr 207, poz. 2110.
} 
cyjnej $^{58}$, warunki awansu zawodowego nauczycieli aż do dokumentów europejskich, określających postulowaną sylwetkę współczesnego nauczyciela w Unii Europejskiej) a także w sposób pośredni, formułując standardy wykształcenia uczniów (jak Podstawa programowa kształcenia ogólnego ${ }^{59}$ czy Standardy edukacji kulturalnej).

\subsubsection{Standardy przygotowania nauczycieli w zakresie technologii informacyjnej $i$ informatyki}

Najpełniej kompetencje informatyczne nauczyciela opisują w Standardy przygotowania nauczycieli $w$ zakresie technologii informacyjnej i informaty$k i$, opracowane przez Radę ds. Edukacji Informatycznej i Medialnej przy Ministrze Edukacji i Sportu, w sierpniu 2003 roku, w zgodzie z wymaganiami Podstawy programowej ${ }^{60}$. Określono tam cztery zakresy omawianych standardów w odniesieniu do czterech kategorii nauczycieli, których dotyczą: każdego nauczyciela, nauczyciela technologii informacyjnej, nauczyciela informatyki oraz szkolnego koordynatora technologii informacyjnej.

W zakresie dotyczącym niniejszej pracy, a więc w standardach przygotowania w zakresie technologii informacyjnej dotyczących każdego nauczyciela, zawarto następujący postulat: „każdy nauczyciel powinien być przygotowany do posługiwania się technologią informacyjną i komunikacyjną w pracy własnej oraz w pracy dydaktycznej z uczniami”. W szczególności zaś powinien posiąść wiedzę i umiejętności z zakresu zastosowań TI w nauczaniu swojego przedmiotu. „Standard takiego przygotowania obejmuje następujące zagadnienia:

- podstawy posługiwania się pojęciami (terminologią), środkami (sprzętem), narzędziami (oprogramowaniem) i metodami TI;

- TI jako składnik warsztatu pracy nauczyciela;

- rola i wykorzystanie TI w dziedzinie nauczanej przez nauczyciela;

- wykorzystywanie TI jako medium dydaktycznego, odpowiednio do nauczanej dziedziny i etapu kształcenia - planowanie i projektowa-

${ }^{58}$ Rada ds. Edukacji Informatycznej i Medialnej, Standardy przygotowania nauczycieli w zakresie technologii informacyjnej i informatyki, Warszawa 2003.

${ }^{59}$ Rozporzadzenie Ministra Edukacji Narodowej z dnia 23 grudnia 2008 r. w sprawie podstawy programowej wychowania przedszkolnego oraz kształcenia ogólnego w poszczególnych typach szkót, Dz.U. z 2009 r., Nr 4, poz. 17.

${ }^{60}$ Rozporzadzenie Ministra Edukacji Narodowej i Sportu z dnia 26 lutego 2002 roku w sprawie podstawy programowej wychowania przedszkolnego oraz kształcenia ogólnego w poszczególnych typach szkół, Dz.U. z 2002 r., $\mathrm{Nr} 51$, poz. 458. 
nie środowiska kształcenia, ewaluacja korzyści i ocenianie osiągnięć uczniów;

- aspekty humanistyczne, etyczno-prawne i społeczne, związane z dostępem do technologii informacyjnej i w korzystaniu $z$ tej technologii" ${ }^{61}$.

Omawiając trzecie z wymienionych zagadnień w rozdziale 3.3. („Rola i wykorzystanie TI w dziedzinie nauczanej przez nauczyciela”), autorzy precyzują postulowany stan opanowania narzędzi informacyjno-komunikacyjnych przez nauczycieli przedmiotów nieinformatycznych. Ważną konstatacją tego podrozdziału jest zauważenie związku pomiędzy znajomością zastosowań czy możliwości integracji technologii informacyjnej z nauczaną dziedziną a motywacją do takiego działania: „Nauczyciel zna i przedstawia najważniejsze zastosowania i wykorzystanie TI w swojej specjalności zawodowej, które mogą stanowić motywację dla integrowania TI z nauczaną dziedziną". Dzięki temu stwierdzeniu dokument każe wykroczyć poza obszar omawiania kwalifikacji i zaczyna dotyczyć kompetencji, w rozumieniu, jakie przyjęliśmy za Czerepaniak-Walczak w rozdziałach 2.1. i 2.2. Potwierdzenie takich intencji autorów znajdujemy w kolejnych podrozdziałach.

Autorzy Standardów... formułują 6 sposobów wykorzystania TI w dziedzinie nauczanej przez nauczyciela przedmiotów nieinformatycznych, składających się na jego postulowane przygotowanie informatyczne we współczesnej szkole - od znajomości edytora tekstu do orientacji w najnowszych trendach rozwoju narzędzi informatycznych wodniesieniu do własnej dziedziny nauczania ${ }^{62}$. Jednak sposób sformułowania tych kryteriów każe rozumieć je - zgodnie z ustaleniami rozdziału 2.1. - jako pożądane kwalifikacje informatyczne nauczyciela. Mówią bowiem jedynie o zakresie wiedzy i umiejętności. Dopiero rozdział „Wykorzystanie TI jako medium dydaktycznego w nauczaniu swojej dziedziny”, według którego „Nauczyciel jest świadomy możliwości tkwiących w TI do wspomagania i wzbogacania uczenia się i nauczania”, przynosi wyszczególnienie kryteriów kompetencji informatycznych (w przyjętym tu rozumieniu), w jakie każdy nauczyciel powinien być wyposażony.

Pierwsze z tych kryteriów określa, że nauczyciel „jest świadomy zmian, jakie wnosi do edukacji TI, zarówno w zakresie i sposobach nauczania, jak

61 [Za:] http://syslo.nq.pl/Edukacja/Dokumenty/Standardy-przygotowania-nauczycieli (stan z dnia 10.05.2012).

${ }^{62}$ Ibidem, rozdział 3.3., Rola i wykorzystanie TI $w$ dziedzinie nauczanej przez nauczyciela. 
i roli nauczyciela”. Takie podejście autorów Standardów... pozwala na wyraźne rozróżnienie kwalifikacji od kompetencji, w jakie powinien być wyposażony współczesny nauczyciel. To ogólne stwierdzenie jest dalej rozwinięte w 14 punktach (od 3.4.1. do 3.4.14.). Te 14 punktów stanowi kwintesencję całego dokumentu w odniesieniu do nauczyciela przedmiotów nieinformatycznych oraz jasną definicję zakresu kompetencji informatyczno-komunikacyjnych współczesnego nauczyciela - w tym m.in. nauczyciela muzyki.

$\mathrm{Na}$ wstępie takiego wyliczenia podkreślone są 3 elementy: świadomość możliwości tkwiących w TI, świadomość korzyści jej zastosowania oraz korzystanie z TI podczas zajęć („Nauczyciel jest świadomy możliwości tkwiących w TI do wspomagania i wzbogacania uczenia się i nauczania. Jeśli przynosi to korzyści uczniom, korzysta wraz z nimi z pomocy TI podczas zajęć, odpowiednio do poziomu i zakresu przewidzianego w Podstawie programowej i programie nauczania" ${ }^{33}$.) Wszystkie one wchodzą w skład przyjętego w rozdziale 2.1. trzeciego składnika kompetencji, zarówno jego części „Czynnej”, jak i „biernej”.

W omawianych 14 punktach ważne jest rozgraniczenie tych, które dotyczą kwalifikacji i tych, które wychodząc poza nie, dotykają problemu kompetencji. W zakresie kwalifikacji dokument postuluje m.in.:

- znajomość zakresu uwzględnienia TI w podstawie programowej swojej dziedziny nauczania;

- umiejętność projektowania zajęć z wykorzystaniem TI;

- znajomość metodycznych zasad posługiwania się TI;

- znajomość niezbędnego wyposażenia;

- znajomość oprogramowania edukacyjnego i zasobów edukacyjnych, takich jak: gry edukacyjne, strony www, listy i grupy dyskusyjne w swojej dziedzinie nauczania;

- znajomość przykładów dobrej praktyki;

- znajomość aktualnej literatury z tego zakresu.

Punkty, dotyczące trzeciego składnika kompetencji postulują m.in.:

- świadomość konsekwencji (korzyści) stosowania TI;

- stosowanie TI zgodnie z zasadami metodycznymi;

- posługiwanie się narzędziami TI w nauczaniu;

- stosowanie oprogramowania edukacyjnego i zasobów edukacyjnych;

- chęć doskonalenia;

- świadomy wybór narzędzi i metod.

\footnotetext{
${ }^{63}$ Ibidem, rozdział 3.4 .
} 
Wszystkie zacytowane wyżej punkty opisują zakres pożądanych kompetencji nauczyciela w zakresie TI. Kompetencji a nie kwalifikacji w rozumieniu, jakie przyjęliśmy za Czerepaniak-Walczak w rozdziale 2.1. Oprócz bowiem elementów wskazujących na pożądaną wiedzę i umiejętności z zakresu technologii informacyjno-komunikacyjnej, wymienione są tu składniki kompetencji utożsamiane ze świadomością oraz pragnieniem jej stosowania. Zgodnie z konstatacją o stopniowalności kompetencji ${ }^{64}$ należy również przyjąć, że spełnienie choćby części z powyższych punktów pozwala uznać nauczyciela za kompetentnego w mniejszym bądź większym stopniu w dziedzinie TI.

Należy również zauważyć, że wszystkie wymienione elementy mają według intencji autorów - dotyczyć „swojej dziedziny nauczania”. Jest to z jednej strony oczywiste, z drugiej zaś każe zauważyć, że edukacja informatyczna realizowana na studiach nauczycielskich rzadko zakłada takie specjalnościowe podejście, co jednak będzie tematem kolejnych rozdziałów (2.5.1.-2.5.3.).

Stanowisko Rady ds. Edukacji Informatycznej i Medialnej przy Ministrze Edukacji i Sportu ewoluowało podobnie jak jej nazwa. Od 25 stycznia 2012 roku nowym organem pomocniczym Ministra Edukacji Narodowej jest Rada do Spraw Informatyzacji Edukacji, której skład, łącznie z przewodniczącym, w dużej części pozostał bez zmian. Propozycje nowej Rady odnośnie kompetencji informatycznych nauczycieli nie zostały jeszcze ujęte przez autorów w formie upublicznionej, najnowszy więc dokument $\mathrm{w}$ tej sprawie $^{65}$ pochodzi z 2010 roku i jest autorstwa Rady ds. Edukacji Informatycznej i Medialnej powołanej w czerwcu 2008 roku. Dokument nosi tytuł Kierunki działań w zakresie nauczania dzieci i młodzieży oraz funkcjonowania szkoły w społeczeństwie informacyjnym, a ponieważ został opublikowany już w trakcie trwania opisywanych tu badań, warto dla aktualnego oglądu sprawy oraz uchwycenia ewolucji stanowiska Rady przytoczyć jego najważniejsze wnioski.

Dokument ten poświęca podrozdział 6.3.1. zagadnieniu standardów przygotowania nauczycieli ${ }^{66}$. Odnosząc się do Standardów... z 2003 roku

\footnotetext{
${ }^{64}$ Rozdział 1.2. niniejszej pracy.

${ }^{65}$ Rada ds. Edukacji Informatycznej i Medialnej przy Ministrze Edukacji Narodowej, Kierunki działań $w$ zakresie nauczania dzieci i młodzieży oraz funkcjonowania szkoły w społeczeństwie informacyjnym. Nowe technologie w edukacji, Warszawa 2010; idem: Dodatki do Kierunków działań dotyczacych nauczania dzieci i młodzieży oraz funkcjonowania szkoły w społeczeństwie informacyjnym. Nowe technologie w edukacji, Warszawa 2009.

${ }^{66}$ Ibidem, Kierunki działań..., s. 32.
} 
Rada stwierdza, że niezbędne jest ich uaktualnienie, które uwzględniać powinno: nowe rozwiązania technologiczne (m.in. tablice interaktywne czy urządzenia mobilne), nowe środowiska kształcenia (m.in. platformy edukacyjne), większy udział podejścia konstruktywistycznego w metodyce oraz wzrost kompetencji informatycznych samych nauczycieli, który zawdzięczać należy powszechnym kursom i szkoleniom a także uwzględnieniu takich kompetencji w programach studiów nauczycielskich. Rada postuluje przyjęcie przez siebie tak zmodyfikowanych standardów (sic!) oraz zwiększenie ich rangi przez zapewnienie obowiązkowości i egzekwowalności. Ostatnim postulatem Rady na temat kompetencji informatycznych nauczycieli jest „utworzenie systemu certyfikowania umiejętności nauczycieli w zakresie technologii informacyjno-komunikacyjnych i informatyki. Istniejący np. certyfikat umiejętności komputerowych (ECDL) nie jest tutaj wystarczającym rozwiązaniem, gdyż nie uwzględnia sfery dydaktycznej i pedagogicznej" ${ }^{67}$. Takie rozwiązanie niewątpliwie ułatwiłoby identyfikację problemu braku kompetencji informatycznych wśród nauczycieli, ujmując je w sztywne i jasno określone ramy, nie pozostawiające dowolności w osądzie samych nauczycieli na temat własnych kompetencji oraz potrzeby ich poszerzania. Na tym kończy się tematyka standardów kompetencji informatycznych nauczycieli, która zajmuje niecałe pół strony w 40-stronicowym dokumencie. Pozostaje zatem czekać na nową, zmodyfikowaną zgodnie z postulatami Rady, wersję standardów.

Pozostałe z wymienionych na początku rozdziału dokumentów dotyczą szerszej problematyki przygotowania nauczycieli, stąd samo przygotowanie informatyczne jest w nich omawiane daleko bardziej lakonicznie i fragmentarycznie.

\subsubsection{Standardy kształcenia nauczycieli}

Z pozostałych dokumentów najpełniej problem kwalifikacji bądź kompetencji informatycznych nauczyciela opisują standardy kształcenia nauczycieli, które zawierają się w kilku dokumentach: Standardy kształcenia nauczycieli na studiach wyższych zawodowych, uzupetniajacych studiach magisterskich, jednolitych studiach magisterskich oraz studiach podyplomowych zawarte w Załączniku do Rozporządzeniu Ministra Edukacji Narodowej i Sportu z dnia 7 września 2004 roku, projekt Standardów kształce-

\footnotetext{
${ }^{67}$ Ibidem.
} 
nia przygotowujacego do wykonywania zawodu nauczyciela $\mathrm{z}$ dnia 15 lutego 2007 roku, przygotowany przez Radę Główną Szkolnictwa Wyższego, oraz Standardy kształcenia nauczycieli w kolegiach nauczycielskich i nauczycielskich kolegiach języków obcych zawarte w Rozporządzeniu Ministra Edukacji Narodowej z dnia 30 czerwca 2006 roku. Z końcem lutego 2012 roku zaczęły obowiązywać nowe Standardy kształcenia przygotowującego do wykonywania zawodu nauczyciela, ogłoszone 17 stycznia 2012 roku w Rozporządzeniu Ministra Nauki i Szkolnictwa Wyższego w sprawie standardów kształcenia przygotowującego do wykonywania zawodu nauczyciela ${ }^{68}$. Ustalenia tego najnowszego dokumentu, mimo jego ogłoszenia niemal rok po wykonaniu omawianych w niniejszej pracy badań, nie mogą zostać tu pominięte. Ukazują bowiem wraz z poprzedzającymi najnowsze rozporządzenie Standardami kształcenia... z 2004 roku oraz projektem Standardów kształcenia... z 2007 roku, logiczny ciąg, ukazujący kierunki zmian, jakie ustawodawca uznał za niezbędne w kompetencjach nauczyciela. W tym kontekście ważne będzie prześledzenie drogi ewolucji, jaką wyznaczono na mocy wymienionych dokumentów dla kompetencji informatycznych przyszłego nauczyciela.

Najstarsze, ale obowiązujące wciąż studentów i absolwentów, którzy podjęli studia przed 2012 rokiem Standardy kształcenia nauczycieli... z 2004 roku, w rozdziale I (Wymagania ogólne), w punkcie 6. deklarują, że „Specjalizacja nauczycielska [...] obejmuje: [...] kształcenie w zakresie technologii informacyjnej - przygotowujące do posługiwania się technologią informacyjną, w tym jej wykorzystywania w nauczaniu przedmiotu (prowadzeniu zajęć)"'69. Rozporządzenie to zatem sugeruje, że kształcenie nauczycieli w zakresie TI powinno zawierać elementy metodyki wykorzystania jej w nauczaniu poszczególnych przedmiotów (w tym muzyki), a nie ograniczać się tylko do podstaw budowy i obsługi komputera czy działania programów z tzw. pakietu biurowego. Ten sam postulat zawarty jest w rozdziale II omawianego dokumentu, pt. Sylwetka absolwenta oraz w rozdziale III - Wymagane umiejętności. Rozporządzenie precyzuje minimalne obciążenia godzinowe dla poszczególnych grup przedmiotów, z czego obciążenia studentów studiów zawodowych oraz jednolitych studiów ma-

${ }^{68}$ Standardy kształcenia przygotowującego do wykonywania zawodu nauczyciela, Załącznik do Rozporządzenia Ministra Nauki i Szkolnictwa Wyższego z dnia 17 stycznia 2012 roku. Dz.U. z 2012 r., Nr 25, poz. 131.

${ }^{69}$ Standardy kształcenia nauczycieli na studiach wyższych zawodowych, uzupetniających studiach magisterskich, jednolitych studiach magisterskich oraz studiach podyplomowych, Załącznik do Rozporządzeniu Ministra Edukacji Narodowej i Sportu z dnia 7 września 2004 roku. Dz.U. z 2004 r., Nr 207, poz. 2110, s. 14552. 
gisterskich w zakresie Technologii Informacyjnej precyzuje następująco: „W wymiarze uzależnionym od posiadanej przez studentów wiedzy i umiejętności oraz potrzeb wynikających z zakresu kształcenia, zapewniającym przygotowanie do posługiwania się technologią informacyjną, w tym jej wykorzystywania w nauczaniu przedmiotu (prowadzenia zajęć), umożliwiającym opanowanie wiedzy i umiejętności w zakresie określonym w rozporządzeniu"70. Zgodnie zatem z ustaleniami dotyczącymi kwalifikacji i kompetencji (rozdział 2.1.) przyjętymi za Czerepaniak-Walczak, autorom rozporządzenia chodzi o nabycie przez studentów kwalifikacji a nie kompetencji w zakresie technologii informacyjnej - wyraźnie bowiem zaznaczają „opanowanie wiedzy i umiejętności”, pomijając pozostałe składniki kompetencji, a więc chociażby świadomość i pragnienie zastosowania nabytej wiedzy i umiejętności.

Rozdział VIII omawianego rozporządzenia (który prawdopodobnie powinien podobnie jak dwa następne rozdziały stanowić jedynie podrozdział rozdziału VII) przynosi więcej szczegółów nt. treści programowych, które zawierać powinien przedmiot Technologia Informacyjna dla studiów wyższych zawodowych i studiów magisterskich w ramach specjalizacji nauczycielskiej. Treści te zostały pogrupowane w cztery kategorie, które kolejno dotyczą: „1. Podstawy posługiwania się terminologią (pojęciami), sprzętem (środkami), oprogramowaniem (narzędziami) i metodami technologii informacyjnej. [...] 2. Technologia informacyjna jako składnik warsztatu pracy nauczyciela. [...] 3. Rola i wykorzystanie technologii informacyjnej w dziedzinie właściwej dla nauczanego przedmiotu (prowadzonych zajęć). [...] 4. Aspekty humanistyczne, etyczno-prawne i społeczne w dostępie i korzystaniu z technologii informacyjnej"71. Każda z hasłowo ujętej kategorii jest następnie rozwijana w kilka-kilkanaście treści szczegółowych, które w przypadku kategorii 1. i 2. ograniczają się do spisu wiedzy i umiejętności, w które student powinien zostać wyposażony. Dopiero rozwinięcia kategorii 3. i 4. dotykają problemów wykraczających poza wiedzę i umiejętności, a więc sugerują wyposażenie studenta nie tylko w same kwalifikacje.

W rozwinięciu kategorii 3. znalazły się następujące treści programowe: „wpływ technologii informacyjnej na zakres i sposoby nauczania (prowadzenia zajęć) oraz rolę nauczyciela, korzyści edukacyjne ze stosowania tej technologii. Rola i zakres uwzględnienia technologii informacyjnej w pod-

\footnotetext{
${ }^{70}$ Ibidem, s. 14553.

${ }^{71}$ Ibidem, s. $14556-14557$.
} 
stawie programowej"72. Sformułowania te wskazują na konieczność świadomego i odpowiedzialnego korzystania z TI przez przyszłych nauczycieli, tym samym częściowo wyczerpują przedmiotowy zakres przyjętej tu definicji kompetencji. Podobnie tematyka kategorii 4. porusza problemy odpowiedzialnego stosowania TI, zwracając uwagę na zagrożenia zarówno społeczne, jak i zdrowotne, prawne czy etyczne. Jest to jedyny fragment omawianego dokumentu, który poprzez zwrócenie uwagi na świadomość celów jak i konsekwencji oraz odpowiedzialne wdrażanie TI do procesu edukacyjnego, dotyka problemów kompetencji informatycznych, w jakie student specjalności nauczycielskiej powinien zostać wyposażony.

Zarówno omówione wyżej Standardy kształcenia nauczycieli... z 2004 roku, jak i projekt nowych Standardów kształcenia przygotowującego do wykonywania zawodu nauczyciela ${ }^{73}$ z 15 lutego 2007 roku, wyszczególniają kształcenie w zakresie technologii informatycznej jako jeden z pięciu (w przypadku studiów dwuprzedmiotowych - sześciu) osobnych obszarów kształcenia w ramach studiów nauczycielskich ${ }^{74}$. Wskazuje to $\mathrm{z}$ jednej strony na założoną ważność tak wyróżnionego bloku przedmiotowego, który ma stanowić integralną część wykształcenia nauczyciela, ale z drugiej strony może świadczyć o odrębności tej kategorii wiedzy i umiejętności oraz braku ich wyraźnego zintegrowania z pozostałymi obszarami, tzn. z kształceniem pedagogicznym (w szczególności metodyką), kształceniem kierunkowym, czy w końcu z praktyką. Trudno tu odwołać się do analogii w zintegrowaniu pozostałych obszarów kształcenia nauczycieli - jest ono bowiem krańcowo różne: od ściśle ze sobą powiązanych, jak kształcenie pedagogiczne i praktyki pedagogiczne, do niemal niezależnego od pozostałych kształcenia w zakresie języka obcego. Samo jednak uwzględnienie kształcenia w zakresie technologii informacyjnej jako integralnego składnika wykształcenia nauczyciela zwraca uwagę na jego ważność i - w założeniach twórców obydwu dokumentów - jego konieczną obecność w warsztacie pracy nauczyciela.

Projekt Standardów... ujmuje kształcenie informatyczne nauczycieli w dwóch kategoriach: „1. przygotowanie ogólne - zgodne ze standardami

\footnotetext{
${ }^{72}$ Ibidem, s. 14556.

${ }^{73}$ Rada Główna Szkolnictwa Wyższego, Standardy kształcenia przygotowujacego do wykonywania zawodu nauczyciela, projekt z 15 lutego 2007 roku.

${ }^{74}$ Pięć obszarów w ramach studiów na specjalizacji nauczycielskiej obejmuje według obowiązujących i projektowanych standardów kształcenia nauczycieli: 1. kształcenie kierunkowe, 2. kształcenie nauczycielskie (pedagogiczne), 3. praktyki pedagogiczne, 4. kształcenie w zakresie technologii informacyjnej, 5. kształcenie w zakresie języka obcego.
} 
kształcenia określonymi na podstawie art. 9 pkt. 2 lub art. 11 ust. 3 ustawy - Prawo o szkolnictwie wyższym; 2. przygotowanie do wykorzystania jej w wyuczonych specjalnościach - wchodzące w zakres dydaktyki przedmiotu (rodzaju zajęć)" 75 . Projektodawca zatem jednoznacznie przewiduje zintegrowanie kształcenia informatycznego z dydaktyką przedmiotu i - co za tym idzie - zintegrowanie umiejętności informatycznych nauczyciela $\mathrm{z}$ jego przyszłą praktyką dydaktyczną. Ten aspekt jest szerzej ujęty w Standardach... z 2004 roku, które w szczegółowym rozwinięciu tematyki kształcenia informatycznego wymienia m.in. takie zagadnienia, jak: „Zastosowania i osiągnięcia informatyki oraz technologii informacyjnej w dziedzinie właściwej dla nauczanego przedmiotu (prowadzonych zajęć) [...] Scenariusze zajęć uwzględniające korzystanie z technologii informacyjnej [...] Ocena edukacyjnej przydatności oprogramowania i zasobów elektronicznych $[\ldots]$ Przykłady dobrej praktyki pedagogicznej wykorzystania technologii informacyjnej [...] Organizacja zajęć wspomaganych i wzbogacanych technologią informacyjną [...] Rola technologii informacyjnej w uczeniu się uczniów [...]"76. Wszystkie powyższe zagadnienia wymagają powiązania kształcenia informatycznego przyszłego nauczyciela zarówno z przedmiotami kształcenia kierunkowego, jak i przedmiotami kształcenia nauczycielskiego czy praktykami pedagogicznymi. Takie podejście do kształcenia informatycznego, zintegrowanego z pozostałymi elementami wykształcenia nauczyciela, daje solidne podstawy do świadomego i odpowiedzialnego a więc kompetentnego - opanowania i korzystania z narzędzi informatycznych w dydaktyce własnego przedmiotu. Obydwa zatem dokumenty dotyczące standardów kształcenia nauczycieli deklaratywnie każą wyposażyć przyszłego nauczyciela nie tylko w kwalifikacje informatyczne, ale w dużą część kompetencji informatycznych w rozumieniu, jakie przyjęliśmy w rozdziale 2.2., czyli harmonijną kompozycję wiedzy i umiejętności wzbogaconą o rozumienie i pragnienie świadomego działania, wykorzystującego technologię informacyjno-komunikacyjną. Do pełni znaczenia kompetencji brakuje jednak odpowiedzialnego działania, do którego uczelnia ma jedynie dać podstawy i motywację.

Standardy kształcenia... ${ }^{77}$ ogłoszone w styczniu 2012 roku nieco odmiennie formułują kompetencje informatyczne przyszłego nauczyciela.

\footnotetext{
${ }^{75}$ Rada Główna Szkolnictwa Wyższego, Standardy kształcenia..., (projekt), s. 3.

${ }^{76}$ Standardy kształcenia nauczycieli na studiach wyższych zawodowych..., rozdział VIII, p. 3, s. 14556-14557.

${ }^{77}$ Rozporządzenie Ministra Nauki i Szkolnictwa Wyższego z dnia 17 stycznia 2012 r. w sprawie standardów kształcenia przygotowującego do wykonywania zawodu nauczyciela, Dz.U. Nr 25 poz. 131 z 6 lutego 2012.
} 
Nakreślając w siedmiu punktach ogólne efekty kształcenia, wyznacza rolę TIK w wykształceniu nauczyciela, dzięki której absolwent „4) wykazuje umiejętność uczenia się i doskonalenia własnego warsztatu pedagogicznego z wykorzystaniem nowoczesnych środków i metod pozyskiwania, organizowania i przetwarzania informacji i materiałów; 5) umiejętnie komunikuje się przy użyciu różnych technik, zarówno z osobami będącymi podmiotami działalności pedagogicznej, jak i z innymi osobami współdziałającymi w procesie dydaktyczno-wychowawczym oraz specjalistami wspomagającymi ten proces"78. W siedmiu ogólnie sformułowanych efektach kształcenia nie znajdujemy innego, bezpośredniego odwołania do TIK, tym bardziej do jej wykorzystywania w dydaktyce własnego przedmiotu, jak to miało miejsce w poprzedniej wersji Standardów...

Nowoczesne technologie znalazły się jednak w szczegółowym ujęciu efektów kształcenia, które w zakresie umiejętności, w punkcie „h” opisują: „[absolwent - przyp. P. S.] potrafi dobierać i wykorzystywać dostępne materiały, środki i metody pracy w celu projektowania i efektywnego realizowania działań pedagogicznych (dydaktycznych, wychowawczych i opiekuńczych) oraz wykorzystywać nowoczesne technologie do pracy dydaktycznej"79. Zauważyć tu należy, że już pierwsza część powyższego zdania, mówiąca o wykorzystywaniu dostępnych materiałów, środków i metod pracy w działaniach pedagogicznych, wyczerpuje w sposób ogólny umiejscowienie TIK w pracy nauczyciela. Ustawodawca jednak w sposób szczegółowy dodatkowo wymienia wyjątkowy rodzaj tych środków, mianowicie „nowoczesne technologie”. Można to interpretować jako wyraźny akcent, wyróżniający TIK spośród innych „materiałów, środków i metod pracy” oraz wyraz wyjątkowej wagi, jaką ustawodawca przykłada do tego rodzaju narzędzi. Można jednak to uszczegółowienie zrozumieć również jako wyłączające. W tym przypadku wyjątkowość nowoczesnych technologii miałaby polegać na zawężeniu jej stosowania „do pracy dydaktycznej”, podczas gdy wszystkie pozostałe „materiały, środki i metody pracy” dotyczyć mają działań pedagogicznych, wyraźnie dookreślonych w tym samym zdaniu jako działania „dydaktyczne, wychowawcze i opiekuńcze”.

Punkt 5. szczegółowych efektów kształcenia omawianych Standardów... precyzuje wymagania w zakresie technologii informacyjnej, ustalając, że absolwent studiów nauczycielskich powinien posiadać: „a) podstawową

\footnotetext{
${ }^{78}$ Standardy kształcenia przygotowujacego..., s. 1.

${ }^{79}$ Ibidem, s. 3.
} 
wiedzę i umiejętności w zakresie technik informatycznych, przetwarzania tekstów, wykorzystywania arkuszy kalkulacyjnych, korzystania z baz danych, posługiwania się grafiką prezentacyjną, korzystania z usług w sieciach informatycznych, pozyskiwania i przetwarzania informacji, b) umiejętność zróżnicowanego wykorzystywania technologii informacyjnej w pracy pedagogicznej;" czas obowiązujących Standardów..., które w zakresie kształcenia informatycznego nauczycieli wyróżniały przygotowanie ogólne oraz przygotowanie do wykorzystania TIK w dydaktyce własnego przedmiotu. W tak sformułowanych dwóch nurtach kształcenia informatycznego nauczycieli zwraca uwagę kilka elementów. Po pierwsze, odwrót od zauważonego wyżej zawężenia stosowania TIK do dydaktyki - w sposób niekonsekwentny Rozporządzenie wymienia w punkcie $5 \mathrm{~b}$ umiejętność wykorzystywania TIK tym razem szerzej - w pracy pedagogicznej.

Po drugie, punkty „ogólny” i „dydaktyczny” kształcenia informatycznego operują zróżnicowanym nazewnictwem TIK: punkt 5a wymienia „techniki informatyczne” natomiast punkt $5 \mathrm{~b}$ - „technologię informacyjną". Obrazuje to z jednej strony niejednorodność nomenklatury, z drugiej zaś - odmienne podejście do rozumienia TIK w obydwu aspektach, które szerzej zostało omówione w rozdziale 2.1 .

Po trzecie, ważną okazuje się analiza gramatyczna punktu 5a najnowszej wersji Standardów... Są w nim bowiem wymienione wiedza i umiejętności z zakresu: „technik informatycznych, przetwarzania tekstów, wykorzystywania arkuszy kalkulacyjnych, korzystania $z$ baz danych, posługiwania się grafiką prezentacyjną, korzystania z usług w sieciach informatycznych, pozyskiwania i przetwarzania informacji”"81. Rozdzielenie przecinkami technik informatycznych oraz pozostałych zakresów wiedzy i umiejętności sugeruje, że są to równoprawne i rozdzielne zakresy kwalifikacji. Należałoby zatem rozumieć, że do technik informatycznych nie zaliczają się pozostałe, wymienione w tym punkcie rodzaje aktywności, co nie odpowiada prawdzie. „Technika” w języku polskim ma bowiem dwa podstawowe znaczenia: w pierwszym oznacza umiejętność, sposób wykonywania pewnych czynności, kunszt w jakiejś dziedzinie działalności (np. technika gry na skrzypcach), w drugim oznacza same urządzenia techniczne niezbędne do wytwa-

\footnotetext{
${ }^{80}$ Ibidem, s. 4.

${ }^{81}$ Ibidem.
} 
rzania pewnych zjawisk lub rzeczy ${ }^{82}$. W tym drugim znaczeniu nie używa się jednak liczby mnogiej, co oznacza, że w przypadku Standardów ksztatcenia... sformułowanie „techniki informatyczne” dotyczy umiejętności wykorzystywania narzędzi informatycznych, jakimi niewątpliwie są: edytor tekstu, arkusz kalkulacyjny, bazy danych itp. Czyli autor ustawy prawdopodobnie mylnie użył przecinka zamiast dwukropka po wyrażeniu „technik informatycznych”. Możliwe jest również, że nieporozumienie dotyczy błędnego użycia liczby mnogiej „techniki”, a autor ustawy życzył sobie, aby przyszły nauczyciel poznał „technikę informatyczną”, czyli narzędzia służące różnym „technikom informatycznym”, np. pozyskiwaniu i przetwarzaniu informacji. W omawianym kontekście chodziłoby więc o budowę (lub raczej „architekturę”) komputera lub programów służących wymienionym umiejętnościom przetwarzania informacji, a więc technikom informatycznym. Niezależnie zatem od znaczenia użytego w Rozporządzeniu słowa „technika”, zauważamy błąd w jego zastosowaniu w takim kontekście.

Kolejne elementy Standardów... z 2012 roku, które dotyczą kompetencji informatycznych to tzw. moduł 3, dotyczący przygotowania w zakresie dydaktycznym. Treści kształcenia podstaw dydaktyki ${ }^{83}$, w swoim ostatnim punkcie zawierają oszczędnie sformułowaną dyspozycję „,edukacyjne zastosowania mediów”. Minimalnie rozbudowaną formę zawierają treści kształcenia $\mathrm{z}$ zakresu dydaktyki przedmiotu na drugim etapie edukacyjnym ${ }^{84}$ : „edukacyjne zastosowania mediów i technologii informacyjnej”. Należy tutaj zauważyć, że skromna adnotacja na temat technologii informacyjnej dotyczy wyraźnie dydaktyki przedmiotu. Nie chodzi więc o ogólne potraktowanie miejsca TIK w dydaktyce ale - w przypadku nauczycieli muzyki - jej zastosowań w dydaktyce muzyki właśnie.

Następnym, bardzo ważnym przytoczeniem TIK jako standardu kształcenia przygotowującego do zawodu nauczyciela jest rozdział poświęcony praktyce. Rozporządzenie mówi tu: „W trakcie praktyki następuje kształtowanie kompetencji dydaktycznych przez [...] współdziałanie z opiekunem praktyk w [...] wykorzystywaniu środków multimedialnych i technologii informacyjnej w pracy dydaktycznej" ${ }^{85}$. Ważność tego zdania polega na bezpośrednim odniesieniu do kompetencji, nabytej przez odpowiedzialne

\footnotetext{
${ }^{82}$ [Za:] pl.wikipedia.org.

${ }^{83}$ Standardy kształcenia przygotowujacego..., s. 14, p. 1.8 .

${ }^{84}$ Ibidem, s. 17, p. 2.2.8.

${ }^{85}$ Ibidem, s. 20, p. 3., pp. 3d.
} 
działanie, oparte na uprzednio opanowanej wiedzy i umiejętnościach w ramach kształcenia w zakresie dydaktyki ogólnej i przedmiotowej. To zdanie przesądza, że intencją ustawodawcy jest, by absolwent studiów nauczycielskich posiadał nie tylko kwalifikacje ale i kompetencje w zakresie technologii informacyjnej. Nakaz wykorzystywania TIK w pracy dydaktycznej we współdziałaniu z opiekunem praktyk, w połączeniu z wcześniej cytowanymi zapisami o treściach kształcenia modułu dydaktycznego, wyczerpują bowiem zakres rozumienia kompetencji, jaki przyjęliśmy w rozdziale 2.1. niniejszej pracy.

Mimo więc skromniejszego (jeśli chodzi o miejsce) wyeksponowania kompetencji informatycznych przyszłego nauczyciela, najnowsze Standar$d y \ldots$ z 2012 roku, dzięki trafnemu choć lapidarnemu umieszczeniu poszczególnych składników kompetencji w konkretnych modułach kształcenia, nakazuje wyposażyć absolwenta studiów nauczycielskich w pełne kompetencje informatyczne, niezbędne w jego przyszłej pracy. Znamiennym jest również fakt, że Rozporządzenie nie pozostawia opiekunowi praktyk problemu zapewnienia studentom odpowiednich informatycznych środków dydaktycznych. Częściowe przeniesienie odpowiedzialności za zgodne z tymi założeniami kształcenie na instytucje edukacyjne, w których te praktyki są odbywane, obwarowane jest warunkiem: „uczelnie mają obowiązek zapewnić studentom (słuchaczom) w trakcie praktyk [...] warunki do prowadzenia lekcji (zajęć) z zastosowaniem technologii informacyjnej, w szczególności z wykorzystaniem treści i zasobów edukacyjnych znajdujących się na portalach internetowych" ${ }^{\text {" }}$.

Jeszcze jednym dokumentem określającym obowiązujące standardy kształcenia nauczycieli jest Rozporządzenie Ministra Edukacji Narodowej $z$ dnia 30 czerwca 2006 roku w sprawie standardów kształcenia nauczycieli $w$ kolegiach nauczycielskich i nauczycielskich kolegiach języków obcych ${ }^{87}$. Nie wprowadza on jednak żadnych nowych elementów do zakresu merytorycznego kształcenia informatycznego i w dużej mierze stanowi kopię analogicznych zapisów omówionych już wyżej Standardów... z roku 2004 oraz 2007.

\footnotetext{
${ }^{86}$ Ibidem, s. 31, p. IV.

${ }^{87}$ Dz.U. z 2006 r., Nr 128, poz. 897.
} 


\subsubsection{Warunki uzyskiwania stopni awansu zawodowego przez nauczycieli}

Rozporzadzenie Ministra Edukacji Narodowej i Sportu z dnia 1 grudnia 2004 r. w sprawie uzyskiwania stopni awansu zawodowego przez nauczycieli $i^{88}$ określa warunki, jakie zobowiązany jest spełnić nauczyciel ubiegający się o kolejny stopień awansu zawodowego. Wśród wymagań niezbędnych do uzyskania stopnia nauczyciela kontraktowego rozporządzenie nie wymienia w żadnym zakresie kompetencji, czy chociażby kwalifikacji w obszarze technologii informacyjno-komunikacyjnej. Nie oznacza to jednak, że Ministerstwo nie widzi potrzeby posiadania takich kompetencji - umieszczone są przecież w wyżej omówionych Standardach kształcenia nauczycieli - posiada je więc każdy nauczyciel rozpoczynający pracę na stanowisku nauczyciela-stażysty. Autorzy rozporządzenia uznali natomiast za niezbędne na tym etapie kariery nauczycielskiej poznanie organizacji, zadań i zasad funkcjonowania szkoły, umiejętność właściwego prowadzenia zajęć oraz ich omawiania, a także poznanie środowiska uczniów ${ }^{89}$. Te wymagania należy zatem w rozumieniu Rozporządzenia uznać za podstawowe oraz niezbędne składniki warsztatu pracy nauczyciela rozpoczynającego karierę zawodową. Kompetencje informatyczne zaś, jako bardziej „zaawansowane” zostały uwzględnione w wymaganiach niezbędnych do ubiegania się o wyższe stopnie awansu nauczyciela.

W omawianym rozporządzeniu są one ujęte dość ogólnikowo, chociaż opatrzone określeniem „niezbędne” i w odniesieniu do kandydata ubiegającego się o stopień nauczyciela mianowanego oraz dyplomowanego sformułowane są jako „umiejętność wykorzystywania w pracy technologii informacyjnej i komunikacyjnej"90. Rozporządzenie nakłada ponadto obowiązek udokumentowania spełnienia wymienionych wymagań ${ }^{91}$, w tym cytowanej umiejętności wykorzystania w pracy technologii informacyjnej i komunikacyjnej. Udokumentowanie to otrzymało bardziej szczegółową formę w nowelizacji Rozporządzenia z 2007 roku², która określa, że dokumentacja załączona do wniosku o podjęcie postępowania kwalifikacyjnego

\footnotetext{
${ }^{88}$ Dz.U. z 2004 r., Nr 260, poz. 2593.

${ }^{89}$ Ibidem, $\$ 6$, ust. 2, punkty $1-4$.

${ }^{90}$ Ibidem, $\$ 7$. ust. 2, p. 3 oraz $\$ 8$, ust. 2, p. 2.

${ }^{91}$ Ibidem, $\$ 9$, ust. 1, p. 5 oraz $\$ 9$, ust. 4, p. 5 .

92 Rozporządzenie Ministra Edukacji Narodowej zdnia 14 listopada 2007 r. zmieniające rozporządzenie w sprawie uzyskiwania stopni awansu zawodowego przez nauczycieli, Dz.U. z 2007 r., Nr 214, poz. 1580.
} 
lub egzaminacyjnego, w przypadku nauczyciela mianowanego obejmować ma „opis i analizę realizacji wymagań określonych w $₫ 8$ ust. 2, w szczególności ze wskazaniem uzyskanych efektów"93. Ta ostatnia adnotacja pozwala na stwierdzenie, że (po raz pierwszy) Rozporządzenie mówi o kompetencjach a nie tylko kwalifikacjach w zakresie stosowania TIK - wskazuje bowiem na obligatoryjną analizę oraz wskazanie efektów zastosowania TIK w pracy nauczyciela. Taka refleksja determinuje świadome wykorzystanie TIK w pracy nauczyciela, które nie epatując nowoczesną technologią każe skupić się na analizie efektywności wykorzystania narzędzi informatycznych w metodyce nauczania własnego przedmiotu.

Należy przy tym zauważyć, że tak sformułowane wymagania dotyczą jedynie nauczyciela mianowanego, starającego się o awans na stopień nauczyciela dyplomowanego, co z kolei można uważać za uznanie przez Ministerstwo kompetencji w zakresie technologii informacyjno-komunikacyjnej za najwyższy stopień „wtajemniczenia” nauczyciela. Dotyczy bowiem najwyższego stopnia awansu zawodowego nauczyciela, o jakim traktuje Rozporządzenie.

\subsubsection{Standardy edukacji kulturalnej}

W 2008 r. Fundacja Polskiej Rady Muzycznej opublikowała Standardy edukacji kulturalnej ${ }^{94}$, w których zawarła kilka istotnych postulatów dotyczących zastosowania TI w nauczaniu muzyki. W dokumencie tym pod hasłem „Edukacja muzyczno-medialna” czytamy: „Tam gdzie jest to możliwe, wprowadza się do procesu nauczania muzyki edukacyjne programy medialne, które drogą zabaw i gier komputerowych będą wspierać procesy zapamiętywania oraz nabywania wiedzy i umiejętności muzycznych" ${ }^{95}$. Postulat ten dotyczy nauczania w klasach I-III. W stosunku do uczniów klas IV-VI ten sam dokument przewiduje konieczność „nabycia umiejętności posługiwania się programami komputerowymi do zapisywania i tworzenia muzyki”" ${ }^{\prime 6}$. Do realizacji powyższych postulatów autorzy uznają za niezbędne: „sale komputerowe, do których nauczyciel muzyki miałby dostęp” oraz

\footnotetext{
${ }^{93}$ Ibidem, $\$ 1$. ust. 1, dot. $\$ 9$, ust. 1, p. 3a Rozporządzenia z 2004 r..

${ }^{94}$ A. Białkowski (red.), Standardy edukacji kulturalnej. Materiały do konsultacji środowiskowych, Fundacja Polskiej Rady Muzycznej, Warszawa 2008.

95 Ibidem, s. 121.

${ }^{96}$ Ibidem, s. 131.
} 
„oprogramowanie komputerowe do zapisywania i tworzenia muzyki”97. Wobec braku w tym dokumencie bezpośrednich dyspozycji dotyczących kwalifikacji bądź kompetencji informatycznych nauczyciela, można jedynie przyjąć, że minimalne wymagania stawiane przed nauczycielem to artykułowana wobec ucznia znajomość programów do tworzenia oraz zapisu muzyki. Nie możemy jednak z tekstu wnioskować czy autorom chodziło o kompetencje czy jedynie o kwalifikacje w tym zakresie.

\subsubsection{Podstawa programowa kształcenia ogólnego}

Najnowsza Podstawa programowa kształcenia ogólnego dla szkót podstawowych i gimnazjów ${ }^{98}$ również formułuje niezbędne w pracy nauczyciela kompetencje informatyczne. We wstępie dokumentu, dotyczącym celów kształcenia ogólnego, najważniejszych umiejętności, które uczeń powinien zdobyć oraz zadań szkoły, znajdujemy następującą deklarację: „Nauczyciele powinni stwarzać uczniom warunki do nabywania umiejętności wyszukiwania, porządkowania i wykorzystywania informacji z różnych źródeł, $\mathrm{z}$ zastosowaniem technologii informacyjno-komunikacyjnych, na zajęciach z różnych przedmiotów" ${ }^{\prime 99}$. Takie działania nauczycieli mają wyposażyć ucznia w jedną z siedmiu wymienionych tu „najważniejszych umiejętności zdobywanych przez ucznia w trakcie kształcenia ogólnego w szkole podstawowej” ${ }^{\prime 100}$, jaką jest „umiejętność posługiwania się nowoczesnymi technologiami informacyjno-komunikacyjnymi”101.

Uszczegółowienie celów kształcenia oraz treści nauczania w dziale dotyczącym przedmiotu muzyka, niezwykle oszczędnie traktuje wykorzystanie nowych technologii. Sprowadza się ono do jednego zdania, które stawia przed uczniem wymóg korzystania $\mathrm{z}$ „multimedialnych źródeł muzyki i informacji o muzyce"102. To nader skromne rozwinięcie deklaracji zawartych we wstępie dokumentu (brak chociażby wzmianki na temat muzycznych programów edukacyjnych) może wzbudzać uzasadniony niedosyt. Pew-

\footnotetext{
${ }^{97}$ Ibidem, s. 125 i 133.

98 Rozporzadzenie Ministra Edukacji Narodowej $z$ dnia 23 grudnia 2008 r. w sprawie podstawy programowej wychowania przedszkolnego oraz kształcenia ogólnego w poszczególnych typach szkół, Dz.U. Nr 4, poz. 17, z 15 stycznia 2009. Załącznik nr 2 - Podstawa programowa kształcenia ogólnego dla szkót podstawowych i gimnazjów.

${ }^{99}$ Ibidem, s. 1-2.

${ }^{100}$ Ibidem, s. 1.

${ }^{101}$ Ibidem, s. 1.

${ }^{102}$ Ibidem, s. 27.
} 
ne dopełnienie jednak może stanowić rozdział dotyczący zajęć komputerowych, który w wymaganiach szczegółowych treści nauczania wymienia m.in. korzystanie przez ucznia „,z komputera, jego oprogramowania i zasobów elektronicznych (lokalnych i w sieci) do wspomagania i wzbogacania realizacji zagadnień $\mathrm{z}$ wybranych przedmiotów” a także $\mathrm{z}$ „zasobów (słowników, encyklopedii, sieci internet) i programów multimedialnych (w tym programów edukacyjnych) z różnych przedmiotów i dziedzin wiedzy"103. Sformułowania „Z wybranych przedmiotów” oraz „Z różnych przedmiotów” sugerują, że można spodziewać się współpracy nauczyciela muzyki oraz nauczyciela zajęć komputerowych w zakresie działań muzycznych z wykorzystaniem komputera. Trudno oczekiwać jednak od nauczyciela będącego informatykiem, by nie posiadając wystarczających kompetencji muzycznych mógł zainteresować uczniów programami edukacyjnymi dotyczącymi tej dziedziny. Być może autorzy Rozporządzenia, zakładając niedostatki w wykształceniu nauczycieli muzyki z zakresu technologii informacyjno-komunikacyjnej, próbowali tym sposobem przerzucić część obciążenia w tej dziedzinie na zajęcia komputerowe? Innym wytłumaczeniem może być dystans autorów co do możliwości edukacyjnego wykorzystania nowych technologii w dydaktyce muzyki. Obydwa zdania wydają się jednak daleko nieprawdopodobne wobec innych dokumentów Ministerstwa Edukacji Narodowej, chociażby przywołanych wcześniej rozporządzeń na temat standardów kształcenia nauczycieli czy standardów przygotowania nauczycieli w zakresie technologii informacyjnej.

Należy zauważyć również, że końcowa część omawianego rozporządzenia, traktująca o zalecanych warunkach i sposobach realizacji powyższych treści programowych, zaleca, aby pracownia muzyczna wyposażona była $\mathrm{w}$,komputer $\mathrm{z}$ dostępem do internetu i oprogramowaniem muzycznym”104. Zalecenie to zostanie skonfrontowane ze stanem faktycznym w toku badań, będących częścią niniejszej pracy.

\subsubsection{Zalecenia Unii Europejskiej}

Kompetencje nauczyciela są również przedmiotem dociekań instytucji europejskich. Program prac dotyczący przyszłych celów systemów eduka-

\footnotetext{
103 Ibidem, s. 47.

${ }^{104}$ Ibidem, s. 56.
} 
cji przygotowany przez Komisję Europejską ${ }^{105}$ zawiera wśród celów strategicznych m.in. taki, który mówi, że „wszystkie szkoły w UE powinny do roku 2010 uzyskać dostęp do internetu oraz multimedialnych pomocy dydaktycznych"106. Dalej dokument szczegółowo omawia wykorzystanie TIK w edukacji: „należy spełnić także inne warunki, aby optymalnie wykorzystywać innowacyjne techniki nauczania i uczenia się oparte na technologiach informacyjno-komunikacyjnych. A oto one:

- W celu wszechstronnego przygotowania uczniów do korzystania z technologii informacyjno-komunikacyjnych, wszyscy nauczyciele powinni do końca 2002 roku być przeszkoleni w zakresie korzystania $\mathrm{z}$ technologii informacyjno-komunikacyjnych.

- Technologie informacyjno-komunikacyjne powinny służyć podnoszeniu jakości kształcenia. W związku z tym należy ustalić, $\mathrm{w}$ jakich obszarach metodologicznych technologie te mają pozytywny wpływ na proces nauczania-uczenia się. Umożliwi to przygotowanie procesu nauczania ukierunkowanego na potrzeby uczniów, studentów i słuchaczy, w którym w pełni zostaną uwzględnione odmienne style uczenia się i zasady dydaktyczne. Szczególnie ważne jest odpowiednie ukierunkowanie pracy nauczycieli i wspieranie ich w trakcie wykonywania zwiększających się i coraz bardziej złożonych obowiązków zawodowych.

- Należy ocenić, czy technologie informacyjno-komunikacyjne są w pełni wykorzystywane i w jaki sposób wpływają na wyniki procesu nabywania wiedzy i umiejętności.

- Konieczne jest również zapewnienie odpowiedniego wsparcia osobom podejmującym decyzje na wszystkich szczeblach kształcenia; chodzi bowiem o to, aby uwzględnić aktualne kwestie polityki edukacyjnej (np. integrowanie nowych grup słuchaczy, innowacje w treściach i metodach nauczania, współpracę na szczeblu lokalnym i międzynarodowym) oraz stworzyć podstawy do wdrażania zmian w programach kształcenia, które wynikają z nowoczesnych technologii informacyjno-komunikacyjnych"107.

${ }^{105}$ Edukacja w Europie: różne systemy kształcenia i szkolenia - wspólne cele do roku 2010. Program prac dotyczacy przyszłych celów systemów edukacji, Komisja Europejska, Dyrektoriat Generalny ds. Edukacji i Kultury, tłum. E. Kolanowska, Warszawa 2003.

${ }^{106}$ Ibidem, s. 9.

${ }^{107}$ Ibidem, s. 9-10. 
Za kluczowe zagadnienia Komisja Europejska uważa: „wyposażenie szkół w odpowiedni sprzęt i oprogramowanie, w celu efektywnego wykorzystywania w praktyce edukacyjnej technologii informacyjno-komunikacyjnych i kształcenia drogą elektroniczną; [oraz] zachęcanie placówek edukacyjnych do optymalnego wykorzystywania innowacyjnych technik nauczania i uczenia się opartych na technologiach informacyjno-komunikacyjnych"108.

Zarówno więc krajowe jak i europejskie stanowisko wyrażane w dokumentach, uchwałach czy postulatach, jednoznacznie formułuje konieczność wprowadzania do szkół rozwiązań metodycznych opartych na technologii informacyjno-komunikacyjnej i - co za tym idzie - konieczność włączenia do niezbędnych kompetencji współczesnego nauczyciela stosowania tych technologii w praktyce edukacyjnej.

\subsection{Kompetencje informatyczne $w$ programach kształcenia kandy- datów na nauczycieli muzyki w uczelniach regionu łódzkiego}

W tym rozdziale zostaną przeanalizowane programy nauczania przedmiotów łączących kompetencje w zakresie TIK z kompetencjami w zakresie metodyki nauczania muzyki w uczelniach regionu łódzkiego, kształcących przyszłych nauczycieli muzyki. Właściwym wydaje się jednak zastąpienie w tym wypadku pojęcia kompetencji kwalifikacjami, na które składają się umiejętności i wiedza, pomijając wyjątkowo świadomość, rozumienie i pragnienie ich wykorzystania, czyli czynnik wyróżniający kompetencje w rozumieniu, jakie przyjęliśmy w rozdziale 2.2. Czynnik ten bowiem standardowo, wobec trudności jego zoperacjonalizowania, nie jest uwzględniany w redagowanych na użytek dokumentacji uczelnianej programach nauczania. Procesowi ewaluacji bowiem zwykle poddawane są wiedza i umiejętności, a świadomość, rozumienie i pragnienie ich wykorzystania możliwe jest do wykształcenia przez takie zabiegi, jak chociażby porównywanie zinformatyzowanych i "tradycyjnych” metod osiągania podobnych celów dydaktycznych, czy uświadamianie studentom wymagań stawianych przed współczesnym nauczycielem przez kreatorów polityki edukacyjnej.

Zaplecze akademickie, którego absolwenci stanowią naturalną bazę aktualnych i przyszłych nauczycieli muzyki w ogólnokształcących szkołach podstawowych Łodzi, stanowią trzy uczelnie naszego regionu. Są to:

${ }^{108}$ Ibidem, s. 10. 
- Uniwersytet Łódzki, kształcący przyszłych nauczycieli muzyki na kierunku Pedagogika ze specjalnością Edukacja przez Sztukę na Wydziale Nauk o Wychowaniu (studia I i II stopnia stacjonarne i niestacjonarne);

- Akademia Muzyczna im. G. i K. Bacewiczów w Łodzi - na kierunku Edukacja Artystyczna w Zakresie Sztuki Muzycznej na Wydziale Kompozycji, Teorii Muzyki, Rytmiki i Edukacji Artystycznej (studia stacjonarne I i II stopnia);

- Kolegium Nauczycielskie w Zgierzu - na kierunku Pedagogika Wieku Dziecięcego i Muzyka (studia stacjonarne I stopnia) ${ }^{109}$.

Absolwenci tych trzech kierunków są uprawnieni do nauczania przedmiotu muzyka w klasach IV-VI szkół podstawowych, a więc w zakresie objętym niniejszymi badaniami. Wszystkie wymienione uczelnie deklarują wyposażenie studenta w ogólne kwalifikacje informatyczne w ramach przedmiotu technologia informacyjna. Zróżnicowanie pojawia się w interpretacji zapisów Standardów kształcenia nauczycieli... ${ }^{110}$, opisanych szczegółowo w rozdziale 5.1.2. dokumentu, a dotyczących umiejętności wykorzystania TIK w dydaktyce prowadzonego przez siebie przedmiotu - w tym przypadku muzyki. Oprócz obowiązującego na wszystkich wymienionych uczelniach przedmiotu technologia informacyjna Uniwersytet Łódzki, czyniąc zadość wymienionym przepisom, włączył do programu nauczania obowiązkowy przedmiot komputerowe programy muzyczne, łódzka Akademia Muzyczna wprowadziła fakultatywny przedmiot informatyka - programy muzyczne, natomiast Kolegium Nauczycielskie w Zgierzu poprzestało na włączeniu do standardowego przedmiotu technologia informacyjna treści związanych z dydaktycznym wykorzystaniem TIK, nie ograniczając się do dydaktyki muzyki. Różny jest zatem zakres kształcenia studentów wymienionych uczelni w obszarze łączenia TIK z dydaktyką muzyki.

109 Absolwenci tego kierunku „posiadają również kwalifikacje do nauczania muzyki w klasach IV-VI” [por:] www.kn.zgierz.pl (stan z dnia 30.03.2010).

${ }^{110}$ Chodzi tu o 3 dokumenty: Standardy kształcenia nauczycieli na studiach wyższych zawodowych, uzupetniajacych studiach magisterskich, jednolitych studiach magisterskich oraz studiach podyplomowych zawarte w Załączniku do Rozporządzeniu Ministra Edukacji Narodowej i Sportu z dnia 7 września 2004 roku, projekt Standardów kształcenia przygotowującego do wykonywania zawodu nauczyciela z dnia 15 lutego 2007 roku, przygotowany przez Radę Główną Szkolnictwa Wyższego, oraz Standardy kształcenia nauczycieli w kolegiach nauczycielskich i nauczycielskich kolegiach języków obcych zawarte w Rozporządzeniu Ministra Edukacji Narodowej z dnia 30 czerwca 2006 roku. 


\subsubsection{Uniwersytet Łódzki}

Uniwersytet Łódzki od roku akademickiego 2004-2005 oferuje studentom Pedagogiki ze specjalnością Edukacja przez Sztukę zajęcia pod nazwą komputerowe programy muzyczne, w wymiarze 30 godzin, na semestrze szóstym studiów I stopnia. Cele przedmiotu sformułowane są następująco:

”- umiejętność zastosowania muzycznych programów komputerowych w dydaktyce;

- wykorzystanie TI w przygotowaniu oraz prowadzeniu lekcji muzyki;

- opanowanie podstawowych umiejętności obróbki dźwięku w różnych formatach;

- edycja zapisu nutowego;

- tworzenie akompaniamentu do piosenek z repertuaru szkolnego;

- korzystanie z zasobów internetowych w dydaktyce muzycznej”"111.

Wyraźne powiązanie TIK $z$ dydaktyką muzyki dominuje w tak wyszczególnionych celach zajęć. Technologia jest tu ujęta jako narzędzie, pozwalające rozszerzyć wachlarz stosowanych środków dydaktycznych zarówno w sposób bezpośredni (jak w punktach 1,2 i 6), jak i pośrednio, przez nabycie umiejętności niezbędnych w przygotowaniu odpowiednich materiałów i pomocy dydaktycznych (dostosowanie do potrzeb lekcji nagrań muzycznych, materiału nutowego, czy przygotowanie akompaniamentu), prezentując jednocześnie wielość potencjalnych zastosowań TIK.

Zestaw komputerowych programów muzycznych, jakie poznają studenci w ramach omawianego przedmiotu znajdujemy w wyszczególnieniu treści i obejmują zarówno programy edukacyjne, możliwe do wykorzystania na zajęciach przez uczniów, jak i użytkowe, przeznaczone dla nauczyciela, umożliwiające przygotowanie materiałów dydaktycznych pomocnych w trakcie lekcji (rejestrator dźwięku, mikser, edytor audio, edytor zapisu nutowego, sequencer).

Takie ujęcie wyraźnie wkomponowuje się w zalecenia zawarte zarówno w projekcie nowych Standardów kształcenia nauczycieli... z 2007 roku, które wymieniają m.in. „przygotowanie do wykorzystania jej [TIK] w wyuczonych specjalnościach - wchodzące w zakres dydaktyki przedmiotu (rodzaju zajęć)" 112 , jak i w Standardach... z 2004 roku, które przewidują

\footnotetext{
${ }^{111}$ Na podst. „Sylabus zajęć z przedmiotu - Komputerowe programy muzyczne; rok akad. 2009/2010”, archiwum Katedry Edukacji Artystycznej Uniwersytetu Łódzkiego.

${ }^{112}$ Rada Główna Szkolnictwa Wyższego, Standardy kształcenia..., (projekt), s. 3.
} 
m.in. takie zagadnienia, jak: „zastosowania i osiągnięcia informatyki oraz technologii informacyjnej w dziedzinie właściwej dla nauczanego przedmiotu (prowadzonych zajęć)" ${ }^{\prime 13}$. Wyraźne odniesienia wymienionych celów do problemów dydaktycznych wyczerpują postulat połączenia kwalifikacji informatycznych z metodycznymi w zakresie przedmiotu muzyka, zgodnie ze wszystkimi dokumentami omówionymi w rozdziale 2.4 .

\subsubsection{Akademia Muzyczna im. G. i K. Bacewiczów w Łodzi}

Łódzka Akademia Muzyczna do cyklu kształcenia na kierunku Edukacja Artystyczna w Zakresie Sztuki Muzycznej włączyła przedmiot o nazwie informatyka - programy muzyczne, który jako fakultatywny oferuje studentom pierwszego semestru studiów I stopnia, w wymiarze 15 godzin. Cele kształcenia w tym zakresie ujęte są następująco: „Umiejętność biegłego i prawidłowego posługiwania się aplikacją Finale 2009 - zapisu nutowego tradycyjnego i elementów zapisu niekonwencjonalnego. Umiejętność przygotowania partytury i głosów utworu do wydruku. Umiejętność przygotowania przykładów muzycznych do umieszczenia w plikach programów zewnętrznych (pakiet Office, aplikacje graficzne) i w sieci www"114.

Szczególną uwagę zwracają tu dwa elementy: fakultatywność przedmiotu oraz ograniczenie treści programowych do jednej aplikacji. Takie ograniczenie wynikać może po pierwsze $\mathrm{z}$ minimalnego wymiaru godzinowego przedmiotu, po drugie zaś, ze specyfiki uczelni, której studenci znają doskonale zapis nutowy, stosują i wykorzystują go na wszystkich niemal zajęciach, traktując jako podstawowy język porozumiewania się na gruncie muzycznym. Program komputerowy do edycji zapisu nutowego stanowi więc współcześnie podstawowe narzędzie dla studiujących muzykę i jest już powszechnie stosowane w uczelniach muzycznych całego świata ${ }^{115}$. Nie jest natomiast podstawowym oprogramowaniem pomocnym w nauczaniu muzyki na etapie ogólnokształcącej szkoły podstawowej. Tu bowiem poznawanie zapisu nutowego stanowi tylko fragment - i to nie najważniejszy - programu nauczania. Ponadto tego rodzaju aplikacje przeznaczone są

\footnotetext{
${ }^{113}$ Standardy kształcenia nauczycieli na studiach wyższych zawodowych..., rozdział VIII, p. 3, s. 14556-14557.

${ }^{114} \mathrm{Na}$ podst. „Opis przedmiotu Informatyka - programy muzyczne” przekazanego przez prowadzącego przedmiot - ad. dr Sławomira Zamuszko.

${ }^{115}$ W większości uczelni muzycznych Europy Zachodniej i USA studenci obowiązkowo poznają jeden z programów do edycji zapisu nutowego (Finale lub Sibelius) oraz program do nagrywania i edycji materiału audio (najczęściej jest to program Cubase).
} 
raczej dla znających pismo nutowe muzyków - nauczycieli przygotowujących materiał nutowy dla uczniów, a ich możliwości wykorzystania na lekcji muzyki są mocno ograniczone. Zatem omawiany przedmiot wyposaża w przydatne narzędzie przyszłego nauczyciela muzyki, nie wzbogacają go jednak o umiejętności wykorzystania technologii informacyjnej bezpośrednio na zajęciach z uczniami. Tak więc zawarty w Standardach kształcenia nauczycieli... z 2004 roku zakres kształcenia informatycznego, ujęty jako „...zastosowania i osiągnięcia informatyki oraz technologii informacyjnej w dziedzinie właściwej dla nauczanego przedmiotu (prowadzonych zajęć) [...] Scenariusze zajęć uwzględniające korzystanie $\mathrm{z}$ technologii informacyjnej [...] Ocena edukacyjnej przydatności oprogramowania i zasobów elektronicznych [...] Przykłady dobrej praktyki pedagogicznej wykorzystania technologii informacyjnej [...] Organizacja zajęć wspomaganych i wzbogacanych technologią informacyjną [...] Rola technologii informacyjnej w uczeniu się uczniów [...]"116 nie znajduje swego odzwierciedlenia w programie kształcenia na kierunku Edukacja Artystyczna w Zakresie Sztuki Muzycznej łódzkiej Akademii Muzycznej.

\section{5·3. Kolegium Nauczycielskie w Zgierzu}

Kolegium Nauczycielskie w Zgierzu nie wprowadziło dotąd (rok akademicki 2013-2014) odrębnego przedmiotu, łączącego kompetencje informatyczne z muzycznymi (lub dydaktycznymi w zakresie muzyki), poprzestając w tym zakresie na przedmiocie technologia informacyjna, w wymiarze 30 godzin na pierwszym roku oraz 60 godzin na drugim roku studiów I stopnia, na kierunku Pedagogika Wieku Dziecięcego i Muzyka. Oznacza to, że przytoczone w projekcie Standardów kształcenia nauczycieli... z 2007 roku dwie kategorie kształcenia informatycznego - „1. przygotowanie ogólne - zgodne ze standardami kształcenia określonymi na podstawie art. 9 pkt. 2 lub art. 11 ust. 3 ustawy - Prawo o szkolnictwie wyższym; 2. przygotowanie do wykorzystania jej w wyuczonych specjalnościach - wchodzące w zakres dydaktyki przedmiotu (rodzaju zajęć)"'117 - zostały umieszczone w programie nauczania jednego, zintegrowanego przedmiotu technologia informacyjna. Cele takiego przedmiotu, realizowanego na roku pierwszym, ujęte są następująco:

\footnotetext{
${ }^{116}$ Standardy kształcenia nauczycieli na studiach wyższych zawodowych..., rozdział VIII, p. 3, s. 14556-14557.

${ }^{117}$ Rada Główna Szkolnictwa Wyższego, Standardy kształcenia..., (projekt), s. 3.
} 
„- Wdrożenie do pracy z systemem operacyjnym Windows XP

- Umiejętność wykorzystania komputera i technologii informacyjnej w kształceniu, samokształceniu; rozumienie znaczenia technologii informacyjnej w procesie kształcenia.

- Zdolność radzenia sobie z podstawowymi problemami występującymi w codziennej pracy z komputerem.

- Poznanie części pakietu Office: Word - umiejętność formatowania tekstu, Excel - umiejętność zestawienia danych i przedstawienia ich za pomocą wykresów, Windows Movie Maker - tworzenie własnych filmów.

- Rozwijanie umiejętności wyszukiwania, gromadzenia, przetwarzania i wykorzystywania do własnych celów informacji z Internetu.

- Korzystanie z Internetu i połączenia sieciowego do komunikacji na odległość"118.

Drugi z przytoczonych tu celów dotyczy interesujących nas elementów integracji TIK z dydaktyką muzyki, nie pozwala jednak na bliższą identyfikację jej zakresu. Zwraca natomiast uwagę fragment dotyczący rozumienia znaczenia TI w procesie kształcenia. Jest to bowiem ten składnik kompetencji informatycznych, który pozwala na ich odróżnienie od kwalifikacji119. W tym samym dokumencie, w części poświęconej głównym treściom przedmiotu technologia informacyjna wymieniono m.in. „rolę komunikacji i mediów w nauczaniu”. Jest to kolejne uwypuklenie kompetencji, a nie tylko kwalifikacji, w jakie powinien zostać wyposażony student - przyszły nauczyciel muzyki.

Wobec tak sformułowanych sugestii wskazujących na wyjątkowe podjęcie tematyki kompetencji informatycznych przyszłego nauczyciela muzyki, musi budzić zdziwienie fakt pominięcia w całym dokumencie jakichkolwiek programów muzycznych (tak edukacyjnych jak i użytkowych). Należy jednak pamiętać, że Kolegium Nauczycielskie w Zgierzu kształci studentów na kierunku Pedagogika Wieku Dziecięcego i Muzyka, a więc łączącego dwie specjalności. Zatem ów brak spowodowany mógł być zachwianiem równowagi między obiema specjalnościami w ujęciu przedmiotu technologia informacyjna. Analizując jednak udział programów edukacyjnych dotyczących nauczania zintegrowanego, w treściach przedmiotu znajdujemy

\footnotetext{
118 A. Gniatkowska, Kolegium Nauczycielskie w Zgierzu. Technologia informacyjna. Autorski program ksztatcenia, 2009, archiwum KN w Zgierzu.

${ }^{119}$ Por.: rozdział 2.1. niniejszej pracy.
} 
następujące: Word, Excel, Windows Movie Maker, przeglądarka i wyszukiwarka internetowa oraz na drugim roku - elementy języka HTML i protokołu FTP. Brak jest zatem jakichkolwiek programów edukacyjnych z zakresu kształcenia, jakim ma zajmować się absolwent Kolegium.

Należy zatem stwierdzić, że absolwent omawianego kierunku jest świadomy konieczności stosowania TIK w edukacji muzycznej, przekonany o jej użyteczności w procesie dydaktycznym, świadomy zarówno jej zagrożeń i ograniczeń jak i własnej odpowiedzialności, natomiast nie posiada wiedzy ani umiejętności związanych ze stosowaniem TIK w edukacji muzycznej - nie zna bowiem żadnych przykładów zastosowania technologii informacyjnej w dydaktyce muzyki i nie potrafi posłużyć się żadnym programem muzycznym - ani edukacyjnym, ani użytkowym. Nie posiada zatem kwalifikacji w tym zakresie, choć jego wykształcenie obejmuje - mówiąc językiem matematycznym - „różnicę zbiorów” kompetencji i kwalifikacji. 


\section{Założenia metodologiczne badań}

\subsection{Przedmiot i cele badań}

W pracy niniejszej przyjęto jednolity system terminologii metodologicznej w odniesieniu do badań ilościowych, zaproponowany przez Tadeusza Pilcha i Teresę Bauman w najnowszym, poprawionym i rozszerzonym wydaniu Zasad badań pedagogicznych z roku 2010․ Przy badaniach jakościowych przyjęto odniesienia do metodologii i terminologii zaproponowane przez Davida Silvermana ${ }^{2}$ oraz Dariusza Kubinowskiego ${ }^{3}$.

Przedmiotem badań jest deklarowany poziom kompetencji informatycznych nauczycieli muzyki klas IV-VI łódzkich szkół podstawowych oraz jego rozbieżności ze stanem postulowanym, wynikającym z dokumentów określających wymagania wobec nauczyciela w tym zakresie.

Zgodnie z ustaleniami dotyczącymi zakresu znaczeniowego pojęcia kompetencji zawartymi w rozdziale 2.1., rozpoznaniu podlegać powinny trzy jego składniki: wiedza, umiejętności oraz składnik związany z odpowiedzialnym działaniem a określany przez różne źródła jako rozumienie i pragnienie wykorzystania owej wiedzy i umiejętności, świadomość potrzeby, konsekwencji i odpowiedzialności w jej stosowaniu, doświadczenie, demonstrowanie czy postawa odpowiednia do sytuacji. Wiedza oraz umiejętności (które razem składają się na kwalifikacje ${ }^{4}$ ), podlegają weryfikacji w trybie testów osiągnięć szkolnych (testów wiedzy i umiejętności) ${ }^{5}$. Ta metoda badania jest adekwatną i wiarygodną w odniesieniu do aktualnego, chwilowego stanu. Zastosowanie jej sprawić jednak może, że otrzymamy zafałszowany obraz ważnej dla badań grupy nauczycieli, którzy zostali wyposażeni w kwalifikacje informatyczne, jednak przez dłuższy czas nie wykorzystując ich (z powodu choćby niewiary w ich potencjał dydaktyczny,

\footnotetext{
${ }^{1}$ T. Pilch, T. Bauman, Zasady badań pedagogicznych. Strategie ilościowe i jakościowe (wydanie trzecie poprawione i rozszerzone), Warszawa 2010.

${ }^{2}$ D. Silverman, Prowadzenie badań jakościowych, tłum. J. Ostrowska, Warszawa 2009. Idem: Interpretacja danych jakościowych. Metody analizy rozmowy, tekstu i interakcji, tłum. M. Głowacka-Grajper, J. Ostrowska, Warszawa 2009.

${ }^{3}$ D. Kubinowski, Jakościowe badania pedagogiczne. Filozofia - metodyka - ewaluacja, Lublin 2010.

${ }^{4}$ Por.: rozdział 2.1. niniejszej pracy.

${ }^{5}$ Według: Łobocki M., Metody i techniki badań pedagogicznych, Kraków 2000, s. 141-142. W tym konkretnym przypadku, z uwagi na podmiot badań, którym jest nauczyciel, stosujący ten rodzaj ewaluacji w odniesieniu do własnych uczniów, właściwe byłoby pominięcie przymiotnika „szkolne”.
} 
czy też nieposiadania własnego sprzętu), utracili owe kwalifikacje. Przyczyną braku kompetencji informatycznych w takiej grupie nauczycieli jest więc nie aktualny brak kwalifikacji, co byłoby wnioskiem z testu wiedzy i umiejętności, ale brak wystarczającego poziomu odpowiedzialności i w konsekwencji odpowiedzialnego działania, nie przesądzając czy brak ów jest wynikiem przeszkód natury wewnętrznej czy zewnętrznej (organizacyjnej, finansowej, braku motywacji i in.). Skutkiem działania takich przeszkód byłaby stopniowa utrata posiadanych wcześniej kwalifikacji.

Dla kontekstu niniejszych badań ważniejszym zatem wydaje się ustalenie czy i dlaczego mimo posiadanych kwalifikacji informatycznych, nauczyciel nie zdecydował się w żadnym momencie swojej kariery zawodowej na podjęcie wyzwania odpowiedzialnego zastosowania TIK w dydaktyce muzyki. Czy i dlaczego nie poczuł pragnienia, świadomej potrzeby jej zastosowania mimo, iż posiadał odpowiednie kwalifikacje? Czy i jakie przyczyny stanęły na przeszkodzie wdrożeniu nowych technologii do jego warsztatu pracy? Zanik uprzednio posiadanych kwalifikacji informatycznych jest w takiej sytuacji skutkiem a nie przyczyną braku kompetencji informatycznych.

W związku z tak sformułowanym problemem ważniejszym jest ustalenie, czy kiedykolwiek w trakcie swojej nauczycielskiej kariery badany posiadał kwalifikacje informatyczne, rozumiane jako zespół wiedzy i umiejętności w tym zakresie. Zatem zasadnym jest, zamiast testu wiedzy i umiejętności, zastosowanie pytania ankietowego o posiadane kwalifikacje, wynikające z programu ukończonych studiów, kursu bądź szkolenia, uwzględniających przedmiot dotyczący technologii informacyjnej. „Uważamy, że jednostka posiada kwalifikacje, kiedy posiada odpowiedni dyplom"6. Wobec powszechnej praktyki samokształcenia w dziedzinie TIK, posiadanie kwalifikacji informatycznych można również przyjąć w przypadku deklaracji badanego o użytkowaniu TIK w sytuacjach pozadydaktycznych, mimo braku formalnych (udokumentowanych) kwalifikacji w tym zakresie.

Cele badań zatem można sformułować następująco:

1. Określenie rzeczywistego poziomu kompetencji informatycznych nauczycieli muzyki.

2. Określenie ewentualnych rozbieżności ww. poziomu ze stanem kompetencji, jakie nauczyciel muzyki zobowiązany jest posiadać.

3. Ustalenie korelatów i prawdopodobnych przyczyn spodziewanych rozbieżności obu stanów.

\footnotetext{
${ }^{6}$ B. Kędzierska, Kompetencje informacyjne $w$ kształceniu ustawicznym, s. 48.
} 
Oprócz tak sformułowanych celów poznawczych badania, celem praktycznym będzie wskazanie słabych punktów w kształceniu przyszłych nauczycieli muzyki w zakresie TIK oraz propozycje zmian w programach kształcenia, których wprowadzenie umożliwiłoby zniwelowanie różnic pomiędzy rzeczywistym i postulowanym poziomem kompetencji informatycznych nauczycieli muzyki.

\subsection{Problemy i hipotezy badawcze}

W toku badań podjęte zostaną następujące problemy badawcze:

1. w jakim stopniu wykorzystywana jest TIK na polu określonym przedmiotem badań;

2. jakie są - w opiniach badanych nauczycieli - przyczyny spodziewanego niedostatecznego wykorzystania TIK;

3. jakie są kompetencje informatyczne nauczycieli przedmiotu muzyka w klasach IV-VI łódzkich szkół podstawowych;

4. w jakim stopniu zgodne są postulowany i rzeczywisty stan kompetencji informatycznych badanej grupy nauczycieli;

5. jakie są przyczyny ewentualnej (spodziewanej) rozbieżności między obydwoma stanami (postulowanym i rzeczywistym) kompetencji informatycznych.

Nadrzędna hipoteza badawcza brzmi: nauczyciele muzyki w znikomym stopniu wykorzystują TIK w pracy dydaktycznej, ponieważ zostali wyposażeni jedynie w kwalifikacje, a nie kompetencje informatyczne.

Hipotezy szczegółowe, sformułowane zgodnie z logiką przedstawionych problemów badawczych brzmią następująco:

- nauczyciele muzyki w niedostatecznym stopniu wykorzystują TIK w swojej pracy dydaktycznej;

- rzeczywisty poziom kompetencji informatycznych nauczycieli muzyki jest daleko niższy od postulowanego;

- uczelnie kształcące nauczycieli muzyki nie wyposażają studentów $\mathrm{w}$ kompetencje informatyczne a jedynie $\mathrm{w}$ kwalifikacje informatyczne, często nieuwzględniające ich zastosowań dydaktycznych;

- brak składnika kompetencji informatycznych nazwanych tu odpowiedzialnym działaniem to główna różnica między stanem postulowanym a rzeczywistym kompetencji informatycznych nauczycieli muzyki. 


\subsection{Metody i techniki badawcze}

Problem pierwszy (w jakim stopniu wykorzystywana jest TIK na polu określonym przedmiotem badań) oraz trzeci (jakie są kompetencje informatyczne nauczycieli przedmiotu muzyka w klasach IV-VI łódzkich szkół podstawowych) rozstrzygnięte zostaną przy pomocy metody sondażu diagnostycznego.

Do rozstrzygnięcia problemu drugiego (jakie są - w opiniach badanych nauczycieli - przyczyny spodziewanego niedostatecznego wykorzystania TIK), oprócz sondażu zostanie wykorzystane studium indywidualnych przypadków, zrealizowane przy pomocy wywiadów, które ma pozwolić na zdefiniowanie indywidualnych postaw badanych nauczycieli w przedmiotowym zakresie, ich świadomości, preferencji, obaw, niechęci oraz innych ograniczeń, w tym instytucjonalnych i organizacyjnych.

Problem czwarty (w jakim stopniu zgodne są postulowany i rzeczywisty stan kompetencji informatycznych badanej grupy nauczycieli) zostanie rozstrzygnięty poprzez konfrontację dokumentów omówionych w rozdziale 2.4. (Postulowany zakres kompetencji informatycznych nauczyciela muzyki), stanowiących podstawę działalności dydaktycznej nauczyciela, ze stanem rzeczywistym, którego obraz zostanie zrekonstruowany za pomocą badań sondażowych.

Ostatni, piąty problem badawczy (jakie są przyczyny ewentualnej rozbieżności między obydwoma stanami kompetencji informatycznych) rozstrzygnięty zostanie poprzez analizę wyników wszystkich powyższych działań, wspartych dodatkowo ankietą własnej konstrukcji, weryfikującą opinie nauczycieli na temat uwarunkowań instytucjonalnych, a skierowaną do dyrektorów szkół. Ponadto wykorzystana zostanie analiza programów nauczania w zakresie TIK na uczelniach wyższych regionu łódzkiego, kształcących przyszłych nauczycieli muzyki. Pozwoli ona na sformułowanie przyczyn spodziewanych rozbieżności, mających swe źródła w programach nauczania omawianych kierunków studiów, oraz propozycji zmian.

W części jakościowej badań posłużono się wywiadem otwartym, którego celem było ujawnienie innych, nieprzewidzianych w badaniach ilościowych, źródeł rozbieżności rzeczywistego i postulowanego stanu kompetencji informatycznych nauczycieli muzyki oraz ich stosunku do wykorzystywania TIK w dydaktyce muzyki. 
Ta część badań ma również za zadanie odtworzyć indywidualne ścieżki dochodzenia badanych do decyzji o włączeniu bądź wykluczeniu TIK ze swojego warsztatu pracy. W takim ujęciu wpisuje się w ramy metody indywidualnych przypadków, którą Pilch zdefiniował, jako „sposób badań polegający na analizie jednostkowych losów ludzkich uwikłanych w określone sytuacje wychowawcze, lub na analizie konkretnych zjawisk natury wychowawczej poprzez pryzmat jednostkowych biografii ludzkich z nastawieniem na opracowanie diagnozy przypadku lub zjawiska w celu podjęcia działań terapeutycznych"”. Jednostkowe losy badanych nauczycieli mają pozwolić na analityczne ujęcie przyczyn, dla których podjęli oni lub zaniechali prób wykorzystywania TIK w pracy dydaktycznej. Taka diagnoza stanowić może podstawę do dalszych działań uzdrawiających, których podjęcie należeć może zarówno do samych nauczycieli, jak i osób czy instytucji nadzorujących ich pracę. Próbą takich działań terapeutycznych jest rozdział 5.3., zawierający praktyczne wskazówki, dotyczące podstawowych ale efektywnych zastosowań TIK w dydaktyce muzyki.

Równie ważnym efektem zastosowania wywiadu będzie sprowokowanie badanego do zastanowienia się nad przedmiotem badań - refleksji na temat, który być może do tej pory nie był przedmiotem zastanowienia, a w związku z tym wyartykułowanie świadomego zdania lub dojście do świadomego stanowiska na temat miejsca technologii informacyjno-komunikacyjnej w życiu zawodowym i pozazawodowym respondentów.

Ponieważ otwartość badań jakościowych zakłada, że „przed przystąpieniem do badań terenowych formułuje się wprawdzie cel i pytania badawcze, ale ich status jest zdecydowanie tymczasowy - lista pytań jest otwarta tak długo, jak długo trwa proces badawczy"', zatem ten rodzaj podejścia do celów, jakie dzięki wywiadowi mają być osiągnięte, zdeterminował jego formę, zawierającą pewne dyspozycje w formie listy tematów, które badający chciał poruszyć w rozmowie. Te tematy, to m.in.:

- stosunek rozmówcy do technologii komputerowej, wyrażający się w:

- sposobie jej wykorzystywania, zarówno w pracy, jak i poza nią;

- dostrzeganiu jej potencjału (dydaktycznego, kulturowego);

- chęci do zgłębiania jej tajników;

${ }^{7}$ T. Pilch, T. Bauman, Zasady badań pedagogicznych..., s. 78.

${ }^{8}$ D. Urbaniak-Zając, J. Piekarski, Jakościowe orientacje $w$ badaniach pedagogicznych. Studia i materiały, Łódź 2001, s. 24. 
- doświadczenia rozmówców z prób stosowania technologii komputerowej w dydaktyce muzyki;

- indywidualne motywacje do stosowania lub niestosowania technologii komputerowej w dydaktyce muzyki, w tym bodźce zewnętrzne, ze strony:

- zwierzchników;

- innych nauczycieli;

- uczniów;

- skutki (pozytywne i negatywne) stosowania technologii komputerowej w dydaktyce muzyki, jakie rozmówcy zauważyli w swojej pracy;

- bariery w stosowaniu technologii komputerowej w dydaktyce muzyki;

- źródła wiedzy i umiejętności na temat technologii komputerowej;

- ocena własnych kompetencji informatycznych;

- chęci i możliwości dokształcania w zakresie dydaktycznych zastosowań technologii komputerowej.

Powyższa lista nie stanowiła sztywnej struktury, w większości bowiem przypadków rozmówcy sami podejmowali niektóre z wymienionych tematów, a chęć ich rozwinięcia przez badającego prowokowała jedynie pytania pozwalające na podtrzymanie tematu, sugerujące szczególne zainteresowanie podjętym problemem.

Ponieważ w centrum zainteresowań badawczych było wykorzystywanie TIK w dydaktyce muzyki, a dokładniej - czynniki wpływające na decyzję nauczyciela (pozytywną lub negatywną) o podjęciu takich działań, perspektywa zastosowanego studium przypadku obejmowała analizę procesu uchwyconą poprzez pryzmat jednostkowych historii badanych nauczycieli. Naturalnym zatem był merytoryczny wybór metody instrumentalnego studium przypadku, „,w którym prowadzi się badanie przede wszystkim w celu dostarczenia wglądu w określone kwestie lub z zamiarem zrewidowania uogólnień. Mimo, że wybrany przypadek jest badany dogłębnie, to jednak uwaga badacza skupia się na czymś innym"9 . Konsekwencją takiego ujęcia było ograniczenie czasowe poruszanych historii do okresu pracy zawodowej, ze szczególnym uwzględnieniem ostatnich 15 lat, gdy zaczęto formułować pierwsze zalecenia dotyczące obecności TIK w szkołach. Taka strategia badań pozwoliła skoncentrować się na danych wysokiej jakości ${ }^{10}$, unikając roz-

\footnotetext{
${ }^{9}$ D. Silverman, Prowadzenie badań jakościowych, s. 169.

${ }^{10}$ Por.: ibidem, s. 216-217.
} 
proszenia, jakie towarzyszyłoby badaniom o odwrotnej perspektywie - analizie jednostkowych biografii nauczycieli, $\mathrm{z}$ ich wszystkimi kontekstami ${ }^{11}$. $\mathrm{Z}$ formalnego punktu widzenia zastosowana metoda badawcza to zbiorowe studium przypadku, „w którym pewna liczba przypadków jest badana w celu poznania pewnego ogólnego zjawiska"12. Owo ogólne zjawisko to sposoby dochodzenia do kompetencji informatycznych, czy sposoby wdrażania tych kompetencji przez nauczycieli muzyki.

\subsection{Zmienne i ich wskaźniki}

Zmienna zależna:

- poziom kompetencji informatycznych badanych nauczycieli - określony zgodnie $\mathrm{z}$ terminologią przyjętą $\mathrm{w}$ rozdziale 2.2. przez trzy zmienne szczegółowe: wiedzę, umiejętności oraz odpowiedzialne działanie;

Zmienne niezależne:

- wiek;

- płeć;

- staż pracy jako nauczyciel muzyki;

- stopień awansu zawodowego;

- częstotliwość wykorzystywania TIK w pracy dydaktycznej;

- częstotliwość wykorzystywania TIK w sytuacjach pozadydaktycznych;

- znajomość muzycznych programów komputerowych;

- znajomość formalnych wymagań wobec nauczycieli w zakresie kompetencji informatycznych;

- stosunek nauczyciela do zastosowań dydaktycznych TIK;

- wyposażenie szkoły w sprzęt komputerowy oraz oprogramowanie dydaktyczne;

- dostępność szkolnej pracowni komputerowej lub przenośnego sprzętu komputerowego dla nauczyciela muzyki;

- ukończenie kursów, szkoleń, studiów z zakresu TIK;

\footnotetext{
${ }^{11}$ Podobną strategię zastosował D. Silverman w swoich badaniach z 1987 roku, poświęconych rozmowom lekarzy z pacjentami chorymi na AIDS (ibidem, s. 154-156) oraz w badaniach z początku lat 80., dotyczących komunikacji lekarzy z pacjentami poradni kardiologii dziecięcej (ibidem, s. 215-218).

${ }^{12}$ Ibidem, s. 169.
} 
- ukończenie kursów, szkoleń, studiów z zakresu zastosowań dydaktycznych TIK;

- ograniczenia wewnętrzne dotyczące zastosowań dydaktycznych TIK (brak motywacji, niechętny stosunek nauczyciela do TIK i in.);

- ograniczenia zewnętrzne dotyczące zastosowań dydaktycznych TIK (organizacyjne, sprzętowe i in.).

Zmienne pośredniczące:

- organizacja pracy szkoły, umożliwiająca lub utrudniająca korzystanie ze sprzętu komputerowego na lekcjach muzyki;

- atmosfera pracy szkoły sprzyjająca lub niesprzyjająca stosowaniu nowych technologii (elementy motywujące ze strony dyrekcji szkoły lub Rady Rodziców, powszechność stosowania TIK przez innych nauczycieli, gotowość do współpracy ze strony nauczyciela informatyki i in.).

Wskaźniki (przykładowe):

- ilość lekcji muzyki przeprowadzonych w ciągu roku szkolnego przy użyciu narzędzi komputerowych;

- częstotliwość korzystania z komputera;

- ilość (nazwy) znanych muzycznych aplikacji komputerowych;

- ilość (nazwy) wykorzystywanych na zajęciach muzycznych aplikacji komputerowych;

- ilość lekcji muzyki przeprowadzonych w ciągu roku w pracowni komputerowej;

- ilość znanych aktów prawnych traktujących o kompetencjach informatycznych nauczycieli;

- ilość szkolnych przenośnych zestawów multimedialnych (laptop + rzutnik) do dyspozycji nauczycieli;

- ilość kursów, szkoleń z zakresu TIK ukończonych przez nauczyciela.

\subsection{Narzędzia badawcze}

Obydwa narzędzia zostały sporządzone przez autora badań oraz zweryfikowane podczas badań pilotażowych. Formularze ankiet zamieszczono $\mathrm{w}$ aneksie. 


\subsubsection{Ankieta dla nauczyciela}

Ankieta składa się z 26 pytań w formie zamkniętej, półotwartej i otwartej. Siedem pierwszych pytań ankiety dotyczy danych statystycznych nauczyciela. Trzy kolejne pytania (8.-10.) dotyczą pierwszego problemu badawczego (w jakim stopniu wykorzystana jest TIK na polu określonym przedmiotem badań) i mają na celu ustalenie sposobów oraz częstotliwości stosowania TIK przez nauczyciela a także rodzajów wykorzystywanych przez niego programów komputerowych.

Pytania 11. i 12. mają na celu ustalenie ewentualnych problemów natury organizacyjnej w szkole, uniemożliwiających lub utrudniających stosowanie TIK przez nauczyciela. W tym zakresie pomocne będą przy rozstrzyganiu drugiego problemu badawczego (jakie są przyczyny spodziewanego niedostatecznego wykorzystania TIK).

Pytania od 13. do końca dotyczą trzeciego problemu badawczego (jakie są kompetencje informatyczne nauczycieli przedmiotu muzyka w klasach IV-VI łódzkich szkół podstawowych) i diagnozują zarówno stan „kwalifikacyjnych” składników kompetencji: wiedzy i umiejętności z zakresu technologii informatycznej - pytania 13.-21., jak i obszar składnika nazwanego $\mathrm{w}$ rozdziale 2.1. odpowiedzialnym działaniem (rozumienie, świadomość, odpowiedzialność, demonstrowanie, odpowiednia postawa) - pytania 22.-26. Ta część ankiety, diagnozując ewentualne braki w elementach składających się na kompetencje informatyczne, wskazywać będzie w tym właśnie zakresie na przyczyny niedostatecznego wykorzystywania TIK przez nauczyciela muzyki, a więc wraz z pytaniami 11. i 12. pomocna będzie przy rozstrzyganiu drugiego problemu badawczego.

Po 26. pytaniu ankietowym zostawiono miejsce na wypowiedź związaną z tematem badań, ale nie uwzględnioną w pytaniach ankietowych. Celem takiego zabiegu jest poznanie ewentualnych stanowisk respondentów, których na etapie projektowania narzędzia ani na etapie badań pilotażowych nie przewidziano.

\subsubsection{Ankieta dla dyrektora szkoły}

Ankieta dla dyrektora szkoły składa się z siedmiu pytań zamkniętych, zarówno jednokrotnego jak i wielokrotnego wyboru i ma za zadanie ustalenie, czy ewentualne problemy natury organizacyjnej, wskazywane w an- 
kiecie przez nauczyciela, znajdują potwierdzenie bądź zaprzeczenie w opinii przełożonego. Ponadto ważne będzie ustalenie czy dyrekcja szkoły ma świadomość konieczności posiadania kompetencji informatycznych przez swoich podwładnych oraz świadomość stanu tych kompetencji. Ostatnie pytanie ma na celu ustalenie stosunku samego dyrektora do zastosowań TIK w dydaktyce przedmiotów nieinformatycznych, co może mieć bezpośrednie przełożenie na motywowanie w tym zakresie nauczycieli.

\subsection{Organizacja badań}

We wrześniu 2010 roku przeprowadzono badania pilotażowe na grupie 5 nauczycieli muzyki: trzech nauczycieli szkół podstawowych (w tym jednym będącym również dyrektorem) i dwóch nauczycieli gimnazjów. Zaowocowały one drobnymi korektami niektórych kafeterii.

Formularze ankiet dla nauczycieli muzyki oraz dyrektorów szkół ${ }^{13}$ rozprowadzono we wszystkich 104 (publicznych oraz niepublicznych z uprawnieniami szkół publicznych) szkołach podstawowych Łodzi ${ }^{14}$, w lutym i marcu 2011 roku. Wypełnione ankiety zebrano z 96 szkół, w tym: 83 szkół publicznych i 13 szkół niepublicznych (10 społecznych i 3 prywatnych) również w lutym i marcu 2011 roku. Pozostałe 8 szkół odmówiło udziału w badaniach (4 z przyczyn merytorycznych: w dwóch - brak klas IV-VI, w kolejnych dwóch - długotrwała absencja nauczyciela muzyki; 4 - z powodu braku chęci i czasu lub bez podania powodu).

W jednej ze szkół zebrano ankiety od dwóch nauczycieli muzyki pracujących w placówce, co skutkowało rozpatrzeniem dwóch niezależnych rekordów (przypadków). W dwunastu przypadkach nauczyciel muzyki zatrudniony był w dwóch szkołach podstawowych w Łodzi. Sytuacja taka skutkowała oddaniem niewypełnionej drugiej ankiety przez nauczyciela $\mathrm{z}$ adnotacją o wypełnieniu jej w innej placówce. W 5 przypadkach pary były niekompletne - 4 dyrektorów i 1 nauczyciel nie wypełnili w ogóle swojej części ankiety, jednak ich dopełnienia wzięto pod uwagę analizując odpowiedzi samych nauczycieli bądź samych dyrektorów. Zatem do badań pozyskano ankiety 85 nauczycieli oraz 93 dyrektorów, wśród których skompletowano 80 par nauczyciel muzyki-dyrektor. Dwie z nich były przypadkami

\footnotetext{
${ }^{13}$ Wzory obu ankiet zamieszczono w aneksie.

${ }^{14}$ Listę szkół sporządzono na podstawie danych z Kuratorium Oświaty w Łodzi: http://www.kuratorium. lodz.pl/page/index.php?str=141\&city=\%C5\%81\%C3\%B3d\%C5\%BA (stan z dnia 7.01.2011).
} 
szczególnymi, w których nauczyciel muzyki biorący udział w badaniach był jednocześnie dyrektorem szkoły.

Na podstawie zgody wyrażonej w formularzu ankiety wyłoniono 7 nauczycieli, z którymi w kwietniu i maju 2011 roku przeprowadzone zostały wywiady wykorzystane do badań. 


\section{Analiza wyników badań}

\subsection{Prezentacja wyników badań ilościowych}

\subsubsection{Charakterystyka badanej grupy}

Dane socjologiczno-demograficzne nauczycieli opracowano na podstawie 84 przypadków - jeden z badanych nie wypełnił tej części ankiety, bez jego udziału udało się jedynie uzupełnić rubrykę dotyczącą płci. Wśród 85 badanych nauczycieli znalazło się zatem 70 kobiet (82,3\%) i 15 mężczyzn $(17,6 \%)$ w wieku od 24 do 62 lat (2 osoby nie podały wieku). Średnia wieku wyniosła niecałe 43 lata $(42,94)$.

Wykres 1. Rozkład wieku w zależności od płci w badanej grupie

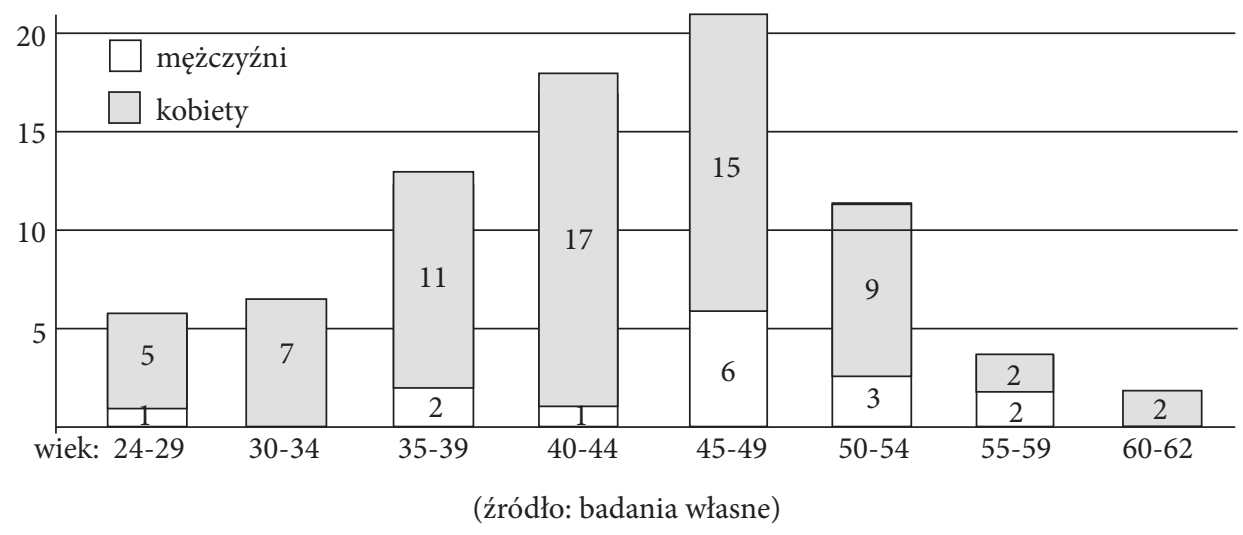

Tabela 1. Statystyki opisowe dla wieku badanej grupy nauczycieli

\begin{tabular}{|l|c|}
\hline Średnia & 42,93975904 \\
\hline Mediana & 44 \\
\hline Odchylenie standardowe & 8,046131319 \\
\hline Zakres & 38 \\
\hline Minimum & 24 \\
\hline Maksimum & 62 \\
\hline Licznik & 83 \\
\hline
\end{tabular}

(źródło: badania własne) 
Wyraźna wśród mężczyzn przewaga przedziałów wiekowych 45-59 z maksimum w przedziale 45-49 kontrastuje z rozkładem wieku kobiet, zbliżonym do rozkładu normalnego, $\mathrm{z}$ maksimum w przedziale 40-44, w niewielkim stopniu przekłada się na kontrast średnich wieku obu płci: średnia wieku kobiet wynosi 42,26, mężczyzn - 46 lat.

Tabela 2. Statystyki opisowe dla stażu pracy badanej grupy nauczycieli

\begin{tabular}{|l|c|}
\hline Średnia & 15,03658537 \\
\hline Mediana & 15,5 \\
\hline Odchylenie standardowe & 9,216792407 \\
\hline Zakres & 31,5 \\
\hline Minimum & 0,5 \\
\hline Maksimum & 32 \\
\hline Licznik & 82 \\
\hline
\end{tabular}

(źródło: badania własne)

Staż pracy ankietowanych waha się między 0,5 roku a 32 lata (średnia 15 lat, przy 3 osobach, które nie podały stażu). Wymiar zatrudnienia 80 nauczycieli, którzy takie dane podali wynosił od 2 do 26 godzin tygodniowo ( przy średniej $=14,89$ i medianie $=18$ godzin).

Większość ankietowanych zatrudniona jest w jednej szkole (68 badanych $=81 \%), 13-$ w dwóch szkołach $(15,5 \%), 2-$ w trzech $(2,3 \%)$ i jedna w czterech szkołach (1,2\%) (1 osoba nie podała danych na ten temat), przy czym tylko w 11 przypadkach oznaczało to zatrudnienie w dwóch szkołach podstawowych (pozostałe osoby pracowały jednocześnie w szkołach podstawowych i ponadpodstawowych).

Wykres 2. Wymiar zatrudnienia ankietowanych nauczycieli

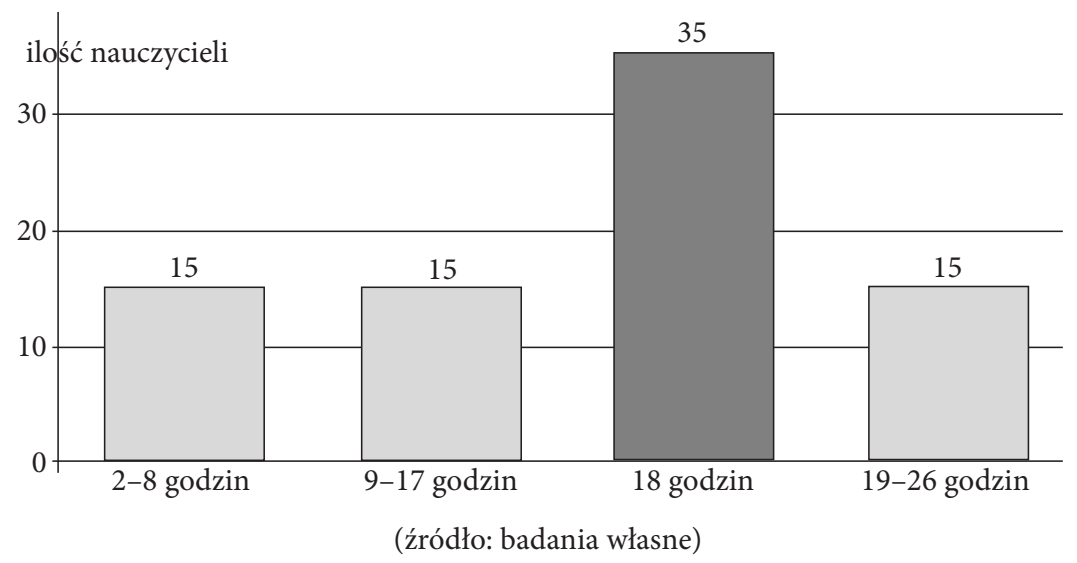


42 nauczycieli (50\% udzielonych odpowiedzi) jest absolwentami akademii muzycznych, tyle samo badanych ukończyło uczelnie o charakterze uniwersyteckim, nieartystycznym (uniwersytet, akademia lub wyższa szkoła pedagogiczna), w tym 40 ankietowanych $(47,6 \%)$ ukończyło wydziały pedagogiczne a $2(2,4 \%)$ - muzykologię. Jedna osoba nie wypełniła tej rubryki.

Wykres 3. Liczebności i procentowy udział absolwentów uczelni artystycznych i nieartystycznych w próbie badawczej $(\mathrm{N}=84)$

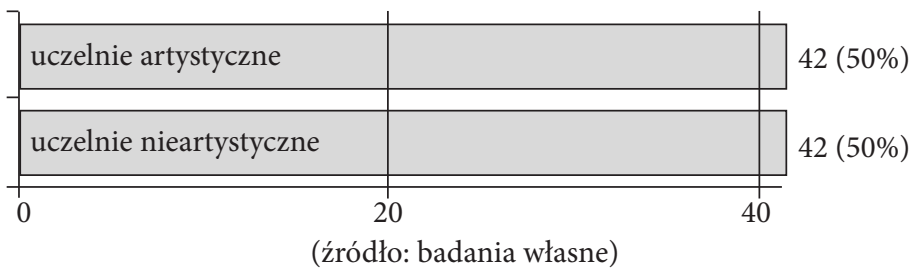

Rubrykę o osiągniętym stopniu awansu zawodowego nauczyciela wypełniło 80 respondentów. 2 z nich (2,5\%) miało status nauczyciela stażysty, $13(16,25 \%)$ - nauczyciela kontraktowego, 25 (31,25\%) - nauczyciela mianowanego a $40(50 \%)$ - nauczyciela dyplomowanego.

Wykres 4. Liczebności i procentowy udział stopnia awansu zawodowego nauczycieli w próbie badawczej $(\mathrm{N}=85)$

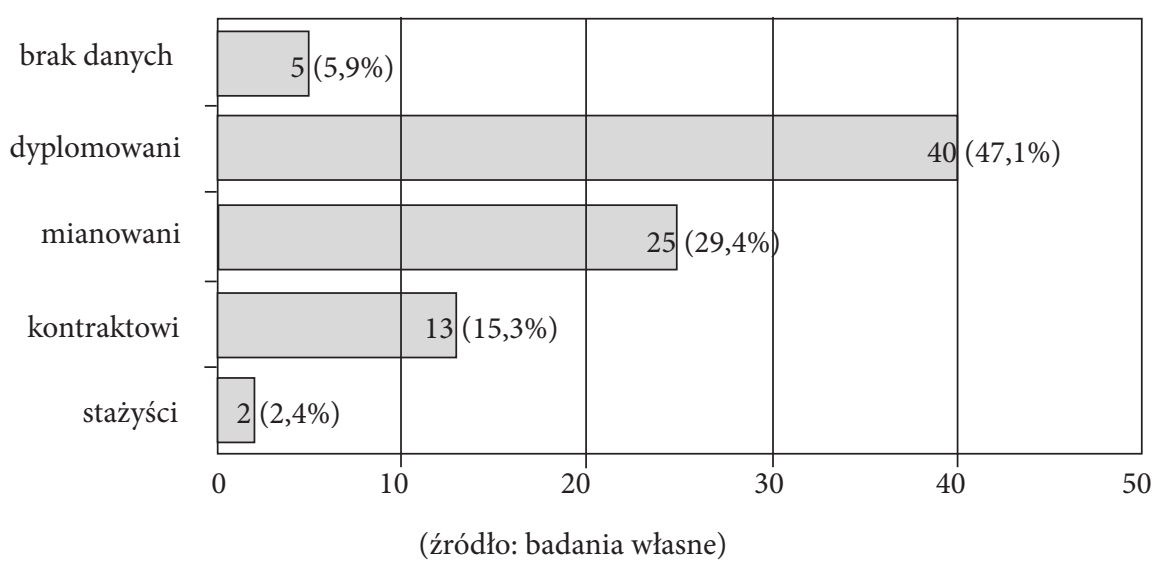

Zależność osiągniętego stopnia awansu zawodowego od rodzaju ukończonej uczelni przedstawia tabela 1 . 
Tabela 3. Stopień awansu zawodowego nauczycieli według rodzaju ukończonej uczelni $(\mathrm{N}=84)$

\begin{tabular}{|l|c|c|c|c|}
\hline \multirow{2}{*}{} & \multicolumn{2}{|c|}{ uczelnie artystyczne } & \multicolumn{2}{c|}{ uczelnie nieartystyczne } \\
\cline { 2 - 5 } & $\mathrm{n}$ & $\%$ & $\mathrm{n}$ & $\%$ \\
\hline stażyści & 1 & 2,4 & 1 & 2,4 \\
\hline kontraktowi & 8 & 19,1 & 5 & 11,9 \\
\hline mianowani & 12 & 28,6 & 13 & 30,9 \\
\hline dyplomowani & 20 & 47,6 & 20 & 47,6 \\
\hline brak danych & 1 & 2,4 & 3 & 7,1 \\
\hline suma & 42 & 100 & 42 & 100 \\
\hline
\end{tabular}

(źródło: badania własne)

Z powyższej tabeli wynika wyjątkowa zgodność stopnia awansu w obu grupach ankietowanych - żaden rodzaj uczelni nie predestynuje do osiągnięcia wyższego stopnia awansu zawodowego nauczyciela. Nieistotność statystyczną różnic potwierdza test chi $(=0,8773$ przy $\mathrm{p}=0,05)$.

Wykres 5. Porównanie stopnia awansu zawodowego badanych nauczycieli z danymi wojewódzkimi i ogólnokrajowymi ${ }^{1}$

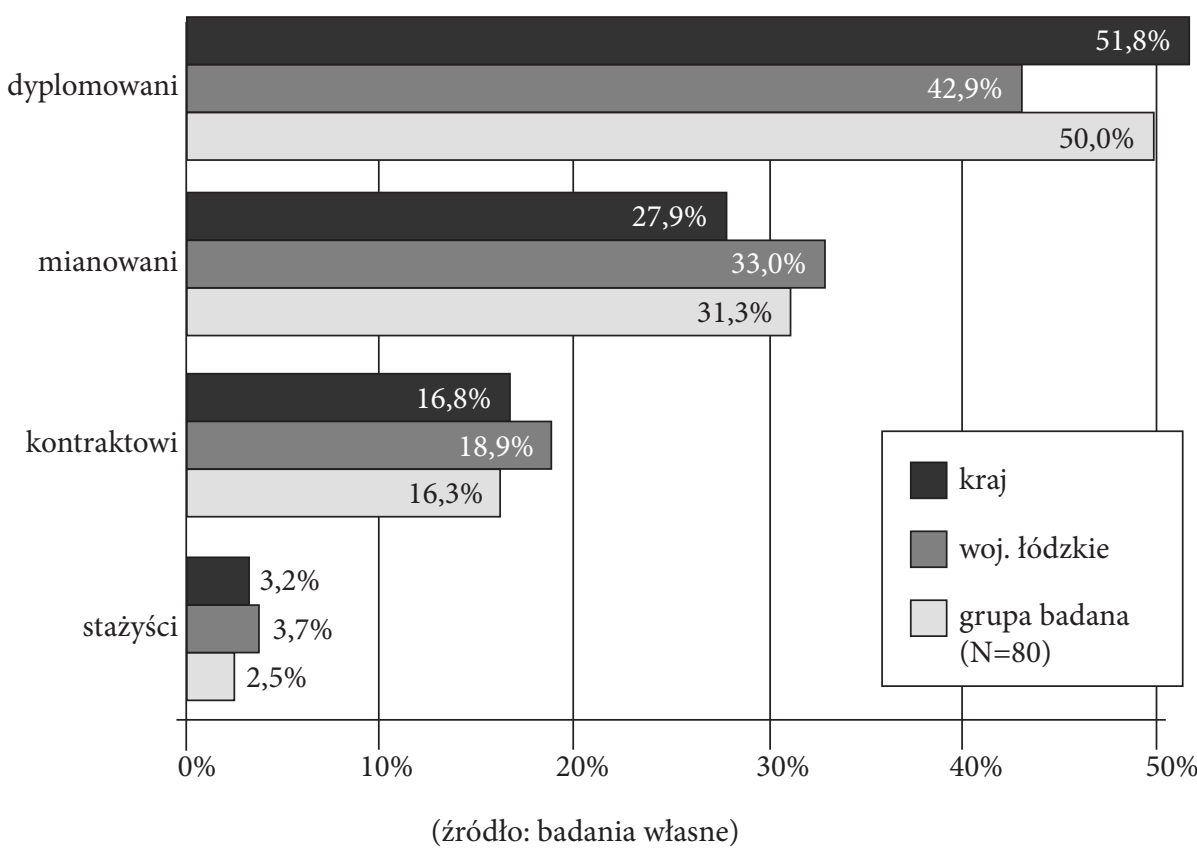

${ }^{1} \mathrm{Na}$ podstawie: GUS, Wydział Statystyki Edukacji i Kultury, Oświata $i$ wychowanie w roku szkolnym 2010/2011, Warszawa 2011, s. 123-124; (http://www.stat.gov.pl/cps/rde/xbcr/gus/PUBL_e_oswiata_i_wychowanie_2010-2011.pdf, stan z dnia 18.03.2012). 
Grupa badanych nauczycieli wykazuje nieznacznie większy udział wyższych stopni awansu zawodowego na tle województwa (tu przewaga nauczycieli dyplomowanych w badanej grupie) i całego kraju (tu przewaga nauczycieli mianowanych), przy odpowiednio mniejszym udziale niższych stopni (stażystów i kontraktowych). Należy przy tym pamiętać, że dane GUS dotyczą wszystkich nauczycieli szkół podstawowych, bez podziału na przedmioty, których nauczają.

\subsubsection{Stopień wykorzystania TIK przez badanych nauczycieli}

W tym rozdziale podjęty zostanie pierwszy problem badawczy, który został sformułowany następująco: w jakim stopniu wykorzystywana jest TIK na polu określonym przedmiotem badań? Na podstawie wyników ankiet przeanalizowane zostaną kolejne elementy składające się na obraz stopnia wykorzystania TIK:

- sytuacje dydaktyczne, w których badani nauczyciele wykorzystują TIK,

- oprogramowanie wykorzystywanie przez nauczycieli,

- częstotliwość stosowania TIK w przygotowaniu lub prowadzeniu zajęć,

- dostępność szkolnego sprzętu komputerowego do lekcji muzyki.

Po 7 pytaniach ankiety składających się na metryczkę respondenta, pozostałe dotyczyły wykorzystywania technologii informacyjnej na prowadzonych przez badanych lekcjach muzyki. Część z nich wymagała odpowiedzi popartych wiedzą na temat stosowanych programów komputerowych, ich przeznaczenia, możliwości, nazwy (pytania: 10., 18.-21.), bądź na temat wymagań stawianych nauczycielowi w zakresie umiejętności zastosowania TI w dydaktyce muzyki (pytania 22. i 24.), inne wymagały jedynie deklaracji bądź opinii, ujawniając własny wizerunek nauczyciela muzyki, niekoniecznie zgodny z rzeczywistością, za to zgodny z chęcią autokreacji wizerunku badanej grupy (pytania 8., 9., 16., 17., 23., 26.). Ankieta zawierała również pytania dotyczące m.in. możliwości lub ograniczeń organizacyjnych szkoły w dostępie do sprzętu komputerowego (pytania 11., 12.) oraz źródeł wiedzy i umiejętności informatycznych nauczyciela (pytania 13., 14.).

Ankieta skierowana do dyrektorów w wielu punktach służyć będzie weryfikacji opinii i deklaracji nauczycieli na temat wykorzystywania TIK do lekcji muzyki oraz skonfrontowaniu oceny kompetencji informatycznych nauczyciela muzyki z jego samooceną. 


\section{Zastosowania}

Pytania, które miały uściślić zastosowania TI w pracy badanych nauczycieli, zawierały kafeterię wyczerpującą takie właśnie sytuacje. W ten sposób, oprócz zadbania o wygodę badanych, jednocześnie można było uzmysłowić im, że np. nawet pozornie bezcelowe przeszukiwanie internetu, dzięki któremu znajdujemy wiadomości użyteczne dla wiedzy muzycznej bądź pedagogicznej, noszą znamiona wykorzystywania TI w pracy nauczyciela. Podobne znamiona posiada wyszukiwanie nagrań lub zapisów nutowych, prezentowanych następnie uczniom. Nie wszyscy nauczyciele mają tego świadomość, co potwierdziły badania pilotażowe.

Pierwsze z merytorycznych pytań miało sprowokować deklarację zgodną lub niezgodną z rzeczywistością - o stosowaniu TI w przygotowaniu lub prowadzeniu lekcji muzyki i brzmiało:

„8. Czy stosuje Pan/i technologię komputerową w:

a. przygotowywaniu się do zajęć (odświeżanie lub pogłębianie własnej wiedzy, szukanie nowych informacji, ciekawych konspektów lekcji $\mathrm{i}$ in.)?

b. przygotowywaniu materiałów dla uczniów (nuty, nagrania, ilustracje, prezentacje $\mathrm{i}$ in.)?

c. prowadzeniu zajęć (prezentacje, filmy, ilustracje, programy i gry edukacyjne)?

d. ocenie osiągnięć uczniów (przygotowanie sprawdzianów, testów $\mathrm{w}$ formie papierowej lub multimedialnej)?

e. żadnej z powyższych sytuacji”.

Tabela 4. Deklaracje nauczycieli o stosowaniu TI $(\mathrm{N}=85)$

\begin{tabular}{|c|c|c|c|c|}
\hline Odpowiedź „a” & Odpowiedź „,b” & Odpowiedź „,c” & Odpowiedź „d” & Odpowiedź „,” \\
\hline $84(98,82 \%)$ & $76(89,41 \%)$ & $54(63,53 \%)$ & $51(60 \%)$ & $0(0 \%)$ \\
\hline
\end{tabular}

(źródło: badania własne)

Sytuacje wymienione w punktach od „a” do „d” wykazują w odpowiedziach wyraźną tendencję spadkową. Tendencja taka jest naturalna, gdyż jest odwrotna do zakresu zaangażowania, niezbędnego do ich realizacji. Najczęstszą więc sytuacją wybieraną przez ankietowanych jest przeglądanie zasobów internetowych w poszukiwaniu przydatnych informacji i materia- 
łów (odpowiedź „a”). Ten sposób wykorzystywania TI jest najmniej pracochłonny wśród wymienionych. Przygotowanie materiałów dla uczniów (odpowiedź „b”) wymaga już - oprócz ich wyszukania - także odpowiedniego opracowania, zapisania i powielenia. Kolejnych operacji wymaga zaprezentowanie wyników obydwu poprzednich czynności podczas zajęć (odpowiedź „c") oraz ich podsumowanie i opracowanie w formę sprawdzianu (odpowiedź „d”).

W odpowiedzi na pytanie 8 . żaden $z$ badanych nie zaznaczył odpowiedzi „e” (o niestosowaniu TI w żadnej z wymienionych sytuacji dydaktycznych), co świadczy o deklarowanej obecności - w mniejszym bądź większym stopniu - odpowiedzialnego działania jako składnika kompetencji informatycznych respondentów. Spośród 4 zaproponowanych w pytaniu sytuacji dydaktycznych badani wybrali średnio 3,118, w których stosują TI. Jest to znaczący wynik, stojący w sprzeczności z hipotezą szczegółową, iż nauczyciele muzyki w niedostatecznym stopniu wykorzystują TI. Każe on wnioskować, iż badani chcą być uważani za kompetentnych informatycznie nauczycieli, mających świadomość jej wagi w procesie dydaktycznym. Pozostaje ustalić czy jest to stan zgodny z rzeczywistością, czemu służyć mają odpowiedzi na pytania wymagające podstawowej wiedzy na temat wykorzystywanych programów komputerowych.

Ilość sytuacji dydaktycznych, w których - zgodnie z odpowiedziami na pytanie 8. - badani nauczyciele wykorzystują TI, nie wykazuje istotnej współzależności (korelacji) z wiekiem, stażem ani stopniem awansu zawodowego (współczynniki korelacji Pearsona odpowiednio: -0,2; -0,19 i 0,06). Natomiast obecna korelacja z odpowiedziami na pytanie 9. - dotyczące częstotliwości korzystania z TI - zostanie omówiona w następnym rozdziale.

Pytanie 10., poprzez dyspozycję o wpisaniu znanych respondentom nazw programów lub adresów stron internetowych, w bezpośredni sposób weryfikuje prawdziwość deklaracji z pytania 8. i brzmi:

„10. Jakiego rodzaju programy lub zastosowania komputerowe wykorzystuje Pan/i w pracy z uczniami (proszę o podanie nazw programów, tytułów stron internetowych):

a. wyszukiwanie i gromadzenie informacji lub nagrań potrzebnych do zajęć; (tytuły stron internetowych:

b. programy do zgrywania muzyki na płyty; (nazwy programów: ......)

c. programy do edycji nagrań muzycznych (przycinanie, zmiana tonacji itp.); (nazwy programów: 
d. programy do edycji i druku zapisu nutowego; (nazwy programów: .)

e. programy pomocne w komponowaniu muzyki, tworzeniu utworu z gotowych elementów; (nazwy programów: .....................)

f. programy do doskonalenia lub sprawdzania wiedzy i umiejętności muzycznych uczniów; (nazwy programów: ......................)

g. programy nie związane z muzyką (do tworzenia prezentacji, obróbki zdjęć, filmów, edytor tekstu) (nazwy programów: .................)

h. żadne z powyższych".

Tylko jedna $\mathrm{z}$ ankietowanych osób zaznaczyła odpowiedź „h”. Ta sama osoba w odpowiedzi na pytanie 8. wybrała odpowiedź „a” - „przygotowywanie się do zajęć (odświeżanie lub pogłębianie własnej wiedzy, szukanie nowych informacji, ciekawych konspektów lekcji i in.)" - czego jednak nie potrafi potwierdzić znajomością adresu jakiejkolwiek strony internetowej, z której skorzystała. Jest to respondentka, która w ramach badanej grupy prezentuje minimalny stopień wykorzystywania TI (62-letnia nauczycielka mianowana $\mathrm{z} 25$-letnim stażem, zatrudniona w wymiarze 3 godzin tygodniowo).

3 osoby nie zaznaczyły żadnej odpowiedzi na pytanie 10., natomiast 19 ankietowanych (25,88\%) zaznaczyło od 1 do 7 odpowiedzi (od „a” do „g”), nie wymieniając jednak żadnej nazwy programu bądź adresu strony internetowej, z których korzystają. Kolejne 3 osoby podały nazwy całkowicie nieadekwatne do możliwości lub przeznaczenia, dając tym samym wyraz nieznajomości w tym zakresie. Zatem w sumie 25 osób $(29,41 \%)$ nie wykazało się znajomością programów ani stron internetowych, których zgodnie z deklaracją zawartą w odpowiedziach na pytanie 8. używają.

Odpowiedzi tych 25 osób zweryfikowano na podstawie odpowiedzi na pytania 18., 19. i 20., w których ankietowani mieli wymienić znane im programy, ujęte w trzy grupy zależne od przeznaczenia programów. Na tej podstawie wyłoniono spośród nich 3 osoby, które mimo nie podania żadnej nazwy programu w odpowiedzi na pytanie 10., wymieniły je w odpowiedziach na pytania 18.-20. Każda z tych trzech osób podała po 4 nazwy programów, dających się zakwalifikować do odpowiedzi na pytanie 10. Grupa ankietowanych nauczycieli, którzy nie wykazali się znajomością programów ani stron internetowych, których używanie wcześniej zadeklarowali zmniejszyła się tym samym do $22(25,9 \%)$. 
Wykres 6. Ilość prawidłowo wymienionych nazw programów lub adresów stron internetowych, których wykorzystywanie w dydaktyce muzyki deklarują ankietowani nauczyciele

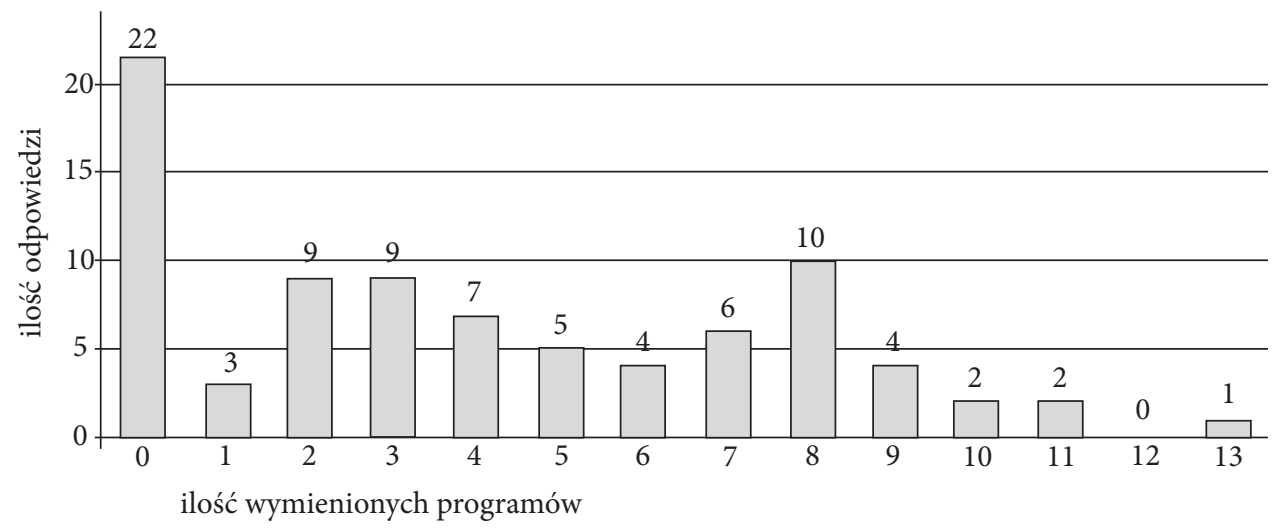

(źródło: badania własne)

Średnio badani wymienili 4,06 tytułów programów lub adresów stron internetowych (przy medianie równej 3). Ilość wymienionych tytułów nie wykazuje korelacji z rodzajem ukończonej uczelni, a średnie dla absolwentów uczelni artystycznych i nieartystycznych różnią się minimalnie na korzyść tych drugich (odpowiednio: 4,05 i 4,10 wymienionych tytułów lub adresów).

Tabela 5. Statystyki opisowe dla ilości wymienionych przez badanych tytułów programów i adresów stron internetowych

\begin{tabular}{|l|l|}
\hline Średnia & 4,058823529 \\
\hline Mediana & 3 \\
\hline Odchylenie standardowe & 3,482448992 \\
\hline Zakres & 13 \\
\hline Minimum & 0 \\
\hline Maksimum & 13 \\
\hline Licznik & 85 \\
\hline
\end{tabular}

(źródło: badania własne)

Zauważalna jest natomiast ujemna korelacja ilości wymienionych tytułów programów i adresów stron internetowych $\mathrm{z}$ wiekiem respondentów (współczynnik korelacji Pearsona równy -0,29 przy założonym poziomie istotności p=0,05). Nauczyciele w wieku poniżej średniego (24-42 lata) wymieniali średnio 5,06 tytułów programów lub adresów stron, podczas gdy 
ich starsi koledzy (43-62 lata) - tylko 3,44 programów lub stron internetowych. Naturalna i znacząca korelacja wieku respondentów ze stopniem ich awansu zawodowego $(\mathrm{r}=0,55)$ nie przekłada się jednak na analogię w korelacji ilości wymienionych programów i stron internetowych ze stopniem awansu $(\mathrm{r}=-0,05)$.

Ujemnego współczynnika korelacji ilości znanych programów z wiekiem ankietowanych nie można oczywiście utożsamiać z tendencją do systematycznej - wraz z wiekiem - rezygnacji z narzędzi informatycznych w odniesieniu do jednostkowych przypadków. Powolny, wieloetapowy proces wyposażania polskich szkół w komputery, przypadający na pierwszą dekadę XXI wieku, każe zauważyć, że aktualny 50-letni nauczyciel nie miał możliwości wykorzystywania TI w dydaktyce jeszcze 10 lat temu. Jego wiedza i umiejętności w tym zakresie nie podlegają w związku z tym demencji, a wręcz przeciwnie. Jedynie tempo poznawania tych narzędzi jest mniej spektakularne niż w przypadku dzisiejszych 30-latków. Ujemny współczynnik korelacji mówi więc, że przy w miarę jednoczesnym starcie (przypadającym na lata 2000-2010), młodsi nauczyciele zdołali opanować nowe narzędzia szybciej i skuteczniej niż ich starsi koledzy. W przypadku więc wszystkich grup wiekowych nauczycieli możemy mówić tylko o wzroście ich umiejętności w zakresie wykorzystywania TI w dydaktyce, zróżnicowane jest tylko tempo tego wzrostu.

Umieszczenie pytania 8. oraz 9. (omawianego w następnym podrozdziale) przed wymagającymi precyzyjniejszych odpowiedzi, dotyczącymi stosowanych programów komputerowych, sposobów wykorzystania TI czy sprzętu komputerowego pozostającego w dyspozycji nauczyciela, pozwoliło na poznanie wstępnej deklaracji respondenta, która nie zawsze musiała zostać potwierdzona w odpowiedziach na bardziej szczegółowe pytania. Taka ewentualna rozbieżność pozwoliłaby sądzić, że badany ma świadomość własnych braków w dziedzinie dydaktycznych zastosowań TI i chce zadeklarować własne kompetencje w tym zakresie jako wyższe od rzeczywistych. Tym samym odpowiedź na tego typu pytania w relacji do faktycznego stopnia wykorzystania TI zdradza w pewnym stopniu poziom świadomości potrzeby jej stosowania na lekcjach muzyki, rozumienie i pragnienie jej stosowania, choć zdradza brak postawy odpowiedniej do sytuacji lub zgodnej z wymogami ustawowymi, czyli dużą część przyjętego w konkluzji rozdziału 2.1. pojęcia składnika kompetencji informatycznych nauczyciela, nazwanego odpowiedzialnym działaniem. 
Kolejne pytanie o zastosowania TI w pracy nauczyciela muzyki, dające już więcej możliwości samodzielnego ich zaproponowania, brzmiało:

„16. Jakie dokonania z zakresu «wykorzystywania w pracy technologii informacyjnej i komunikacyjnej» przedstawił/a Pan/i przy ubieganiu się o kolejny stopień awansu zawodowego?"

W tym przypadku otwarta forma pytania przełożyła się m.in. na swobodę w udzielaniu odpowiedzi. Aż 21 respondentów nie udzieliło żadnej odpowiedzi. Z pozostałych: 5 odpowiedzi brzmiało „nie pamiętam”, 7 - „nie ubiegałam się" lub „nie dotyczy”, po jednej odpowiedzi: „nie było takiego wymogu”, „nie mam możliwości” i „nie wykorzystałam”. Jedna z respondentek stwierdziła, że jest właśnie w trakcie stażu na stopień nauczyciela dyplomowanego, nie podając interesujących szczegółów z poprzedniego stażu - tym samym można ją zaliczyć do tej samej kategorii, co nauczyciele odpowiadający „nie pamiętam”. Tylko 48 odpowiedzi zawierało konkretne dokonania $\mathrm{z}$ kategorii zastosowania TI w pracy nauczyciela.

21 nauczycieli, którzy nie odpowiedzieli na to pytanie, można spróbować zaliczyć do takich, którzy:

1. właśnie rozpoczęli pracę jako stażyści;

2. są nauczycielami kontraktowymi a ich przygotowania do kolejnego awansu nie uwzględniły jeszcze tego warunku;

3. są nauczycielami mianowanymi sprzed reformy z 2004 roku i nie ubiegali się o kolejny stopień awansu;

4. nie pamiętają tych dokonań.

Dwie pierwsze grupy można łatwo zidentyfikować na podstawie danych o stażu pracy i stopniu awansu zawodowego (pytania 6. i 7. ankiety) - takich przypadków jest 7 (nauczyciele stażyści i kontraktowi). Do tej grupy należy zaliczyć również 2 przypadki nauczycieli kontraktowych, którzy udzielili odpowiedzi „nie wykorzystałam” oraz „nie dotyczy”.

Kolejne pytanie (17.) jest pomocne, by - oprócz jawnej warstwy informacyjnej - wyłonić spośród 21 nauczycieli, którzy nie udzielili odpowiedzi na pytanie 16., grupy tych, którzy nie pamiętają takich dokonań. Pytanie to brzmiało:

„17. Czy były to dokonania faktyczne czy fikcyjne?
a. faktyczne;
b. fikcyjne;
c. trochę faktycznych, trochę fikcyjnych". 
Zakreślenie którejkolwiek z proponowanych odpowiedzi zdradza, iż respondent faktycznie musiał przedstawić jakieś dokonania z zakresu stosowania TI i na tej podstawie zaliczyć go możemy do grupy, która owych dokonań po prostu nie pamięta. Takie przypadki są 3, co zwiększa grupę zasłaniającą się brakiem pamięci do 8 . Najtrudniej jest zidentyfikować grupę 4. - nauczycieli mianowanych sprzed reformy. Do niej z pewnością należy respondentka, która udzieliła odpowiedzi „nie było takiego wymogu” oraz część respondentów, którzy udzielili odpowiedzi „nie ubiegałam się”. Jednak z grupy 21 badanych, pomniejszonej o 10 zidentyfikowanych jako stażyści, kontraktowi lub niepamiętający, którzy pozostawili to pytanie bez odpowiedzi, nie można w sposób jednoznaczny wskazać nauczycieli mianowanych sprzed reformy. Możemy jedynie wyróżnić tych, którzy spełniają warunki konieczne ale niewystarczające: ich staż pracy wynosi co najmniej 12 lat oraz stopień ich awansu zawodowego to co najmniej nauczyciel mianowany. Takich respondentów wśród omawianych 21 jest 13.

Reasumując, dysponujemy 48 odpowiedziami na pytanie 16. Spośród pozostałych 37 jedynie 8 dokonania z zakresu stosowania TI zawarło w swoich dokumentach, lecz ich nie pamięta. Jedna osoba przyznała, że takich dokonań mimo awansu nie miała na swoim koncie a pozostałych 28 ankietowanych ten problem $\mathrm{z}$ różnych przyczyn nie dotyczy.

W 48 udzielonych odpowiedziach znalazło się łącznie 109 zastosowań TI, które nauczyciele umieścili w dokumentacjach swojego stażu jako własne dokonania, potwierdzające umiejętność stosowania TI w dydaktyce muzyki. Ilość wymienionych zastosowań jest wyraźnie dodatnio skorelowana z częstotliwością wykorzystywania TI w dydaktyce - współczynnik Pearsona jest tu największy ze wszystkich zaobserwowanych korelacji i wynosi 0,50 .

Zwraca w tym zestawieniu uwagę udział zastosowań typowo muzycznych, wymagających specjalistycznego oprogramowania i nie poznawanych na typowych zajęciach $\mathrm{z}$ technologii informacyjnej. Takie formy wykorzystania TI wymagają również specjalistycznej wiedzy muzycznej. Deklarowane zastosowania, przedstawione w tabeli 6 . obejmują: podkłady muzyczne (13 odpowiedzi), własne kompozycje (8), zapis nutowy (7), nagranie płyty z piosenkami śpiewanymi przez uczniów (1). Łącznie jest to 29 zastosowań na 109 wszystkich (26,6\%). Odpowiedzi zawierających takie zastosowania udzieliło 15 ankietowanych (31,25\% przy N=48). Oznacza to, że niecała $1 / 3$ nauczycieli muzyki, którzy odpowiedzieli na to pytanie 
(a 17,65\% wszystkich 85 respondentów) potrafi w sposób jednoznacznie muzyczny wykorzystać potencjał TI.

Tabela 6. Dokonania nauczycieli z zakresu stosowania TI, deklarowane przy ubieganiu się o kolejny stopień awansu zawodowego

\begin{tabular}{|l|c|}
\hline \multicolumn{1}{|c|}{ Rodzaje dokonań z zakresu TI } & $\begin{array}{c}\text { Ilość } \\
\text { odpowiedzi }\end{array}$ \\
\hline prezentacje multimedialne & 14 \\
\hline podkłady muzyczne & 13 \\
\hline pomoce dydaktyczne (np. teksty piosenek) & 12 \\
\hline karty pracy, testy, arkusze ewaluacyjne & 11 \\
\hline dokumentacja stażu & 9 \\
\hline własne kompozycje & 8 \\
\hline dokumentacja szkolna (m.in. dyplomy, podziękowania) & 7 \\
\hline zapis nutowy & 7 \\
\hline informacje z internetu & 6 \\
\hline zgrywanie muzyki na płyty & 6 \\
\hline kurs komputerowy & 5 \\
\hline prowadzenie lekcji z użyciem komputera & 3 \\
\hline studia podyplomowe & 1 \\
\hline własna strona internetowa dla uczniów & 1 \\
\hline praca domowa uczniów & 1 \\
\hline „podstawowe umiejętności” & 1 \\
\hline email (sic!) & 1 \\
\hline płyta z piosenkami śpiewanymi przez uczniów & 1 \\
\hline płyta ze zdjęciami uczniów & 1 \\
\hline teledysk z udziałem uczniów & 1 \\
\hline & łącznie: 109 \\
\hline
\end{tabular}

(źródło: badania własne)

Nie jest to duży odsetek, zważywszy, że chodzi o nauczycieli muzyki. Pozwala jednak na umiarkowany optymizm $z$ uwagi na to, że pierwsi absolwenci pedagogiki, których program nauczania zawierał przygotowanie do wykorzystania TI w dydaktyce własnego przedmiotu, w momencie badań mogli mieć zaledwie półroczny staż pracy nauczycielskiej. Nie byli zatem zobowiązani do przedstawienia własnych dokonań w tym zakresie wśród podstaw do awansu zawodowego. Należy więc przyjąć, że tych 15 uczestników badań, którzy stosują specjalistyczne oprogramowanie muzyczne, umiejętności takie zdobyło we własnym zakresie. Kolejne roczniki wchodzące na rynek pracy, będą mogły polegać nie tylko na samokształceniu ale na kwalifikacjach i - być może - kompetencjach nabytych w trakcie studiów. 
Przemawiać za tym mogą odpowiedzi 36 ankietowanych (75\% przy $\mathrm{N}=48$ ), które zawierały zastosowania pakietu Office (edytor tekstu oraz prezentacje multimedialne). Tak duży udział podstawowego w programach nauczania technologii informacyjnej narzędzia, w znacznej części musi mieć swoje źródła w kwalifikacjach nabytych właśnie w trakcie studiów lub na wcześniejszych etapach kształcenia.

Pytanie 26. było otwarte i brzmiało: "Jakie widzi Pan/i możliwe zastosowania technologii komputerowej we wspomaganiu nauczaniu muzyki?" Odpowiedzi na to pytanie zawierają zarówno faktyczne doświadczenia badanej grupy nauczycieli jak i tylko proponowane możliwości zastosowań, ujawniając tym samym potencjał wyobraźni nauczycieli lub sygnalizowane w ten sposób potrzeby w tym zakresie.

38 ankietowanych nie odpowiedziało na to pytanie w ogóle. Spośród zaś 47 udzielonych odpowiedzi 17 nie zawiera konkretnych informacji na temat możliwych zastosowań TI w dydaktyce muzyki, choć są wartościowe dla dalszych analiz - choćby oceny stosunku badanych nauczycieli do stosowania TI na lekcjach muzyki. Te odpowiedzi, pozostające na dużym stopniu ogólności, prezentujące jednocześnie skrajnie różne oceny, można przedstawić w kilku grupach:

1. Bezrefleksyjne:

- „Nie zastanawiałam się”.

2. Lakonicznie-entuzjastyczne:

- „Tak”.

- „Duże”.

- „Ogromne”.

- „W bardzo szerokim zakresie”.

- „Wykorzystanie tego, o czym mowa w ankiecie we wszystkich wcześniejszych punktach”.

3. Refleksyjnie-pozytywne:

- „Jest to już niezbędny element podtrzymania koncentracji i zainteresowania uczniów sprawiający, że muzyka zaczyna być znów postrzegana jako przedmiot atrakcyjny”.

- „Uważam, że stały dostęp do komputerów podczas lekcji muzyki i korzystanie z programów służących do komponowania utworów, poprawiłyby atrakcyjność zajęć i spełniałyby oczekiwania uczniów". 
- „Wykorzystanie istniejących na rynku programów wzbogacające rozwój wrażliwości muzycznej uczniów szczególnie w muzyce klasycznej”.

4. Pozytywne z zastrzeżeniem priorytetu „żywej muzyki”:

- „Zastosowanie technologii komputerowej we wspomaganiu nauczania muzyki jest ogromne, ale nie jest podstawowym narzędziem mojej pracy. Należy dążyć do bezpośredniego kontaktu dziecka/ucznia z żywą muzyką, instrumentem, ze śpiewem".

- „Prawdopodobne możliwości są bardzo duże ale braki dostępu do komputera na lekcjach muzyki, za małe umiejętności moje w znajomości programów komputerowych, czas lekcyjny wolę przeznaczyć na żywe muzykowanie".

5. Pozytywne z zastrzeżeniami organizacyjnymi:

- „Widzę szerokie zastosowanie komputerów w nauczaniu muzyki wówczas gdy organizacyjnie nie będzie to problemem (w konkretnych warunkach szkolnych) oraz gdy nauczyciel będzie dysponował wiedzą o legalnych programach muzycznych, umiejętnościami związanymi z obsługą takich programów, a także przy dostępności bezpośredniej do Internetu (na lekcji)".

6. Postulatywno-lakoniczne:

- „Możliwość korzystania z komputera - programów przez rzutnik w pracowni muzycznej”.

- „W sali muzycznej powinien być rzutnik i laptop”.

7. Ambiwalentne:

- „Zastosowanie technologii komputerowej jest szczególnie pomocne dla nauczycieli uczących muzyki ale nie będących muzykami. Muzycy korzystając z technologii uatrakcyjniają lekcję. Z drugiej strony muzyki jest tak niewiele godzin, że trudno wybrać co ważniejsze - gra na instrumentach, słuchanie, śpiew, tworzenie?"

8. Negatywne:

- „Nie widzę”.

- „Nie widzę konieczności stosowania technologii komputerowej w nauczaniu muzyki. Szczerze mówiąc przywiązuję największą 
wagę do tzw. «żywej muzyki» przy instrumencie (nie-elektronicznym). Słuchamy również muzyki klasycznej nie odtwarzanej komputerowo".

Znalazły się w tej grupie sądy negatywne (2 odpowiedzi), neutralne (2) oraz pozytywnie odnoszące się do udziału TI we wspomaganiu nauczania muzyki (13).

Znamienne w przytoczonych odpowiedziach jest podejście do pozytywów wykorzystywania TI, które kładzie akcent na korzyści po stronie ucznia (3. grupa odpowiedzi):

- większe zainteresowanie przedmiotem;

- atrakcyjność zajęć;

- spełnienie oczekiwań uczniów;

- rozwój wrażliwości muzycznej.

Formułowane zastrzeżenia zaś dotyczą głównie perspektywy nauczyciela:

- TI nie jest podstawowym narzędziem pracy (4. grupa odpowiedzi);

- brak umiejętności (p. 4. i 5.);

- niedostępność sprzętu (p. 4., 5. i 6.).

Gdyby traktować obydwa wyliczenia in gremio, jako wspólny głos wszystkich ankietowanych, oznaczałoby to, że nauczyciele mają świadomość, iż niedostatki po stronie nauczyciela i szkoły, objawiające się brakiem wykorzystania TI na lekcjach muzyki, są źródłem frustracji uczniów, mierzonej brakiem zainteresowania przedmiotem, nieatrakcyjnością zajęć, niespełnieniem oczekiwań oraz zanikiem wrażliwości muzycznej. Tak radykalny wniosek nie jest jednak uprawniony w sytuacji, gdy przeciwstawne opinie formułowane są przez różne osoby, które akcentując pozytywy lub ograniczenia jedynie sygnalizują pewną perspektywę spojrzenia na problem, a nie jaskrawe zależności między nimi.

Ważne jest również zauważenie rysującej się tu, w świadomości niektórych nauczycieli, opozycji: technologii informatycznej oraz „żywej muzyki”, rozumianej jako śpiewanie oraz granie na instrumentach akustycznych (p. 4., 7. i 8.). Zauważanie w TI zagrożenia dla muzyki akustycznej, poruszane w części teoretycznej niniejszej pracy, zamiast jej komplementarności, może przybierać formę wręcz karykaturalną - jak w ostatniej z cytowanych wypowiedzi z grupy 8.: „Słuchamy również muzyki klasycznej nie odtwarzanej komputerowo" (wypowiedź 50-letniej nauczycielki dyplomowanej, z 28-letnim stażem, pracującej w trzech szkołach, w łącznym 
wymiarze 21 godzin tygodniowo, absolwentki Uniwersytetu Łódzkiego). W tym zdaniu nie chodzi prawdopodobnie o cotygodniowe lub comiesięczne wizyty w filharmonii lub koncerty organizowane w szkole, a raczej o muzykę odtwarzaną "niekomputerowo” - czyli z odtwarzacza CD (w odpowiedzi na pytanie 10. wspomniana nauczycielka deklaruje korzystanie z programu do nagrywania płyt - Windows Media Player) lub innych, starszych nośników - płyt winylowych lub kaset magnetofonowych. Uznanie wyższości takiego nośnika nad odtwarzaniem „komputerowym” nosi znamiona nieracjonalnej awersji do nowych narzędzi, związanych z technologią informatyczną.

Zasadne w tym miejscu będzie prześledzenie pozostałych odpowiedzi $\mathrm{z}$ ankiety zacytowanej nauczycielki dla potwierdzenia lub zaprzeczenia opinii o jej awersji do narzędzi informatycznych.

W pierwszym zdaniu swojej odpowiedzi na pytanie 26. napisała ona: „Nie widzę konieczności stosowania technologii komputerowej w nauczaniu muzyki”. Zgodnie z tą deklaracją, wybiera w odpowiedzi na pytanie 8 . najmniej „inwazyjny” sposób wykorzystywania TI w dydaktyce - przygotowywanie się do zajęć (pogłębianie wiedzy, szukanie informacji, materiałów). Częstotliwość takich zabiegów określa jako „kilka razy w ciągu roku szkolnego" (odp. 9 d) mimo, że w odpowiedzi na pytanie 15. określa częstotliwość korzystania z komputera w domu jako „kilka razy w tygodniu”. Ze stosowanych programów (pytanie 10.) deklaruje korzystanie ze strony „Muzyczne Porządki - PC World” (odp. „a”). Jest to strona poświęcona programom do zarządzania kolekcjami plików muzycznych - tzw. katalogom multimedialnym. W punkcie „b” tej samej odpowiedzi wymienia Windows Media Player w kategorii programów do zgrywania muzyki na płyty oraz w punkcie "g" - programów nie związanych z muzyką - wymienia „Picasa 3" - program do katalogowania i podstawowej obróbki (edycji) plików graficznych.

Rysuje się tu więc profil nauczycielki poszukującej w internecie muzyki i ilustracji przydatnych do zajęć. Kolekcje tak ściągniętych plików są na tyle obszerne, że wymagają użycia programów do ich katalogowania. Następnie, kilka razy w roku, nauczycielka prezentuje uczniom fragmenty swojej kolekcji, nagrywając je uprzednio na CD.

Odpowiedzi 11 „c" oraz 12 „d” zdradzają, że mimo opisanych wysiłków, nauczycielka nie ma możliwości skorzystania ze szkolnego sprzętu komputerowego (przenośnego czy stacjonarnego) ani ze szkolnej pracow- 
ni komputerowej. Zatem nagrane na potrzeby lekcji przykłady muzyczne zmuszona jest odtwarzać przy pomocy odtwarzacza CD, a ilustracje prawdopodobnie zmuszona jest wcześniej wydrukować i zaprezentować w formie papierowej.

Mamy więc do czynienia z nauczycielką, która mimo braków sprzętowych szkoły nie rezygnuje z nowoczesnych narzędzi, a jej opinie: „Nie widzę konieczności stosowania technologii komputerowej w nauczaniu muzyki” oraz „Słuchamy również muzyki klasycznej nie odtwarzanej komputerowo” nabierają innego znaczenia, akcentując jej determinację w korzystaniu z TI mimo obiektywnych przeciwności.

Z odpowiedzi na pytanie 13. dowiadujemy się, że omawiana nauczycielka swoje umiejętności z zakresu TI zawdzięcza kursom i szkoleniom (odp. „c) oraz studiom podyplomowym (odp. „d”). Nie przekreśla więc narzędzi informatycznych a priori (zakładając dobrowolną motywację uczestnictwa w takich formach dokształcania). Założenia tego nie możemy traktować jako pewnik wobec kolejnej odpowiedzi (pyt. 14.), która zdradza, że „dyrektor szkoły zachęcał lub nakazywał” jej ukończenie takiego szkolenia.

Przy awansie na stopień nauczyciela dyplomowanego, z zastosowań TI umieściła w swoim dorobku „Projekty dyplomów i podziękowań dla uczniów należących do szkolnego zespołu wokalnego" (pyt. 16.), zaznaczając w następnej odpowiedzi, iż były to dokonania częściowo fikcyjne. Najprawdopodobniej, owa częściowa fikcyjność mogła wynikać z pomocy osoby bardziej zaawansowanej w obsłudze programów graficznych. W kategorii używanych programów komunikacyjnych ta sama nauczycielka zakreśliła 3 grupy programów, nie przytaczając jednak żadnej ich nazwy. W kategorii programów biurowych zadeklarowała znajomość Microsoftowego edytora tekstu i programu do tworzenia prezentacji multimedialnych, umieszczając jednak obydwa w grupie edytorów tekstu. Drobne błędy w nazwach zdradzają niezbyt częste korzystanie z nich („World” oraz „Power Paint”). Pamiętać jednak należy, że tych programów nauczycielka nie zadeklarowała, jako składnika swojego warsztatu dydaktycznego. Kategoria programów muzycznych zawiera natomiast wcześniej sygnalizowany odtwarzacz programowy z funkcją nagrywania Windows Media Player. W tym wypadku, mimo dłuższej nazwy, ankietowana nie popełniła żadnego błędu ortograficznego. Potwierdzać to może częstsze i samodzielne jego stosowanie. 
Bardzo ważne pytania 22. i 23. ujawniają stosunek omawianej nauczycielki do zastosowań TI na lekcjach muzyki. Jest ona zdania, że kompetencje informatyczne są bez znaczenia w pracy nauczyciela muzyki, a posługiwanie się komputerem na lekcjach muzyki jest bez znaczenia zarówno dla nauczyciela jak i dla uczniów. A więc niestosowanie TI na lekcjach jest w przypadku tej nauczycielki nie tylko koniecznością (brak sprzętu szkolnego) ale wynika również z jej przekonania o braku znaczenia takich działań dla efektów nauczania. Jest ona zdania, że Podstawa programowa, z której korzysta nie uznaje kompetencji informatycznych nauczyciela muzyki za konieczne, choć nie ma co do tego pewności, zaznaczając odpowiedzi „b” $\mathrm{i}$ „d” na pytanie 24. Być może fakt, że korzysta z podręcznika zawierającego CD-ROM zasiał w niej pewne wątpliwości. Z drugiej jednak strony, interesująca nas nauczycielka zatrudniona jest $\mathrm{w}$ dwóch szkołach podstawowych (w wymiarze 18 oraz 3 godzin) oraz w jednym gimnazjum (6 godzin). W odpowiedzi na pytanie 25. wymieniła jedynie podręcznik „Gra muzyka” przeznaczony dla gimnazjum, wiedząc, że jest on wyposażony w dodatkową płytę multimedialną. Być może nie wymienione $z$ tytułu podręczniki dla szkół podstawowych nie posiadają takiego rozszerzenia, co skłoniło nauczycielkę do wniosku o braku konieczności posiadania kompetencji informatycznych na drugim etapie kształcenia.

Powyższy opis w formie dygresji daje podstawę do uznania pierwszego wniosku, o możliwej nieracjonalnej awersji do nowych narzędzi u omawianej nauczycielki, za pochopny. Co więcej, jej wypowiedź sprowokowana pytaniem 26. ankiety, trudno w tej sytuacji uznać za negatywną. Wykorzystuje przecież - choć w ograniczonym zakresie - TI w przygotowaniach do zajęć, mimo niedostatków sprzętowych szkoły.

Po omówieniu części odpowiedzi o charakterze ogólnym na pytanie 26. przejdziemy do pozostałych trzydziestu, które prezentują na tyle skonkretyzowane propozycje zastosowań TI w dydaktyce muzyki, że możliwe jest ich przedstawienie tabelaryczne: 
Tabela 7. Możliwe zastosowania TI w dydaktyce muzyki według ankietowanych $(\mathrm{N}=30)$

\begin{tabular}{|c|c|}
\hline Rodzaje zastosowań & $\begin{array}{c}\text { Ilość } \\
\text { wyborów }\end{array}$ \\
\hline Prezentacje multimedialne; $w$ tym: & $(28)$ \\
\hline - ogólnie (bez podziału) & 9 \\
\hline - wykonań utworów muzycznych & 5 \\
\hline - stylów muzycznych, historii muzyki & 4 \\
\hline - sylwetek kompozytorów, artystów & 4 \\
\hline - instrumentów muzycznych & 3 \\
\hline - zespołów muzycznych & 1 \\
\hline - tańców & 1 \\
\hline - lekcji tańca & 1 \\
\hline Tworzenie muzyki przez uczniów & 7 \\
\hline Gromadzenie nagrań z internetu & 6 \\
\hline Gromadzenie informacji z internetu & 5 \\
\hline Odtwarzanie filmów muzycznych & 5 \\
\hline Odtwarzanie muzyki & 5 \\
\hline Nauka zasad muzyki & 4 \\
\hline Tworzenie muzyki przez nauczyciela & 4 \\
\hline Przygotowywanie tekstów dla uczniów & 2 \\
\hline Przygotowywanie sprawdzianów, kart pracy & 2 \\
\hline Tworzenie podkładów muzycznych (m.in. karaoke) & 2 \\
\hline Śpiewanie z podkładem muzycznym (m.in. karaoke) & 2 \\
\hline Przegrywanie muzyki z płyt i na płyty & 2 \\
\hline Edycja audio (m.in. dodawanie efektów, ścieżek perkusyjnych) & 2 \\
\hline Udźwiękowienie prezentacji przez uczniów & 1 \\
\hline Muzyczne gry edukacyjne & 1 \\
\hline Nauczanie na odległość & 1 \\
\hline Nagrywanie uczniów (piosenka z podkładem) & 1 \\
\hline Pokaz nagrywania muzyki & 1 \\
\hline Przygotowanie zapisu nutowego dla uczniów & 1 \\
\hline Kontakt z uczniami (email) & 1 \\
\hline Obsługa imprez szkolnych & 1 \\
\hline Korzystanie z płyt dołączanych do podręcznika & 1 \\
\hline
\end{tabular}

(źródło: badania własne)

Analiza tych szczegółowo artykułowanych zastosowań TI w dydaktyce muzyki pozwala na pewien ogląd stanu świadomości nauczycieli na temat możliwości tkwiących w tzw. nowych technologiach. Część bowiem z nich jest możliwa do zrealizowania wyłącznie przy pomocy narzędzi informa- 
tycznych, a co za tym idzie - skłania do refleksji o konieczności ich zastosowań wobec ich niezastępowalności przez inne media czy środki, lub też wobec ich nowatorskiego potencjału. Zauważenie takich elementów pozwala wnioskować o istnieniu tego składnika kompetencji informatycznych, który w konkluzji rozdziału 2.2. nazwany został świadomością potrzeby odpowiedzialnego i opartego na wiedzy wykorzystywania TI. Do takich niezastępowalnych możliwości TI należy zaliczyć:

- prezentacje multimedialne (28 odpowiedzi);

- tworzenie podkładów muzycznych (2 odpowiedzi);

- śpiewanie z podkładem muzycznym (2);

- edycja plików audio (2);

- udźwiękowienie prezentacji przez uczniów (1);

- muzyczne gry edukacyjne (1);

- nauczanie na odległość (1);

- pokaz nagrywania muzyki (1);

- przygotowanie zapisu nutowego dla uczniów (1);

- kontakt z uczniami przez email (1);

- korzystanie z płyt dołączanych do podręcznika (1).

Drugą grupę stanowią zastosowania możliwe bez użycia komputera, jednak zastosowanie go zdecydowanie uatrakcyjnia lub ułatwia dotychczasowe formy aktywności. Są to:

- tworzenie muzyki przez uczniów (7 odpowiedzi);

- nauka zasad muzyki (4);

- tworzenie muzyki przez nauczyciela (4);

- nagrywanie uczniów (1).

Trzecią grupę tworzą zastosowania będące rozwinięciem technologicznym stosowanych dotychczas rozwiązań i jako takie mogą z pozycji ucznia pozostać niezauważalnie wzbogacone o możliwości TI:

- gromadzenie nagrań z internetu (6) - TI jako kontynuacja tradycyjnej płytoteki szkolnej;

- gromadzenie informacji z internetu (5) - TI jako nowa forma encyklopedii i słowników;

- odtwarzanie filmów muzycznych (5) - TI jako nowa wersja wideoodtwarzacza;

- odtwarzanie muzyki (5) - TI jako nowa forma odtwarzacza CD;

- przygotowywanie tekstów dla uczniów (2) oraz sprawdzianów i kart pracy (2) - TI jako nowa wersja maszyny do pisania i kserokopiarki; 
- przegrywanie muzyki z płyt i na płyty (2) - TI jako nowa wersja magnetofonu;

- obsługa imprez szkolnych (1) - TI jako nowa wersja odtwarzacza i miksera muzycznego.

Kolejny wniosek wynika z porównania powyższych odpowiedzi (tabela 7.) z omawianymi wcześniej odpowiedziami na pytanie 16., dotyczące zastosowań TI nauczycieli ubiegających się o kolejny stopień awansu zawodowego (tabela 6.). Tabela 6. zawiera zastosowania poparte własnym doświadczeniem nauczycieli, co potwierdzają odpowiedzi na pytanie 17. - (57 odpowiedzi „a”, żadnej odpowiedzi „b” i tylko 4 odpowiedzi „„”). W tabeli 7. natomiast ankietowani wykazali się także wyobraźnią, formułując również takie rodzaje zastosowań TI, których do tej pory nie wypróbowali. Te potencjalne zastosowania, nieobecne $\mathrm{w}$ odpowiedziach na pytanie 16., to m.in.: tworzenie muzyki przez uczniów, nauka zasad muzyki, edycja materiału audio, udźwiękowienie prezentacji przez uczniów, muzyczne gry edukacyjne, nauczanie na odległość, pokaz nagrywania muzyki oraz korzystanie z płyt dołączanych do podręcznika (łącznie w 18 odpowiedziach).

Zatem diagnoza nauczycieli, ujawniająca w cytowanych propozycjach potencjał ich wyobraźni czy sygnalizowane potrzeby, jest budująca. Podkreśla bowiem takie zastosowania TI, które kładą akcent na stymulowanie ekspresji twórczej uczniów oraz na udziale gier komputerowych w przyswajaniu wiedzy i umiejętności muzycznych. Tym samym trzy odpowiedzi na pytanie 26. ankiety, zaliczone wyżej do grupy o charakterze ogólnym jako "ambiwalentne” i „negatywne”, można uznać za jednostkowe i wyjątkowe wśród badanej grupy nauczycieli.

\section{Oprogramowanie}

Podstawowym elementem warunkującym wykorzystanie TI przez nauczycieli jest znajomość narzędzi informatycznych a w szczególności oprogramowania, którego potencjał pozwala na zastosowania edukacyjne. Grupa programów stricte edukacyjnych, dedykowanych nauczaniu lub uczeniu się muzyki, jest dość uboga. Najpopularniejsze z nich to multimedialne encyklopedie, słowniki i leksykony. Znane na polskim rynku programy tego segmentu, to m.in. Multimedialna encyklopedia powszechna ${ }^{2}$, czy specjalistycznie muzyczne: Słownik szkolny - Muzyka3, Fryderyk Chopin - życie

\footnotetext{
${ }^{2}$ Multimedialna encyklopedia powszechna, PWN, 2010.

${ }^{3}$ Poniatowska I., Wroński M., Słownik szkolny - Muzyka, WSiP, 1998.
} 
twórcy w kontekście kultury, wśród ludzi i zdarzeń ${ }^{4}$ a także dwa tomy Muzycznych wędrówek (Barok i Romantyzm)5. Oferta oprogramowania w zakresie gier edukacyjnych dotyczących muzyki jest również skromna i adresowana raczej do uczniów pierwszego etapu edukacji. Do tej kategorii należą m.in. programy: Klik uczy śpiewać ${ }^{6}$ oraz Uczę się muzyki

Daleko bogatsze są w tym zakresie zasoby internetowe online. Oprócz popularnych portali encyklopedycznych (Wikipedia, Edupedia), leksykonów muzycznych (np. na stronie RMF Classic) istnieje wiele portali oferujących darmowe gry online $\mathrm{z}$ bogato reprezentowaną kategorią gier muzycznych, z których część oprócz warstwy rozrywkowej nosi znamiona gier edukacyjnych (ogromną ofertę takich portali znajdziemy wpisując do wyszukiwarki hasło "gry muzyczne”).

Bardzo użyteczną w pracy nauczyciela muzyki jest grupa programów przeznaczonych do edycji plików muzycznych, edytory zapisu nutowego czy tzw. trackery, służące do układania utworów muzycznych z gotowych elementów - tzw. próbek (ang. sample).

Nie można pominąć tutaj programów niezwiązanych z muzyką ale przydatnych w pracy każdego nauczyciela, przeznaczonych do tworzenia prezentacji multimedialnych czy edytory teksu, pomocne w pisaniu nie tylko wszelkich dokumentów ale również w przygotowywaniu kart pracy czy testów. Sprawdzeniu z jakiego oprogramowania korzystają badani nauczyciele służyły pytania: 10. oraz 18.-21.

Odpowiedzi na pytanie 10. w kontekście zastosowań TI w przygotowaniu i prowadzeniu zajęć przez ankietowanych omówiono w części dotyczącej zastosowań. W tym miejscu te same odpowiedzi pozwolą zidentyfikować konkretne programy komputerowe, które respondenci wykorzystują w swojej pracy. Treść pytania 10. została przytoczona w poprzednim podrozdziale.

Zgodnie z ustaleniami poprzedniego podrozdziału tylko 60 osób (70,59\% przy $\mathrm{N}=85)$ udzieliło pełnych i poprawnych odpowiedzi, wymie-

\footnotetext{
${ }^{4}$ Tomaszewski M., Fryderyk Chopin - życie twórcy w kontekście kultury, wśród ludzi i zdarzeń. Leksykon multimedialny, Neurosoft, 1995.

${ }^{5}$ Muzyczne wędrówki. Barok. Multimedialna podróż po Europie XVII i XVIII wieku, PWN, 1998. Muzyczne wędrówki. Romantyzm. Multimedialna podróż po Europie XIX wieku, PWN, 1998. Obie pozycje, wyjątkowo starannie wydane pod względem graficznym jak i merytorycznym, niestety przeznaczone są pod system operacyjny Windows Millenium, który praktycznie wyszedł z użycia. Uniemożliwia to wykorzystanie tej wartościowe publikacji na szkolnych komputerach i zastanawia jednocześnie brak wysiłku poważnego wydawnictwa, by swój produkt uaktualnić.

${ }^{6}$ Klik uczy śpiewać. Multimedialne zabawy muzyczne dla dzieci w wieku 6-10 lat, WSiP, 2002.

${ }^{7}$ Uczę się muzyki, Albion, 1998.
} 
niając tytuły programów lub stron internetowych, z których korzysta. Do pełnych i poprawnych odpowiedzi należy również zaliczyć jedyny przypadek wyboru odpowiedzi „h”, deklarującej, że respondent nie korzysta w ogóle z TI w przygotowaniu lub prowadzeniu zajęć. Te 61 osób stanowi 71,76\% z 85 ankietowanych. Wymienili oni od 0 do 13 tytułów programów i stron internetowych, z których korzystają, co daje średnią 5,36 tytułu na jednego nauczyciela (doliczając tych, którzy nie wymienili żadnego tytułu, deklarując jednak korzystanie z TI, średnia wynosi odpowiednio 3,85). Tabela 8. przedstawia rodzaje programów i stron internetowych, z których korzystanie zadeklarowali ankietowani, precyzując ich nazwy, tytuły lub adresy stron internetowych. Te sprecyzowane nazwy, tytuły i adresy były podstawą zaliczenia do określonej na tej podstawie kategorii. Kategorie z tabeli 8. są więc rozwinięciem kategorii z pytania 10. i ich uszczegółowieniem na podstawie uzyskanych odpowiedzi.

Tabela 8. Kategorie programów komputerowych i stron internetowych używanych przez ankietowanych

\begin{tabular}{|l|c|c|c|}
\hline \multirow{2}{*}{$\begin{array}{c}\text { Kategorie stron internetowych } \\
\text { i programów komputerowych }\end{array}$} & \multicolumn{2}{|c|}{$\begin{array}{c}\text { Ilość używających } \\
\text { ich badanych } \\
(\mathrm{N}=85)\end{array}$} & $\begin{array}{c}\text { Max. ilość } \\
\text { tytułów z tej } \\
\text { kategorii } \\
\text { u jednego } \\
\text { badanego }\end{array}$ \\
\cline { 2 - 3 } & $\mathrm{n}$ & $\%$ & 3 \\
\hline do nagrywania i zgrywania płyt & 45 & 52,9 & 1 \\
\hline pakiet Office & 39 & 45,9 & 5 \\
\hline inne strony* & 38 & 44,7 & 3 \\
\hline edytory audio & 28 & 32,9 & 1 \\
\hline do edycji grafiki i foto & 21 & 24,7 & 2 \\
\hline edytory tekstu nutowego & 18 & 21,2 & 2 \\
\hline strony muzyczne* & 13 & 15,3 & 1 \\
\hline wyszukiwarki internetowe & 13 & 15,3 & 2 \\
\hline odtwarzacze audio & 8 & 9,4 & 1 \\
\hline do edycji video & 7 & 8,2 & 1 \\
\hline inne programy*** & 4 & 4,7 & 1 \\
\hline programy dołączone do podręcznika muzyki & 2 & 2,4 & 1 \\
\hline programy do karaoke & 2 & 2,4 & \\
\hline
\end{tabular}

* głównie: wikipedia, youtube, chomikuj, wrzuta;

** strony oferujące podkłady muzyczne, teksty piosenek, partytury, pliki karaoke, strony poświęcone F. Chopinowi i inne;

*** Ares - dwukrotnie (program kliencki sieci P2P), Hot Potatoes (program do tworzenia ćwiczeń i testów online) oraz multimedialne życiorysy kompozytorów. 
Z pięciu pierwszych kategorii, o popularności wśród badanych większej niż średnia (średnie $n=18,7$ czyli $22 \%$ ), tylko edytory plików audio stanowią grupę programów specjalistycznie muzycznych. Pozostałe cztery stanowią zestaw podstawowych i popularnych wśród większości amatorskich, niemuzycznych zastosowań programów lub stron internetowych. Oznacza to, że ankietowani mimo braków w znajomości specjalistycznych programów muzycznych szukają zastosowań przydatnych w edukacji muzycznej, opartych na programach powszechnie znanych, dostępnych, choć nie dedykowanych zastosowaniom muzycznym. Brak wiedzy zatem na temat oprogramowania muzycznego nie implikuje braku chęci i inicjatywy w stosowaniu TI. W kategoriach programów czy stron internetowych, których popularność lokuje się poniżej średniej, znajdujemy m.in. typowo muzyczne: edytory tekstu nutowego, strony internetowe oferujące podkłady muzyczne, teksty, partytury, pliki karaoke, programy z płyt dołączanych do podręczników czy programy do karaoke (zarówno tworzenia jak i odtwarzania). Można zatem rozumieć, że samokształcenie w zakresie poznawania programów i stron internetowych poświęconych zastosowaniom muzycznym, mimo iż nie jest zjawiskiem masowym wśród badanej grupy nauczycieli, skutkuje dostrzeżeniem ich potencjału edukacyjnego i wykorzystaniem, jako użytecznego składnika warsztatu nauczyciela muzyki.

Charakterystyczna jest tu wyraźna dodatnia korelacja ilości wymienionych programów i stron internetowych z częstotliwością ich wykorzystywania - współczynnik korelacji Pearsona równy 0,41 - z czego wynika, że wyposażony w wyższe kwalifikacje informatyczne nauczyciel z większym prawdopodobieństwem wykorzysta je w dydaktyce lub częstsze korzystanie z TI prowokuje do poznawania nowych narzędzi.

Pytania 18.-21. stanowią grupę pytań mających na celu precyzyjniejsze określenie programów, które badani potrafią obsługiwać, z podziałem na grupy zależne od przeznaczenia. Brzmiały one następująco:

„18. Jakie programy komunikacyjne potrafi Pan/i obsługiwać (proszę podać nazwę)?

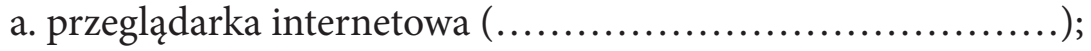

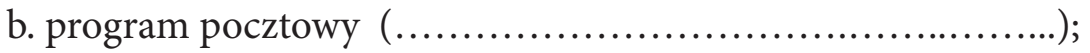

c. komunikator internetowy $(\ldots \ldots \ldots \ldots \ldots \ldots \ldots \ldots \ldots \ldots \ldots \ldots \ldots)$;

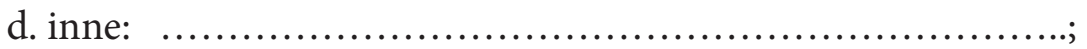

19. Jakie programy pakietu biurowego potrafi Pan/i obsługiwać (proszę podać nazwę)? 


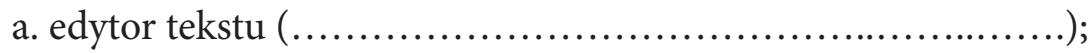

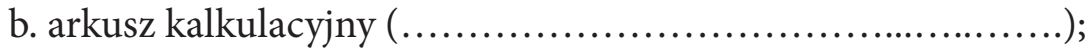

c. program do tworzenia prezentacji multimedialnych (..........);

d. inne:

20. Jakiego rodzaju programy muzyczne potrafi Pan/i obsługiwać (proszę podać nazwę)?

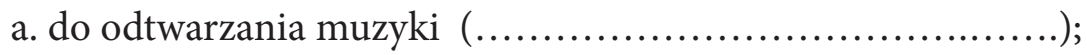

b. do zgrywania muzyki na płyty $(\ldots \ldots \ldots \ldots \ldots \ldots \ldots \ldots \ldots \ldots \ldots . . . \ldots \ldots \ldots \ldots$

c. do edycji zapisu nutowego $(\ldots \ldots \ldots \ldots \ldots \ldots \ldots \ldots \ldots \ldots \ldots \ldots \ldots)$;

d. do obróbki i konwersji plików dźwiękowych (...............);

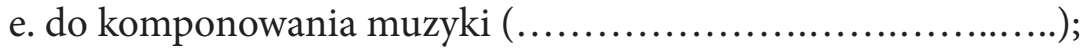

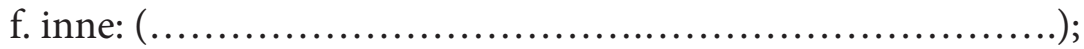

21. Jakie programy komputerowe o innym przeznaczeniu - w tym rozrywkowym - używa Pan/i (proszę podać nazwy lub do czego służą)?

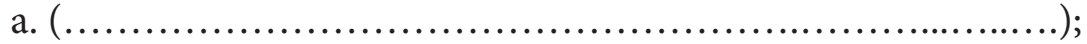

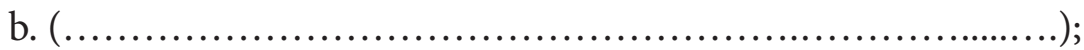

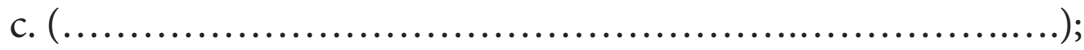

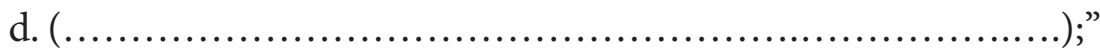

Tabela 9. Znajomość obsługi programów komunikacyjnych

\begin{tabular}{|c|c|c|c|c|c|c|c|c|}
\hline $\begin{array}{c}\text { Ilość } \\
\text { odpowie- } \\
\text { dzi: } \\
(\mathrm{N}=85)\end{array}$ & \multicolumn{2}{|c|}{ ogółem } & \multicolumn{2}{c|}{$\begin{array}{c}\text { z podaniem tytułów } \\
\text { programów }\end{array}$} & \multicolumn{2}{c|}{$\begin{array}{c}\text { bez podania } \\
\text { tytułów }\end{array}$} & \multicolumn{2}{c|}{$\begin{array}{c}\text { ilość odpowie- } \\
\text { dzi z blędnymi } \\
\text { tytułami }\end{array}$} \\
\cline { 2 - 9 } & $\mathrm{n}$ & $\%$ & $\mathrm{n}$ & $\%$ & $\mathrm{n}$ & $\%$ & $\mathrm{n}$ & $\%$ \\
\hline „a" & 82 & 96,47 & 48 & 56,47 & 34 & 40,00 & 18 & 21,18 \\
\hline „b" & 71 & 83,53 & 40 & 47,06 & 31 & 36,47 & 23 & 27,06 \\
\hline „c" & 65 & 76,47 & 39 & 45,88 & 26 & 30,59 & 2 & 2,35 \\
\hline „d" & 4 & 4,71 & 3 & 3,53 & 1 & 1,18 & 1 & 1,18 \\
\hline \hline Suma: & 222 & & 130 & 58,56 & 92 & 41,44 & 44 & 19,82 \\
\hline
\end{tabular}

(źródło: badania własne)

W sumie, 85 ankietowanych zaznaczyło 222 razy kategorie programów komunikacyjnych oznaczone od „a” do „d”, co średnio daje średnio 2,65 kategorii na jednego ankietowanego. Jedna osoba nie zaznaczyła żadnej z kategorii, cztery wybrały wszystkie kategorie od „a” do „d”. W każdej kategorii możliwe było wymienienie więcej niż jednego tytułu lub nazwy programu, stąd w wielu przypadkach błędnie podane tytuły występują obok poprawnych $z$ tej samej kategorii, nie powodując uznania za błędną całej odpowie- 
dzi. Słaba korelacja ujemna ilości znanych programów komunikacyjnych oraz wieku ankietowanych (współczynnik Pearsona równy -0,2) każe zauważyć, że młodsi nauczyciele chętniej komunikują się przy użyciu TI.

Najpopularniejszą kategorią wśród programów komunikacyjnych okazały się przeglądarki internetowe - odpowiedzi „a”. Jednak wśród 82 odpowiedzi dotyczących tej kategorii podano 18 błędnych nazw programów, które w 15 przypadkach dotyczyły wyszukiwarki internetowej google i w 3 przypadkach portali internetowych (Interia, Onet oraz szukampracy. pl [sic!]). 34 wskazania odpowiedzi „a” nie zostały uzupełnione żadną nazwą programu.

W kategorii programów pocztowych (do obsługi kont poczty internetowej) - odpowiedzi „b” - ankietowani popełnili najwięcej błędów. 40 z nich wymieniło nazwy takich programów, wśród których 23 nazwy dotyczyły portali oferujących usługę założenia konta poczty internetowej (onet, wp, $\mathrm{O} 2$, interia oraz jedna odpowiedź „mail”) a nie samych programów do obsługi takich kont. 31 osób nie podało żadnej nazwy programu pocztowego mimo deklaracji o korzystaniu $\mathrm{z}$ tego rodzaju aplikacji.

Odpowiedź „, dotyczy komunikatorów internetowych i zakreśliło ją 65 badanych. $26 \mathrm{z}$ nich nie podało żadnej nazwy odpowiedniego programu, w pozostałych zaś 39 odpowiedziach najczęściej wymieniano Gadu-gadu (32 wskazania) i Skype (29 wskazań). Dwie nieprawidłowe nazwy programów dotyczyły dziennika internetowego oraz Facebooka.

Wykres 7. Znajomość nazw oraz przeznaczenia programów komunikacyjnych wśród nauczycieli muzyki

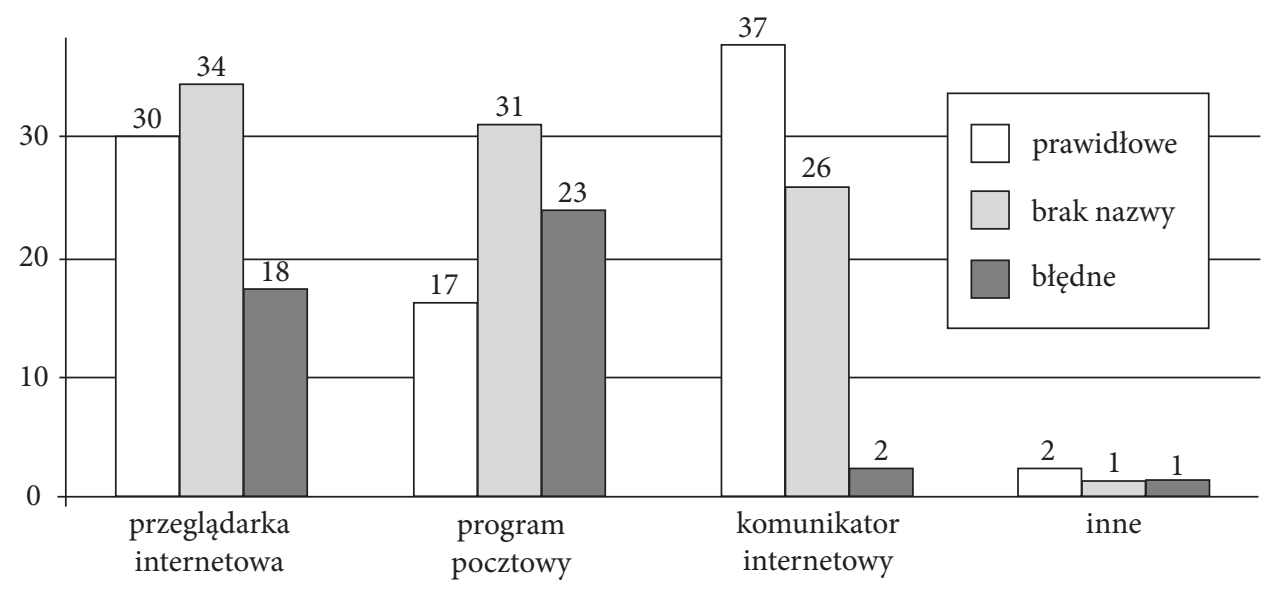

(źródło: badania własne) 
Odpowiedź „d” („inne”) zakreśliło 4 ankietowanych. Jeden z nich nie dookreślił z jakiego programu korzysta, pozostali wpisali: „portale społecznościowe (NK)”, „Facebook i czat” oraz „Skype i programy obsługujące radio internetowe". Ostatnią odpowiedź zaliczono do nieprawidłowych wobec faktu, że Skype jest komunikatorem głosowym (kategoria „c") a radio internetowe jedynie w wersji interaktywnej można byłoby uznać za szczególną formę programu komunikacyjnego.

Na wykresach 7.-9. kategoria „prawidłowe” zawiera tylko odpowiedzi z bezbłędnie podanymi tytułami programów, stąd ich wartość liczbowa jest różnicą ilości odpowiedzi z podanymi tytułami i odpowiedzi z błędnymi tytułami programów, zawartymi w odpowiadających im tabelach. Wykresy zatem ilustrują skale błędów w znajomości nazw i przeznaczenia poszczególnych programów (słupki białe i czarne) oraz skalę nieznajomości tych nazw (słupki szare).

Kategoria „c” - komunikatory internetowe - wyróżnia się w grupie programów komunikacyjnych stosunkowo najmniejszą ilością błędnie podanych nazw programów. Zważywszy mniejszą od przeglądarek internetowych oraz programów pocztowych popularność tego rodzaju programów wśród ankietowanych, stwierdzić należy, że szczególność komunikatorów sprawia, iż grono ich użytkowników jest mniejsze ale za to bardziej kompetentne. Popularność programu implikuje więc pobieżność jego znajomości.

Kolejna grupa programów ujęta została w pytaniu 19. Sześcioro ankietowanych nie odpowiedziało na to pytanie, deklarując tym samym brak umiejętności obsługi programów tej grupy.

Tabela 10. Znajomość obsługi programów pakietu biurowego

\begin{tabular}{|c|c|c|c|c|c|c|c|c|}
\hline \multirow{2}{*}{$\begin{array}{c}\text { Ilość od- } \\
\text { powiedzi: } \\
\text { (N=85) }\end{array}$} & \multicolumn{2}{|c||}{ ogółem } & \multicolumn{2}{c|}{$\begin{array}{c}\text { z podaniem tytu- } \\
\text { lów programów }\end{array}$} & \multicolumn{2}{c|}{$\begin{array}{c}\text { bez podania } \\
\text { tytułów }\end{array}$} & \multicolumn{2}{c|}{$\begin{array}{c}\text { ilość odpowie- } \\
\text { dzi z błędnymi } \\
\text { tytuami }\end{array}$} \\
\cline { 2 - 9 } & $\mathrm{n}$ & $\%$ & $\mathrm{n}$ & $\%$ & $\mathrm{n}$ & $\%$ & $\mathrm{n}$ & $\%$ \\
\hline „a" & 77 & 90,59 & 53 & 62,35 & 24 & 28,24 & 0 & 0 \\
\hline „b” & 38 & 44,71 & 29 & 34,12 & 9 & 10,59 & 0 & 0 \\
\hline „c" & 49 & 57,65 & 33 & 38,82 & 16 & 18,82 & 0 & 0 \\
\hline „d” & 5 & 5,88 & 5 & 5,88 & 0 & 0 & 3 & 3,53 \\
\hline Suma: & 169 & & 117 & 69,23 & 49 & 28,99 & 3 & 1,78 \\
\hline
\end{tabular}

(źródło: badania własne)

W odpowiedzi na to pytanie 79 ankietowanych zaznaczyło 169 razy kategorie od „a” do „d”. Największą popularnością wśród pakietu biurowego 
(Microsoft Office oraz Open Office) cieszy się edytor tekstu, który zaznaczyło 77 osób, w tym 53 podały jego nazwę (MS Word lub Write). Arkusz kalkulacyjny zaznaczyło 38 osób, w tym 29 podały jego nazwę (wyłącznie MS Excel). Edytor prezentacji multimedialnych zaznaczyło 49 osób, w tym 33 podały jego nazwę (MS Power Point oraz po jednej odpowiedzi: Impress i MediaBlender). Najwięcej trudności sprawiło wymienienie programu z kategorii „d” („inne”). Na 5 udzielonych odpowiedzi 3 dotyczyły programów spoza pakietu biurowego (Photoshop, Corell, Flash), natomiast dwie osoby wskazały prawidłowo na program MS Publisher.

Należy zauważyć, że ankietowani nie popełnili żadnego błędu (poza kilkoma ortograficznymi) w nazewnictwie najpopularniejszych programów pakietu biurowego. Znane są im dobrze przede wszystkim edytory tekstu (90,6\% ankietowanych), w mniejszym stopniu również arkusz kalkulacyjny $(44,7 \%)$ oraz edytor prezentacji multimedialnych (57,6\%). Dla pełnego obrazu należy pamiętać o 6 ankietowanych (7\%), którzy nie wybrali żadnej odpowiedzi, przyznając się tym samym do nieznajomości żadnego programu z tzw. pakietu biurowego.

Wykres 8. Znajomość nazw oraz przeznaczenia programów pakietu biurowego wśród nauczycieli muzyki

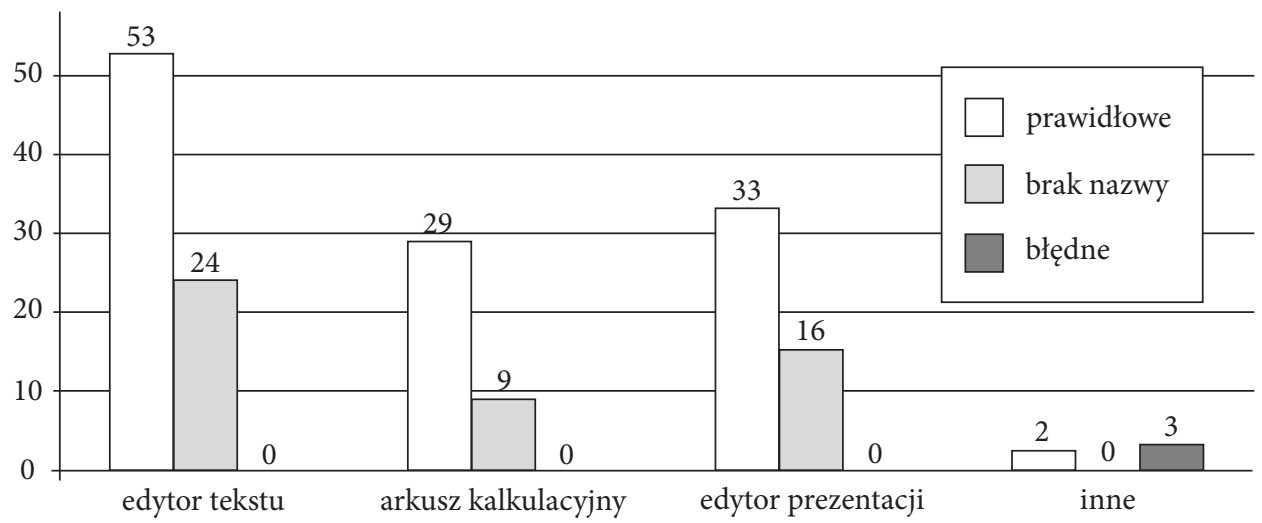

(źródło: badania własne)

Znajomość programów tzw. pakietu biurowego, choć nieco niższa niż znajomość programów komunikacyjnych, jest jednak bardziej usystematyzowana wśród ankietowanych nauczycieli. Brak odpowiedzi błędnych w przypadku trzech podstawowych programów tego pakietu (odpowiedzi 
„a”, „b” i „c") każe sądzić, że ich ugruntowana znajomość jest wynikiem obecności w programach nauczania przedmiotu informatyka (lub podobnych: podstawy informatyki, technologia informatyczna itp.) na wszystkich etapach edukacji oraz ich powszechnego wykorzystywania, znajdującego swoje potwierdzenie w wynikach ankiety. Reguła z poprzedniego zestawienia, według której popularność programu implikowała pobieżność jego znajomości znajduje więc tutaj swoje przeciwieństwo. Dodatkową przyczyną takiej rozbieżności jest również ogromna dominacja pakietu programów firmy Microsoft, sprawiająca, że każdą z kategorii ankietowani kojarzą z jednym, konkretnym, dominującym programem. Taka sytuacja nie ma miejsca w oprogramowaniu komunikacyjnym, gdzie w każdej z kategorii funkcjonuje i rywalizuje ze sobą co najmniej kilka aplikacji, skutecznie demonopolizując zarówno rynek jak i świadomość ich użytkowników.

Kolejne pytanie dotyczy programów muzycznych, które, jako specjalistyczne, nie są objęte programem nauczania przedmiotu mającego na celu powszechną informatyzację. Sześcioro ankietowanych pozostawiło to pytanie bez odpowiedzi, pozostałe 79 odpowiedzi ujęto w tabeli 11.

Tabela 11. Znajomość obsługi programów muzycznych

\begin{tabular}{|c|c|c|c|c|c|c|c|c|}
\hline \multirow{2}{*}{$\begin{array}{c}\text { Ilość od- } \\
\text { powiedzi: } \\
(\mathrm{N}=85)\end{array}$} & \multicolumn{2}{|c|}{ ogółem } & \multicolumn{2}{c|}{$\begin{array}{c}\text { z podaniem tytu- } \\
\text { łów programów }\end{array}$} & \multicolumn{2}{c|}{$\begin{array}{c}\text { bez podania } \\
\text { tytułów }\end{array}$} & \multicolumn{2}{c|}{$\begin{array}{c}\text { ilość odpowie- } \\
\text { dzi z błędnymi } \\
\text { tytułami }\end{array}$} \\
\cline { 2 - 11 } & $\mathrm{n}$ & $\%$ & $\mathrm{n}$ & $\%$ & $\mathrm{n}$ & $\%$ & $\mathrm{n}$ & $\%$ \\
\hline „a” & 73 & 85,88 & 54 & 63,53 & 19 & 22,35 & 1 & 1,18 \\
\hline „b” & 73 & 85,88 & 54 & 63,53 & 19 & 22,35 & 2 & 2,35 \\
\hline „c” & 24 & 28,24 & 20 & 23,53 & 4 & 4,71 & 1 & 1,18 \\
\hline „d” & 33 & 38,82 & 29 & 34,12 & 4 & 4,71 & 0 & 0 \\
\hline „e” & 15 & 17,65 & 12 & 14,12 & 3 & 3,53 & 0 & 0 \\
\hline „f” & 5 & 5,88 & 4 & 4,71 & 1 & 1,18 & 0 & 0 \\
\hline Suma: & 223 & & 169 & 75,78 & 50 & 58,82 & 4 & 4,71 \\
\hline
\end{tabular}

(źródło: badania własne)

W odpowiedzi na to pytanie ankietowani wskazali odpowiedzi od „a” do „f” 223 razy (średnio 2,62 kategorie programów na jednego ankietowanego). Najczęściej wybierano odpowiedzi „a” oraz „b” (po 73 razy). 19 ankietowanych w obu punktach nie podało nazwy żadnego programu, pozostałe 54 odpowiedzi zawierały nazwy konkretnych programów do odtwarzania muzyki oraz do zgrywania muzyki na płyty. Trzykrotnie nazwy 
te były błędne: jeden $\mathrm{z}$ badanych w obydwu punktach podał odpowiedź „youtube”, inny w punkcie „b” wpisał Windows Movie Maker jako program do zgrywania muzyki na płyty. Charakterystyczne jest, że wraz z większą znajomością programów muzycznych rośnie częstotliwość wykorzystywania TI przez badanych w ramach lekcji. Współczynnik korelacji Pearsona dla tych zmiennych wynosi 0,33 .

Popularność dwóch pierwszych kategorii programów muzycznych („a” $\mathrm{i}$ „b”) wynika $\mathrm{z}$ ich funkcji rozrywkowych - nie są to programy przeznaczone dla muzyków ale dla tych użytkowników komputerów, którzy lubią słuchać muzyki. Dopiero kolejne grupy programów („c”, „d” i „e”) dedykowane są znacznie mniejszemu kręgowi użytkowników, w tym profesjonalnym muzykom oraz amatorom szczególnie zainteresowanym tworzeniem muzyki. To sprawiło, że w badanej grupie nauczycieli te kategorie programów wybierano dużo rzadziej: edytory zapisu nutowego - 24 razy $(28,2 \%$ ankietowanych), edytory plików dźwiękowych - 33 razy (38,8\%) oraz aplikacje pomocne przy komponowaniu muzyki - 15 razy (17,6\%). Tak niska popularność specjalistycznych aplikacji muzycznych wśród profesjonalistów, jakimi są nauczyciele muzyki, wynikać musi między innymi z ich nieformalnego sposobu poznawania. Absolwenci studiów bowiem, których program nauczania obejmował poznanie programów komputerowych użytecznych w edukacji muzycznej, dopiero zaczynają wchodzić na rynek pracy.

Wykres 9. Znajomość nazw oraz przeznaczenia programów muzycznych wśród nauczycieli muzyki

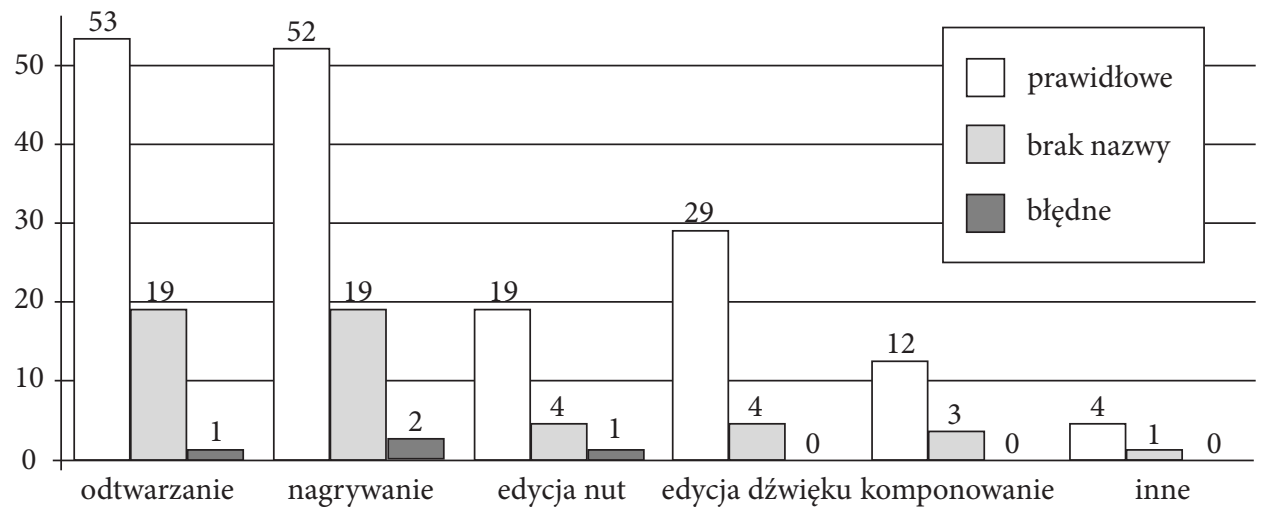

(źródło: badania własne)

Ostatnią kategorię programów muzycznych - „inne” - wybrało pięcioro ankietowanych. Czworo z nich sprecyzowało swoje odpowiedzi: „programy 
do nadawania audycji radia internetowego”, „CDex”, „converter MP3” oraz „MidConverter”. Trzy ostatnie programy całkowicie mieszczą się w grupie „d” - „programy do obróbki i konwersji plików dźwiękowych”, co jednak nie zwiększa grupy nauczycieli korzystających z tej grupy programów muzycznych, gdyż wszystkie uszczegółowione odpowiedzi „f” współistnieją z odpowiedziami "d”.

W tym zestawieniu zwraca uwagę, że reguła obecna przy okazji programów komunikacyjnych, według której popularność programu implikowała pobieżność jego znajomości, i która znalazła swoje przeciwieństwo w grupie programów pakietu biurowego, w grupie programów muzycznych nie ma zastosowania ani wprost, ani jako przeciwieństwo. Programy muzyczne niezależnie od ich popularności (grupy „a” i „,b” - wysokiej, zaś „c”, „d” i „e” - znacznie niższej) nie są mylone co do nazwy oraz przeznaczenia.

Odpowiedzi na pytanie 21. (o „inne programy”) stanowią najmniej liczną grupę. Tylko 39 ankietowanych wypowiedziało się na ten temat, wskazując głównie na programy graficzne oraz odtwarzacze plików filmowych. Taka liczebność nie pozwala na wiarygodną analizę i każe upatrywać przyczynę w zbyt ogólnie sformułowanym pytaniu, co nie ujawniło się i - co za tym idzie - nie znalazło podstaw do korekty w badaniach pilotażowych.

Sumaryczne przedstawienie popularności wśród badanych trzech zaprezentowanych wyżej grup programów komputerowych (pytania 18.-20.) przedstawia wykres 10.

Proporcjonalnie wyjątkowo małe ilości odpowiedzi z prawidłowymi nazwami programów pocztowych oraz przeglądarek internetowych (zasygnalizowane w omówieniu wykresu 7.) można tłumaczyć różnorodnością tych aplikacji ale też wyjątkowym ich usytuowaniem wśród reszty oprogramowania we wszystkich systemach operacyjnych. „Menu start” większości systemów oferuje szybsze odnalezienie tych dwóch aplikacji pod hasłami: „Internet” oraz „E-mail” z nazwą podaną mniej czytelną czcionką. Wszystkie inne programy posługują się własną nazwą jako etykietą, dlatego ich każdorazowe uruchomienie łączy się z zauważeniem tej nazwy i mimowolnym jej zapamiętywaniem. Nie należy zatem łączyć odstępstwa tych dwóch rodzajów aplikacji od ogólnego trendu zauważalnego na wykresie 10. z ich faktyczną nieznajomością - ta bowiem, wobec powszechności obu grup programów, nie wydaje się istotna dla oceny prawdziwości deklaracji respondentów. 
Wykres 10. Znajomość nazw i przeznaczenia programów komputerowych oraz deklaracja umiejętności ich obsługi wśród nauczycieli muzyki

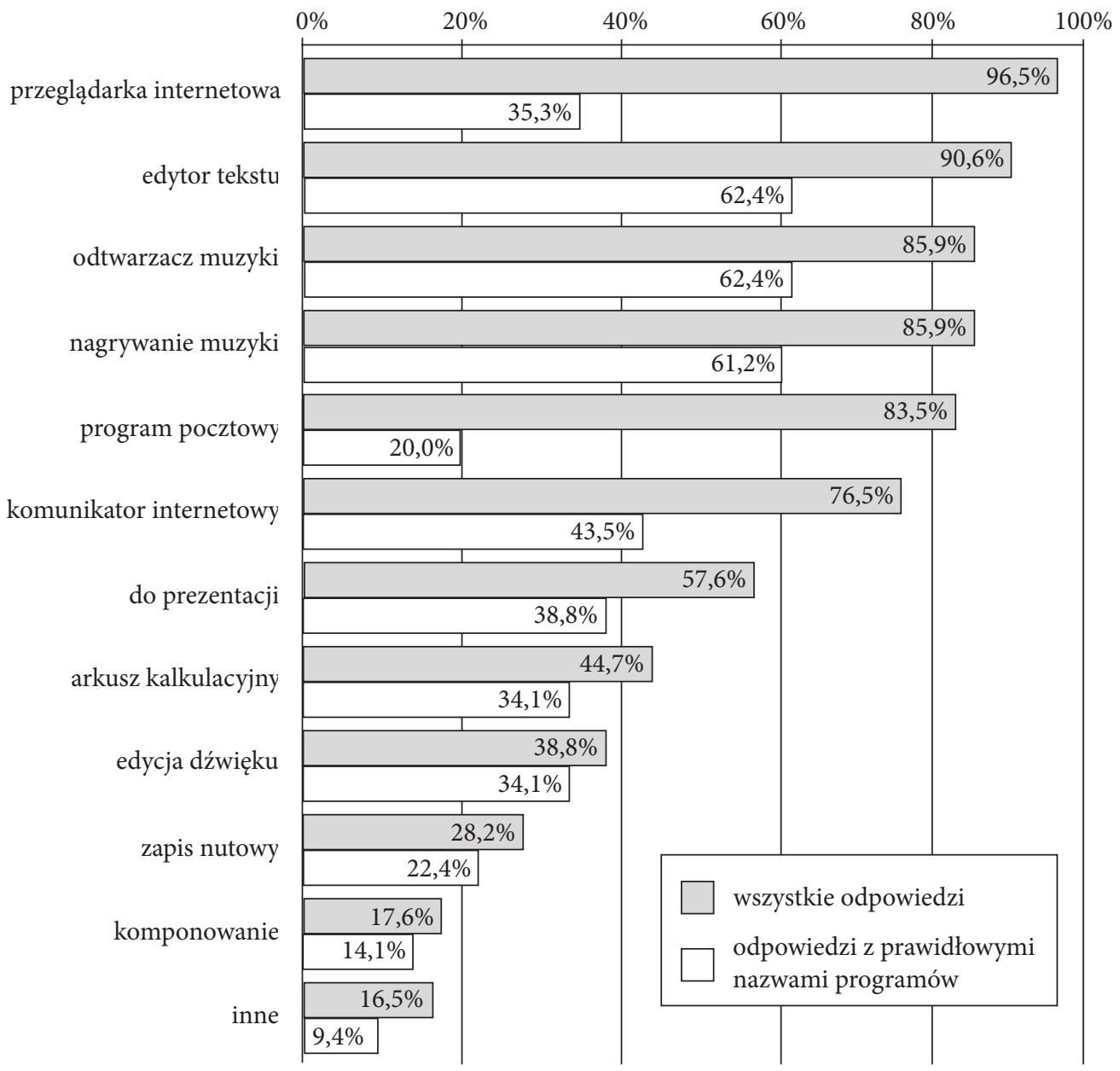

(źródło: badania własne)

Pytania 18.-20. dotyczyły umiejętności obsługi konkretnych aplikacji, wchodzących w skład sprecyzowanej grupy programów komputerowych (komunikacyjnych, biurowych i muzycznych). Odpowiedzi na te pytania można więc traktować jedynie jako deklaracje ankietowanych. Wymienienie jednak nazwy programu w odpowiadającej mu grupie (bez sugerowania tej nazwy w kafeterii) pozwala wnioskować na temat faktycznej znajomości nazw i przeznaczenia poszczególnych aplikacji a nie tylko o deklaracji 
w tym zakresie (z wyjątkiem wskazanym w poprzednim akapicie). Z odpowiedzi zatem na pytania 18.-20. ankiety dla nauczycieli wnioskować możemy, że nauczyciele znają nazwę przytaczanego programu (przywołując ją z własnej pamięci), wiedzą jakie jest jego przeznaczenie (umieszczając w odpowiedniej kategorii) oraz deklarują umiejętność jego obsługi.

$\mathrm{Z}$ ujęcia tych odpowiedzi w formie wykresu 10., obrazującego zarówno wiedzę jak i deklarację umiejętności w zakresach wymienionych wyżej, wynika zatem, że według deklaracji ankietowanych nauczycieli:

- 96,5\% z nich umie obsługiwać program niezbędny do szukania i odnajdywania potrzebnych wiadomości i materiałów (w tym muzycznych - nagrania, nuty, teksty) w internecie;

- 90,6\% potrafi obsługiwać program, dzięki któremu można te wiadomości sformatować w pliku tekstowym, zapisać, przekształcić na arkusz sprawdzianu lub kartę pracy ucznia;

- 85,9\% potrafi odtworzyć plik dźwiękowy odnaleziony winternecie oraz zapisać go na płycie, którą potrafią następnie odtworzyć w klasie;

- 83,5\% potrafi kontaktować się z uczniami w formie pisemnej pośredniej, rozsyłać materiały tekstowe i dźwiękowe, odbierać prace domowe w formie plików tekstowych lub dźwiękowych;

- 76,5\% potrafi obsługiwać program umożliwiający bezpośrednią rozmowę z wieloma uczniami w formie pisemnej lub głosowej;

- 57,6\% potrafi przygotować prezentację multimedialną, do której jest w stanie użyć materiałów tekstowych, dźwiękowych i innych, odszukanych w internecie, a następnie zaprezentować ją w klasie lub rozesłać uczniom pocztą internetową;

- 44,7\% potrafi zestawić dane w arkuszu kalkulacyjnym, przedstawić je uczniom bądź przedstawić zwierzchnikom tabelaryczne ujęcie wyników nauczania;

- 38,8\% potrafi edytować znaleziony w internecie plik dźwiękowy: skrócić go, zmienić tonację, tempo lub format zapisu, następnie nagrać go i odtworzyć lub włączyć do prezentacji multimedialnej;

- 28,2\% potrafi przygotować zapis nutowy przy pomocy komputera, zmienić jego dowolne parametry (tonację, tempo, formę zapisu, skład instrumentalny, wyselekcjonować poszczególne partie itp.), dołączyć przykład nutowy do dokumentu tekstowego (np. karty pracy lub arkusza sprawdzianu), prezentacji multimedialnej lub rozesłać uczniom pocztą internetową; 
- 17,6\% potrafi swoje lub uczniów pomysły kompozytorskie zapisać przy pomocy komputera jako partyturę lub plik dźwiękowy, następnie nagrać go i rozpowszechnić lub włączyć do prezentacji multimedialnej.

Zatem ponad $85 \%$ badanych nauczycieli deklaruje umiejętność wykorzystania w podstawowym, najprostszym zakresie potencjału muzycznego technologii komputerowej - wyszukanie interesujących utworów w internecie, nagranie ich na płytę oraz odtworzenie. Ponad połowa deklaruje nieco szersze umiejętności - potrafi przygotować prezentację multimedialną, zawierając w niej - zgodnie z poprzednią, szerszą kategorią - wyszukane i nagrane utwory muzyczne czy pliki tekstowe. Specjalistycznie muzyczne zastosowania TI znajdują się na końcu tej listy. Tylko 33 osoby $(38,8 \%)$ deklarują znajomość programów, do których zaliczyć należy edytory dźwię$\mathrm{ku}$, edytory zapisu nutowego, miksery muzyczne, trackery, wirtualne studia nagraniowe, konwertery, samplery, sequencery itp. Trudno tłumaczyć to brakiem zainteresowania nauczycieli muzyki takimi aplikacjami - przecież zainteresowanie muzyką zdecydowało o wyborze ich drogi życiowej. Być może poznanie specjalistycznych programów wymaga czasu i doświadczenia w użytkowaniu podstawowych aplikacji - stąd zauważona dodatnia korelacja z deklarowaną częstotliwością wykorzystywania TIK.

Prawdopodobną przeszkodą jest daleko posunięta specjalizacja tych programów, która nie dotyczy jedynie wiedzy i umiejętności z zakresu muzyki. Większą barierą wydają się wiedza i umiejętności z zakresu produkcji muzyki czy reżyserii dźwięku, pozostające raczej w domenie inżynierów niż muzyków. W obu przypadkach - kwalifikacji muzycznych i technicznych - twórcy aplikacji potrafią jednak zadbać o większą powszechność swoich produktów przez ich maksymalne uproszczenie przynajmniej w jednym z tych aspektów. Dzięki takiemu uprzystępnieniu zarówno muzyk, któremu obce są kwestie techniczne jak i zdolny technicznie (lub raczej informatycznie) amator muzyczny są w stanie wybrać dla siebie odpowiednią aplikację, dającą możliwość tworzenia muzyki na miarę własnych możliwości.

W przypadku badanej grupy nauczycieli, bariery techniczne nie powinny być uważane za niemożliwe do pokonania. Ilość znanych respondentomprogramów nie pozwala na takie wnioski. Wykres 11. obrazuje dane zebrane z odpowiedzi na trzy pytania - od 18. do 20. - sumując ilość kategorii znanych respondentom programów komputerowych. We wszystkich trzech grupach aplikacji (komunikacyjne, biurowe i muzyczne) ankieta proponowała łącznie 14 kategorii (w tym kategorie „inne” w każdej grupie). Bada- 
ni nauczyciele wybrali od 0 do 12 kategorii, w sposób zbliżony do rozkładu normalnego z maksimum w punkcie „7” (tyle kategorii wskazało 16 osób).

Wykres 11. Ilość kategorii programów komputerowych deklarowanych jako znane przez nauczycieli muzyki

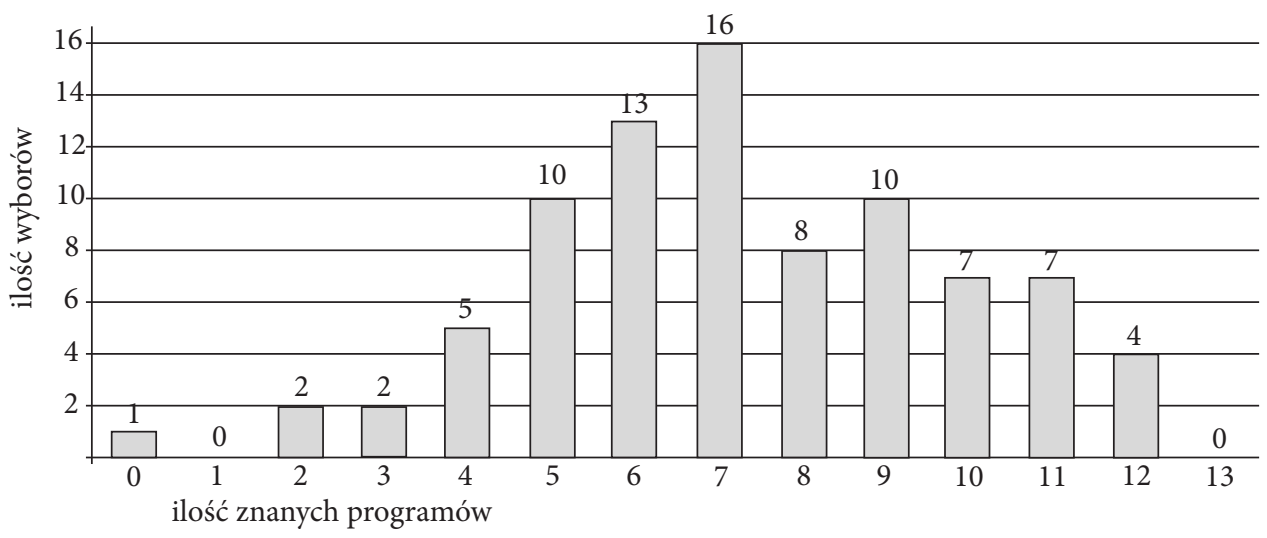

(źródło: badania własne)

Modelowy dla badanej grupy nauczyciel muzyki zna zatem i potrafi obsługiwać $7 \mathrm{z}$ uwzględnionych w ankiecie programów (średnia $=7,28$, mediana $=7$ ), w tym: 3 programy komunikacyjne (średnia=2,65, mediana=3), 2 programy biurowe (średnia $=2,01$, mediana $=2$ ) oraz 2 programy muzyczne (średnia $=2,62$, mediana $=2$ ). Rodzaje tych programów możemy doprecyzować na podstawie wykresu 8., wskazując najczęściej wymieniane przez badanych kategorie. 7 najwyższych pozycji tego wykresu zawiera: przeglądarkę internetową, program pocztowy, komunikator internetowy (3 programy komunikacyjne), edytor tekstu i edytor prezentacji multimedialnych (2 programy pakietu biurowego) a także programy do nagrywania i odtwarzania muzyki (2 programy muzyczne). Zauważalna jest w tym przypadku ujemna korelacja ilości wymienionych jako znane kategorii programów komputerowych z wiekiem badanych - współczynnik korelacji Pearsona wynosi -0,27, a także oczekiwana dodatnia korelacja z częstotliwością wykorzystywania TI na zajęciach - współczynnik korelacji Pearsona równy jest 0,41 przy założonym poziomie istotności $\mathrm{p}=0,05$.

Takie zestawienie nie odbiega od tendencji zauważalnych w wielu zestawieniach najpopularniejszych programów komputerowych ${ }^{8}$ i świadczy

\footnotetext{
${ }^{8}$ Por. rankingi najpopularniejszych programów komputerowych, np.: http://www.softpedia.com/popularity/; http://www.soft32.com/windows/most-popular; http://windows-xp.software.informer.com/software/ (stan $\mathrm{z}$ dnia 3.03.2012).
} 
o nieznaczącym wpływie specjalizacji użytkowników, jakimi są nauczyciele muzyki, na znajomość specjalistycznego oprogramowania. Zasadnym zatem będzie wniosek, że nieodbiegający od ogólnych preferencji sposób wykorzystywania komputerów wynika ze standardowej ścieżki poznawania ich możliwości. Opanowanie zaś aplikacji bardziej specjalistycznych wymaga profilowanych kursów, dla których znakomitym miejscem są programy studiów. Skorelowanie profilu studiów z dedykowanym konkretnej specjalizacji oprogramowaniem jest powszechną praktyką na studiach technicznych, inżynierskich (programy AutoCAD, ArchiCAD i inne). Podobne rozwiązania stosowane są w wielu zachodnich krajach na studiach muzycznych (programy Sibelius, Cubase i inne). Studia pedagogiczne nie dysponują tak jednoznacznie specjalistycznie dedykowanym oprogramowaniem, stąd prawdopodobnie tak późne i wciąż niepowszechne włączanie do programów studiów pedagogicznych aplikacji wspomagających edukację.

Kilka kategorii programów z pytania 20. powtarza się w pytaniu 10. Zawierały one jednak istotną różnicę: pytanie 20. dotyczyło znajomości i umiejętności obsługi aplikacji typowo muzycznych, podczas gdy pytanie 10. dotyczyło ich wykorzystywania w pracy z uczniami. Zestawienie odpowiedzi na te pytania pozwoli ocenić różnicę w ilości znanych oraz używanych w szkole programów. Poniżej porównano ilość odpowiedzi w kategoriach powtarzających się w obydwu pytaniach: programy do nagrywania muzyki, do edycji dźwięku, do edycji zapisu nutowego oraz do tworzenia muzyki. Różnicę w odpowiedziach na te pytania w kategoriach specjalistycznie muzycznych programów ukazują wykresy 12a., 12b. i 12c. Wykres 12a. zawiera wszystkie odpowiedzi, łącznie z tymi, w których badani ograniczyli się tylko do wskazania kategorii programu bez wpisywania jego tytułu bądź nazwy.

Zaskakująca przewaga programów wykorzystywanych nad programami znanymi (w kategorii aplikacji do edycji dźwięku oraz do komponowania) musi oczywiście wynikać z błędu. Nie można przecież wykorzystywać programu, którego się nie zna. Po szczegółowym przeanalizowaniu odpowiedzi można stwierdzić, że część programów wymienionych w odpowiedziach na pytanie 10. ankietowani pominęli w odpowiedziach na pytanie 20. Być może znużenie kolejnymi pytaniami nie pozwoliło na utrzymanie koncentracji obecnej przy pytaniu 10. na tym samym poziomie 10 pytań później. 
Wykres 12a. Porównanie znajomości muzycznych programów komputerowych (pyt. 20.) oraz ich wykorzystania w pracy z uczniami (pyt. 10.) - wszystkie odpowiedzi

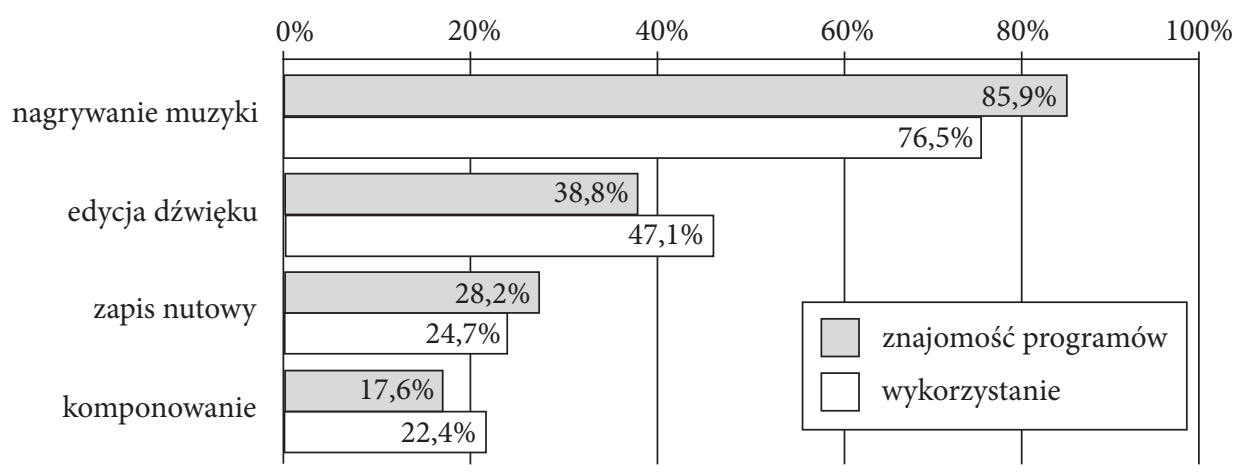

(źródło: badania własne)

Obowiązkiem wnikliwego badacza było zatem uzupełnienie odpowiedzi na pytanie 20. o programy, których wykorzystywanie zadeklarowali badani w odpowiedzi na pytanie 10. Założyć bowiem należy, że programy, które nauczyciele wykorzystują w swojej pracy oraz wymienili je z nazwy, muszą być im znane. Wykres 12b. obrazuje liczebność odpowiednich kategorii wykresu 12a. po takim właśnie uzupełnieniu.

Wykres 12b. Porównanie znajomości muzycznych programów komputerowych (pyt. 20.) oraz ich wykorzystania w pracy z uczniami (pyt. 10.) - wszystkie odpowiedzi (z uzupełnieniem)

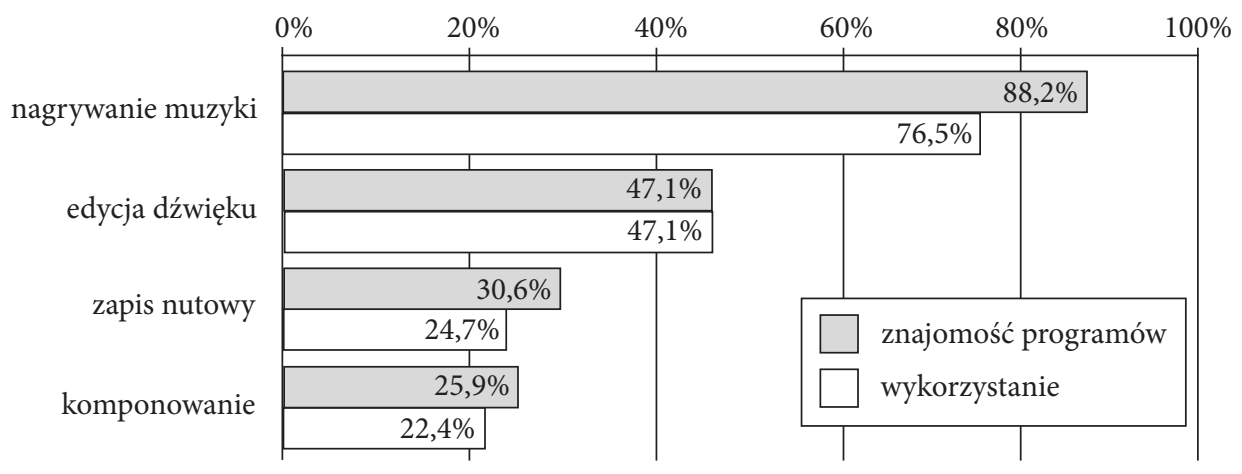

(źródło: badania własne) 
Do odpowiedzi na pytanie 20. doliczono więc: po 2 odpowiedzi w kategoriach programów do nagrywania muzyki oraz do edycji zapisu nutowego, a także po 7 odpowiedzi w kategoriach programów do edycji dźwięku oraz programów pomocnych w komponowaniu, których znajomością ankietowani wykazali się w odpowiedziach na pytanie 10 . W tak uzupełnionym zestawieniu proporcje aplikacji znanych i wykorzystywanych nie zawierają już ewidentnych sprzeczności.

Kolejnym działaniem przybliżającym wyniki zobrazowane wykresem 10b. do rzeczywistego stanu jest uwzględnienie wyłącznie kompletnych odpowiedzi, tzn. takich, w których podane zostały nazwy adekwatnych do kategorii programów i pominięcie tym samym jedynie deklaracji nie popartych znajomością takich nazw. Zestawienie takich odpowiedzi zawiera wykres 12c.

Wykres 12c. Porównanie znajomości muzycznych programów komputerowych (pyt. 20.) oraz ich wykorzystania w pracy z uczniami (pyt. 10.) - odpowiedzi $\mathrm{z}$ podanymi nazwami programów (z uzupełnieniem)

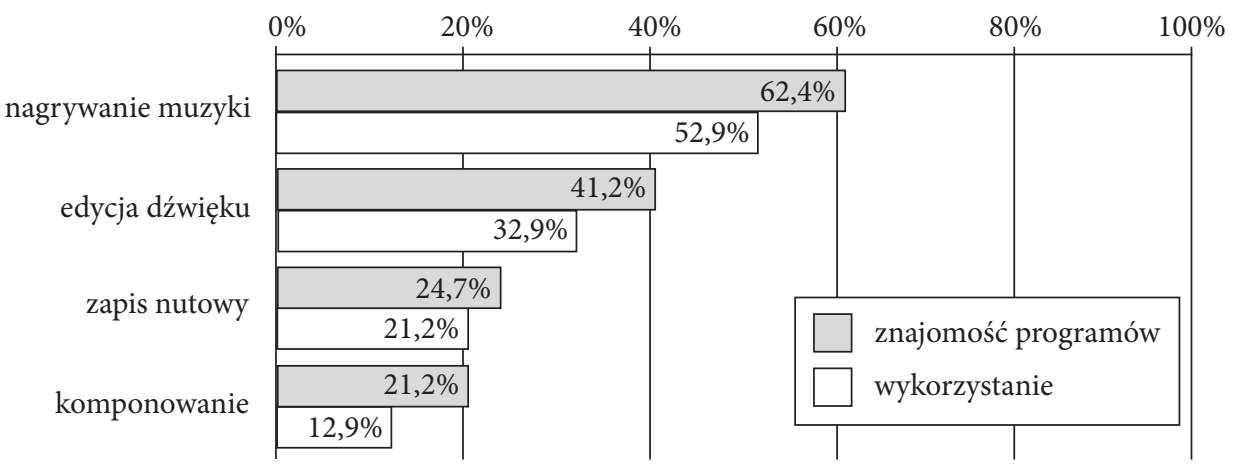

(źródło: badania własne)

Z porównania różnic w punktach procentowych, obrazujących znajomość i wykorzystywanie odpowiednich kategorii programów (odpowiednio: 9,$5 ; 8,3 ; 3,5 ; 8,3)$ zauważamy, że w każdej z kategorii odpowiednio: ośmioro, siedmioro, troje i siedmioro ankietowanych nauczycieli nie wykorzystuje muzycznych programów komputerowych do lekcji muzyki mimo ich znajomości. Innymi słowy, nauczyciele ci - zgodnie z przyjętym tu rozumieniem kompetencji - posiadają wystarczające kwalifikacje informatycz- 
ne lecz nie posiadają odpowiednich kompetencji. Nie rozstrzygając tutaj, czy ów brak odpowiedniego działania w sferze dydaktycznej, różnicujący kwalifikacje i kompetencje, jest skutkiem niedostatków sprzętowych, organizacyjnych, czy też wyobraźni co do zastosowania dydaktycznego znanego sobie narzędzia, zauważyć należy sam brak takiego działania. Konstatacja ta jest o tyle ważna, że zbiega się z treściami hipotez szczegółowych, sformułowanych w rozdziale 3.2.

\section{Częstotliwość}

Pytanie dotyczące częstotliwości wykorzystywania TI przez nauczycieli brzmiało:

„9. Jak często wykorzystuje Pan/i technologię komputerową w przygotowaniu lub prowadzeniu zajęć:

a. w ogóle nie wykorzystuję;

b. zdarzyło mi się raz lub dwa w całej mojej pracy nauczycielskiej;

c. 1-2 razy w ciągu roku szkolnego;

d. kilka razy w ciągu roku szkolnego;

e. częściej (jak często?).

Na 85 udzielonych odpowiedzi punkty „a” i „b” zakreślono po jednym razie $(1,18 \%$ każdy), punkt „c” wybrało 5 ankietowanych $(5,88 \%)$, natomiast punkty „d” i „e" odpowiednio: 38 badanych (44,71\%) oraz 40 badanych (47,06\%). Punkt „e" ankietowani dookreślali następująco:

- „codziennie” lub „prawie codziennie” - 6 odpowiedzi (7,05\% wszystkich badanych);

- „na każdej lekcji” lub „kilka razy w tygodniu” - 9 odpowiedzi $(10,59 \%)$;

- „1-2 razy w tygodniu” lub „kilka razy w miesiącu” - 14 odpowiedzi $(16,47 \%)$;

- „1-2 razy w miesiącu” - 6 odpowiedzi (7,05\%).

Pozostałe określenia nie były precyzyjne (np. „w zależności od potrzeb”, „W zależności od tematu zajęć”, „w razie potrzeby”). Należy zauważyć, że rozbieżność powyższych dookreśleń punktu „e” jest tylko pozorna, zważywszy na wymiar zatrudnienia nauczycieli. Przy standardowym wymiarze etatu (18 godzin dydaktycznych) określenie „prawie codziennie” jest godzinowo bliskie określeniu „1-2 razy w tygodniu” lub „kilka razy w miesiącu”.

Powyższe wyniki przedstawia wykres 13. 
Wykres 13. Częstotliwość wykorzystywania TI w przygotowaniu lub prowadzeniu zajęć $(\mathrm{N}=85)$

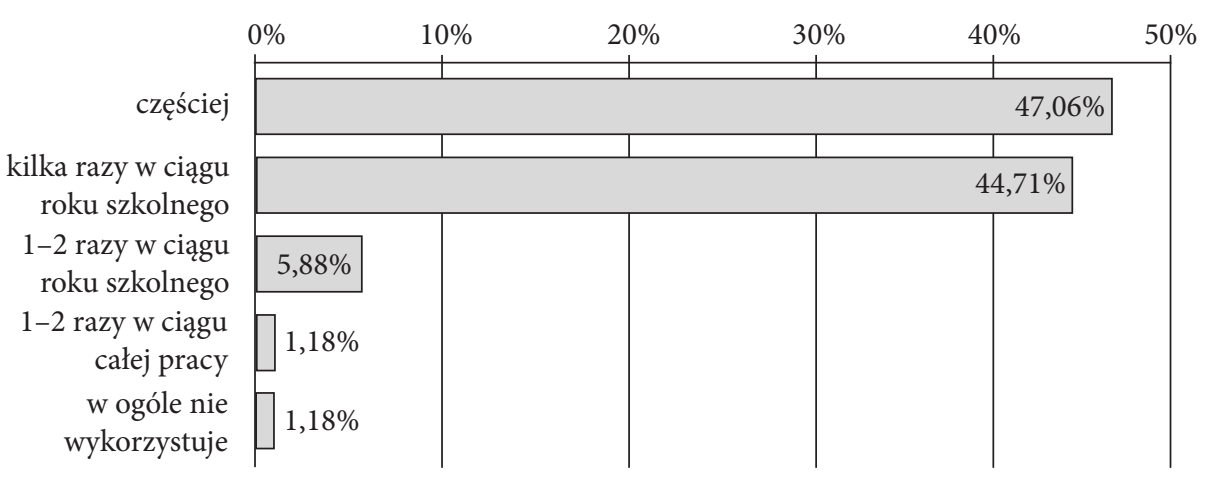

(źródło: badania własne)

Odpowiedź „e” wybrana przez 40 nauczycieli $(47,06 \%)$, przy dookreśleniu „więcej niż raz w miesiącu” w 35 przypadkach (41,16\%) jest wynikiem bardzo optymistycznym. Suma tych odpowiedzi z odpowiedziami „d” („kilka razy w ciągu roku szkolnego”) jest już imponująca i wynosi 78 (91,76\%). Jedynie siedmioro ankietowanych (8,23\%) wykazało się żadnym bądź incydentalnym stosowaniem narzędzi informatycznych w swojej pracy. Częstotliwość wykorzystywania TI nie wykazuje korelacji z wiekiem, płcią czy stopniem awansu zawodowego (współczynnik korelacji Pearsona równy odpowiednio: $-0,10 ; 0,08$ oraz $-0,01$ przy założonym poziomie istotności $\mathrm{p}=0,05)$.

Hipotezę szczegółową, brzmiącą: „nauczyciele muzyki w niedostatecznym stopniu wykorzystują TIK w swojej pracy dydaktycznej" należy zatem uznać za sprzeczną z deklaracją samych nauczycieli. Pozostaje ustalić na ile deklaracje nauczycieli są zgodne z rzeczywistością bądź z intencjami zawartymi w pytaniu. Należy bowiem zauważyć, że część nauczycieli mogła na przykład - wbrew intencjom badania - uważać codzienną obsługę dziennika elektronicznego za stosowanie TI w dydaktyce muzyki.

W tym miejscu zasadne będzie sięgnięcie do ankiety przeznaczonej dla dyrektorów szkół i porównanie dotychczasowych wyników z odpowiedziami dyrektorów na temat wykorzystywania TI przez nauczycieli muzyki w ich szkołach. Jedną z funkcji tej dodatkowej ankiety miała być weryfikacja odpowiedzi nauczycieli. I tak, trzecie z pytań skierowanych do dyrektorów brzmiało: 
„3. Czy nauczyciel muzyki w Pani/a szkole stosuje technologię komputerową na lekcjach:
a. tak;
b. nie;
c. nie wiem".

W 83 ankietach dyrektorzy zakreślili 46 odpowiedzi „a”, 30 odpowiedzi „b” oraz 7 odpowiedzi „c” (odpowiednio: 55,42\%, 36,14\% i 8,43\%).

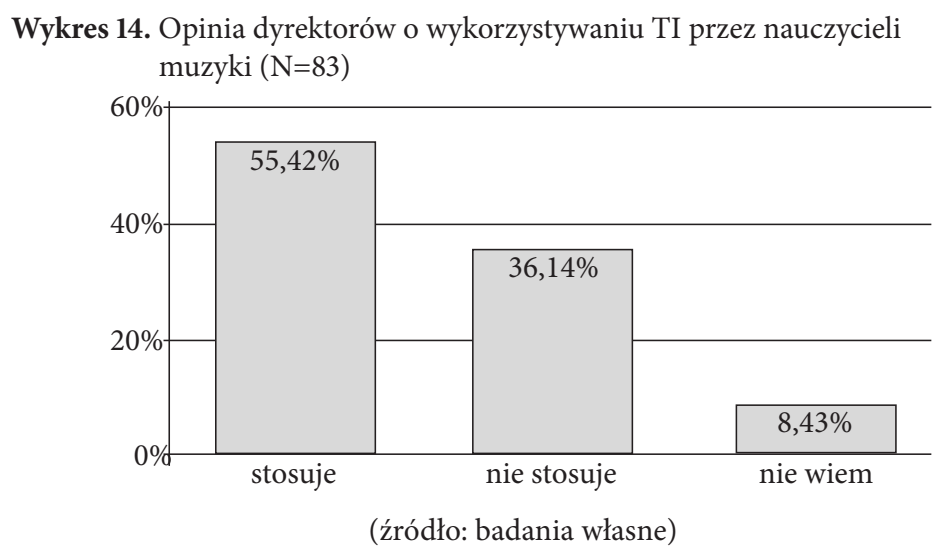

Powyższe wyniki nie są już tak optymistyczne. Nie jeden (jak wynika z deklaracji nauczycieli) ale aż 30 nauczycieli muzyki (36,14\%), według wiedzy dyrektorów, w ogóle nie stosuje TI w swojej pracy.

Porównanie danych wykresu 13. oraz wykresu 14. zdradza dwie możliwości: 29 nauczycieli (niemal 35\%) niezgodnie z prawdą podało, że wykorzystuje TI w przygotowaniu lub prowadzeniu zajęć lub też odpowiedzi dyrektorów mijają się z prawdą. Ta ostatnia sytuacja może mieć miejsce z dwóch powodów: odpowiedzi „b”, „c" i „d” na pytanie 9. ankiety nauczycielskiej zdradza na tyle rzadkie korzystanie z TI, iż może skutkować „nie zauważeniem" przez dyrektora tego aspektu działalności dydaktycznej nauczyciela muzyki bądź jego zbagatelizowaniem, uznaniem za bliższe ostrej kategorii zaproponowanej odpowiedzi „nie” niż „tak”.

Dyrektor szkoły może również nie mieć świadomości stosowania TI przez nauczyciela muzyki w sytuacji, gdy ten korzysta $\mathrm{z}$ komputera jedynie w domu, przygotowując się do lekcji i nie demonstruje swoich kompetencji w tym zakresie na lekcjach. Za tym wytłumaczeniem może świadczyć liczba nauczycieli deklarujących wykorzystanie TI na lekcjach, czyli odpowiedź „c" na pytanie 8 . ankiety nauczycielskiej (54 odpowiedzi $=63,53 \%$ ), 
która jest niemal równa sumie odpowiedzi „tak” oraz „nie wiem” na pytanie 3. ankiety dyrektorskiej (53 odp. $=63,85 \%$ ).

Brak świadomości dyrektora na temat stosowania TI przez nauczyciela muzyki może być również skutkiem braku takiej wiedzy lub wręcz braku zainteresowania taką wiedzą, co w pewnym stopniu może sugerować odpowiedź „nie wiem” - wybrana siedmiokrotnie przez dyrektorów $(8,43 \%)$ na interesujące nas pytanie.

Poniższy wykres obrazuje różnice w ocenie częstotliwości stosowania TI przez nauczycieli muzyki. Odpowiedzi „nie stosuje” w ankiecie dyrektorów utożsamiono tu z odpowiedziami o braku lub znikomym wykorzystaniu TI (odpowiedzi „a”, „b” i „c” nauczycieli na pytanie 9.), zaś odpowiedzi „stosuje” w ankiecie dyrektorów utożsamiono z odpowiedziami „d” oraz „e" nauczycieli (czyli „kilka razy w ciągu roku szkolnego” lub „częściej”).

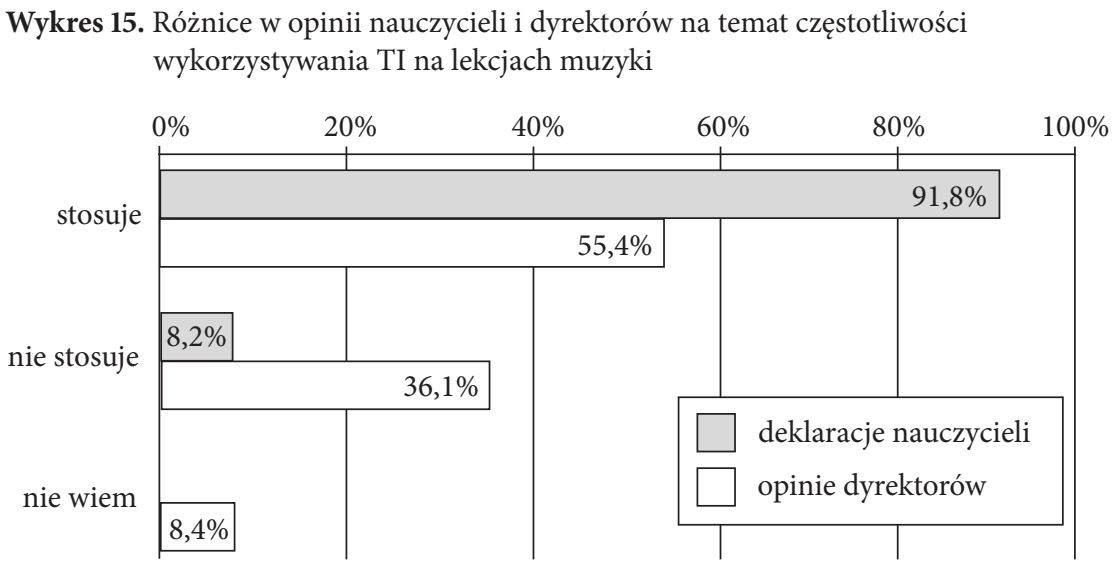

(źródło: badania własne)

Bardzo duże rozbieżności uwidocznione na powyższym wykresie nie pozwalają na przyjęcie za obiektywnie prawdziwe ani wersji nauczycieli ani wersji dyrektorów. Próba uwiarygodnienia takich wyników i znalezienia kompromisowego poziomu częstotliwości wykorzystywania TI przez nauczycieli muzyki, może opierać się na różnych przesłankach. Najprostszym sposobem byłoby uśrednienie obu wyników, które mimo ułomności metodologicznej pozwoliłoby na zbliżenie do wyników rzeczywistych. Korzystając $z$ takiego rozwiązania otrzymalibyśmy grupę 73,6\% nauczycieli stosujących TI w dydaktyce muzyki oraz 22,15\% nauczycieli nie stosujących takich rozwiązań. 
Drugim sposobem uwiarygodnienia wyników deklaracji nauczycieli może być porównanie danych z wykresów 12b. i 12c. Na ich podstawie możemy wyliczyć jaką częścią grupy nauczycieli deklarujących wykorzystywanie muzycznych programów komputerowych jest grupa nauczycieli, która nie podała żadnej nazwy takiego programu. Można spróbować przyjąć bowiem, że ta ostatnia grupa, wykazując się nieznajomością żadnego programu, w sposób niezgodny z prawdą chce uchodzić za stosujących TI w dydaktyce muzyki. Takie porównanie daje następujące wyniki: 69,15\% nauczycieli deklarujących wykorzystywanie programów do nagrywania muzyki wymieniło ich przykładową nazwę, można zatem przyjąć, że $30,85 \%$ z nich podało odpowiedź, która może być nieprawdziwa. W pozostałych kategoriach oprogramowania analogiczne grupy nauczycieli kształtują się następująco: edytory dźwięku - 30,15\%, edytory zapisu nutowego - 14,18\%, programy pomocne w tworzeniu muzyki - 42,42\%. Średnio więc 29,4\% ankietowanych, którzy udzielali pozytywne odpowiedzi na pytanie o wykorzystywanie muzycznych programów komputerowych w pracy z uczniami nie podało żadnego przykładu takiego programu. Jeśli uznać, że jest to grupa nauczycieli niezgodnie z prawdą zawyżająca swoje kompetencje informatyczne to celowe byłoby odliczenie takiego właśnie procentu odpowiedzi z 91,8\% odpowiedzi pozytywnych, uwidocznionych na wykresie 15. i dodanie ich do odpowiedzi negatywnych. Otrzymamy w efekcie takiej operacji następujący wynik: 76,9\% odpowiedzi „stosuje” oraz 23,1\% odpowiedzi „nie stosuje”.

Jeszcze jednym (trzecim) sposobem pozbycia się jawnej rozbieżności wyników ujętych w wykresie 15. jest próba ich uśrednienia, uwzględniającego wagę skrajnych wartości, szacowaną na podstawie możliwych (ewentualnych) motywów, powodujących zafałszowanie prawdziwego obrazu kompetencji informatycznych nauczycieli uczestniczących w badaniach. Do takich ewentualnych motywów, zawyżających statystyki po stronie nauczycieli można zaliczyć:

1. Chęć zaprezentowania się jako kompetentny fachowiec lub strach przed zdemaskowaniem własnej niekompetencji.

2. Chęć zaprezentowania się jako nowoczesny nauczyciel, otwarty na nowe rozwiązania, nie zamykający się w kręgu rutynowych działań.

3. Chęć dopasowania własnego obrazu do wymagań zawartych w warunkach awansu zawodowego. 
Po stronie dyrektorów trudniej jest znaleźć możliwe motywy zaniżające prawdziwe wyniki. Mogłyby one jednak być następujące:

1. Chęć pokazania, że ewentualny mały udział TI w dydaktyce przedmiotowej nie wynika z zaniedbań infrastrukturalnych szkoły, wykazanie, że aktualny stan sprzętu komputerowego w szkole jest całkowicie wystarczający.

2. Chęć zaprezentowania siebie jako lidera w zastosowaniach TI wśród nauczycieli bądź usprawiedliwienie własnych braków w tym zakresie ogólnym słabym stanem kompetencji informatycznych wśród własnych podwładnych.

Dalsza procedura, polegająca na przypisaniu odpowiedniej wagi każdemu z ewentualnych motywów, skutkowałaby zbliżeniem wyliczonej średniej do jednej (nauczycielskiej) lub drugiej (dyrektorskiej) wersji wyników. Dokładniejsza analiza takich elementów wykracza jednak poza ramy niniejszej pracy. W tym miejscu, dla ukazania wielości możliwych rozwiązań, poprzestaniemy na prostym wyliczeniu wagi błędu w oparciu o liczbę możliwych motywów (nauczyciele - 3; dyrektorzy - 2). Stąd do wyliczenia średniej przyjmiemy 2/5 wyniku nauczycieli (którzy, matematycznie rzecz ujmując, mają więcej motywów do zafałszowania wyników) oraz 3/5 wyniku dyrektorów. Taki sposób uśrednienia wyników skutkuje następującymi wartościami: $69,97 \%$ odpowiedzi „stosuje” i $24,96 \%$ odpowiedzi „nie stosuje".

Uwzględniając trzy opisane możliwości uśrednienia zebranych danych, ich wyniki ujęto $\mathrm{w}$ formę wykresu 16 . Dla przejrzystości pominięto odpowiedzi „nie wiem” w ankiecie dyrektorów, która nie podlegała uśrednianiu.

Mimo pozorów większej obiektywności tak przekształconych wyników, należy pamiętać, że nie mogą być one zweryfikowane dostępnymi w tym badaniu narzędziami. Należy również pamiętać, że ewentualne motywacje dyrektorów, mogące mieć wpływ na zniekształcenie odpowiedzi na pytanie 3., mogły przyjąć odwrotny od rozpatrywanego kierunek. Za równie prawdopodobną bowiem należałoby uznać postawę dyrektorów, zmierzającą do uznania kompetencji informatycznych nauczycieli za wyższe niż w rzeczywistości, chcąc w ten sposób nakreślić jak najlepszy obraz prowadzonej przez siebie placówki. W takim wypadku obniżenie wyników odpowiedzi „tak” dyrektorów przybliżałoby je do rzeczywistości. 
Wykres 16. Różnice w opinii nauczycieli i dyrektorów na temat częstotliwości wykorzystywania TI na lekcjach muzyki - próby uśrednienia danych

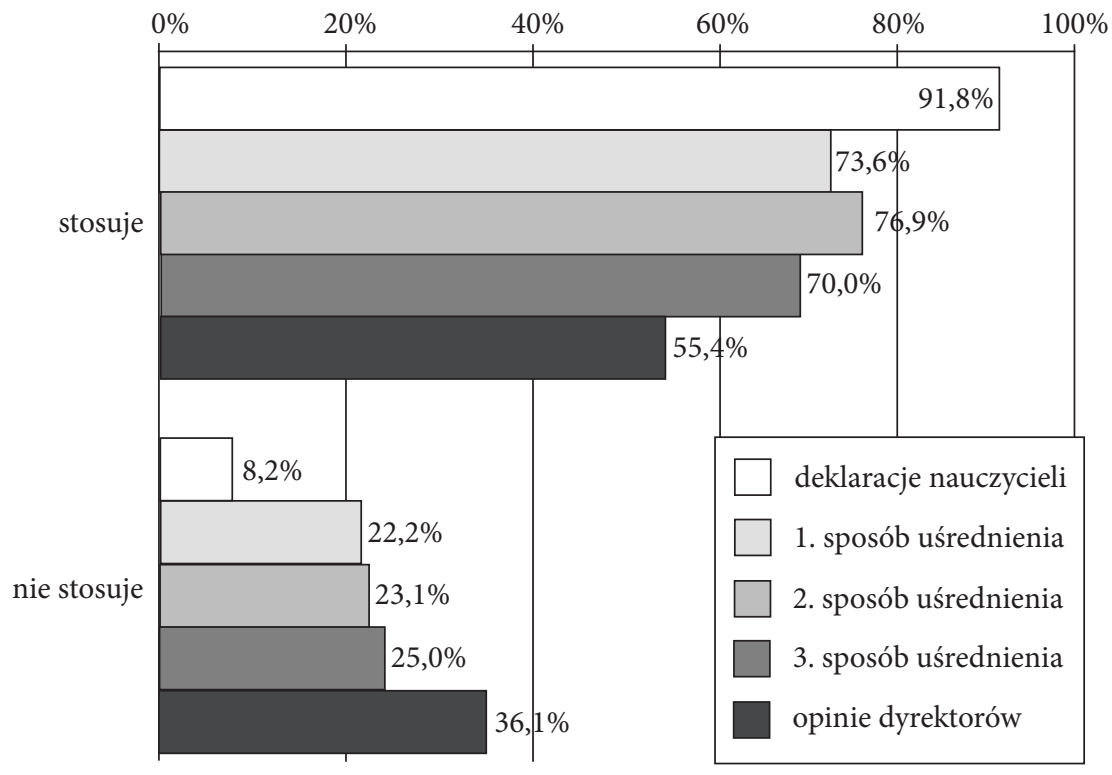

(źródło: badania własne)

Pozostaje zatem jedynie zauważyć dużą rozbieżność w odpowiedziach nauczycieli i dyrektorów na temat wykorzystywania TI przez nauczycieli muzyki oraz uznać, że przynajmniej jedna z tych wersji odbiega znacznie od rzeczywistości.

Zestawienie odpowiedzi nauczycieli na pytania 8. i 9. ujawnia pewne drobne rozbieżności. Otóż odpowiedzi 8e oraz 9a winny być równo liczebne. Tymczasem jeden $\mathrm{z}$ ankietowanych przyznał, że w ogóle nie wykorzystuje TI w przygotowaniu lub prowadzeniu zajęć (odpowiedź 9a) choć wcześniej zadeklarował jej stosowanie w „przygotowywaniu się do zajęć (odświeżanie lub pogłębianie własnej wiedzy, szukanie nowych informacji, ciekawych konspektów lekcji i in.)" - czyli odpowiedź 8a. Rozbieżność ta dotyczy 62-letniej nauczycielki mianowanej z 25-letnim stażem. Jest ona zarazem skrajnym przypadkiem w rozpatrywanej grupie, jeśli chodzi o częstotliwość wykorzystywania TI do lekcji muzyki.

Na drugim biegunie - deklarujących najczęstsze stosowanie TI - znalazło się 26 nauczycieli, czyli 30,59\% wszystkich badanych, którzy na pytanie 
8. zakreślili 4 zaproponowane odpowiedzi („a”, „b”, „c” oraz „d”) oraz odpowiedź „e" na pytanie 9. Wśród nich nie ma dominującego modelu nauczyciela - staż pracy tych 26 badanych zawiera się w przedziale od 1 roku do 26 lat, wiek: 27-53 lata, wymiar zatrudnienia: 2-23 godziny tygodniowo. Jest wśród nich 3 nauczycieli kontraktowych, 8 mianowanych i 14 dyplomowanych (porównanie parametrów tej grupy ze wszystkimi badanymi zawiera tabela 12.).

Tabela 12. Zestawienie niektórych danych 26 nauczycieli najczęściej stosujących TI z całą grupą badanych nauczycieli

\begin{tabular}{|l|c|c|c|}
\hline \multicolumn{2}{|c|}{ Parametry } & $\begin{array}{c}\text { Grupa 26 } \\
\text { wiodących } \\
\text { nauczycieli }\end{array}$ & $\begin{array}{c}\text { Wszyscy } \\
\text { badani }\end{array}$ \\
\hline \multirow{3}{*}{ Staż pracy } & średnia & 14,6 & 15,1 \\
\cline { 2 - 4 } & mediana & 14 & 16 \\
\hline \multirow{3}{*}{ Wiek } & średnia & 41,5 & 42,8 \\
\cline { 2 - 4 } & mediana & 42 & 44 \\
\hline \multirow{3}{*}{$\begin{array}{l}\text { Wymiar } \\
\text { zatrudnienia }\end{array}$} & średnia & 16,3 & 14,9 \\
\hline \multirow{3}{*}{$\begin{array}{l}\text { Stopień awansu } \\
\text { zawodowego }\end{array}$} & mediana & 18 & 18 \\
\cline { 2 - 4 } & stażyści & $0 \%$ & $2,5 \%$ \\
\cline { 2 - 4 } & kontraktowi & $11,5 \%$ & $16,25 \%$ \\
\cline { 2 - 4 } & mianowani & $30,8 \%$ & $31,25 \%$ \\
\cline { 2 - 4 } & dyplomowani & $53,8 \%$ & $50 \%$ \\
\hline
\end{tabular}

(źródło: badania własne)

Grupa najczęściej stosujących TI nauczycieli nie wyróżnia się wiekiem, stażem pracy, wymiarem zatrudnienia ani stopniem awansu zawodowego spośród wszystkich ankietowanych (chi kwadrat dla stażu, wieku i wymiaru zatrudnienia $=0,9559$; zaś dla stopnia awansu zawodowego $=0,3367)$. Nie są to zatem parametry predestynujące do zwiększonej aktywności w zakresie wykorzystywania TI. Należy również pamiętać, że odpowiedzi, na podstawie których wyodrębniono wyróżniającą się grupę nauczycieli mogą być przeszacowane, uwzględniając naturalną chęć do przedstawienia się w lepszym niż rzeczywiste świetle. Tendencja taka została już zauważona wcześniej, przy zestawianiu odpowiedzi nauczycieli i dyrektorów na podobne 
pytania oraz przy zestawianiu deklaracji nauczycieli z odpowiedziami na pytania wymagające wiedzy opartej na rzeczywistym doświadczeniu.

Pośrednio na temat częstotliwości wykorzystywania TI w pracy nauczyciela muzyki wypowiedzieli się również dyrektorzy w odpowiedziach na pytanie 5. Nie można było jednak zastosować tu kafeterii analogicznej do pytania 9. ankiety nauczycielskiej. Trudno oczekiwać bowiem od dyrektora szkoły, by potrafił określić częstotliwość stosowania TI na lekcjach prowadzonych przez wszystkich zatrudnionych w szkole nauczycieli. Z konieczności więc kafeteria ograniczona została tu do określeń mniej jednoznacznych, subiektywnych, które jednak powinny być znane każdemu dyrektorowi, jako pierwszemu recenzentowi pracy swoich podwładnych.

„5. Czy stan wykorzystania technologii komputerowej na lekcjach muzyki w Pani(a) szkole jest:
a. wystarczający;
b. przesadny;
c. zbyt mały;
d. stanowczo niedostateczny;
e. zerowy;
f. nie wiem;"

Odpowiedzi na to pytanie kształtują się następująco:

Tabela 13. Stan wykorzystania TI przez nauczycieli muzyki w opinii dyrektorów $(\mathrm{N}=82)$

\begin{tabular}{|l|c|c|}
\hline \multirow{2}{*}{\multicolumn{1}{|c|}{ Opinia }} & \multicolumn{2}{c|}{ Ilość odpowiedzi } \\
\cline { 2 - 3 } & $\mathrm{n}$ & $\%$ \\
\hline wystarczający & 31 & 37,8 \\
\hline przesadny & 1 & 1,2 \\
\hline zbyt mały & 25 & 30,5 \\
\hline stanowczo niedostateczny & 6 & 7,3 \\
\hline zerowy & 10 & 12,2 \\
\hline nie wiem & 9 & 11,0 \\
\hline
\end{tabular}

(źródło: badania własne)

Jedyna odpowiedź „b - przesadny” jest opinią o nauczycielu, który w odpowiedzi na pytanie 9., o częstość stosowania TI w przygotowywaniu lub prowadzeniu zajęć, napisał: „prawie codziennie, jestem też informatykiem”. Ma w związku z tym niemal nieograniczone możliwości korzystania z pracowni komputerowej, co potwierdził w odpowiedzi na pytanie 12 . 
Zaplanowanie takiej kafeterii, uwzględniającej opcję „przesadnego” wykorzystywania TI na lekcjach muzyki, miało na celu zidentyfikowanie przypadków, kiedy ewentualne zbyt małe kompetencje informatyczne dyrektora znajdują rodzaj kompensacji, czy usprawiedliwienia w negatywnie zabarwionej ocenie znacznie wyższych kompetencji informatycznych nauczyciela muzyki. W tym przypadku jednak mamy do czynienia z sytuacją wyjątkową, w której nauczyciel muzyki posiada znacznie wyższe od przeciętnych kompetencje informatyczne oraz niemal nieograniczone możliwości korzystania z pracowni komputerowej na użytek lekcji muzyki. Odpowiedź „przesadny” może więc w tym przypadku znaczyć tyle, co „znacznie wyższy od wystarczającego" i mieć zabarwienie zdecydowanie pozytywne. Ponieważ jednak żadne dokumenty przytoczone w rozdziale 2.4 . nie przewidują maksymalnego poziomu kompetencji informatycznych, ponad którym należałoby uznać je za przesadne, tą jedną, wyjątkową odpowiedź dyrektora zasadne będzie rozumieć, jako należącą do kategorii „wystarczające”.

Zatem 32 dyrektorów (39,0\%) ocenia stan wykorzystania TI przez nauczycieli muzyki jako wystarczający, zaś 41 (50,0\%) - jako zbyt mały, stanowczo niedostateczny lub wręcz zerowy. Taka ocena dyrektorów prowokuje oczywiście do zestawienia z deklaracjami nauczycieli na ten sam temat, zawartymi w odpowiedziach na pytanie 9. Dla większej wiarygodności porównania zrezygnowano z trzech przypadków odpowiedzi nauczycieli, których dyrektorzy nie podzielili się swoją opinią. W ten sposób skompletowano 82 pary nauczyciel-dyrektor, których odpowiedzi przedstawiono w tabeli 14a.

Połączenie dwóch kategorii odpowiedzi dyrektorów: „wystarczający” i „przesadny”, wytłumaczono dwa akapity wyżej. Połączenie zaś kategorii: „kilka razy w ciągu roku szkolnego” oraz „częściej” w odpowiedziach nauczycieli, wynika z subiektywnej oceny autora, uznającej taką właśnie częstotliwość za wystarczającą. Widać natomiast z powyższego zestawienia, że prawdopodobnie dyrektorzy subiektywnie uznają za stan „wystarczający” częstotliwość większą niż „kilka razy w ciągu roku szkolnego”. Po uwzględnieniu takiego punktu widzenia, przeszeregowano odpowiedź nauczycieli „kilka razy w ciągu roku szkolnego” na poziom „zbyt mały” według dyrektorów oraz analogicznie odpowiedź nauczycieli „1-2 razy w ciągu roku szkolnego” na poziom odpowiadający opinii dyrektorów „stanowczo niedostateczny". 
Tabela 14a. Porównanie opinii dyrektorów i deklaracji nauczycieli na temat częstości wykorzystania TI na lekcjach muzyki $(\mathrm{N}=82)$ - wg kryteriów autora

\begin{tabular}{|c|c|c|c|c|c|}
\hline \multirow{2}{*}{$\begin{array}{l}\text { Opinie } \\
\text { dyrektorów } \\
\text { (pytanie 5.) }\end{array}$} & \multicolumn{2}{|c|}{$\begin{array}{c}\text { Ilość } \\
\text { odpowiedzi } \\
\text { (dyrektorzy) }\end{array}$} & \multicolumn{2}{|c|}{$\begin{array}{c}\text { Ilość } \\
\text { odpowiedzi } \\
\text { (nauczyciele) }\end{array}$} & \multirow[t]{2}{*}{$\begin{array}{l}\text { Deklaracje nauczycieli } \\
\text { (pytanie 9.) }\end{array}$} \\
\hline & $\mathrm{n}$ & $\%$ & $\mathrm{n}$ & $\%$ & \\
\hline $\begin{array}{c}\text { „wystarczający” } \\
\text { lub } \\
\text { „przesadny” }\end{array}$ & $\begin{array}{c}32 \\
(31+1)\end{array}$ & 39 & $\begin{array}{c}75 \\
(36+39)\end{array}$ & 91,5 & $\begin{array}{c}\text { „kilka razy w ciągu roku szkolnego” } \\
\text { lub } \\
\text { „częściej” }\end{array}$ \\
\hline „zbyt mały” & 25 & 30,5 & 5 & 6,1 & „1-2 razy w ciągu roku szkolnego” \\
\hline $\begin{array}{l}\text { "stanowczo } \\
\text { niedostateczny” }\end{array}$ & 6 & 7,3 & 1 & 1,2 & $\begin{array}{c}\text { „zdarzyło mi się raz lub dwa w całej } \\
\text { mojej pracy nauczycielskiej” }\end{array}$ \\
\hline „zerowy” & 10 & 12,2 & 1 & 1,2 & „w ogóle nie wykorzystuję” \\
\hline „nie wiem” & 9 & 11,0 & & & \\
\hline
\end{tabular}

(źródło: badania własne)

Dylemat może dotyczyć tylko odpowiedzi nauczycieli „zdarzyło mi się raz lub dwa w całej mojej pracy nauczycielskiej”. Analogiczne do poprzednich zaliczenie takiej odpowiedzi do niższej kategorii opinii dyrektorów „zerowy”, może budzić sprzeciw wobec ostrości sformułowania. „Raz lub dwa” ewidentnie nie jest równe „zeru”. Jednak określenie „zerowy” nie funkcjonuje tu jako pojęcie matematyczne, a raczej jako przymiotnik opisujący stan wykorzystania TI przez nauczyciela, jako „bliski zera”, „praktycznie zerowy”, „niezauważalny”. Takie rozumienie kategorii „zerowy” pozwala na rozciągnięcie operacji obniżania rangi deklaracji nauczycieli na wszystkie ich przedziały.

Zestawienie danych po takiej operacji przedstawia tabela $14 \mathrm{~b}$.

Większa przystawalność takich wyników świadczy o dobrym kierunku korekty i lepszym zrozumieniu intencji dyrektorów. Mimo wszystko, różnice deklaracji nauczycieli oraz opinii dyrektorów są znaczące tak pod względem wartości jak i kierunku. 
Tabela 14b. Porównanie opinii dyrektorów i deklaracji nauczycieli na temat częstości wykorzystania TI na lekcjach muzyki $(\mathrm{N}=82)$ - wg kryteriów dyrektorów

\begin{tabular}{|c|c|c|c|c|c|}
\hline \multirow{2}{*}{$\begin{array}{c}\text { Opinie } \\
\text { dyrektorów } \\
\text { (pytanie 5.) }\end{array}$} & \multicolumn{2}{|c|}{$\begin{array}{c}\text { Ilość } \\
\text { odpowiedzi } \\
\text { (dyrektorzy) }\end{array}$} & \multicolumn{2}{|c|}{$\begin{array}{c}\text { Ilość } \\
\text { odpowiedzi } \\
\text { (nauczyciele) } \\
\end{array}$} & \multirow[t]{2}{*}{$\begin{array}{c}\text { Deklaracje nauczycieli } \\
\text { (pytanie 9.) }\end{array}$} \\
\hline & $\mathrm{n}$ & $\%$ & $\mathrm{n}$ & $\%$ & \\
\hline $\begin{array}{c}\text { „wystarczający” } \\
\text { lub } \\
\text { „przesadny” }\end{array}$ & $\begin{array}{c}32 \\
(31+1)\end{array}$ & 39 & 39 & 47,6 & „częściej” \\
\hline „zbyt mały" & 25 & 30,5 & 36 & 43,9 & „kilka razy w ciągu roku szkolnego" \\
\hline $\begin{array}{c}\text { „stanowczo } \\
\text { niedostateczny” }\end{array}$ & 6 & 7,3 & 5 & 6,1 & „1-2 razy w ciągu roku szkolnego” \\
\hline „zerowy” & 10 & 12,2 & $\begin{array}{c}2 \\
(1+1)\end{array}$ & 2,4 & $\begin{array}{c}\text { „zdarzyło mi się raz lub dwa w całej } \\
\text { mojej pracy nauczycielskiej” } \\
\text { lub } \\
\text { „w ogóle nie wykorzystuję" }\end{array}$ \\
\hline „nie wiem” & 9 & 11,0 & & & \\
\hline
\end{tabular}

(źródło: badania własne)

Wykres 17. przedstawia wartości różnic: odpowiedzi nauczycieli minus odpowiedzi dyrektorów z tabeli $14 b$.

Wykres 17. Rozmiar oraz kierunek rozbieżności deklaracji nauczycieli i opinii dyrektorów na temat częstości wykorzystania TI na lekcjach muzyki $(\mathrm{N}=82)$

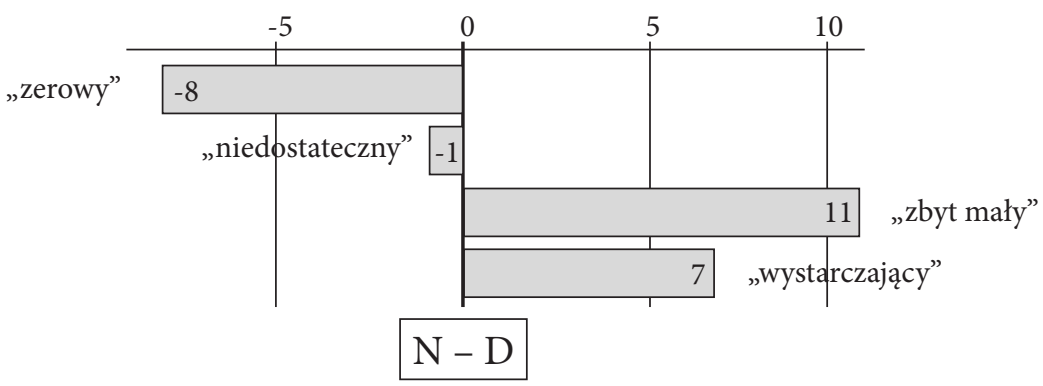

(źródło: badania własne)

Poza opinią dyrektorów „zbyt mały”, skojarzoną tu z deklaracją nauczycieli „kilka razy w ciągu roku szkolnego”, pozostałe wyniki świadczą, że nauczyciele mają o sobie lepsze zdanie niż wskazują opinie dyrektorów. 
Największa rozbieżność, dotycząca kategorii „zbyt mały”, może być rozpatrywana zarówno od strony ilościowej jak i jakościowej. Pierwszy aspekt kazałby uznać, że jedenastu nauczycieli udzieliło odpowiedzi odbiegających od opinii dyrektorów. Drugi aspekt każe zastanowić się nad odmiennym rozumieniem przez obie grupy kategorii „wystarczającego” i „zbyt małego” stanu wykorzystania TI w dydaktyce muzyki. Mimo uprzednio dokonanej korekty „kalibracji” wyników, prawdopodobne jest, że granica między wystarczającym a zbyt małym stanem wykorzystania TI rozumiana jest inaczej w obydwu grupach. Rozbieżność ta może być spowodowana nie tylko odmiennymi standardami, ale także innym punktem odniesienia. Lekcje muzyki są bowiem najmniej licznymi zajęciami w szkole podstawowej. Dyrektor polonista lub matematyk może postrzegać deklarację „kilka razy w ciągu roku szkolnego" przez pryzmat rozmiaru godzinowego własnego przedmiotu, stąd jego ocena takiej częstotliwości różnić się będzie znacznie od oceny nauczyciela muzyki. Mimo więc dołożenia wszelkich starań, nie możemy w sposób obiektywny rozpatrywać różnic wyników tabeli 14b. oraz wykresu 17.

Wyjątek stanowić tu może jedynie kategoria dotycząca opinii dyrektorów o zerowym stanie wykorzystania TI przez nauczycieli muzyki, a w deklaracjach nauczycieli ujęta jako połączenie odpowiedzi „zdarzyło mi się raz lub dwa w całej mojej pracy nauczycielskiej” oraz „w ogóle nie wykorzystuję". Ta dosyć duża rozbieżność (8 odpowiedzi - niemal 10 punktów procentowych) pozwala na obiektywny wniosek: blisko $10 \%$ ankietowanych nauczycieli nie przyznało się do unikania narzędzi informatycznych.

\section{Sprzęt}

Możliwość skorzystania ze sprzętu komputerowego jest podstawowym czynnikiem warunkującym wykorzystywanie TI w dydaktyce. W przypadku zajęć muzycznych wymagania takie są wyjątkowe. Oprócz bowiem warstwy wizualnej, dominującej w przekazie sporządzanym na użytek każdego innego przedmiotu szkolnego, nadrzędną z założenia jest tu warstwa dźwiękowa. Niezbędne zatem, oprócz samego komputera oraz ewentualnego rzutnika multimedialnego, są: wzmacniacz audio oraz kolumny głośnikowe. Te elementy sprzętowe nie zostały jednak ujęte w pytaniach ankiety z uwagi na ich powszechną obecność na zajęciach muzycznych sprzed „ery komputerów”. Możliwość połączenia komputera ze sprzętem audiofonicznym uznajemy tu zatem za warunek niezbędny ale i powszechny. 
Wobec takich założeń, możliwości skorzystania ze sprzętu komputerowego w odniesieniu do badanej grupy możemy przeanalizować w oparciu o odpowiedzi na pytania 11. i 12. ankiety nauczycielskiej oraz pytanie 6 . ankiety dyrektorskiej.

Rozpatrywane pytania skierowane do nauczycieli brzmiały:

„11. Czy ma Pan/i możliwość wykorzystania sprzętu komputerowego na lekcji muzyki (jaki: laptop, rzutnik multimedialny, zestaw komputerowy, inny.......................)?

a. zawsze, gdy zgłoszę taką potrzebę;

b. czasami, gdy akurat sprzęt nie jest zajęty przez innego nauczyciela;

c. nie mam takiej możliwości;

d. nie wiem".

„12. Czy ma Pan/i możliwość przeprowadzenia lekcji muzyki w pracowni komputerowej?

a. zawsze, gdy zgłoszę taką potrzebę;

b. czasami, jeśli akurat pracownia komputerowa jest wolna;

c. tylko gdy informatyk jest na zwolnieniu;

d. nie mam takiej możliwości;

e. nie wiem".

Odpowiedzi na te pytania przedstawiają kolejne tabele:

Tabela 15. Dostępność sprzętu komputerowego na lekcjach muzyki według opinii nauczycieli $(\mathrm{N}=85)$

\begin{tabular}{|c|c|c|c|}
\hline $\begin{array}{c}\text { Odpowiedź „a” } \\
\text { (zawsze) }\end{array}$ & $\begin{array}{c}\text { Odpowiedź „b” } \\
\text { (czasami) }\end{array}$ & $\begin{array}{c}\text { Odpowiedź „,c” } \\
\text { (brak) }\end{array}$ & $\begin{array}{c}\text { Odpowiedź „d” } \\
\text { (nie wiem) }\end{array}$ \\
\hline 49 & 27 & 5 & 4 \\
$(57,65 \%)$ & $(31,76 \%)$ & $(5,88 \%)$ & $(4,71 \%)$ \\
\hline
\end{tabular}

(źródło: badania własne)

Tabela 16. Dostępność pracowni komputerowej do lekcji muzyki według opinii nauczycieli $(\mathrm{N}=85)$

\begin{tabular}{|c|c|c|c|c|}
\hline $\begin{array}{c}\text { Odpowiedź „a” } \\
\text { (zawsze) }\end{array}$ & $\begin{array}{c}\text { Odpowiedź „b” } \\
\text { (czasami) }\end{array}$ & $\begin{array}{c}\text { Odpowiedź „,c” } \\
\text { (incydentalnie) }\end{array}$ & $\begin{array}{c}\text { Odpowiedź „d” } \\
\text { (brak) }\end{array}$ & $\begin{array}{c}\text { Odpowiedź „e” } \\
\text { (nie wiem) }\end{array}$ \\
\hline 35 & 33 & 1 & 8 & 8 \\
$(41,18 \%)$ & $(38,82 \%)$ & $(1,18 \%)$ & $(9,41 \%)$ & $(9,41 \%)$ \\
\hline
\end{tabular}

(źródło: badania własne) 
Analogiczne pytanie skierowane do dyrektorów brzmiało:

„6. Nauczyciel muzyki w Pani(a) szkole ma możliwość wykorzystania do własnych zajęć:

a. pracowni komputerowej;

b. pojedynczego komputera i rzutnika multimedialnego we własnej pracowni;

c. pojedynczego komputera i rzutnika multimedialnego w innej pracowni;

d. przenośnego szkolnego zestawu komputerowego (laptop i rzutnik multimedialny) - po uzgodnieniu terminu;

e. nie ma żadnych z powyższych możliwości”.

Odpowiedzi na to pytanie udzieliło 82 dyrektorów. Rozkład odpowiedzi wygląda następująco:

Tabela 17. Dostępność sprzętu komputerowego na lekcjach muzyki według opinii dyrektorów $(\mathrm{N}=82)$

\begin{tabular}{|c|c|c|c|c|}
\hline $\begin{array}{c}\text { Odpowiedź „,a” } \\
\text { (pracownia } \\
\text { komputerowa) }\end{array}$ & $\begin{array}{c}\text { Odpowiedź „b” } \\
\text { (komputer } \\
\text { w pracowni } \\
\text { muzycznej) }\end{array}$ & $\begin{array}{c}\text { Odpowiedź „c” } \\
\text { (komputer } \\
\text { w innej } \\
\text { pracowni) }\end{array}$ & $\begin{array}{c}\text { Odpowiedź „d” } \\
\text { (komputer prze- } \\
\text { nośny) }\end{array}$ & $\begin{array}{c}\text { Odpowiedź „e” } \\
\text { (brak } \\
\text { dostępności) }\end{array}$ \\
\hline 61 & $\begin{array}{c}23 \\
(74,39 \%)\end{array}$ & $\begin{array}{c}27 \\
(32,93 \%)\end{array}$ & $\begin{array}{c}50 \\
(60,98 \%)\end{array}$ & $\begin{array}{c}2 \\
(2,44 \%)\end{array}$ \\
\hline
\end{tabular}

(źródło: badania własne)

Z powyższej tabeli wynika, że tylko dwoje nauczycieli (według wiedzy dyrektorów) nie ma możliwości skorzystania ze sprzętu komputerowego do prowadzenia zajęć. Skoro więc możliwości wynikające z kompetencji wykluczają 9 nauczycieli (odpowiedź „d” na pytanie 2. ankiety dyrektorów), a wynikające $\mathrm{z}$ dostępności sprzętu komputerowego w szkole - tylko 2, pozostaje w dalszym ciągu co najmniej 19 nauczycieli (w przypadku rozdzielności obu wykluczających zbiorów), którzy według dyrektorów posiadają zarówno kompetencje informatyczne jak i dostęp do sprzętu komputerowego a mimo wszystko nie wykorzystują tego potencjału na prowadzonych przez siebie lekcjach. Zgodnie bowiem z odpowiedziami na pytanie 3. ankiety dyrektorów, aż 30 nauczycieli muzyki nie wykorzystuje TI do swoich zajęć.

Jednocześnie stwierdzamy na podstawie odpowiedzi nauczycieli na pytania 11. i 12., że 8 nauczycieli nie ma możliwości skorzystania z pracowni komputerowej a 5 nie ma możliwości skorzystania w ogóle ze sprzętu kom- 
puterowego na lekcji muzyki. Tych 5 nauczycieli, pozostających bez możliwości skorzystania z jakiegokolwiek sprzętu komputerowego w szkole, wobec tylko dwóch takich przypadków stwierdzonych przez dyrektorów, sugeruje brak świadomości 3 dyrektorów o fakcie niedostępności sprzętu komputerowego w ich szkole. Jeden przypadek incydentalnej możliwości skorzystania z pracowni komputerowej należy doliczyć do powyższej liczby przypadków, wobec niemożliwości zaplanowanego - a więc celowego - jej wykorzystania, co zwiększa omawianą grupę nauczycieli do poziomu $10,6 \%$. Suma obydwu zbiorów nauczycieli, wobec przypadków powtarzających się, wynosi 10, czyli 11,8\% wszystkich ankietowanych.

Zauważalna i naturalna jest dodatnia korelacja dostępności szkolnego sprzętu komputerowego z częstotliwością wykorzystywania TI przez nauczycieli - współczynnik korelacji Pearsona równy 0,43 przy założonym poziomie istotności $\mathrm{p}=0,05$.

Wykres 18. Brak dostępności sprzętu komputerowego na lekcjach muzyki - zestawienie odpowiedzi nauczycieli oraz dyrektorów

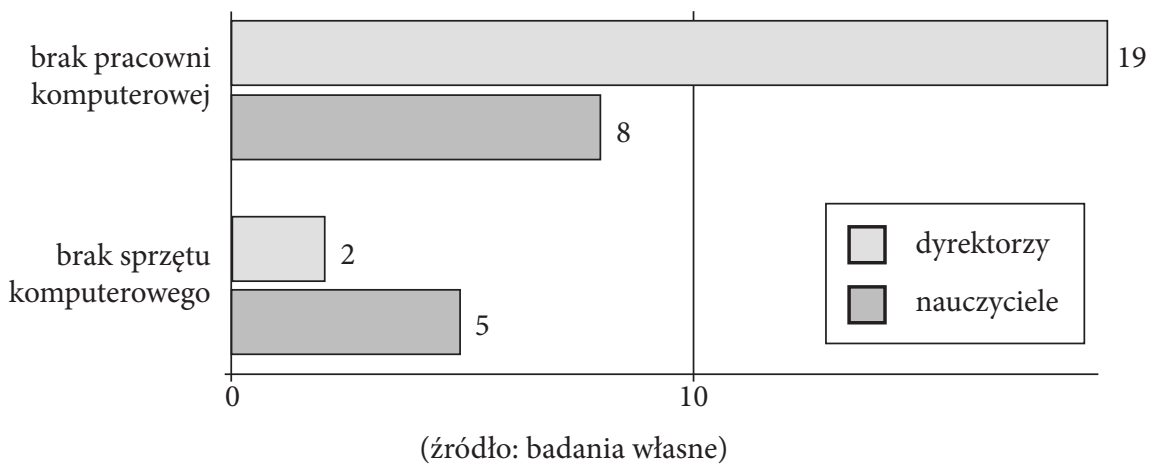

Natomiast 7 nauczycieli więcej niż myślą dyrektorzy (odp. 12a+12b nauczycieli -6a dyrektorów) ma możliwość przeprowadzenia lekcji muzyki w pracowni komputerowej, zaś 13 nauczycieli więcej niż sądzą dyrektorzy ma możliwość skorzystania na lekcji ze szkolnego sprzętu komputerowego. Z przeciwnych wartości rozbieżności dotyczących dostępności pracowni komputerowej wynika wniosek, że żadna z grup (nauczyciele i dyrektorzy) prawdopodobnie nie zamierzała zniekształcić wyników ankiet tak, by zatuszować ewentualny własny brak zainteresowania problemem wykorzystywania sprzętu komputerowego na lekcjach muzyki. 
Wykres 19. Dostępność sprzętu komputerowego na lekcjach muzyki - zestawienie odpowiedzi nauczycieli oraz dyrektorów

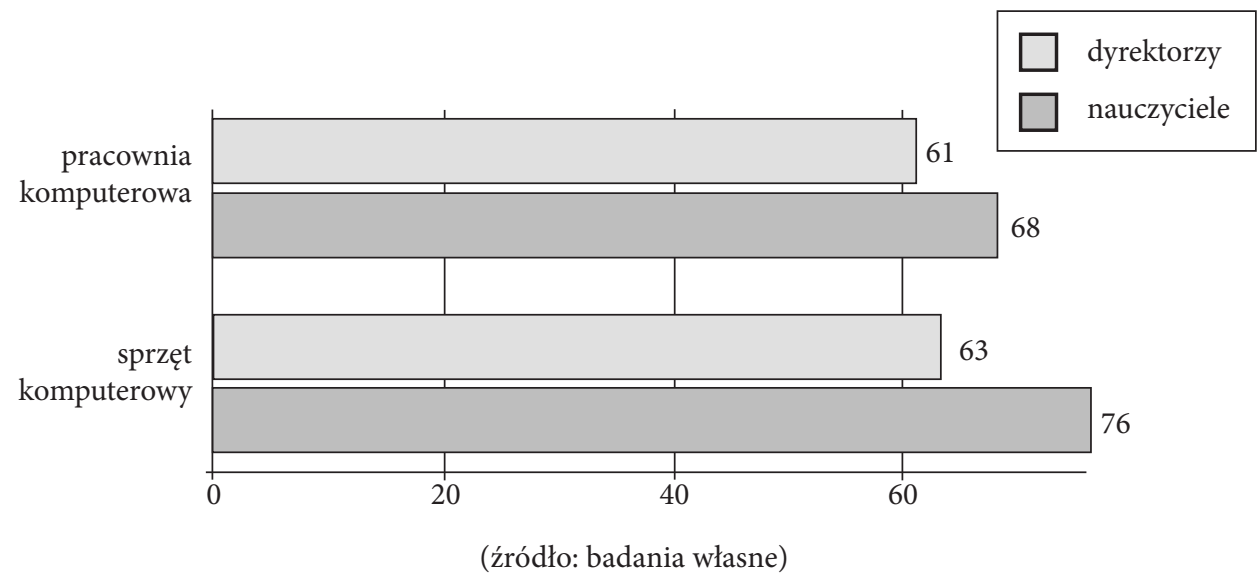

Opinie nauczycieli na temat dostępności sprzętu komputerowego oraz pracowni komputerowej na użytek lekcji muzyki w swoim optymizmie przewyższają nawet deklaracje dyrektorów. Aż 76 z badanych nauczycieli $(89,4 \%)$ twierdzi, że zawsze lub czasami ma dostęp do sprzętu komputerowego, a $68 \mathrm{z}$ nich (80\%) zawsze lub czasami może skorzystać z pracowni komputerowej9. Powszechność dostępności sprzętu komputerowego nie stanowi zatem znaczącej bariery w jego zastosowaniach na lekcjach muzyki.

Niezaprzeczalnym jest natomiast fakt, że w 10 przypadkach problem ten nie był nigdy rozpatrywany między nauczycielem a dyrektorem (suma odpowiedzi „nie wiem” na pytania 11. i 12. ankiety nauczycieli, pomniejszona o dwa przypadki nauczycieli, którzy w obydwu odpowiedziach zakreślili „nie wiem”).

\subsubsection{Przyczyny niedostatecznego wykorzystania TIK w opiniach badanych nauczycieli}

Drugi problem badawczy sprowadza się do pytania: jakie są - w opiniach badanych nauczycieli - przyczyny spodziewanego niedostatecznego wykorzystania TIK? Aby poznać przyczyny zbyt małego udziału narzędzi

\footnotetext{
${ }^{9}$ Badania przeprowadzone przez B. Siemienieckiego przytaczają zbliżone wyniki: $74,01 \%$ badanych nauczycieli może (zawsze lub czasami) skorzystać z pracowni internetowej, ale zaskakująco 79,02\% z tej możliwości nie korzysta, podając za przyczynę przede wszystkim niedostępność pracowni (69,96\% odpowiedzi) (sic!). [Za:] B. Siemieniecki, Technologia informacyjna w polskiej szkole. Stan i zadania, Toruń 2002, s. 119, 142-143.
} 
informatycznych w warsztacie dydaktycznym badanej grupy nauczycieli niezbędnym jest określenie poziomu wystarczającego, obowiązujących norm, do których można odnieść poziom faktyczny, zrekonstruowany na podstawie badań. Takie porównanie jest treścią następnego rozdziału (4.2.) niniejszej pracy. W tym miejscu natomiast punktem odniesienia jest opinia badanych nauczycieli, ich subiektywne rozumienie „poziomu dostatecznego" i w tym kontekście identyfikacja barier i ograniczeń, które nie pozwalają na pełniejsze wykorzystanie TI w dydaktyce muzyki. Rozumienie zatem samych ograniczeń również nosi znamiona subiektywizmu, nie wiemy bowiem, czy deklarowane bariery nie są jedynie próbą usprawiedliwienia własnej bezczynności, czy nauczyciele podejmowali bezskuteczne próby przezwyciężenia owych barier oraz czy nie są one jedynie wynikiem braku kompetencji informatycznych, uniemożliwiającego dostrzeżenie czasem prostych rozwiązań, omijających potencjalne bariery natury organizacyjnej, sprzętowej czy innej.

Przyjmując takie założenia, do przybliżenia subiektywnego rozumienia wystarczającego poziomu wykorzystania TI do lekcji muzyki posłużą odpowiedzi nauczycieli na pytania ${ }^{10}$ :

- 14. - zdradzające ewentualny brak zachęty dyrekcji do pogłębienia kompetencji informatycznych nauczyciela;

- 15. - deklarujące ewentualny brak wykorzystywania TI wynikający z braku zainteresowania nią, co może być wnioskiem z deklaracji o zerowym lub minimalnym wykorzystywaniu TI w warunkach domowych;

- 22. - zdradzające ewentualny niski lub wręcz zerowy (w świadomości badanych) poziom wymaganych od nauczyciela muzyki kompetencji informatycznych;

- 23. - ujawniające możliwy negatywny stosunek do przydatności kompetencji informatycznych w lekcji muzyki;

- 24. - dotyczące świadomości wymagań w zakresie kompetencji informatycznych w stosunku do nauczycieli przedmiotów nieinformatycznych;

- 25. - które mogą być próbą tłumaczenia braku stosowania TI brakiem takich sugestii w podręczniku lub programie nauczania, utożsamianych $\mathrm{z}$ wymaganiami wobec nauczycieli.

${ }^{10}$ Treść wszystkich pytań ankiety zamieszczona została zamieszczona w Aneksie - Wzór ankiety dla nauczycieli. 
Same bariery w wykorzystywaniu TI, w subiektywny sposób nauczyciele mają okazję zasygnalizować w odpowiedziach na pytania:

- 11. i 12. - dotyczące dostępności sprzętu komputerowego w szkole;

- 13. - zdradzające ewentualny zbyt mały poziom kompetencji informatycznych nauczyciela jako skutek braku odpowiednich szkoleń;

- 18., 19. i 20. - ujawniające ewentualną nieznajomość przydatnego w dydaktyce muzyki oprogramowania.

Ponadto w zidentyfikowaniu obu problemów pomocne będą odpowiedzi na pytanie 26. - otwarte, zachęcające do refleksji na temat możliwych zastosowań TI w dydaktyce muzyki. Odpowiedzi te, mimo iż nieliczne, mogą zdradzać zarówno stosunek badanych nauczycieli do konieczności wykorzystywania TI, jak i ujawniać bariery, na jakie autorzy odpowiedzi natrafiają w swojej praktyce pedagogicznej. Te same walory posiadają - mimo że jeszcze mniej liczne - przemyślenia ankietowanych sformułowane na zakończenie ankiety, dotyczące problematyki wykorzystywania TI w dydaktyce muzyki, która nie została poruszona w 26 wcześniejszych pytaniach.

W tym miejscu zasadne będzie również odesłanie do analizy wywiadów przeprowadzonych z wybranymi nauczycielami, choć wnioski z tych analiz, opisujących jednostkowe przypadki, rozpatrywać można również tylko jednostkowo, bez odniesień ilościowych do całej grupy badanych nauczycieli.

Próbę określenia więc subiektywnego poczucia „odpowiedniego poziomu” kompetencji informatycznych nauczyciela muzyki zaczniemy od odpowiedzi na pytanie 24 . ankiety skierowanej do nauczycieli, bezpośrednio weryfikującej świadomość konieczności posiadania kompetencji informatycznych:

„24. Czy sądzi Pan/i, że Podstawa programowa czy Standardy kształcenia nauczycieli określają kompetencje informatyczne nauczyciela jako:

a. niezbędny składnik warsztatu pracy;

b. pomocne ale nie konieczne;

c. w/w dokumenty nie dotyczą kompetencji informatycznych nauczyciela;

d. nie wiem".

Podstawa programowa kształcenia ogólnego dla szkót podstawowych i gimnazjów ${ }^{11}$ nie formułuje kategorycznego warunku wykorzystywania TI na zajęciach muzycznych, poprzestając na zaleceniach korzystania przez

\footnotetext{
${ }^{11}$ Rozporządzenie Ministra Edukacji Narodowej z dnia 23 grudnia 2008 r., op. cit.
} 
uczniów z multimedialnych źródeł informacji ${ }^{12}$. Dla tego dokumentu zatem odpowiedź „,b” jest wystarczająca.

Standardy kształcenia nauczycieli... ${ }^{13}$ niezależnie od ich wersji, już w kategoryczny sposób każą wyposażyć nauczyciela (w tym nauczyciela muzyki) w kompetencje informatyczne. W odniesieniu więc do tego dokumentu właściwą odpowiedzią jest punkt „a”. Należy zatem przyjąć, że zaznaczenie przez ankietowanego odpowiedzi „c lub „d” oznacza brak świadomości, że kompetencje informatyczne są ważnym składnikiem warsztatu pracy nauczyciela muzyki. Poniższa tabela przedstawia rozkład odpowiedzi udzielonych na to pytanie.

Tabela 18. Świadomość wymagań konieczności posiadania kompetencji informatycznych przez nauczycieli $(\mathrm{N}=85)$

\begin{tabular}{|c|c|c|c|c|}
\hline $\begin{array}{c}\text { Odpowiedź „a” } \\
\text { (niezbędny } \\
\text { składnik warszta- } \\
\text { tu pracy) }\end{array}$ & $\begin{array}{c}\text { Odpowiedź „b” } \\
\text { (pomocne ale nie } \\
\text { konieczne) }\end{array}$ & $\begin{array}{c}\text { Odpowiedź „,c” } \\
\text { (w/w dokumenty } \\
\text { nie dotyczą kompe- } \\
\text { tencji informatycz- } \\
\text { nych nauczyciela) }\end{array}$ & $\begin{array}{c}\text { Odpowiedź „d” } \\
\text { (nie wiem) }\end{array}$ & $\begin{array}{c}\text { Brak } \\
\text { odpowiedzi }\end{array}$ \\
\hline $33(38,8 \%)$ & $29(34,1 \%)$ & $8(9,4 \%)$ & $13(15,3 \%)$ & $5(5,9 \%)$ \\
\hline
\end{tabular}

(źródło: badania własne)

Uznając brak odpowiedzi za brak wiedzy na ten temat, 26 nauczycieli należy zakwalifikować do grupy tych, którzy nie mają świadomości konieczności posiadania kompetencji informatycznych, zatem ewentualny niedostateczny stopień wykorzystywania TI na lekcjach muzyki w ich przypadku wynika z samej nieświadomości takiej potrzeby i nie jest przez nich samych interpretowana jako niesprostanie wymaganiom czy brak niezbędnych kompetencji. W przypadku 26 nauczycieli więc, przyczyną niedostatecznego wykorzystywania TI może być brak świadomości na temat wskazanego, zalecanego poziomu jej wykorzystania. „Może” - ponieważ z tej grupy należy wykluczyć tych nauczycieli, którzy mimo braku świadomości na temat zawartości przytoczonych dokumentów, wykorzystują TI w przygotowaniu lub prowadzeniu lekcji muzyki, kierując się własnymi preferencjami, nie popartymi urzędowymi dokumentami. Do tej grupy należy zaliczyć respondentów, którzy deklarują wykorzystywanie TI co najmniej kilka razy w ciągu roku szkolnego (odpowiedzi „d” i „e” na pytanie 9.) oraz znają nazwy przynajmniej kilku programów z kategorii zaproponowanych w pytaniach

\footnotetext{
12 Por.: rozdział 2.4.5.

${ }^{13}$ Dokumenty dotyczące standardów kształcenia nauczycieli omówiono w rozdziale 2.4.2.
} 
10. lub 18.-20. Takich respondentów, stosujących TI w dydaktyce muzyki bez świadomości, że robią tak zgodnie $\mathrm{z}$ wymaganiami stawianymi przed nimi, jest 14. Po wykluczeniu ich z wyłonionych wcześniej 26 nauczycieli, pozostała 12-osobowa grupa, która nie wykorzystuje w swojej pracy TI, nie wiedząc, że taki obowiązek formułują Standardy kształcenia nauczycieli..., a Podstawa programowa kształcenia ogólnego takie rozwiązania zaleca. Taki brak świadomości może więc być przyczyną niedostatecznego wykorzystywania TI do lekcji muzyki w przypadku 12 badanych nauczycieli.

Kolejną przesłanką do określenia „wystarczającego poziomu” wykorzystania TI w świadomości badanych nauczycieli jest odpowiedź na pytanie 23., mogąca ujawnić traktowanie TI jako niemające znaczenia (odpowiedź „f”) lub wręcz utrudnienie dla uczniów (odpowiedź „h”). Pytanie to brzmi: „23. Posługiwanie się komputerem na lekcjach muzyki jest według Pana/i:

a. koniecznością dla nauczyciela;

b. koniecznością dla uczniów;

c. pomocne dla nauczyciela;

d. pomocne dla uczniów;

e. bez znaczenia dla nauczyciela;

f. bez znaczenia dla uczniów;

g. utrudnieniem dla nauczyciela;

h. utrudnieniem dla uczniów".

Odpowiedź „f” wybrało 4 nauczycieli (ci sami wybrali również odpowiedź „e") natomiast odpowiedź „h” nie została zaznaczona ani razu. Za przyczynę niedostatecznego wykorzystania TI w tych czterech przypadkach możemy więc uznać ocenę takich działań, jako bez znaczenia dla uczniów, czyli nie przynoszące żadnych pozytywnych efektów. Taka przesłanka bezpośrednio, w sposób ujemny, wpływa na rozumienie przez badanych „dostatecznego poziomu” wykorzystania TI. Spośród tak wyłonionych czterech nauczycieli, jeden z nich należy do grupy wyłonionej wcześniej, na podstawie kryterium odpowiedzi na pytanie 24 .

Pytanie 22. pozwala określić, czy nauczyciele mają świadomość konieczności posiadania kompetencji informatycznych.

„22. Kompetencje informatyczne w pracy nauczyciela muzyki są według Pana/i:
a. niezbędne;
b. wskazane;
c. bez znaczenia”. 
Konieczność posiadania kompetencji informatycznych przez nauczyciela wynika $z$ dokumentów opisywanych w rozdziale 2.4., szczególnie zaś z warunków uzyskiwania awansu zawodowego nauczycieli ${ }^{14}$, jako bezpośrednio i szczegółowo formułujących wymagania wobec nauczycieli na każdym stopniu awansu. Dokument ten określa kompetencje informatyczne nauczycieli przedmiotów nieinformatycznych jako niezbędne ${ }^{15}$. Taką odpowiedź na pytanie 22. zaznaczyło 24 ankietowanych. Wszystkie odpowiedzi na to pytanie ujęto w poniższej tabeli:

Tabela 19. Opinie nauczycieli o przydatności kompetencji informatycznych w pracy nauczyciela muzyki $(\mathrm{N}=85)$

\begin{tabular}{|c|c|c|}
\hline $\begin{array}{c}\text { Odpowiedź „a” } \\
\text { (niezbędne) }\end{array}$ & $\begin{array}{c}\text { Odpowiedź „b” } \\
\text { (wskazane) }^{*}\end{array}$ & $\begin{array}{c}\text { Odpowiedź „c” } \\
\text { (bez znaczenia) }\end{array}$ \\
\hline $24(28,2 \%)$ & $57(67,1 \%)$ & $4(4,7 \%)$ \\
\hline
\end{tabular}

* troje nauczycieli, którzy zaznaczyli po dwie odpowiedzi: „a” i „b”, zaliczono do pierwszej grupy (odpowiedź „a”)

(źródło: badania własne)

Zatem aż 61 badanych nauczycieli nie zdaje sobie sprawy z konieczności posiadania kompetencji informatycznych, uważając je jedynie za wskazane lub bez znaczenia. W przypadku tych nauczycieli zatem, ewentualny niewystarczający poziom wykorzystania TI wynika z niewiedzy na temat wymagań stawianych nauczycielom lub dokładniej - rozbieżności wymagań oraz opinii nauczycieli na temat przydatności narzędzi informatycznych w dydaktyce muzyki.

W tym miejscu należy zidentyfikować grupę badanych, którzy mimo ujawnionej w ten sposób niewiedzy wykorzystują narzędzia informatyczne w swojej pracy. Wzorem uściśleń poczynionych przy okazji pytania 24. należy więc wykluczyć z 61-osobowej grupy tych nauczycieli, którzy deklarują wykorzystywanie TI co najmniej kilka razy w ciągu roku szkolnego (odpowiedzi „d” i „e” na pytanie 9.) oraz znają nazwy przynajmniej kilku programów z kategorii zaproponowanych w pytaniach 10. lub 18.-20. Takich przypadków zidentyfikowano 33. Po wykluczeniu ich z grupy 61 nauczycieli nieświadomych niezbędnej obecności kompetencji informatycznych otrzymamy grupę 28 ankietowanych, u których bardzo niski lub zerowy poziom

\footnotetext{
${ }^{14}$ Rozporzadzenie Ministra Edukacji Narodowej i Sportu $z$ dnia 1 grudnia 2004 r. w sprawie uzyskiwania stopni awansu zawodowego przez nauczycieli, op. cit.

${ }^{15}$ Por.: rozdział 2.4.3.
} 
wykorzystywania TI łączy się z brakiem wiedzy o konieczności posiadania kompetencji w tym zakresie. Jest to zatem możliwa przyczyna niedostatecznego wykorzystywania TI na lekcjach muzyki prowadzonych przez 28 spośród badanych nauczycieli. Żaden z tych przypadków nie został zaliczony do grupy, w której niedostateczne wykorzystanie TI łączy się z opinią o braku znaczenia takich działań dla ucznia (kryterium odpowiedzi na pytanie 23.) natomiast 3 nauczycieli spośród tej grupy zostało wcześniej wyłonionych na podstawie kryterium odpowiedzi na pytanie 24 .

Odpowiedzi na pytanie 15. stanowią kolejne kryterium identyfikacji przyczyn ewentualnego niedostatecznego wykorzystywania TI na lekcjach muzyki, związanych z błędnym rozumieniem "poziomu dostatecznego". Pytanie to brzmi:

„15. Jak często korzysta Pan/i z komputera w domu lub pracy?

a. w ogóle nie korzystam;

b. najwyżej kilka razy w roku;

c. kilka razy w miesiącu;

d. kilka razy w tygodniu;

e. codziennie;

f. kilka godzin dziennie".

Zaznaczenie odpowiedzi „a” lub „b”, zdradzających niemal zerowy stopień wykorzystywania TI w warunkach domowych, sugeruje brak zainteresowania możliwościami narzędzi informatycznych oraz brak umiejętności w tym zakresie, wypływający z braku praktyki. Odpowiedź „a” nie została wybrana ani razu, zaś odpowiedź „b” wybrał jeden ankietowany, który należy do grupy 28 nauczycieli wyłonionych już wcześniej, na podstawie odpowiedzi na pytanie 22 . W tym przypadku zatem na niedostateczny poziom wykorzystania TI do lekcji muzyki złożyły się dwie przyczyny: nikły stopień korzystania z komputera w domu (stąd brak umiejętności oraz zainteresowania możliwościami) oraz brak przekonania o niezbędności posiadania przez nauczyciela kompetencji informatycznych (stąd brak motywacji do dokształcania).

Częstotliwość korzystania z komputera jest nieznacznie, choć zauważalnie skorelowana ujemnie $\mathrm{z}$ wiekiem ankietowanych (współczynnik korelacji Pearsona równy - 0,22 przy założonym poziomie istotności $\mathrm{p}=0,05$ ) oraz dodatnio skorelowana z częstotliwością wykorzystywania TI w dydaktyce (współczynnik korelacji Pearsona równy 0,25). 
Kolejnym pytaniem, naświetlającym ewentualne przyczyny niedoceniania zastosowań TI przez nauczycieli muzyki, jest pytanie 14., które brzmi:

„14. Czy dyrektor szkoły zachęcał lub nakazywał Panu/i udział w szkoleniu komputerowym?

a. tak - dzięki temu ukończyłam/łem takie szkolenie;

b. tak - ale mimo to nie skorzystałam/łem z żadnego szkolenia komputerowego;

c. nie - ponieważ dyrektor zna moje wysokie kwalifikacje w tej dziedzinie;

d. nie - ponieważ dyrektor nie przykłada większej wagi do takich szkoleń;

e. nie - z dowolnych innych przyczyn".

Wybór odpowiedzi „d” zdradzałby źródło braku motywacji do podejmowania działań włączających narzędzia informatyczne do warsztatu nauczyciela, jednak wobec faktu, że ani razu ta odpowiedź nie została zaznaczona, demotywujący wpływ postawy dyrektora szkoły możemy wykluczyć spośród przyczyn mogących wpływać na niedostateczny stopień wykorzystania TI w pracy nauczycieli muzyki uczestniczących w badaniu.

Kolejne pytanie - 25. - dotyczy programów nauczania oraz podręczników, z których badani korzystają:

„25. Czy program nauczania, z którego korzysta Pan/i w swojej pracy zakłada wykorzystanie technologii komputerowej do zajęć (proszę o podanie obok odpowiedzi tytułu programu lub podręcznika)?

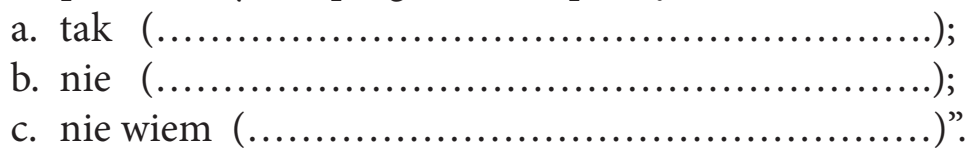

Wybór odpowiedzi „b” sugeruje, że ankietowany nie odczuwa zachęty czy wręcz presji ze strony autorów programu lub podręcznika do wykorzystywania TI na zajęciach muzycznych i każe sądzić, że kompetencje informatyczne nie są niezbędnym składnikiem warsztatu nauczyciela muzyki. Daje nauczycielom wygodne alibi dla ich braków kompetencyjnych i nie prowokuje do ich poszerzenia. Oczywiście wybór programu i podręcznika należy do nauczyciela, więc unikanie pozycji wymagających stosowania narzędzi informatycznych jest świadomym wyborem takiego „alibi”, dlatego „współsprawstwo” autorów podręcznika, zaniedbujących zastosowania narzędzi informatycznych, nie zdejmuje odpowiedzialności z samych nauczycieli. 
Odpowiedzi „b”, sugerujących brak konieczności stosowania TI, i w związku z tym świadomość niskich wymagań w zakresie kompetencji informatycznych nauczycieli muzyki, udzielono $29.8 \mathrm{z}$ nich udzielili nauczyciele, którzy mimo to wykorzystują TI w dydaktyce muzyki co najmniej kilka razy w ciągu roku szkolnego i potrafią podać nazwy kilku wykorzystywanych przez siebie programów. W tych ośmiu przypadkach zatem brak zaleceń zawartych w programie nauczania czy w podręczniku nie wpłynął demotywująco na nauczycieli, którzy znaleźli gdzie indziej inspiracje do stosowania narzędzi informatycznych. W świadomości zatem pozostałych 21 nauczycieli, bardzo nisko sytuowany „dostateczny poziom” wykorzystywania TI może być wynikiem braku jakichkolwiek sugestii wykorzystywania TI w programie nauczania oraz podręczniku. W tej grupie wszyscy nauczyciele zostali wcześniej wyłonieni z badanej grupy na podstawie kryteriów odpowiedzi na pytania 14., 15., 22., 23. i 24.

Poniższy wykres przedstawia liczebności grup nauczycieli, których ewentualne bliskie zeru rozumienie „wystarczającego poziomu” wykorzystywania TI na lekcjach muzyki, wynikać może z sytuacji zidentyfikowanych na podstawie powyższych sześciu pytań.

Wykres 20. Przyczyny obniżonego poczucia standardów wykorzystywania TI u badanych nauczycieli $(\mathrm{N}=85)$

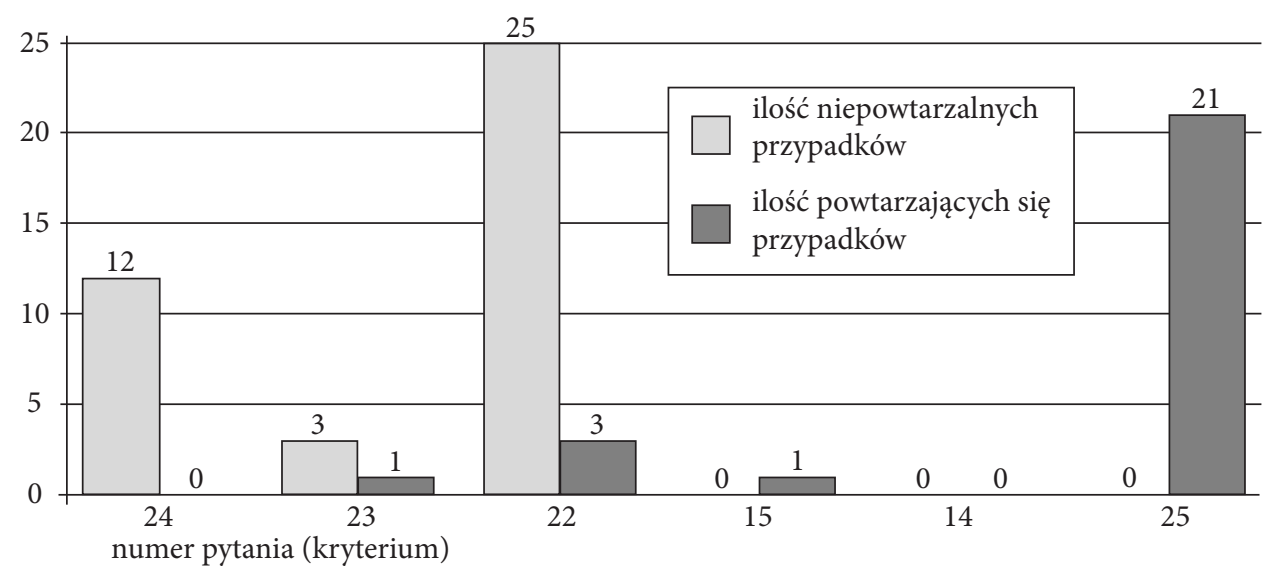

(źródło: badania własne)

Z przedstawionych danych wynika, że 40 nauczycieli $(47,1 \%)$ nie wykorzystuje wcale lub w bardzo nikłym stopniu TI w dydaktyce muzyki ale ich poczucie odpowiedniego lub wystarczającego poziomu wykorzystywa- 
nia narzędzi informatycznych jest również bliskie lub równe zeru. To nieuzasadnienie niskie rozumienie dostatecznego poziomu wykorzystywania TI, które jest pośrednią przyczyną jej niewystarczającego wykorzystywania, wynikać może z pięciu przesłanek:

- część nauczycieli błędnie uważa, że Podstawa programowa... ani Standardy kształcenia nauczycieli... nie dotyczą i nie regulują tego problemu, a więc sam problem (wykorzystywania TI) nie dotyczy nauczycieli (odpowiedzi na pytanie 24.);

- część nauczycieli uważa, że korzystanie na lekcji z komputera jest dla ucznia bez znaczenia - nie przekłada się więc ani na większe zainteresowanie ani na lepsze wyniki nauczania (odpowiedzi na pytanie 23.);

- część nauczycieli nie wie, że kompetencje informatyczne nauczyciela muzyki są niezbędną częścią jego warsztatu pracy, o czym bezpośrednio mówią m.in. warunki uzyskiwania kolejnych stopni awansu zawodowego nauczyciela (odpowiedzi na pytanie 22.);

- jedna $\mathrm{z}$ ankietowanych osób twierdzi, że korzysta w domu z komputera zaledwie kilka razy w roku, co musi implikować brak umiejętności posługiwania się komputerem oraz brak takiej potrzeby;

- część nauczycieli nie uważa TI za niezbędną, czy choćby przydatną, wobec braku jakichkolwiek odniesień do wykorzystywania TI w programach nauczania oraz podręcznikach, z których korzystają.

Wśród tak wyłonionych 40 nauczycieli, w przypadku 26 z nich $(30,1 \%$ wszystkich badanych) mamy do czynienia z nałożeniem się dwóch z powyższych przesłanek.

Oprócz tak sformułowanych przyczyn poczucia braku konieczności czy choćby przydatności zastosowań narzędzi informatycznych w dydaktyce muzyki, co w przypadku niewystarczającego wykorzystywania TI może być uznane za barierę pośrednią, bezpośrednimi przyczynami uniemożliwiającymi takie zastosowania mogą być: braki sprzętowe, brak odpowiednich szkoleń oraz brak znajomości przydatnego w dydaktyce oprogramowania. Wymienione braki zidentyfikujemy na podstawie odpowiedzi na pytania 11., 12., 13., 18., 19. i 20. ankiety nauczycieli.

Odpowiedzi na pytania 11. i 12. przytoczone i omówione zostały w rozdziale 4.1.2. Wynika z nich, że brak dostępu do szkolnego sprzętu komputerowego ogranicza zastosowanie tych narzędzi w przypadku 5 badanych nauczycieli, natomiast brak możliwości skorzystania ze szkolnej pracowni komputerowej ogranicza 8 nauczycieli. Czworo z nauczycieli zasygnalizo- 
wało braki w obydwu kategoriach (sprzęt oraz pracownia), co oznacza, że brak dostępu do sprzętu lub pracowni komputerowej zgłosiło 9 różnych nauczycieli (10,6\%). W tych 9 przypadkach zatem bezpośrednią przyczyną niewystarczającego wykorzystywania TI na lekcjach muzyki jest brak dostępu do sprzętu lub pracowni komputerowej, ale tylko w 4 przypadkach $(4,7 \%)$ ów brak dotyczy łącznie sprzętu i pracowni, co skutecznie uniemożliwia zastosowanie komputerów na lekcji muzyki. Mimo takich przeciwności, dwoje z należących do tej grupy nauczycieli deklaruje wykorzystywanie TI na lekcjach muzyki poparte także znajomością użytecznych programów. Oznaczać to może pokonanie ograniczeń sprzętowych szkoły przez wykorzystanie własnego przenośnego sprzętu komputerowego. Zatem braki sprzętowe stanowić mogą faktyczną barierę w wykorzystywaniu TI na lekcji muzyki zaledwie w dwóch przypadkach (2,4\% wszystkich badanych).

Pytanie 13. dotyczy źródeł wiedzy i umiejętności w posługiwaniu się komputerem i brzmi:

„13. W jaki sposób nauczył/a się Pan/i posługiwać komputerem?

a. zajęcia w ramach studiów pedagogicznych;

b. zajęcia w ramach studiów muzycznych;

c. kursy lub szkolenia w ramach doskonalenia zawodowego;

d. studia podyplomowe;

e. pozaformalne (samokształcenie, lektura, pomoc członka rodziny, znajomych);

f. inne (jakie:......................................);

g. nie potrafię posługiwać się komputerem".

Odpowiedzi na to pytanie przedstawia poniższa tabela:

Tabela 20. Źródła wiedzy i umiejętności w posługiwaniu się komputerem u badanych nauczycieli $(\mathrm{N}=85)$

\begin{tabular}{|c|c|c|c|c|c|c|}
\hline $\begin{array}{c}\text { zajęcia } \\
\text { w ramach } \\
\text { studiów } \\
\text { pedago- } \\
\text { gicznych }\end{array}$ & $\begin{array}{c}\text { zajęcia } \\
\text { w ramach } \\
\text { studiów } \\
\text { muzycznych }\end{array}$ & $\begin{array}{c}\text { kursy lub } \\
\text { szkolenia } \\
\text { w ramach } \\
\text { doskonalenia } \\
\text { zawodowego }\end{array}$ & $\begin{array}{c}\text { studia } \\
\text { podyplo- } \\
\text { mowe }\end{array}$ & $\begin{array}{c}\text { pozaformalne } \\
\text { (samokształ- } \\
\text { cenie, lektura, } \\
\text { pomoc członka } \\
\text { rodziny, znajo- } \\
\text { mych) }\end{array}$ & inne & $\begin{array}{c}\text { nie potrafię } \\
\text { posługiwać } \\
\text { się kompu- } \\
\text { terem }\end{array}$ \\
\hline $\begin{array}{c}8 \\
(9,4 \%)\end{array}$ & $\begin{array}{c}47 \\
(4,7 \%)\end{array}$ & $\begin{array}{c}20 \\
(55,3 \%)\end{array}$ & $\begin{array}{c}71 \\
(23,6 \%)\end{array}$ & $\begin{array}{c}1 \\
(83,5 \%)\end{array}$ & $\begin{array}{c}(1,2 \%) \\
(0 \%)\end{array}$ \\
\hline
\end{tabular}

(źródło: badania własne) 
Wobec braku odpowiedzi „g”, deklarującej brak umiejętności posługiwania się komputerem, należy przyjąć, że brak kwalifikacji informatycznych - czyli wiedzy i umiejętności - nie powinien stanowić realnej bariery w korzystaniu z TI wśród ankietowanych nauczycieli, a przynajmniej sami ankietowani nie upatrują w tej dziedzinie takich barier. Należy jednak pamiętać, że 83,5\% badanych zadeklarowało pozaformalny sposób zdobycia kwalifikacji w zakresie obsługi komputera, a więc poziom w ten sposób zdobytych umiejętności nie został zweryfikowany żadnym certyfikatem czy podobnym dokumentem. Poziom zatem tak zdobytych kwalifikacji, wobec braku ich formalnego potwierdzenia, może być użyteczny jedynie w opinii samych ankietowanych nauczycieli, a nie podejmowanie prób wykorzystania tak zdobytych kwalifikacji może być skutkiem ich zbyt niskiego poziomu, którego ankietowani mogą być nieświadomi. Taka nieuświadomiona bariera sprawiać może, że wskazywane przez nauczycieli inne, łatwe do pokonania lub tylko pozorne bariery, zyskują rangę przeszkód pierwszoplanowych, systemowych, nie do pokonania, zniechęcających do działania.

Takie zjawisko byłoby do zidentyfikowania jedynie na drodze testu kompetencyjnego lub praktycznego sprawdzianu, pozwalającego określić faktyczny poziom kwalifikacji informatycznych badanej grupy nauczycieli. Ten rodzaj badań wychodzi jednak poza zakres wyznaczony przyjętą metodologią. Przyjmujemy zatem opinie ankietowanych, wyrażone w odpowiedziach na pytanie 13. ankiety, za zgodne ze stanem rzeczywistym i uznajemy, że umiejętność posługiwania się komputerem jest wśród badanych nauczycieli powszechna, a więc nie może stanowić istotnej bariery w wykorzystywaniu TI na użytek zajęć muzycznych.

Pytania 18., 19. i 20. weryfikują powyższe deklaracje, ujawniając ewentualny nikły bądź zerowy poziom kwalifikacji informatycznych, objawiający się nieznajomością podstawowych programów komputerowych. Odpowiedzi na te pytania przytoczone zostały w rozdziale 4.1.2. Pozostaje ustalić jaką ilość znanych badanemu programów należy uznać za wystarczającą lub minimalną, by stwierdzić, że nauczyciel posiadł kwalifikacje informatyczne. Takich kryteriów nie przedstawiają jednak żadne z dokumentów omówionych w rozdziale 2.4., dotyczących m.in. kompetencji informatycznych nauczycieli. Na szczęście w tym miejscu nie chodzi o wyznaczenie obiektywnej granicy kompetencji lub choćby kwalifikacji informatycznych a - zgodnie z tytułem rozdziału - zidentyfikowanie grupy badanych, według których zbyt niski poziom takich kwalifikacji może być istotną barierą 
w wykorzystywaniu ich w pracy nauczyciela muzyki. Ponieważ jednak ankieta skierowana do nauczycieli nie zawiera tak sformułowanego pytania, posłużyć się musimy innymi kryteriami dla wyłonienia takich przypadków.

Pierwszym z nich jest deklaracja o zerowym lub bliskim zeru poziomie wykorzystywania TI na użytek prowadzonych lekcji muzyki, drugim - deklaracja o zbyt niskiej znajomości programów komputerowych. Wracamy zatem do problemu określenia „zbyt niskiego poziomu” znajomości programów komputerowych, który uniemożliwia ich efektywne wykorzystanie. Wobec braku obiektywnych granic takiego poziomu, usprawiedliwioną będzie próba ich sprecyzowania, oparta na możliwie obiektywnych i praktycznych kryteriach.

Racjonalną przesłanką do takiego uściślenia będzie prześledzenie przykładowych zastosowań narzędzi informatycznych w dydaktyce muzyki oraz ich wzajemne powiązanie. Takie przykładowe zastosowania, wymagające minimalnych kwalifikacji informatycznych, mogą wyglądać następująco:

- wyszukanie w internecie potrzebnego przykładu muzycznego w formie pliku dźwiękowego, zapisanie go na płycie CD i odtworzenie na lekcji;

- wyszukanie w internecie przykładu muzycznego lub ilustracji, jego edycja, zamieszczenie w prezentacji multimedialnej oraz odtworzenie prezentacji na lekcji;

- wyszukanie w internecie przykładu nutowego lub ilustracji, zamieszczenie go w dokumencie tekstowym oraz wydrukowanie lub nagranie dokumentu na płytę CD jako karty pracy lub formularza sprawdzianu.

Przytoczone powyżej przykłady zastosowań bazują na minimalnych kwalifikacjach, łącząc jednak jednostkowe umiejętności w kompleksowe działania dydaktyczne, złożone zwykle z trzech elementów, zgodnych z trzema kategoriami programów zawartymi w pytaniach 18., 19. i 20. Oznacza to, że możliwy do przyjęcia minimalny lub wystarczający poziom znajomości programów komputerowych można ograniczyć do umiejętności skorzystania z jednego programu z każdej grupy: komunikacyjnych, biurowych i muzycznych. Ich wyszczególnienie odnajdziemy w rozdziale 4.1.2.

Na podstawie odpowiedzi na pytania 18., 19. i 20. ankiety nauczycieli możemy zidentyfikować grupę nauczycieli spełniających tak wyznaczone kryterium posiadania kwalifikacji informatycznych na dwa sposoby. Bardziej liberalny sposób pozwala na uznanie odpowiedzi ograniczającej się do zakreślenia jednego z zaproponowanych w kafeterii punktów. Na tej pod- 
stawie możemy wyróżnić grupę 10 nauczycieli, z których ośmioro przyznało, że nie zna żadnego programu z jednej z będących przedmiotem pytania kategorii (jedno z pytań 18.-20. pozostawione bez odpowiedzi), jeden ankietowany zadeklarował nieznajomość programów z dwóch kategorii oraz jeden, który pozostawił wszystkie trzy pytania bez odpowiedzi. Na podstawie tak przyjętego kryterium możemy uznać, że 10 ankietowanych nauczycieli $(11,8 \%)$ nie posiada kwalifikacji informatycznych w stopniu pozwalającym na zastosowanie narzędzi informatycznych w dydaktyce muzyki.

Kryterium bardziej rygorystycznym jest uznanie jedynie odpowiedzi pełnych, zawierających tytuły znanych odpowiadającemu i prawidłowo przytoczonych programów. Takie podejście skutkuje wyłonieniem spośród badanej grupy 39 nauczycieli, którzy nie wymienili z nazwy żadnego programu w co najmniej jednej z zaproponowanych kategorii. Stanowi to 45,9\% wszystkich badanych, przy czym 23 z nich konsekwentnie nie podało żadnej nazwy programu we wszystkich trzech kategoriach, pozostałych 16 zaś - tylko w jednej lub dwóch kategoriach.

Zatem na podstawie odpowiedzi nauczycieli na pytania o znajomość programów komputerowych można uznać, że dla 10 z nich (11,8\%) przy liberalnym kryterium lub 39 (45,9\%) przy podejściu bardziej rygorystycznym, brak wystarczających kwalifikacji w zakresie umiejętności posługiwania się komputerem może stanowić barierę w wykorzystywaniu TI. Rozbieżność obu liczb w dużej mierze ma swoje przyczyny w niekompletnych odpowiedziach na pytania 18.-20. Część z nich nie została uzupełniona o nazwy programów z braku ich znajomości, druga część - z chęci skrótowego potraktowania zadania, jakim było wypełnienie ankiety. Bez znajomości wszystkich przesłanek brak jest kryteriów do uśrednienia obu wyników.

Podsumowanie barier w stosowaniu TI przez badaną grupę nauczycieli, polegających na brakach sprzętowych (pytania 11. i 12.), braku odpowiednich szkoleń (pytanie 13.) oraz braku znajomości przydatnego w dydaktyce oprogramowania (pytania 18., 19. i 20.) przedstawia wykres 21.

Sumując ilości niepowtarzających się przypadków otrzymujemy dwie wersje liczebności grupy nauczycieli, dla których braki sprzętowe oraz braki w znajomości oprogramowania stanowią barierę w wykorzystywaniu narzędzi informatycznych do lekcji muzyki: 12 w wersji liberalnej $(14,1 \%)$ oraz 39 w wersji bardziej rygorystycznej $(45,9 \%)$. W tym dosyć szerokim przedziale mieści się zatem liczba odpowiadająca faktycznej wielkości szukanej grupy. 
Wykres 21. Przyczyny niedostatecznego wykorzystywania TI w opinii badanych nauczycieli $(\mathrm{N}=85)$

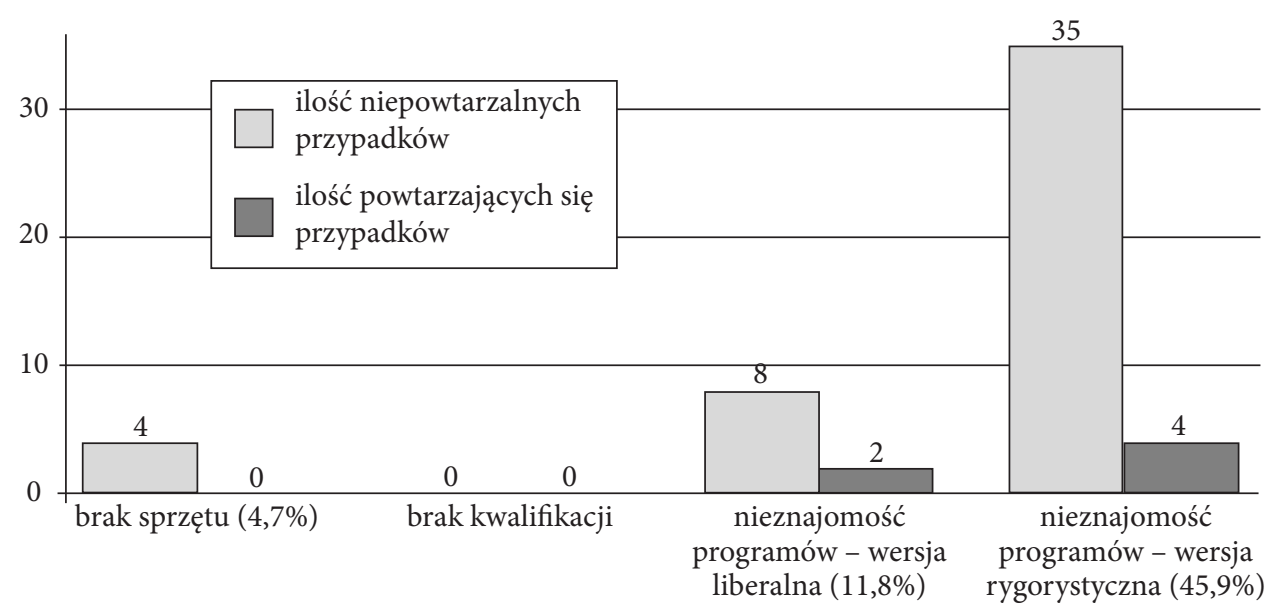

(źródło: badania własne)

Zgodnie więc z deklaracjami badanych nauczycieli, tylko dla $14,1 \%$ z nich (4+8 przypadków) przyczyną niedostatecznego wykorzystywania TI w dydaktyce muzyki może być niedostępność szkolnego sprzętu komputerowego lub nieznajomość użytecznego oprogramowania. Weryfikacja takiej deklaracji na podstawie umiejętności wymienienia nazw znanych nauczycielom programów komputerowych każe zwiększyć przyjęty odsetek ankietowanych do $45,9 \%$ (4+35 przypadków). Jednak ten poziom, mimo iż prawdopodobnie bliższy prawdzie, nie odzwierciedla samej opinii badanych nauczycieli, a to właśnie opinia była przedmiotem dociekań tego rozdziału. Pozostając zatem przy wskaźniku 14,1\% należy dodać, że wśród badanej grupy nauczycieli poczucie umiejętności obsługi komputera jest powszechne i nie jest przez nich identyfikowane jako bariera w jego stosowaniu.

Ważnym wnioskiem tego rozdziału jest również rozumienie przez ankietowanych „dostatecznego poziomu” wykorzystywania TI w dydaktyce muzyki. Dla 47,1\% z nich bowiem ten poziom jest bliski zeru, dlatego subiektywne poczucie sprostania tak niskim wymaganiom nie implikuje refleksji na temat przyczyn obiektywnie niedostatecznego wykorzystywania TI w dydaktyce muzyki. Dla blisko połowy ankietowanych więc, fakt niedostatecznego wykorzystywania TI nie wynika z jakichkolwiek braków w warsztacie nauczyciela, a jedynie z braku znajomości takich wymagań. 


\subsubsection{Poziom kompetencji informatycznych badanych nauczycieli}

Trzeci problem badawczy zawiera się w pytaniu: jakie są kompetencje informatyczne nauczycieli przedmiotu muzyka w klasach IV-VI łódzkich szkół podstawowych?

Rekonstrukcję poziomu kompetencji informatycznych badanej grupy nauczycieli przeprowadzić można na kilka sposobów. Najprostszym jest analiza odpowiedzi na pytanie 2 . ankiety skierowanej do dyrektorów, które brzmi:

„2. Poziom kompetencji informatycznych nauczyciela muzyki w Pani/a szkole ocenia Pan/i jako:
a. wyższy od wymaganych;
b. zgodny z wymaganiami;
c. poniżej poziomu wymaganego;
d. zerowy;
e. nie wiem".

Odpowiedzi na to pytanie ujęto w tabeli 21.

Tabela 21. Poziom kompetencji informatycznych nauczycieli muzyki według opinii dyrektorów odpowiedzi na pytanie 2 . $(\mathrm{N}=82)$

\begin{tabular}{|c|c|c|c|c|}
\hline $\begin{array}{c}\text { Odpowiedź „,a” } \\
\text { (wyższy od } \\
\text { wymaganych) }\end{array}$ & $\begin{array}{c}\text { Odpowiedź „b” } \\
\text { (zgodny } \\
\text { z wymaganiami) }\end{array}$ & $\begin{array}{c}\text { Odpowiedź „,c” } \\
\text { (poniżej } \\
\text { wymagań) }\end{array}$ & $\begin{array}{c}\text { Odpowiedź „,d” } \\
\text { (zerowy) }\end{array}$ & $\begin{array}{c}\text { Odpowiedź „,e” } \\
\text { (nie wiem) }\end{array}$ \\
\hline $15(18,3 \%)$ & $55(67,1 \%)$ & $9(11,0 \%)$ & $0(0 \%)$ & $3(3,7 \%)$ \\
\hline
\end{tabular}

(źródło: badania własne)

Opinie dyrektorów są bardzo pochlebne. Według nich aż 70 nauczycieli $(85,4 \%$ odpowiedzi dyrektorów) posiada kompetencje informatyczne na wystarczającym poziomie, umożliwiającym stosowanie TI na lekcjach muzyki. W przypadku 9 nauczycieli, dyrektorzy określili ich kompetencje informatyczne jako niższe od wymaganych. Porównanie odpowiedzi na pozostałe pytania ankiety dyrektorów pozwoli na bliższe określenie „poziomu wymaganego" w ich rozumieniu.

Spośród więc tych dziewięciu przypadków, dyrektorzy deklarują, że siedmioro nauczycieli nie stosuje TI na lekcjach muzyki (odpowiedzi na pytanie 3.), jeden stosuje, zaś ostatni z wypowiadających się dyrektorów nie wie czy takie sytuacje mają miejsce. 
Nauczycielka, która wedle opinii dyrektora stosuje TI, mimo posiadania zbyt małych kompetencji w tej dziedzinie, sama określa częstotliwość takich sytuacji, jako „1-2 razy w ciągu roku szkolnego” (odpowiedź „c” na pytanie 9.). Mimo tak znikomego udziału TI w dydaktyce muzyki, dyrektor zauważył ten fakt, odnotowując go w swojej ankiecie. Ograniczeniem w tym przypadku nie jest niedostępność sprzętu czy pracowni komputerowej (odpowiedzi 11. „b” i 12. „b” nauczyciela oraz 6. „a" dyrektora). Mimo jednak ukończenia szkolenia informatycznego, podjętego za zachętą dyrektora (odpowiedzi 13. „c” i 14. „a” nauczyciela), komputera w domu używa najwyżej kilka razy w roku (odpowiedź 15.). Stąd nieznajomość użytecznych programów komputerowych czy adresów stron internetowych (brak tytułów czy adresów w odpowiedziach na pytania: 10., 18., 19., 20. i 21.). Według interesującej nas nauczycielki, kompetencje informatyczne w pracy nauczyciela muzyki są bez znaczenia (odpowiedź 22. „c”), choć dostrzega, że TI na lekcji muzyki jest pomocna dla uczniów (odpowiedź 23. „d”). Wobec takiej charakterystyki, opinia dyrektora, określająca stan wykorzystania TI na lekcjach muzyki jako „zbyt mały” (odpowiedź 5. „c” dyrektora), jest wyjątkowo łagodna (dyrektor miał jeszcze do wyboru odpowiedzi: „stanowczo niedostateczny” i „zerowy”) i zdradza pozory wyrozumiałej przychylności dla znikomych poczynań nauczycielki w tym zakresie. Taka przychylna opinia może być wynikiem docenienia uczestnictwa nauczycielki w szkoleniu komputerowym (za namową dyrektora) i wykorzystania nowych umiejętności na jednej lub dwóch lekcjach, mimo przytoczonych wyżej przesłanek, a także możliwym podobnym stosunkiem dyrektora do dydaktycznych zastosowań TI. Ostatnie, siódme pytanie bowiem, o stosowanie technologii komputerowej na własnych zajęciach, dyrektor pozostawił bez odpowiedzi.

Mamy więc w grupie 9 nauczycieli o zbyt małych (według opinii dyrektorów) kompetencjach informatycznych, siedmioro nie stosujących narzędzi informatycznych, jedną nauczycielkę - omówioną wyżej - wykazującą minimalną dobrą wolę przy braku wiedzy i doświadczenia w tej dziedzinie oraz jeden przypadek, w którym dyrektor nie wie, czy nauczyciel stosuje TI na lekcjach muzyki, a mimo to uważa, że jego kompetencje informatyczne są zbyt małe. W tym ostatnim przypadku, 60-letnia nauczycielka mianowana deklaruje korzystanie z TI na lekcjach muzyki „kilka razy w ciągu roku szkolnego” (odpowiedź 9. „d”). Być może nie zasłużyła na wyrozumiałą przychylność dyrektora, skoro nie uczestniczyła w żadnym szkoleniu komputerowym (odpowiedź 13. „e”) albo ewentualny brak stosowania 
informatycznych narzędzi dydaktycznych ze strony dyrektora (znowu brak odpowiedzi na pytanie 7. ankiety dyrektora) skutkuje brakiem jego zainteresowania stosowaniem TI przez innych nauczycieli.

Nieco dokładniejszy obraz kompetencji informatycznych badanych nauczycieli wyłonić się powinien z zestawienia odpowiedzi na pytania 2. i 3. ankiety dyrektorów.

Tabela 22. Wykorzystywanie TI przez nauczycieli muzyki według opinii dyrektorów - odpowiedzi na pytanie 3. $(\mathrm{N}=83)$

\begin{tabular}{|c|c|c|}
\hline $\begin{array}{c}\text { Odpowiedź „a” } \\
\text { (stosuje) }\end{array}$ & $\begin{array}{c}\text { Odpowiedź „b” } \\
\text { (nie stosuje) }\end{array}$ & $\begin{array}{c}\text { Odpowiedź „c” } \\
\text { (nie wiem) }\end{array}$ \\
\hline $46(55,4 \%)$ & $30(36,1 \%)$ & $7(8,4 \%)$ \\
\hline
\end{tabular}

(źródło: badania własne)

Z porównania takiego wynika, że dyrektorzy mają świadomość, iż mimo tego, że tylko 9 nauczycieli (11\%) ma ich zdaniem zbyt niskie kompetencje informatyczne (odpowiedź 13. „c), to co najmniej 30 nauczycieli $(36,1 \%)$ nie korzysta z TI na lekcjach (odpowiedź 3. „b” ankiety dyrektorów). Zatem $21 \mathrm{z}$ nich (25\%) nie ma możliwości bądź chęci wykorzystania swoich kompetencji informatycznych, o których istnieniu dyrektorzy są przekonani. Formułując ten wniosek zgodnie $\mathrm{z}$ ustaleniami rozdziału 2.1. i 2.2. należy stwierdzić, że 21 dyrektorów błędnie uważa, iż nauczyciele muzyki w ich szkołach posiadają wystarczające kompetencje informatyczne ale ich nie wykorzystują. Jeśli bowiem nie wykorzystują w sposób świadomy i odpowiedzialny swojej wiedzy i umiejętności, to ich potencjał należy określić jedynie jako kwalifikacje a nie kompetencje.

Rozmiar grupy wyłonionej na podstawie powyższego zestawienia - 30 nauczycieli, którzy nie wykorzystują TI, stanowiąca 36,1\% wszystkich badanych - jest przyczynkiem do potwierdzenia hipotezy szczegółowej o niedostatecznym stopniu wykorzystywania TIK w pracy dydaktycznej nauczycieli muzyki.

Dysponujemy zatem już dwiema wersjami liczby niekompetentnych informatycznie nauczycieli muzyki, wyłonionych na podstawie opinii dyrektorów: 9 - zgodnie z odpowiedziami na pytanie 2. oraz 30 - zgodnie z odpowiedziami na pytanie 3. ankiety dyrektorów.

Pozostaje skonfrontować te wyniki z obrazem kompetencji informatycznych, zrekonstruowanym na podstawie deklaracji samych nauczycieli. 
Kompetencje - zgodnie z definicją przyjętą w rozdziale 2.1. - składają się z trzech składników: wiedzy, umiejętności oraz składnika, który dla przejrzystości i zwięzłości nazwaliśmy odpowiedzialnym działaniem. Pod tym ostatnim określeniem kryją się, zidentyfikowane w rozdziale 2.1.: rozumienie i pragnienie zastosowania swoich kwalifikacji, świadomość potrzeby i konsekwencji takiego właśnie zachowania, przyjmowanie na siebie odpowiedzialności za nie, doświadczenie, demonstrowanie i postawa odpowiednia do sytuacji.

Na podstawie odpowiedzi nauczycieli na pytania 18., 19., 20. i 21. możemy ocenić wiedzęi umiejętności badanej grupy w odniesieniu do podstawowego oprogramowania w ramach czterech jego kategorii: komunikacyjne, biurowe, muzyczne i inne. Zgodnie z ustaleniami rozdziału 2.2., przyjętymi za dokumentami określającymi standardy przygotowania informatycznego nauczycieli ${ }^{16}$, przyjmujemy stopniowalność kompetencji informatycznych nauczycieli. Oznacza to, że nie możemy arbitralnie przyjąć granicy, od której poziom kompetencji uznać można za wystarczający, w związku z czym nawet minimalny zakres takich kompetencji należy uznać za wystarczający wyróżnik kompetentnego nauczyciela. Taki minimalny zakres, który można wywnioskować z odpowiedzi na pytania ankiety dla nauczycieli, oznacza przynajmniej jedną twierdzącą odpowiedź na pytania 18., 19. lub 20. - dotyczące umiejętności posługiwania się programami komunikacyjnymi, biurowymi lub muzycznymi. Czwarta kategoria - „inne” - ujęta w pytaniu 21., może przyjmować jedynie funkcje pomocnicze wobec trzech wcześniejszych. W olbrzymiej większości przypadków znalazły się tu bowiem programy wymienione już wcześniej przez nauczycieli w odpowiedziach na pytania 18.-20. oraz kilka programów do edycji grafiki (którą należy najpierw odnaleźć w internecie, bądź zamieścić w prezentacji, korzystając z programów komunikacyjnych, biurowych lub muzycznych).

Zatem z grupy nauczycieli posiadających kompetencje informatyczne należy wykluczyć tych, którzy nie zakreślili żadnej odpowiedzi na pytania 18.-20. Jest tylko jeden taki przypadek, który jednak nie jest wynikiem braku umiejętności, a raczej braku chęci do udzielenia wyczerpujących odpowiedzi. W odpowiedzi na pytanie 10. bowiem, ten sam nauczyciel deklaruje wykorzystywanie w pracy z uczniami 4 aplikacji (Windows Media Player, Nero, Picasa, Power Point) oraz znajomość serwisu edukacyjnego profesor.pl.

\footnotetext{
${ }^{16}$ Najpełniej standardy te opisuje dokument cytowany w rozdziale 2.4.1.: Rada ds. Edukacji Informatycznej i Medialnej, Standardy przygotowania nauczycieli w zakresie technologii informacyjnej i informatyki, op. cit.
} 
Na podstawie tak przyjętego kryterium uznać musimy, że wszyscy ankietowani, w mniejszym bądź większym stopniu, posiadają kwalifikacje informatyczne - umiejętności w zakresie korzystania z oprogramowania oraz wiedzę na temat jego przeznaczenia i możliwości. Możemy jednak zaostrzyć nieco warunki akceptacji deklaracji badanych nauczycieli i uznania ich za oddające stan rzeczywisty. Takim ostrzejszym kryterium będzie wymienienie nazwy programu, którego wykorzystywanie badani deklarują. Zatem z 85 przypadków wykluczymy te, które ograniczyły się w pytaniach 18.-20. jedynie do zakreślenia proponowanej w kafeterii odpowiedzi, bez jej uzupełniania adekwatnymi tytułami programów. Takich niepełnych odpowiedzi, zdradzających możliwość nieznajomości deklarowanych programów, jest 23. 7 spośród nich wymienia jednak konkretne nazwy wykorzystywanych programów w innym miejscu ankiety - w odpowiedzi na pytanie 10., co każe zmniejszyć grupę wykluczonych nauczycieli do 16 (23-7=16) i tym samym grupę kompetentnych informatycznie nauczycieli $\mathrm{w}$ badanej grupie do $69(85-16=69)$.

Z tak wyselekcjonowanej grupy możemy wykluczyć kolejne przypadki na podstawie odpowiedzi zdradzających brak trzeciego składnika kompetencji informatycznych, określonego w rozdziale 2.1. i 2.2. „odpowiedzialnym działaniem”. Elementy kryjące się pod tym sformułowaniem możemy zidentyfikować na podstawie niektórych odpowiedzi na pytania ankiety:

- pytania 8., 9. i 10. - dotyczą demonstrowania i doświadczenia;

- pytanie 22., 24. i 25. - dotyczą świadomości konieczności odpowiedniego zachowania;

- pytanie 23. - dotyczy odpowiedzialności;

- pytanie 26. - dotyczy rozumienia i pragnienia odpowiedniego zachowania.

Z grupy kompetentnych informatycznie nauczycieli muzyki możemy zatem wykluczyć tych, którzy:

- na pytanie 8. odpowiedzieli zaznaczając punkt „e” (ankietowany nie stosuje TI w żadnej z wymienionych w pytaniu sytuacji) - nie ma takich odpowiedzi;

- na pytanie 9. odpowiedzieli wybierając punkt „a” (nie wykorzystuje TI w przygotowaniu lub prowadzeniu zajęć) - 1 przypadek, ale wykluczony wcześniej na podstawie kryteriów dotyczących kwalifikacji; 
- na pytanie 10. odpowiedzieli wskazując punkt „h” (nie wykorzystuje żadnej z wymienionych grup programów w pracy z uczniami) 1 przypadek, wykluczony wcześniej);

- na pytanie 22. odpowiedzieli zaznaczając punkt „c” (uważa kompetencje informatyczne nauczyciela za bez znaczenia) - 4 przypadki, w tym 3 wykluczone wcześniej;

- na pytanie 24. odpowiedzieli wybierając punkt „c” (uważa, że Podstawa programowa nie mówi nic o kompetencjach informatycznych nauczyciela) - 6 przypadków, w tym 3 wykluczone wcześniej;

- na pytanie 25. odpowiedzieli wskazują punkt „c” (nie wie, czy program nauczania, z którego korzysta, zakłada wykorzystanie TI do zajęć) - 9 przypadków, w tym 2 wykluczone wcześniej;

- na pytanie 23. odpowiedzieli zaznaczając punkt „f” lub „h” (uważa, że wykorzystywanie komputera na lekcji muzyki jest dla uczniów bez znaczenia lub utrudnieniem) - 4 przypadki, w tym 3 wykluczone wcześniej;

- na pytanie 26. odpowiedzieli jednoznacznie negatywnie „nie widzę..." (nie znajduje zastosowań TI w nauczaniu muzyki) - 2 przypadki, obydwa wykluczone wcześniej.

W sumie zidentyfikowaliśmy więc 27 odpowiedzi zdradzających brak któregoś z niezbędnych komponentów kompetencji informatycznych nauczyciela. $15 \mathrm{z}$ nich dotyczyło nauczycieli wykluczonych z grupy kompetentnych informatycznie na podstawie wcześniejszych kryteriów. Zatem wcześniej zidentyfikowaną grupę 69 ankietowanych możemy pomniejszych o kolejne 12 przypadków, co daje liczbę 57 kompetentnych informatycznie nauczycieli w badanej grupie (67\% wszystkich biorących udział w badaniu).

Wiedza i umiejętności w zakresie zastosowań dydaktycznych TI nie była obecna w programach nauczania studiów aktualnych nauczycieli. Wobec braku kursów komputerowych, oferujących wiedzę i umiejętności z zakresu zastosowań TI w dydaktyce muzyki, przyjąć należy, że jedyną formą zdobycia kwalifikacji w tym zakresie dla obecnych nauczycieli muzyki było samokształcenie. Nie było zatem powodów umieszczania w ankiecie pytania o formalne kwalifikacje w zakresie muzycznych zastosowań dydaktycznych TI. Identyfikacja więc tych spośród ankietowanych, którzy posiadają niezbędne kwalifikacje, a następnie kompetencje z zakresu zastosowań TI w dydaktyce muzyki, musiała przybrać formę jak powyżej. 
Zamiast jednak dokonywać selekcji tych spośród badanych, którzy posiadają kwalifikacje informatyczne, a następnie spośród nich wyławiać działających świadomie i odpowiedzialnie, można wybrać inną drogę - wyselekcjonowanie spośród badanych grupy nauczycieli, którzy deklarują wykorzystywanie TI w przygotowaniu lub prowadzeniu lekcji muzyki (pytanie 8.). Ta grupa nauczycieli bowiem, swoje działania dydaktyczne opierać musi na wiedzy i umiejętnościach w tej dziedzinie - a więc kwalifikacjach. Trudno przecież stosować narzędzia informatyczne, nie mając na ten temat chociaż minimalnej wiedzy oraz podstawowych umiejętności.

Grupa wyselekcjonowana na podstawie takiego kryterium składa się z 85 (wszystkich badanych!) nauczycieli. Wszyscy oni bowiem zadeklarowali wykorzystywanie TI w co najmniej jednej z zaproponowanych w kafeterii sytuacjach:

- przygotowywanie się do zajęć (odświeżanie lub pogłębianie własnej wiedzy, szukanie informacji, ciekawych konspektów lekcji i in.);

- przygotowywanie materiałów dla uczniów (nuty, nagrania, ilustracje, prezentacje i in.);

- prowadzenie zajęć (prezentacje, filmy, ilustracje, programy i gry edukacyjne);

- ocena osiągnięć uczniów (przygotowanie sprawdzianów, testów $\mathrm{w}$ formie papierowej lub multimedialnej).

Zestawienie wyników liczebności grupy kompetentnych informatycznie nauczycieli muzyki, wyliczonych za pomocą czterech powyższych metod, opartych na kryteriach zaczerpniętych $\mathrm{z}$ ankiet dyrektorów oraz nauczycieli, przedstawia następujący wykres:

Wykres 22. Liczebność grupy kompetentnych informatycznie nauczycieli w zależności od metody jej wyliczenia

kryterium:

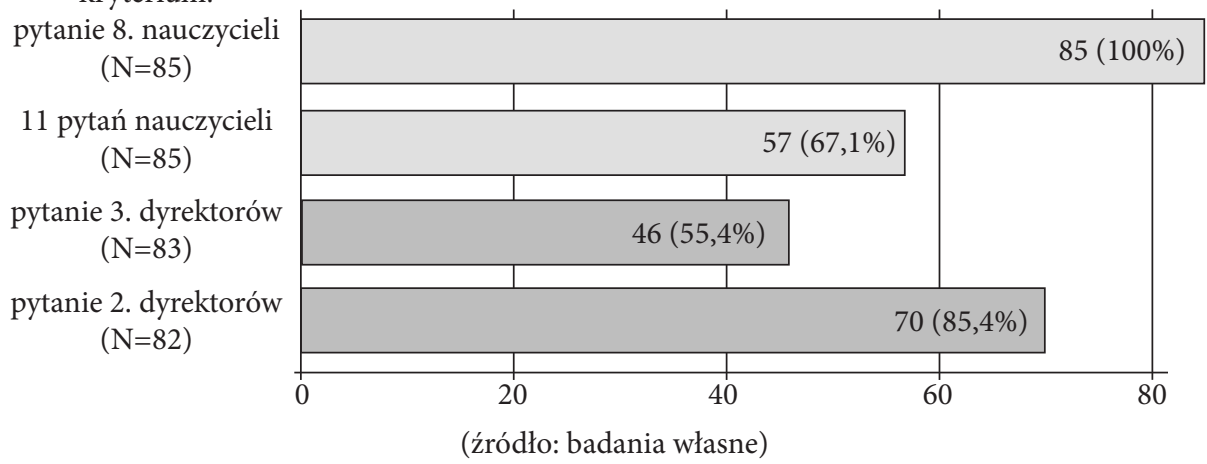


Wykres powyższy weryfikuje bezpośrednio drugą hipotezę szczegółową, która zakłada, że poziom kompetencji informatycznych nauczycieli muzyki jest daleko niższy od postulowanego. Wszystkie cztery wersje weryfikacji dotyczą jedynie aspektu ilościowego: ilu nauczycieli jest kompetentnych informatycznie, na podstawie opinii dyrektorów oraz samych zainteresowanych. Na tej płaszczyźnie, otrzymane wyniki (od 55,4\% do 100\%) nie pozwalają na jednoznaczne potwierdzenie lub zaprzeczenie wstępnej hipotezy. Uwzględnione wersje poziomu kompetencji bowiem, sytuują się między dwoma skrajnościami: od daleko niższej do dokładnie równej poziomowi postulowanemu. Dokładniejszą weryfikację, uwzględniającą również aspekt jakościowy, stanowi rozdział 4.2.3. niniejszej pracy, poświęcony rozbieżnościom między stanem postulowanym i faktycznym kompetencji informatycznych badanych nauczycieli.

Duża rozbieżność wyników liczebności grupy nauczycieli kompetentnych informatycznie, otrzymanych dwoma sposobami, opartymi na kryteriach $\mathrm{z}$ ankiety nauczycieli, każe zastanowić się nad jej przyczyną. 28 nauczycieli bowiem, którzy deklarują wykorzystywanie TI w przygotowywaniu lub prowadzeniu zajęć, odpowiedziało na pytanie 8. niezgodnie z prawdą albo wykorzystuje TI w sposób niekompetentny. Niekompetentny sposób wykorzystania TI nie może wynikać z braku wiedzy czy umiejętności - korzystanie z komputera bez choćby podstawowej wiedzy jak to zrobić należy uznać za niemożliwe. Niekompetencja może w tym wypadku oznaczać jedynie brak trzeciego składnika kompetencji, nazwanego tu „odpowiedzialnym działaniem”, a składającego się, według różnych autorów, z: rozumienia i pragnienia wykorzystywania swojej wiedzy i umiejętności, postawy odpowiedniej do sytuacji, demonstrowania, doświadczenia, świadomości potrzeby i konsekwencji odpowiedniego zachowania oraz przyjmowania na siebie odpowiedzialności za nie.

Skoro nauczyciele deklarują działania z użyciem komputera, możemy odrzucić składniki czynne ${ }^{17}$ (demonstrowanie, doświadczenie, postawa odpowiednia do sytuacji) i skupić się na brakach w składnikach biernych. Nie próbując hierarchizować tych składników, należy uznać, że 28 (32,9\%) nauczycielom brakuje: rozumienia i pragnienia wykorzystywania swojej wiedzy i umiejętności, świadomości potrzeby i konsekwencji takiego zachowania oraz przyjmowania na siebie odpowiedzialności za nie. Oznacza to, że działaniom tych nauczycieli brakuje odpowiedzialności, świadomej

\footnotetext{
${ }^{17}$ Por.: konkluzja rozdziału 2.1.
} 
potrzeby działania oraz pragnienia działania opartego na zrozumieniu. Takie właśnie cechy uznaliśmy za możliwe do rekonstrukcji na podstawie 8 odpowiedzi na pytania ankiety dla nauczycieli (pytania 8., 9., 10., 22., 23., 24., 25., 26.) i na tej podstawie wykluczyliśmy kilkunastu nauczycieli z grupy kompetentnych informatycznie.

Uznać zatem możemy, że 28 nauczycieli albo wbrew deklaracji nie wykorzystuje TI albo robi to w sposób nieodpowiedzialny (np. nie wierząc w pozytywne efekty takich działań), bez świadomej potrzeby (np. na skutek presji dyrekcji, innych nauczycieli, uczniów) lub bez zrozumienia implikującego pragnienie takiego działania (np. udostępnienie uczniom komputerów bez jasno nakreślonego celu, dla zapełnienia czasu do dzwonka).

\subsection{Porównanie postulowanego i rzeczywistego stanu kompetencji informatycznych badanej grupy nauczycieli}

\subsubsection{Ustalenie wyznaczników postulowanego stanu kompetencji informatycznych nauczycieli muzyki}

Dla dokonania tytułowej konfrontacji obydwu stanów kompetencji informatycznych badanej grupy nauczycieli niezbędne będzie syntetyczne ujęcie wytycznych, ujętych w dokumentach omówionych w rozdziale 2.4. Zastosowany możliwie szeroki wybór tych dokumentów niezbędny był dla ukazania wielości podejść do problemu kompetencji informatycznych nauczyciela muzyki, zarówno w kontekście ilościowym jak i jakościowym. Obydwa konteksty utrudniają ewentualne syntetyczne ujęcie tym bardziej, że wspomniane konteksty dotyczą zarówno sposobu opisu postulowanego stanu kompetencji, jak i samego zakresu tych kompetencji.

Wyznaczenie zatem kryteriów postulowanego poziomu kompetencji informatycznych nauczyciela muzyki należy zacząć od ustalenia wagi dokumentów zawierających takie kryteria. Sposób określenia wagi dokumentu dotyczyć powinien nie subiektywnej oceny ważności zawartych w nim sformułowań ale takich cech, jak dyrektywność (obowiązkowość, stanowienie i wyznaczanie zasad działania), bezpośredniość oraz powszechność. Rozróżnimy zatem dokumenty, które: wyznaczają obowiązujące zasady prawne, dotyczą bezpośrednio nauczycieli oraz dotyczą wszystkich nauczycieli muzyki, w odróżnieniu od dokumentów, które: formułują jedynie opinie czy sugestie, ich adresatem są organy stanowiące prawo oświatowe lub 
w jakikolwiek sposób ograniczają się do zawężonej podgrupy nauczycieli muzyki. Uwzględnienie takich kryteriów skutkuje ustaleniem dwóch podstawowych grup dokumentów:

- dokumenty stanowiące prawo, dotyczące bezpośrednio wszystkich nauczycieli;

- dokumenty będące wyrazem postulatów różnych środowisk, kierowanych do władz oświatowych i mające na celu zmianę obowiązujących przepisów na drodze profesjonalnej dyskusji i konsultacji.

Do pierwszej grupy zaliczyć należy rozporządzenia dotyczące:

- Podstawy programowej kształcenia ogólnego dla szkół podstawowych i gimnazjów ${ }^{18}$

- Standardów kształcenia przygotowującego do wykonywania zawodu nauczyciela ${ }^{19}$

- warunków awansu zawodowego nauczycieli ${ }^{20}$.

Na drugą grupę dokumentów składają się:

- Standardy przygotowania nauczycieli w zakresie technologii informacyjnej $i$ informatyki ${ }^{21}$, będące opinią Rady ds. Edukacji Informatycznej i Medialnej przy Ministrze Edukacji Narodowej;

- Standardy edukacji kulturalnej22, będące opinią Polskiej Rady Muzycznej;

- zalecenia Komisji Europejskiej, sformułowane przez Dyrektoriat Generalny ds. Edukacji i Kultury ${ }^{23}$.

Podstawa programowa kształcenia ogólnego dla szkół podstawowych i gimnazjów z roku 2009 jest dokumentem określającym bezpośrednio działania nauczyciela i posiada walory aktu prawnego, zobowiązującego do takich działań. Jednak analiza jego treści pod względem kompetencji informatycznych nauczycieli muzyki (rozdział 2.4.5. niniejszej pracy) przynosi jeden tylko element: uczeń powinien być wyposażony w umiejętność ko-

\footnotetext{
${ }^{18}$ Rozporządzenie Ministra Edukacji Narodowej z dnia 23 grudnia 2008 r..., (Dz.U. Nr 4, poz. 17, z 15 stycznia 2009).

${ }^{19}$ Rozporządzenie Ministra Nauki i Szkolnictwa Wyższego z dnia 17 stycznia 2012 r..., (Dz.U. Nr 25 poz. 131 z 6 lutego 2012).

${ }^{20}$ Rozporzadzenie Ministra Edukacji Narodowej i Sportu z dnia 1 grudnia 2004 r. w sprawie uzyskiwania stopni awansu zawodowego przez nauczycieli, op. cit.

${ }^{21}$ Rada ds. Edukacji Informatycznej i Medialnej, Standardy przygotowania nauczycieli w zakresie technologii informacyjnej i informatyki, op. cit.

${ }^{22}$ A. Białkowski (red.), Standardy edukacji kulturalnej..., op. cit.

${ }^{23}$ Edukacja w Europie: różne systemy kształcenia i szkolenia..., op. cit.
} 
rzystania $\mathrm{z}$ „multimedialnych źródeł muzyki i informacji o muzyce”24. Zadaniem nauczyciela jest zatem wskazanie uczniom takich źródeł. Pośrednio więc formułowane kompetencje informatyczne nauczyciela ograniczają się według tego dokumentu do umiejętności wyszukiwania niezbędnych informacji przy wykorzystaniu TI.

Warunki awansu zawodowego nauczycieli, wprowadzone Rozporzadzeniem Ministra Edukacji Narodowej i Sportu z dnia 1 grudnia 2004 r. w sprawie uzyskiwania stopni awansu zawodowego przez nauczycieli, są obowiązującym aktem prawnym, jednak zobowiązuje on nauczycieli do wykazania się odpowiednimi kompetencjami informatycznymi w zależności od aktualnego stopnia awansu. Obowiązku takiego Rozporządzenie nie nakłada na nauczycieli-stażystów oraz nauczycieli z różnych przyczyn nie podejmujących starań o awans zawodowy. Powszechność zatem tego dokumentu jest ograniczona, choć z drugiej strony uznać można, że to cała ścieżka awansu, a nie pojedynczy jej stopień, jest powszechnie obowiązującym nauczycieli prawem. Sformułowanie wymagań w sferze TI wobec nauczycieli sprowadza się w tym Rozporzadzeniu do stwierdzenia: „umiejętność wykorzystywania w pracy technologii informacyjnej i komunikacyjnej" ${ }^{25}$ i w tym zakresie należy włączyć ten dokumentu do kanonu wyznaczającego postulowany poziom kompetencji informatycznych wszystkich nauczycieli muzyki.

Dwa powyższe dokumenty są jedynymi, które nakreślają ramy prawne działań zawodowych nauczycieli, opisując między innymi zakres, w jakim każdy nauczyciel powinien wykorzystywać TI. Wyjątkowo skromnie nakreślony postulowany stan kompetencji informatycznych nauczyciela sprowadza się więc do dwóch kryteriów:

- umiejętność korzystania z multimedialnych źródeł muzyki i informacji o muzyce;

- umiejętność wykorzystywania w pracy technologii informacyjnej i komunikacyjnej.

Drugie z przytoczonych kryteriów postulowanego stanu kompetencji informatycznych nauczyciela muzyki nosi cechy tautologizmu: kompetencje informatyczne nauczyciela mają polegać na wykorzystywaniu TI. Jednak ważne jest tu użycie zwrotu „wykorzystywanie w pracy”, które sprawia, że kryterium to nie ogranicza się jedynie do kwalifikacji, potencjalnych możliwości, zastosowań domowych, rozrywkowych czy hobbystycznych,

\footnotetext{
${ }^{24}$ Rozporzadzenie Ministra Edukacji Narodowej z dnia 23 grudnia 2008 r..., s. 27.

${ }^{25}$ Dz.U. z 2004 r., Nr 260, poz. 2593, \$ 7. ust. 2, p. 3 oraz $\$ 8$, ust. 2, p. 2.
} 
nie związanych z pracą. To pozornie nic nie precyzujące kryterium każe traktować wykorzystywanie narzędzi informatycznych przez nauczyciela w kategoriach właśnie kompetencji, przez zauważenie trzeciego składnika tychże kompetencji, omawianego szeroko w rozdziałach 2.1. i 2.2.

Odmiennie sformułowane jest pierwsze $z$ kryteriów - wyprowadzone pośrednio z postulatu dotyczącego jednego z celów kształcenia - które żąda od nauczyciela jedynie przekazania uczniom umiejętności w zakresie korzystania z multimedialnych źródeł muzyki i informacji o muzyce. Można taką umiejętność przekazać przy pomocy narzędzi informatycznych ale można ograniczyć się do tradycyjnych form przekazu wiedzy i egzekwowania umiejętności samodzielnie opanowanych przez ucznia na podstawie przekazanej wiedzy. Tym samym nauczyciel może wyegzekwować umiejętność korzystania z multimedialnych źródeł informacji mimo, że sam z takich źródeł nie korzysta. Więcej - nauczyciel może posiadać taką umiejętność, ale korzystać z niej wyłącznie w celach prywatnych, nie związanych $\mathrm{z}$ pracą. Sformułowane w ten sposób kryterium nie dotyczy zatem kompetencji informatycznych nauczyciela, a jedynie jego kwalifikacji, które są tylko składnikiem kompetencji.

Najniższy możliwy poziom kompetencji informatycznych nauczyciela, czyniący zadość obydwu kryteriom, można sformułować jako „wykorzystywanie w pracy dydaktycznej multimedialnych źródeł muzyki i informacji o muzyce". Takie wspólne kryterium zatem możemy przyjąć jako postulowany stan kompetencji informatycznych nauczyciela muzyki, sformułowany na podstawie dokumentów, które wyznaczają prawne ramy jego działalności zawodowej. Dla ułatwienia odwoływania się do tej wersji stanu postulowanego nadamy jej porządkowy numer „1” lub przymiotnik „aktualna”. Odnosząc się w dalszej części do aktualnej wersji stanu postulowanego kompetencji informatycznych nauczycieli muzyki, używać będziemy skrótu SP1.

Ostatnim $\mathrm{z}$ omawianych $\mathrm{w}$ rozdziale 2.4 . dokumentów stanowiących prawo jest rozporządzenie określające Standardy kształcenia przygotowujacego do zawodu nauczyciela. W podrozdziale 2.4.2. omówione zostały trzy wersje tego dokumentu (z 2004 r., projekt z 2007 r. oraz z 2012 r.). Skupiając się na najnowszej wersji Standardów spróbujemy określić postulowany poziom kompetencji informatycznych nauczyciela muzyki. Dokument ten bowiem posiada walor obowiązującego aktu prawnego, dotyczy bezpośrednio kompetencji, w jakie powinien być wyposażony nauczyciel u progu swojej 
kariery zawodowej oraz dotyczy każdego początkującego nauczyciela. Nauczyciele posiadający już pewne doświadczenie zawodowe, ubiegający się o kolejny stopień awansu, mimo nowych, wyższych wymagań, nie zostają zwolnieni z wymagań podstawowych. Należy jednak zauważyć, że Standardy...w swojej wersji z 2012 roku określają sylwetkę absolwenta studiów nauczycielskich, rozpoczynającego studia w roku 2013. Poprzednie wersje Standardów..., które zawierały dyspozycje odnoszące się do kompetencji informatycznych przyszłego nauczyciela, pochodzące z roku 2004 oraz 2003, dotyczą wciąż niewielkiej ilości aktualnie pracujących nauczycieli. Większość z nich jest absolwentami wykształconymi w oparciu o standardy nie zawierające odniesień do kompetencji informatycznych. Możemy zatem mówić o dyrektywności Standardów... w obszarze kompetencji informatycznych nauczycieli jedynie w czasie przyszłym.

Druga zatem wersja postulowanego stanu kompetencji informatycznych, wywiedziona ze Standardów kształcenia przygotowującego do zawodu nauczyciela, dla odróżnienia od poprzedniej, opatrzona zostanie przymiotnikiem "przyszłościowa” i symbolizowana skrótem SP2. Należy przy tym wziąć pod uwagę nie literę prawa a jego ducha, czyli intencje przyświecające wszystkim współautorom Rozporządzenia, które sprowadzają się do postulatu, aby każdy nauczyciel wyposażony był w opisywane kompetencje, a tylko jedną z dróg do tak sformułowanego celu jest spełnienie odpowiednich standardów kształcenia w ramach studiów nauczycielskich. Intencja powszechności takiego stanu kompetencji każe twierdzić, że każdy nauczyciel powinien dążyć do takiego właśnie poziomu, instytucjonalnie zachęcany do doskonalenia poprzez samokształcenie czy uczestnictwo w kursach i szkoleniach, realizując w ten sposób postulat kształcenia przez całe życie.

Opisując zatem drugą wersję - „przyszłościową” - postulowanego stanu kompetencji informatycznych nauczyciela muzyki, posłużymy się Rozporządzeniem Ministra Nauki i Szkolnictwa Wyższego z dnia 17 stycznia 2012 r. w sprawie standardów kształcenia przygotowującego do wykonywania zawodu nauczyciela ${ }^{26}$. Szczegółowe omówienie tego dokumentu w rozdziale 2.4.2. pozwala na przytoczenie samych wniosków, składających się na obraz kompetentnego nauczyciela. Sprowadzają się one do następujących postulatów na poziomie ogólnym:

\footnotetext{
${ }^{26}$ Dz.U. Nr 25 poz. 131 z 6 lutego 2012.
} 
1. „umiejętność uczenia się i doskonalenia własnego warsztatu pedagogicznego z wykorzystaniem nowoczesnych środków i metod pozyskiwania, organizowania i przetwarzania informacji i materiałów;

2. umiejętnie komunikuje się przy użyciu różnych technik, zarówno z osobami będącymi podmiotami działalności pedagogicznej, jak i z innymi osobami współdziałającymi w procesie dydaktyczno-wychowawczym oraz specjalistami wspomagającymi ten proces"27.

Kolejny postulat, na nieco niższym poziomie ogólności określa, że absolwent studiów nauczycielskich potrafi:

3. „wykorzystywać nowoczesne technologie do pracy dydaktycznej”28.

Kolejne, szczegółowe ujęcie efektów kształcenia określa kompetencje informatyczne nauczyciela, jako:

4. „podstawową wiedzę i umiejętności w zakresie technik informatycznych, przetwarzania tekstów, wykorzystywania arkuszy kalkulacyjnych, korzystania $z$ baz danych, posługiwania się grafiką prezentacyjną, korzystania z usług w sieciach informatycznych, pozyskiwania i przetwarzania informacji,

5. umiejętność zróżnicowanego wykorzystywania technologii informacyjnej w pracy pedagogicznej"29.

Szczegółowe odniesienie do treści kształcenia w zakresie dydaktyki zawiera następującą dyspozycję:

6. „edukacyjne zastosowania mediów i technologii informacyjnej”30.

Ostatnim i niezwykle ważnym dla rozumienia pojęcia „kompetencji” odniesieniem w omawianym dokumencie jest fragment dotyczący praktyk pedagogicznych:

7. „w trakcie praktyki następuje kształtowanie kompetencji dydaktycznych przez [...] współdziałanie z opiekunem praktyk w [...] wykorzystywaniu środków multimedialnych i technologii informacyjnej w pracy dydaktycznej"31.

$\mathrm{Na}$ podstawie siedmiu przytoczonych tu fragmentów Standardów kształcenia przygotowującego do wykonywania zawodu nauczyciela z roku 2012, możemy zrekonstruować postulowany stan kompetencji informatycznych nauczyciela muzyki, ujmując go w poniższy sposób.

\footnotetext{
${ }^{27}$ Ibidem, s. 1.

${ }^{28}$ Ibidem, s. 3.

${ }^{29}$ Ibidem, s. 4.

${ }^{30}$ Ibidem, s. 17, p. 2.2.8.

${ }^{31}$ Ibidem, s. 20, p. 3., pp. 3d.
} 
Nauczyciel wykorzystuje TI do:

1. doskonalenia własnego warsztatu pedagogicznego;

2. komunikowania się;

3. pracy dydaktycznej.

W ramach tych trzech obszarów wykorzystuje następujące środki i narzędzia informatyczne:

1. edytor tekstu;

2. arkusz kalkulacyjny;

3. bazy danych;

4. prezentacje multimedialne;

5. przeglądarka internetowa;

6. wyszukiwarka internetowa;

7. program pocztowy.

Uproszczone ujęcie powyższych punktów służy wyłącznie przejrzystości jego formy, nie zwalniając jednak z rozpatrywania całego kontekstu, jaki zawarty został w przytoczonych dosłownie fragmentach rozporządzenia. Te 10 punktów, będących schematycznym ujęciem 7 cytatów rozporządzenia, składają się więc na drugą wersję - „przyszłościową” - stanu postulowanego kompetencji informatycznych nauczycieli muzyki (SP2).

Odmiennie wygląda postulowany stan kompetencji informatycznych nauczycieli, zrekonstruowany na podstawie sugestii i zaleceń środowisk opiniotwórczych, mających aspiracje do kształtowania polityki edukacyjnej państwa. Do tej grupy dokumentów należą Standardy przygotowania nauczycieli w zakresie technologii informacyjnej i informatyki, opracowane przez Radę ds. Edukacji Informatycznej i Medialnej przy Ministrze Edukacji i Sportu w 2003 roku, które szeroko zostały omówione w rozdziale 2.4.1. Jest to dokument o charakterze jedynie doradczym dla ministra, nie obowiązujący nauczycieli. Mimo to zasługuje na uwagę ze względu na swą wyjątkową wnikliwość i obszerność. Wyznaczniki ujętego w tym dokumencie stanu kompetencji informatycznych nauczycieli, można ująć w 14 szczegółowych punktach (zacytowanych w rozdziale 2.4.1.). Jest to zestaw 14 warunków, których ze względu na swoją kompleksowość i wygórowany poziom, prawdopodobnie nie spełnia żaden z objętych badaniem nauczycieli. Traktować je należy raczej jako cel, do którego dążyć ma edukacyjna rzeczywistość w perspektywie wieloletniej i wieloetapowej. W takim ujęciu i zgodnie z założeniami dokumentu, jest on podstawą do działań w obszarze stanowienia prawa, wyznaczanego dalekosiężnymi celami polityki oświatowej. 
Porównywanie zatem postulowanego w ten sposób, dalekosiężnego w swych celach stanu kompetencji informatycznych nauczycieli $\mathrm{z}$ ich aktualnym stanem faktycznym, musi skutkować dużą dysproporcją na niekorzyść współczesnych nauczycieli, która nie świadczy jednak o braku chęci rozwoju, czy ogromnym zapóźnieniu, ale o daleko zakreślonej perspektywie postulatów zawartych w omawianym dokumencie. Zakres tych postulatów daleko również wykracza poza obszar objęty badaniem sondażowym, mimo że 6-stronicowa forma ankiety mogła swą objętością zbliżać się do granicy zniechęcającej niektórych nauczycieli do udziału w badaniach. Porównywanie takie zatem nie byłoby ani rzetelne ani zasadne. Jedynym celem takiego zabiegu może być monitorowanie urzeczywistniania śmiałych postulatów i wyznaczanie bieżących celów operacyjnych na drodze do realizacji wizji nakreślonej przez grono ambitnie i niewątpliwie profesjonalnie ujmujących problem doradców ministra. Takie ujęcie nie mieści się jednak w celach badawczych niniejszej pracy, dlatego zasadnym będzie ograniczenie tytułowego porównania do dokumentów, które posiadając aspekt dyrektywności, zachowują warunki porównywalności, dotyczące wzorem dramatu antycznego - jedności czasu, miejsca i akcji.

Polska Rada Muzyczna, która również ma aspiracje wpływania na kreowanie polityki oświatowej państwa, daleko skromniej formułuje postulaty angażowania TI w proces dydaktyczny, za to - zgodnie ze swoją misją - eksponuje takie działania w ramach przedmiotu muzyka. Standardy edukacji kulturalnej ${ }^{32}$, opracowane przez Fundację Polskiej Rady Muzycznej, posiadają jedynie opiniotwórczy charakter, podkreślony podtytułem: Materiały do konsultacji środowiskowych, co każe je traktować jako jeszcze mniej sprecyzowane, bo na etapie konsultacji środowiskowych, sugestie. Rezygnując z dalekowzrocznie formułowanych postulatów, Rada przewiduje w stosunku do uczniów klas IV-VI konieczność „nabycia umiejętności posługiwania się programami komputerowymi do zapisywania i tworzenia muzyki" ${ }^{33}$. Jest to bardzo skromne ujęcie ale niezwykle celne i ważne dla edukacji muzycznej. Skupia się bowiem na zaangażowaniu TI w proces ekspresji twórczej dziecka, a więc najwyższą formę obcowania z kulturą muzyczną. Potencjał TI polegający na uprzystępnianiu artystycznej formy wypowiedzi nie jest dostępny przy zastosowaniu powszechnych w edukacji informatycznej programów komunikacyjnych czy pakietu programów biu-

\footnotetext{
${ }^{32}$ A. Białkowski (red.), Standardy edukacji kulturalnej...

${ }^{33}$ Ibidem, s. 131.
} 
rowych. Podkreślenie potrzeby specjalistycznie muzycznego oprogramowania jest obecne tylko w dokumencie Polskiej Rady Muzycznej i dlatego wart jest uwzględnienia w tytułowym porównaniu, mimo bardzo skromnego ilościowo potraktowania TI w edukacji muzycznej. W takim więc bardzo skromnym ilościowo ale znaczącym jakościowo - zakresie, należy uwzględnić Standardy edukacji kulturalnej... w alternatywnym do dyrektywnego, złożonym jedynie z sugestii, postulowanym stanie kompetencji informatycznych nauczycieli muzyki. Trzecia zatem wersja postulowanego stanu kompetencji informatycznych nauczyciela, oparta na sugestiach Polskiej Rady Muzycznej, opatrzona zostanie przymiotnikiem „muzyczna” i reprezentowana skrótem SP3.

Ostatni z przytoczonych niedyrektywnych dokumentów, dotyczących kompetencji informatycznych nauczycieli - Edukacja w Europie: różne systemy kształcenia i szkolenia..., sformułowany przez Dyrektoriat Generalny ds. Edukacji i Kultury Komisji Europejskiej - ogranicza się do postulatów wobec polityki oświatowej, formułując kompetencje informatyczne nauczycieli jako efekt działań władz oświatowych. Zatem samo porównanie kompetencji na podstawie tak formułowanych sugestii staje się bezzasadne wobec różnych podmiotów jak i przedmiotów stanu postulowanego oraz faktycznego kompetencji informatycznych.

Konkludując, porównanie stanu postulowanego ze stanem faktycznym kompetencji informatycznych nauczycieli muzyki można dokonać na podstawie dokumentów dyrektywnych, wyznaczających prawem obowiązki nauczyciela. Stosując takie kryterium możemy określić stan postulowany w dwóch wersjach: „aktualnej” (SP1) i „przyszłościowej” (SP2). Natomiast z omówionych dokumentów niedyrektywnych, zasadnym będzie uwzględnienie jedynie lakonicznej choć ważnej sugestii Polskiej Rady Muzycznej, zawartej w Standardach edukacji kulturalnej..., która jest treścią trzeciej wersji stanu postulowanego - „muzycznej” (SP3).

Przyjęte zatem zostaną trzy różne wersje postulowanego stanu kompetencji informatycznych nauczycieli muzyki:

SP1 - dyrektywna - „aktualna”;

SP2 - dyrektywna - „przyszłościowa”;

SP3 - niedyrektywna - „muzyczna”,

które będą podstawą do porównania ze stanem rzeczywistym (SR), ustalonym w toku badań. Takie punkty odniesienia stanowić będą podstawę do wniosków formułowanych w dalszej części niniejszej pracy. 


\subsubsection{Zestawienie stanu rzeczywistego (SR) kompetencji informatycznych badanych nauczycieli z trzema wersjami stanu postulowanego (SP)}

Treścią tego rozdziału jest odpowiedź na pytanie, będące czwartym problemem badawczym: w jakim stopniu zgodne są postulowany i faktyczny stan kompetencji informatycznych badanej grupy nauczycieli?

Na podstawie ustalonych wyznaczników trzech wersji stanu postulowanego (rozdział 4.2.1.) oraz wynikającego $\mathrm{z}$ badań faktycznego stanu kompetencji informatycznych badanej grupy nauczycieli (rozdział 4.1.4.), zidentyfikowany zostanie stopień podobieństwa obu stanów, będący wyrazem zadośćuczynienia wymaganiom stawianym nauczycielom.

\section{Zestawienie SR - SP1}

Pierwsza wersja ustalonego stanu postulowanego kompetencji informatycznych nauczycieli muzyki (SP1) sprowadza się do następującego kryterium: „wykorzystywanie w pracy dydaktycznej multimedialnych źródeł muzyki i informacji o muzyce". Konfrontacja tego warunku ze stanem rzeczywistym kompetencji informatycznych badanej grupy nauczycieli (SR) polegać będzie na zestawieniu tego warunku z odpowiedziami na pytanie 8 . ankiety.

Punkt „a” tego pytania zawiera deklarację wykorzystywania multimedialnych źródeł informacji o muzyce i brzmi:

„8. Czy stosuje Pan/i technologię komputerową w:

a) przygotowywaniu się do zajęć (odświeżanie lub pogłębianie własnej wiedzy, szukanie nowych informacji, ciekawych konspektów lekcji $\mathrm{i}$ in.)?"

Odpowiedź „b” natomiast wyczerpuje drugą część postulowanej dyspozycji i brzmi:

„b) przygotowywaniu materiałów dla uczniów (nuty, nagrania, ilustracje, prezentacje i in.)?”

Zaznaczenie przez ankietowanego obydwu punktów w odpowiedzi na pytanie 8. oznaczać będzie deklarację spełnienia warunków pierwszej wersji postulowanego stanu kompetencji informatycznych. Weryfikację takiej deklaracji stanowić może odpowiedź „a” na pytanie 10. ankiety nauczycielskiej, które brzmi: 
„10. Jakiego rodzaju programy lub zastosowania komputerowe wykorzystuje Pan/i w pracy z uczniami (proszę o podanie nazw programów, tytułów stron internetowych):

a) wyszukiwanie i gromadzenie informacji lub nagrań potrzebnych do zajęć; (tytuły stron internetowych: .)".

Weryfikacja taka będzie dwustopniowa. Odpowiedź polegająca jedynie na zaznaczeniu interesującego nas punktu będzie powtórzeniem deklaracji z pytania 8. Natomiast uzupełnienie odpowiedzi, zgodnie z instrukcją, o tytuły wykorzystywanych stron internetowych zweryfikuje deklarację, nadając odpowiedzi walor wiarygodności. Z uwagi na nieco szerszy zakres odpowiedzi 8. „a” i 8. „b”, w stosunku do precyzyjnie odzwierciedlającej wymagania stanu postulowanego odpowiedzi 10. „a”, pierwszy z zaproponowanych wyżej sposobów weryfikacji należy uznać za wymagany. Drugi sposób weryfikacji możemy traktować jedynie orientacyjnie, przyjmując, że przyczyny braku doprecyzowania odpowiedzi mogą być różne (np. korzystanie z zasobów internetowych bez preferowania konkretnych portali) i niekoniecznie muszą polegać na fałszywości deklaracji.

Na pytanie 8. odpowiedzi „a" i „b” traktowane łącznie udzieliło 75 badanych $(88,2 \%)$, deklarując w ten sposób spełnienie warunków SP1. W odpowiedziach na pytanie 10 . tylko 58 badanych $(68,2 \%)$ potwierdziło wcześniejszą deklarację i tą liczbę przyjąć należy jako odsetek nauczycieli spełniających w warstwie deklaratywnej warunek SP1. Natomiast tylko 48 badanych $(56,5 \%)$ potwierdziło swoje deklaracje przez podanie tytułów stron internetowych wykorzystywanych jako źródła nagrań muzycznych i informacji o muzyce.

Wykres 23. Wskaźnik zbieżności poziomu kompetencji informatycznych badanych nauczycieli (SR) z pierwszą wersją poziomu postulowanego (SP1)

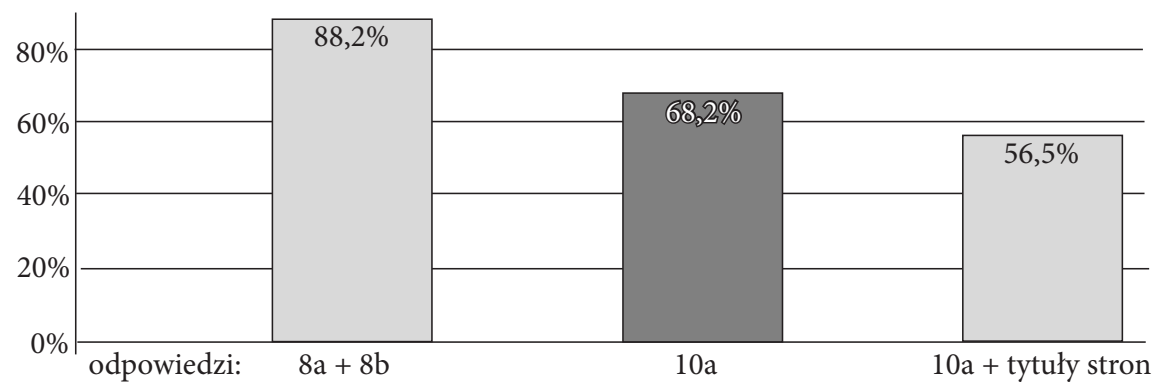

(źródło: badania własne) 
Na podstawie poczynionych wcześniej założeń, spełnienie warunków SP1 jest udziałem $68,2 \%$ nauczycieli z badanej grupy. Nieco ponad połowa badanych $(56,5 \%)$ spełniła ostrzejsze kryteria - potrafiła udowodnić swoją deklarację przez podanie adekwatnych do postulowanych zastosowań stron internetowych.

\section{Zestawienie SR - SP2}

Druga, „przyszłościowa” wersja stanu postulowanego kompetencji informatycznych nauczycieli muzyki (SP2), wyznaczona została na podstawie zapisów Standardów kształcenia przygotowującego do wykonywania zawodu nauczyciela. Wymagania te zostały przez ministerstwo ujęte w trzech płaszczyznach omówionych w rozdziale 4.2.1.:

1. doskonalenie własnego warsztatu pedagogicznego;

2. komunikowanie się;

3. praca dydaktyczna ${ }^{34}$.

Do weryfikacji pierwszego punktu pomocne będą odpowiedzi ankietowanych nauczycieli na pytanie 8a.: „Czy stosuje Pan/i technologię komputerową w przygotowywaniu się do zajęć (odświeżanie lub pogłębianie własnej wiedzy, szukanie nowych informacji, ciekawych konspektów lekcji i in.)?” Dodatkowym kryterium będzie również udział w kursach doskonalących lub studiach podyplomowych z zakresu TI (odpowiedzi 13c. i 13d.), będący bezpośrednim wyrazem doskonalenia warsztatu pedagogicznego w obszarze dotyczącym przedmiotu badań.

Na pytanie 8a. tylko jeden $\mathrm{z}$ badanych nauczycieli udzielił odpowiedzi negatywnej. Jest to jednak przypadek nauczyciela, który wskazał zarówno kursy lub szkolenia w ramach doskonalenia zawodowego (odpowiedź 13c.), jak i studia podyplomowe (odpowiedź 13d.), jako źródła własnych umiejętności w posługiwaniu się komputerem. Możemy zatem uznać, że badana grupa nauczycieli deklaruje w 100\% wypełnienie pierwszego z wymogów kompetencyjnych, nałożonych na nich na mocy obowiązujących rozporządzeń.

Drugi z punktów wymagań SP2 wobec nauczycieli, podlegać będzie weryfikacji na podstawie odpowiedzi na pytanie 18.: "Jakie programy komunikacyjne potrafi Pan/i obsługiwać...?” Umiejętność obsługi programów komunikacyjnych jest bowiem warunkiem niezbędnym w komunikowaniu się za pośrednictwem TI. Nie jest to jednak warunek wystarczający,

\footnotetext{
${ }^{34}$ Por.: tekst odsyłający do przypisów 27 i 28.
} 
można bowiem korzystanie $\mathrm{z}$ usług internetowych ograniczyć do biernego czerpania $\mathrm{z}$ dostępnych $\mathrm{w}$ sieci zasobów, poprzestając tym samym na jednostronnym modelu komunikacji. Taka bierna forma nie wyczerpuje jednak znamion „umiejętnego komunikowania się przy użyciu różnych technik...", będącego podstawą sformułowania tego warunku SP2. Odpowiedź „a” („przeglądarka internetowa”) na pytanie 18. ankiety skierowanej do nauczycieli, nie wyczerpuje zatem jednoznacznie znamion komunikowania się, o jakim mówi rozporządzenie o standardach kształcenia przyszłych nauczycieli, choć istnieją formy korzystania z przeglądarki internetowej, spełniające te warunki (np. fora internetowe). Odpowiedzi „,”” („program pocztowy”) oraz „c” („komunikator internetowy”) dotyczą już jednoznacznie informatycznych narzędzi komunikowania się, zgodnych z intencją autorów rozporządzenia.

Należy również zauważyć, że ustalenia co do narzędzi komunikacji nie implikują wniosków na temat przedmiotu komunikacji ani podmiotów, z którymi badani nauczyciele się komunikują. Jasno sformułowany postulat standardów kształcenia: „umiejętnie komunikuje się przy użyciu różnych technik, zarówno z osobami będącymi podmiotami działalności pedagogicznej, jak i z innymi osobami współdziałającymi w procesie dydaktyczno-wychowawczym oraz specjalistami wspomagającymi ten proces”, nie może zatem zostać zweryfikowany na podstawie odpowiedzi na pytania ankiety. Weryfikacji może podlegać jedynie warunek instrumentalny - deklarowana przez badanych umiejętność obsługi programów niezbędnych do postulowanej formy komunikacji, czyli odpowiedzi na pytanie 18. ankiety skierowanej do nauczycieli.

Traktując deklarację o umiejętności obsługi programów komunikacyjnych jako warunek konieczny do spełnienia drugiego kryterium SP2, uznać za niekompetentnych należy tych z badanych, którzy na pytanie 18. ankiety nie udzielili żadnej pozytywnej odpowiedzi.

Strukturę i analizę odpowiedzi na pytanie 18. zaprezentowano w rozdziale 4.1.2. (oprogramowanie). W tym miejscu należy tylko odnotować rozmiary braków odpowiedzi na to pytanie. Tylko jedna $z$ badanych osób pozostawiła to pytanie bez zaznaczenia jakiejkolwiek kategorii programów. Ta sama jednak osoba nie zaznaczyła również żadnej z odpowiedzi na pytania 19., 20. i 21. - podobne w formie, ale dotyczące innej grupy programów. Możliwe zatem, że nie przyczyny merytoryczne były przyczyną braku odpowiedzi na te pytania. Przypuszczenie takie potwierdzają inne odpowiedzi. 
Na pytanie 10. - „Jakiego rodzaju programy lub zastosowania komputerowe wykorzystuje Pan/i w pracy z uczniami (proszę o podanie nazw programów, tytułów stron internetowych)” - w punkcie „a” nauczyciel podał serwis internetowy profesor.pl, będący głównie forum wymiany konspektów i scenariuszy lekcji, zbiorem przepisów prawa oświatowego, miejscem publikacji własnych materiałów oraz zbiorem aktualności dotyczących działalności nauczyciela. Takie forum spełnia warunki komunikacji „z osobami będącymi podmiotami działalności pedagogicznej, jak i z innymi osobami współdziałającymi w procesie dydaktyczno-wychowawczym oraz specjalistami wspomagającymi ten proces”. Zatem brak odpowiedzi na pytanie 18. nie oznacza niekompetencji w zakresie objętym tym pytaniem.

Należy zatem uznać, że $100 \%$ badanych nauczycieli spełnia - w sferze deklaratywnej - warunek postulowanego stanu kompetencji informatycznych w zakresie umiejętności komunikowania się.

Trzeci z ogólnie nakreślonych postulatów (obszarów) SP2 dotyczy stosowania narzędzi informatycznych w pracy dydaktycznej. Odwołanie do tej sfery kompetencji informatycznych nauczyciela odnajdziemy w pytaniach 8., 10. i 26. Na podstawie analizy odpowiedzi na te pytania, przeprowadzonej $\mathrm{w}$ rozdziale 4.1.2. (zastosowania) można wysnuć wniosek, że na poziomie deklaracji (pytanie 8.) warunek ten spełniają wszyscy ankietowani nauczyciele $^{35}$. Jednak weryfikacja deklaracji dokonana na podstawie odpowiedzi na pytanie 10. każe przyjąć mniej optymistyczne wnioski. 22 ankietowanych $(25,9 \%)$ nie podało bowiem w odpowiedzi na to pytanie żadnej nazwy znanego i używanego przez nich w pracy dydaktycznej programu lub adresu strony internetowej. Należy więc uznać, że taki właśnie odsetek badanych nauczycieli nie spełnia postulatu o stosowaniu TI w pracy dydaktycznej ${ }^{36}$.

Graficzne ujęcie trzech obszarów zastosowania TI przez nauczycieli, stanowiących kryteria SP2, przedstawia wykres 24.

\footnotetext{
${ }^{35}$ Por.: tabela 4.

${ }^{36}$ Przyjęcie ostrzejszych warunków weryfikacji prawdziwości deklaracji nauczycieli niż w przypadku ich konfrontacji z pierwszą wersją stanu postulowanego wynika z dużo szerszego pola zastosowań dydaktycznych. O ile bowiem zrozumiałe może być wyszukiwanie źródeł informacji bez zapamiętywania adresu strony, o tyle korzystanie $\mathrm{z}$ dowolnego programu w pracy dydaktycznej wiąże się z jego opanowaniem oraz zapamiętaniem nazwy, co jest niezbędne choćby do samego uruchomienia programu na komputerze. Jeśli nauczyciel nie zna nazwy programu, z dużym prawdopodobieństwem można przyjąć, że nie zdoła go odnaleźć, uruchomić, a tym bardziej wykorzystać w pracy dydaktycznej.
} 
Wykres 24. Wskaźnik zbieżności SR z SP2 w 3 obszarach ogólnych

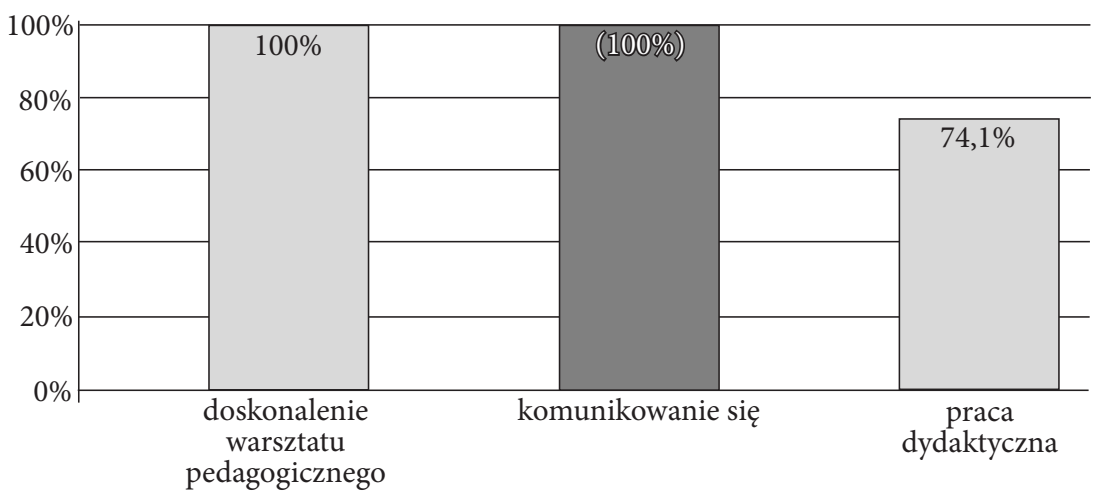

(źródło: badania własne)

Wyróżnienie obszaru komunikowania się wynika z ograniczonej porównywalności stanu postulowanego, który w Standardach... dookreślony został następująco: „umiejętnie komunikuje się przy użyciu różnych technik, zarówno z osobami będącymi podmiotami działalności pedagogicznej, jak i z innymi osobami współdziałającymi w procesie dydaktyczno-wychowawczym oraz specjalistami wspomagającymi ten proces" ${ }^{\prime 3}$, ze stanem rzeczywistym, który określony został jedynie jako znajomość narzędzi komunikacji, bez identyfikowania podmiotów komunikacji. Zbieżność w tym przypadku polega więc wyłącznie na wspólnych narzędziach, niezbędnych do uznania ankietowanych za kompetentnych informatycznie w obszarze komunikowania się i nie wyczerpuje wszystkich warunków stanu postulowanego, sprecyzowanego w dokumentach.

W ramach tak ogólnie nakreślonych obszarów SP2, wymagane jest korzystanie przez nauczycieli $\mathrm{z}$ następujących narzędzi informatycznych:

1. edytor tekstu;

2. arkusz kalkulacyjny;

3. bazy danych;

4. prezentacje multimedialne;

5. przeglądarka internetowa;

6. wyszukiwarka internetowa;

7. program pocztowy.

\footnotetext{
${ }^{37}$ Dz.U. Nr 25 poz. 131 z 6 lutego 2012, s. 1.
} 
Należy podkreślić, że stan postulowany ma ograniczyć się, według omawianych dokumentów, do „podstawowej wiedzy i umiejętności” ${ }^{38} \mathrm{~W}$ zakresie posługiwania się narzędziami informatycznymi.

Do weryfikacji tak sformułowanych postulatów posłużyły odpowiedzi na pytania 18. oraz 19., przytoczone i analizowane w rozdziale 4.1.2. (oprogramowanie). Zakres przedmiotowy obydwu pytań ogranicza się do umiejętności obsługi interesujących programów i w całości wyczerpuje warunek posiadania „podstawowej wiedzy i umiejętności”. W tym miejscu zasadne jednak będzie przytoczenie liczebności odpowiedzi dotyczących znajomości konkretnych programów, bez ujmowania ich w grupy programów komunikacyjnych i programów biurowych, jak miało to miejsce w rozdziale dotyczącym używanego przez ankietowanych oprogramowania.

Pierwsze z narzędzi - edytor tekstu - było treścią odpowiedzi 19 „a”. Opcję taką zakreśliło 77 ankietowanych (90,6\%), deklarując w ten sposób umiejętność posługiwania się takim programem. Dodatkowo $53 \mathrm{z}$ nich (62,4\% wszystkich badanych) potwierdziło znajomość programu podając jego nazwę. Znowu więc możemy posłużyć się dwoma sposobami interpretacji odpowiedzi: biorąc pod uwagę same deklaracje ankietowanych lub odpowiedzi potwierdzone znajomością nazwy adekwatnego programu.

Następne narzędzie - arkusz kalkulacyjny - było przedmiotem odpowiedzi 19 „b”. Jego znajomość zadeklarowało 38 badanych nauczycieli (44,7\%) a potwierdziło ją podaniem właściwej nazwy 29 (34,1\%).

Znajomość kolejnego narzędzia nie daje się już w tak łatwy sposób zidentyfikować ze względu na jego niedookreślenie. Po stronie stanu postulowanego „umiejętność [...] korzystania z baz danych” może bowiem oznaczać - analogicznie do dwóch wcześniejszych umiejętności - znajomość programów do tworzenia i obsługi baz danych (np. Microsoft Access lub Open Office Base), lub tylko korzystanie z zewnętrznych baz, które w najprostszej formie można utożsamić np. z bazą konspektów lekcji, dostępnych na portalach poświęconych edukacji, czy nawet $\mathrm{z}$ książką adresową programu pocztowego.

$\mathrm{W}$ ankiecie dla nauczycieli program do obsługi baz danych wraz $\mathrm{z}$ innymi, nie wymienionymi z nazwy składnikami pakietów biurowych, został umieszczony w punkcie 19 „d” („inne”), co było wyrazem subiektywnie niskiej oceny autora możliwych jego zastosowań dydaktycznych. Pozostając przy takiej ocenie, można przyjąć, że tworzenie i obsługa baz danych wy-

\footnotetext{
${ }^{38}$ Ibidem, s. 4.
} 
kracza daleko poza „korzystanie z baz danych w podstawowym zakresie”. Wyrazem tego są również odpowiedzi ankietowanych: tylko $5 \mathrm{z}$ nich (5,9\%) zaznaczyło odpowiedź „d” - ,inne” i żadna z tych odpowiedzi nie zawierała nazwy programu do obsługi baz danych.

Dodatkową okolicznościąjest fakt, że coraz więcej szkółkorzysta z dziennika elektronicznego, który również jest rodzajem bazy danych. Duża część nauczycieli posługuje się już taką wersją dziennika a coraz powszechniejsze jego stosowanie każe sądzić, że w najbliższym czasie wszyscy nauczyciele będą przeszkoleni i zobowiązani do jego obsługi. Wobec powyższego możemy przyjąć, że korzystanie z baz danych, choć nie zweryfikowane ankietą, jest lub w najbliższym czasie będzie umiejętnością powszechną wśród wszystkich nauczycieli, a stan ten osiągnięty zostanie osobną, , uprzywilejowaną" ścieżką, wymuszoną przez konieczność obsługi elektronicznej wersji dziennika.

Kolejny punkt szczegółowo ujętych „przyszłościowych” kompetencji postulowanych dotyczy wykorzystywania prezentacji multimedialnych. Odpowiedź 19 „" ankiety nauczycieli dotyczy tej właśnie umiejętności. 49 respondentów $(57,6 \%)$ przyznało, że potrafi obsługiwać program o takim zastosowaniu, przy czym 33 osoby (38,8\%) podały jego prawidłową nazwę (MS Power Point oraz po jednej odpowiedzi: Impress i MediaBlender). Porównując znajomość wśród badanych nauczycieli kolejnych składników pakietu biurowego, musi martwić, że program do prezentacji multimedialnych o ewidentnie dydaktycznym potencjale, pozwalający na wizualizację treści nauczania, jest mniej znany od typowo „administracyjnego" edytora tekstu czy „księgowego” arkusza kalkulacyjnego. Może to świadczyć o istotnym zachwianiu proporcji w obowiązkach nauczyciela, który być może zobowiązany jest do coraz większego zaangażowania w sprawy administracyjno-księgowe, sprawozdawcze itp., ze szkodą dla aktywności dydaktycznej.

Kolejne trzy składniki SP2 sprowadzają się do umiejętności korzystania z programów ujętych w ankiecie jako komunikacyjne. Są to: przeglądarka internetowa, której znajomość zadeklarowało w odpowiedzi 18 „a" 82 ankietowanych (96,5\%); program pocztowy, który znany jest 71 ankietowanym $(83,5 \%$ odpowiedzi 18 „b) oraz wyszukiwarka internetowa, która nie była przedmiotem oddzielnego zapytania ankietowego.

Pośrednio możemy jednak wnioskować na temat wykorzystywania wyszukiwarki przez ankietowanych na podstawie odpowiedzi na pytanie 8 „a" - „Czy stosuje Pan/i technologię komputerową w: a) przygotowywaniu się 
do zajęć (odświeżanie lub pogłębianie własnej wiedzy, szukanie nowych informacji, ciekawych konspektów lekcji i in.)” oraz na pytanie 10 „a” - „Jakiego rodzaju programy lub zastosowania komputerowe wykorzystuje Pan/i w pracy z uczniami (proszę o podanie nazw programów, tytułów stron internetowych): a) wyszukiwanie i gromadzenie informacji lub nagrań potrzebnych do zajęć”. Odpowiedzi twierdzące na te pytania udzieliło odpowiednio: 84 ankietowanych $(98,8 \%)$ oraz 67 ankietowanych $(78,8 \%)$, przy czym zbiory odpowiedzi negatywnych na obydwa pytania są rozłączne, co oznacza, że na podstawie jednej lub drugiej odpowiedzi możemy uznać, że wszyscy ankietowani potrafią wyszukiwać w internecie potrzebne informacje. Nie można stwierdzić na podstawie tak sformułowanych pytań, czy badani wykorzystują zdefiniowane w postulatach narzędzie (wyszukiwarka internetowa) ale efekt ich działań jest w 100\% zgodny z założeniami postulatu. Uznać zatem można, że ten postulat znalazł swoje potwierdzenie w umiejętnościach badanych nauczycieli, tym bardziej, że wielu z nich utożsamia przeglądarkę internetową $\mathrm{z}$ wyszukiwarką, wymieniając nazwę google w odpowiedzi na pytanie o stosowaną przeglądarkę internetową (21 odpowiedzi „google” na pytanie 18 „a”).

Graficzne ujęcie siedmiu szczegółowo formułowanych kryteriów dotyczących składników SP2 przedstawia poniższy wykres.

Wykres 25. Wskaźniki zbieżności SR z 7 szczegółowymi składnikami SP2

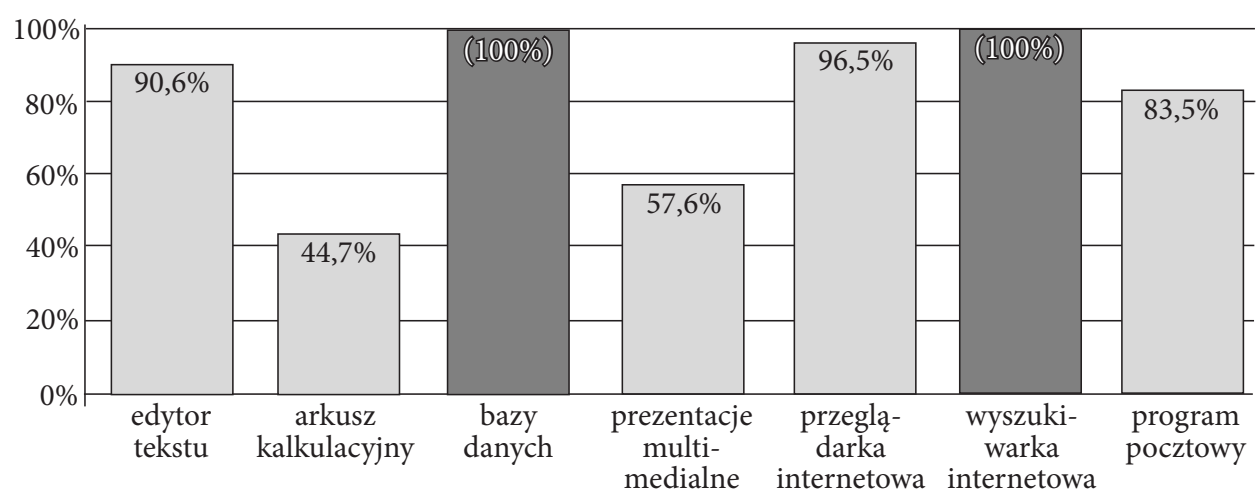

(źródło: badania własne)

Odmienne graficzne potraktowanie dwóch kategorii (baz danych oraz wyszukiwarki internetowej) symbolizuje omówiony wyżej odmienny sposób porównania, wynikający z braku bezpośredniego odniesienia badanych 
poziomów. Przyjęty w obu przypadkach poziom 100\% również został uzasadniony powyżej.

Wysoki odsetek nauczycieli znających większość narzędzi informatycznych zawartych w SP2, nie znajduje potwierdzenia jedynie w przypadku arkusza kalkulacyjnego oraz edytora prezentacji multimedialnych. Omówienie tych dwóch przypadków rozbieżności znajduje się w następnym rozdziale. W tym miejscu należy odnotować oscylujący blisko $90 \%$ poziom znajomości, dających się potwierdzić bezpośrednimi wynikami ankiety, trzech elementów postulowanego stanu kompetencji informatycznych oraz szacowany na bliski $100 \%$, na podstawie pośrednich przesłanek, poziom pozostałych dwóch składników.

Pozostaje określić odsetek badanych nauczycieli, którzy spełniają łącznie wszystkie warunki drugiej wersji postulowanego stanu kompetencji informatycznych. Na podstawie trzech zakreślonych obszarów stosowania TI, z całej grupy 85 ankietowanych wykluczyć musimy 22, którzy w odpowiedzi na pytanie 10. nie potrafili podać żadnego programu wykorzystywanego w pracy dydaktycznej. Z pozostałej grupy 63 nauczycieli tylko 25 zadeklarowało znajomość wszystkich siedmiu narzędzi informatycznych (pięciu weryfikowalnych bezpośrednio ankietą i dwóch zweryfikowanych jedynie pośrednio i częściowo), składających się na kryteria SP2. Zatem tylko tych 25 nauczycieli $(29,4 \%)$ możemy uznać za spełniających kryteria SP2.

\section{Zestawienie SR - SP3}

Ostatnia, trzecia wersja postulowanego stanu kompetencji informatycznych nauczycieli muzyki, nie posiadająca waloru prawnego, ogranicza się do jednego warunku: „uczniowie klas IV-VI powinni nabyć umiejętność posługiwania się programami komputerowymi do zapisywania i tworzenia muzyki” ${ }^{39}$. Jest to postulat dotyczący efektów kształcenia, który pośrednio przypisać możemy do niezbędnych kompetencji nauczyciela, pod kierunkiem którego uczniowie mają nabyć wspomniane umiejętności.

Do umiejętności obsługi programów komputerowych, służących zapisywaniu i tworzeniu muzyki, odwołuje się pytanie 20 . ankiety skierowanej do nauczycieli, które brzmi:

„20. Jakiego rodzaju programy muzyczne potrafi Pan/i obsługiwać (proszę podać nazwę)?

\footnotetext{
${ }^{39}$ A. Białkowski (red.), Standardy edukacji kulturalnej..., s. 131.
} 


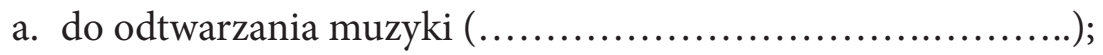

b. do zgrywania muzyki na płyty $(\ldots \ldots \ldots \ldots \ldots \ldots \ldots \ldots \ldots \ldots)$;

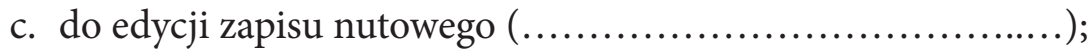

d. do obróbki i konwersji plików dźwiękowych (...............);

e. do komponowania muzyki (..............................);

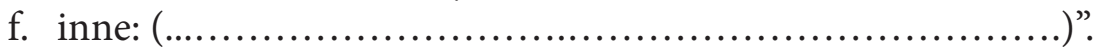

Programy przeznaczone do zapisu muzyki to kategoria programów nie dookreślona jednoznacznie. Zapisywanie muzyki może bowiem polegać zarówno na utrwaleniu jej na nośniku CD (odpowiedź „b”), w formie zapisu nutowego (odpowiedź „c”) lub jako edytowalny plik dźwiękowy (odpowiedź „d”). Przynajmniej jedną więc odpowiedź „b”, „c" lub „d” uznać się powinno za spełnienie warunku umiejętności zapisu muzyki. Programy zaś do tworzenia muzyki mieszczą się w kategorii „e” odpowiedzi na pytanie 20. ankiety. Zatem zaznaczenie łączne odpowiedzi „e” oraz jednej z trzech: „b”, „c" lub „d”, oznacza posiadanie przez nauczyciela postulowanych przez Polską Radę Muzyczną kwalifikacji. Jedynie kwalifikacji, ponieważ pytanie 20. dotyczy jedynie umiejętności obsługi wymienionych programów. Potwierdzenie zaś kompetencji wypływać będzie bezpośrednio $\mathrm{z}$ analogicznych odpowiedzi na pytanie 10. ankiety:

„10. Jakiego rodzaju programy lub zastosowania komputerowe wykorzystuje Pan/i w pracy z uczniami (proszę o podanie nazw programów, tytułów stron internetowych):

a. wyszukiwanie i gromadzenie informacji lub nagrań potrzebnych do zajęć; (tytuły stron internetowych: ...........)

b. programy do zgrywania muzyki na płyty; (nazwy programów:

c. programy do edycji nagrań muzycznych (przycinanie, zmiana tonacji itp.); (nazwy programów:

d. programy do edycji i druku zapisu nutowego; (nazwy programów:

e. programy pomocne w komponowaniu muzyki, tworzeniu utworu z gotowych elementów; (nazwy programów: .........)

f. programy do doskonalenia lub sprawdzania wiedzy i umiejętności muzycznych uczniów; (nazwy programów:

g. programy nie związane z muzyką (do tworzenia prezentacji, obróbki zdjęć, filmów, edytor tekstu) (nazwy programów: ...)

h. żadne z powyższych". 
W tym przypadku pytanie dotyczy wykorzystywania odpowiednich programów w pracy z uczniami, dotyczy więc pojęcia kompetencji. Spełnienie warunków SP3, tożsame będzie więc z zaznaczeniem przynajmniej dwóch odpowiedzi: „e” oraz jednej z trzech: „b”, „c” lub „d”.

Do ustalenia kompetencji w zakresie objętym wersją SP3 wystarczą odpowiedzi na pytanie 10., jednak odpowiedzi na pytanie 20. pozwolą na ustalenie, czy przyczyną zbyt małych kompetencji są braki w kwalifikacjach, czy też może brak trzeciego składnika kompetencji, opisanego w rozdziałach 2.1. i 2.2.

Odpowiedzi „e” na pytanie 10. udzieliło jedynie 19 ankietowanych (22,4\%), z których tylko jedna osoba nie zaznaczyła jednocześnie żadnej z odpowiedzi „b”, „C" lub „d”. Tak więc tylko 18 ankietowanych nauczycieli $(21,2 \%)$ spełnia kompetencyjne warunki SP3. Największą przeszkodą zatem okazał się składnik kryterium polegający na wykorzystywaniu programów do tworzenia muzyki - tylko 19 osób przyznało, że korzysta z takich narzędzi. 69 z badanych (81,2\%) spełniło drugi warunek, stwierdzając, że wykorzystuje na lekcjach co najmniej jedną kategorię programów do zapisu muzyki, zaznaczając odpowiedź „b” lub „c lub „d”.

Wykres 26. Wskaźniki zbieżności SR (kompetencji) ze składnikami oraz całością SP3 (N=85)

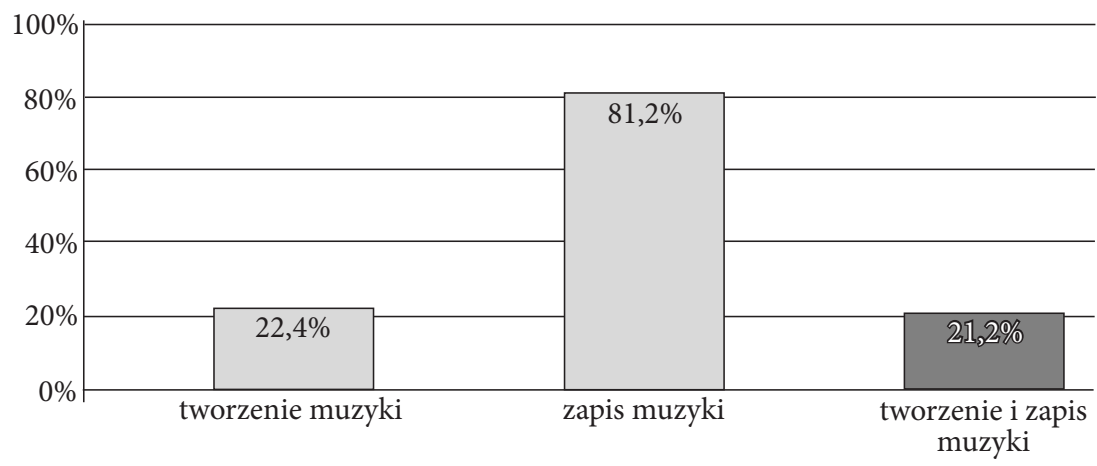

(źródło: badania własne)

Na podstawie odpowiedzi na pytanie 20. porównać można same kwalifikacje, będące podstawą wyżej sformułowanych kompetencji. Porównanie takie, ujęte $\mathrm{w}$ wykresie 27., przynosi następujące wyniki: $21 \mathrm{z}$ badanych nauczycieli $(24,7 \%)$ potrafi obsługiwać programy do tworzenia muzyki (odpowiedź 20 „e"), 74 respondentów $(87,1 \%)$ potrafi obsługiwać programy do zapisu muzyki (odpowiedź 20 „b” lub „c" lub „d”). Łącznie obydwa warunki spełnia 19 spośród ankietowanych nauczycieli $(22,4 \%)$. 
Wykres 27. Wskaźniki zbieżności kwalifikacji informatycznych badanych nauczycieli ze składnikami oraz całością SP3 $(\mathrm{N}=85)$

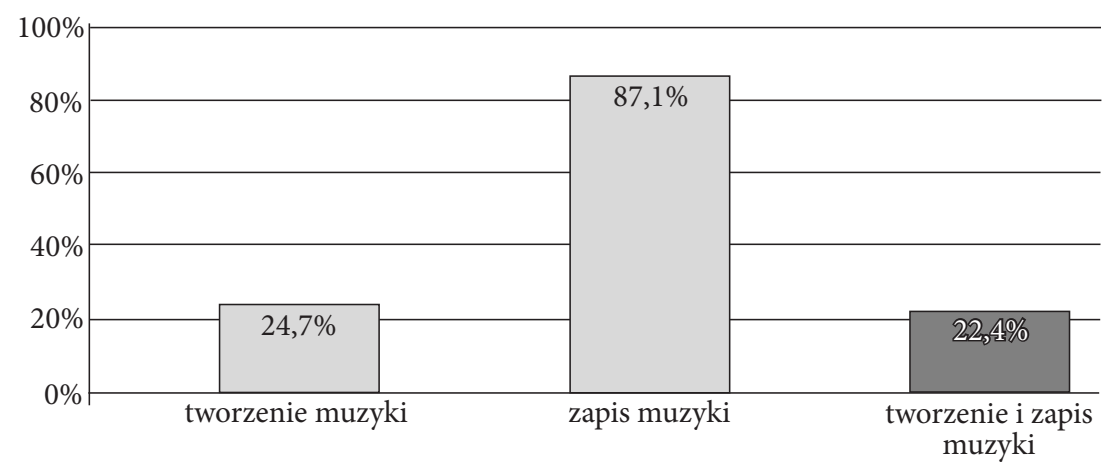

(źródło: badania własne)

W sześciu przypadkach brak kompetencji postulowanych w wersji trzeciej, polega na braku wykorzystywania posiadanych kwalifikacji. 4 ankietowanych bowiem deklaruje znajomość programów do zapisu muzyki, nie korzystając jednak z nich na lekcjach. 1 respondent nie wykorzystuje programów do tworzenia muzyki mimo posiadanych w tym zakresie kwalifikacji oraz $1 \mathrm{z}$ ankietowanych nie korzysta w pracy $\mathrm{z}$ uczniami ze swoich kwalifikacji w obszarze obydwu zastosowań. W przypadku pozostałych nauczycieli brak kompetencji zawartych w SP3, łączy się z brakiem umiejętności obsługi programów do zapisu i tworzenia muzyki - a więc brakiem kwalifikacji. 


\section{Podsumowanie}

Podsumowując wyniki zestawienia postulowanego stanu kompetencji muzycznych nauczycieli muzyki w trzech przyjętych w rozdziale 4.2.1. wersjach (SP1, SP2 i SP3), ze stanem rzeczywistym (SR), opartym na wynikach badania ankietowego, otrzymujemy 3 różne poziomy zgodności obydwu stanów, przedstawione na wykresie 28.

Wykres 28. Wskaźniki zbieżności SR z trzema wersjami SP ( $\mathrm{N}=85)$

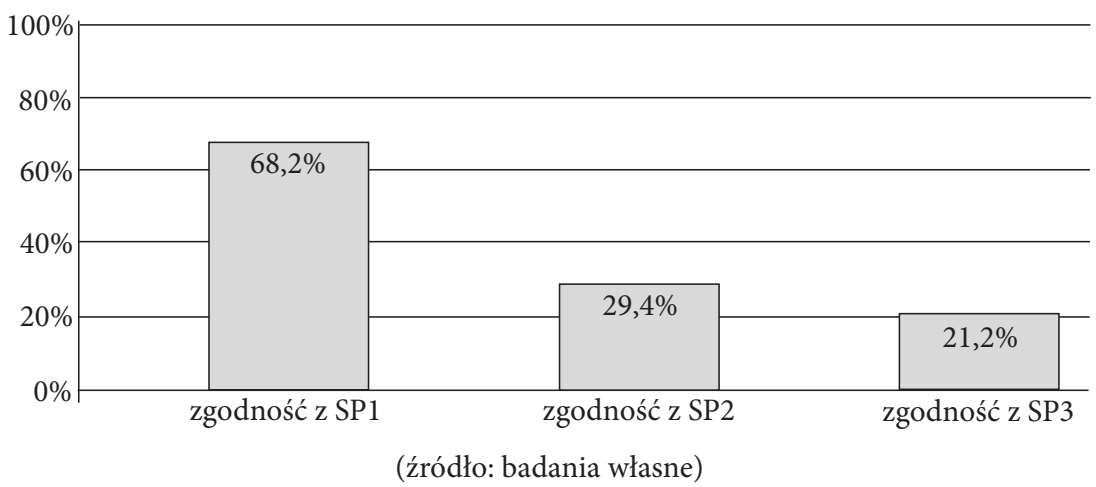

Obszary i skala rozbieżności między obydwoma poziomami kompetencji są przedmiotem następnego rozdziału.

\subsubsection{Rozbieżności między stanem postulowanym i rzeczywistym kompetencji informatycznych badanych nauczycieli}

Rozbieżności, podobnie jak samo zestawienie obu stanów kompetencji informatycznych nauczycieli, należy przedstawić w trzech wersjach, dotyczących trzech ujęć stanu postulowanego, przyjętych w rozdziale 4.2.1.

Ustalenie rozbieżności SR z SP1, wobec prostej, jednozdaniowej formy kryterium tego ostatniego, ogranicza się do wyznaczenia spośród badanych grupy nauczycieli niespełniających tego warunku. Zgodnie z ustaleniami poprzedniego rozdziału, 31,8\% ankietowanych nie spełnia kryterium SP1, polegającym na „wykorzystywaniu w pracy dydaktycznej multimedialnych źródeł muzyki i informacji o muzyce". Tak ustalona skala rozbieżności dotyczy deklaracji nauczycieli i ma charakter jakościowy. Ustalony w ten sposób rozmiar rozbieżności dotyczy stanu aktualnego, obowiązującego 
wszystkich nauczycieli i ten aspekt sprawia, że należy go interpretować ze szczególną uwagą i zaniepokojeniem. Każdy bowiem z niemal 32 procentów, składających się na tą rozbieżność, to konkretny nauczyciel, który nie spełnia warunków zatrudnienia określonych rozporządzeniami Ministra Edukacji Narodowej. Uzupełnienie ich kompetencji powinno więc mieć znaczenie priorytetowe a rozmiar rozbieżności należy traktować ze szczególnym zaniepokojeniem.

Ustalone w rozdziale 4.2.1. wyznaczniki SP2, polegają na znajomości 7 narzędzi informatycznych i stosowaniu ich w trzech obszarach aktywności nauczyciela. Znajomość 2 z tych narzędzi (bazy danych i wyszukiwarka internetowa) nie miała bezpośredniego odniesienia do danych zawartych $\mathrm{w}$ ankiecie a o ich znajomości wnioskowano na podstawie pośrednich przesłanek, opartych na zbliżonych przedmiotowo odpowiedziach ankietowych nauczycieli. Bezpośrednio więc na podstawie ankiety ustalono poziom SR badanych nauczycieli, dotyczący jedynie pięciu z postulowanych narzędzi, przyjmując poziom opanowania dwóch pozostałych za zadowalający.

Z grupy nauczycieli kompetentnych informatycznie na podstawie kryteriów SP2 wyłączono 22 badanych (25,9\%), którzy nie potrafili wymienić ani jednego programu, wykorzystywanego w ich pracy dydaktycznej. Taki obszar wykorzystywania był bowiem jednym z trzech obowiązkowych w tej wersji kryteriów. Kryteria dotyczące znajomości 5 weryfikowanych ankietą narzędzi informatycznych, spełnia tylko 28 ankietowanych. Pozostałych $57 \mathrm{z}$ nich $(67,1 \%)$ przyznało w ankiecie, że nie potrafi obsługiwać od jednego do pięciu programów uznanych za wyznaczniki SP2. Dokładne dane na ten temat, z podziałem na rozmiary braków, przedstawia poniższa tabela.

Tabela 23. Liczebność ankietowanych nauczycieli w zależności od ilości brakujących wyznaczników SP2 $(\mathrm{N}=85)$

\begin{tabular}{|c|c|c|c|c|c|c|c|}
\hline \multirow{2}{*}{$\begin{array}{c}\text { Ilość brakujących składników } \\
\text { SP2 }\end{array}$} & 0 & 1 & 2 & 3 & 4 & 5 \\
\cline { 4 - 8 } & & \multicolumn{7}{|c|}{ narzędzia } \\
\hline \multirow{2}{*}{$\begin{array}{c}\text { Liczba } \\
\text { respondentów }\end{array}$} & $\mathrm{n}$ & 28 & 26 & 18 & 10 & 2 & 1 \\
\cline { 2 - 8 } & $\%$ & 32,9 & 30,6 & 21,2 & 11,8 & 2,4 & 1,2 \\
\hline \multirow{2}{*}{ Suma } & $\mathrm{n}$ & 28 & \multicolumn{7}{c|}{57} \\
\cline { 2 - 8 } & $\%$ & 32,9 & \multicolumn{7}{|c|}{67,1} \\
\hline
\end{tabular}

(źródło: badania własne) 
Rozbieżności zatem SR i SP2 u 22 badanych $(25,9 \%)$ dotyczą niespełnienia kryteriów „obszarowych” a u 57 badanych $(67,1 \%)$ - niespełnienia kryteriów „narzędziowych” SP2. Na podstawie łącznie traktowanych obydwu kategorii kryteriów, z grupy nauczycieli kompetentnych informatycznie na podstawie SP2 wykluczyć należy 60 ankietowanych (70,6\%).

Znamiennym jest, że obszar zastosowań TI, w którym nauczyciele deklarują braki, to obszar zastosowań dydaktycznych TI. Natomiast nie budzi niedosytu wykorzystywanie TI przez nauczycieli w dwóch pozostałych obszarach: doskonalenie warsztatu pedagogicznego oraz komunikowanie się. Rozbieżność więc w 25,9\% ma charakter jakościowy i dotyczy wszystkich trzech składników kompetencji: wiedzy, umiejętności oraz „odpowiedzialnego działania" 40 .

Rozbieżność o charakterze ilościowym dotyczy natomiast znajomości narzędzi informatycznych i jest znacznie większa - 67,1\% - tylu nauczycieli nie zna co najmniej jednego z wymaganych kryteriami SP2 programów komputerowych. Największa z tych rozbieżności dotyczy znajomości arkusza kalkulacyjnego, który zgodnie z wykresem 25. jest znany tylko 44,7\% badanych nauczycieli. 63,3\% nauczycieli należy zatem wykluczyć z grona kompetentnych informatycznie w oparciu tylko o to jedno kryterium. Dla $19 \mathrm{z}$ nich $(22,4 \%)$ jest to jedyna rozbieżność ze stanem postulowanym w tej wersji, co każe zastanowić się nad jego kategorycznością. Zgodnie bowiem z kryteriami SP2, nauczyciel muzyki, który często wykorzystuje TI w swojej pracy dydaktycznej, wyszukując i prezentując uczniom materiały audiowizualne, prezentacje multimedialne, gry edukacyjne, quizy, testy, zaznajamia uczniów z programami umożliwiającymi tworzenie własnych kompozycji, zapis i edycję muzyki, nawet prowadzi własną stronę internetową, wykorzystywaną m.in. do komunikacji z uczniami - jeśli nie zna arkusza kalkulacyjnego, nie spełnia warunków kompetentnego informatycznie nauczyciela muzyki. Dyskusja jednak z kryteriami ustalonych stanów postulowanych możliwa jest tylko w aspekcie przyczyn omawianych tutaj rozbieżności, będących treścią rozdziału 4.3.

$57,6 \%$ ankietowanych natomiast deklaruje nieznajomość programu do tworzenia prezentacji multimedialnych, a więc narzędzia o największym, spośród zawartych w SP2, potencjale zastosowań dydaktycznych. Ta rozbieżność nie budzi już takich wątpliwości jak poprzednia, ponieważ w dużej mierze może być przyczyną braków w obszarze przytoczonych wcześniej

\footnotetext{
${ }^{40}$ Określenie przyjęte i rozwinięte w rozdziale 2.1. niniejszej pracy.
} 
zastosowań dydaktycznych. $Z$ tego względu należy tą rozbieżność uznać za ważną i tym bardziej podkreślić jej duży rozmiar.

Pozostałe, uwzględnione $w$ wykresie 25. narzędzia informatyczne, opanowane są przez badanych w dużym odsetku $(83,5 \%$ - 96,5\%). Pozwala to na stwierdzenie, że w ich przypadku rozbieżności można uznać za minimalne. Ich nieznacząco niski poziom pozwala sądzić, że naturalny proces wymiany kadr na rynku pracy pozwoli w krótkim czasie na ich zupełne wyeliminowanie, bez konieczności organizowania form doskonalenia zawodowego w tym zakresie dla obecnych nauczycieli muzyki.

Rozbieżności zatem SR i SP2 są natury zarówno jakościowej, jak i ilościowej, i dotyczą wszystkich trzech składników definicji kompetencji, którą przyjęliśmy w rozdziale 2.1 .

Trzecia wersja ustalonego stanu postulowanego kompetencji informatycznych nauczycieli muzyki (SP3), oparta na sugestiach Polskiej Rady Muzycznej, rodzi największe rozbieżności w zestawieniu ze stanem faktycznym. Aż 78,8\% badanych nauczycieli nie spełnia jego kryterium, polegającego na znajomości oprogramowania do zapisu i tworzenia muzyki. W tym przypadku budzi obawy zarówno rozmiar jak i przedmiot rozbieżności. Okazuje się bowiem, że specjalistycznie muzyczne oprogramowanie jest nieznane ogromnej większości nauczycieli muzyki. Naprawa tego stanu wydaje się niezbędna $z$ dwóch powodów: po pierwsze, nie można liczyć na to, że przybliżenie uczniom specjalistycznego muzycznego oprogramowania uzupełnić może nauczyciel informatyki, nie znający się na muzyce; po drugie zaś, ten rodzaj oprogramowania może być niezwykle pomocny w bardzo ważnej formie edukacji muzycznej - ekspresji twórczej.

Uznać zatem należy, że olbrzymi rozmiar rozbieżności SR i SP3, jak i jej zakres przedmiotowy, powinny budzić zaniepokojenie mimo braku obligatoryjności rozpatrywanego tu stanu postulowanego. Wyraźnie jakościowy charakter tej rozbieżności dotyczy dwóch pierwszych składników kompetencji: wiedzy i umiejętności, czyli kwalifikacji nauczycieli.

Powyższe wnioski oraz ich ujęcie w tabeli 24. potwierdzają drugą z hipotez szczegółowych, która została sformułowana następująco: poziom kompetencji informatycznych nauczycieli muzyki jest daleko niższy od postulowanego. Zwrot „daleko niższy” można uznać za całkowicie uzasadniony wobec rozbieżności sięgających od 31,8\% aż do 78,8\%. 
Tabela 24. Zestawienie parametrów rozbieżności SR z trzema wersjami SP

\begin{tabular}{|c|c|c|c|c|c|}
\hline \multicolumn{2}{|c|}{$\begin{array}{l}\text { wersja stanu postulowanego } \\
\text { konfrontowanego ze stanem } \\
\text { rzeczywistym }\end{array}$} & \multicolumn{2}{|c|}{ rozmiar rozbieżności } & $\begin{array}{l}\text { charakter } \\
\text { rozbieżności }\end{array}$ & $\begin{array}{l}\text { składnik kompe- } \\
\text { tencji, którego } \\
\text { dotyczy }^{*}\end{array}$ \\
\hline \multicolumn{2}{|c|}{ SP1 - „aktualna” } & \multicolumn{2}{|c|}{$31,8 \%$} & jakościowy & 3. \\
\hline \multirow{2}{*}{$\begin{array}{l}\text { SP2 - „przy- } \\
\text { szłościowa” }\end{array}$} & $\begin{array}{l}\text { rozbieżności ob- } \\
\text { szarów } \\
\text { zastosowań }\end{array}$ & $25,9 \%$ & \multirow{2}{*}{$\begin{array}{l}\text { suma } \\
\text { zbiorów } \\
=70,6 \%\end{array}$} & jakościowy & 1., 2., 3. \\
\hline & $\begin{array}{l}\text { rozbieżności w zna- } \\
\text { jomości narzędzi }\end{array}$ & $67,1 \%$ & & ilościowy & $1 ., 2$. \\
\hline \multicolumn{2}{|c|}{ SP3 - „muzyczna” } & \multicolumn{2}{|c|}{$78,8 \%$} & jakościowy & $1 ., 2$. \\
\hline
\end{tabular}

* trzy składniki kompetencji ustalono i przyjęto w rozdziale 2.1. (1. - wiedza, 2. - umiejętności oraz 3. - „odpowiedzialne działanie”)

(źródło: badania własne)

Na tej samej podstawie możemy zweryfikować ostatnią - czwartą hipotezę szczegółową, mówiącą, że brak składnika kompetencji informatycznych nazwanych tu odpowiedzialnym działaniem, to główna różnica między stanem postulowanym a rzeczywistym kompetencji informatycznych nauczycieli muzyki. Prawdziwość tej hipotezy należy uznać w odniesieniu do pierwszej wersji stanu postulowanego (SP1) oraz do tej części drugiej wersji (SP2), która dotyczy obszarów zastosowań TI. W pozostałych przypadkach różnica polega na nieznajomości konkretnych narzędzi informatycznych $\mathrm{w}$ postaci oprogramowania przydatnego w pracy nauczyciela muzyki.

\subsection{Przyczyny rozbieżności między stanem postulowanym i rzeczywistym kompetencji informatycznych badanych nauczycieli}

Ostatni, piąty problem badawczy sformułowany został następująco: jakie są przyczyny ewentualnej (spodziewanej) rozbieżności między obydwoma stanami (postulowanym i rzeczywistym) kompetencji informatycznych?

Przyczyny, dla których stan rzeczywisty kompetencji informatycznych nauczycieli muzyki nie dorównuje stanowi postulowanemu, formułowanemu w cytowanych dokumentach, można rozpatrywać na różnych poziomach. Na najogólniejszym z nich, rozbieżności są naturalną konsekwencją założeń oraz celów, dla których dokumenty te powstały. Standardy kształce- 
nia przygotowującego do zawodu nauczyciela to najnowsza wersja (2012 rok), kreowanego na mocy przepisów, wizerunku współczesnego nauczyciela. Jednym z celów Standardów... jest nadążanie za nowymi wyzwaniami czy nowymi koncepcjami pedagogicznymi tak, aby współczesny nauczyciel miał szansę współkreowania nowoczesnego społeczeństwa. Uaktualnianie zatem standardów kształcenia przyszłych nauczycieli musi wiązać się ze zmianami, wynikającymi z naturalnego procesu ich dezaktualizowania się. Dotychczasowe standardy stają się niewystarczające, a artykułowanie nowych ich wersji musi wiązać się ze stawianiem nowych wymagań, dotychczas nieuwzględnianych w wykształceniu nauczyciela. Naturalne więc jest, że nowe kompetencje, formułowane wobec przyszłego nauczyciela, wykraczają poza dotychczasowe ramy, a oczywiste rozbieżności to tylko nakreślenie nowych perspektyw, do których należy dążyć.

Podobnie Standardy edukacji kulturalnej są wyrazem postulowanych zmian w profilu kształcenia przyszłych nauczycieli muzyki. Formułowane przez Polską Radę Muzyczną niezbędne zmiany w kompetencjach nauczyciela muzyki są wynikiem obserwowanych potrzeb i sugestią ich uzupełnienia. Sugestie rozszerzenia tych kompetencji, podyktowane troską o poziom powszechnego kształcenia muzycznego, są nie tyle przyczyną, co konsekwencją zauważonych rozbieżności. Zatem same rozbieżności są przyczyną sugerowanych zmian w kompetencjach nauczyciela, a ich ewentualny brak byłby wystarczającym powodem do zignorowania tak sformułowanych postulatów.

Rozbieżności stanu rzeczywistego kompetencji informatycznych nauczycieli muzyki (SR) ze stanem postulowanym przez Podstawe programowa kształcenia ogólnego oraz warunki awansu zawodowego nauczycieli (SP1) nie pozwalają na podobne uzasadnienie, jak w przypadku pozostałych dwóch wersji. Są to bowiem podstawy prawne funkcjonowania zawodowego aktualnych nauczycieli i wskazują na poziom kompetencji, jaki powinien być ich udziałem. Nie ma zatem naturalnych przyczyn, formułowanych na podobnie ogólnym poziomie, dla których SP1 odbiega od aktualnego poziomu SR.

$\mathrm{Na}$ drugim biegunie ogólności sytuują się przyczyny rozpatrywanych rozbieżności omówione szczegółowo w rozdziale 4.1.3. Dotyczą one subiektywnego poczucia nauczycieli, na temat barier, jakich doświadczają, próbując wykorzystywać TI w dydaktyce muzyki, bądź przyczyn braku podejmowania takich prób. 
Między obydwoma biegunami ogólności odnajdziemy przyczyny rozbieżności, które należy traktować jako podstawę do zmian zarówno w profilu kształcenia przyszłych nauczycieli, dokształcania aktualnych, jak i weryfikacji wymagań oraz warunków pracy nauczycieli. Zostały one ujęte w trzech kolejnych podrozdziałach, reprezentujących trzy grupy przyczyn zidentyfikowanych rozbieżności.

\subsubsection{Przyczyny związane z postawą nauczyciela}

W każdym z przypadków omawianych rozbieżności, ich przyczynę można upatrywać po stronie nauczycieli, którzy nie podejmują wysiłków by uzupełnić swoje kompetencje. Jest to jednak obraz bardzo uproszczony. Nie wiemy bowiem czy to kompetencje nauczycieli wymagają rozszerzenia czy być może wymagania im stawiane są zbyt wysokie lub wręcz chybione. Ustalono do tej pory, że kompetencje rzeczywiste są mniejsze od postulowanych, co nie równa się stwierdzeniu, że są one zbyt małe. Druga z matematycznych możliwości każe wziąć pod uwagę również sytuację, gdy kompetencje postulowane są zbyt duże. Sytuacja taka miałaby miejsce, gdyby „nadwyżkę" kompetencji postulowanych uznać za zbędną.

Także uznanie rzeczywistych kompetencji nauczycieli za zbyt małe nie musi prowadzić do wniosku o niechęci do ich uzupełnienia. Uczestniczenie w różnych formach doskonalenia zawodowego nie jest skutkiem jedynie chęci nauczycieli ale przede wszystkim oferty szkoleniowej, która w zakresie zastosowań TI w dydaktyce muzyki jest wyjątkowo skromna.

Jednak przyczyny rozbieżności, które jednoznacznie leżą po stronie nauczycieli, również istnieją i należy je zidentyfikować. Należą do nich sytuacje, w których nauczyciel posiada niezbędną wiedzę oraz umiejętności ale brak mu trzeciego składnika kompetencji - odpowiedzialnego działania. Jeśli takie zaniechanie nie wynika np. z braku dostępności szkolnego sprzętu komputerowego, to należy uznać, że to postawa nauczyciela jest przyczyną braku odpowiednich kompetencji.

$\mathrm{W}$ odniesieniu do SP1, zgodnie $\mathrm{z}$ analizą rozbieżności przytoczoną w rozdziale 4.2.2., przypadki przyczyn leżących po stronie nauczyciela zidentyfikować można na podstawie różnicy liczebności grupy ankietowanych potrafiących korzystać z przeglądarki internetowej oraz grupy, która wykorzystuje tą umiejętność w przygotowaniu lub prowadzeniu zajęć. Grupa pierwsza to nauczyciele, którzy na pytanie 18. ankiety: „Jakie programy 
komunikacyjne potrafi Pan/i obsługiwać (proszę podać nazwę)?” zakreślili odpowiedź „a”: „przeglądarka internetowa”. Liczebność tej grupy wynosi 82 . Grupa druga to nauczyciele, którzy na pytanie 8.: „Czy stosuje Pan/i technologię komputerową w:” wybrali odpowiedź „a”: „przygotowywaniu się do zajęć (odświeżanie lub pogłębianie własnej wiedzy, szukanie nowych informacji, ciekawych konspektów lekcji i in.)?” oraz „,": „przygotowywaniu materiałów dla uczniów (nuty, nagrania, ilustracje, prezentacje i in.)?”, a następnie potwierdzili swoją deklarację, odpowiadając na pytanie 10.: „Jakiego rodzaju programy lub zastosowania komputerowe wykorzystuje Pan/i w pracy z uczniami (proszę o podanie nazw programów, tytułów stron internetowych):” przez wybór odpowiedzi „a”: „wyszukiwanie i gromadzenie informacji lub nagrań potrzebnych do zajęć”. Liczebność w ten sposób ustalonej grupy ankietowanych wynosi 58 . Zatem różnica tych dwóch liczb, wynosząca 24 (28,2\% wszystkich badanych), to ilość nauczycieli, którzy posiadając niezbędne kwalifikacje, nie przeistoczyli ich w kompetencje z własnej winy. Nie znajdujemy bowiem zewnętrznych uwarunkowań, dla których nauczyciel posiadając niezbędne kwalifikacje oraz możliwości, nie wykorzystuje ich do wzbogacenia swojego warsztatu pracy.

Rozbieżności SR z SP2 rozpatrywane były w dwóch płaszczyznach: obszarów zastosowań oraz znajomości narzędzi informatycznych. W płaszczyźnie obszarów zastosowań rozbieżności dotyczą jedynie wykorzystywania TI w pracy dydaktycznej i dotyczą 22 ankietowanych $(25,9 \%)^{41}$. Aby rozstrzygnąć ewentualne przypisanie nauczycielom winy za taki rozmiar rozbieżności, należy rozpatrzyć następujące możliwości:

1. Nauczyciel posiada niezbędne kwalifikacje lecz nie ma możliwości ich wykorzystania z powodu braku dostępności szkolnego sprzętu komputerowego.

2. Nauczyciel posiada niezbędne kwalifikacje lecz ich nie wykorzystuje w pracy pedagogicznej mimo dostępności sprzętu, dając tym samym wyraz braku kompetencji.

3. Nauczyciel nie posiada wystarczających kwalifikacji do stosowania TI w obszarze pracy dydaktycznej, ale posiadanie przynajmniej dostatecznych kompetencji w pozostałych dwóch obszarach zastosowań każe sądzić, że:

a. pozaformalny proces samokształcenia zatrzymał się u nich na etapie podstawowym i nie znajdują wystarczającej motywacji

\footnotetext{
${ }^{41}$ Por.: rozdział 4.2.2. (zestawienie SR-SP2) niniejszej pracy.
} 
do rozszerzenia swoich kwalifikacji o użyteczne w dydaktyce muzyki oprogramowanie;

b. zdając sobie sprawę z własnej nieporadności w zakresie TI, aktualne, minimalne kwalifikacje zdobyli aktywnie korzystając z podstawowych szkoleń informatycznych, których oferta jednak nie obejmuje zastosowań dydaktycznych TI.

W przypadkach 2. oraz 3a. możemy uznać postawę nauczyciela za przyczynę niespełnienia postulatów w zakresie jego kompetencji informatycznych. Do przypadku 2. zaliczymy tych z 22-osobowej grupy niespełniających kryteriów SP2, którzy na pytanie 11.: „Czy ma Pan/i możliwość wykorzystania sprzętu komputerowego na lekcji muzyki...?”; lub pytanie 12.: „Czy ma Pan/i możliwość przeprowadzenia lekcji muzyki w pracowni komputerowej?”; odpowiedzieli zakreślając odpowiedzi „a”: „Zawsze, gdy zgłoszę taką potrzebę” lub „,b”: „czasami, gdy akurat sprzęt nie jest zajęty przez innego nauczyciela / jeśli akurat pracownia komputerowa jest wolna". Takich nauczycieli wśród badanej grupy jest 19 (22,4\% wszystkich badanych).

Przypadek 3a. zidentyfikować możemy na podstawie odpowiedzi „e”: „pozaformalne (samokształcenie, lektura, pomoc członka rodziny, znajomych)” na pytanie 13.: „W jaki sposób nauczył/a się Pan/i posługiwać komputerem?". Wśród 22 rozpatrywanych nauczycieli taką odpowiedź zaznaczyło 9 (10,6\%). Wszyscy z nich należą do grupy wyłonionej wyżej, spełniającej warunki przypadku 2. W sumie więc 19 nauczycieli należy uznać za winnych braku kompetencji informatycznych w obszarze pracy dydaktycznej, który jest jednym z wyznaczników SP2.

Drugą płaszczyzną omawianej wersji rozbieżności jest znajomość narzędzi informatycznych. W rozdziale 4.2.3. zasygnalizowano problem zasadności uwzględnienia jednego z nich - arkusza kalkulacyjnego - w zestawie niezbędnych składników kompetencji informatycznych nauczyciela muzyki. Na podstawie tych wątpliwości, uznać należy, że przyczyn rozbieżności w tym zakresie należy szukać poza nauczycielem, natomiast drugi co do wielkości rozbieżności element tego zestawu, nie daje się w ten sposób obronić. Program do tworzenia i odtwarzania prezentacji multimedialnych to jedno z podstawowych narzędzi informatycznych, znajdujące bardzo szerokie zastosowanie w edukacji na każdym etapie kształcenia, a także obecne w programach nauczania informatyki, począwszy od szkoły podstawowej a skończywszy na uczelniach wyższych. Ponieważ aplikacja ta należy również do podstawowego kanonu oprogramowania przedstawianego na 
powszechnie dostępnych szkoleniach z zakresu alfabetyzacji informatycznej, jej nieznajomość nie może być tłumaczona ani jego nieprzydatnością w dydaktyce, ani też niedostępnością szkoleń z zakresu jego zastosowań. Należy zatem uznać, że 42,4\% badanych nauczycieli² ${ }^{42}$ którzy deklarują nieznajomość tego narzędzia, wykazuje istotny brak w swoich kompetencjach informatycznych, którego przyczyn należy upatrywać w postawie samego nauczyciela. Brak motywacji do uzupełnienia takiego braku nie znajduje bowiem usprawiedliwienia $\mathrm{w}$ warunkach zewnętrznych, niezależnych od nauczyciela.

Pozostałe ze składników płaszczyzny narzędziowej SP2 (edytor tekstu, przeglądarka internetowa czy program pocztowy), w dużo mniejszym zakresie stanowią barierę dla badanych nauczycieli. Przyczyny jednak istnienia tych nawet małych barier, wobec tych samych argumentów, pozostają analogiczne, jak w przypadku opisanym powyżej.

Przyczyny rozbieżności SR z SP3, mają swe źródła poza samym nauczycielem czy jego postawą. Dlatego omówione zostaną w następnych podrozdziałach.

Abstrahując od konkretnej wersji rekonstrukcji stanu postulowanego, przypadki braku kompetencji informatycznych u badanych nauczycieli muzyki możemy również wiązać z ich postawą na podstawie odpowiedzi na pytania ankiety, dotyczące świadomości respondenta na temat potrzeby posiadania takich kompetencji. Analizę taką przeprowadzono w rozdziale 4.1.3., z którego wnioski należy włączyć do przyczyn rozbieżności rozpatrywanych stanów kompetencji informatycznych nauczycieli muzyki, mających swe źródło w postawie nauczyciela.

Podsumowując przyczyny leżące po stronie nauczycieli, należy wyróżnić trzy z nich: brak wykorzystania własnych kwalifikacji (czyli brak trzeciego składnika kompetencji), niewystarczające kwalifikacje (przede wszystkim nieznajomość programu do prezentacji multimedialnych) oraz brak świadomości o konieczności posiadania kompetencji informatycznych przez nauczyciela muzyki. Zestawienie liczbowe tych przyczyn przedstawia tabela 25 .

\footnotetext{
${ }^{42}$ Ibidem, wykres 25.
} 
Tabela 25. Zestawienie przyczyn rozbieżności badanych stanów kompetencji informatycznych, związanych z postawą nauczycieli $(\mathrm{N}=85)$

\begin{tabular}{|c|c|c|c|c|}
\hline \multicolumn{2}{|c|}{$\begin{array}{c}\text { Zidentyfikowana } \\
\text { przyczyna: }\end{array}$} & $\begin{array}{c}\text { brak wykorzystania } \\
\text { posiadanych kwali- } \\
\text { fikacji }\end{array}$ & $\begin{array}{c}\text { brak } \\
\text { kwalifikacji }\end{array}$ & $\begin{array}{c}\text { nieświadomość } \\
\text { wymagań }\end{array}$ \\
\hline \multirow{2}{*}{$\begin{array}{c}\text { Ilość } \\
\text { przypadków }\end{array}$} & $\mathbf{n}$ & 24 & 36 & 40 \\
\cline { 2 - 5 } & $\%$ & 28,2 & 42,4 & 47,1 \\
\hline
\end{tabular}

(źródło: badania własne)

\subsubsection{Przyczyny związane z systemem kształcenia i dokształcania nauczycieli}

Kompetencje nauczyciela są przede wszystkim efektem jego kształcenia. Jeśli więc mówimy o niewystarczającym poziomie kompetencji nauczycieli, musimy szukać przyczyn takiego stanu w systemie kształcenia i dokształcania nauczycieli.

Nie wszyscy aktualnie pracujący nauczyciele mieli okazję poznać podstawy TI w ramach studiów. Na podstawie danych o stażu pracy możemy szacunkowo ocenić, że około 40\% nauczycieli muzyki biorących udział w badaniach mogło mieć w programie studiów przedmiot związany z TI (informatyka, podstawy informatyki, technologia informacyjna lub podobne). Na podstawie odpowiedzi na pytanie 13. ankiety („W jaki sposób nauczył/a się Pan/i posługiwać komputerem?”) możemy określić dokładniej grupę badanych, którzy wskazują zajęcia w ramach studiów, jako źródło swoich kwalifikacji informatycznych. Odpowiedzi „a” („zajęcia w ramach studiów pedagogicznych”), „b” („zajęcia w ramach studiów muzycznych”) lub „d” („studia podyplomowe”) udzieliło łącznie 28 ankietowanych (32,9\%). Z pozostałej grupy, 31 nauczycieli (36,5\%) przyznało, że swoje kwalifikacje informatyczne zawdzięczają szkoleniom (odpowiedzi „c” - „kursy lub szkolenia w ramach doskonalenia zawodowego"). Łącznie więc 59 ankietowanych $(69,4 \%)$ wskazało system kształcenia i dokształcania nauczycieli jako źródło swojej wiedzy i umiejętności informatycznych.

W odniesieniu zatem do tych 59 nauczycieli, możemy wnioskować, że ewentualne braki w wiedzy i umiejętnościach z zakresu TI mają swoje źródło w niedostosowaniu treści kształcenia do potrzeb lub wymagań zawartych w opisie stanu postulowanego ich kompetencji informatycznych. 
Ponieważ przyjąć należy, że treści kształcenia przedmiotów informatycznych, składające się zarówno na programy studiów jak i programy szkoleń, zawierają podstawowy kanon kwalifikacji, który obejmuje podstawowe zastosowania i oprogramowanie, możemy uznać, że zarówno SP1 jak i obszary zastosowań przytoczone w SP2, znajdują wystarczające podstawy w tak zdobytych kwalifikacjach. Rozbieżności wynikające z nieznajomości wymaganych stanem postulowanym programów komputerowych, mimo nabycia podstawowych kwalifikacji, mogą dotyczyć jednak tej części wersji SP2, która opisuje zestaw niezbędnych kompetentnemu nauczycielowi narzędzi informatycznych oraz wersji SP3, skoncentrowanej na specjalistycznie muzycznym oprogramowaniu. Rozbieżności w tym zakresie, w odniesieniu do 59-osobowej grupy nauczycieli, którzy swoje kwalifikacje informatyczne zawdzięczają studiom i szkoleniom, muszą mieć swoje źródło w rozmijaniu się treści kształcenia $\mathrm{z}$ formułowanymi w ramach SP2 i SP3 wymaganiami.

Sytuacja taka w odniesieniu do SP2 ma miejsce w przypadku 36 ankietowanych (42,4\%), a w stosunku do SP3 - 46 ankietowanych $(54,1 \%)$. Zatem 59 nauczycieli badanej grupy posiada kwalifikacje informatyczne nabyte $\mathrm{w}$ ciągu studiów lub szkoleń, a mimo to, $36 \mathrm{z}$ nich nie zna narzędzi informatycznych, wymaganych przez dotychczasową i najnowszą wersję Standardów kształcenia przygotowującego do zawodu nauczyciela, a 46 nie zna narzędzi informatycznych postulowanych przez Standardy edukacji kulturalnej. Można więc sformułować wniosek, że w 42,4\% badanych przypadków system kształcenia i dokształcania nauczycieli muzyki jest przyczyną rozbieżności SR z SP2 oraz w 54,1\% przypadków podobna sytuacja zachodzi w odniesieniu do SP3.

Równoległa droga dochodzenia do wniosków dotyczących dwóch odmiennych wersji stanu postulowanego nie oznacza jednak ich podobnej wagi. O ile logika dowodowa dotycząca rozbieżności z SP3 jest klarowna programy nauczania nie uwzględniają postulatów Polskiej Rady Muzycznej, dlatego nauczyciele nie spełniają warunków kompetencji informatycznych przez nią formułowanych - o tyle na rozbieżność z SP2 należy spojrzeć stosując odwrotną logikę wynikania. Badania uchwyciły różnicę, która była wynikiem pierwotnej obserwacji sylwetki absolwenta studiów nauczycielskich i jej konfrontacji z wizją współczesnego nauczyciela, konstruowaną przez urzędników Ministerstwa Nauki i Szkolnictwa Wyższego, doradców, środowiska opiniotwórcze. Ta rozbieżność była impulsem do sformułowania nowej wersji Standardów kształcenia przygotowującego do zawodu nauczyciela, 
które z kolei były podstawą sformułowania drugiej wersji postulowanego stanu kompetencji informatycznych nauczycieli muzyki w niniejszych badaniach. W tym więc przypadku przyczyny rozbieżności są wtórne wobec samych rozbieżności, wobec czego trudno przypisywać winę za taki stan najnowszej wersji Standardów kształcenia..., które mają za zadanie zniwelować zauważone rozbieżności. Za ewentualną „winę” systemu kształcenia możnaby poczytywać co najwyżej tak późne uaktualnienie Standardów..., choć z drugiej strony, nierozsądne będzie wymaganie corocznej aktualizacji programów studiów dla nadążania za zmieniającą się rzeczywistością. Nie możemy zatem rozbieżności w tym wypadku poczytywać za winę systemu kształcenia nauczycieli, ale w dalszym ciągu uważać należy system kształcenia za ich przyczynę w sensie genetycznym, niewartościującym.

W kontekście winy można jednak rozpatrywać rozbieżność zestawu niezbędnych nauczycielowi narzędzi informatycznych, wyeksponowanych w nowej wersji Standardów... z zestawem narzędzi, których zastosowanie w dydaktyce muzyki wydaje się wyjątkowo użyteczne. Nauczyciel muzyki powinien bowiem umieć: obsługiwać płyty multimedialne dołączane do podręczników, wykorzystywać gry dydaktyczne, tworzyć prezentacje, posługiwać się edytorem nut, edytorem plików dźwiękowych, programem do nagrywania, odtwarzania i konwertowania muzyki oraz filmów. Natomiast wśród „obowiązkowych” narzędzi według Standardów... znajdujemy m.in.: arkusz kalkulacyjny, bazy danych, program pocztowy, edytor teksu itp. Taka rozbieżność musi być wynikiem uśrednienia wizerunku nauczyciela przedmiotów nieinformatycznych, bez uwzględnienia specyfiki pracy i potrzeb nauczyciela muzyki. Trudno też wyobrazić sobie wspólną bazę narzędziową nauczycieli takich przedmiotów, jak matematyka i język polski. Ujednolicenie zatem zestawu narzędzi informatycznych niezbędnych wszystkim nauczycielom można uznać za winę Standardów..., nie zapominając jednak, że rozszerzenie takiego zestawu w ramach programu kształcenia konkretnej specjalności studiów nie stoi w sprzeczności z zaleceniami rozporządzenia.

Do zadań tego podrozdziału należy jeszcze rozpatrzenie przyczyn, leżących po stronie systemu kształcenia i dokształcania nauczycieli, rozbieżności SR i SP2 w odniesieniu do kryteriów „obszarowych”. Ustalone w rozdziale 4.2.3. zakres i rozmiar tej rozbieżności ogranicza się do $25,9 \%$ badanych nauczycieli, którzy nie wykorzystują TI w obszarze pracy dydaktycznej. Ten aspekt wymaga jedynie ujęcia ogólnego, pozbawionego statystycznych wyliczeń, z powodów przytoczonych poniżej. 
Otóż część nauczycieli w ramach studiów wyposażona została w wiedzę i umiejętności w zakresie TI. Tylko w wiedzę i umiejętności - a więc posiedli odpowiednie kwalifikacje. W ramach studiów przyszły nauczyciel nie nabywał kompetencji informatycznych, nie miał bowiem okazji do odpowiedzialnego działania (trzeci składnik pojęcia kompetencji), wykorzystującego kwalifikacje informatyczne. Wersja Standardów kształcenia przygotowującego do zawodu nauczyciela z 2012 roku zmienia tę sytuację ${ }^{43}$. Zapis rozporządzenia brzmiący: „w trakcie praktyki następuje kształtowanie kompetencji dydaktycznych przez [...] współdziałanie z opiekunem praktyk $\mathrm{w}[\ldots]$ wykorzystywaniu środków multimedialnych i technologii informacyjnej w pracy dydaktycznej" ${ }^{44}$ każe już na etapie studiów wykazać się odpowiedzialnym działaniem, wykorzystującym TI w dydaktyce muzyki. Tak więc postulat posiadania kompetencji informatycznych w obszarze pracy dydaktycznej, traktowany jako cel kształcenia, znalazł w tym samym dokumencie swoje praktyczne rozwiązania, traktowane jako procedura osiągnięcia wyznaczonego celu. Można więc uznać, że nauczyciel wykształcony w oparciu o najnowszą wersję Standardów..., której zapisy posłużyły do wyznaczenia SP2, będzie posiadał pełne kompetencje w zakresie wykorzystywania TI w pracy dydaktycznej.

Zatem przyczyny rozbieżności polegającej na braku wykorzystywania TI w pracy dydaktycznej u 25,9\% badanych należy upatrywać nie tylko w samej postawie nauczyciela ale również częściowo w dotychczasowym systemie kształcenia. Proporcje obu składników przyczyn nie są możliwe do ustalenia na podstawie wyników przeprowadzonych ankiet, natomiast zauważyć należy, że wersja Standardów... z 2012 roku pozwoli na wykluczenie tej przyczyny u nauczycieli wykształconych zgodnie z jej zapisami.

Trzeba również zauważyć naturalne dodatnie skorelowanie ilości znanych nauczycielom programów komputerowych z częstotliwością wykorzystywania TI do zajęć muzycznych $(r=0,41)$, w tym ilości znanych muzycznych programów komputerowych skorelowanych $\mathrm{z}$ wymienioną częstotliwością na poziomie r=0,33. Można powyższe korelacje odczytywać jako związek poziomu kwalifikacji informatycznych z kompetencjami.

Weryfikacja trzeciej hipotezy szczegółowej, mówiącej, że uczelnie kształcące nauczycieli muzyki nie wyposażają studentów w kompetencje

\footnotetext{
${ }^{43}$ Standardy kształcenia nauczycieli... z 2004 roku sygnalizują już pewne zmiany w tym zakresie, które jednak dopiero w Standardach... z 2012 roku przybrały jednoznaczną formę. Por.: rozdział 4.1.2. niniejszej pracy.

${ }^{44}$ Standardy kształcenia przygotowujacego..., s. 20, p. 3., pp. 3d.
} 
informatyczne a jedynie w kwalifikacje informatyczne, często nieuwzględniające ich zastosowań dydaktycznych, nie jest jednoznacznie pozytywna. Przykłady dydaktycznych zastosowań oraz odniesienia do „biernej” części trzeciego składnika kompetecji odnajdziemy bowiem w jednostkowych przypadkach omówionych w rozdziale 2.5., a szczególny optymizm dotyczyć musi najnowszych zapisów Standardów kształcenia przygotowującego do zawodu nauczyciela, które skromnie ale jednoznacznie formułują wymóg stosowania TI w trakcie praktyk organizowanych $\mathrm{w}$ ramach studiów nauczycielskich. W tym przypadku można mówić o niezwykłym związku czasowym (choć nie przyczynowo-skutkowym) opisywanych badań oraz instytucjonalnej reakcji na właśnie formułowane wnioski z nich.

Tabela 26. Zestawienie przyczyn rozbieżności badanych stanów kompetencji informatycznych, związanych z systemem kształcenia i dokształcania nauczycieli $(\mathrm{N}=85)$

\begin{tabular}{|c|c|c|c|}
\hline \multicolumn{2}{|c|}{$\begin{array}{c}\text { Zidentyfikowana } \\
\text { przyczyna: }\end{array}$} & $\begin{array}{c}\text { brak w programach kształce- } \\
\text { nia narzędzi } \\
\text { wymaganych przez SP2 }\end{array}$ & $\begin{array}{c}\text { brak w programach } \\
\text { kształcenia narzędzi } \\
\text { wymaganych przez SP3 }\end{array}$ \\
\hline $\begin{array}{c}\text { Ilość } \\
\text { przypadków }\end{array}$ & $\mathbf{n}$ & 36 & 46 \\
\cline { 2 - 4 } & $\%$ & 42,4 & 54,1 \\
\hline
\end{tabular}

(źródło: badania własne)

\subsubsection{Przyczyny związane $z$ organizacją funkcjonowania szkoły}

Współczesna szkoła zmienia się nie tylko w sferach objętych szeregiem reform. Zaplecze materialne placówek, począwszy od przełomu XX i XXI wieku, ulega przeobrażeniom z niezwykłą dynamiką. Jednym z jego elementów jest sprzęt komputerowy oraz pracownie informatyczne, obecne $\mathrm{w}$ każdej szkole. Ilość takiego sprzętu wraz $\mathrm{z}$ organizacją funkcjonowania szkoły wyznaczają możliwości jego wykorzystywania na zajęciach innych niż informatyka.

W badanej grupie nauczycieli, przypadki niedostępności sprzętu komputerowego oraz pracowni informatycznych omówione zostały w rozdziale 4.1.2. Rozmiar tej niedogodności w opinii nauczycieli ustalony został na poziomie $11,8 \%$. Niezależnie więc od tego, czy nauczyciel posiada wystarcza- 
jące kwalifikacje, w 11,8\% przypadków za przyczynę rozbieżności rozpatrywanych stanów kompetencji informatycznych należy uznać ograniczenia związane z niedostępnością szkolnego sprzętu komputerowego. Naturalny związek dostępności szkolnego sprzętu komputerowego z częstotliwością wykorzystywania TI na lekcjach muzyki unaocznia współczynnik korelacji Pearsona tych dwóch zmiennych, który wynosi 0,43.

Do przyczyn związanych z funkcjonowaniem szkoły można również zaliczyć ewentualny brak atmosfery sprzyjającej rozwojowi kompetencji informatycznych. Sytuacja taka może być wynikiem braku kompetencji informatycznych pozostałych nauczycieli w szkole lub brakiem bodźców ze strony dyrektora do rozwijania warsztatu dydaktycznego podległych mu nauczycieli. Odpowiedzi na pytanie 14. ankiety nauczycielskiej pozwalają na zidentyfikowanie tej ostatniej sytuacji. Brzmi ono: „Czy dyrektor szkoły zachęcał lub nakazywał Panu/i udział w szkoleniu komputerowym?”. Odpowiedzi, które zdradzają sytuację braku zainteresowania dyrektora podwyższaniem kompetencji informatycznych nauczycieli brzmią:

„d. nie - ponieważ dyrektor nie przykłada większej wagi do takich szkoleń;

e. nie - z dowolnych innych przyczyn".

Odpowiedzi „d” ankietowani wybrali 2 razy, odpowiedzi „e" - 27 razy. Można więc stwierdzić, że brak zachęty dyrektora szkoły do uczestnictwa w szkoleniach komputerowych można uznać przynajmniej za współprzyczynę rozbieżności SR z wszystkimi trzema wersjami SP, w 29 przypadkach badanej grupy $(34,1 \%)$.

Warto zauważyć, że sformułowana w ten sposób postawa dyrektora nie znajduje potwierdzenia w świadomości samych dyrektorów. Na pytanie 1. ankiety skierowanej do dyrektorów: „Czy według Pani/a technologia komputerowa jest na lekcjach muzyki:
a. niezbędna;
b pożądana;
c. pomocna;
d. bez znaczenia;
e. niepotrzebna;
f. szkodliwa",

żaden $\mathrm{z}$ ankietowanych nie zaznaczył odpowiedzi „d”, „e" lub „f”. Wybrano natomiast 4 razy odpowiedź „a”, 26 razy odpowiedź „b” oraz 54 razy odpowiedź „c", potwierdzając rozumienie potrzeby posiadania kompetencji informatycznych przez nauczyciela muzyki. 
Duże znaczenie może mieć tu również przykład dyrektora, który sam stosuje (lub nie) TI we własnej pracy dydaktycznej. Sytuację taką zidentyfikować można na podstawie odpowiedzi dyrektorów na pytanie 7., które brzmi: "Stosuję technologię komputerową na własnych zajęciach (jakich:...)”. 61 ankietowanych dyrektorów odpowiedziało „tak”, a 16 - „nie”. Trzy negatywne odpowiedzi można usprawiedliwić: jeden przypadek, gdy dyrektor nie prowadzi żadnych zajęć dydaktycznych oraz dwa przypadki dyrektorów prowadzących zajęcia wychowania fizycznego ${ }^{45}$. Przykład pozostałych 13 dyrektorów można uznać za kolejną z przyczyn rozbieżności, mających swe źródło w funkcjonowaniu szkoły.

Kolejnym ważnym elementem w poszukiwaniu przyczyn rozbieżności SR i SP są odpowiedzi dyrektorów na pytanie 5., które brzmi: „Czy stan wykorzystania technologii komputerowej na lekcjach muzyki w Pani(a) szkole jest:
a. wystarczający;
b. przesadny;
c. zbyt mały;
d. stanowczo niedostateczny;
e. zerowy;
f. nie wiem".

Dyrektorzy odpowiadali w następujący sposób:

Tabela 27. Stan wykorzystania TI na lekcjach muzyki według opinii dyrektorów $(\mathrm{N}=82)$

\begin{tabular}{|l|c|c|c|c|}
\hline \multirow{2}{*}{ Opinie: } & \multirow{2}{*}{$\mathrm{n}$} & $\%$ & \multicolumn{2}{c|}{ suma } \\
& & & $\mathrm{n}$ & $\%$ \\
\hline „wystarczający” & 31 & 37,8 & \multirow{2}{*}{32} & \multirow{2}{*}{39,0} \\
\hline „przesadny” & 1 & 1,2 & & \\
\hline „zbyt mały” & 25 & 35,4 & & \\
„stanowczo niedostateczny” & 6 & 7,3 & \multirow{2}{*}{50} & \multirow{2}{*}{61,0} \\
\hline „zerowy” & 10 & 12,2 & & \\
\hline „nie wiem” & 9 & 11,0 & & \\
\hline
\end{tabular}

(źródło: badania własne)

\footnotetext{
${ }^{45} \mathrm{O}$ ile trudno o zastosowania TIK w dydaktyce wychowania fizycznego, to już narzędzia informatyczne mają swoje miejsce w ewaluacji takich zajęć. Por.: J. Kozłowska, Użycie arkusza kalkulacyjnego MS Excel jako narzędzia pomiaru dydaktycznego na lekcjach wychowania fizycznego, [w:] M. Bereziński (red.), Polska szkoła wobec wyzwań społeczeństwa informacyjnego. Interdyscyplinarność, komputery i Internet w nauczaniu, Warszawa 2004.
} 
Tylko 32 dyrektorów uważa, że kompetencje informatyczne nauczycieli muzyki nie wymagają pogłębienia, 41 jest przeciwnego zdania a 9 nie zna poziomu tych kompetencji. 50 dyrektorów zatem powinno motywować nauczycieli muzyki do rozwoju swoich kompetencji informatycznych przez udział w kursach i szkoleniach. Takie motywowanie odczuło 42 ankietowanych nauczycieli (odpowiedzi „a” lub „b” na pytanie 14. ankiety nauczycieli), co w całości wyczerpuje grupę dyrektorów oceniających niedostatecznie kompetencje swoich nauczycieli. Pozostaje jednak grupa 9 dyrektorów (11,0\%), którzy nie zainteresowali się do tej pory poziomem kompetencji swoich podwładnych. Taki więc procent bezpośrednich zwierzchników nauczycieli muzyki można uznać za przyczyniających się do rozbieżności rozpatrywanych stanów kompetencji.

Tabela 28. Zestawienie przyczyn rozbieżności badanych stanów kompetencji informatycznych, związanych z organizacją funkcjonowania szkoły $(\mathrm{N}=85)$

\begin{tabular}{|c|c|c|c|c|c|}
\hline \multicolumn{2}{|c|}{$\begin{array}{c}\text { Zidentyfikowana przy- } \\
\text { czyna: }\end{array}$} & $\begin{array}{c}\text { niedostępność } \\
\text { sprzętu }\end{array}$ & $\begin{array}{c}\text { brak } \\
\text { zachęty dyrek- } \\
\text { tora }\end{array}$ & $\begin{array}{c}\text { brak przykładu } \\
\text { dyrektora }\end{array}$ & $\begin{array}{c}\text { brak zaintereso- } \\
\text { wania dyrektora }\end{array}$ \\
\hline \multirow{2}{*}{$\begin{array}{c}\text { Ilość } \\
\text { przypadków }\end{array}$} & $\mathrm{n}$ & 10 & 29 & 13 & 9 \\
\cline { 2 - 6 } & $\%$ & 11,8 & 34,1 & 15,3 & 10,6 \\
\hline
\end{tabular}

(źródło: badania własne)

\subsection{Motywacje nabywania kompetencji informatycznych w kontekście indywidualnych przypadków - analiza wywiadów}

Zgodnie z definicją zaproponowaną przez Kubinowskiego, „studium przypadku/przypadków to jednocześnie proces badania i jego produkt w postaci szczegółowego, wieloaspektowego opisu. Jego komponentami są przeważnie: istota przypadku, jego tło historyczne, otoczenie fizyczne, konteksty ekonomiczne, polityczne, prawne, estetyczne i inne, dodatkowe przypadki służące do jego lepszego rozpoznania, respondenci, dzięki którym przypadek został poznany" ${ }^{\prime 6}$. W tym znaczeniu zastosowano studium przypadków, którego istotą jest opis praktyki dydaktycznej, zarysowany w wymienionych kontekstach. Przedmiotem zainteresowania badawczego są przypadki, czyli „splot relacji między różnymi czynnikami odzwiercie-

\footnotetext{
${ }^{46}$ D. Kubinowski, Jakościowe badania pedagogiczne. Filozofia - metodyka - ewaluacja, Lublin 2010, s. 172.
} 
dlony w doświadczeniach osoby lub osób, funkcjonowaniu instytucji czy elementach sytuacji, zdarzeń, zachowań" ${ }^{47}$. Granice przypadku wyznaczają doświadczenia związane z wykorzystywaniem TIK w pracy pedagogicznej badanych nauczycieli, ich uwarunkowania związane doświadczeniem zawodowym, wykształceniem, doświadczeniem w pozazawodowym stosowaniu TIK, wpływem środowiska szkolnego i pozaszkolnego, infrastrukturą szkoły, polityką oświatową wyrażającą się m.in. w obowiązujących aktach prawnych oraz sytuacją ekonomiczną instytucji szkoły, czy w końcu z pojmowaniem dydaktycznego i artystycznego potencjału narzędzi informatycznych - czyli obszarami, które mogą być źródłem wewnętrznej lub zewnętrznej motywacji ${ }^{48}$ nabywania kompetencji informatycznej przez badanych nauczycieli.

W rozdziale 3.3. opisano założenia dotyczące formy przeprowadzonych wywiadów oraz dyspozycji do nich. Przyjęte dyspozycje pozwoliły na wstępne zakreślenie tematyki wywiadów, w formie syntetycznie ujętych problemów badawczych ${ }^{49}$ tak, by jednostkowe przypadki mogły służyć uzupełnieniu i pogłębieniu wniosków z badań sondażowych. Nadrzędnym więc i ogólnie sformułowanym problemem, którego uwarunkowania były tematem wywiadów, było użytkowanie narzędzi informatycznych, jako składnika warsztatu dydaktycznego. Zgodnie z warunkiem swobody narracji, to rozmówca decydował o wyeksponowaniu czynników, które uważał za istotne we własnym doświadczeniu, budując w ten sposób jednostkowy i niepowtarzalny wizerunek nauczyciela skonfrontowanego z rzeczywistością, do której coraz szerzej wkracza TIK, nie czekając na reakcję zinstytucjonalizowanej formy edukacji.

Każdy z wywiadów poddano podobnej procedurze, składającej się z trzech etapów: deskrypcja, konceptualizacja i strukturalizacja. W deskrypcji posłużono się przede wszystkim sposobami zaproponowanymi przez Silvermana ${ }^{50}$, z drobnymi modyfikacjami, wyjaśnionymi w cytowanych tekstach. Kategoryzacja poszczególnych wypowiedzi oraz przypisywanie im znaczeń, $\mathrm{w}$ formie skondensowanej zostało zaprezentowane w każdym z omawianych przypadków, w formie cytatów oraz ich interpretacji. Strukturalizacja skutkowała graficznym ujęciem, nazywanym tu „siecią

\footnotetext{
${ }^{47}$ Ibidem, s. 172.

${ }^{48}$ Por.: hasło motywacja [w:] Nowy słownik pedagogiczny..., s. 245.

${ }^{49}$ Por.: K. Rubacha, Metodologia badań nad edukacją, Warszawa 2008, s. 331.

${ }^{50}$ Zastosowano symbole transkrypcji zaproponowane w: D. Silverman, Interpretacja danych jakościowych. Metody analizy rozmowy, tekstu i interakcji, tlum. M. Głowacka-Grajper, J. Ostrowska, Warszawa 2009, s. 328.
} 
przyczynową - źródłami kompetencji informatycznych”, charakterystycznym dla każdego, niepowtarzalnego przypadku. Jego analiza stanowi kluczowe, podsumowujące ujęcie studium, stanowiące podstawę do wniosków formułowanych $\mathrm{w}$ rozdziale 4.4.8.

Zgodnie z zasadą otwartości, procedura ta nie była podporządkowana zasadzie linearności a każdy następny wywiad pozwalał na weryfikację poprzednich kroków, zarówno w zakresie kategoryzacji, jak i strukturalizacji zebranego materiału ${ }^{51}$. Podobnie ewolucji podlegały cele i pytania badawcze, początkowo skoncentrowane na poziomie kompetencji informatycznych badanych nauczycieli, by poprzez zainteresowanie przyczynami wykorzystywania TI w praktyce pedagogicznej uczestników wywiadów skoncentrować się na mechanizmie wzajemnych oddziaływań tych przyczyn, co pozwoliło odnaleźć również relację odwrotną, w której to kompetencje informatyczne mogły pełnić rolę przyczyn wobec elementów rozumianych wcześniej jako przyczyny kompetencji. Takie rozumienie zależności nie było możliwe do uchwycenia na etapie przygotowawczym, a tym bardziej do ujęcia czy zauważenia w trakcie badań sondażowych.

Ankieta dla nauczycieli zawiera pytanie-propozycję udziału w dalszej części badań w formie wywiadu. Tylko 7 ankietowanych wyraziło zgodę na taką formę badań, podając swoje dane kontaktowe. Przeprowadzono zatem 7 wywiadów bez wstępnej selekcji rozmówców, co sprawia, że dobór przypadków nie posiada waloru celowości. Zasadne zatem będzie porównanie parametrów tak wyłonionej grupy rozmówców z grupą wszystkich uczestników sondażu. Takie zestawienie przedstawia tabela 29.

Różnice zawarte w przedziale od $1 \%$ do $16,8 \%$ nie skłaniają do uznania grupy biorącej udział w wywiadach za reprezentatywną dla wszystkich ankietowanych nauczycieli. Należy jednak zauważyć, że różnica jednej osoby w grupie 7-osobowej to $14,3 \%$, co oznacza, że tylko w dwóch wypadkach przekroczone zostały granice dokładnej reprezentatywności. Do ideału brakuje, by jeden $\mathrm{z}$ nauczycieli mianowanych był stażystą, oraz by każdy $\mathrm{z}$ nich pracował o 2,5 godziny mniej.

${ }^{51}$ D. Urbaniak-Zając, J. Piekarski (red.), Jakościowe orientacje w badaniach pedagogicznych. Studia i materiały, Łódź 2001, s. 24. 
Tabela 29. Porównanie niektórych danych demograficznych uczestników wywiadów z całą grupą badanych nauczycieli

\begin{tabular}{|l|c|c|c|}
\hline \multicolumn{1}{|c|}{ Parametry (średnie): } & $\begin{array}{c}\text { wartości dla } \\
\text { uczestników } \\
\text { wywiadów }\end{array}$ & $\begin{array}{c}\text { wartości dla } \\
\text { wszystkich } \\
\text { badanych }\end{array}$ & $\begin{array}{c}\text { różnica } \\
\text { w procen- } \\
\text { tach }\end{array}$ \\
\hline wiek & 40,9 & 42,9 & 4,7 \\
\hline staż pracy nauczycielskiej & 13,6 & 15,0 & 9,3 \\
\hline $\begin{array}{l}\text { udział absolwentów uczelni } \\
\text { artystycznych }\end{array}$ & $57,1 \%$ & $50,0 \%$ & 7,1 \\
\hline wymiar zatrudnienia (w godzinach) & 17,4 & 14,9 & 16,8 \\
\hline udział zatrudnionych w jednej szkole & $85,7 \%$ & $81,0 \%$ & 4,7 \\
\hline udział mężczyzn & $14,3 \%$ & $17,6 \%$ & 3,3 \\
\hline $\begin{array}{l}\text { rozkład procentowy stopni awansu (sta- } \\
\text { żýci, kontraktowi, mianowani, dyplo- } \\
\text { mowani) }\end{array}$ & $\begin{array}{c}14,3 \%, 14,3 \%, \\
57,1 \%\end{array}$ & $\begin{array}{c}2,4 \%, \\
15,3 \%, 29,4 \%,\end{array}$ & $\begin{array}{c}11,9,1,0,15,1, \\
10,0\end{array}$ \\
\hline
\end{tabular}

(źródło: badania własne)

\subsubsection{Przypadek N1}

N1 to 45-letnia nauczycielka dyplomowana z 23-letnim stażem w zawodzie nauczyciela (wcześniej również instruktora domu kultury), absolwentka Uniwersytetu Łódzkiego, pracująca w jednej szkole podstawowej w wymiarze 18 godzin tygodniowo.

Bardzo energiczny sposób opowiadania zaowocował w tym przypadku obszernym choć nieco chaotycznym potraktowaniem tematu, z licznymi odniesieniami i dygresjami. Wstępna deklaracja N1 ujawniła, że stosuje TI zarówno w przygotowywaniu jak i prowadzeniu lekcji muzyki. Spośród wielu opisanych zastosowań jedno zwraca szczególną uwagę:

\section{$[252-265]^{52}$}

N1: „Nie, muzycznych programów na lekcji nie używam. Nie nie (.) muzyczne programy, z muzycznych programów korzystam na zajęciach z gitary $(2,0)^{53}$ z dzieciakami, które przychodzą na gitarę (.) Bo my sobie tam zapisujemy po prostu tabulaturę. Mam taki program iii grając na pianinie dźwięki, one wklikują te dźwięki tam w komputer, bo tam jest taka możliwość, >i się zapisuje im tabulatura i potem sobie drukujemy to i się uczymy danej melodii<

\footnotetext{
${ }^{52} \mathrm{~W}$ nawiasach kwadratowych przed cytatami podano numery wersów w transkrypcji wywiadów.

${ }^{53}$ Przerwy w wypowiedzi podano w sekundach; znak (.) oznacza przerwę ok. 1 sekundy.
} 
Autor: I na gitarze z tabulatury się uczą [i wtedy jest łatwiej] $]^{54}$

N1: [I na], tak jest, no. No tak, ja nie miałam co prawda na gita..., jak byłam na studiach z panem $\mathrm{K}((\ldots))$ miałam gitarę $(2,0)$ nieee miałam czegoś takiego, no bo my się z nut uczyliśmy, no wiadomo (.) Nie biorę się za naukę dzieci z nut. Jakoś po prostu tam mała ilość czasu i to, że te dzieciaki tak naprawdę no nie robią tego systematycznie, no, one to traktują jako coś dodatkowego, coś takiego (.) rozrywkowego. Nie biorę się za naukę nut właśnie przy gitarze, no, tylko już z tej tabulatury. Nie wiem z czego to wyniknęło, gdzieś kiedyś mi to tak..."

Jest to jeden z nielicznych opisanych przez N1 przypadek wykorzystania programu muzycznego (nie biurowego czy komunikacyjnego) i zarazem jedyny przypadek, w którym to uczniowie obsługują komputer. Specyficzna sytuacja organizacyjna - zajęcia pozalekcyjne, w małej grupie - pozwala na skorzystanie z sali z komputerem oraz łatwiejszą kontrolę użytkowania komputera przez uczniów.

Przytoczony fragment zdradza charakterystyczny dla całego wywiadu stosunek N1 do uczniów, czy szerzej - do pracy pedagogicznej. Nie używa zwrotu „uczniowie”, unika formy zaimkowej „oni”, posługuje się za to chętnie zwrotem „dzieciaki” lub „dzieci”. Często używa pierwszej osoby liczby mnogiej, mówiąc: „my sobie tam zapisujemy”, „potem sobie drukujemy to i się uczymy danej melodii”. Utożsamiając się w ten sposób z grupą uczniów specjalnie zainteresowanych muzyką (zajęcia dodatkowe) oraz mówiąc o nich z pewną dozą protekcjonalizmu, stwarza wrażenie, że wykorzystywanie komputera do zajęć jest elementem zbliżającym nauczyciela do uczniów, wyrazem szczególnego zaufania, szczególnej dbałości o atrakcyjność i przystępność zajęć. Być może jest też formą zachęty lub nagrody za udział w zajęciach, traktowanych jako „coś dodatkowego, coś takiego (.) rozrywkowego”. Jest również odreagowaniem własnych doświadczeń: „nieee miałam czegoś takiego, no bo my się z nut uczyliśmy, no wiadomo”. Odnajdujemy więc w tej krótkiej wypowiedzi szereg elementów sugerujących traktowanie TI jako formy nagrody za ponadobowiązkową aktywność muzyczną uczniów.

Sposoby wykorzystania TI stanowią dużą część wypowiedzi N1. Każde z wymienionych zastosowań nauczycielka natychmiast uzasadnia odwołując się do efektywności zastosowanych narzędzi, zarówno w odniesieniu do pracy nauczyciela jak i samych uczniów:

\footnotetext{
${ }^{54}$ Modyfikacja symbolu transkrypcji: w nawiasy kwadratowe ujęto wypowiedzi nakładające się na siebie.
} 
[143-147]

N1: „No więc najczęściej no to oczywiście korzystam z tego, żeby te karty przygotować jakieś pracy, bo dla dzieci to jest bardzo ważne, żeby mieć coś przed oczami, tak? Coś im położyć, gdzie one mogą wypełnić, narysować, nakreślić, bardzo to jest dla nich ważne niestety, mimo że to jest muzyka”.

[357-362]

N1: „no w internecie sobie szukam pomysłów jakiś, prawda? No szukam gdzieś tam $\mathrm{z}$ jakiś może testów, $\mathrm{z}$ jakiś różnych (.) opracowań czy $\mathrm{z}$ jakiś no życiorysów wybieram jakieś śmieszne czy ciekawe rzeczy, no bo to muszą być takie rzeczy dostosowane do tych dzieciaków. No jakieś jedno słowo może być obce, jakieś jedno pojęcie bardzo poważne, ale resztę musi być jakaś otoczka, która je troszkę zainteresuje, no".

[398-402]

N1: „No Power Point też, no ale to mówię, już tak kiedyś zrobiłam taką prezentację na temat instrumentów, no powiedzmy robiłam sobie różne grupy instrumentów i wtedy wiadomo, że jak był i obrazek i brzmienie tego instrumentu, prawda, jakieś kolorowe informacje, jakieś kolorowe ludziki, które gdzieś tam coś robiły, to dzieciakom się też to bardzo podobało".

Zarówno więc przygotowywane karty pracy, prezentacje multimedialne jak i wiadomości wyszukane w internecie, służą przede wszystkim zainteresowaniu uczniów tematem zajęć poprzez ciekawą i atrakcyjną formę. Nauczycielka nie szuka po omacku zastosowań TI, ma wyraźnie sprecyzowane cele takich działań i w sposób jasny potrafi wyartykułować korzyści płynące ze stosowania wymienionych narzędzi. Ten sposób podejścia w połączeniu z dużym doświadczeniem pedagogicznym determinuje drogę dochodzenia do wprowadzania TI do warsztatu dydaktycznego. Punktem wyjścia jest u N1 potrzeba wynikająca z chęci uzyskania lepszych efektów kształcenia. Ambicja w połączeniu z dużym entuzjazmem zawodowym wydają się tu głównym motorem, którego paliwem jest niewątpliwie satysfakcja zawodowa i poczucie spełnienia w jednoznacznie akceptowanej roli pedagoga. Ową akceptację podkreśla aktywność zawodowa: zajęcia szkolne, zajęcia pozalekcyjne z gry na gitarze oraz tańca, zajęcia taneczne w domach kultury, rytmika w przedszkolach (w ramach własnej działalności gospodarczej).

N1 nie stosuje więc TI w sposób bezrefleksyjny (niekompetentny) i stara się zachować odpowiednie proporcje w stosowaniu różnych środków dydaktycznych. Mimo dużych kompetencji nie podchodzi do dydaktycznych zastosowań TI w sposób przesadnie entuzjastyczny, za każdym razem analizując korzyści, jakie może takie rozwiązanie przynieść. 
[692-694]

N1: „wie Pan co, na pewno, ja to mówię, w życiu to musi być urozmaicenie. Musi być i tablica (.) i komputer, i wszystko. Bo nieraz jak rysuję coś na tablicy dzieciakom (.) to one też są bardzo zaintrygowane tym”.

[711-712]

N1: „Także na pewno multimedialne bardzo urozmaicają, natomiast ja bym tutaj no mówię, nie tylko to (.) Dużo musi być (.) urozmaicenia”.

Ponadprzeciętna aktywność zawodowa nie przekłada się na poczucie braku czasu czy braku chęci aktywności w obszarach pozazawodowych. N1 uczestniczyła w rozmaitych szkoleniach, w tym informatycznych, m.in. z podstaw obsługi komputera, obsługi programów pakietu biurowego, a następnie ukończyła dwuletnie studia podyplomowe w Katedrze Informatyki Stosowanej na Politechnice Łódzkiej. W ramach poszerzania kwalifikacji ukończyła szkolenia z tańca, prowadzenia zajęć rytmicznych dla dzieci oraz kolejne studia podyplomowe na Politechnice Łódzkiej, tym razem na wydziale mechanicznym, co dało jej uprawnienia do prowadzenia przedmiotu technika. Mimo to przyznaje, że taka aktywność nie jest czymś niezwykłym i twierdzi, że poziom jej kompetencji mógłby być wyższy:

[488-494]

N1: „Na przykład bardzo mnie interesuje zakładanie stron internetowych. A nie umiem tego zrobić. Nie umiem i czuję się w tym strasznie licho. Zresztą tak jak Pan mówi, samo opracowywanie muzyki, gdyby coś takiego było, no to w ogóle jak w dym, no. Ale czegoś takiego nie ma. W ogóle czegoś takiego się nie proponuje. $(2,0)$ No, także tutaj bardzo bym chciała. $(3,0)$ Rozkładanie na przykład muzyki na części pierwsze. Przecież ile jest takich pięknych rzeczy, gdzie jest piękny podkład, żeby tylko umieć wykasować tą (.) tą prawda, to co się mówi karaoke”.

[500-507]

N1: „jak są te różne płyty tam »Wygraj sukces« i tak dalej i one są w takich rozszerzeniach ponagrywane i jakoś tak, że nieraz nie można ich skopiować. (.) I ja nie umiem nieraz tego robić, no. Robię, taki mam ripper, CD Ripper, i wtedy wrzucam to w ten ripper, on mi zrzuca na ten, na kompa i dopiero wtedy nagrywam. Ale nie umiem tego zrobić, a ludzie robią to. Zresztą dużo jest umiejętności, które ludzie robią (.) a które ja nie umiem. Bardzo bym chciała z Corela (.) jakieś szkolenie (.) większe, grafika, robienie różnych wizytówek, różnych zaproszeń fajnych w szkole, nie, przecież to się bardzo przydaje $(2,0)$ no".

[716-718]

N1: „Ja jestem przeciętna bardzo. (.) Naprawdę, u nas ludzie i strony internetowe zakładają (.) bo tam jedna koleżanka na przykład to ma takie hobby i potem wszyscy głosują tam, która strona lepsza w internecie”. 
Taka samoocena jest m.in. wynikiem wysokich kompetencji pozostałych nauczycieli szkoły, w której pracuje. Ten sam czynnik jest również jedną z przyczyn, dla których N1 podejmuje trud podnoszenia własnych kompetencji, a kontakt z pozostałymi nauczycielami inspiruje do stosowania nowych, ciekawych rozwiązań dydaktycznych. Charakterystyczne, że nauczyciele tej samej szkoły nie znajdują w natłoku obowiązków czasu do rozmów, konsultacji, wymiany poglądów na te tematy, a środowisko wsparcia znalazła N1 w koleżankach spoza szkoły:

[567-575]

N1: „ja mam dużo koleżanek też bardzo aktywnych (.), które nie są (.) akurat muzyczkami (.) ale są bardzo zainteresowane sprawami informatyki.

A: Ale też nauczycielkami są?

N1: Tak (...) I $(2,0)$ one bardzo dużo też (.) robią właśnie takich rzeczy związanych właśnie z pracą przy komputerze i sobie wzajemnie, no, przekazujemy często, często się inspirujemy, no nie, tymi sprawami, że ktoś do czegoś coś doszedł (.) gdzieś tam i (.) jak to zrobić, no".

[580-586]

N1: „Także (.) tutaj między koleżankami to tak, tylko że to takie właśnie kontakty bardziej już osobiste, nie (.) nie związane z pracą (.)

A: Rozumiem.

N1: Bo w pracy nie ma czasu, naprawdę nie ma czasu (.) W pracy wystarczy, że my sobie przekażemy sprawy dotyczące pewnych spraw wychowawczych dzieci, żeby umieć zapobiec jakimś tam sytuacjom w szkole (.) to już jest dużo".

Do środowiska szkolnego zaliczyć należy również dyrekcję, której znaczenie w inspirowaniu do podnoszenia kompetencji swoich pracowników wielokrotnie N1 podkreśla:

[438-442]

N1: „Sporo te studia nam dały. Tam poszly chyba, plastyczka poszła od nas ze szkoły (.) jakieś tam matematyczki (.) i te [studia nam]

A: [A, czyli taka] silna grupa ze szkoły [poszła na te studia]

N1: [Silna grupa, tak tak] Dyrekcja bardzo wypychała nas, żebyśmy (.) [tak]

A: [Aha], z inicjatywy dyrekcji to było".

[469-477]

N1: „To było tak, że dyrekcja nam pokrywała jakąś część kosztów, bo to jest, u nas jest tak, że tam (.) kursy to tam nie wiem $-50 \%$ (.) studia to tam nie wiem - 40\% szkoła pokrywa (.) także wszystkie te te szkolenia w jakimś tam stopniu dyrekcja nam pokrywa (.)

A: Rozumiem. Czyli bardzo tutaj na rękę [dyrekcja idzie]

N1: [Bardzo] $(2,0)$ Zresztą dyrekcja analizuje u nas (.) jakie są zmiany (.) w oświacie (.) w jakim to kierunku idzie (.) i podpowiada. Patrzy w nasze upraw- 
nienia, nasze tam jakieś zainteresowania i jakieś tego i mówi: słuchaj, czy ty byś się nie wzięła za to, bo może to być potrzebne (.) tak?”

Przyczynę swoich braków N1 upatruje jednoznacznie w braku odpowiedniej oferty szkoleniowej, którą śledzi na bieżąco. Zdaje sobie sprawę, że poznawanie interesujących programów na własną rękę to proces bardzo żmudny i czasochłonny, więc udział w takich szkoleniach traktuje jak oszczędność czasu, ani przez chwilę nie myśląc, że udział w takim kursie łączy się również z poświęceniem czasu. Bardzo racjonalne podejście do czasu mimo ogromnego zaangażowania zawodowego, widoczne jest w następującej wypowiedzi:

[403-410]

N1: „Wie Pan, ja jeszcze mam też takie troszkę życie, że staram się żyć bardzo poza pracą. (.) I też a to zdjęcia sobie opracowuję, a to filmy sobie opracowuję różne z wyjazdów, a to staram się na przykład na moją czterdziestkę zrobiłam jakąś tam prezentację bardzo szeroką, także $(2,0)$ no szkoła też nie jest tak, że zajmuje mi całe życie, tak? (.) Więc na pewno mogłabym to robić lepiej, na pewno mogłabym więcej tego zrobić, tylko że $(2,0)$

A: Kosztem życia?

N1: No właśnie".

Oprócz braku interesujących szkoleń oraz subiektywnego poczucia braku czasu, N1 wskazuje również na inne ograniczenia w wykorzystywaniu TI, natury organizacyjnej, wymagające poświęcenia zarówno energii jak i czasu.

[154-157]

N1: „Natomiast niewygodą jest to, że każdą lekcję mam w innej sali $(2,0)$ Rozumie Pan? I to jest tak, że nieraz dojdę do sali i mi się przypomina na przykład, że czegoś nie wzięłam z pokoju. I już nie mam powrotu (.) A każda lekcja jest inna”.

[163-165]

N1: „Druga sprawa to jest to, że sam rzutnik nie wystarcza, trzeba jeszcze podłączyć (.) komputer. Kiedy ten ten komputer podłączyć proszę Pana?”

[185-186]

N1: „Ale tak jak mówię (.) no organizacyjnie jest to bardzo trudne. Co z tego, że mamy umiejętności?"

[191-196]

N1: „Natomiast tak jak dla mnie sama organizacja: idę z tym komputerem, idę $\mathrm{z}$ siatką, tak, jeszcze na przykład no nieraz mam lekcję z gitary czy z czegoś, no to jeszcze dodatkowo coś niosę, tak? (.) No widzi Pan? To tak przychodzę na lekcję, dzieci żżżżż, więc ja je opanowuję: «dzieci, ja podłączę komputer». No i komputer się otwiera, rozgrzewa się, tak? No i to trwa no. I mnie nieraz, powiem szczerze, że jest szkoda tej lekcji”. 
Te ograniczenia natury organizacyjnej sprowadzają się do jednej niedogodności: brak własnej pracowni z zainstalowanym na stałe komputerem. Przezwyciężanie tego ograniczenia łączy się w świadomości rozmówczyni z rodzajem poświęcenia ze strony nauczyciela. Motyw poświęcenia jest obecny w całej jej wypowiedzi.

[212-213]

N1: „ale to jest naprawdę dużym kosztem (.) Dużym kosztem, mimo że szkoła jest wyposażona nieźle".

\section{[222-224]}

$\mathrm{N1}$ „ „U nas teraz jest taka koncepcja, ponieważ jest cały czas bunt rodziców na ciężkie tornistry (.) że to my przychodzimy do dzieci (.) a nie dzieci do nas. $(2,0)$ Nie dyskutuję z tym czy to jest dobre czy złe, no. Dla mnie złe (('́miech))".

[656-663]

N1: „Ja miałam kiedyś taki pomysł, że przynosiłam swój laptop na przykład też (.) z domu (...) Ale to też nie jest wygodne (...) Ale to nie jest wygodne, no sam Pan jest w stanie to sobie wyobrazić, prawda? Chodziłam z tym po klasie, ale to takie".

Nauczycielka często zwraca uwagę na to, jak dużym kosztem organizuje sprzęt na zajęcia, uczestniczy w szkoleniach, konsultuje się z koleżankami po pracy, wyszukuje materiały dla uczniów, przygotowuje prezentacje, jednak nie używa ani razu pojęcia „poświęcenie” lub podobnego. Jej aktywność podporządkowana jest korzyściom, jakie wynikają dla uczniów i za każdym razem taki rodzaj dodatkowych obowiązków tłumaczy wygodą uczniów, lepszymi wynikami kształcenia, łatwiejszym przyswajaniem wiedzy, zainteresowaniem uczniów.

Wszystkie zaobserwowane i zacytowane elementy, które wpływają na świadome i odpowiedzialne działanie w obszarze dydaktycznego wykorzystania TI, składają się na źródła kompetencji informatycznych w przypadku N1, rozumianej zgodnie z przyjętą definicją jako wiedza, umiejętności i „odpowiedzialne działanie”. Źródła tego ostatniego składnika są tutaj centralną kategorią, z uwagi na jej konstytutywny charakter oraz kluczowe znaczenie dla problemów badawczych. Oprócz bowiem źródeł i poziomu kwalifikacji informatycznych, ważne dla niniejszej pracy jest zidentyfikowanie bodźców, dzięki którym kwalifikacje zostają przekształcone w kompetencje. Ten element umykał analizom ilościowym ze względu na swoją złożoność i indywidualny charakter, trudny do przewidzenia i uchwycenia przy pomocy pytań ankietowych. Tą złożoność próbuje uchwycić prezentowana poniżej sieć przyczynowa. 
Wykres 29. Sieć przyczynowa. Źródła kompetencji informatycznych N1

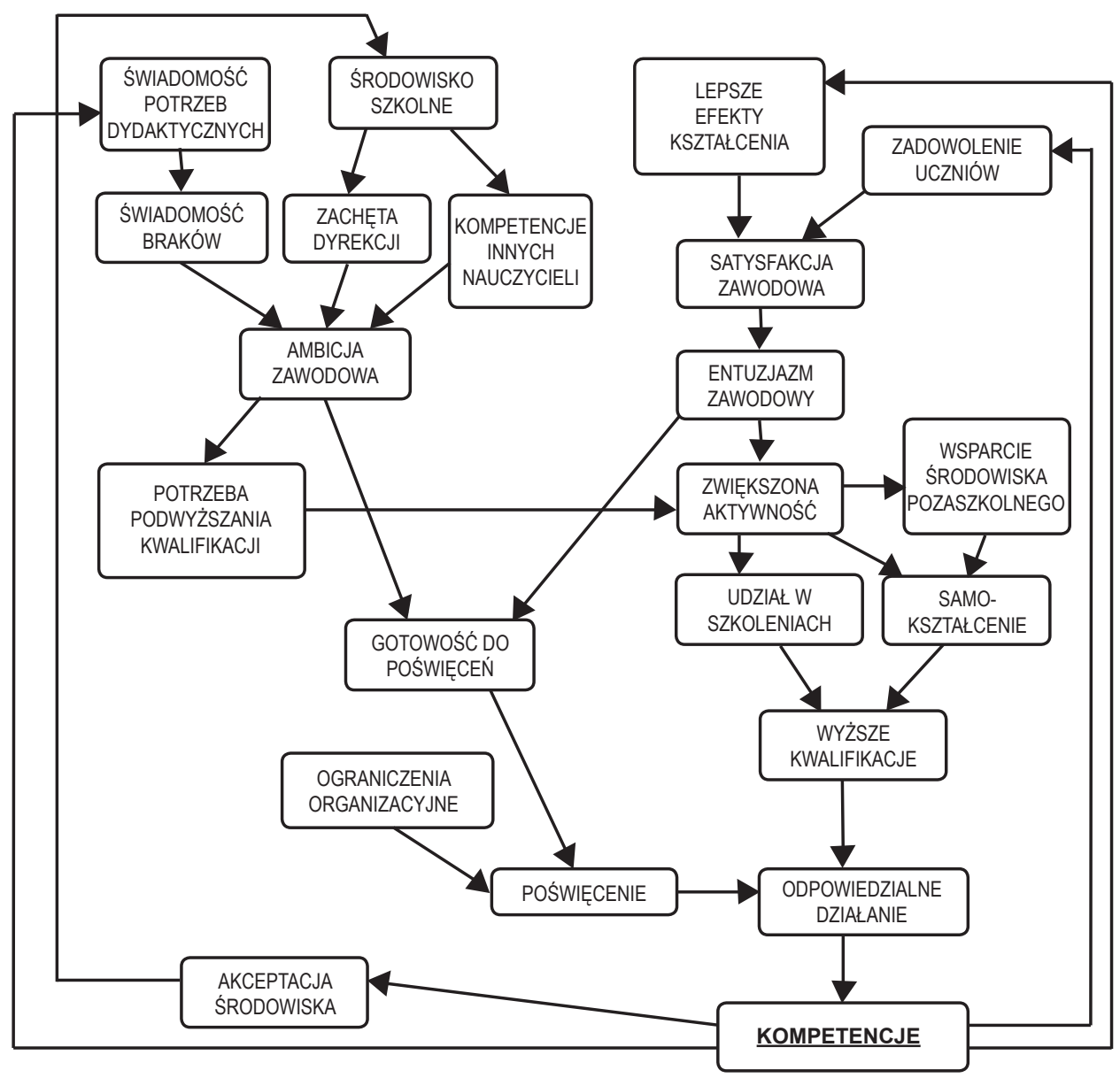

(źródło: badania własne)

W powyższym schemacie zauważyć można dwa charakterystyczne obiegi zamknięte, rozgałęzione na prawo i na lewo od „kompetencji”. Po wzmocnieniu sygnału w kolejno powiązanych ze sobą ogniwach, wracają do punktu docelowego „kompetencje”, dzięki czemu tworzą dwustronny mechanizm podwyższania kompetencji, który może działać bez przerywania. Każde kolejne okrążenie skutkuje bowiem z jednej strony intensyfikacją „odpowiedzialnego działania” (głównie lewa strona schematu), z drugiej - podwyższeniem kwalifikacji, za co odpowiada przede wszystkim prawa strona schematu. Potencjalnego źródła przerwania tak działającego 
mechanizmu można upatrywać z jednej strony w obniżeniu ambicji zawodowych, $\mathrm{z}$ drugiej zaś $\mathrm{w}$ obniżeniu poziomu entuzjazmu, obserwowanemu w działaniach nauczyciela, czyli w ujęciu graficznym, na osłabieniu ogniw kluczowych dla jednego lub drugiego obiegu. Na razie jednak, po 23 latach pracy pedagogicznej, N1 nie zdradza objawów obniżenia poziomu żadnego z tych czynników.

Podwójne sprzężenie każdego z obiegów skutkuje bardzo silnym, poczwórnym „mechanizmem wzrostu kompetencji”, co wyróżnia przypadek N1 spośród wszystkich pozostałych.

\subsubsection{Przypadek N2}

N2 to również 45-letnia nauczycielka, pracująca w jednej szkole w wymiarze 18 godzin tygodniowo. Pozostałe dane różnią się od poprzedniego przypadku: N2 jest absolwentką Akademii Muzycznej, posiada stopień nauczyciela kontraktowego a jej staż pracy pedagogicznej wynosi 7 lat, z czego 3 lata przypadają jeszcze na okres studiów. Po około 20-letniej przerwie, od 4 lat pracuje jako nauczyciel muzyki, plastyki i techniki.

Nieco ściszony głos i pełny zastanowienia tok narracji, spowalniający trochę wypowiedź, skłania do wniosku, że sposób mówienia N2 nie jest wynikiem 20-letniego doświadczenia pedagogicznego, a raczej pracownika muzeum, czy podobnej instytucji. Budzić to może obawy zarówno o możliwości w zakresie utrzymania dyscypliny na lekcji, jak i zbytnio nacechowany pietyzmem, odrealniony stosunek do samego przedmiotu muzyka. Obawy te jednak w toku wywiadu zostały całkowicie rozwiane.

Pierwsze ustalenia dotyczyły szkolnego sprzętu komputerowego, którego brak sprawia, że N2 korzysta na lekcjach z własnego sprzętu zarówno komputerowego jak i audiowizualnego.

[1-6]

A: „Widzę, że tutaj już laptop Pani ma rozpieczęto[wany]

N2: [Swój]

A: Swój, tak? Prywatny?

N2: Przynoszę z domu, tak. Właściwie większość to ja muszę sobie sama (.) zabezpieczyć, także tutaj nie jest aż tak (.) Właściwie nie ma, nie ma tak bardzo możliwości. Jest, są dwa laptopy, no ale to...” 
[45-52]

N2: „kupiłam w antykwariacie stare podręczniki, od dzieci (.) odkupiłam też stare no i mamy tutaj właśnie te podręczniki w klasie, że dzieci mogą z nich korzystać

A: Są w biblioteczkach.

N2: Taka biblioteczka jest.

A: O, i telewizor też widzę.

N2: No też mój, z domu przyniosłam.

A: Odtwarzacz DVD też.

N2: Też z domu przyniosłam ((śmiech))".

Braki sprzętowe szkoły nie są więc dla N2 problemem. Nie czekając na inicjatywę szkoły w tym zakresie sama organizuje potrzebny sprzęt, poświęcając własny czas i środki finansowe, wykazując umiarkowaną zaradność. Umiarkowaną - ponieważ nie szuka fundatorów, sponsorów, nie organizuje zbiórki pieniędzy, kiermaszy itp., ale najprostszą drogą osiąga zamierzony cel. Wyjątkiem jest tu sprzęt w postaci rzutnika multimedialnego, którego brak odczuwa N2, ale jego koszty wykraczają poza wypróbowany przez nią sposób.

Umiejętności informatyczne nabyła w trakcie studiów podyplomowych „Z pedagogiki wczesnoszkolnej i z dydaktyki nauczania plastyki” oraz „na Politechnice z techniki”. W obszarze dydaktycznych zastosowań TI, studia podyplomowe wyposażyły ją w umiejętność tworzenia prezentacji multimedialnych, co uznaje za bardzo przydatne w aktualnej pracy.

Pierwszy rok pracy pedagogicznej po niemal 20-letniej przerwie zaowocował wnioskami zawartymi w zdaniu:

[90-93]

N2: „No i się okazało, że że jednak no pierwszy rok to tak na tym, co co (.) miałam, co pamiętałam, no ale zauważyłam, że jednak no jest to nudne. Zresztą ja się sama też nudzę jeżeli (.) jeżeli lekcja jest tylko (.) oparta na podręczniku i wykładzie".

W trakcie tego roku N2 skorzystała z zaproszenia jednego z wydawnictw na prezentację podręczników wraz z dołączonymi do nich płytami multimedialnymi. To wzbogaciło nauczycielkę o nowe umiejętności oraz skłoniło do wyboru prezentowanego podręcznika na użytek własnych zajęć.

[114-116]

N2: „ja yyy te muzyczne programy, takie strony internetowe, na których można tam sobie znaleźć takie rzeczy (.) na jednym z (.) yyy takich pokazów wydawnictwa (.) muzycznego" 
[121-123]

N2: „I tam też było pokazane jak wykorzystać (.) właśnie (.) internet, czy też w ogóle komputer do (.) no przekazywania tych treści muzycznych".

W przypadku N2 droga od kwalifikacji do kompetencji była bardzo krótka. Ośmielona nowymi umiejętnościami chętnie zaczęła je wykorzystywać na lekcjach.

[124-129]

A: „I to Panią zachęciło też do tego, żeby wejść, śmielej z tym komputerem wejść do klasy, tak?

N2: [Tak]

A: [Czy już] (.) czy już Pani [ośmielona była wcześniej?]

N2: [Nieee], właśnie to jest to następuje tak stopniowo. Ja się sama tak ośmielam, najpierw muszę się sama nauczyć yyy $(2,0)$ i dopiero (.) przychodzę z tym na lekcję".

Bardzo ważne jest stwierdzenie, że ograniczenia w kwalifikacjach nie prowadzą do zaniechania wykorzystywania TI. Zdając sobie sprawę, że nie jest ekspertem w tej dziedzinie, N2 chętnie polega na umiejętnościach uczniów, którzy tym chętniej je prezentują, przy obopólnej korzyści i jeszcze większej satysfakcji uczniów.

\section{[133-136]}

N2: „Właśnie muszę powiedzieć, że bardzo się opieram też na pomocy dzieci, bo dzieci są bardzo chętne, ja je właśnie wtedy mo motywuję tym, że, że (.) właśnie że są dla mnie ważni (.) że wiedzą ode mnie więcej, że ja się chętnie od nich nauczę. I one się bardzo dobrze z tym czująa".

Dzięki wykorzystaniu TI, po początkowym złym doświadczeniu z pracy w pierwszym roku, N2 zaczęła czerpać satysfakcję z pracy nauczyciela:

[160]

N2: „Bardzo mi się to podoba, bo jest to (.) po prostu (.) przyjemniejsze prowadzenie".

Korzyści, które zauważa N2 w stosowaniu TI na lekcjach muzyki nie ograniczają się do samego nauczyciela. Dostrzega ona pozytywny wpływ takiego sposobu prowadzenia lekcji na uczniów.

[163-167]

N2: „No daje to to, że dziecko yyy $(2,0)$ zapamiętuje lepiej te te (.) informacje przekazywane na lekcji. Łatwiej to, ponieważ to przechodzi poprzez (.) właśnie słuch, wzrok, (.) yyy one mogą jeszcze praktycznie same yyy poćwiczyć, pobawić się (.) właśnie przy komputerze i to, ta lekcja nooo (.) wtedy (.) z lekcji dziecko więcej wynosi”. 
Warte podkreślenia jest to, że uczniowie zaskakująco entuzjastycznie podchodzą do sprawdzania ich wiedzy przy pomocy komputera, co w warunkach tradycyjnych napotyka zwykle na dużą niechęć.

[177-191]

N2: „tam jest również część, gdzie jest test. I dziecko sobie tworzy test (.) ile pytań, no i musi na te pytania odpowiedzieć i one bardzo chętnie, nawet takie dzieci, które $(2,0)$ są niechętne, to one mnie proszą, teraz chcą test (.)

A: Aha.

$\mathrm{N} 2$ : I one same właśnie (.) z uwagą czytają pytania, no muszą te pytania przeczytać, zrozumieć i odpowiedzieć na nie.

A: I ma Pani takie porównanie z taką lekcją (.) o tych samych treściach, też $\mathrm{z}$ jakimś testem ale $\mathrm{w}$ formie papierowej na przykład?

N2: No to nieee.

A: [Niechętnie?]

N2: [To już nie ma] takiej chęci, jest niechęć. A tutaj właśnie, no aż jestem zdziwiona, no bo (.) yyy był (.) wczoraj przykładowo, instrumenty smyczkowe (.) iii $(2,0)$ jakby podsumowaniem tego był ten test krótki. I dzieciaki same poprosiły, ja już nawet nie zauważyłam, że tam jest test (.) na dole w takiej tam części: proszę Pani chcemy test. Także no (.) które dziecko pyta, że chce test?”

N2 ma świadomość braków w swoich kwalifikacjach informatycznych ale wskazuje środowisko szkoły, jako forum wsparcia w tej dziedzinie.

[327-328]

N2: „Ostatnio miałam problem to koleżanki mi pomogły”

[333-334]

N2: „no po prostu jeżeli tam czegoś nie wiem, to pytam koleżanek, które akurat nie mają $\mathrm{z}$ tym programem (.)”

[338-339]

N2: „widzę, że jednak mam takie duże braki, jest tych pytań mnóstwo. No ale jak jest potrzeba, no to po prostu pytam koleżanek".

Jako jedną z barier, ograniczającą możliwość dokształcania z TI nauczycielka wskazuje nadmiar pracy biurokratycznej, związanej z funkcjonowaniem szkoły.

[375-380]

A: „Jest bariera technologiczna.

N2: Tak. W przyszłym roku dopiero, jak będę miała czas na to, żeby tą wiedzę ugruntować, na razie nie miałam kompletnie czasu, żeby się tym zająć, bo jest dużo takiej pracy w szkole też yyy $(3,0)$ która no biurokracji dużo jest, muszę dużo pisać (.) różnych takich planów, protokołów i tak dalej, że nie mam na to czasu, żeby się tak zająć faktycznie tą stroną tutaj (.) techniczną, jeśli chodzi o część muzyczną". 
Dotychczasowe, jednoznacznie pozytywne doświadczenia w stosowaniu TI na lekcjach muzyki sprawiają, że N2 dostrzega szeroką, wręcz sielską jeśli nie bajeczną perspektywę wykorzystania TI, jeśli tylko wyposażenie szkoły nie będzie stanowiło istotnej bariery.

[397-402]

A: „A jak by było więcej tych komputerów, rzutnik do tego, nagłośnie[nie?]

N2: [No to] w ogóle byłaby super zabawa, można byłoby się w ogóle rozwijać, [bawić się w tworzenie muzyki]

A: [A nie bałaby się Pani wtedy, że właściwie] pół lekcji się zajmie tą tą aparaturą i nie starczy na (.) prawdziwe (.) lekcje?

N2: Nnno nie, no bo (.) to już jest inny świat".

Dramatyczny kontrast między wrażeniami z pierwszego roku pracy, bez korzystania z TI, określanego jako nudny, a wizją pełnej optymizmu i rozmarzenia przyszłości, przy pełnej dostępności sprzętu, pozwalającej na zabawę w tworzenie muzyki, oddaje entuzjazm, z jakim N2 podchodzi do dydaktycznych zastosowań TI. Trzeba pamiętać, że kontrast ten wynika $\mathrm{z}$ doświadczenia a nie z naiwnego podejścia do słabo jeszcze opanowanego narzędzia. Entuzjazm N2 wyraźnie dominuje w podejściu do TI, choć ma inne korzenie niż w przypadku N1. Zatem i źródła kompetencji informatycznych są wynikiem innych, w tym przypadku mniej skomplikowanych wpływów (wykres 30.).

Linia przerywana oznacza w tym przypadku połączenie jeszcze nieobecne ale oczekiwane. N2 bowiem deklaruje chęć podwyższenia kwalifikacji, jednak na razie takich działań nie podjęła, wskazując na brak czasu, spowodowany dotychczasowym dokształcaniem w ramach studiów podyplomowych oraz nadmiarem czynności biurokratycznych, którymi jest obciążona w szkole. Po „domknięciu” brakującego ogniwa, cała prawa strona schematu może stworzyć samonapędzający się mechanizm, zwiększający kompetencje nauczyciela. W tym przypadku czteroletni okres zatrudnienia nie wystarczył do skonstruowania w pełni działającego mechanizmu, lub jak w przypadku N1 - mechanizmu "napędzającego się” dwustronnie. 
Wykres 30. Sieć przyczynowa. Źródła kompetencji informatycznych N2

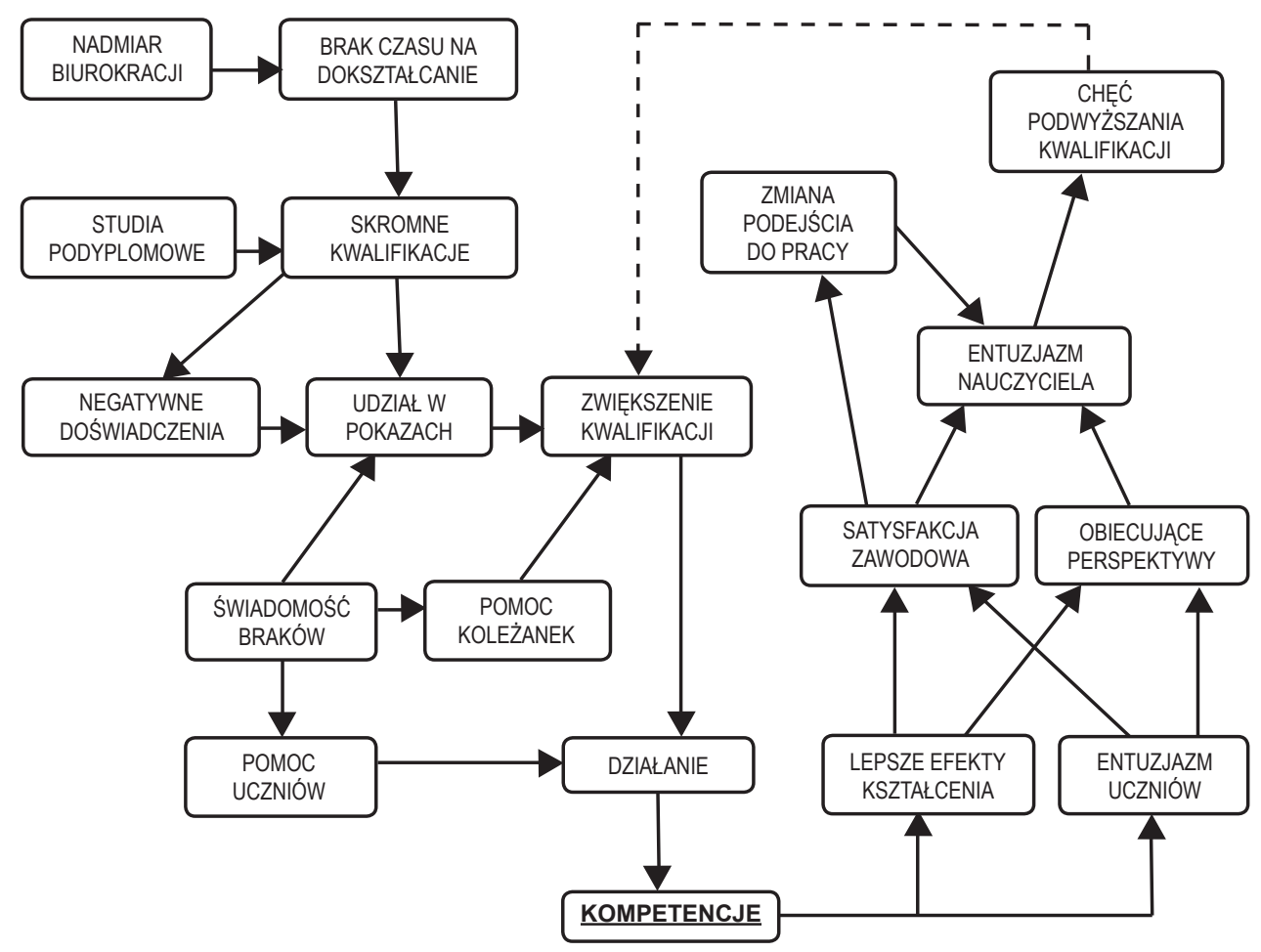

(źródło: badania własne)

Oczywiście na drodze przerywanej linii musi znaleźć się jakaś forma doskonalenia kwalifikacji. Może to być szkolenie, kurs albo samokształcenie. Udział w formalnym szkoleniu poprzedzony musi być jego poszukiwaniem lub - jak przywołane przez N2 pokazy - być przypadkowym, szczęśliwym zbiegiem okoliczności. Ważne jest jednak istnienie ogniwa „chęci podwyższania kwalifikacji” podbudowane entuzjazmem nauczycielki, który z kolei jest wynikiem pierwszych prób zastosowań narzędzi informatycznych w dydaktyce muzyki. Pozytywne doświadczenie daje podstawy, by sądzić, że N2 w niedługim czasie domknie kołowy mechanizm wzrostu kompetencji informatycznych, wzmacniając jednocześnie oddziaływania „napędzające" jego kolejnych ogniw. 


\subsubsection{Przypadek N3}

N3 to 43-letnia nauczycielka mianowana z 15-letnim stażem, pracująca w jednej szkole, w wymiarze 18 godzin tygodniowo, absolwentka Akademii Muzycznej. Zarówno staż jak i sposób opowiadania sytuują N3 dokładnie pomiędzy niezwykle entuzjastyczną postawą N1 a nieco wycofaną i wyciszoną postawą N2. Podejście N3 zarówno do tematyki rozmowy jak i samego sposobu komunikacji, pozbawione obu skrajności, najtrafniej można określić jako racjonalne.

Rozmówczyni nakreśliła bardzo naturalny sposób włączenia TI do własnego warsztatu dydaktycznego, nie wynikającego ani z potrzeby reakcji na złe doświadczenia (jak u N2) ani z potrzeby zastosowania świeżo nabytych, obiecujących kwalifikacji.

\section{[70-75]}

N3: „to po prostu samo przyszło (.) Płyty chyba kupiłam z gazetą po prostu, jakieś pierwsze takie właśnie encyklopedie multimedialne. No a skoro już miałam takie płyty, w domu sprawdziłam, że to jest bardzo fajnie zrobione, przystępnie dla dzieci, no to (.) przecież nie

A: Pomyślała Pani: [czemu nie skorzystać?]

N3: [Wiadomo, że trzeba] to wykorzystać w pracy".

Na razie multimedialne encyklopedie są jedynymi narzędziami z obszaru TI, jakie N3 używa. Inne, szczególnie muzyczne aplikacje, są w mniemaniu N3 zbyt drogie, dlatego szkoła ich nie posiada.

[128-132]

N3: „Nnnie mam takich programów, nie mam do zapisu nutowego, karaoke mam nadzieję, że się doczekam (.) Na razie nie było pieniędzy na to.

A: Czyli takie po prostu (.) na razie bazuje Pani tylko na tych encyklopedycznych programach, które tam przez jakieś wydawnictwa [takie poważne są wydane?]

N3: [Tak, tak, tak]".

Przyznaje jednak, że nie poświęca czasu na szukanie w sieci darmowych ciekawych programów i bazuje na tym, co w dość przypadkowy, okazjonalny sposób uda się jej pozyskać.

[153-156]

N3: „No nie, nie znalazłam nic takiego (.) Może za mało szukałam (.) Bo powiem szczerze, że ja tak na zasadzie, jak coś wchodzi w rękę (.) to kupuję, natomiast nie siedzę przed internetem, żeby szszszukać (.) tego wszystkiego, bo po prostu (.) czas mi za bardzo na to nie pozwala".

N3 uczestniczyła w kilku kursach komputerowych organizowanych przez szkołę a także poznała podstawy obsługi komputera w trakcie stu- 
diów podyplomowych. Tematyka tych szkoleń ograniczała się do podstaw informatyzacji i nie dotyczyła edukacyjnego potencjału TI.

Sprzęt RTV (telewizor, wideo, DVD, odtwarzacz CD, wzmacniacz, kolumny) jest do dyspozycji nauczycielki, zainstalowany na stałe w pracowni muzycznej. Komputer nie należy jednak do stałego wyposażenia i na każdą lekcję trzeba go zorganizować i przynieść. N3 nie odbiera tego jako niedogodność ograniczającą wykorzystanie TI.

[218-230]

A: „Aha, ale generalnie, jak chce Pani skorzystać z komputera to trzeba go najpierw sobie przynieść na tą konkretną, jedną lekcję, [tak?]

N3: [Tak]

A: Nie to, że na cały dzień, czy na cały tydzień?

N3: Nie, [nie, nie, na jedną lekcję]

A: [Na jedną lekcję to trzeba przynieść], później odnieść, czyli kawałek przerwy już (.) wypada, tak? $(2,0)$ i kawałek lekcji pewnie, żeby to podłączyć wszystko, żeby to [zagrało?]

N3: [Nie, no] to jest szybko [Dwie minuty podłączyć]

A: [Szybko idzie?]

N3: [Tak]

A: [Czyli] takich organizacyjnych problemów nie ma?

N3: Nie, nie".

Za główną zaletę stosowania TI na lekcji N3 uważa zwiększone zainteresowanie i skupienie uczniów. Jest zdania, że zbyt częste wykorzystywanie komputera sprawiłoby, że taka sytuacja spowszedniałaby dzieciom i efekt zainteresowania byłby coraz mniejszy. Być może to jest przyczyną, dla której N3 nie szuka nowych zastosowań, nowych programów, poprzestając na okazjonalnym wykorzystaniu komputera, dbając w ten sposób o podtrzymanie zainteresowania i zaciekawienia u uczniów. N3 nie wymienia po stronie korzyści lepszych efektów kształcenia (jak miało to miejsce u N1 i N2).

[247-251]

N3: „Nie codziennie, ale nawet jeżeli już zapowiem, że coś takiego będzie, to już są zachwycone i czekają na taką lekcje z utęsknieniem.

A: Aha. I jak [widzą]

N3: [Także] powiem szczerze, że nawet gdyby to było na każdej lekcji to przestałoby być atrakcją i przestałoby też spełniać takie zadanie, jakie $\underline{\mathrm{w} \text { tej chwili }}$ pełni".

N3 myśli o poszerzeniu swoich kwalifikacji informatycznych w sposób ukierunkowany przez uświadomione potrzeby dydaktyczne. 
[320-323]

A: „A myśli Pani o tym, żeby (.) jakoś jeszcze (.) uzupełnić tą swoją wiedzę z zakresu wykorzystania komputera w edukacji muzycznej, czy [czy]

N3: [Na pewno] bo ja sama nie potrafię pisać nut w żadnym programie”.

[544-545]

N3: „na przykład gdyby mogły sobie same komponować utwory, wykonywać, dobierać instrumenty, bawić się tymi brzmieniami”.

Widzi więc potencjalne korzyści płynące z wykorzystania specjalistycznie muzycznych aplikacji, których jednak nie zna ani nie podejmuje trudu ich poznania czy choćby tylko znalezienia. Korzystanie z internetu nie łączy się u N3 z poznawaniem czy szukaniem takiego oprogramowania i ogranicza się do ściągania gotowych materiałów (prezentacje multimedialne) lub pozyskiwania informacji. Sama, z powodu braku czasu, nie próbuje opanować żadnych programów, choć przyznaje, że potrafiłaby samodzielnie poznać interesującą aplikację, korzystając z pliku pomocy czy samouczków, bazując na dotychczasowym poziomie opanowania komputera.

[332-336]

N3: „na zasadzie po prostu metody prób i błędów i (.) myślę, że (.)

A: Mhm.

N3: nie, tutaj nie powinno być problemu.

A: Czyli tu żadnych ograniczeń Pani nie ma?

N3: Nie, nie boję się komputera ((śmiech))".

[386-387]

N3: „Znaczy samodzielnie takiej prezentacji nie wykonywałam jeszcze ale $(2,0)$ myślę, że (.) spróbuję".

N3 nie boi się o utratę autorytetu w sytuacji, gdy problemy techniczne związane z TI przekraczają jej kompetencje i - podobnie jak N2 - chętnie korzysta z pomocy uczniów w takich sytuacjach, widząc w takim działaniu korzyści wychowawcze.

[404-412]

N3: „Jak nie działa, jeżeli czegoś nie potrafię i coś nie działa to (.) dzieci wiedzą. I one się czują wtedy też (.) dobrze, bo o!, potrafiły mi w czymś pomóc. Także ja się cieszę, jak one coś wiedzą

A: Rozumiem, nie boi się [Pani takiej]

N3: [Nie nie] boję się tego

A: [zdemaskowania, że czegoś]

N3: [że ja będę czegoś wiedziała] (.) wiedziała mniej od nich. Nie.

A: Aha, wręcz przeciwnie [korzysta Pani]

N3: [Bo to je dowartościowuje] tak”. 
N3 nie odczuwa presji środowiska szkolnego, ani ze strony innych nauczycieli, ani ze strony dyrekcji i mimo swych nienajwyższych kompetencji informatycznych, zalicza się do czołówki informatycznej swojej szkoły. [455-460]

A: „A jak inni nauczyciele w tej samej szkole? Czy czy $(3,0)$ jeśli chodzi o obsługę tych (.) urządzeń komputerowych, to czuje Pani, że jest Pani w awangardzie tutaj nauczycieli czy

N3: No, chyba tak.

A: czy to jest normalna rzecz [w tej szkole?]

N3: [No, to nie jest] normalna, nie jest normalna".

Taki stan może dziwić z uwagi na niezwykle życzliwą i pomocną postawę nauczycielki informatyki w tej szkole.

[460-468]

N3: „ale każdy, kto chce skorzystać w taki sposób $(2,0)$ powiedzmy z tego rzutnika (.) i coś pokazać inaczej, to myślę, że pani od informatyki zawsze służy pomocą jeżeli tylko może.

A: Aha. I wytłumaczy (.) [podpowie]

N3: [Tak] wytłumaczy, podłączy [wszystko]

A: [czy nawet sama] przyjdzie, obsłuży, na lekcję, nie?

N3: przyjdzie, obsłuży, jeżeli [może]

A: [Też]

N3: Tak. Czy przygotuje nawet prezentację jeżeli ktoś potrzebuje. Jest taka możliwość".

N3 przyznaje, że część nauczycieli również wykorzystuje TI na własnych lekcjach, jednak nie wymieniają się doświadczeniami ani nie komentują nawzajem własnych dokonań w tym zakresie. Na takie konsultacje brak jest czasu.

[482-488]

N3: „bo już na taką (.) typową wymianę doświadczeń po prostu nie ma czasu, bo to nie jest tak, że zawsze jest tak (.) luźno, jak w tym momencie. Trzeba przyjść wcześniej do pracy, żeby był luz.

A: Aha, no tak.

N3: A tak to każda przerwa jest zajęta bo są dyżury na korytarzach, a na lekcji trzeba być już w klasie”.

N3, jako jedyna spośród uczestników wywiadów formułuje minus stosowania TI w edukacji. Jest to - jak sama podkreśla - minus w odległej perspektywie, jednak niezwykle ważny, bo dotyczący odhumanizowania procesu nauczania, co w przypadku takiego przedmiotu, jakim jest muzyka, musi budzić zaniepokojenie. 
[582-590]

A: „a widzi Pani jakiś minus?

N3: $(4,0)$ Jakiś minus? No widzę minus. Jeżeli dzieci będą (.) w ten sposób (.) odrabiać prace domowe, że wszystko przez komputer, że można będzie klasówki zrobić przez komputer, że wiedzę zdobywać przez komputer, to niedługo dojdzie do tego, że właściwie szkoła będzie niepotrzebna (.) nauczyciele też nie za bardzo, no jeden, który będzie w jakiś sposób tym sterował, no już nie mówiąc o tym, że jakieś takie (.) kontakty międzyludzkie też zaczną się zacierać, bo już każdy, dziecko tylko w ten komputer (.) będzie (.) wpatrzone i myślę, że nie należy aż tak bardzo w to brnąć”.

[621-626]

A: ,a teraz (.) aktualnie?

N3: Nie, teraz nie widzę, ponieważ nie ma takiej ilości sprzętu, nieprędko na pewno będzie...

A: Mhm.

N3: Pracownie są na bieżąco doposażane w różne rzeczy, w jakieś tablice interaktywne, ale to jeszcze trochę. $(2,0)$ Przynajmniej tutaj”.

N3 widzi więc, paradoksalnie, w niedostatkach sprzętowych jakiś plus, pozwalający na zachowanie rozsądnej równowagi w stosowaniu różnych środków dydaktycznych. Spokojny i nieco zrezygnowany ton ostatniej wypowiedzi, zdradza, że jest spokojna o tempo komputeryzacji szkół (przynajmniej własnej szkoły), który nie zagrozi technicyzacją edukacji w perspektywie jeszcze wielu lat.

$\mathrm{Z}$ wykresu 31. wynika, że mechanizmy samonapędzające kompetencje, dostrzeżone we wcześniejszych przypadkach, tutaj nie działają. Jeden z obiegów urywa się na ogniwie „brak wzrostu kwalifikacji”, drugi - mimo że domknięty - jest mocno wyhamowywany przez ogniwo „brak czasu”. Trudno w takich warunkach mówić o wzroście kompetencji przy każdym kolejnym obiegu, a jedynie o stosunkowo słabym podtrzymywaniu tego obiegu przez przypadkowo pozyskiwane materiały. W prawidłowo funkcjonującym obiegu ogniwo „myśl o poszerzeniu kwalifikacji” powinno mieć swoją naturalną konsekwencję w postaci „inicjatywy w poszerzaniu kwalifikacji”. Tu jednak „brak czasu” spowodował przekierowanie do ogniwa „brak inicjatywy poszerzania kwalifikacji”, co uniemożliwiło przyrost kompetencji w kolejnym obiegu.

Charakterystyczne jest w tym przypadku uformowanie małego „ślepego” obiegu, składającego się z ogniw: „nieznajomość oprogramowania”, „myśl o poszerzeniu kwalifikacji”, „brak czasu” oraz „brak poszukiwań programów”. 
Wykres 31. Sieć przyczynowa. Źródła kompetencji informatycznych N3

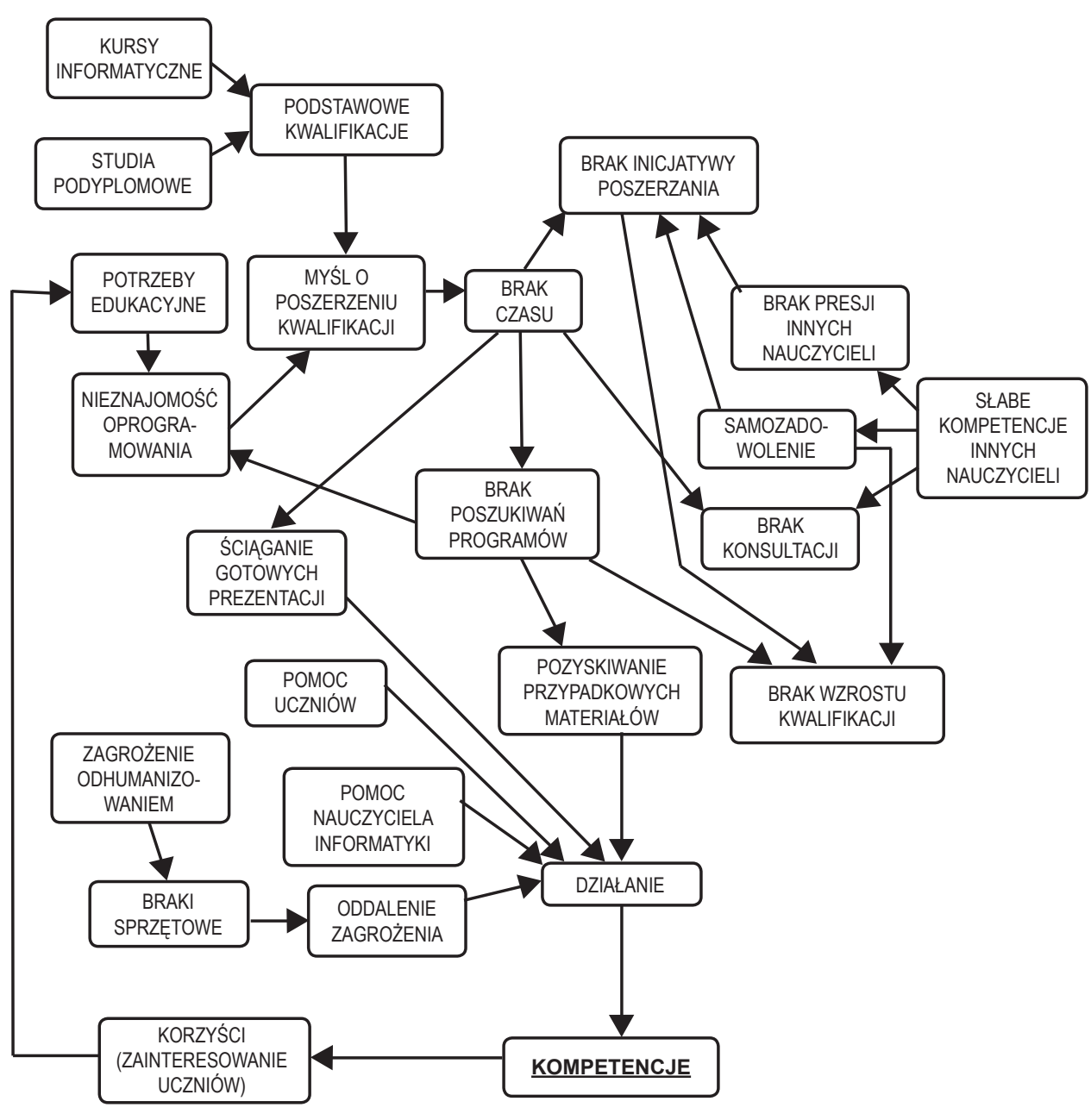

(źródło: badania własne)

Utworzenie takiego obiegu znacznie utrudnia wytworzenie efektu „samonapędzania” i ma funkcję hamującą. W takim „wyhamowywanym” obiegu przyrostu kompetencji ważne jest wykształcenie połączenia lub ogniwa przekierowującego ze ślepego obiegu do obiegu głównego, co dla nauczyciela może być oczywiste („nie mam czasu”), jednak dla dyrektora odpowiedzialnego za rozwój nauczycieli jest kluczową informacją.

$\mathrm{Z}$ drugiej strony omawianej sieci przyczynowej, słabe kompetencje innych nauczycieli stanowią pierwotną skazę potencjalnego drugiego obiegu przyrostu kompetencji, która nie pozwala na skierowanie łańcucha ogniw 
w stronę podwyższenia kwalifikacji, zrywając ciągłość obiegu na ogniwie „brak wzrostu kwalifikacji”.

W przypadku N3 zatem wzrostu kompetencji informatycznych można oczekiwać dopiero po uporaniu się z brakiem czasu, który obok słabych kompetencji innych nauczycieli w szkole, w sposób pośredni wpływa na „brak wzrostu kwalifikacji”. Te dwa ogniwa: „brak czasu” oraz „słabe kompetencje innych nauczycieli” wydają się decydujące dla domknięcia głównego obiegu mechanizmu wzrostu kompetencji.

\subsubsection{Przypadek N4}

N4 to 46-letnia nauczycielka dyplomowana z 23-letnim stażem nauczycielskim, absolwentka Akademii Muzycznej, zatrudniona w dwóch szkołach, w wymiarze 13 oraz 9 godzin tygodniowo.

Początkowa wypowiedź N4 ujawniła raczej niechętny stosunek do wykorzystywania TI w dydaktyce muzyki, mimo że w ankiecie zadeklarowała jej stosowanie „1-2 razy w tygodniu”. Sprzeczność ta zdominowała część wstępną wywiadu, tym bardziej, że negatywna i stanowcza zapowiedź stosunku do TI kontrastowała z włączonym i używanym właśnie przez N4 komputerem.

[1-14]

N4: „Tylko wszystkie odpowiedzi będą: nie, nie wiem.

A: ((ze śmiechem)) Widzę, że Pani ma laptopa otwartego na biurku

N4: ((kontrastowo poważnie)) Mamy dziennik elektroniczny.

A: Aha, i tylko $\mathrm{z}$ tego powodu, tak?

N4: Tylko (.) i wyłącznie. Znaczy nie, no pocztę otworzyłam, bo mam przerwę to otworzyłam swoją [pocztę]

A: [To znaczy] deklaruje Pani na początek, że generalnie z komputerów na lekcjach muzyki nie korzysta?

N4: Nie.

A: Nie.

N4: To znaczy (.) inaczej. Korzystam w tej drugiej szkole, w której pracuję, korzystam zzzz mmm podręcznika Nowej Ery i tam do każdego podręcznika dodana jest płyta (.) w której są, na której są $(3,0)$ różnego rodzaju prezentacje

A: Aha".

Stanowcza i negatywna deklaracja wstępna została natychmiast osłabiona przez serię zaprzeczających jej przykładów: używany właśnie komputer, korzystanie z dziennika elektronicznego, korzystanie z poczty elektronicz- 
nej, korzystanie z multimediów w drugiej szkole. Po takim „zdemaskowaniu” N4 opisuje sposób wykorzystywania przez siebie TI w ramach lekcji muzyki. Sprowadza się on do zadania domowego, polegającego na skorzystaniu przez uczniów z dołączonej do podręcznika płyty multimedialnej. Brak sprzętu uniemożliwia skorzystanie z niej na lekcji.

[15-19]

N4: „Ja tego nie wykorzystuję na lekcji, ponieważ tam w szkole nie mam ani ani komputera ani ani, no no mogłabym ewentualnie próbować w pracowni informatycznej, która jest obłożona w taki sposób, że nawet się tam nie wcisnę. Natomiast czasami jest tak, że na przykład jeśli mówimy o balecie na lekcji to wtedy (.) formą pracy domowej jest na przykład obejrzenie tego (.) co oni mają".

Skorzystanie ze sprzętu komputerowego jest jednak możliwe na zajęciach pozalekcyjnych, prowadzonych w mniejszych grupach (podobnie jak w przypadku N1).

[28-34]

N4: ,Z tych prezentacji korzystam tutaj, na ((nazwa ulicy)) yyy $(2,0)$ na takich zajęciach (.) artystycznych, bo napisałam innowację $(2,0)$ pedagogiczną Sztuka nie zna granic i to jest połączenie (.) przedmiotów artystycznych z językiem angielskim, bo to jest generalnie kształcenie kompetencji językowych, prowadzimy to razem $\mathrm{z}$ anglistką już drugi rok $\mathrm{i}$ to jest mniejsza grupa dzieci i wtedy no na na tych zajęciach czasami właśnie wykorzystuję te te płyty Nowej Ery, które (.) które są dołączone do podręcznika".

N4 przyznaje, że TI jest dla niej trudna, choć korzysta z niej, jak twierdzi, w podstawowym zakresie (programy komunikacyjne, edytor tekstu, gry).

[38-51]

A: „A w domu Pani korzysta $\mathrm{z}$ komputera?

N4: W jakim zakresie?

A: W jakimkolwiek.

N4: ((ze śmiechem)) No pewnie, że korzystam (.) [pasjanse układam]

A: [Aha] czyli to nie jest to że Pani jakąś awersję ma?

N4: Nie (.) nie, no dla mnie to jest po prostu trudne, no.

A: Trudne?

N4: No a nie?

A: No, jeżeli Pani korzysta w domu to znaczy, że

N4: Nieee no ale w takim zakresie powiedziałabym, bardzo (.) bardzo ograniczonym. No wszystkie dok cała dokumentacja szkolna, którą prowadzimy, no wiadomo, wszystkie sprawozdania, to wszystko, no to wszystko trzeba (.) trzeba napisać już nie (.) pismem (.) odręcznym tylko trzeba to napisać na komputerze, to po pierwsze, więc no w takim zakresie. Po drugie no, to poczta, internet, no". 
Czyli podstawowe kwalifikacje informatyczne N4 posiada, jednak zdaje sobie sprawę, że ich poziom jest na tyle niski, że nie pozwala na efektywne ich wykorzystywanie na lekcjach muzyki. Przede wszystkim zakres znanych programów jest ograniczeniem dla ich muzycznych zastosowań, z czym jednak N4 sobie radzi, korzystając z pomocy męża.

[52-64]

A: „A do żadnych muzycznych zastosowań nie? $(2,0)$ Nie było takiej potrzeby? $(2,0)$ Czy czasu?

N4: Ja mam męża muzyka, który (.) takie rzeczy robi, w związku z tym

A: Aha, czyli po prostu (.) wykorzystuje go Pani?

N4: ((śmiech))

A: Wyręcza się Pani tutaj.

N4: To znaczy, no jest przydatny w tym zakresie ((śmiech))

A: Ale to to co robi za Panią?

N4: $(2,0)$ Nagrywa aranże (.)

A: Aha (.) i później Pani je wykorzystuje tutaj (.) na lekcjach?

N4: Tak.

A: Mhm. Coś jeszcze?

N4: $(3,0)$ Jeśli chodzi o muzykę to chyba już (.) nnnie, chyba nie".

N4 czuje i nie ukrywa swojej słabości w dziedzinie TI, jednak nie jest to powodem frustracji, czy niskiego poczucia własnej wartości.

[65-72]

A: „Ale czuje tu Pani jakąś nie wiem (.) słabość swoją, jakąś ułomność w tym, że nie korzysta Pani? Czy nie (.) spokojnie (.) tak można (.) przecież szkoła nie wymaga nic takiego?

N4: To znaczy $(2,0)$ yyy

A: Bo tak z zakłopotaniem mi Pani tutaj opowiada o tym, że że (.) troszkę nie umie

N4: Tak, bo mam świadomość, że mamy XXI wiek i technologia (.) komputerowa nas (.) zewsząd (.) otacza. $(2,0)$ Fajnie by było, gdybym to potrafiła, natomiast tego nie potrafię (.) O,w ten sposób".

Brak dyskomfortu, spowodowanego niską oceną własnych kwalifikacji informatycznych sprawia, że N4 nie odczuwa potrzeby dokształcania w tej dziedzinie.

[73-75]

A: „A nie próbowała Pani, żeby na jakiś kurs się zapisać, na jakieś szkolenie czy coś?

N4: W pewnym wieku człowiek już ogranicza (.) ilość kursów (('śmiech))”. 
Bazuje więc na swoich dotychczasowych, nie związanych z TI kompetencjach i doświadczeniach, mając świadomość ich wystarczającego poziomu, aby skutecznie i profesjonalnie uczyć muzyki. Opinia o wysokiej fachowości prowadzonych przez nią zajęć, mimo braku na nich narzędzi informatycznych, jest potwierdzana przez studentów kierowanych do niej na praktyki pedagogiczne oraz samych opiekunów praktyk. Ma to niewątpliwy wpływ na stosunek do własnych braków w znajomości i chęci dydaktycznego wykorzystywania TI.

Kolejnym czynnikiem jest brak zainteresowania ze strony dyrekcji, które mogłoby zaowocować zachętą do uczestnictwa w szkoleniach czy do wykorzystania swoich nawet skromnych kwalifikacji. Brak bodźca z tej strony dziwi tym bardziej, że dyrektor jest jednocześnie informatykiem.

[77-82]

N4: „Dyrekcja chyba nie do końca jest zorientowana po pierwsze, po drugie (.) myślę, że ma wystarczająco dużo innych spraw związanych z funkcjonowaniem placówki, żeby interesować się, czy nauczyciel określonego przedmiotu w jakiś sposób (.) wykorzystuje to czy nie. No wszyscy musimy posługiwać się komputerem jako narzędziem $\mathrm{w}(2,0)$ podczas wypełniania dokumentacji, natomiast cała reszta to już jest chyba nasza (.) nasza sprawa, tak, a nie dyrekcji”.

Brak chęci do podwyższenia kwalifikacji informatycznych jest również częściowo skutkiem małej wiary w ich potencjał dydaktyczny. N4 zdaje sobie bowiem sprawę, że zajęcia z udziałem TI są dla uczniów atrakcyjniejsze ale nie jest przekonana o ich efektywności.

[83-95]

A: „A czy myśli Pani, że gdyby to wykorzystać (.) na lekcji, to coś by się zyskało czy nie?

N4: Nie no, pewnie, że by się zyskało bo zawsze $(2,0)$ uatrakcyjnienie zajęć to (.) zawsze jest (.) z korzyścią dla dla ucznia, tak? No to na pewno, to nie ulega [wątpliwości]

A: [Mhm. A to] by się przełożyło na jakąś wiedzę, umiejętności uczniów też? (.) Czy więcej by umieli przez to?

N4: ((głośne westchnięcie)) (.) Nie wiem, czy by umieli więcej, na pewno bylaby ta wiedza podana $\mathrm{w}$ ciekawszy sposób (.)

A: Mhm, [czyli zainteresowania więcej]

N4: [A czy] (.) umieli by więcej, to $(2,0)$ to wie Pan, czasami jest tak, że że (.) żeby człowiek nie wiem co robił to uczeń $i$ tak więcej w siebie nie wrzuci, a (.) a czasami jest tak, że nawet wiedza podana $w$ tradycyjny sposób, czy powiedzmy bez wykorzystania komputera, też do niego trafi, także to $(2,0)$ powiedziałabym bardzo indywidualnie (.) a nie (.) a nie ogólnie”. 
Brak wiary w dydaktyczną efektywność narzędzi informatycznych ma swoją granicę w formułowanych wątpliwościach i nie objawia się przekonaniem o negatywnych skutkach wykorzystywania TI, czy innymi uprzedzeniami.

$$
\text { [96-102] }
$$

A: „A taka technologia byłaby jakimś zagrożeniem ewentualnie? Czy coś coś by (.) umknęło, nie wiem, coś (.) ze szkodą dla (.) dla dydaktyki by było gdyby

N4: Nie. Według [mnie nie]

A: [taki komputer] zastosować? Nie.

N4: Według mnie nie, bo to jest po prostu narzędzie (.) tak jak kiedyś podręcznik, nie wiem, zeszyt ćwiczeń, czy cokolwiek innego. Wydaje mi się, że nie (.) No ale (.) ponieważ nie używam to nie wiem".

Jeszcze jednym powodem, dla którego N4 nie wykorzystuje TI może być fakt, że nie ma problemów dydaktycznych, które byłyby łatwiejsze do rozwiązania przy zastosowaniu TI. Nie ma bieżącej potrzeby takiego działania, wynikającej z niedostatków tradycyjnych metod i środków dydaktycznych.

[111-131]

A: „I nie ma Pani takich takich (.) konkretnych, takich bieżących problemów, które rozwiązałaby technologia komputerowa, ale niestety nie rozwiąże bo Pani tutaj widzi swoje ograniczenia?

N4: Na ten moment (.) [nie widzę nie widzę takich problemów]

A: [że fajnie by było] to umieć albo tamto umieć z komputerów (.) Nie ma takiego problemu?

N4: To znaczy (.) pewnie (.) pewnie (.) [jest]

A: [ale nie, konkretnego]

N4: tylko na ten moment (.)

A: coś konkretnego

N4: nie jestem w stanie sobie tego (.)

A: wyobrazić w ogóle?

N4: przypomnieć, wyobrazić. Przypuszczam, że no w danym momencie, kiedy coś takiego (.)

A: Czyli nie przeszkadza to Pani, w jakimś sensie, [wręcz przeciwnie?]

N4: [A powinno?] ((śmiech))

A: Nie, nie, broń Boże, ja nie [oceniam tego]

N4: [No właśnie] ((śmiech))

A: Nie oceniam, [tylko próbuję właśnie]

N4: [Nie, nie przesz]

A: poznać Pani [świadomość na ten temat]".

Paradoksalnie, działać tu może wysoki profesjonalizm N4, dzięki któremu nie musi szukać niekonwencjonalnych sposobów radzenia sobie z pro- 
blemami dydaktycznymi, skoro metody konwencjonalne takich problemów nie generują.

W środowisku szkoły N4 nie ma okazji zaobserwować ewentualnych korzyści płynących z wykorzystania TI na zajęciach, ponieważ inni nauczyciele również nie stosują takich rozwiązań. Brak motywacji ze strony dyrekcji działa więc na wszystkich pracujących w szkole nauczycieli.

[144-145]

N4: „ja się obracam w takim gronie koleżanek, które też nie stosują (('śmiech))”.

Rozmówczyni kreśli jednak bliską perspektywę powszechnego stosowania TI w dydaktyce, nie rozstrzygając jednak kontekstu swoich przemyśleń: nadziei czy obaw. Prawdopodobnie obydwa rodzaje uczuć mogą być jej udziałem.

[166-170]

N4: „No bo wiadomo, że no jeśli to są podręczniki - a będą to pewnie w większości podręczniki napisane prawie od początku - no to one będą obudowane już nowoczesnymi (.) pomocami dydaktycznymi, tak? Na to liczę.

A: Rozumiem.

N4: Ale to zobaczymy".

Ze strony uczniów N4 również (podobnie jak ze strony dyrekcji czy innych nauczycieli) nie spotkała się z przypadkami zachęty do wykorzystywania TI na lekcji muzyki. Na taką jednak ewentualność ma przygotowaną reakcję, przenoszącą jej odpowiedzialność na nauczyciela informatyki, bagatelizując całkowicie własny udział w pomocy uczniom zainteresowanym muzycznymi zastosowaniami TI.

[171-182]

A: „A nie spotkała Pani się tutaj z jakimiś takimi (.) prośbami, pytaniami uczniów w tym zakresie, jak z tą muzyką w komputerze [coś można zrobić?]

N4: [Nie]

A: Nie.

N4: Nie, nie. Znaczy (.) wie Pan, dzieciaki są bystre, w związku z tym myślę, że doskonale widzą (.) do kogo się mogą zwrócić z tego rodzaju problemem ((śmiech))

A: Ale też widzą laptopa na biurku

N4: Aaa ((śmiech)) i widzą moje usilne starania, bo tutaj jest problem z serwerem (.)

A: Aha.

N4: i walkę o to, żeby sprawdzić obecność, bo cały czas spada połączenie, w związku z tym myślę, ((śmiech)) że spokojnie mają Pana od informatyki tudzież inne źródła i ja tutaj nie jestem dobrym źródłem informacji ((śmiech))". 
Podsumowaniem tego krótkiego ale bogatego wywiadu jest sieć przyczynowa, obrazująca źródła kompetencji informatycznych, która w tym przypadku obrazuje mechanizm powodujący ograniczenie lub zanik tychże kompetencji. Jak bowiem ustalono wcześniej, jedyną sytuacją dydaktyczną, w której N4 wykorzystuje TI, są pozalekcyjne zajęcia językowe, dla których treści muzyczne stanowią jedynie środek wspomagający i stymulujący.

Wykres 32. Sieć przyczynowa. Źródła kompetencji informatycznych N4

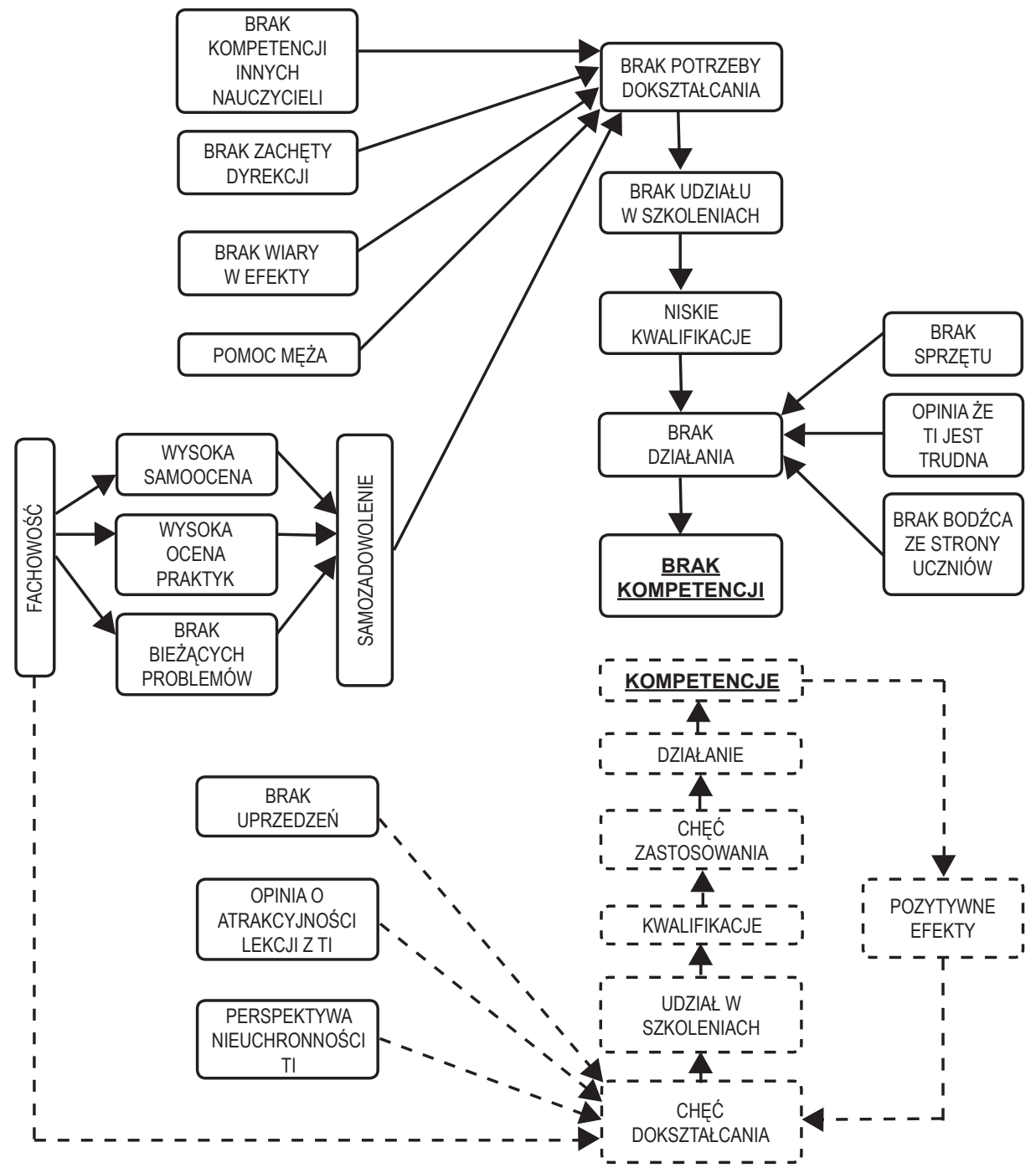

(źródło: badania własne) 
Część ogniw oraz połączeń sieci, wyróżnionych przerywaną linią, jest w przypadku N4 nieobecna. Stąd ścieżka dochodzenia do kompetencji urywa się na potencjalnych źródłach chęci dokształcania (połączenia najniższego na schemacie ogniwa). Ilość i waga czynników wpływających na brak potrzeby dokształcania przewyższa analogiczne parametry czynników mogących wzbudzić chęć dokształcania. Brak uprzedzeń, opinia o atrakcyjności lekcji prowadzonych z użyciem TI oraz perspektywa nieuchronnej konieczności nabycia kompetencji informatycznych, stanowią razem zbyt mały potencjał, by zaowocowały chęcią dokształcania. W tym przypadku uaktywnienie ścieżki dochodzenia do kompetencji można uzyskać przez zmianę proporcji czynników pozytywnych i negatywnych. Poprawy sytuacji należy więc upatrywać przede wszystkim w zachęcie ze strony dyrekcji, która wpłynęłaby jednocześnie na poprawę poziomu kompetencji innych nauczycieli. Brak środowiska wspierającego nabywanie kompetencji informatycznych wydaje się być w tym przypadku kluczową przyczyną, dla której N4 nie podejmuje trudu podwyższenia własnych kwalifikacji w tym zakresie.

Należy również zauważyć, że wysoko oceniana fachowość N4, zgodnie ze schematem owocuje jedynie samozadowoleniem i nie jest źródłem chęci doskonalenia, przynajmniej w zakresie wykorzystywania TI. Być może przekierowanie tylko tego połączenia wpłynęłoby na uruchomienie ogniwa „chęć dokształcania”, skąd już prosta droga do osiągnięcia kompetencji.

\subsubsection{Przypadek $N_{5}$}

Przypadek N5 to 38-letnia nauczycielka dyplomowana, z 8-letnim stażem pracy nauczycielskiej, absolwentka Uniwersytetu Łódzkiego, pracująca w jednej szkole, w wymiarze 18 godzin tygodniowo. $Z$ ankiety wynika, że opanowała dużą ilość użytecznych dydaktycznie programów komputerowych, w tym specjalistycznie muzycznych, które wykorzystuje w swojej pracy z dużą częstotliwością („średnio co drugie zajęcia”). Jako źródło swoich umiejętności wskazuje samokształcenie.

[4-7]

A: „gdzie się Pani tego nauczyła przede wszystkim?

N5: A ja sobie sama się uczę (.)

A: Całkowicie?

N5: Tak". 
Poznawanie nowych programów jest u niej reakcją na pojawiającą się potrzebę. Jest to więc bardzo praktyczne i zarazem przedmiotowe podejście do TI, całkowicie podporządkowane potrzebom dydaktycznym.

[31-33]

N5: „jak pojawiła się taka potrzeba, że muszę coś ściąć, skrócić, wydłużyć czy coś zrobić z tym dźwiękiem to wtedy zaczęłam szukać, tak? Tak, jak mówię no (.) jak jest potrzeba to i trzeba szukać”.

[69-70]

N5: „bo ja tak (.) wpada mi coś kiedy przeszukuję internet, nagle coś gdzieś znajduję i wtedy to ściągam i sprawdzam jak to działa, ale tego jeszcze nie zdążyłam”.

N5 ma do dyspozycji sprzęt komputerowy, dostęp do pracowni informatycznej, z czego chętnie korzysta, wykorzystując prezentacje i materiały wideo wyszukane w internecie.

[36-43]

N5: „Jeżeli już chodzi o lekcje, to (.) jeżeli mam coś wykorzystać to tak: wykorzystuję prezentacje multimedialne, pokazuję dzieciom plansze różne, które są, bo mamy salę informatyczną więc tam wchodzę czasami, mamy duży rzutnik, gdzie także można dzieciom puszczać różne rzeczy (.) pokazuję dzieciakom (.) no wiadomo, że no komputer do czego jest, także do ściągania plików różnych, tak. Więc wszystkie rzeczy których sama nie mogę dojść to po prostu gdzieś tam ściągam jakieś fajne przedstawienia czy tam baletowe, czy coś, co można dzieciom pokazać, czy czy opery i i oni to oglądają po prostu na miejscu”.

Mimo dostępności szkolnego sprzętu komputerowego, N5 twierdzi, że przynosi na zajęcia własnego laptopa, co jest praktyką powszechną również wśród pozostałych nauczycieli.

[105-108]

N5: „zresztą u nas każdy ma laptopa, więc jak gdyby to nie ma problemu.

A: Swojego prywatnego rozumiem?

N5: No (.) Każdy nosi (.) jak potrzeba”.

Wpływ środowiska szkoły jest tu bardzo wyraźny. Wywiad przeprowadzono w pokoju nauczycielskim, do którego co jakiś czas wchodził ktoś z nauczycieli, trzymając pod pachą laptopa. Przy stoliku obok, jeden z nauczycieli korzystał również z laptopa. Mała ilość uczniów (po jednym oddziale klasowym na każdym poziomie) pozwala na dość swobodny dostęp do pracowni komputerowej. Niespotykane w innych szkołach nasycenie sprzętem komputerowym skutkowało poczuciem pewnego rodzaju egzotyki, podkreślonego usytuowaniem szkoły na zupełnych peryferiach miasta.

Środowisko szkolne bardzo sprzyja poszukiwaniu nowych rozwiązań metodycznych, szczególnie związanych z TI. N5 może liczyć na wsparcie 
zarówno innych nauczycieli jak i dyrekcji, która jednak prowadząc zajęcia wychowania fizycznego, sama nie ma okazji wykorzystywania podobnych rozwiązań w ramach swoich zajęć.

[309-316]

A: ,jest taka atmosfera sprzyjająca [wykorzystaniu komputerów?]

N5: [Bo to jest taka szkoła] poszukująca mocno. Tak, tak, jednak tak, że tutaj staramy się jak najczęściej.

A: I jak, jest jakaś wymiana doświadczeń, jakaś jakaś dyskusja na ten temat, co można by zrobić [jeszcze i jak?]

N5: [Tak, na przy...] no oczywiście, na przykład to jak mówiłam, jeżeli na przykład ktoś znajdzie coś fajnego to przekazuje całej reszcie”.

[321-323]

A: „Mhm, a ze strony dyrekcji jest podobne wsparcie?

N5: A tak, dyrektorka tak, dyrekcja zachęca nas do tego, żeby poszukiwać, żeby żeby różne rzeczy takie ciekawe".

Taki wpływ zarówno dyrektora, jak i pozostałych nauczycieli, stwarza atmosferę pozytywnej presji, zachęcającej do poszukiwań nowych rozwiązań i chęci akceptacji przez tak kompetentne środowisko. Oprócz takiej inspiracji, do stosowania TI skłania N5 chęć urozmaicenia swojego warsztatu i jednocześnie samych zajęć. Lubi nowości i nie poprzestaje na wypróbowanych wielokrotnie scenariuszach.

[77-83]

N5: „No lubię takie nowości, żeby żeby tak w rutynę nie wpaść, żeby to wszystko nie wyglądało ciągle tak samo (.)

A: Czyli to ewoluuje jeszcze do tego, tak?

N5: No ba!

A: Jakieś nowe programy cały czas Pani [szuka, coś innego znajduje]

N5: [No oczywiście cały czas] To nie tak, że już mam jakąś tam bazę i już jest OK., nie nie nie. To to zawsze zawsze jest coś nowego, zawsze coś można fajnego znaleźć".

Mimo dość powszechnego stosowania komputera na lekcjach, uczniowie cały czas reagują większym skupieniem i zainteresowaniem na treści przekazywane w ten sposób. N5 zdaje sobie sprawę, że korzyści z wykorzystania TI polegają nie tylko na większym skupieniu uczniów ale i na lepszym opanowaniu wiedzy.

[118-121]

N5: „Teraz komputer ma po prostu inne znaczenie. Wszystko co komputerowe to fajniejsze (.) Dzieci mają takie podejście do życia. Że ten komputer jak gdyby, ja mówię, tak jak się mówi do dzieci to (.) słyszą szumy, jak powiem komputer (.) to jest natychmiast uwaga". 
[125-129]

N5: „no i generalnie (.) jakoś tak oni chyba bardziej się skupiają, kiedy jeszcze coś widzą, kiedy mają poparcie tego mojego słowa mówionego jeszcze na czymś, co widzą.

A: Czyli zyskuje Pani większe skupienie po [prostu, tak?]

N5: [Na pewno] na pewno. I więcej, myślę, że wynoszą z tego, zapamiętują więcej”.

Stosowanie więc TI skutkuje u N5 satysfakcją z lepszych efektów kształcenia i zainteresowania ze strony uczniów. To zainteresowanie powoduje również, że niektóre prace domowe wykonywane są jako prezentacje multimedialne, choć ta forma nie jest obowiązkowa.

W obszarze zabaw lub gier edukacyjnych N5 nie wykorzystuje TI, z jednej strony nie spotkała się jeszcze $\mathrm{z}$ takimi programami, $\mathrm{z}$ drugiej zaś bazuje na tradycyjnych formach zabawy przy lub z muzyką, nie odczuwając potrzeby informatyzacji w tym zakresie.

[189-192]

N5: ,ja, jeżeli chodzi o tam gry, zabawy muzyczne no to raczej (.) korzystam z tych takich (.) no może i banalnych tam Orffy, Klanzy i tak dalej, więc jak gdyby tutaj te te muzyczne takie sensu stricte, więc w komputerze jeszcze mi się nie trafiły".

Stosowanie komputerów na lekcji łączy się jednak z pewnymi wyrzeczeniami. Jak podkreśla N5, wymiar godzinowy lekcji muzyki nie wystarcza na przekazanie całego materiału, zabawy muzyczne, granie na instrumentach, przygotowanie oprawy muzycznej imprez szkolnych i gry edukacyjne z komputerem. Stąd ograniczenie zastosowania TI do przekazu niezbędnych treści kształcenia.

[256-259]

N5: „praca na komputerze też wymaga następnego nakładu jak gdyby, nie tyle mojej pracy, bo to akurat nie jest ważne, ale tego, że jeszcze muszę gdzieś tam uszczknąć (.) z tego materiału, żeby jeszcze z tymi komputerami (.) No, ale staram się, żeby tak, żeby to było urozmaicone".

Inspiracja do wykorzystania TI na lekcji pojawiła się przypadkowo. Pomysł znalazła N5 w internecie i postanowiła go wykorzystać. Można więc uznać, że dzięki domowemu wykorzystywaniu TI doszło w tym przypadku do rozszerzenia kompetencji na obszar zawodowy. W dalszym ciągu traktuje internet jako inspirację oraz źródło materiałów dydaktycznych.

[359-362]

N5: „Ale, ale po prostu (.) mówię no $(2,0)$ uważam, że komputer jest kopalnią wszystkiego, kopalnią wiedzy, kopalnią informacji, kopalnią pomysłów. Tylko wystarczy, tylko trzeba dużo czasu spędzić przy przy komputerze, żeby coś znaleźć (.) Ale można". 
Szkoleń informatycznych N5 nie szuka, choć przyznaje, że śledzi ofertę szkoleniową ale kursu na temat muzycznych zastosowań TI nie znalazła, dlatego w dalszym ciągu bazuje jedynie na samokształceniu. Prowadzi również własną stronę internetową, na której zamieszcza materiały dla uczniów.

$$
\text { [441-444] }
$$

N5: Mam też swoją stronę internetową, którą prowadzę i tam na przykład zamieszczam informacje dla uczniów, na przykład - nie wiem - treści do sprawdzianów, które mogą sobie ściągnąć jeżeli czegoś nie wiedzą, to jeżeli ktoś na przykład nie wiem (.) nie zdążył na lekcji zrobić notatki to ma to w formie (.) komputerowej".

Brak oporów w stosowaniu TI przez N5 ma swe źródła również w poczuciu pewności swoich kompetencji i braku obaw związanych z technicznymi aspektami takich działań. Źródła kompetencji N5 przedstawia poniższy schemat.

Wykres 33. Sieć przyczynowa. Źródła kompetencji informatycznych N5

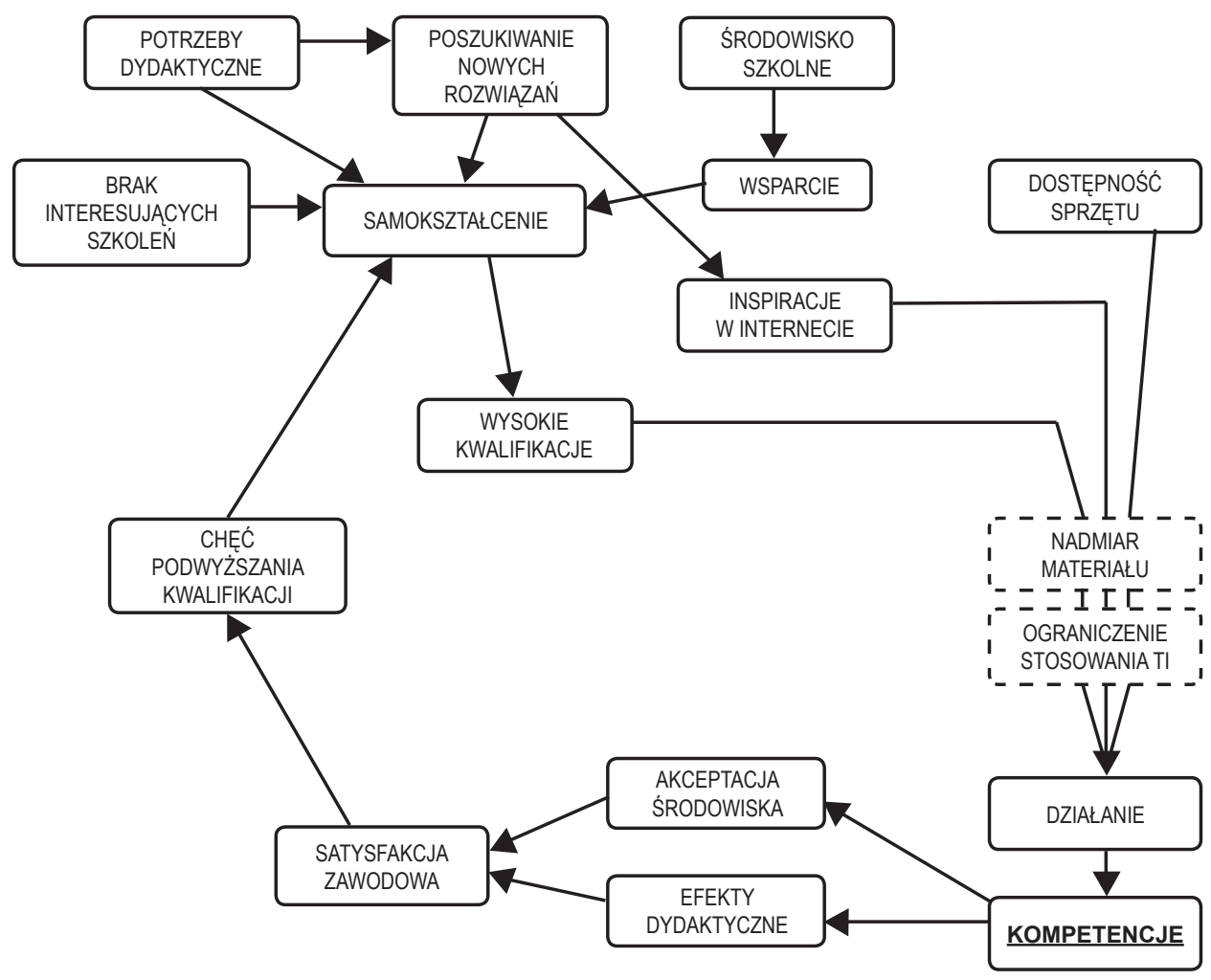

(źródło: badania własne) 
Dwa ogniwa, zaznaczone jaśniejszą przerywaną linią, pełnią negatywną rolę - wyhamowują bezpośredni wpływ bodźców na ogniwo „działanie”.

W konstrukcji całego schematu dostrzec można pewne podobieństwa do przypadku N1. W obydwu bowiem „kompetencje” zapoczątkowują drugi obieg dzięki dwóm ogniwom - „pozytywnym efektom dydaktycznym” oraz „akceptacji środowiska”, które jednak w przypadku N1 skutkują dwoma oddzielnymi obiegami, stymulującymi wzrost kompetencji, wyraźnie zwerbalizowanymi w trakcie wywiadu. W przypadku N5 takie rozłożenie akcentów nie miało miejsca, bowiem zajmujące w schemacie N1 centralne miejsca kategorie „entuzjazm zawodowy” czy „ambicja zawodowa” nie zostały wyeksponowane w trakcie wywiadu z N5. Te mocne, „obiegotwórcze” ogniwa zastąpione zostały w przypadku N5 dużo słabszą formą „,satysfakcji zawodowej”, generującą tylko pojedynczy obieg wzrostu kompetencji.

Zauważamy zatem istnienie domkniętego obiegu wzrostu kompetencji, bez „ślepych obiegów” czy urwanych połączeń, jednak jego działanie nie jest skutkiem szczególnie energetycznych ogniw (w porównaniu choćby z N1) i dodatkowo napotyka na wyhamowujące ogniwo „nadmiar materiału”.

\subsubsection{Przypadek N6}

N6 to jedyny mężczyzna wśród uczestników wywiadów, 45-letni nauczyciel dyplomowany z 18-letnim stażem, pracujący w jednej szkole podstawowej, w wymiarze 18 godzin tygodniowo, absolwent Akademii $\mathrm{Mu}-$ zycznej.

Podobnie jak N5 bardzo często wykorzystuje TI w pracy dydaktycznej („kilka razy w miesiącu”) i zna dużo specjalistycznie muzycznych programów komputerowych (Audacity, Cubase, ACID XPress, Nuendo, Cakewalk, Finale, Sibelius i in.). Tego rodzaju programami próbuje zainteresować uczniów, co ze względu na złożoność aplikacji, każe ograniczyć krąg adresatów do najstarszych uczniów (klasy szóste), którzy wykazują zainteresowanie takimi zastosowaniami TI.

[14-22]

N6: „Na przykład $(2,0)$ generalnie to w starszych klasach, w szóstych klasach (.) bo (.) młodsze dzieci to jeszcze nie bardzo orientują się na komputerze, nie bardzo znają, w starszych klasach już tak, bo (.) są na przykład uczniowie zainteresowani i w ogóle no oprogramowaniem muzycznym. Wiem, że niektórzy jakiś taki program e-DJ się nazywa, że tam się bawili troszkę. Więc ja tutaj (.) że tak powiem, ukierunkowuję ich mówiąc jakie programy, pokazuję, demonstruję, żeby ucznio- 
wie, że tak powiem, zaznajomili się tak troszkę chociażby z takimi poważniejszymi (.) programami typu ACID XPress (.) który daje bardzo (.) duże możliwości”.

Jednym $z$ impulsów więc do takiego działania są doświadczenia uczniów, sygnalizowane nauczycielowi.

Takie działania nie są skierowane do wszystkich uczniów, a jedynie do zainteresowanych takimi sposobami wykorzystania komputera. Dlatego nie są elementem ocenianej wiedzy, czy obowiązkowej pracy domowej.

[174-182]

N6: „Wie Pan co, powiem tak: ponieważ (.) nie zdarzyło mi się, żeby w stu procentach klasa była zainteresowana takim działaniem, a że tak powiem no nie ma wymagań $(2,0)$ właśnie, skorzystania z takiego oprogramowania czy tworzenia w ogóle w takim oprogramowaniu muzyki przez dzieci, dlatego po prostu no to nie jest przeze mnie traktowane jako że tak powiem wymóg (.)

A: Mhm.

N6: Jest to bardziej na zasadzie takiej zainteresowania, zaciekawienia i pokazania (.) kolejnej możliwości, jaką daje no komputer i po prostu możliwości muzykowania w inny sposób.

A: Mhm.

N6: Więc to nie jest na takiej zasadzie, że dziecko ma coś zrobić na ocenę, bo jak nie zrobi to będzie gorsza ocena.

A: Rozumiem.

N6: Więc no, nie chcę tutaj, że tak powiem (.) [odstraszyć]

A: [To jest coś ponad], dla niektórych, dla [wybranych]

N6: [Tak] tak. To jest dla osób (.)

A: [zainteresowanych]

N6: [które chcą], żeby zainteresować, żeby wskazać drogę współczesnej muzyki”.

Brak oceniania takich działań u uczniów jest skutkiem selektywnego adresowania w pewien sposób „ekskluzywnej” wiedzy, którą nauczyciel traktuje w kategoriach zachęty do samodzielnych prób a nie obowiązującego wszystkich elementu programu nauczania.

N6 znajduje czas, by w ramach lekcji zademonstrować działanie wybranego programu, natomiast uczniowie w domu próbują zastosować tak nabytą wiedzę.

[27-31]

A: „Ale tutaj mogą korzystać w szkole (.) na lekcji?

N6: To znaczy na lekcji ja demonstruję, a generalnie to uczniowie w domu (.)

A: Aha.

N6: Bo (.) chodzi o to, że że wie Pan, no (.) jeden komputer, który mam w sali, no (.) nie nie dałby możliwości, żeby każdy spróbował chociaż, prawda?” 
N6 wskazuje więc ograniczenia sprzętowe, jako przyczynę wyboru formy pokazu zamiast aktywnego ćwiczenia. Dysponuje jednym komputerem, za to do swojego wyłącznego użytku.

[32-43]

A: „A ma Pan komputer w sali, [tak?]

N6: [Tak] mam.

A: Czyli może Pan spokojnie

N6: Tak, [tak]

A: [Na stałe] on jest, tak?

N6: Tak, [na stałe]

A: [Nie to], że trzeba przynosić na lekcję?

N6: To znaczy mam na zapleczu, także no (.)

A: Aha i [w każdej chwili]

N6: [wystawiam] go (.) [na takim wózku]

A: [Nie trzeba nikogo] pytać, tak?

N6: Tak, no, w każdej chwili, kiedy chcę mogę ten komputer wystawić i użyć".

Sytuacja sprzętowa pozwala tylko czasem na to, by uczniowie pojedynczo mogli sami wypróbować swoje umiejętności. Priorytetem jest tu dla nauczyciela dyscyplina.

[114-120]

N6: „wie Pan, no to to jest system (.) lekcyjny, gdzie gdzie no nie można sobie podejść i każdy, jak kto chce w danej chwili prawda, zrobić, bo to jest lekcja, no i to są dzieci (.) przeze mnie wybrane, które mogą po prostu, że tak powiem skorzystać w danej chwili (.) [na lekcji].

A: [Aha], to pojedynczo mogą podejść [do komputera i coś zrobić?]

N6: [Pojedynczo] tak, żeby nie było tak, że że (.) cała klasa nagle przy jednym komputerze stoi i każdy chce coś tam zrobić, no. To musi być uporządkowany system pracy".

N6 samemu korzystając z wymienionych programów, znajduje niekonwencjonalne ich zastosowania, prezentując uczniom efekty takich działań związane z tematyką lekcji.

[54-68]

N6: „((westchnięcie)) (3,0) zawsze można coś zastosować (.) do danego programu, chociażby, prawda, przy omawianiu (.) jakiegoś twórcy powiedzmy (.)

A: Mhm

N6: czy twórczości Beethovena. Zawsze można to wpleść, bo można przetworzyć, zmiksować ten utwór, prawda, omawiany, dodać jakieś instrumenty, co daje, no (.) pewną zabawę dzieciom (.)

A: [Mhm]

N6: [I to], że tak powiem, daje (.) rozszerza horyzonty ich wiedzy. 
A: Mhm.

N6: Także, no (.) w taki sposób. Czy na przykład w $(2,0)$ przy $(2,0)$ nauce, na przykład, śpiewu jakiejś piosenki. Można, prawda, nagrać głos i, i no to posłuchajcie jak to (.) brzmi (.) [Żeby dzieci miały]

A: [Aha, na lekcji nagrać] głos [dziecka, tak?]

N6: [Nawet na lekcji]".

Należy tu podkreślić nieszablonowość zastosowań TI, świadczące o dużej inwencji nauczyciela, choć - z drugiej strony - trudno o jasne powiązanie takich pomysłów z założonymi w programie nauczania treściami kształcenia.

N6 dostrzega starania dyrektora o podnoszenie kwalifikacji informatycznych nauczycieli, choć sam nie korzysta ze szkoleń informatycznych. Nie znalazł interesujących go kursów, dlatego bazuje na samokształceniu. Pozostali nauczyciele, mimo korzystania z takich kursów, nie wykorzystują TI na zajęciach, przynajmniej nie w zauważalny dla N6 sposób. Środowisko szkolne zatem, z którego N6 może czerpać inspiracje do dydaktycznych zastosowań TI, ogranicza się tylko do uczniów.

[127-132]

A: „A Pan skąd się dowiedział?

N6: (.) Nauczyłem [się]

A: [O tych] możliwościach? (.) [Samemu, zupełnie?]

N6: [Jestem muzykiem], więc...

A: Prywatnie?

N6: Prywatnie”.

[81-83]

A: „A to jest dosyć powszechne tu w szkole? Tak wszyscy nauczyciele (.) korzystają, czy nie?

N6: No (.) raczej nie".

[98-102]

N6: „No dyrekcja raczej (.)

A: Tak, było coś takiego?

N6: Tak (.) wspiera, żeby nauczyciele [brali udział].

A: [Skorzystał Pan] z tego?

N6: Ja (.) ja raczej nie korzystam".

Korzyści, jakie dostrzega N6 ze stosowania TI na lekcjach muzyki, nie ograniczają się do większego zainteresowania uczniów. Widzi on potencjał TI dotyczący ekspresji twórczej uczniów, do której przykłada duże znaczenie. 


\section{[154-163]}

N6: „Po prostu to jest po pierwsze zaciekawienie, dalej (.) pokazanie dzieciom narzędzia, które mogą stosować w domu i, że tak powiem, rozwijać się muzycznie. No wiadomo, no jeżeli prawda ktoś zainteresuje się tym programem i zainstaluje sobie w domu na komputerze, to kolejnym krokiem będzie to, że no, żeby spróbować, jak to działa. A więc poznaje i instrumenty, jak one brzmią, w jaki sposób można je zastosować, jak na przykład, na zasadzie prawda, próbek dźwiękowych układać je w jakąś kompozycję, a więc takie, no można powiedzieć (.) sposoby komponowania pierwsze, co myślę, że jest cenną rzeczą, bo to wiadomo, każde działanie muzyczne, które pobudza myślenie jest pozytywnym elementem w rozwoju dziecka. I myślę, że to jest głównym $(3,0)$ działaniem”.

N6 zauważa, że większe wykorzystanie TI na lekcjach muzyki musiałoby się łączyć z ograniczeniem innych elementów obowiązkowego programu nauczania. Oznacza to, że wykorzystanie przedmiotowe narzędzi informatycznych jako innej formy przekazu obowiązkowych treści, nie uważa N6 za pierwszoplanowe. Poznawanie natomiast programów do tworzenia muzyki, co uważa za największy muzyczny potencjał TI, traktuje jako naturalny sposób jej wykorzystania. Uprzystępnianie więc takich rozwiązań uważa za rodzaj swojej misji, której warto poświęcić nawet fragment obowiązkowego programu nauczania.

Impulsem do wykorzystania TI nie są w tym przypadku bieżące potrzeby dydaktyczne. Są one wręcz potraktowane drugoplanowo, jako wtórne wobec potencjału informatycznych środków dydaktycznych. N6 jako muzyk używający zaawansowanych programów do „tworzenia aranżacji piosenek, komponowania i nagrywania utworów”" ${ }^{55}$, próbuje podzielić się swoją fascynacją z uczniami, z góry zakładając, że trafi jedynie do nielicznej grupy zainteresowanych tworzeniem muzyki przy pomocy komputera. Dydaktyczne więc zastosowania muzycznych programów komputerowych, w przypadku N6 wyraźnie ciążą w stronę muzyczną a nie dydaktyczną, a źródeł wysokich kompetencji informatycznych upatrywać tu należy w inspiracjach muzycznych a nie dydaktycznych.

Efekty dydaktyczne tak realizowanych kompetencji informatycznych nauczyciela ograniczone zostają zarówno przedmiotowo (do ekspresji twórczej uczniów), jak i podmiotowo (krąg zainteresowanych uczniów), dlatego bardziej adekwatną formą dla takich oddziaływań byłyby zajęcia pozalekcyjne, dla których obydwa ograniczenia nie stanowią przeszkody - są wręcz pożądane.

\footnotetext{
${ }^{55}$ Fragment odpowiedzi N6 na pytanie 16. ankiety.
} 
Wykres 34. Sieć przyczynowa. Źródła kompetencji informatycznych N6

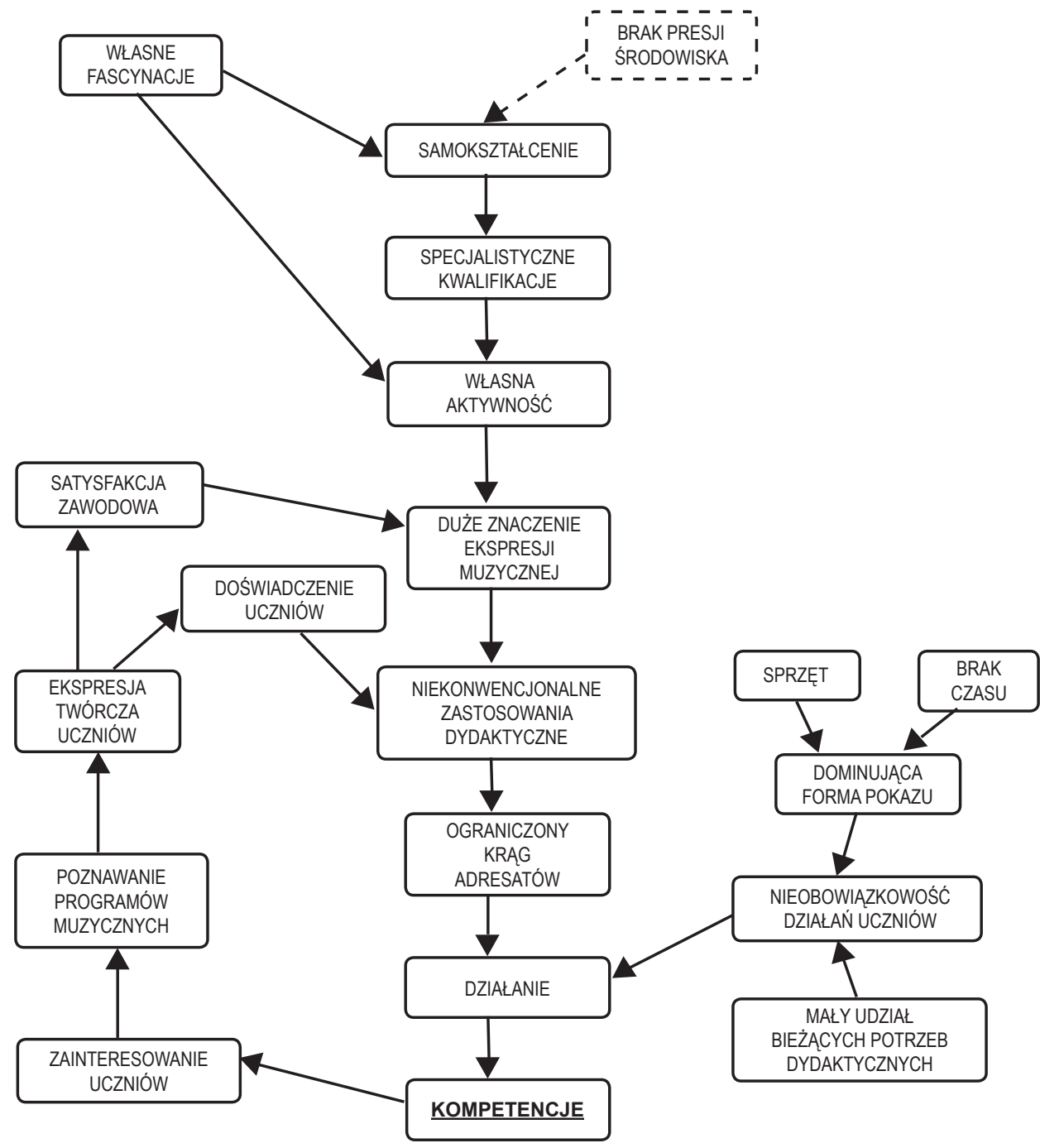

(źródło: badania własne)

W powyższym schemacie odnajdujemy zamknięty obieg wzrostu kompetencji, jednak ograniczony krąg adresatów działań N6 wyłącza część uczniów bezpośrednio zaangażowanych w działania z użyciem TI. Powodem tego ograniczenia są zarówno specjalistyczne zastosowania, jak i braki sprzętowe, możliwym skutkiem zaś - zmniejszenie siły działania zamkniętego obiegu wzrostu kompetencji. 
Rekomendacją dla N6 byłoby więc rozszerzenie kręgu odbiorców działań z wykorzystaniem TI poprzez ich powszechniejsze i mniej specjalistyczne wykorzystywanie. Wysokie kwalifikacje informatyczne byłyby pełniej wykorzystane w trakcie zajęć pozalekcyjnych, natomiast zastosowanie bardziej przystępnego oprogramowania na lekcjach muzyki pozwoliłoby być może na zainteresowanie większego grona uczniów, dla których intensywność zainteresowań muzycznych nie jest wystarczającym bodźcem do poznawania specjalistycznych programów muzycznych.

Ograniczony ale działający mechanizm powodujący wzrost kompetencji informatycznych u N6, pozwala mieć nadzieję, że doprowadzi nauczyciela do powyższych wniosków, które zrodzić się mogą jako uświadomione konsekwencje podejmowanych działań.

\subsubsection{Przypadek N7}

N7 to aktualna absolwentka Uniwersytetu Łódzkiego, 24-letnia stażystka, zatrudniona zaraz po studiach, pracująca w jednej szkole, w wymiarze 10 godzin tygodniowo ${ }^{56}$. Jest to jedyny wśród badanych przypadek nauczyciela, u którego program studiów zawierał przedmiot traktujący o dydaktycznych zastosowaniach TI.

Mimo znikomego stażu pracy, N7 stara się wykorzystywać TI, ponieważ uważa, że:

\section{[9-10]}

N7: „multimedia zawładnęły młodzieżą i (.) dużo szybciej i bardziej (.) prze-

konywująco trafiają do nich (.) niż lekcje prowadzone starą, tradycyjną metodą".

Priorytetem jednak jest u niej opanowanie wszystkich organizacyjnych spraw związanych z pracą oraz sprostanie wymaganiom związanym z dużym - jak na jej doświadczenie - wymiarem zajęć. Zastosowanie TI traktuje więc jako dodatkowe obciążenie w przerastającym ją na razie natłoku obowiązków.

\section{[268-273]}

N7: „To znaczy, no właśnie tak, do tego zmierzałam, że (.) weszłam tam z marszu i niestety, ale $(2,0)$ nie mając kompletnie żadnego doświadczenia w nauczaniu w szkole, bo co innego są praktyki a co innego jest wejść tam, (.) obyć się z tymi wszystkimi dziennikami, jeszcze my mamy dodatkowo dzienniki internetowe, (.) z tymi wszystkimi sprawami formalnymi i tak dalej. Ja nie zostałam w to wprowadzona w żaden sposób”.

\footnotetext{
${ }^{56}$ Dane N7 zostały nieznacznie zmienione, ze względu na etyczny aspekt badań.
} 
Wrażenie zagubienia pod ciężarem nowych, nieznanych obowiązków, zdradza sposób mówienia o uczniach, jako „osobach”, „grupie ludzi” czy nawet „osobnikach”, co podkreśla dystans oraz poczucie potencjalnego i uosabianego w ten sposób zagrożenia.

Półroczne doświadczenie wystarczyło jednak, by opanować początkowe wrażenie zagubienia i podjąć pierwsze próby wykorzystania TI.

\section{[35-42]}

N7: „bo to od takiego najbardziej (.) prozaicznego wykorzystania pod tytułem przyniesienia przykładów (.) chociażby teledysków, wideoklipów. Akurat w tym wypadku omawialiśmy gatunki muzyczne, więc przedstawienie danych wideoklipów w ramach porównania, tak? (.) na laptopie (.) a chociażby omówienie gatunku muzycznego poezji śpiewanej taką tradycyjną metodą z wykorzystaniem plakatów, z wykorzystaniem (.) no odsłuchu, ale tylko i wyłącznie bez tej części wizualnej, tak? No, zainteresowanie jedną a drugą lekcją było niesamowicie różne.

(.) Pomiędzy jedną a drugą lekcją była bardzo duża przepaść".

Już te elementarne sposoby wykorzystania TI pozwoliły N7 zauważyć płynące z nich korzyści. Szukanie scenariuszy zajęć oraz przykładów muzycznych to najczęstsze, doraźne sposoby wykorzystania internetu przez N7, zapewniające poczucie odciążenia w natłoku przytłaczających obowiązków.

[324-327]

N7: „często szukam albo scenariuszy albo (.) zabaw (.) pod kątem pracy z dziećmi, tak, takich podpowiedzi do tego, jak te zajęcia przeprowadzić i tego typu portali szukam, najczęściej jeśli chodzi o taką część edukacyjną. Z tego dużo korzystam".

[441-446]

N7: „raczej bardziej podpowiedzi tego, jak, jakie ktoś ma pomysły na przykład na zabawę $(2,0)$ prowadzenia, no jakąś taką przyjętą do tego tematu, do zajęć (.) czy, czy może jakieś ciekawe pomysły na realizacje. Znaczy to nie szukam całych gotowych scenariuszy tylko raczej konkretnych pomysłów, które są mi potrzebne do tego tematu albo pomysłu na jakąs jedną zabawę albo na jakieś jedno ćwiczenie albo na (.) na przeprowadzenie danej, danej części zajęć”.

Pomysły jednak, które angażowałyby TI do dydaktyki muzyki, są w internecie reprezentowane nader skromnie, stąd N7 nie może liczyć na wypróbowane rozwiązania czy materiały w tym zakresie.

[449-451]

A: „A znajduje też Pani takie rozwiązania żeby, generalnie z użyciem komputera należy coś takiego zrobić i wtedy jest łatwiej, takie podpowiedzi?

N7: $(2,0)$ Nnn, (.) chyba nnnnnie. (.) Nie przypominam (.)”. 
Z podobnych powodów N7 gromadzi również tradycyjne, papierowe źródła:

[349-351]

N7: „natomiast (.) przyznam szczerze, że zaopatrzyłam się przed tym nowym rokiem (.) w antykwariacie w stertę różnego rodzaju podręczników, ćwiczeniówek i tak dalej".

Brakujące umiejętności w zakresie TI uzupełnia na bieżąco, samodzielnie opanowując narzędzia niezbędne do rozwiązywania doraźnie pojawiających się problemów.

[473-475]

N7: „Przyznam szczerze, że ewentualnie (.) tego też się uczyłam na biegu (.) montowania $(3,0)$ fragmentów filmów, tak, ściąganych na przykład z programu youtube".

Na wsparcie we wdrażaniu TI ze strony środowiska szkolnego (podobnie jak w opanowaniu spraw organizacyjnych), nie może liczyć. Zainteresowanie bowiem innych nauczycieli wykorzystywaniem TI na własnych lekcjach należy w tej szkole do rzadkości.

[308-309]

N7: „No, to mało osób i rzadko. $(3,0)$ Najprędzej $(2,0)$ pan, który uczy fizyki w tej szkole i jest jednocześnie informatykiem”.

[312-314]

N7: „wiem, że katechetka (.) energiczna, odważna i bardzo często też $(3,0)$ wspomaga się, ale tak poza tym to przyznam, że rzadko".

Bodźce ze strony uczniów nie są natomiast skuteczne, prawdopodobnie ze względu na brak chęci N7 do obarczania się dodatkowymi obowiązkami wobec trudności z uporaniem się z dotychczasowymi.

[223-225]

N7: „Jeden chłopiec mi zgłosił, że (.) on ma kilka swoich utworów (.) nagranych na telefonie. $(4,0)$ Nie słyszałam ich jeszcze, miał przynieść telefon, miał przynieść i odtworzyć mi gdzieś w chwili wolnej, natomiast nie wiem jak to wygląda”.

Brak powszechnego stosowania TI przez innych nauczycieli nie jest efektem braku szkolnego sprzętu komputerowego. Dostępne są zarówno przenośne komputery, jak i pracownia komputerowa. Warunki społecznej, płatnej szkoły skutkują małą ilością i liczebnością klas, dlatego wystarczające jest zastosowanie ekranu komputerowego bez użycia rzutnika multimedialnego.

[109-111]

A: „A to ma Pani taką możliwość, jak Pani chce to wchodzi do pracowni komputerowej? 
N7: No, po wcześniejszym uzgodnieniu z nauczycielem (.) który ma tam w tej chwili lekcję - tak. Jest możliwość zamiany klas".

[121-125]

N7: „Z rzutnika to tylko trzy razy na dobrą sprawę korzystaliśmy, przy okazji prezentacji gimnazjów (.) gimnazjum - jednej klasy, a tak to (.) tylko i wyłącznie $z$ laptopa. $Z$ racji tego, że tych mówię tych osób jest niewiele, toteż ten laptop, to co się dzieje na ekranie laptopa jest w miarę widoczne dla wszystkich”.

Pozytywne choć skromne doświadczenie w wykorzystaniu TI na lekcjach muzyki, są dla N7 wyraźną zachętą do podejmowania kolejnych prób w tym kierunku. Zamierza wykorzystać również typowo muzyczne programy, czego do tej pory nie próbowała.

[19-26]

N7: „ostatnio zastanawiałam się nad tym żeby ze swoją aktualną szóstą klasą wykorzystać program (.) Karafun do stworzenia karaoke do (.)

A: Żeby uczniowie zrobili?

N7: Tak, tak. Myślę o tym intensywnie ponieważ (.) widzę w jakim kierunku oni idą, tak?, co ich interesuje i wszelkiego rodzaju prace wykonywane przy komputerze tudzież z wykorzystaniem komputera działają na nich zupełnie inaczej niż mówię lekcje przygotowywane tradycyjną metodą".

[29-31]

A: „Skąd Pani wie, że inne mają (.) nastawienie do takich zajęć?

N7: Bo i prowadziłam taką lekcję tradycyjną i prowadziłam też takie lekcje z wykorzystaniem komputerów".

Potrafi również zidentyfikować nastawienie klasy do takich rozwiązań i stosować je selektywnie - w tych klasach, w których spodziewać się może zarówno pozytywnej reakcji, jak i pozytywnych efektów.

[71-78]

N7: „Znaczy, myślę, że w dużej mierze jest to kwestia grupy, z jaką mam do czynienia. $(2,0)$ Bo (.) są takie grupy, są takie klasy, które $(3,0)$ no nie wiem jak to określić ale które mają bardzo duże parcie na komputer ((śmiech)), duże parcie na multimedia i jakby to jest (.) wiadomo, że jak się wykorzysta ten element w swojej lekcji to jest to murowany sukces, tak?, przynajmniej w dużej mierze (.) [bardzo to ułatwi]

A: $[$ Czy ( )] od wieku to zależy czy nie?

N7: Od wieku na pewno. Od wieku na pewno. Im młodsze klasy tym to zapotrzebowanie na na (.) na urozmaicanie zajęć jest mniejsze".

N7 posiada kwalifikacje informatyczne, nabyte w trakcie studiów, jednak nie są jej mocną stroną, z czego zdaje sobie sprawę. W dużym stopniu jest to efekt dotychczasowego braku zainteresowania TI, nie tylko w aspekcie dydaktycznym ale ogólnym. 
[140-141]

N7: „Znaczy właśnie problem w tym, że ja generalnie $(2,0)$ nie lubię aż tak bardzo tych multimediów i ja nie jestem w tym jakoś też szczególnie lotna”.

Dlatego chętnie oddaje inicjatywę uczniom w zakresie obsługi sprzętu, odnajdując w tym korzyści przede wszystkim dla siebie (odciążenie w obowiązkach i sprawniejsze przeprowadzenie lekcji), a nie jak w przypadku N2 - satysfakcji i dowartościowania uczniów.

[142-146]

N7: „oddaję pałeczkę uczniom i oni przygotowują cały sprzęt, przygotowują komputer, nagłośnienie i tak dalej. W związku z czym ja jestem od tego odciążona, nie ma ryzyka, że coś popsuję ((śmiech)) (.) no a oni to na tyle dobrze robią, że trzy minuty im to zajmuje może i wszystko działa”.

Jeśli jest zmuszona sytuacją do samodzielnego działania, wybiera bezpieczną drogę - użycie własnego, wypróbowanego sprzętu, co niweluje ryzyko związane ze słabą umiejętnością obsługi sprzętu komputerowego.

[482-493]

N7: „Dlatego jeśli już coś przygotowuję na większą skalę to zazwyczaj biorę swojego laptopa (.) żeby nie ryzykować, że znowu nie (.) nie wyjdzie to na lekcji. (.) No i czasem właśnie tak bywa (.) związane z komputerem, że jak przygotuję sobie nawet jakąś taką ciekawą formą dramową jakieś zajęcia, to wiem, że tutaj przynajmniej nie ma ryzyka, że mi coś nie wyjdzie, tak?

A: Pewniejsze są takie zajęcia. Czyli ten element komputeryzacji wprowadza taką trochę niepewność? (.) Wyjdzie - nie wyjdzie, uda się - nie uda się, nie wiadomo?

N7: No więc właśnie to jest (.) jednak sprzęt, to jest jednak jakiś wymysł techniczny, który $(2,0)$ z różnych przyczyn może nie zafunkcjonować, nie zadziałać i w tym momencie praktycznie cała praca, którą w to włożyłam załóżmy (.) idzie, idzie (.) może nie na marne, bo wcześniej czy później ja z tego znowu skorzystać zdążę tam, no ale w tym danym momencie, kiedy jest mi to potrzebne no nawala".

Znamiennym jest, że przyczyn ewentualnych zakłóceń w funkcjonowaniu sprzętu komputerowego N7 upatruje głównie po stronie tegoż sprzętu, nie obwiniając siebie za brak umiejętności czy doświadczenia w jego obsłudze. Ważnym powodem lepszej znajomości sprzętu przez uczniów, jest według N7 codzienne obcowanie przez nich z nowymi urządzeniami technicznymi, których posiadanie łączy się według niej z ponadprzeciętną sytuacją finansową uczniów płatnej szkoły. Ten argument jeszcze skuteczniej niweluje u N7 poczucie winy, związane z zagubieniem wobec nowoczesnych technologii. 
[88-91]

N7: „niewątpliwie tutaj ma ten czynnik finansowy duże znaczenie, bo (.) ich rodzice (.) i rodzice (.) i rodzina sytuowana jest lepiej, w związku z czym oni też mają dobre wyposażenie w postaci telefonów, tych iPhonów, i tak dalej, i tak dalej $(3,0)$ ".

Inaczej ma się rzecz, jeśli chodzi o oprogramowanie. N7 czuje na sobie obowiązek umiejętności jego obsługi, być może wynikający z zaliczonych w ramach studiów zajęć. Niedostatki w tym obszarze hamują wykorzystywanie programów muzycznych przez N7, co jednak planuje przezwyciężyć, dostrzegając potencjalne korzyści płynące z takiej praktyki.

[152-155]

N7: „natomiast obawiam się, że jakby mnie uczeń zapytał i (.) no i pojawiłby się problem $\mathrm{z}$ wytłumaczeniem danego polecenia to (.) dużo bym straciła w jego oczach. $(2,0)$ No i to jest jedyne (.) chyba jedyna taka bariera, która powoduje, że ja tych programów nie wykorzystuję aż tak często na lekcjach".

Zauważalne w całym wywiadzie poczucie zagubienia N7 wobec ogromu nowych obowiązków, owocuje specyficznym potraktowaniem dydaktycznych zastosowań TI. Odnajduje ona bowiem w narzędziach informatycznych rodzaj wsparcia, ale nie wsparcia procesu dydaktycznego a wsparcia własnej roli, pozwalającego na chwilę oddechu i poczucia panowania nad sytuacją. Ten rodzaj poczucia bezpieczeństwa jest tym ważniejszy, że N7 nie odczuwa wsparcia $z$ innych źródeł - pozostałych nauczycieli oraz dyrekcji szkoły.

[496-499]

A: „A jak Pani przygotuje taką prezentację sobie, to czuje Pani jakąś ulgę, że teraz wchodzi Pani do klasy i właściwie ma wszystko przygotowane, tylko odpalić (.) i robi się samo, a Pani patrzy na reakcje uczniów?

N7: No jest to (.) tak, no pod tym względem jest to duża pomoc i ułatwienie". [65-66]

N7: „miałam wrażenie, że właśnie komputer i (.) te prezentacje multimedialne byłyby dla mnie dużym wsparciem".

Ten zaskakujący wymiar wykorzystywania TI, nieopisywany w literaturze, mimo dużego dystansu N7 do samych narzędzi opartych na nowych technologiach, mógł zaistnieć tylko w przypadku początkującego nauczyciela. Stąd jego nieobecność w innych wywiadach oraz - tym bardziej w badaniach ankietowych. Ten niedostrzeżony dotąd potencjał TI może więc służyć poczuciu bezpieczeństwa rozpoczynających karierę zawodową nauczycieli oraz być formą łatwiejszego przełamania początkowych barier między nauczycielem a uczniami. 
Źródła skromnych, ale bardzo pomocnych kompetencji informatycznych N7 przedstawia poniższy schemat.

Wykres 35. Sieć przyczynowa. Źródła kompetencji informatycznych N7

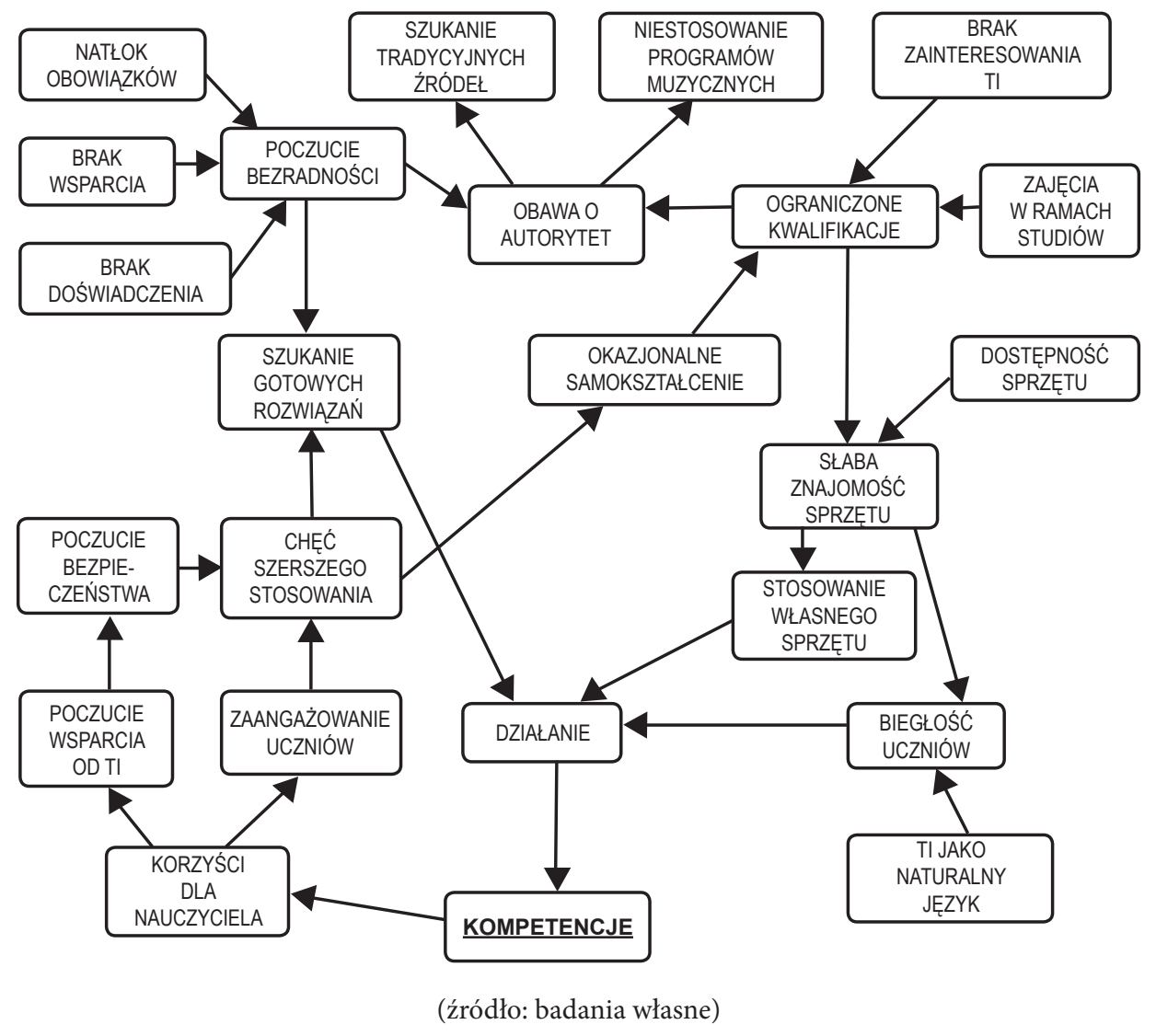

W przypadku N7 zauważamy również zamknięty obieg wzrostu kompetencji. Od ogniwa „chęć szerszego stosowania TI” rozdwaja się, przy czym druga odnoga, której elementem są kwalifikacje, jest wyraźnie słabsza. $\mathrm{Na}$ taką ocenę wpływają: „okazjonalne samokształcenie”, „ograniczone kwalifikacje” oraz „słaba znajomość sprzętu”. Słabość trzech kolejnych ogniw przekłada się na niską energię tej drogi obiegu. Jest to o tyle ważne, że słabość obiegu zawierającego ogniwo kwalifikacji musi skutkować niewielkim przyrostem kompetencji, kwalifikacje są bowiem jej elementem.

Większość energii obiegu u N7 pożytkowana jest na szukanie gotowych rozwiązań, co bezpośrednio wpływa na częstotliwość działań z wykorzy- 
staniem TI. Niestety, kolejne działania nie poparte równie dużym, równoległym wzrostem kwalifikacji, nie pozwalają na wzrost kompetencji wyższy niż wyznacza to „słabsza odnoga” obiegu. Zatem to właśnie słabsza droga obiegu wyznacza tempo wzrostu kompetencji w przypadku N7.

Dodatkowym osłabieniem tego obiegu jest istnienie „ślepego zaułka” zapoczątkowanego „obawą o autorytet”. Tej obawy N7 nie potrafi wykorzystać pozytywnie, a część i tak już niewielkiego potencjału energetycznego „ograniczonych kwalifikacji” pochłania ten właśnie ślepy zaułek.

O ile za pierwotne źródło kompetencji uznać należy poczucie bezradności, które zmusiło nauczycielkę do poszukiwań gotowych rozwiązań, o tyle ważne jest, że każdy kolejny obieg pomija to pierwotne, stresogenne ogniwo. To chyba doraźnie najważniejszy i najbardziej zauważalny efekt wykorzystania TI w omawianym przypadku. Poczucie bezradności bowiem jest mocno eksponowanym, dominującym elementem, towarzyszącym początkowej fazie pracy N7. Skromne ale skrzętnie wykorzystane kompetencje informatyczne pozwoliły więc na wyeliminowanie tego niezwykle ważnego, negatywnego uczucia.

\subsubsection{Podsumowanie wyników badań jakościowych}

Według zarówno Silvermana, jak i Kubinowskiego, celem zbiorowego studium przypadku jest „poznanie pewnego ogólnego zjawiska”, „pogłębienie rozumienia badanego zjawiska, problemu, procesu i tym samym skonstruowania teorii o szerszym zasięgu"58. Przy założeniu odrębności i niepowtarzalności subiektywnych doświadczeń badanych, można z powyższych analiz wyprowadzić wnioski, dotyczące wszystkich omawianych przypadków.

Analiza wypowiedzi nauczycieli pozwoliła przede wszystkim zauważyć istnienie mechanizmu, dzięki któremu poziom ich kompetencji informatycznych może wzrastać. Mechanizm ten w zaskakująco syntetyczny sposób łączy dwa pozornie przeciwne sposoby definiowania pojęcia kompetencji. Większość przedstawionych w rozdziale 2.1. ujęć koncentruje się przede wszystkim na wyliczeniu składników pojęcia kompetencji. Co do dwóch z nich, przytoczone definicje są zgodne i utożsamiają je z wiedzą oraz umiejętnościami. Trzeci ze składników, wobec niejednomyślnego formułowania

\footnotetext{
${ }^{57}$ D. Silverman, Prowadzenie badań jakościowych, s. 169.

${ }^{58}$ D. Kubinowski, Jakościowe badania pedagogiczne..., s. 172.
} 
przez różnych autorów, kompromisowo nazwano „odpowiedzialnym działaniem”. Taki sposób definiowania przyjęto dla określenia zarówno postulowanego, jak i rzeczywistego poziomu kompetencji informatycznych nauczycieli muzyki, będących przedmiotem dociekań części ilościowej badań.

Podobne podejście legło u podstaw konstruowania schematów, przedstawiających źródła kompetencji nauczycieli, z którymi przeprowadzono wywiady: graficzne ujęcie ogniwa „kompetencje”, wynika zawsze z bezpośrednio je poprzedzających ogniw „kwalifikacje” oraz „działanie”.

Powyższe, statyczne ujęcie kontrastuje $\mathrm{z}$ dynamiczną koncepcją kompetencji, przytoczoną za A. Męczkowskąa ${ }^{59}$. Przedstawiona przez nią dwoistość natury kompetencji, zawierająca się w jej charakterze adaptacyjnym lub transgresyjnym, ujawnia się w skonstruowanych schematach jako sieć łącząca kolejne ogniwa z finałową „kompetencją” oraz uruchamiająca mechanizm przyrostu kompetencji. Z jednej strony - adaptacyjnej - wyznacza drogę połączeń opartych na behawiorystycznych podstawach efektywnego działania, poprzez ogniwa związane z potrzebami dydaktycznymi, w powiązaniu z posiadanymi kwalifikacjami i warunkami dyktowanymi przez środowisko. W tym ujęciu skromne nawet kwalifikacje są instrumentem efektywnego działania. Inna droga działania mechanizmu przyrostu kompetencji - transgresyjna - oparta na aktywnym i twórczym poznaniu, prowadzi przez takie ogniwa, jak entuzjazm zawodowy, samokształcenie, chęć podwyższania kwalifikacji, a wywodzi się z chęci osiągania lepszych, a nie łatwiej osiągalnych, efektów kształcenia.

Niezależnie od perspektywy, skonstruowane sieci przyczynowe pozwoliły na zauważenie istnienia mechanizmu przyrostu kompetencji oraz identyfikację zakłóceń w jego funkcjonowaniu, w postaci ślepych odgałęzień lub zapętleń, wytracających energię mechanizmu, w postaci brakujących ogniw lub połączeń, które uniemożliwiają jego uruchomienie lub w postaci słabo wykształconych ogniw, osłabiających pożądany obieg.

Wobec takich ustaleń, pierwszoplanowym wnioskiem z części jakościowej badań jest identyfikacja źródeł (bądź ich braku) kompetencji informatycznych nauczycieli i ujęcie ich w schemat, umożliwiający lokalizację zakłóceń w kołowym mechanizmie wzrostu kompetencji. W każdym z przypadków schemat miał odmienną, indywidualną budowę oraz odmienne, indywidualne zakłócenia. Okazuje się bowiem, że źródła kompetencji informatycznych nauczycieli muzyki mogą być kontrastująco różne:

\footnotetext{
${ }^{59}$ Por.: rozdział 2.1 .
} 
od bardzo skromnych do specjalistycznych kwalifikacji, od poczucia entuzjazmu do poczucia bezradności, od przypadkowo odkrytych zastosowań do poznanych w ramach wieloetapowego dokształcania, od chęci twórczego zaangażowania uczniów do chęci przetrwania na lekcji.

W tym kontekście, kompetencje rozumieć należy bardziej jako potencjał, uruchamiany w toku odpowiednich powiązań kolejnych ogniw i - w przypadku domknięcia mechanizmu obiegu - znajdujący się w permanentnym ruchu. Ruch ten podlega jednak również statycznemu prawu, możliwemu do ascetycznego ujęcia w formie matematycznej: kompetencje=kwalifikacje+działanie. Wartość tak „obliczonych” kompetencji oddaje jedynie stan chwilowy, aktualny, natomiast odtworzenie stanu zaawansowania budowy mechanizmu, pozwalającego na wzrost kompetencji, każe spojrzeć na kompetencje perspektywicznie, zarówno w przód jak i wstecz, co wydaje się bardzo ważnym wnioskiem z prezentowanych badań.

Warto również zauważyć, że przypisując praktyczne znaczenie teoretycznej konstrukcji opisywanego mechanizmu, można wyróżnić przypadki, w których pierwotne uruchomienie łańcucha ogniw prowadzących do świadomego wykorzystania kwalifikacji informatycznych (czyli kompetencji), nie skutkuje kolejnym okrążeniem. Są to przypadki, gdy jedno- czy dwukrotne doświadczenie nie jest uwieńczone pozytywnymi efektami korzyściami zauważalnymi przez nauczyciela, lub skutki takiego działania są wręcz negatywne. Niezależnie od przyczyn takich efektów (np. zbyt małe kwalifikacje, nieprzemyślane działanie), ich skutkiem jest niewykształcenie połączenia lub ogniwa umożliwiającego kolejny obieg przyrostu kompetencji. W takiej sytuacji, w całej 85-osobowej grupie badanych, znajduje się sześcioro nauczycieli, którzy przyznali, że raz lub dwa razy w ciągu całego roku szkolnego (lub w całej swojej pracy) skorzystali z narzędzi informatycznych. W tych przypadkach pożądana byłaby prezentacja przykładów dobrej praktyki, być może przez innych nauczycieli tej samej szkoły, umożliwiająca dostrzeżenie pozytywnych efektów wykorzystania TIK i refleksję na temat własnych braków. Takie zapożyczone z obcego mechanizmu ogniwo pozytywnych efektów może zapoczątkować kolejny obieg, skutkujący przyrostem kompetencji i - pełniąc rolę chwilowej "protezy” - naprawić mechanizm „biorcy”.

Równie ważnym wnioskiem z części jakościowej badań jest unaocznienie płynności kompetencji. Każde bowiem połączenie dwóch ogniw prezentowanych schematów może wzmocnić, osłabić lub zatrzymać mecha- 
nizm wzrostu kompetencji. Każdy kolejny obieg zobrazowany schematem, jeśli nie zostanie całkowicie zatrzymany, prowadzi do nowego - wyższego lub niższego - poziomu kompetencji. Taka zmienność każe nauczycielowi uświadomić sobie, że posiadanie przez niego kompetencji informatycznych nie gwarantuje takiego stanu w przyszłości. Podtrzymywanie lub wzrost poziomu kompetencji należy zatem do obowiązków nauczyciela, wynikających nie tyle z zapisów ustawowych, co z natury samych kompetencji. Nie można bowiem posiadać kompetencji na stałe, bez wysiłku ich utrzymywania.

Powyższy wniosek jest ważny nie tylko dla refleksyjnego nauczyciela, ale również dla osób czy instytucji, mających wpływ na ogniwa wzmacniające obieg mechanizmu wzrostu kompetencji, takie jak: satysfakcja zawodowa, akceptacja środowiska, docenienie przez zwierzchników, presja środowiska, zachęta zwierzchnika, system wyróżnień i nagród itp. Ich istnienie oraz siła oddziaływania, niezależne od samego nauczyciela, powinny być troską środowiska edukacyjnego na wszystkich jego szczeblach.

Przeprowadzone wywiady pozwoliły więc na jeszcze jedno, inne spojrzenie na przyczyny niewystarczających kompetencji informatycznych badanych nauczycieli. W tym ujęciu najważniejszym było prześledzenie drogi i niezbędnych warunków uaktywniania i rozwijania kompetencji informatycznych nauczyciela, a nie tylko uchwycenie ich chwilowego stanu. 


\section{Wnioski i postulaty}

Opisane dotąd wyniki badań wymagają konfrontacji z przyjętymi hipotezami oraz weryfikacji tych ostatnich.

Pierwszą hipotezę szczegółową, która brzmi „nauczyciele muzyki w niedostatecznym stopniu wykorzystują TIK w swojej pracy dydaktycznej", należy uznać za częściowo sprzeczną z ustaleniami. $74,1 \%$ badanych nauczycieli bowiem, według ustaleń rozdziału 4.2.2., wykorzystuje TI w swojej pracy dydaktycznej. „Niedostateczny stopień” nie oznacza również zbyt małej częstotliwości, co wynika z ustaleń rozdziału 4.1.2. Zatem potwierdzenie tej hipotezy odnajdujemy w przypadku $1 / 4$ nauczycieli łódzkich szkół podstawowych. Taka wielkość grupy nauczycieli nie pozwala na jednoznaczne określenie subiektywnym zwrotem "niedostateczny stopień”, choć z drugiej strony - każdy pojedynczy przypadek niekompetentnego nauczyciela powinien budzić zaniepokojenie.

Potwierdzona została druga hipoteza szczegółowa (wnioski z rozdziału 4.2.3.), mówiąca, że „poziom kompetencji informatycznych nauczycieli muzyki jest daleko niższy od postulowanego" - rozbieżność bowiem sięga od 31,8\% do 78,8\%, w zależności od rozpatrywanej wersji stanu postulowanego. Elementem optymistycznym jest fakt, że najniższy poziom rozbieżności $(31,8 \%)$ dotyczy wersji SP1 - „aktualnej”, wywiedzionej z Podstawy programowej... oraz warunków awansu zawodowego nauczycieli, a więc dokumentów bezpośrednio wyznaczających standardy pracy i kompetencji wszystkich nauczycieli.

Trzecia hipoteza szczegółowa, według której „uczelnie kształcące nauczycieli muzyki nie wyposażają studentów w kompetencje informatyczne a jedynie w kwalifikacje informatyczne, często nieuwzględniające ich zastosowań dydaktycznych", nie została całkowicie potwierdzona. O ile potwierdziło się, że wszystkie rozpatrywane uczelnie zapewniają studentom jedynie kwalifikacje informatyczne, o tyle rozdział 2.5. przynosi przykład uczelni zapewniającej w programie kształcenia kwalifikacje uwzględniające zastosowania dydaktyczne TI oraz elementy „biernej” części trzeciego składnika kompetencji. Wśród badanych jednak znalazła się tylko jedna osoba w ten sposób wykształcona, stąd należy jednak uznać potwierdzenie w badaniach trzeciej hipotezy szczegółowej. Należy przy tym pamiętać, że jest to stan, który doczekał się naprawy w zapisach najnowszej wersji Standardów kształcenia przygotowujacego do zawodu nauczyciela, której działa- 
niem zostaną objęci studenci rozpoczynający naukę w roku akademickim 2012/2013.

Z ustaleń rozdziału 4.2.3. wynika, że czwarta hipoteza szczegółowa („brak składnika kompetencji informatycznych nazwanych tu odpowiedzialnym działaniem to główna różnica między stanem postulowanym a rzeczywistym kompetencji informatycznych nauczycieli muzyki”) została potwierdzona w odniesieniu do SP1 w 31,8\% (przy braku innych przyczyn). Pozostałe wersje SP nie potwierdzają tej hipotezy. W odniesieniu do SP2, w przypadku $25,9 \%$ badanych nauczycieli brak trzeciego składnika kompetencji jest kluczowy, jednak przyczyny wynikające z braku kwalifikacji obejmują 67,1\% badanych nauczycieli. Nie można więc uznać prawdziwości tej hipotezy w odniesieniu do SP2. Rozbieżność SR-SP3 dotyczy głównie kwalifikacji, więc czwarta hipoteza szczegółowa nie znajduje tu w ogóle zastosowania.

Ustalenia wcześniejszych rozdziałów (4.3.1., 4.3.2. oraz 4.3.3.) upatrują przyczyn niedostatecznego wykorzystywania TI przez badanych nauczycieli w braku pozytywnych bodźców do podwyższania swoich kompetencji w tym zakresie. Ci z badanych, których uznać należy za niekompetentnych informatycznie, nie odnajdują takich bodźców ani bezpośrednio we własnej postawie, ani w systemie kształcenia i dokształcania nauczycieli, ani również w warunkach funkcjonowania szkoły. Wnioski te są niezbędnym uzupełnieniem przyczyn rozbieżności SR z SP, zamieszczonymi jako konkluzja rozdziału 4.2.3. Nie mogły jednak zostać uwzględnione w zestawieniu jako przyczyna rozbieżności z uwagi na brak odniesień do tak sformułowanych kryteriów w rozpatrywanych wersjach SP.

Wnioski z rozdziału 4.2.3. weryfikują natomiast hipotezę główną, która brzmi: „Nauczyciele muzyki w znikomym stopniu wykorzystują TIK w pracy dydaktycznej, ponieważ zostali wyposażeni jedynie w kwalifikacje, a nie kompetencje informatyczne". Pozorna tautologia tego sformułowania zasadza się na warunku posiadania kompetencji informatycznych w postaci wykorzystywania ich w pracy dydaktycznej. Kto jest kompetentny informatycznie, ten wykorzystuje TI w pracy dydaktycznej. Ta sama jednoznaczność ale o przeciwnym kierunku jest elementem przyjętej w rozdziale 2.1. definicji kompetencji: kto odpowiedzialnie działa w oparciu o wiedzę i umiejętności, posiada kompetencje. Hipotezą zaś nie może być przyjęta wcześniej definicja. Jednak kluczowe jest tu sformułowanie „zostali wyposażeni”, które każe zwrócić uwagę nie na samo posiadanie kompetencji 
ale na jej źródła, lub raczej brak takich źródeł. Tak sformułowana hipoteza kieruje uwagę na fakt, że w czasie studiów nauczycielskich nie ma wymogu (dokładniej: nie było do tej pory takiego wymogu) odpowiedzialnego zastosowania wiedzy i umiejętności informatycznych w pracy dydaktycznej. W ten sposób wyposażony nauczyciel, jeśli nie odczuje samodzielnie pominiętego przez system kształcenia nauczycieli wymogu lub nie odczuje zachęty (presji) środowiska szkolnego, dyrektora, nie będzie wykorzystywał TIK, pozostając przy tradycyjnych sposobach przekazu treści kształcenia.

Aby zweryfikować główną hipotezę badawczą należy ustalić ilu z badanych posiada wiedzę i umiejętności z zakresu TI ale, nie wypełniając trzeciego warunku posiadania kompetencji (czyli nie wykorzystując swoich kwalifikacji w pracy dydaktycznej), nie można nazwać ich kompetentnymi informatycznie nauczycielami. Jeśli tak wyselekcjonowana grupa będzie relatywnie duża, weryfikację hipotezy badawczej będzie można uznać za pozytywną.

Zgodnie z założeniami metodologicznymi badań, posiadanie kwalifikacji informatycznych można zweryfikować na podstawie odpowiedzi na pytanie 13. ankiety nauczycieli:

„13. W jaki sposób nauczył/a się Pan/i posługiwać komputerem?

a. zajęcia w ramach studiów pedagogicznych;

b. zajęcia w ramach studiów muzycznych;

c. kursy lub szkolenia w ramach doskonalenia zawodowego;

d. studia podyplomowe;

e. pozaformalne (samokształcenie, lektura, pomoc członka rodziny, znajomych);

f. inne (jakie:...........................................);

g. nie potrafię posługiwać się komputerem".

Nie wartościując poszczególnych źródeł wiedzy i umiejętności, należy uznać, że odpowiedzi od „a” do „f” potwierdzają ich posiadanie. Wszystkie 85 odpowiedzi mieści się w tym przedziale, tym samym wszyscy ankietowani nauczyciele przyznają się do posiadania dwóch składników kompetencji informatycznych - wiedzy i umiejętności. Brak trzeciego składnika odczytamy z wniosków rozdziału 4.2.3. ujętych w tabeli 24. Zgodnie z tymi ustaleniami 25,9\% ankietowanych nauczycieli nie wykorzystuje TI w obszarze pracy dydaktycznej i taką część badanej grupy należy uznać za niekompetentnych, choć posiadających kwalifikacje informatyczne. Pozostali, którzy wykorzystują TI w pracy dydaktycznej, stanowią więc 74,1\% badanej 
grupy. Taki odsetek nie pozwala na użycie przymiotnika „znikomy” i w tym aspekcie - ilościowym - każe negatywnie zweryfikować główną hipotezę badawczą. Prawdziwy pozostaje aspekt jakościowy: nauczyciele w ramach kształcenia zostają wyposażeni w kwalifikacje informatyczne, natomiast o nabycie kompetencji muszą zadbać we własnym zakresie.

Przyczyną takiego stanu nie jest jedynie system kształcenia przyszłych nauczycieli. Przytoczone w rozdziale 4.3. przyczyny odnaleźć można zarówno po stronie nauczycieli, systemu ich kształcenia i dokształcania a także po stronie organizacji funkcjonowania szkoły. Ponadto, przeprowadzone wywiady pozwoliły zauważyć, że wdrożenie TI do warsztatu dydaktycznego nauczyciela muzyki podlega pewnym prawidłowościom, całemu łańcuchowi okoliczności wpływających na taką decyzję.

Wnioski z całościowo ujętych analiz implikują postulaty, które ujęto w kilka kategorii. Uzupełniają one cele poznawcze badań, wzbogacając je o aspekt praktyczny, zawierający się w propozycjach zmian, dotyczących różnych aspektów kształcenia jak i funkcjonowania zawodowego nauczyciela muzyki.

Zasadnym byłoby kontynuowanie podobnych badań, dla uchwycenia zmian problemu, będącego tytułem pracy, jak również monitorowania systemu kształcenia przyszłych nauczycieli, w celu diagnozowania zarówno drogi nabywania przez nich kompetencji informatycznych, jak i ich zgodności z zapisami dokumentów oraz postulatami zainteresowanych tym tematem środowisk.

\subsection{Wnioski i postulaty w kontekście pedeutologicznym}

Wnioski w odniesieniu do kształcenia nauczycieli i - w konsekwencji jego kompetencji, wydają się naturalnym i bezpośrednim efektem przeprowadzonych badań. Na poziomie ogólnym zauważyć należy, że kompetencje nie są powszechnym efektem wykształcenia nauczyciela. Wiedza i umiejętności, formułowane jako cele kształcenia w różnych obszarach, stanowią tylko podstawę kompetencji, tylko jej dwa składniki, określane jako kwalifikacje. Do pełni kompetencji niezbędny jest ich trzeci składnik, szeroko omówiony w rozdziale 2.1., a skrótowo nazwany na użytek niniejszej pracy „odpowiedzialnym działaniem”. Ukryte pod tym określeniem elementy, czyli: rozumienie i pragnienie zastosowania nabytej wiedzy i umiejętności, świadomość potrzeby i konsekwencji takiego właśnie zachowania oraz 
przyjmowanie na siebie odpowiedzialności za nie, zgrupowane jako część bierna trzeciego składnika kompetencji, a także elementy składające się na jego część czynną: doświadczenie, demonstrowanie czy postawy odpowiednie do sytuacji, nie w pełni są udziałem absolwenta studiów nauczycielskich.

Elementy części czynnej w niewielkim tylko stopniu są możliwe do zdobycia w trakcie zajęć objętych programem studiów. Główny obszar działań nauczyciela - praca dydaktyczna - nie ma zbyt wiele możliwości praktycznego wypróbowania w ramach studiów. Zajęcia w formie ćwiczeń dają pewne możliwości w tym zakresie, pod warunkiem jednak, że demonstrowane w ich trakcie umiejętności dotyczą nie tylko treści merytorycznych przedmiotu (np. biegłości w posługiwaniu się narzędziami informatycznymi) ale również ich zastosowań w dydaktyce. Mimo jednak spełnienia takiego warunku, wciąż będzie to tylko symulacja sytuacji prawdziwej, nie dająca możliwości poczucia autentycznej interakcji i reagowania postawą odpowiednią do sytuacji. W ten sposób zdobyte doświadczenie może okazać się tak różne od rzeczywistości, że stanowić może źródło dodatkowych problemów i stresów, uniemożliwiających kompetentne działanie w warunkach realnej sytuacji pedagogicznej.

Jedyną prawdziwą sytuacją pedagogiczną, sprawdzającą nabyte kwalifikacje przez ich demonstrowanie i wyposażającą w elementarne doświadczenie, są praktyki pedagogiczne. Tylko w trakcie praktyk student ma możliwość przekształcenia swoich świeżo nabytych kwalifikacji w kompetencje. Taka droga obowiązywać musi również w kształtowaniu kompetencji informatycznych. Nabyte w toku studiów kwalifikacje w zakresie dydaktycznych zastosowań narzędzi informatycznych mogą stać się kompetencjami, jeśli $\mathrm{w}$ trakcie praktyk student odczuje potrzebę ich świadomego i odpowiedzialnego wykorzystania, przewidując jego konsekwencje i stosownie do sytuacji dobierze i zastosuje adekwatne narzędzia.

Standardy kształcenia nauczycieli z roku 2003 oraz 2004 nie precyzowały udziału TI, jako niezbędnego elementu prowadzonych przez studentów, w ramach praktyk pedagogicznych, zajęć. Dopiero najnowsza wersja Standardów kształcenia przygotowującego do zawodu nauczyciela z 2012 roku taki obowiązek formułuje: „w trakcie praktyki następuje kształtowanie kompetencji dydaktycznych przez [...] współdziałanie z opiekunem praktyk w [...] wykorzystywaniu środków multimedialnych i technologii in- 
formacyjnej w pracy dydaktycznej"'. Znamiennym jest, że dokument ten w sposób zgodny z przyjętą w rozdziale 2.1. definicją oraz zaprezentowanymi powyżej wnioskami dotyczącymi nabywania kompetencji, przyjmuje, że to właśnie praktyki wyposażają studenta w kompetencje poprzez wykorzystywanie TI w pracy dydaktycznej. Wydanie więc nowych Standardów kształcenia... wyprzedziło sformułowany na podstawie wniosków z badań postulat obligatoryjności wykorzystania TI w trakcie praktyk pedagogicznych, co wraz z nabytymi kwalifikacjami daje możliwość wyposażenia przyszłego nauczyciela w pełne kompetencje informatyczne, służące dydaktyce muzyki.

Dotychczasowy brak takiej obligatoryjności nie stanowił oczywiście bariery w praktykowaniu podobnych rozwiązań, jednak inne bariery, jak niedostatki sprzętowe, kwalifikacje nie obejmujące zastosowań dydaktycznych TI, a także ogrom innych, dydaktycznych kompetencji, które należy w trakcie praktyk ukształtować, sprawiły, że brak obowiązku był skrzętnie wykorzystywany. Warto zauważyć również, że wspomniane niedostatki sprzętowe, na które nakładała się obawa przed przekazaniem do dyspozycji studentów cennego dla szkoły sprzętu, również na mocy najnowszych Standardów kształcenia... przestały być istotną barierą. Rozporządzenie bowiem nakłada obowiązek zapewnienia sprzętu komputerowego na uczelnię delegującą swoich studentów na praktykę. W ten sposób problem wyposażenia przyszłych nauczycieli w kompetencje informatyczne został rozwiązany w obszarze trzeciego składnika definicji pojęcia kompetencji. Należy tylko zauważyć, że zapisy prawne stanowią jedynie podstawę do zmian w praktyce kształcenia nauczycieli, niezbędne zatem jest egzekwowanie i monitorowanie wprowadzania w życie obowiązujących przepisów.

Problemem pozostaje jednak wyposażenie absolwentów kierunków nauczycielskich w kwalifikacje niezbędne do wykorzystywania TI w dydaktyce muzyki. W rozdziale 2.4.2. omówiono szczegółowo zapisy aktualnych oraz poprzednich Standardów kształcenia... w aspekcie dotyczącym uwzględnienia TI w pracy dydaktycznej. W tym miejscu ograniczymy się do zauważenia obecności tego wątku w obydwu dokumentach. Równocześnie wnioski z rozdziału 2.5. każą zwrócić uwagę na fakt, że tylko jedna z omawianych uczelni przed rokiem akademickim 2011/2012, uwzględniała zapisy rozporządzeń poprzez umieszczenie w programie studiów nauczy-

\footnotetext{
${ }^{1}$ Standardy kształcenia..., s. 20, p. 3., pp. 3d.
} 
cielskich przedmiotu traktującego o zastosowaniach TI w dydaktyce muzyki. W tym obszarze więc sytuacja wymaga niezwłocznej naprawy.

Uzasadnionym również postulatem jest, by przekształcenie kwalifikacji w kompetencje następowało po procesie kształtowania samych kwalifikacji. W praktyce przekłada się to na takie usytuowanie przedmiotu traktującego o edukacyjnych zastosowaniach TI, by poprzedzał on praktyki pedagogiczne. Taka ewentualna korekta organizacyjna jest niezbędna, by zachować naturalną kolejność poznawania narzędzi a następnie ich odpowiedzialnego wykorzystywania.

Przedstawione wyżej postulaty dotyczą przyszłych nauczycieli, którzy rozpoczną swoją pracę dopiero za kilka lat. Aktualnie pracujący nauczyciele muzyki, którzy nie mieli możliwości nabycia kompetencji ani nawet kwalifikacji informatycznych w ramach studiów, mają do dyspozycji jedynie kursy i szkolenia organizowane przez instytucje wspomagające metodycznie kadrę pedagogiczną. Już pobieżna analiza oferty szkoleniowej, skierowanej do nauczycieli objętego badaniami obszaru, pozwala zauważyć jej znaczącą obecność w obszarze alfabetyzacji komputerowej oraz trochę skromniejszą, skierowaną do zaawansowanych użytkowników TI. Można na tej podstawie przyjąć, że nauczyciel odczuwający własne braki w zakresie kwalifikacji informatycznych ma pełny wachlarz możliwości poznania takich narzędzi informatycznych, jak edytor tekstu, przeglądarka internetowa, grupy dyskusyjne, edytor prezentacji multimedialnych, może również dowiedzieć się jak stworzyć własną stronę internetową i wiele innych przydatnych narzędzi. Próżno jednak szukać szkoleń skierowanych do nauczycieli muzyki, przybliżających specjalistycznie muzyczne oprogramowanie wraz z jego potencjałem dydaktycznym. Ten brak jest odczuwalny przez nauczycieli muzyki, z którymi autor miał okazję rozmawiać osobiście. Uzupełnienie więc oferty ośrodków szkoleniowych należy uznać za niezbędne, w celu uzupełnienia kwalifikacji aktualnych nauczycieli muzyki. W tym przypadku chodzi oczywiście wyłącznie o kwalifikacje, bowiem przekształcenie ich w kompetencje zależy wyłącznie od inicjatywy i chęci samych nauczycieli.

\subsection{Wnioski i postulaty dotyczące organizacji pracy szkoły}

Zgodnie z konkluzją rozdziału 4.1.2., dostępność szkolnego sprzętu komputerowego jest problemem tylko dla około $10 \%$ badanych. Nie jest to znaczący odsetek, każe jednak sformułować postulat o pełnej dostępności 
sprzętu komputerowego dla wszystkich nauczycieli muzyki. Pytania ankiety różnicowały dostępność takiego sprzętu na możliwość skorzystania z pojedynczego zestawu komputerowego lub możliwość przeprowadzenia lekcji muzyki w pracowni komputerowej. Do wielu zastosowań dydaktycznych pojedynczy zestaw (komputer, rzutnik multimedialny oraz sprzęt nagłaśniający) jest całkowicie wystarczający, pod warunkiem jednak, że jest to zawsze ten sam egzemplarz komputera, którego konfiguracja jest nauczycielowi znana i w miarę potrzeb uzupełniana. Jest to niezbędne dla uniknięcia sytuacji, gdy przygotowane przed zajęciami, dużym nakładem sił materiały, nie mogą być zaprezentowane na lekcji z powodu innej konfiguracji sprzętu (innego formatu danych, innego odtwarzacza, innych kodeków, innego oprogramowania itp.). Idealnym rozwiązaniem jest więc dysponowanie zestawem komputerowym wyłącznie na użytek nauczyciela muzyki, lub przypisanego wyłącznie do pracowni muzycznej. Takie sytuacje identyfikują odpowiedzi dyrektorów na pytanie 6. ankiety, omówione w rozdziale 4.1.2., w części dotyczącej sprzętu. 28,05\% dyrektorów stwierdziło, że nauczyciel dysponuje sprzętem komputerowym we własnej pracowni, co jest sytuacją wzorcową. Postulować więc należy aby sytuacja wzorcowa była sytuacją powszechną i możliwość wyłącznego dysponowania sprzętem komputerowym dotyczyła wszystkich nauczycieli muzyki.

Należy zdawać sobie sprawę z faktu, że nie zawsze dostępność sprzętu zależy wyłącznie od organizacji pracy szkoły, jednak w przypadkach niedostatków w wyposażeniu szkoły odpowiednia organizacja w zakresie koordynacji zajęć wymagających takiego sprzętu jest tym bardziej niezbędna.

Jeszcze jednym elementem wpływającym na wykorzystywanie TI na lekcjach muzyki, który umiejscowić należy w obszarze funkcjonowania szkoły, jest aktywność bezpośredniego przełożonego - dyrektora - w stwarzaniu warunków do takich działań oraz zachęcaniu nauczycieli do poszerzania warsztatu dydaktycznego, uwzględniając udział narzędzi informatycznych w przygotowaniu i prowadzeniu zajęć.

Wnioski wypływające z ustaleń rozdziału 4.3.3. dają podstawę do oceny rozmiaru takich oddziaływań. Postulat większej aktywności dyrektorów w zachęcaniu nauczycieli muzyki do wykorzystywania TI dotyczy sytuacji braku zachęty do uczestnictwa w szkoleniach informatycznych $(34,1 \%$ dyrektorów), braku dobrego przykładu w stosowaniu TI na własnych zajęciach $(15,9 \%)$ oraz braku zainteresowania poziomem kompetencji informatycznych nauczycieli (11,0\%). Ostatnia z opisywanych sytuacji zasługuje na 
wyjątkowe potraktowanie i wyjątkowo kategoryczny postulat formułowany wobec dyrektorów - znajomość kompetencji nauczycieli jest bowiem podstawą do działań motywujących do ich zwiększenia.

\subsection{Wnioski i postulaty dotyczące dydaktyki muzyki - rozwiązania praktyczne}

Oczywistym wnioskiem dotyczącym dydaktyki muzyki jest konieczność zauważenia i wykorzystania potencjału dydaktycznego technologii informacyjnej, mimo obaw nauczycieli, niedostatków sprzętowych czy braku wypróbowanych przykładów takich zastosowań. Konstruktywnym ujęciem takiego wniosku będzie propozycja praktycznych rozwiązań, możliwych do wykorzystania przez tych nauczycieli, którzy dysponują nawet bardzo skromnymi kwalifikacjami informatycznymi lub własną niekompetencję tłumaczą brakiem takich przykładów lub niedostatkami wyobraźni².

Duża część badań dotycząca kompetencji informatycznych nauczycieli przedmiotów nieinformatycznych przysparzać może nauczycielom kompleksów. Skupiają się one bowiem na wiedzy i umiejętnościach dotyczących nazewnictwa podzespołów komputerowych, ich parametrów, znajomości terminów informatycznych, umiejętności tworzenia stron internetowych, obsługi baz danych a nawet umiejętności programowania. Tymczasem narzędzia informatyczne użyteczne w dydaktyce muzyki nie wymagają umiejętności większych niż obsługa przeglądarki internetowej, czy uruchomienie programowego odtwarzacza multimedialnego.

Poniżej zaproponowano kilka najprostszych rozwiązań, które wykorzystując narzędzia informatyczne umożliwiają bardziej zrozumiałe i atrakcyjne $\mathrm{w}$ formie przekazanie treści programowych przedmiotu muzyka na dowolnym etapie powszechnej edukacji. Celami takiej prezentacji są:

- egzemplifikacja praktycznych rozwiązań, ilustrujących dotychczasowe teoretyczne rozważania;

- wskazanie przykładów, które zostały sprawdzone i pozytywnie zweryfikowane w praktyce edukacyjnej autora;

- wyeksponowanie prostoty narzędzi informatycznych, co powinno stanowić zachętę obawiających się ich stosowania nauczycieli muzyki do poszerzenia swojego warsztatu metodycznego.

\footnotetext{
${ }^{2}$ Godne polecenia są tu również nieliczne artykuły publikowane na łamach „Edukacji Muzycznej w Szkole”, m.in. autorstwa B. Panasiuk i E. Parkity - zob. bibliografia.
} 
Zestaw poniższych przykładów ilustruje jednocześnie typologię narzędzi informatycznych, możliwych do zastosowania w dydaktyce muzyki, do której odwołują się przedstawione badania.

Najprostszym zastosowaniem zasobów sieci, pozwalającym na „oswojenie" mało zrozumiałej dla ucznia tzw. muzyki poważnej mogłoby być odtworzenie na zajęciach omawianych utworów nie tylko w formie audiofonicznej ale - wzorem portalu youtube - razem $z$ obrazem. W takiej bowiem formie dociera większość komercyjnych przekazów muzycznych do młodego człowieka - jako teledyski, wideoklipy z atrakcyjną i narzucającą się słuchaczowi warstwą wizualną. Ogromna popularność portalu youtube ${ }^{3}$, szczególnie wśród młodzieży, prowokuje wręcz, by posłużyć się językiem czy nośnikiem przybliżającym Beethovena do współczesnych idoli muzyki rozrywkowej. I nie chodzi tu o spłycenie tego pierwszego a bardziej o wskazanie innych ścieżek jego zrozumienia, zaciekawienie formą przekazu, by sprowokować do skupienia się na jego treści. Jeśli bowiem uznać muzykę za swoisty, dźwiękowy przekaż emocji w łańcuchu kompozytor-wykonawca-słuchacz, to głównym problemem jest tu nieczytelność owych emocji dla współczesnego odbiorcy w warstwie ograniczonej do ścieżki dźwiękowej. Obraz Herberta von Karajana, dyrygującego V Symfonia Beethovena, pozwala odczytać te emocje z gestów, którymi dyrygent się posługuje, dramatycznego montażu, zbliżenia na twarz orkiestrowego muzyka, na pojedynczy instrument. Ta warstwa jest bliższa konsumentowi współczesnej popkultury niż pojęcie formy allegra sonatowego, czy brzmienie kwintetu smyczkowego. Innymi słowy zyskujemy formę przekazu $\mathrm{z}$ „dodatkowym tłumaczem”, który pozwala na pełniejsze zrozumienie przekazywanych za pośrednictwem muzyki emocji, czy - w najprostszej funkcji - pozwala skupić się na utworze poprzez obraz - medium daleko bardziej zrozumiałym niż abstrakcyjna ścieżka dźwiękowa i angażującym zmysł, który w przekazie uboższym, bo tylko dźwiękowym, musi szukać innych bodźców, niezwiązanych z celowym przekazem.

Śmiałą propozycją wykorzystania zasobów internetu na lekcjach muzyki są próby konfrontacji rozrywkowych przeróbek „utworów poważnych” $\mathrm{z}$ ich oryginałami. Wspomniany portal youtube jest pełen takich przykładów zarówno w wersji amatorskiej jak i profesjonalnej. Zabieg ten wymaga jednak umiejętności wyważenia celów, które chcemy osiągnąć. Bardzo

\footnotetext{
${ }^{3}$ Pod koniec 2007 roku z serwisu youtube korzystało 5,7 miliona polskich internautów i liczba ta bardzo szybko rośnie. [Por.:] http://wyborcza.biz/biznes/1,101562,4840999.html (stan z dnia 27.11.2010).
} 
łatwo wzbudzić jest u uczniów przekonanie, że nauczyciel muzyki „w głębi duszy” jest „po ich stronie” - tzn. jego fascynacja muzyką poważną jest jedynie urzędową, nieprawdziwą pozą, a faktyczne wartości estetyczne „nieoficjalnie” odnajduje w świecie muzyki rozrywkowej. Konfrontacja świata artystycznego z pop-kulturą powinna mieć za zadanie jedynie poprzez formę przekazu zainteresować treścią, która nagle może wydać się uczniom wcale nie tak odległa. Skupienie się nie na różnicach a na podobieństwach prezentowanych wersji pozwala na analityczne i „mniej bolesne” skupienie się na klasycznym brzmieniu, klasycznej formie, klasycznej interpretacji muzyki.

Innym elementem szkolnego programu w zakresie nauki muzyki jest nauka zapisu nutowego. Ogromna większość uczniów, nie dysponując w domu żadnym instrumentem, nie będzie miała okazji nigdy wykorzystać takiej wiedzy, co sprawia, że jej wirtualność w połączeniu z wyjątkowo rzadką okazją zastosowania (w końcu to tylko jeden z wielu elementów programu nauczania przedmiotu o wymiarze jednej godziny tygodniowo) przesądza o jej wyjątkowej nietrwałości czy ulotności. W tej materii technologia komputerowa może mieć zastosowanie co najmniej w dwojaki sposób. Po pierwsze, udostępniając wirtualną klawiaturę jako namiastkę instrumentu, pozwalając na praktyczne zastosowanie umiejętności czytania nut. Stwarza to również możliwość rozszerzenia sztywnego programu o repertuar, który zainteresowany uczeń jest w stanie opracować samodzielnie na podstawie materiałów dostępnych w sieci www ale przede wszystkim daje możliwość praktycznego wykorzystania teoretycznej wiedzy wyniesionej ze szkoły poza salą lekcyjną. Komputer zbliża się tym samym do idei Carla Orffa, według którego muzykowanie na instrumentach nie wymagających wieloletnich treningów jest podstawą edukacji muzycznej w aspekcie twórczym, kreatywnym. Ilość serwisów udostępniających w sieci wirtualne klawiatury jest dość duża, wśród nich warto wymienić:

http://www.gamegape.com/pl-63785-virtual-keyboard.html

http://www.bgfl.org/bgfl/custom/resources_ftp/client_ftp/ks2/music/ piano/

http://method-behind-the-music.com/piano

http://www.newconcept.com/Reference/virtual_piano_keyboard.html

lub: http://en.softonic.com/s/virtual-keyboard-piano - gdzie znaleźć można darmowe wersje programowych klawiatur, działających w trybie off-line. 
Duże możliwości w tym zakresie posiadają również iPady czy telefony komórkowe.

Drugą możliwością zastosowania komputera w nauce notacji muzycznej są gry i testy muzyczne. Dzięki takim aplikacjom zyskujemy na atrakcyjności nauki, w której element współzawodnictwa, punktacji czy wirtualnej nagrody stanowi dodatkowy bodziec dla uczącego się. Rozwiązania takie są dość popularne w sieci, a ich przykłady można znaleźć pod adresami:

http://primarygamesarena.com/redirect.php?id=2295

http://www.classicsforkids.com/games/notename/notename.html

http://www.emusictheory.com/practice/noteNames.html

http://www.musictheory.net/exercises/note.

Pewną odmianą powyższych gier jest ćwiczenie umiejętności kojarzenia nuty z konkretnym klawiszem na wirtualnej klawiaturze:

http://www.emusictheory.com/practice/pianoKeys.html

http://www.musictheory.net/exercises/keyboard.

Dwa ostatnie serwisy oferują daleko większy zakres ćwiczeń i gier o różnym poziomie zaawansowania uczniów, przydatnych nawet w szkolnictwie muzycznym na poziomie szkoły średniej. Poprzestaniemy jednak na zasobach sieciowych adresowanych do nauczycieli szkół ogólnokształcących, i których wymagania w zakresie kompetencji informatycznych ich użytkowników są na poziomie całkowicie podstawowym. Nauczyciel nieco bardziej zaawansowany $\mathrm{z}$ łatwością znajdzie w wymienionych serwisach ciekawe materiały edukacyjne dotyczące budowy instrumentów muzycznych, ćwiczeń rytmicznych w formie gier, czy też najciekawszych - pozwalających na tworzenie własnej muzyki, a właściwie drobnych próbek twórczości, przybliżających problemy struktury niektórych form muzycznych.

Wielu sceptycznie nastawionych do takich rozwiązań praktyków eksponuje ich zastępczy charakter i sztuczność. Owszem, wirtualna klawiatura nie wytrzymuje konkurencji z prawdziwym fortepianem, najwierniejsze zdjęcie nie zastąpi kontaktu z żywym instrumentem, najlepsze nagranie będzie gorsze od prezentacji możliwości brzmieniowych instrumentu na żywo. Nie mówimy jednak o tym, by zamiast fortepianów czy skrzypiec udostępniać uczniom komputerowe namiastki, ale by zamiast opowiadać o instrumencie, dać uczniowi możliwość jego obejrzenia na ekranie komputera, posłuchania nagrań próbek jego możliwości brzmieniowych, zobaczenia i usłyszenia go na tle orkiestry symfonicznej, czy nawet zajrzenia do środka instrumentu lub podejrzenia procesu jego produkcji. 
Rozwiązania włączające technologię komputerową do dydaktyki muzyki funkcjonują w praktyce edukacyjnej amerykańskiej i zachodnioeuropejskiej. Tam jednak zwykle wspierane są dodatkowym wyposażeniem, instrumentami midi oraz komercyjnym oprogramowaniem. Niebagatelną rolę pełnią też publikacje $\mathrm{z}$ tej dziedziny, opisujące doświadczenia pojedynczych nauczycieli muzyki, często eksperymentujących na polu łączenia informatyki z dydaktyką muzyki. Polskojęzyczne serwisy na ten temat są niestety wyjątkowo ubogie i zawierają materiały pełne błędów, zarówno merytorycznych jak i technicznych, dlatego przytaczanie w tym miejscu ich adresów mija się z celem. Pozostaje mieć nadzieję, że już niedługo, wobec wzrastającego zainteresowania tą tematyką, będziemy mogli wesprzeć się w pracy pedagogicznej materiałami i opracowaniami w pełni funkcjonalnymi i równie atrakcyjnymi, jak źródła zachodnie. Świadectwa i opisy takiej dobrej praktyki w pedagogice zachodniej są dostępne w sieci na takich portalach, jak m.in.: www.teachingmusic.org.uk, www.mitpressjournals. org/loi/comj i wielu innych. Różne konteksty kulturowe jak i organizacyjne systemów kształcenia mocno ograniczają ich proste przeniesienie na grunt polskiej edukacji, jednak mogą zainspirować czy choćby tylko zainteresować rodzimych nauczycieli muzyki obdarzonych dozą wyobraźni, pozwalającej twórczo przekształcić proponowane rozwiązania.

Kolejne ciekawe możliwości zastosowania technologii komputerowej na lekcjach muzyki stwarza prosty oraz - co ważne - darmowy program do nagrywania dźwięku o nazwie Audacity. Daje on możliwość przy pomocy zaledwie jednego kliknięcia nagrywania własnego głosu, dodawania ścieżki drugiego głosu bądź akompaniamentu, łączenia wszystkich ścieżek w jedno nagranie, które można następnie poddawać edycji, zależnej od stopnia zaawansowania w poznawaniu kolejnych funkcji programu. Uczniowie mogą w ten sposób wyprodukować własny materiał gotowy do nagrania na płytę. Pozostaje jedynie kwestią wyobraźni zawartość owego materiału: piosenka z podręcznika do muzyki, fragment utworu omawianego na lekcji i następnie opracowanego przez nauczyciela na zespół instrumentów szkolnych (flety, dzwonki, instrumenty perkusyjne), fragment wiersza lub opowiadania wzbogacony o ścieżkę ilustracji muzycznej (kompilację gotowej muzyki lub wykonywanej przez uczniów na żywo), tworząc w ten sposób formę słuchowiska.

Skromne nawet doświadczenie w zakresie obsługi programu Audacity, pozwalające na korzystanie z nieco bardziej zaawansowanych funkcji niż 
tylko kliknięcie w czerwoną kropkę inicjującą nagrywanie, stwarza możliwości daleko ciekawsze. Jedną z nich, zapewniających dydaktyczną użyteczność i jednoczesną dużą radość u uczniów jest zabawa z najprostszą formą samplowania. W tym celu należy nagrać krótką próbkę dowolnego dźwięku: własnego głosu, głosu domowego zwierzaka, efektu skrzypiących drzwi, ziewnięcia, uderzenia w ławkę itd. Traktując taki dźwięk jako tonika wirtualnej tonacji (np. C), zwielokrotniamy nagraną ścieżkę i przy pomocy efektu zmiany wysokości, na kolejnych ścieżkach tworzymy kolejne stopnie gamy: D, E, F, G, A, H oraz C. Korzystając z takiego szeregu dźwięków, na osobnej ścieżce układamy próbki w kolejności zgodnej z zapisem nutowym, tworząc w ten sposób dowolną melodię wykorzystującą cały materiał skompletowanej skali. Przybliżyć w ten sposób możemy pojęcie gamy, zilustrować pojęcie wartości rytmicznej za pomocą długości próbki, a uzyskany efekt najczęściej gwarantuje dużo zabawy, komentarzy i prowokuje do samodzielnego eksperymentowania już poza obowiązkowymi lekcjami muzyki.

Wymienione wyżej najprostsze zastosowania technologii komputerowej w dydaktyce muzyki - jak założono na wstępie - mają „odczarować” niezrozumiałą dla wielu dziedzinę i zachęcić do skorzystania z niej, podkreślając prostotę konkretnych rozwiązań. W przypadku zainteresowania takimi rozwiązaniami i ich pozytywnym zweryfikowaniem w praktyce, rozwiązania nieco bardziej zaawansowane nie muszą stanowić istotnej bariery. Próbując zachęcić do wykorzystania popularnej serii programów do „układania utworów" eJay, zakładamy, że zupełnie początkujący poziom znajomości technologii komputerowej może w tym przypadku nie być wystarczający. W takich jednak sytuacjach najprostszym i niezwykle efektywnym rozwiązaniem jest skorzystanie z doświadczenia informatycznego własnych uczniów. Przygotowanie prezentacji programu przez grupę uczniów stanowić może atrakcyjne rozszerzenie lekcji muzyki.

Seria programów eJay: Club eJay, Dance eJay, eJay RnB, eJay Techno, Hip Hop eJay, House eJay, oferuje możliwość samodzielnego tworzenia utworów opartych na współczesnej, rozrywkowej stylistyce, z tysięcy gotowych, wysokiej jakości próbek, składanych jak klocki w jedną konstrukcję, której ramy formalne możemy dowolnie narzucić uczniom. W ten sposób można bez żadnego w tej mierze doświadczenia wyprodukować ciekawie brzmiący utwór w formie ABA, wariacji, ronda czy kanonu nie obawiając się śmieszności wynikającej z jego niedoskonałości. Doświadczenie wskazuje na nie- 
zwykłe zaangażowanie uczniów korzystających z takiego narzędzia oraz brak jakichkolwiek ograniczeń w postaci nieznajomości zasad kompozycji, zapisu nutowego, harmonii i innych elementów wiedzy muzycznej niezbędnej $\mathrm{w}$ tradycyjnie pojmowanym procesie tworzenia muzyki ${ }^{4}$. Entuzjazm uczniów po raz pierwszy tworzących muzykę, widzących, że efekt ich pracy w wielu elementach nie odstaje od osiągnięć profesjonalnych muzyków, sprawia, że ich pośrednie zainteresowanie konstrukcją formy, którą tworzą, przekłada się na jej dogłębne zrozumienie. Stąd już krok do próby uchwycenia i zrozumienia podobnych konstrukcji w muzyce, której dotąd nie rozumieli: Mozarta, Beethovena czy Chopina.

Czy w takim razie istnieje potrzeba rewolucyjnych zmian w programach nauczania? Nie wymagało reformy przejście uczniów z używania piór na długopisy, a przecież podobną - służebną jedynie rolę pełnić powinna technologia informacyjna w procesie dydaktycznym. To, czy nauczyciel podeprze się w swojej pracy innymi pomocami niż tylko kreda i tablica, nie zależy od programów nauczania tylko od decyzji samego zainteresowanego.

\subsection{Wnioski i postulaty dotyczące teorii wychowania estetycznego}

Zasygnalizowane we wstępie oraz w rozdziale 1.4. nowe zadania stojące przed wychowaniem estetycznym, w pełni zasługują na powtórzenie i zaakcentowanie jako postulaty wobec teoretyków i praktyków zajmujących się tą tematyką.

Już B. Suchodolski „krytykował wąski zasięg i odświętny charakter kontaktów ze sztuką polegający na obcowaniu z nią najczęściej w muzeach i galeriach, a nie w wyniku przeżywania jej w sytuacjach życiowych" ${ }^{5}$. Technologia skutecznie zmieniła te proporcje w skali, której B. Suchodolski nie mógł się nawet domyślać. Nowe narzędzia przede wszystkim rozszerzyły możliwości oddziaływania sztuki na człowieka o obszary, których istnienia nie można było przewidzieć jeszcze dwie-trzy dekady temu. Ogrom-

\footnotetext{
${ }^{4}$ Przykład wykorzystania programu Dance eJay w klasie 9-latków opisują: John Finney, Pamela Burnard (eds), Music Education with Digital Technology, London 2007, [za:] Andrew King, Reviews, „Journal of Music, Technology and Education” 2008, vol. 1, No 2\&3, pp. 167-185; [źródło:] http://web.ebscohost.com/ehost/ pdf?vid=14\&hid=5\&sid=4c30556c-8e13-4d37-b037-a838119ca049\%40sessionmgr110 (stan z dnia 07.03.2010). Podobne doświadczenia ale z 10- i 11-latkami opisują: Marina Gall, Nick Breeze, Music and eJay: An opportunity for creative collaborations In the classroom, "International Journal of Educational Research" 2008, vol. 47, p. 27-40; [źródło:] http://www.sciencedirect.com/science/article/pii/S0883035508000232 (stan z dnia 07.03.2010).

${ }^{5}$ [Za:] J. Gajda, Współczesne pojmowanie twórczości i sztuki, [w:] K. Pankowska (red.), Sztuka i wychowanie..., s. 85.
} 
na powszechność informatycznych mediów sprawiła, że rodzące się nowe możliwości obcowania ze sztuką i tworzenia sztuki, pozostały poza obszarem naukowych dociekań teoretyków wychowania estetycznego. Podjęte w ostatniej dekadzie próby uwspółcześnienia zakresu zadań teorii wychowania estetycznego ${ }^{6}$ zainicjowało pierwsze dyskusje zainteresowanych środowisk, formułujących swoje postulaty wobec polityki edukacyjnej ${ }^{7}$. W kontekście niniejszej pracy należy zauważyć, że współcześni nauczyciele muzyki w niewystarczającym stopniu dysponują kompetencjami informatycznymi, umożliwiającymi praktyczną realizację edukacji przez sztukę w oparciu o nowe technologie, a programy kształcenia przyszłych nauczycieli muzyki nie zawsze uwzględniają typowo muzyczne możliwości TI. Potrzebna jest zatem intensyfikacja wysiłków w konstruowaniu teoretycznych podstaw, by ich praktyczna realizacja nadążała za zmieniającą się perspektywą nowych możliwości uczestniczenia w kulturze.

Warto zauważyć, że dostrzeżenie nowych zadań, nowych obszarów podlegających prawom estetyki, powinno nie tylko prowokować do namysłu ale skutkować ich wykorzystaniem również przez teoretyków wychowania estetycznego. Nowe kanały komunikacyjne powinny być nie tylko zauważone i obecne w dyskursie naukowym ale wykorzystywane dla propagowania wniosków. Tymczasem trudno o poważną refleksję na podjęte tu tematy, obecną w sieci. Wychowawca dostrzega korzyści i zagrożenia nowych mediów, ale niezwykle rzadko sam z nich korzysta.

Dylematy związane $\mathrm{z}$ włączeniem nowych mediów do kręgu zainteresowań teoretyków wychowania estetycznego pogłębiają problemy formułowane na polu samej estetyki: „Chociaż estetycy, zasiedziali w filozofii sztuki, nie nadążają za tą pośpiesznie tworzoną terminologią, to nie mogą przecież ignorować wyrażonej w niej autentycznej potrzeby objęcia refleksją estetyczną obszarów tak naprawdę jeszcze estetyce nieznanych"8. W obliczu nowych możliwości tworzenia redefiniowania wymagają tak podstawowe pojęcia dla estetyki, jak dzieło sztuki czy twórca ${ }^{9}$. Wobec tak fundamentalnych dylematów wychowanie estetyczne musi znaleźć drogę unowocześnienia swych zadań nie czekając na refleksję filozofów lecz czerpiąc inspirację z globalnych doświadczeń i globalnych przemyśleń.

\footnotetext{
${ }^{6}$ Por.: wstęp do niniejszej pracy i cytowane stanowiska m.in. I. Wojnar, K. Pankowskiej i J. Gajdy.

${ }^{7}$ Por.: rozdział 2.4.4.

${ }^{8}$ K. Wilkoszewska, Estetyki nowych mediów, [w:] eadem (red.), Piękno w sieci. Estetyka a nowe media, Kraków 1999, s. 7.

${ }^{9}$ Por.: rozdział 1.3. niniejszej pracy.
} 
Jednym $\mathrm{z}$ aspektów powszechnie formułowanych doświadczeń są zagrożenia, które szczególnie w aspekcie wychowawczym wymagają specjalnej uwagi. J. Gajda dostrzega potencjalne zagrożenia, mówiąc o „swoistym technologicznym zniewoleniu człowieka przez bezkrytyczne uznanie i podporządkowanie niemal wszystkich form życia technice i technologii oraz braku pełnej świadomości, że technologia jest jednocześnie ciężarem i błogosławieństwem"10. Rozróżnienie tych dwóch aspektów nowoczesnych technologii jest szczególnie ważnym i aktualnym zagadnieniem. Jeszcze ostrzej formułowane są problemy przemocy informatycznej, poczynając od cyberbullyingu a skończywszy na elektronicznym terrorze. Wszystkie te zjawiska i obawy powinny stanowić temat rozważań oraz działań wychowawczych, by optymistyczna wizja przyszłości miała szanse ziszczenia: „rewolucja informatyczna oraz technologie inteligentne nie zastąpią człowiekowi prawdziwego świata, ale wzbogacą go i udoskonalą, tym samym wzbogacając możliwości twórcze człowieka, czyniąc go bardziej ludzkim"ll.

Taki humanistyczny potencjał technologii informacyjno-komunikacyjnej wymaga zwrócenia uwagi na kolejne problemy, jak globalizacja, multikulturowość, regionalizacja, podejmowane w dyskursie pedagogów, a obecne jako problem nie tylko pedagogiczny, ale społeczny, polityczny, kulturalny ${ }^{12}$. Te przeciwne tendencje wymagają zgodnego współistnienia, jako budulca tożsamości współczesnego człowieka, wolnego od takich przejawów radykalnych skrajności jak szowinizm czy fanatyzm. Tolerancja i szacunek dla drugiego człowieka, osiągane między innymi udziałem sztuki w wychowaniu, winny być i są ważnym zadaniem współczesnej pedagogiki, która nie może pozostawić jedynie technologii informacyjnej pola do kreowania postaw człowieka w tym zakresie.

Ogromna powszechność informacji w formie przekazu medialnego sprawiła, że aspekt estetyczny przekazu stał się ważnym jego składnikiem, służącym wyróżnieniu komunikatu i zauważeniu przez odbiorcę jego treści. Podlega on jednak dwóm prawom: prawu inflacji, które sprawia, że jakość składnika estetycznego przekazu maleje ze wzrostem jego powszechności, oraz prawu spowszednienia, według którego nadmiar jednolitych bodźców ogranicza możliwość ich percepcji. „Ogromna ilość i różnorodność produktów powszechnej estetyzacji prowadzi do zobojętniania i stę-

${ }^{10}$ Ibidem, s. 91.

${ }^{11}$ W. W. Szczęsny, Filozofia edukacji @ Internet i media, [w:] M. Tanaś (red.), Pedagogika @ środki informatyczne i media, Warszawa - Kraków 2004, s. 141.

${ }^{12}$ Por.: wstęp do niniejszej pracy. 
pienia wrażliwości estetycznej, czego świadomi są zarówno teoretycy, jak i praktycy wychowania"13. Jesteśmy więc świadkami permanentnego stanu stępienia wrażliwości estetycznej, wobec którego „zarówno teoretycy, jak i praktycy wychowania" muszą wykazać się nie tylko świadomością, ale nie cierpiącym zwłoki działaniem.

Wyważoną refleksję M. Zalewskiej-Pawlak jeszcze dobitniej formułuje K. Pankowska, która przytaczając stanowisko i terminologię Jeana Baudrillarda twierdzi, że „funkcja sztuki została tu zatem sprowadzona do produkcji symulakrów (znaków pozbawionych swego odniesienia, co uniemożliwia im emancypację i uczestniczenie $\mathrm{w}$ grze $\mathrm{z}$ innymi znakami). W tym sensie sztuka może być wszędzie. Ale też jednocześnie nie ma jej nigdzie, bowiem nie istnieją już rzeczywistość i transcendencja"14. Wraca tu więc podstawowy problem należący do sfery estetyki: co jest sztuką? A na poziomie edukacji estetycznej: jak rozpoznać lub jak czytać sztukę?

Ten problem nabiera jeszcze większego znaczenia wobec postulatu rozszerzenia obszaru zainteresowania wychowania estetycznego o sztukę popularną. Jej wszechobecność oraz prowokowanie do współuczestnictwa nie pozwalają na pominięcie w działaniach wychowawczych a narzędzia jej opisu muszą swym działaniem objąć zarówno funkcje nobilitujące, doceniające, jak i demaskujące. „Większość tego, co tworzą amatorzy, jest doprawdy okropna, ale kwitnąca kultura potrzebuje obszarów, w których ludzie mogą robić kiepską sztukę, otrzymywać informację zwrotną i się doskonalić"15. Uwieńczeniem takiej działalności nie jest więc tylko „robienie kiepskiej sztuki” - najważniejsze dzieje się później: otrzymanie informacji zwrotnej i doskonalenie. Obecność na tych etapach świadomego swej roli nauczyciela powinna być niezbędna. A ponieważ „kulminacją tej rewolucji twórczej jest sieć”'16, to zarówno znajomość informatycznych narzędzi tworzenia jak i obecność w sieci powinny być atutami współczesnego nauczyciela muzyki.

Pole do działania szkoły jest tu nie do przecenienia. „Szkoła jest wartością trwałą, którą trzeba chronić, by zapewnić realizację powszechnej edukacji estetycznej przy zmieniających się treściach, formach i warto-

\footnotetext{
${ }^{13}$ M. Zalewska-Pawlak, Estetyzacja życia a edukacja szkolna. Analiza historyczna zainspirowana słowami Herberta Reada: „samo życie w swoich najistotniejszych, najbardziej tajemniczych źródłach jest estetyczne”, [w:] K. Pankowska (red.), Sztuka i wychowanie..., s. 244.

${ }^{14}$ K. Pankowska, Sztuka i kultura współczesna..., s. 32.

${ }^{15}$ H. Jenkins, Kultura konwergencji..., s. 135.

${ }^{16}$ Ibidem, s. 135.
} 
ściach samej sztuki”17. Nauczyciel muzyki, będący głównym realizatorem powszechnej edukacji estetycznej, musi mieć świadomość wagi swej misji, co zapewnić można tylko przez wsparcie teoretyków oraz zorganizowanych środowisk opiniotwórczych, czy lobbystycznych.

Należy odebrać zasadom marketingowym prawo do negocjowania norm kulturowych. Szkoła powinna konsekwentnie starać się odzyskiwać swoją pozycję, demaskując działania quasi-estetyczne i pseudo-estetyczne, ucząc obcowania ze sztuką opartego na prawdziwym przeżyciu estetycznym, zarówno z pozycji odbiorcy, jak i współtwórcy, posługującego się coraz nowszymi narzędziami, ale twardo osadzonym w normach kulturowych, wynikających nie z zasad marketingu, ale z zasad formułowanych przez nadążającą za rzeczywistością teorią wychowania estetycznego.

\subsection{Zakończenie}

Szkoła przegrywa walkę o kształt wychowania młodego pokolenia. W dużej mierze sama oddaje pole bardziej agresywnym kreatorom postaw i potrzeb, dając się spychać do funkcji egzekutora wiedzy. Arsenał środków, jakimi dysponuje szkoła sprawia, że ofensywne działania innych ośrodków wychowawczych, przede wszystkim mediów, kreujących model życia bez problemów, bez trosk, bez odpowiedzialności, staje się atrakcyjną przeciwwagą dla młodego człowieka.

Nauczyciel pełniący rolę dozorcy w skansenie wiedzy rzadko z niej wychodzi, by zainteresować czy porwać młodych ludzi zapatrzonych w przyszłość, ciekawych najnowszych osiągnięć, którzy wychodząc ze szkoły widzą zupełnie inny świat. Nieprzystawanie obu światów - szkolnego i pozaszkolnego - prowokuje do zanegowania jednej z funkcji szkoły: poznanie, opisanie i zrozumienie rzeczywistości. Szkoła nie nadąża za zmianami, za współczesnością i choćby na gruncie technologii, która w dużej mierze wypełnia życie i świadomość młodych ludzi, najpóźniej asymiluje wszelkie nowości, nie dlatego, że nie zauważa takiej potrzeby, ale z przyziemnych powodów, choćby finansowych. Być może równie ważną przyczyną jest strukturalna antynomia, polegająca na chęci włączenia do arsenału współczesnej szkoły, tak mimo wszystko obcych, bo polegających na pełnej wolności narzędzi.

Rozdźwięk poznawczy między szkołą a mediami stawia je w dramatycznej kontrze, czy wręcz na wrogich pozycjach. Młodzież z wielką zachłan-

\footnotetext{
${ }^{17}$ K. Pankowska, Sztuka i kultura współczesna..., s. 252.
} 
nością chłonie wszechobecną muzykę, inwestuje w przenośne odtwarzacze, niecierpliwie wyczekuje nowych płyt swoich idoli, jednak nie przekłada się to na uwielbienie dla Mozarta, Chopina czy Moniuszki. Te dwa światy różni zarówno treść przekazu jak i jego forma, medium. Ale taki układ sił nie jest nieuchronny. Skoro świat kreowany w mediach, a przede wszystkim w internecie, wygrywa swą atrakcyjnością ze szkołą, trzeba próbować dotrzeć do ucznia poprzez lub przy pomocy nowoczesnych mediów, dzięki czemu nie postawimy szkoły w pozbawionej szans konfrontacji lecz przeciwnie pokażemy, że to, co tak porywa młodych ludzi może być wręcz integralną częścią życia szkolnego. W końcu internet narodził się z praktyki edukacyjnej, akademickiej.

Na szczęście tak ciemny obraz edukacji jest już coraz mniej powszechny. By go móc całkiem rozjaśnić należy zdefiniować i zintensyfikować działania na rzecz jej unowocześnienia. Wychowawca musi być obecny w nowych mediach, by móc wpływać na kształt wychowania. Nowoczesne media zaś muszą być obecne w szkole, by nie budować murów, które odwracają logikę wirtualności: rzeczywistość szkolna, nie nadążająca za przemianami realnego świata, będzie postrzegana jako daleka od tej rzeczywistości, a więc wirtualna. „Rozwój zakłada uwzględnienie przemian społeczno-cywilizacyjnych, spojrzenie na kulturę i edukację jako wzajemnie przenikających się procesów. Stąd konieczność uwzględnienia w edukacji humanistycznej realiów życia, zwłaszcza kiedy stają się one dominujące"18. Perspektywa nadążania za realiami życia, w optymistycznych wizjach może nawet zostać odwrócona, by „konsekwencje postępu i jego perspektywy były inspirowane postępem oświatowym i rozprzestrzeniane w życiu społecznym"19.

Co zatem hamuje nauczycieli w tym, aby posłużyć się atrakcyjnym dla uczniów narzędziem? Czego brakuje nauczycielom muzyki?

Chęci, odwagi, zaangażowania, przełamania uprzedzeń i schematów, wyobraźni, czyli tego, co stanowi ważny i kluczowy składnik kompetencji nauczyciela. Nie wiedza i umiejętności, które wcale nie muszą wykraczać poza zakres całkowicie podstawowy, ale możliwości, chęć i motywacja do włączenia ich w metodyczny warsztat pracy nauczyciela muzyki na każdym etapie kształcenia, tak ogólnego jak i artystycznego. Motywacja taka może wypływać nie tylko z obowiązku, jaki narzuci na nauczyciela ustawa czy dy-

\footnotetext{
${ }^{18}$ J. Gajda, Determinanty cywilizacyjne i kulturowe edukacji medialnej, [w:] J. Gajda, S. Juszczyk, B. Siemieniecki, K. Wenta (red.), Edukacja medialna, Toruń 2002, s. 18.

19 T. Gumuła, T. Dyrda, Wprowadzenie. Kształcenie kandydatów na nauczycieli - postęp oświatowy, [w:] idem (red.), Kształcenie kandydatów na nauczycieli. Teoria - praktyka, Kielce 2006, s. 17.
} 
rektor szkoły ale z doświadczenia, z chęci podjęcia wyzwania, ryzyka, z odpowiedzialności, z drobnej choćby próby tych wszystkich, którzy traktują technologię komputerową jako zagrożenie, konkurencję czy wręcz wroga $\mathrm{w}$ wychowaniu młodego pokolenia.

„Warunki naszego uczestnictwa w nowej kulturze konwergencji ciągle są przedmiotem dyskusji. Kształtuje je polityka rządów i sądowe wyroki, ale też decyzje podejmowane w korporacyjnych gabinetach i w pokojach nastolatków" ${ }^{20}$. Przedstawiona praca ma nadzieję wpisać się w tą dyskusję.

\footnotetext{
${ }^{20}$ H. Jenkins, Kultura konwergencji..., s. VII.
} 


\section{Bibliografia}

\section{Wydawnictwa zwarte:}

1. Adams D., Hamm M., Media and Literacy. Learning in the Information AgeIssues, Ideas, and Teaching Strategies, Springfield, Illinois, U.S.A., 2006.

2. Bereziński M. (red.), Polska szkoła wobec wyzwań społeczeństwa informacyjnego. Interdyscyplinarność, komputery i Internet w nauczaniu, Warszawa 2004.

3. Białkowski A. (red.), Standardy edukacji kulturalnej. Materiały do konsultacji środowiskowych, Warszawa, 2008.

4. Bralczyk J. (red.), Słownik 100 tysięcy potrzebnych słów, Warszawa, 2005.

5. Czerepaniak-Walczak M., Aspekty i źródła profesjonalnej refleksji nauczyciela, Toruń, 1997.

6. Dryden G., Vos J., Rewolucja w uczeniu się, Poznań, 2000.

7. Fiut I. S., Media@ Internet. Szkice filozoficzno-medioznawcze z lat 2000-2006, Kraków, 2006.

8. Furmanek M. (red.), Technologie informacyjne $w$ warsztacie pracy nauczyciela, Zielona Góra, 2008.

9. Gajda J., Juszczyk S., Siemieniecki B., Wenta K. (red.), Edukacja medialna, Toruń 2002.

10. Gawlina Z. i in. (red.), Słownik słów kluczowych z pedagogiki, Kraków 1988

11. Godzic W., Bednarz A. (red.), Humanista w cyberprzestrzeni, Kraków, 1999.

12. Gumuła T., Dyrda T. (red.), Kształcenie kandydatów na nauczycieli. Teoria praktyka, Kielce 2006,

13. Hopfinger M., Nowe media w komunikacji społecznej w XX wieku. Antologia, Warszawa, 2002.

14. Izdebska J., Media elektroniczne w życiu dziecka w kontekście wartości wychowawczych oraz zagrożeń, Białystok, 2008.

15. Jabłoński W., Wacławiak J., Wszelak S., Komputer i Internet w pracy nauczyciela, Toruń, 2003.

16. Jenkins H., Kultura konwergencji. Zderzenie starych i nowych mediów, tłum. M. Bernatowicz, M. Filiciak, Warszawa, 2007.

17. Jenkins H. O., Getting it Right. a Handbook for Successful School Leadership, Oxford, 1991.

18. Juszczyk S., Edukacja na odległość. Kodyfikacja pojęć, reguł i procesów, Toruń, 2002.

19. Juszczyk S. (red.), Edukacja medialna w społeczeństwie informacyjnym, Toruń, 2002. 
20. Kataryńczuk-Mania L., Karcz J. (red.), Edukacja artystyczna wobec przemian społeczno-oświatowych, Zielona Góra, 2002.

21. Kędzierska B., Informatyczne kształcenie i doskonalenie nauczycieli, Kraków , 2005.

22. Kędzierska B., Kompetencje informacyjne w kształceniu ustawicznym, Warszawa, 2007.

23. Kluszczyński R. W., Film, wideo, multimedia. Sztuka ruchomego obrazu w erze elektronicznej, Warszawa 1999.

24. Kluszczyński R. W., Społeczeństwo informacyjne. Cyberkultura. Sztuka multimediów, Kraków, 2002.

25. Kobyłecka E., Kozioł E. (red.), W poszukiwaniu wyznaczników kompetencji nauczyciela XXI wieku, Zielona Góra, 2002.

26. Koczniewska-Zagórska L., Nowacki T. W., Wiatrowski Z. (red.), Słownik pedagogiki pracy, Wrocław-Warszawa-Kraków-Gdańsk-Łódź, 1986.

27. Kubinowski D., Jakościowe badania pedagogiczne. Filozofia - metodyka ewaluacja, Lublin 2010.

28. Kwieciński Z., Śliwerski B. (red.), Pedagogika. Podręcznik akademicki, t. 1, Warszawa 2004.

29. Lewowicki T., Siemieniecki B. (red.), Media w edukacji - szanse i zagrożenia, Toruń, 2008.

30. Lewowicki T., Siemieniecki B. (red.), Rola i miejsce technologii informacyjnej w okresie reform edukacyjnych $w$ Polsce, Torun, 2003.

31. Łobocki M., Metody i techniki badań pedagogicznych, Kraków, 2000.

32. Michalewska M., Kowolik P. (red.), Kompetencje nauczycieli w reformowanej szkole, Katowice, 2003.

33. Migdałek J., Kędzierska B. (red.), Informatyczne przygotowanie nauczycieli. Konkurencja edukacji informatycznej (Tom 2.), Kraków, 2002.

34. Migdałek J., Zając M. (red.), Informatyczne przygotowanie nauczycieli: kompetencje i standardy kształcenia, Kraków, 2006.

35. Morbitzer J., (red.), Komputer w Edukacji. 14. Ogólnopolskie sympozjum naukowe, Kraków 2004.

36. Morbitzer J. (red.), Techniki komputerowe w przekazie edukacyjnym, Kraków, 2002.

37. Okoń W., Nowy słownik pedagogiczny. Wydanie drugie rozszerzone, Warszawa 1998.

38. Okoń W., Słownik pedagogiczny. Wydanie trzecie, Warszawa 1984.

39. Osiński Z., Technologia informacyjna w edukacji humanistycznej, Toruń 2006.

40. Osmańska-Furmanek W., Nowe technologie informacyjne w edukacji, Zielona Góra, 1999.

41. Pachociński R., Oświata XXI wieku. Kierunki przeobrażeń, Warszawa, 1999. 
42. Pachociński R., Technologia a oświata, Warszawa, 2002.

43. Pankowska K. (red.), Sztuka i wychowanie. Współczesne problemy edukacji estetycznej, Warszawa 2010.

44. Patora P., Raport z badania realizacji priorytetu MEN „Ocena jakości pracy szkoły $w$ zakresie informatyzacji procesu edukacyjnego - zastosowanie technologii informacyjnej i komunikacyjnej" w województwie łódzkim, www. kuratorium.lodz.pl/data/other/raport_2.pdf (stan z dnia 10.10.2010).

45. Pilch T. (red.), Encyklopedia pedagogiczna XXI wieku, Warszawa, 2003.

46. Pilch T. (red.), Encyklopedia pedagogiczna XXI wieku, Suplement A-Ż, Warszawa 2010.

47. Pilch T., Bauman T., Zasady badań pedagogicznych. Strategie ilościowe i jakościowe (wydanie trzecie poprawione i rozszerzone), Warszawa, 2010.

48. Pomykało W., Encyklopedia pedagogiczna (wyd. 1), Warszawa, 1997.

49. Rubacha K., Metodologia badań nad edukacją, Warszawa 2008.

50. Rudolph T. E., Teaching Music with Technology, Chicago 2004; [źródło:] http://books.google.pl/books?id=OnPnMsWOkVAC ( $\operatorname{stan} \mathrm{z}$ dnia 20.02.2012).

51. Serdyński A., Kompetencje informatyczno-medialne nauczyciela, Szczecin, 2007.

52. Siemieniecka-Gogolin D., Zdolności i postawa twórcza a styl użytkowania elektronicznych mediów, Toruń, 2005.

53. Siemieniecki B., Komputer w edukacji. Podstawowe problemy technologii informacyjnej, Toruń, 2002.

54. Siemieniecki B., Technologia informacyjna w polskiej szkole. Stan i zadania, Toruń 2002.

55. Siemińska-Łosko A., Internet w przygotowaniu nauczycieli do stosowania technologii informacyjnej, Toruń 2006.

56. Silverman D., Interpretacja danych jakościowych. Metody analizy rozmowy, tekstu i interakcji, tlum. M. Głowacka-Grajper, J. Ostrowska, Warszawa 2009.

57. Silverman D., Prowadzenie badań jakościowych, tłum. J. Ostrowska, Warszawa 2009.

58. Strykowski W., Skrzydlewski W. (red.), Kompetencje medialne społeczeństwa wiedzy, Poznań, 2004.

59. Szuman S., O sztuce i wychowaniu estetycznym, Warszawa, 1969.

60. Tanaś M., Edukacyjne zastosowania komputerów, Warszawa, 1997.

61. Tanaś M. (red.), Pedagogika @ środki informatyczne i media, WarszawaKraków, 2004.

62. Urbaniak-Zając D., Piekarski J. (red.), Jakościowe orientacje w badaniach pedagogicznych. Studia i materiały, Łódź 2001.

63. Wilkoszewska K. (red.), Piękno w sieci. Estetyka a nowe media, Kraków 1999. 
64. Wojnar I., Kubin J. (red.), Edukacja wobec wyzwań XXI wieku, Warszawa, 1996.

65. Zalewska-Pawlak M. (red.), Sztuka i wychowanie w dialogu polsko-włoskim, Łódź 2005.

\section{Artykuły w czasopismach - wydania papierowe i internetowe}

1. Aftański A., Kompetencje informatyczne i moralne nauczycieli - $w$ dobie budowy społeczeństwa informacyjnego, „Kultura i Edukacja” 2004, nr 1, s. 78-86.

2. Al-Fudail M., Mellar H., Investigating teacher stress when using technology, “Computers \& Education" 2008, vol. 51, p. 1103-1110; [źródło:] http:// www.sciencedirect.com/science/article/pii/S0360131507001352 (stan z dnia 07.03.2010).

3. Burnard P., Reframing creativity and technology: promoting pedagogic chance In music education, "Journal of Music, Technology and Education” 2007, vol. 1, No 1, p. 37-55; [źródło:] http://web.ebscohost. com/ehost/pdf?vid=14\&hid=5\&sid=4c30556c-8e13-4d37-b037a838119ca049\%40sessionmgr110 (stan z dnia 07.03.2010).

4. Burns A., Integrating Technology into Your Elementary Music Classroom, „General Music Today” [serial online], Fall 2006; 20(1), p. 6-10. Available from: Academic Search Complete, Ipswich, MA. Accessed March 16, 20102006, nr 20(1), s. 6-10.

5. Crow B., Musical creativity and the new technology, „Music Education Research" [serial online] March 2006, 8 (1), p. 122-123. Available from: Academic Search Complete, Ipswich, MA. Accessed March 14, 2010, 2006, 8 (1), s. 121-130.

6. Czerepaniak-Walczak M., Kompetencja: słowo kluczowe czy wytrych w edukacji?, „Neodidagmata” 1999, nr XXIV.

7. Gall M., Breeze N., Music and eJay: An opportunity for creative collaborations In the classroom, "International Journal of Educational Research" 2008, vol. 47, p. 27-40; [źródło:] http://www.sciencedirect.com/science/article/pii/ S0883035508000232 (stan z dnia 07.03.2010).

8. Gańko-Karwowska M., Kompetencje informatyczne nauczycieli szkót podstawowych, www.uz.zgora.pl/kmti/konferencje/media_a_edukacja/ referaty/ganko.pdf ( $\operatorname{stan} \mathrm{z}$ dnia 10.10.2010).

9. Gawrach R., Zmiany w kompetencjach współczesnych nauczycieli w kontekście wyzwań społeczno-ekonomicznych, „Przegląd Naukowy” 2006, nr 5, s. 67-74.

10. Ho W.-Ch., Student's experiences with and preferences for using information technology in music learning in Shanghai's secondary schools, "British Journal of Educational Technology" 2007, Vol. 38, No 4, p. 699-714; [źródło:] http:// web.ebscohost.com $/$ ehost $/$ pdf? vid=6\&hid=106\&sid=4c30556c-8e13-4d37b037-a838119ca049\%40sessionmgr110 ( $\operatorname{stan} z$ dnia 06.03.2010). 
11. Jackowski M., Podmiotowość w nauczaniu sztuki w globalnym społeczeństwie informacyjnym; [źródło:] jjk.nazwa.pl/ensil/index.php?option=com_ weblinks\&task=view\&catid=123\&id=47 (stan $\mathrm{z}$ dnia 11.11.2004).

12. Karauda K., Oglądanie czy czytanie. Ogólnie o problemach metodyki zdalnego nauczania, http://www.puw.pl/elearning.html?akcja=elearning\&P[aid]=281 (stan z dnia 11.11.2004).

13. King A., Reviews, „Journal of Music, Technology and Education” 2008, vol. 1, No 2\&3, p. 167-185; [źródło:] http://web.ebscohost.com/ehost/pdf?vid= $14 \&$ hid $=5 \&$ sid $=4 c 30556 \mathrm{c}-8 \mathrm{e} 13-4 \mathrm{~d} 37-\mathrm{b} 037-\mathrm{a} 838119 \mathrm{ca} 049 \% 40$ sessionmgr 110 ( stan z dnia 07.03.2010).

14. Kirk S., Do Music Teachers Have a Responsibility to Teach with Technology?, "American Music Teacher" 2006, August/September, p. 72-73; [źródło:] http:// web.ebscohost.com/ehost/pdf?vid=6\&hid=106\&sid=4c30556c-8e13-4d37b037-a838119ca049\%40sessionmgr110 (stan z dnia 06.03.2010).

15. Makiewicz M., Rozwijanie myślenia twórczego uczniów za pomoca technik komputerowych jako kompetencja dydaktyczna nauczyciela, „ChemiaDydaktyka-Ekologia” 2000, nr 1/2, s. 57-61.

16. Osiński Z., E-learning w kształceniu i dokształcaniu nauczycieli, gazeta-it. pl/200305225087/E-learning-w-ksztalceniu-i-doksztalcaniu-nauczycieli.html ( $\operatorname{stan} \mathrm{z}$ dnia 11.11.2004).

17. Osmańska-Furmanek., Furmanek M., Technologie informacyjne cel czy narzędzie? Kształcenie informacyjne pedagogów i nauczycieli, „Chowanna” 2003, s. 132-149.

18. Panasiuk B., Multimedialny komputer w nauczaniu muzyki, „Edukacja Medialna" 2000, nr 3, s. 47-49.

19. Panasiuk B., Muzyka z komputera, „Wychowanie Muzyczne w Szkole” 2005, nr 1, s. 22-28.

20. Panasiuk Bernard, Multimedialne programy komputerowe w zapoznawaniu uczniów z literaturą muzyczną, „Wychowanie Muzyczne w Szkole” 2005, nr 4, s. 34-46.

21. Parkita E., Komputer w kształceniu odbiorcy muzyki, „Wychowanie Muzyczne w Szkole" 1999, nr 2.

22. Parkita E., Miejsce multimediów w edukacji muzycznej, „Wychowanie Muzyczne w Szkole” 1998, nr 5.

23. Parkita E., Muzyka $w$ Sieci, czyli edukacyjne zasoby Internetu, „Wychowanie Muzyczne w Szkole" 2000, nr 4.

24. Parkita E., Rola muzycznych programów komputerowych w integracji międzyprzedmiotowej, „Wychowanie Muzyczne w Szkole” 2000, nr 2/3, s. 100-106.

25. Popławska A. D., Podmiotowość uczestników procesu kształcenia w społeczeństwie informacyjnym, gazeta-it.pl/200305225085/Podmiotowosc-uczestnikowprocesu-ksztalcenia-w-spoleczenstwie-informa.html (stan z dnia 11.11.2004). 
26. Skoczylas C., Komputer na lekcjach muzyki, „Wychowanie Muzyczne w Szkole" 1992, nr 2, s. 81-87.

27. Stanisławska A., Uczyć się w Internecie. Kilka wybranych problemów $z$ metodyki zdalnego nauczania, http://www.puw.pl/downloads/docs/1_ elearning/2_teoria_elearning/referat\%20Media\%20a\%20edukacja04_2002.pdf (stan z dnia 11.11.2004).

28. Stasińska K., Muzyka z komputera (program multimedialny Romantyzm Muzyczne wędrówki), „Wychowanie Muzyczne w Szkole” 1999, nr 4, s. 184186.

29. Strykowski W., Kompetencje współczesnego nauczyciela, „Neodidagmata” 2004/2005, t. 27/28, s. 15-28.

30. Strykowski W., Rola mediów i edukacji medialnej we współczesnym społeczeństwie, chowanna.us.edu.pl/vol/ch20.pdf (stan z dnia 10.10.2010).

31. Vennemeyer J., Orff + technology = composition for Kids, „Teaching Music” [serial online] June 1999; 6(6):36. Available from: Academic Search Complete, Ipswich, MA. Accessed March 16, 2010, 1999, nr 6.

32. Żak-Bucholc J., Bricolag Lévi-Straussa i dekonstrukcjonizm Derridy [2], racjonalista.pl/kk.php/s,2508/k,2 (stan z dnia 17.04.2008).

\section{Dokumenty:}

1. GUS, Wydział Statystyki Edukacji i Kultury, Oświata i wychowanie w roku szkolnym 2010/2011, Warszawa 2011, s. 123-124; (http://www.stat.gov.pl/cps/ rde/xbcr/gus/PUBL_e_oswiata_i_wychowanie_2010-2011.pdf, stan z dnia 18.03.2012).

2. Komisja Europejska, Dyrektoriat Generalny ds. Edukacji i Kultury, Edukacja w Europie: różne systemy kształcenia i szkolenia - wspólne cele do roku 2010. Program prac dotyczacy przyszłych celów systemów edukacji, Warszawa, 2003.

3. Komisja Europejska, Dyrektoriat Generalny ds. Edukacji i Kultury, Zalecenia Parlamentu Europejskiego i Rady z dnia 18 grudnia 2006 roku w sprawie kompetencji kluczowych w procesie uczenia się przez całe życie.

4. Rada ds. Edukacji Informatycznej i Medialnej, Standardy przygotowania nauczycieli w zakresie technologii informacyjnej i informatyki, Warszawa, 2003.

5. Rada ds. Edukacji Informatycznej i Medialnej przy Ministrze Edukacji Narodowej, Kierunki działań w zakresie nauczania dzieci i młodzieży oraz funkcjonowania szkoły w społeczeństwie informacyjnym. Nowe technologie w edukacji, Warszawa 2010.

6. Rada ds. Edukacji Informatycznej i Medialnej przy Ministrze Edukacji Narodowej, Dodatki do Kierunków działań dotyczacych nauczania dzieci i młodzieży oraz funkcjonowania szkoły w społeczeństwie informacyjnym. Nowe technologie w edukacji, Warszawa 2009. 
7. Rada Główna Szkolnictwa Wyższego, Standardy kształcenia przygotowującego do wykonywania zawodu nauczyciela, projekt $z 15$ lutego 2007 roku, Warszawa, 2007.

8. Rozporządzenie Ministra Edukacji Narodowej i Sportu z dnia 1 grudnia 2004 r. w sprawie uzyskiwania stopni awansu zawodowego przez nauczycieli, Dz.U. z 2004 r., Nr 260, poz. 2593.

9. Rozporządzenie Ministra Edukacji Narodowej i Sportu $z$ dnia 26 lutego 2002 r. $w$ sprawie podstawy programowej wychowania przedszkolnego oraz kształcenia ogólnego w poszczególnych typach szkół, Dz.U. z 2002 r., Nr 51, poz. 458.

10. Rozporzadzenie Ministra Edukacji Narodowej z dnia 23 grudnia 2008 r. $w$ sprawie podstawy programowej wychowania przedszkolnego oraz kształcenia ogólnego w poszczególnych typach szkół, Dz.U. z 2009 r., Nr 4, poz. 17.

11. Rozporzadzenie Ministra Edukacji Narodowej z dnia 7 września 2004 r. w sprawie standardów kształcenia nauczycieli, Dz.U. z 2004 r., Nr 207, poz. 2110.

12. Rada Główna Szkolnictwa Wyższego, Standardy kształcenia przygotowującego do wykonywania zawodu nauczyciela, projekt z 15 lutego 2007 roku.

13. Rozporzadzenie Ministra Edukacji Narodowej z dnia 17 stycznia 2012 r. $w$ sprawie standardów kształcenia przygotowującego do wykonywania zawodu nauczyciela, Dz.U. z 2012 r., Nr 25, poz. 131.

\section{Elektroniczne materiały edukacyjne:}

1. Multimedialna encyklopedia powszechna, PWN, 2010.

2. Klik uczy śpiewać. Multimedialne zabawy muzyczne dla dzieci w wieku 6-10 lat, WSiP, 2002.

3. Muzyczne wędrówki. Barok. Multimedialna podróż po Europie XVII i XVIII wieku, PWN, 1998.

4. Muzyczne wędrówki. Romantyzm. Multimedialna podróż po Europie XIX wieku, PWN, 1998.

5. Uczę się muzyki, Albion, 1998.

6. Poniatowska I., Wroński M., Słownik szkolny - Muzyka, WSiP, 1998.

7. Tomaszewski M., Fryderyk Chopin - życie twórcy w kontekście kultury, wśród ludzi i zdarzeń. Leksykon multimedialny, Neurosoft, 1995. 


\title{
Aneks \\ Formularz ankiety dla nauczyciela muzyki
}

\author{
ANKIETA \\ (czas wypełniania - ok. 10 minut)
}

\section{Szanowni Państwo.}

Zwracam się do Państwa z prośba o wypełnienie poniższej ankiety, która jest elementem badań prowadzonych na Uniwersytecie Łódzkim i ma na celu określenie w jakim stopniu nauczyciele muzyki posługują się technologia komputerowa. Ankieta jest anonimowa $i w \dot{z}$ adnym stopniu nie może być i nie będzie wykorzystana $w$ celach innych niż badawcze, w szczególności nie może zostać ujawniona osobom trzecim (w tym Państwa przełożonym) $w$ celu weryfikacji Państwa kompetencji.

Uprzejmie prosze o złożenie wypetnionej ankiety w załączonej kopercie ( $w$ celu zapewnienia poufności) w sekretariacie Szkoły, skąd w ciagu kilku dni ją odbiorę.

Bardzo dziękuję za poświęcony mi czas -

Piotr Soszyński

Katedra Edukacji Artystycznej

Uniwersytet Łódzki

1. Wykształcenie (ukończona uczelnia):

2. W ilu szkołach podstawowych w Łodzi jest Pan/i zatrudniony/a:

3. Aktualny wymiar zatrudnienia w poszczególnych szkołach:

4. Wiek:

5. Płeć: K M

6. Staż w zawodzie nauczyciela muzyki:...............

7. Stopień awansu zawodowego:

Prosze o zaznaczenie jednej lub więcej odpowiedzi oraz ewentualne uściślenie odpowiedzi w miejscach wykropkowanych: 
8. Czy stosuje Pan/i technologię komputerową w:

a. przygotowywaniu się do zajęć (odświeżanie lub pogłębianie własnej wiedzy, szukanie nowych informacji, ciekawych konspektów lekcji i in.)?

b. przygotowywaniu materiałów dla uczniów (nuty, nagrania, ilustracje, prezentacje i in.)?

c. prowadzeniu zajęć (prezentacje, filmy, ilustracje, programy i gry edukacyjne)?

d. ocenie osiągnięć uczniów (przygotowanie sprawdzianów, testów w formie papierowej lub multimedialnej)?

e. żadnej z powyższych sytuacji;

9. Jak często wykorzystuje Pan/i technologię komputerową w przygotowaniu lub prowadzeniu zajęć:

a. w ogóle nie wykorzystuję;

b. zdarzyło mi się raz lub dwa w całej mojej pracy nauczycielskiej;

c. 1-2 razy w ciągu roku szkolnego;

d. kilka razy w ciągu roku szkolnego;

e. częściej (jak często?)

10. Jakiego rodzaju programy lub zastosowania komputerowe wykorzystuje Pan/i w pracy z uczniami (proszę o podanie nazw programów, tytułów stron internetowych):

a. wyszukiwanie i gromadzenie informacji lub nagrań potrzebnych do zajęć; (tytuły stron internetowych: .................)

b. programy do zgrywania muzyki na płyty;

(nazwy programów:

c. programy do edycji nagrań muzycznych (przycinanie, zmiana tonacji itp.); (nazwy programów:

d. programy do edycji i druku zapisu nutowego;

(nazwy programów:

e. programy pomocne w komponowaniu muzyki, tworzeniu utworu z gotowych elementów;

(nazwy programów:

f. programy do doskonalenia lub sprawdzania wiedzy i umiejętności muzycznych uczniów; (nazwy programów: 
g. programy nie związane z muzyką (do tworzenia prezentacji, obróbki zdjęć, filmów, edytor tekstu)

(nazwy programów:

h. żadne z powyższych;

11. Czy ma Pan/i możliwość wykorzystania sprzętu komputerowego na lekcji muzyki (jaki: laptop, rzutnik multimedialny, zestaw komputerowy, inny.......................)?

a. zawsze, gdy zgłoszę taką potrzebę;

b. czasami, gdy akurat sprzęt nie jest zajęty przez innego nauczyciela;

c. nie mam takiej możliwości;

d. nie wiem;

12. Czy ma Pan/i możliwość przeprowadzenia lekcji muzyki w pracowni komputerowej?

a. zawsze, gdy zgłoszę taką potrzebę;

b. czasami, jeśli akurat pracownia komputerowa jest wolna;

c. tylko gdy informatyk jest na zwolnieniu;

d. nie mam takiej możliwości;

e. nie wiem;

13. W jaki sposób nauczył/a się Pan/i posługiwać komputerem?

a. zajęcia w ramach studiów pedagogicznych;

b. zajęcia w ramach studiów muzycznych;

c. kursy lub szkolenia w ramach doskonalenia zawodowego;

d. studia podyplomowe;

e. pozaformalne (samokształcenie, lektura, pomoc członka rodziny, znajomych);

f. inne (jakie:

g. nie potrafię posługiwać się komputerem;

14. Czy dyrektor szkoły zachęcał lub nakazywał Panu/i udział w szkoleniu komputerowym?

a. tak - dzięki temu ukończyłam/łem takie szkolenie;

b. tak - ale mimo to nie skorzystałam/lem z żadnego szkolenia komputerowego;

c. nie - ponieważ dyrektor zna moje wysokie kwalifikacje w tej dziedzinie; 

d. nie - ponieważ dyrektor nie przykłada większej wagi do takich szkoleń;
e. nie - $z$ dowolnych innych przyczyn;

15. Jak często korzysta Pan/i z komputera w domu lub pracy?
a. w ogóle nie korzystam;
b. najwyżej kilka razy w roku;
c. kilka razy w miesiącu;
d. kilka razy w tygodniu;
e. codziennie;
f. kilka godzin dziennie;

16. Jakie dokonania z zakresu „wykorzystywania w pracy technologii informacyjnej i komunikacyjnej" przedstawił/a Pan/i przy ubieganiu się o kolejny stopień awansu zawodowego?

17. Czy były to dokonania faktyczne czy fikcyjne?
a. faktyczne;
b. fikcyjne;
c. trochę faktycznych, trochę fikcyjnych;

18. Jakie programy komunikacyjne potrafi Pan/i obsługiwać (proszę podać nazwę)?
a. przeglądarka internetowa ..............................);

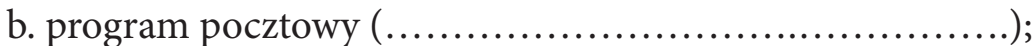

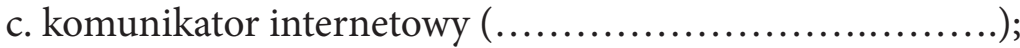

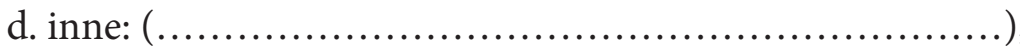

19. Jakie programy pakietu biurowego potrafi Pan/i obsługiwać (proszę podać nazwę)?

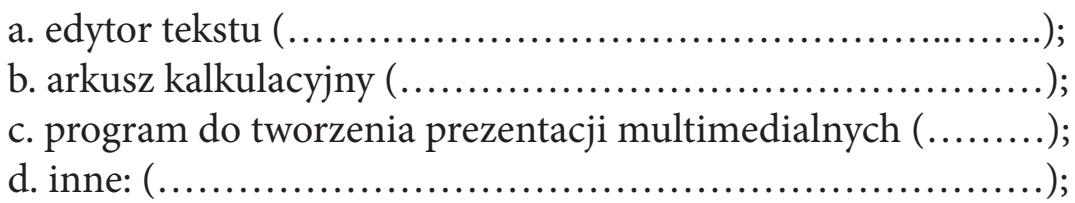

20. Jakiego rodzaju programy muzyczne potrafi Pan/i obsługiwać (proszę podać nazwę)? 


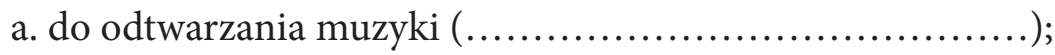

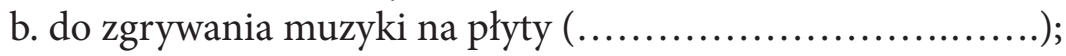
c. do edycji zapisu nutowego $(\ldots \ldots \ldots \ldots \ldots \ldots \ldots \ldots \ldots \ldots \ldots)$;
d. do obróbki i konwersji plików dźwiękowych (...............);

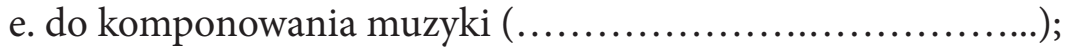

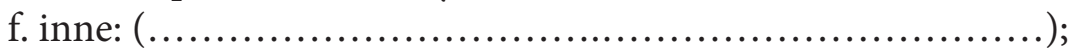

21. Jakie programy komputerowe o innym przeznaczeniu - w tym rozrywkowym - używa Pan/i (proszę podać nazwy lub do czego służą)?

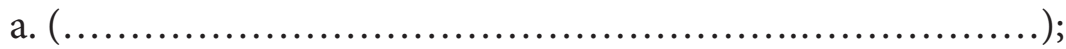

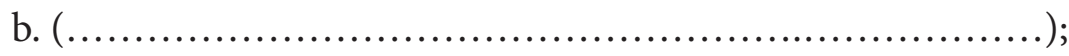

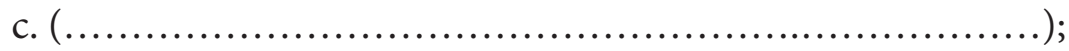

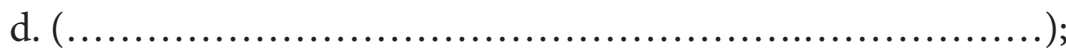

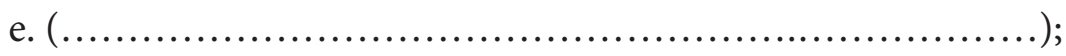

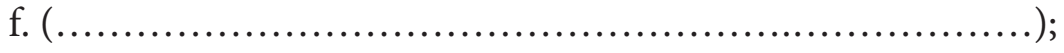

22. Kompetencje informatyczne w pracy nauczyciela muzyki są według Pana/i:
a. niezbędne;
b. wskazane;
c. bez znaczenia;

23. Posługiwanie się komputerem na lekcjach muzyki jest według Pana/i:
a. koniecznością dla nauczyciela;
b. koniecznością dla uczniów;
c. pomocne dla nauczyciela;
d. pomocne dla uczniów;
e. bez znaczenia dla nauczyciela;
f. bez znaczenia dla uczniów;
g. utrudnieniem dla nauczyciela;
h. utrudnieniem dla uczniów;

24. Czy sądzi Pan/i, że Podstawa programowa czy Standardy kształcenia nauczycieli określają kompetencje informatyczne nauczyciela jako:

a. niezbędny składnik warsztatu pracy;

b. pomocne ale nie konieczne;

c. w/w dokumenty nie dotyczą kompetencji informatycznych nauczyciela;

d. nie wiem; 
25. Czy program nauczania, z którego korzysta Pan/i w swojej pracy zakłada wykorzystanie technologii komputerowej do zajęć (proszę o podanie obok odpowiedzi tytułu programu lub podręcznika)?

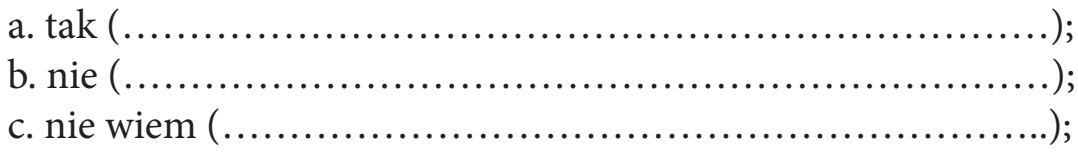

26. Jakie widzi Pan/i możliwe zastosowania technologii komputerowej we wspomaganiu nauczaniu muzyki?

27. Czy wyraził(a)by Pan(i) chęć na uczestnictwo w obszerniejszym badaniu w formie wywiadu (ok. pół godziny - max. godzina) na temat własnych doświadczeń (bądź ich braku) w stosowaniu technologii komputerowej na lekcjach muzyki?

a. tak (proszę o podanie telefonu kontaktowego:

b. nie

Jeśli ma Pan/i dodatkowe refleksje lub spostrzeżenia na temat wykorzystania technologii komputerowej w pracy nauczyciela muzyki proszę o podzielenie się nimi w tym miejscu: 


\title{
Formularz ankiety dla dyrektora szkoły
}

\author{
ANKIETA \\ (czas wypełniania - ok. 3 minut)
}

Szanowni Państwo.

Zwracam się do Państwa z prośbą o wypełnienie poniższej ankiety, która jest elementem badań prowadzonych na Uniwersytecie Łódzkim i ma na celu określenie w jakim stopniu nauczyciele muzyki posługują się technologia komputerowa. Ankieta jest anonimowa $i w \dot{z}$ adnym stopniu nie może być $i$ nie będzie wykorzystana $w$ celach innych niż badawcze, $w$ szczególności nie może zostać ujawniona osobom trzecim (w tym Państwa przełożonym) $w$ celu weryfikacji Państwa kompetencji.

Bardzo dziękuję za poświęcony mi czas -

Piotr Soszyński

Katedra Edukacji Artystycznej

Uniwersytet Łódzki

Prosze o zaznaczenie wybranych odpowiedzi:

1. Czy według Pani/a technologia komputerowa jest na lekcjach muzyki:
a. niezbędna;
b. pożądana;
c. pomocna;
d. bez znaczenia;
e. niepotrzebna;
f. szkodliwa;

2. Poziom kompetencji informatycznych nauczyciela muzyki w Pani/a szkole ocenia Pan/i jako:
a. wyższy od wymaganych;
b. zgodny z wymaganiami;
c. poniżej poziomu wymaganego;
d. zerowy;
e. nie wiem; 
3. Czy nauczyciel muzyki w Pani/a szkole stosuje technologię komputerową na lekcjach:
a. tak;
b. nie;
c. nie wiem;

4. Jeśli tak, to z czyjej inicjatywy:
a. własnej;
b. dyrekcji;
c. uczniów;
d. rodziców;
e. nie wiem;
f. nie stosuje;

5. Czy stan wykorzystania technologii komputerowej na lekcjach muzyki w Pani(a) szkole jest:
a. wystarczający;
b. przesadny;
c. zbyt mały;
d. stanowczo niedostateczny;
e. zerowy;
f. nie wiem;

6. Nauczyciel muzyki w Pani(a) szkole ma możliwość wykorzystania do własnych zajęć:
a. pracowni komputerowej;
b. pojedynczego komputera i rzutnika multimedialnego we wła- snej pracowni;
c. pojedynczego komputera i rzutnika multimedialnego $\mathrm{w}$ innej pracowni;
d. przenośnego szkolnego zestawu komputerowego (laptop i rzut- nik multimedialny) - po uzgodnieniu terminu;
e. nie ma żadnych z powyższych możliwości;

7. Stosuję technologię komputerową na własnych zajęciach (jakich:......)
a. tak;
b. nie; 


\section{Indeks tabel}

Tabela 1. Statystyki opisowe dla wieku badanej grupy nauczycieli 92

Tabela 2. Statystyki opisowe dla stażu pracy badanej grupy nauczycieli 93

Tabela 3. Stopień awansu zawodowego nauczycieli według rodzaju ukończonej uczelni $(\mathrm{N}=84)$

Tabela 4. Deklaracje nauczycieli o stosowaniu TI $(\mathrm{N}=85)$

Tabela 5. Statystyki opisowe dla ilości wymienionych przez badanych tytułów programów i adresów stron internetowych $\quad 100$

Tabela 6. Dokonania nauczycieli z zakresu stosowania TI, deklarowane przy ubieganiu się o kolejny stopień awansu zawodowego 104

Tabela 7. Możliwe zastosowania TI w dydaktyce muzyki według ankietowanych $(\mathrm{N}=30)$

Tabela 8. Kategorie programów komputerowych i stron internetowych używanych przez ankietowanych 115

Tabela 9. Znajomość obsługi programów komunikacyjnych 117

Tabela 10. Znajomość obsługi programów pakietu biurowego 119

Tabela 11. Znajomość obsługi programów muzycznych 121

Tabela 12. Zestawienie niektórych danych 26 nauczycieli najczęściej stosujących TI z całą grupą badanych nauczycieli

Tabela 13. Stan wykorzystania TI przez nauczycieli muzyki w opinii dyrektorów $(\mathrm{N}=82)$

Tabela 14a. Porównanie opinii dyrektorów i deklaracji nauczycieli na temat częstości wykorzystania TI na lekcjach muzyki $(\mathrm{N}=82)$ - wg kryteriów autora

Tabela 14b. Porównanie opinii dyrektorów i deklaracji nauczycieli na temat częstości wykorzystania TI na lekcjach muzyki $(\mathrm{N}=82)$ - wg kryteriów dyrektorów

Tabela 15. Dostępność sprzętu komputerowego na lekcjach muzyki według opinii nauczycieli $(\mathrm{N}=85)$

Tabela 16. Dostępność pracowni komputerowej do lekcji muzyki według opinii nauczycieli $(\mathrm{N}=85)$

Tabela 17. Dostępność sprzętu komputerowego na lekcjach muzyki według opinii dyrektorów $(\mathrm{N}=82)$

Tabela 18. Świadomość wymagań konieczności posiadania kompetencji informatycznych przez nauczycieli $(\mathrm{N}=85)$ 
Tabela 19. Opinie nauczycieli o przydatności kompetencji informatycznych w pracy nauczyciela muzyki $(\mathrm{N}=85)$

Tabela 20. Źródła wiedzy i umiejętności w posługiwaniu się komputerem u badanych nauczycieli $(\mathrm{N}=85)$

Tabela 21. Poziom kompetencji informatycznych nauczycieli muzyki według opinii dyrektorów - odpowiedzi na pytanie 2. $(\mathrm{N}=82)$

Tabela 22. Wykorzystywanie TI przez nauczycieli muzyki według opinii dyrektorów - odpowiedzi na pytanie 3. $(\mathrm{N}=83)$

Tabela 23. Liczebność ankietowanych nauczycieli w zależności od ilości brakujących wyznaczników SP2 $(\mathrm{N}=85)$

Tabela 24. Zestawienie parametrów rozbieżności SR z trzema wersjami SP 196

Tabela 25. Zestawienie przyczyn rozbieżności badanych stanów kompetencji informatycznych, związanych z postawą nauczycieli $(\mathrm{N}=85)$

Tabela 26. Zestawienie przyczyn rozbieżności badanych stanów kompetencji informatycznych, związanych z systemem kształcenia i dokształcania nauczycieli $(\mathrm{N}=85)$

Tabela 27. Stan wykorzystania TI na lekcjach muzyki według opinii dyrektorów $(\mathrm{N}=82)$

Tabela 28. Zestawienie przyczyn rozbieżności badanych stanów kompetencji informatycznych, związanych z organizacją funkcjonowania szkoły $(\mathrm{N}=85)$

Tabela 29. Porównanie niektórych danych demograficznych uczestników wywiadów z całą grupą badanych nauczycieli

\section{Indeks wykresów}

Wykres 1. Rozkład wieku w zależności od płci w badanej grupie 92

Wykres 2. Wymiar zatrudnienia ankietowanych nauczycieli 93

Wykres 3. Liczebności i procentowy udział absolwentów uczelni artystycznych i nieartystycznych w próbie badawczej $(\mathrm{N}=84) \quad 94$

Wykres 4. Liczebności i procentowy udział stopnia awansu zawodowego nauczycieli w próbie badawczej $(\mathrm{N}=85)$

Wykres 5. Porównanie stopnia awansu zawodowego badanych nauczycieli z danymi wojewódzkimi i ogólnokrajowymi 
Wykres 6. Ilość prawidłowo wymienionych nazw programów lub adresów stron internetowych, których wykorzystywanie w dydaktyce muzyki deklarują ankietowani nauczyciele

Wykres 7. Znajomość nazw oraz przeznaczenia programów komunikacyjnych wśród nauczycieli muzyki

Wykres 8. Znajomość nazw oraz przeznaczenia programów pakietu biurowego wśród nauczycieli muzyki

Wykres 9. Znajomość nazw oraz przeznaczenia programów muzycznych wśród nauczycieli muzyki

Wykres 10. Znajomość nazw i przeznaczenia programów komputerowych oraz deklaracja umiejętności ich obsługi wśród nauczycieli muzyki

Wykres 11. Ilość kategorii programów komputerowych deklarowanych jako znane przez nauczycieli muzyki

Wykres 12a. Porównanie znajomości muzycznych programów komputerowych (pyt. 20.) oraz ich wykorzystania w pracy z uczniami (pyt. 10.) - wszystkie odpowiedzi

Wykres 12b. Porównanie znajomości muzycznych programów komputerowych (pyt. 20.) oraz ich wykorzystania w pracy z uczniami (pyt. 10.) - wszystkie odpowiedzi (z uzupełnieniem)

Wykres 12c. Porównanie znajomości muzycznych programów komputerowych (pyt. 20) oraz ich wykorzystania w pracy z uczniami (pyt. 10) - odpowiedzi z podanymi nazwami programów (z uzupełnieniem)

Wykres 13. Częstotliwość wykorzystywania TI w przygotowaniu lub prowadzeniu zajęć $(\mathrm{N}=85)$

Wykres 14. Opinia dyrektorów o wykorzystywaniu TI przez nauczycieli muzyki $(\mathrm{N}=83)$

Wykres 15. Różnice w opinii nauczycieli i dyrektorów na temat częstotliwości wykorzystywania TI na lekcjach muzyki

Wykres 16. Różnice w opinii nauczycieli i dyrektorów na temat c zęstotliwości wykorzystywania TI na lekcjach muzyki próby uśrednienia danych

Wykres 17. Rozmiar oraz kierunek rozbieżności deklaracji nauczycieli i opinii dyrektorów na temat częstości wykorzystania TI na lekcjach muzyki $(\mathrm{N}=82)$ 
Wykres 18. Brak dostępności sprzętu komputerowego na lekcjach muzyki zestawienie odpowiedzi nauczycieli oraz dyrektorów

Wykres 19. Dostępność sprzętu komputerowego na lekcjach muzyki zestawienie odpowiedzi nauczycieli oraz dyrektorów

Wykres 20. Przyczyny obniżonego poczucia standardów wykorzystywania TI u badanych nauczycieli $(\mathrm{N}=85)$

Wykres 21. Przyczyny niedostatecznego wykorzystywania TI w opinii badanych nauczycieli $(\mathrm{N}=85)$

Wykres 22. Liczebność grupy kompetentnych informatycznie nauczycieli w zależności od metody jej wyliczenia

Wykres 23. Wskaźnik zbieżności poziomu kompetencji informatycznych badanych nauczycieli (SR) z pierwszą wersją poziomu postulowanego (SP1)

Wykres 24. Wskaźnik zbieżności SR z SP2 w 3 obszarach ogólnych 184

Wykres 25. Wskaźniki zbieżności SR z 7 szczegółowymi składnikami SP2 187

Wykres 26. Wskaźniki zbieżności SR (kompetencji) ze składnikami oraz całością SP3 $(\mathrm{N}=85)$

Wykres 27. Wskaźniki zbieżności kwalifikacji informatycznych badanych nauczycieli ze składnikami oraz całością SP3 $(\mathrm{N}=85)$

Wykres 28. Wskaźniki zbieżności SR z trzema wersjami SP $(\mathrm{N}=85)$

Wykres 29. Sieć przyczynowa. Źródła kompetencji informatycznych N1 219

Wykres 30. Sieć przyczynowa. Źródła kompetencji informatycznych N2 225

Wykres 31. Sieć przyczynowa. Źródła kompetencji informatycznych N3 231

Wykres 32. Sieć przyczynowa. Źródła kompetencji informatycznych N4 238

Wykres 33. Sieć przyczynowa. Źródła kompetencji informatycznych N5 243

Wykres 34. Sieć przyczynowa. Źródła kompetencji informatycznych N6 249

Wykres 35. Sieć przyczynowa. Źródła kompetencji informatycznych N7 256 